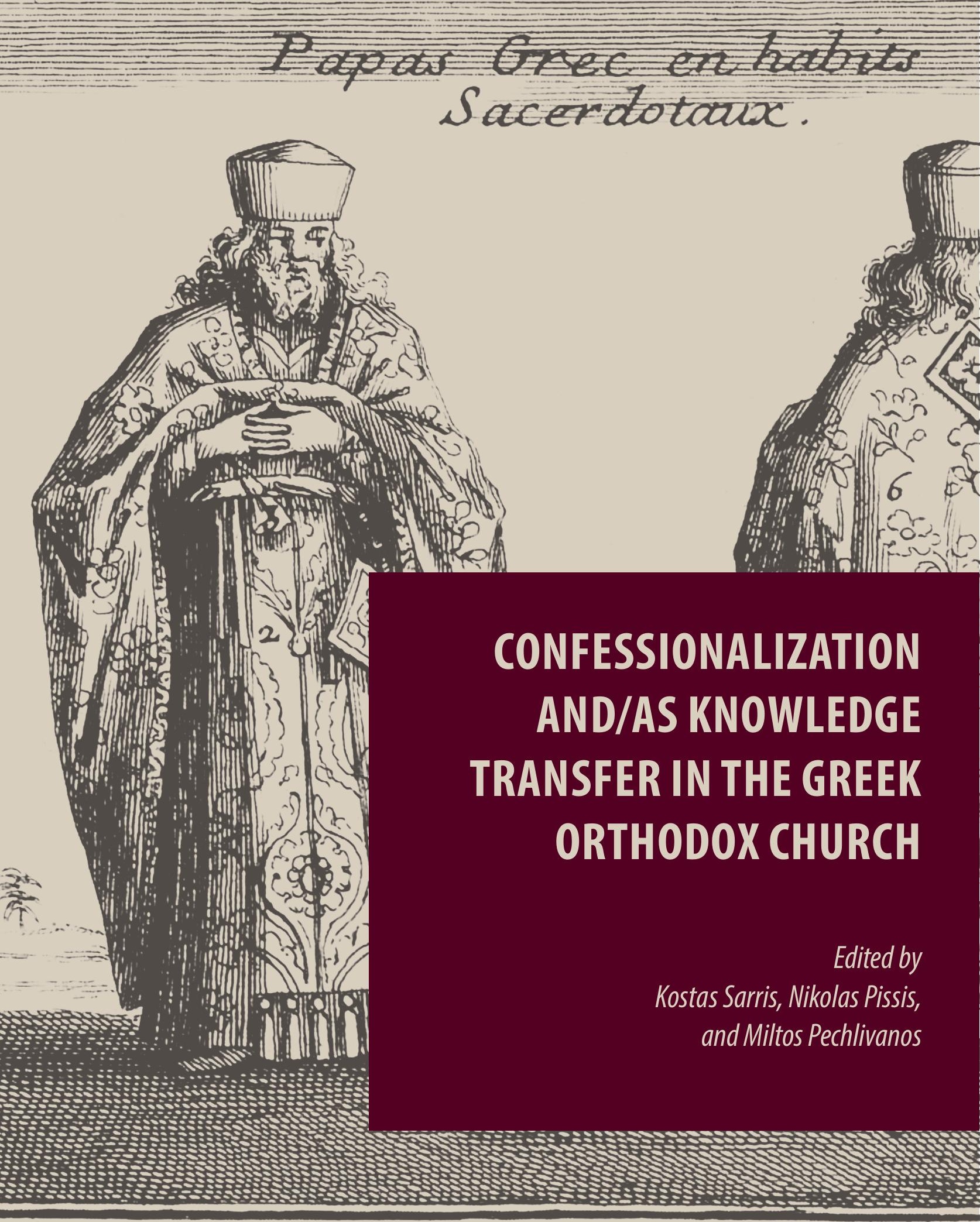


Confessionalization and/as Knowledge Transfer in the Greek Orthodox Church 


\section{Episteme in Bewegung}

Beiträge zu einer transdisziplinären Wissensgeschichte

Herausgegeben von Gyburg Uhlmann im Auftrag des Sonderforschungsbereichs 980

„Episteme in Bewegung.

Wissenstransfer von der Alten Welt

bis in die Frühe Neuzeit"

\section{Band 23}

2021

Harrassowitz Verlag · Wiesbaden 


\title{
Confessionalization and/as Knowledge Transfer in the Greek Orthodox Church
}

\author{
Edited by
}

Kostas Sarris, Nikolas Pissis, and Miltos Pechlivanos

2021

Harrassowitz Verlag · Wiesbaden 
Die Reihe „Episteme in Bewegung“ umfasst wissensgeschichtliche Forschungen mit einem systematischen oder historischen Schwerpunkt in der europäischen und nicht-europäischen Vormoderne. Sie fördert transdisziplinäre Beiträge, die sich mit Fragen der Genese und Dynamik von Wissensbeständen befassen, und trägt dadurch zur Etablierung vormoderner Wissensforschung als einer eigenständigen Forschungsperspektive bei.

Publiziert werden Beiträge, die im Umkreis des an der Freien Universität Berlin angesiedelten Sonderforschungsbereichs 980 „Episteme in Bewegung. Wissenstransfer von der Alten Welt bis in die Frühe Neuzeit" entstanden sind.

Herausgeberbeirat:

Anne Eusterschulte (FU Berlin)

Kristiane Hasselmann (FU Berlin)

Andrew James Johnston (FU Berlin)

Jochem Kahl (FU Berlin)

Klaus Krüger (FU Berlin)

Beate La Sala (FU Berlin)

Christoph Markschies (HU Berlin)

Tilo Renz (FU Berlin)

Anita Traninger (FU Berlin)

Gefördert durch die Deutsche Forschungsgemeinschaft (DFG) -

Projektnummer 191249397 - SFB 980.

Abbildung auf dem Umschlag:

„Papas Grec en habits Sacerdotaux“: Joseph Pitton de Tournefort, Relation d'un Voyage du Levant, Paris 1717,

vol. I, p. 117 (Courtesy of the Aikaterini Laskaridis Foundation, Athens)

\section{(1) (1) (}

Dies ist ein Open-Access-Titel, der unter den Bedingungen der CC BY-SA 4.0-Lizenz veröffentlicht wird. Diese erlaubt die kommerzielle Nutzung, Verbreitung und Vervielfältigung in allen Medien.

Weitere Informationen: https://creativecommons.org/licenses/by-sa/4.0/deed.de

Die Bedingungen der CC-Lizenz gelten nur für das Originalmaterial. Die Verwendung von Material aus anderen Quellen (gekennzeichnet durch eine Quellenangabe) wie Schaubilder, Abbildungen, Fotos und Textauszüge erfordert ggf. weitere Nutzungsgenehmigungen durch den jeweiligen Rechteinhaber.

Der Harrassowitz Verlag behält sich das Recht vor, die Veröffentlichung vor unbefugter Nutzung zu schützen. Anträge auf kommerzielle Verwertung, Verwendung von Teilen der Veröffentlichung und/oder Übersetzungen sind an den Harrassowitz Verlag zu richten.

Bibliografische Information der Deutschen Nationalbibliothek

Die Deutsche Nationalbibliothek verzeichnet diese Publikation in der Deutschen

Nationalbibliografie; detaillierte bibliografische Daten sind im Internet

über https://www.dnb.de abrufbar.

Informationen zum Verlagsprogramm finden Sie unter

https://www.harrassowitz-verlag.de

(c) bei den Autor/innen

Verlegt durch Otto Harrassowitz GmbH \& Co. KG, Wiesbaden 2021

Gedruckt auf alterungsbeständigem Papier.

Druck und Verarbeitung: Memminger MedienCentrum AG

Printed in Germany

ISSN 2365-5666

eISSN 2701-2522

DOI: $10.13173 / 2365-5666$
ISBN 978-3-447-11722-7

eISBN 978-3-447-39227-3

DOI: $10.13173 / 9783447117227$ 


\section{Preface}

\section{Andrew James Johnston and Gyburg Uhlmann}

Since its inception in July 2012, the Collaborative Research Centre (CRC) 980 "Episteme in Motion. Transfer of Knowledge from the Ancient World to the Early Modern Period", based at the Freie Universität Berlin, has been engaging with processes of knowledge change in premodern European and non-European cultures.

The project aims at a fundamentally new approach to the historiography of knowledge in premodern cultures. Modern scholars have frequently described premodern knowledge as static and stable, bound by tradition and highly dependent on authority, and this is a view that was often held within premodern cultures themselves.

More often than not, modern approaches to the history of premodern knowledge have been informed by historiographical notions such as 'rupture' or 'revolution', as well as by concepts of periodization explicitly or implicitly linked to a master narrative of progress.

Frequently, only a limited capacity for epistemic change and, what is more, only a limited ability to reflect on shifts in knowledge were attributed to premodern cultures, just as they were denied most forms of historical consciousness, and especially so with respect to knowledge change. In contrast, the CRC 980 seeks to demonstrate that premodern processes of knowledge change were characterised by constant flux, as well as by constant self-reflexion. These epistemic shifts and reflexions were subject to their very own dynamics, and played out in patterns that were much more complex than traditional accounts of knowledge change would have us believe.

In order to describe and conceptualise these processes of epistemic change, the CRC 980 has developed a notion of 'episteme' which encompasses 'knowledge' as well as 'scholarship' and 'science', defining knowledge as the 'knowledge of something', and thus as knowledge which stakes a claim to validity. Such claims to validity are not necessarily expressed in terms of explicit reflexion, howeverrather, they constitute themselves, and are reflected, in particular practices, institutions and modes of representation, as well as in specific aesthetic and performative strategies.

In addition to this, the CRC 980 deploys a specially adapted notion of 'transfer' centred on the re-contextualisation of knowledge. Here, transfer is not understood as a mere movement from A to B, but rather in terms of intricately entangled processes of exchange that stay in motion through iteration even if, at first glance, they appear to remain in a state of stasis. In fact, actions ostensibly geared towards the 
transmission, fixation, canonisation and codification of a certain level of knowledge prove particularly conducive to constant epistemic change.

In collaboration with the publishing house Harrassowitz the CRC has initiated the series "Episteme in Motion. Contributions to a Transdisciplinary History of Knowledge" with a view to showcase the project's research results and to render them accessible to a wider scholarly audience. The volumes published in this series represent the full scope of collaborating academic disciplines, ranging from ancient oriental studies to medieval studies, and from Korean studies to Arabistics. While some of the volumes are the product of interdisciplinary cooperation, other monographs and discipline-specific edited collections document the findings of individual sub-projects.

What all volumes in the series have in common is the fact that they conceive of the history of premodern knowledge as a research area capable of providing insights that are of fundamental interest to scholars of modernity as well. 


\section{Contents}

Kostas Sarris, Nikolas Pissis, and Miltos Pechlivanos

Introduction

\section{Confessional Brokers}

Ovidiu Olar

'Io se puotesse riformare la mia Chiesa ...': Patriarch Kyrillos Loukaris

and the Protestant 'Public Library' of Constantinople (1628-1636) .........

Nikolas Pissis

Zacharias Gerganos in Wittenberg: New Findings and Considerations .....

Stefano Saracino

Greek Orthodox Alms Collectors from the Ottoman Empire in the Holy

Roman Empire: Extreme Mobility and Confessionalized Communication . .

\section{Confessional Ambiguities}

Nikolaos Chrissidis

What's Confessionalization got to do with it?

Indulgences and Education in Seventeenth-Century Eastern Orthodoxy ...

Kostas Sarris

'come una tavola ad uno che si annega in mare': The Transfer(s)

of a Jesuit Catechism to the Edges of the Greek Confessional Seas

Marco Cerasoli

'Slipping away from the claws of Roman Propaganda' or

wishing to be 'at the service of the Apostolic Throne'?

The Ambiguous Relation between the Greek Rite and the Latin Rite

in the Life and Works of Antonios Katiforos.......................

Niki Papaïliaki

Institution-building Processes in Eastern Christianity:

Pantelis Sevastopoulos and the Foundation of the Evangelical School

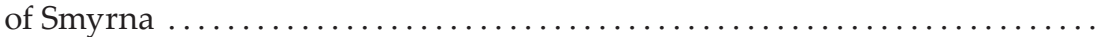

\section{Between Akribeia and Oikonomia}

\section{Vassa Kontouma}

The Archimandrite and the Astronomer. The Visit of Chrysanthos Notaras to Giovanni Domenico Cassini: a new Approach ................... 
Ionuț-Alexandru Tudorie

The Eucharistic Controversy between the 'Orthodox' Dositheos II

of Jerusalem and the 'Calvinist' Ioannis Karyofyllis (1689-1697)

Ioannis Zelepos

Confessionalization in Ottoman Orthodoxy in Comparative Perspective:

The Publishing Program of the Kollyvades and Jewish Ladino Musar

Literature in the 'long' Eighteenth Century

Vasilios N. Makrides

Ecumenical Orthodoxy vs Confessional Orthodoxy: Evgenios Voulgaris and Nikiforos Theotokis Addressing Russian Orthodoxy

Dimitris Stamatopoulos

Confessionalization vs Secularization Paradigm?

The Patriarchate of Constantinople and the Problem of the Management

of the Private Sphere in the Eighteenth and Early Nineteenth Centuries ....

Tijana Krstić

Afterword

391

Notes on Contributors ......................................... 401

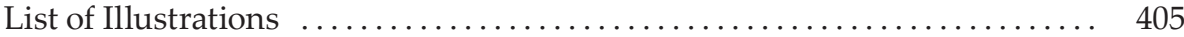

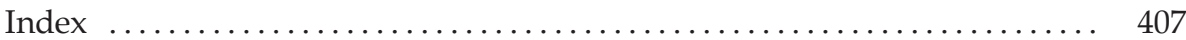




\title{
Introduction
}

\author{
Kostas Sarris, Nikolas Pissis, and Miltos Pechlivanos
}

Whereas the confessionalization paradigm, as it was originally connected to the formation of the early modern state and the accompanying imposition of social discipline, seems to have exhausted its dynamism, ${ }^{1}$ growing tendencies in recent scholarship have attempted to refresh the debate by expanding the paradigm in a twofold sense: On the one hand by applying it to historical contexts different than the western and central European, Protestant and Catholic, i.e. by tracing confessionalization processes on a global scale as part of a transreligious 'age of confessionalization'; ${ }^{2}$ on the other hand, by shifting its focus from social history to the history of knowledge and by understanding confessionalization primarily as an epistemic phenomenon, as consisting primarily in posing and answering new questions on confessional contents, questions that had not been posed before. ${ }^{3}$ This is accompanied by a greater attention to the theological issues at stake, the propria of each confession. However, in contrast to the older literature on confession-building (Konfessionsbildung), contemporary research has now become more sensitive to discursive and performative aspects of confessional identities. Such identities are treated as a cultural praxis dependent on communicative contexts. Instead of prioritizing the rise of religious uniformity as an effect of modernization, recent studies rather highlight the ambiguity of religious discourses, the emergence and negotiation of confessional identities, their variety and fluidity. Concepts such as multi-confessionalism, inter-confessionality, trans-confession-

1 Th. Brockmann and D. J. Weiß (eds), Das Konfessionalisierungsparadigma. Leistungen, Probleme, Grenzen (Münster 2013); U. Lotz-Heumann, 'Confessionalization', in A. Bamji, G. H. Janssen and M. Laven (eds), The Ashgate Research Companion to the Counter-Reformation (Surrey-Burlington VT 2013) 33-53.

2 N. Terpstra (ed.), Global Reformations: Transforming Early Modern Religions, Societies, and Cultures (London-New York 2019); Ch. H. Parker, 'The Reformation in Global Perspective', History Compass 12 (2014) 924-34; T. Krstić, Contested Conversions to Islam. Narratives of Religious Change in the Early Modern Ottoman Empire (Stanford 2011); B. Heyberger, 'Pour une "histoire croisée" de l'occidentalisation et de la confessionalisation chez les chrétiens du Proche-Orient', The MIT Electronic Journal of Middle East Studies 3 (2003) 36-49.

3 C. Zwierlein, “"Konfessionalisierung” europäisch, global als epistemischer Prozess. Zu den Folgen der Reformation und zur Methodendiskussion', in Chr. Strohm (ed.), Reformation und Recht. Ein Beitrag zur Kontroverse um die Kulturwirkungen der Reformation (Tübingen 2017) 1-51; C. Zwierlein, Imperial Unknowns. The French and British in the Mediterranean, 1650-1750 (Cambridge 2016); N. Hardy and D. Levitin (eds), Confessionalisation and erudition in early modern Europe: an episode in the history of the humanities [Proceedings of the British Academy, 225] (Oxford 2019). 
ality, confessional dissimulation or intra-confessional plurality form part of this research agenda. ${ }^{4}$ A crucial breakthrough of this current of studies consists in showing the dialectics of confessionalization processes: that it was precisely the pressure for confessional uniformity and normativity that produced ambiguity.

The first of these shifts, the concept of a global 'age of confessionalization', concerns the Ottoman Empire in particular. ${ }^{5}$ Scholars have outlined trends towards the imposition of religious uniformity and the demarcation of boundaries in Ottoman Islam that constituted a process of 'sunnitization', contemporary to the sixteenth-century developments in Christendom. ${ }^{6}$ Moreover, current research on 'entangled confessionalizations' in the Ottoman context has explored not just the possible links to and entanglements with European confessionalization but also pertinent interactions among the three monotheistic religions of the Empire (Muslims, Jews and Christians) in efforts to determine their confessional identities.? In the same direction, there is a growing interest in the dialectics of those types of 'confessionalization' that produce ambiguities, like the Crypto-Christians in the Ottoman dominions (characteristically depicted in the novel Filotheou Parerga (1710s) by the Phanariot prince Nikolaos Mavrokordatos).

In the context of this shift, the discussion of the applicability or the heuristic potential of the concept for the history of the Orthodox churches has gained momentum. ${ }^{8}$ Although it would be premature to ask for conclusions out of this still

4 Th. M. Safley (ed.), A Companion to Multiconfessionalism in the Early Modern World (Leiden-Boston 2011); A. Pietsch and B. Stollberg-Rilinger (eds), Konfessionelle Ambiguität. Uneindeutigkeit und Verstellung als religiöse Praxis in der Frühen Neuzeit [Schriften des Vereins für Reformationsgeschichte, 214] (Gütersloh 2013); K. von Greyerz et al. (eds), Interkonfessionalität-Transkonfessionalität-binnenkonfressionelle Pluralität. Neue Forschungen zur Konfessionalisierungsthese [Schriften des Vereins für Reformationsgeschichte, 201] (Gütersloh 2003); N. Terpstra, 'Reframing Reformation: Framing, Mobilizing, and Transcending Religious Difference in Early Modern Europe' in N. Terpstra (ed.), Reframing Reformation: Understanding Religious Difference in Early Modern Europe (Toronto 2020) 17-28.

5 See the project 'OTTOCONFESSION' at the CEU Budapest and its conference 'Entangled Confessionalizations? Dialogic Perspectives on Community and Confession-Building Initiatives in the Ottoman Empire, 15th-18th Centuries' (Budapest, 1-4 June 2018); cf. the workshops 'Books and Eastern Christian confessions. Connected histories between the Ottoman Empire, the Slavic world and the West (16th-18th c.)' (Rome, December 2016), 'Building Confessional Identities in the Ottoman Empire (16th-18th centuries)' (Rome, February 2017), 'Religious Diversity and Confessionalization in Ottoman Europe' (Munich, July 2019) and 'Westliche Konfessionskirchen und orthodoxes Christentum: Ein Thema der Interkonfessionalitätsforschung?' (Hamburg, February 2021).

6 T. Krstić, 'State and Religion, "Sunnitization" and "Confessionalism” in Süleyman's Time', in P. Fodor (ed.), The Battle for Central Europe (Leiden-Boston 2019) 65-91; D. Terzioğlu, 'How to Conceptualize Ottoman Sunnitization: A Historiographical Discussion', Turcica 44 (20122013) 301-38.

7 The volume by T. Krstić (ed.), Entangled Confessionalizations? Dialogic Perspectives on the Politics of Piety and Community Building in the Ottoman Empire, 15th-18th Centuries (forthcoming) is being issued almost simultaneously with the present volume.

8 M.-D. Grigore and Fl. Kührer-Wielach (eds), Orthodoxa Confessio? Konfessionsbildung, Konfessionalisierung und ihre Folgen in der östlichen Christenheit Europas (Göttingen 2018). 
young and promising discussion, one may observe as a provisional consensus that scholars prefer to speak of 'confessionalization processes' with contingent features and an open outcome in the Orthodox World instead of a full-blown 'Orthodox Confessionalization'. It has been more or less evident that a fruitful application of the paradigm goes hand in hand with a shortening of its original lists of criteria, a development that has already been underway in pertinent debates and polemics on the Western Churches. It has also been shown that such processes affected the mental outlook of Orthodox elites and church hierarchies rather than involving an effective disciplining of the Orthodox laity. ${ }^{9}$

Nevertheless, this volume focuses less on the ongoing discussion about the applicability and the historical utility of the confessionalization paradigm to the Ottoman Empire or the Orthodox Church according to the criteria developed for its original historical contexts. Instead, the central question concerns the potential of the confessionalization paradigm for the purposes of a history of knowledge regarding the clerical milieus of the Great Church. Its point of departure is an understanding of confessionalization processes in the Greek Orthodox Church as an epistemic challenge posed in a historical context that was determined by the controversies in the West born out of the Reformations. It is in this sense that Konrad Zwierlein proposed that the confessionalization of the Eastern Church be understood as having its nucleus in posing and replying to questions that have previously not been put, which in the Orthodox case implies a need to enter a previously defined epistemic field and provide normative, representative, and authoritative statements that should meet the demands of this asymmetric communication. This communication was a product of and a response to an 'epistemic pressure' exerted by representatives of the Western Christian confessions (missionaries, diplomats, professors of theology) on Greek Orthodox believers (bishops, itinerant monks, or students, the Phanariot members of the Orthodox elite in the Ottoman administration). However, to conceptualize the Orthodox confessionalization processes simply as 'collateral effects' of the Catholic-Protestant clash does not tell the whole story. It has been argued that several developments in seventeenth-century Orthodoxy should be understood as the standard program of reform (reinforcement of church discipline, reforms in education, dogmatic uniformity, critique of popular superstition etc.) through the ages of ecclesiastical history. ${ }^{10}$ Oscillation between knowledge exchanges and parallel developments is a problem intrinsic to entan-

9 A. Brüning, 'Confessionalization in the Slavia Orthodoxa (Belorussia, Ukraine, Russia)?-Potentials and Limits of a Western Historiographical Concept', in Th. Bremer (ed.), Religion and Conceptual Boundary in Central and Eastern Europe. Encounters of Faiths (Basingstoke 2008) 6697, here p. 73; V. N. Makrides, 'Konfessionalisierungsprozesse in der orthodox-christlichen Welt. Ein Periodisierungs- und Systematisierungsversuch', in M.-D. Grigore and Fl. KührerWielach (eds), Orthodoxa Confessio? Konfessionsbildung, Konfessionalisierung und ihre Folgen in der östlichen Christenheit Europas (Göttingen 2018) 77-110.

10 Brüning, 'Confessionalization in the Slavia Orthodoxa', 88; A. Brüning, 'Die Orthodoxie im konfessionellen Zeitalter: Von der kirchlichen Reform zur Konfessionalisierung-oder nicht? Beobachtungen in universalgeschichtlicher Perspektive', in M.-D. Grigore and Fl. Kührer- 
gled histories. This volume attempts to address the problem by shedding light on the various links between the confessionalization concept in the Greek Orthodox setting and knowledge change. On the one hand, communication born out of this 'epistemic pressure' applied by the Western confessions on the Orthodox and the latter's need to articulate novel, authoritative positions resulted in epistemic movements. In this sense, confessionalization functioned as knowledge transfer. On the other hand, confessionalization may be perceived as the very context of an unfolding communication process that triggered knowledge mobility in a wide range of epistemic fields, beyond the strictly theological: confessionalization and knowledge transfer.

In analyzing epistemic phenomena under the label of knowledge transfers, this volume applies the guiding concepts developed in the CRC 'Episteme in Motion'. The term 'episteme' implies knowledge which is always invested with some claim to validity-a claim which becomes manifest in particular discourses and practices. 'Transfer' signifies not simply movements of a fixed and defined knowledge, since the basic assumption is that knowledge always constitutes itself in processes of transfer. Contrary to older comparative approaches which described cultural exchange in terms of influences and as a one-way process, the concept of transfer is understood as an interactive process covering a broad spectrum: transfer in space, but also in time, from one culture to another, from one language to another, from one medium to another, from one knowledge field to another, or from one function to another, in short: from one context to another. It is these re-contextualizations that transform knowledge within new configurations and entanglements. The adaptation of this transferred knowledge can range from differentiation of already existing ideas, their codification or recontextualization in a new framework, their reaffirmation or modification corresponding to different needs and experiences, to the tacit integration of the new ideas or their explicit refutation and negation. Even in societies and cultures described from the modern point of view as static, stable and traditional or perceiving themselves as preserving an old tradition as their main value, knowledge is always in motion, although in terms less manifest and radical. The complexity of such a motion is not to be grasped and described with the usual modern notions of originality, innovation, break and revolution. Similarly, cultural exchange, the 'transcultural entanglements' of the pre-modern world cannot be adequately understood if 'traditional' cultures are seen as primarily autonomous and self-sufficient. This means that knowledge change is marked by constantly shifting reciprocal relations in which implicit norms, selection processes, invisible rules and power structures play a crucial role.

Discussing epistemic developments in early modern Orthodoxy presents a particular challenge: on the one hand, the knowledge culture of the Greek Orthodox Church has been described as stable and static, essentially unreceptive to change,

Wielach (eds), Orthodoxa Confessio? Konfessionsbildung, Konfessionalisierung und ihre Folgen in der östlichen Christenheit Europas (Göttingen 2018) 45-75, here p. $61 f ., 67$. 
and caught in its traditionalism; ${ }^{11}$ on the other hand, however, historical change has been acknowledged but at the same time bemoaned as an ominous alienation. Western influences are perceived as resulting in an alienation of Orthodox spirituality. The mineralogical term of Oswald Spengler 'pseudomorphosis', adopted by Georges Florovsky and later 'neo-patristic' Orthodox theologians to conceptualize an 'over-layering' of Orthodox theology by rationalistic elements alien to Orthodoxy's very spirit, describes more or less the phenomena which make up the confessionalization processes in question. Yet, from the point of view of the history of knowledge the paramount question concerns the modalities which condition the formation of this knowledge culture in processes of multiple transfers that shaped confessional boundaries, intellectual profiles and epistemic curricula. Whether and how such readjustments and reconfigurations of knowledge transfers, which amounted to readjustments and reconfigurations of Orthodoxy itself, were conceptualized, legitimized or denied, were questions that implied a negotiation of the principles of Oikonomia and Akribeia, as marks for leniency, flexibility and elasticity on the one hand, and strictness, firm application of church canons on the other. ${ }^{12}$ The notion of accommodation with its theological background as a principle of biblical exegesis and as a concept for adjustment (adjustment of the Divine to the human condition as well as adjustment of the Gospel and of Christian teaching to local cultures, especially in missionary contexts) ${ }^{13}$ acquires a particular quality in this context. That is, it may capture the character of epistemic challenges faced by Orthodox churchmen and the responses they embarked upon to settle epistemic conflicts. The alternative choices of conversion (e.g., to the Roman Catholic Church) or the controversialist negation of the confessional 'other'

11 For recent attempts to overcome such reductionist views, see N. A. Chrissidis, 'The World of Eastern Orthodoxy', in H. Scott (ed.), The Oxford Handbook of Early Modern European History, 1350-1750, vol. I. Peoples and Places (Oxford-New York, 2015) 626-51; T. Anastassiadis, 'Eastern Orthodoxy. An histoire croisée and connected history approach', Bulletin de correspondance hellénique moderne et contemporain, 2 (2020). http://journals.openedition.org/bchmc/463; DOI: https://doi.org/10.4000/bchmc.463.

12 J. Meyendorff, Byzantine Theology. Historical Trends and Doctrinal Themes, 2nd edn (New York 1983) 88-90; G. Richter, Oikonomia. Der Gebrauch des Wortes Oikonomia im Neuen Testament, bei den Kirchenvätern und in der theologischen Literatur bis ins 20. Jahrhundert [Arbeiten zur Kirchengeschichte, 90] (Berlin-New York 2005); G. Dagron, 'La règle et l'exception. Analyse de la notion d'économie', in D. Simon (ed.), Religiöse Devianz. Untersuchungen zu sozialen, rechtlichen und theologischen Reaktionen auf religiöse Abweichung im westlichen und östlichen Mittelalter (Frankfurt a.M. 1990) 1-18.

13 St. D. Benin, The Footprints of God: Divine Accommodation in Jewish and Christian Thought (New York 1993); I. G. Županov, 'Accommodation', in R. Azria and D. Hervieu-Leger (eds), Dictionnaire des fais religieux (Paris 2010) 1-4; L. Dannenberg, 'Hermeneutik zwischen Theologie und Naturphilosophie: der sensus accomodatus am Beginn des 17. Jahrhunderts', in D. Thouard, Fr. Vollhardt and F. M. Zini (eds), Philologie als Wissensmodell/La philologie comme modèle de savoir [Pluralisierung und Autorität, 20] (Berlin-New York 2010) 261-5. Cf. M. Pechlivanos, 'Bibliothoiconomy: Greek homines novi in the Ottoman Tulip Era', in N.Schmidt, N. Pissis and G. Uhlmann (eds), Wissensoikonomien. Ordnung und Transgression vormoderner Kulturen [Episteme in Bewegung: Beiträge zu einer transdisziplinären Wissensgeschichte, 18] (Wiesbaden 2021) 161-77. 
may represent a suspension of accommodation. However, at the same time, they involve manifest or hidden epistemic movements which legitimize and rationalize the choices made.

First and foremost, this kind of knowledge transfers is reflected in the emergence of new genres in the field of theological knowledge. One might outline an Orthodox

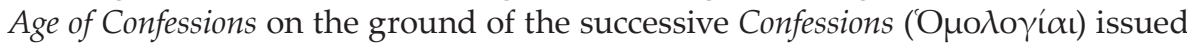
in Greek in the seventeenth and eighteenth centuries (e.g., by Kyrillos Loukaris in 1629, Mitrofanis Kritopoulos in 1625, Petro Mohyla in 1640/1642, Dositheos II of Jerusalem in 1672, the Constantinople Council in 1727) ${ }^{14}$. Similarly, numerous catechisms of different origins were composed and some of them circulated in the same period in the Greek-speaking world (e.g. those of Vincenzo Castagnola in 1595, Bellarmino in 1602 and 1616, Zacharias Gerganos in 1622, Nikolaos Voulgaris in 1681, Michail Mitros in 1686). Besides, even the emergence of a controversialist theological output (e.g. Meletios Pigas, Kyrillos Loukaris, Zacharias Gerganos, Paisios Ligaridis, Meletios Syrigos, Georgios Koressios, Nikolaos Keramefs, Nektarios of Jerusalem) is related to new discourses, since it was closely intertwingled to Western models and in some case consisted in re-contextualizing late Byzantine anti-papal works, which were embedded in controversialist editorial projects (e.g. the volumes of Dositheos II of Jerusalem: Tome of Reconciliation, Tome of Love, Tome of Joy). ${ }^{15}$ These novel genres in their overlappings with inherited ones reconfigured and readjusted the structure and the content of the theological knowledge they carried, in order to response to the 'epistemic pressure' applied by the Western confessions.

Nevertheless, next to the field of the Confessions of faith, of confessional propaganda and controversial theology, which has attracted the main interest of researchers, this period is marked by several variants of confessionality that demand a micro-historical examination of case-studies. This plurality should not be reduced to the binary opposition of Orthodox vs Convert. Approaching these phenomena from the viewpoint of knowledge transfer may contribute to distinguishing and examining a broad spectrum of confessional identities which are constructed, proclaimed, modified, exchanged, and replaced in the context of confessionalization processes. Positioned in such a varied confessional landscape,

14 O. Olar, 'Les Confessions de Foi de Cyrille Loukaris († 1638)', in M.-H. Blanchet and Fr. Gabriel (eds), L'Union à l'èpreuve du formulaire. Professions de foi entre églises d'orient et d'occident (XIII'XVIII' siècle) (Leuven-Paris-Bristol CT 2016) 271-310; V. Kontouma, 'La Confession de foi de Dosithée de Jérusalem. Les versions de 1672 et de 1690', in ibid., 341-72.

15 N. Russell, 'From the "Shield of Orthodoxy" to the "Tome of Joy": The Anti-Western Stance of Dositheos of Jerusalem (1641-1707)", in G. E. Demacopoulos and A. Papanicolaou (eds), Orthodox Constructions of the West (New York 2013) 71-82; O. Olar, "“A time to speak”. The printing activity of Dositheos Notaras, Patriarch of Jerusalem († 1707)', Annales Universitatis Apulensis.

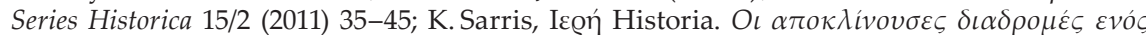

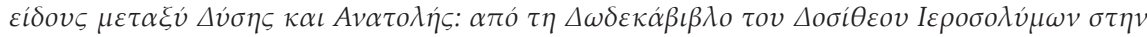

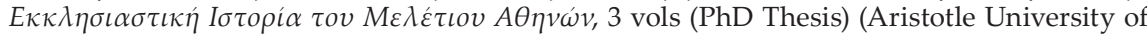
Thessaloniki, Thessaloniki 2010). 
the Greek experience might enrich current debates that aim to expand the confessionalization paradigm by studying early modern confessional dynamics in a European and global context. The notions of 'inter-confessionality', 'trans-confessionality', '(intra-confessional) plurarity', 'confessional ambiguity' and 'multi-confessionalism', as mentioned above, appear to be promising for the study of the Greek Orthodox Church in the Confessional Age.

Exchanges between persons or groups of different confessions who assert their distinct confessional identities and participate in the exchange precisely as confessional subjects or groups, such as the correspondence between the Lutheran theologians of Tübingen and the Patriarch of Constantinople Ieremias II Tranos in 1573-1581 fit the label 'interconfessional communication'. Pertinent cases abound in the seventeenth century, from single Greek Orthodox travelers (students, bishops and monks in alms-seeking missions) visiting Western Christian centers (e.g. Christoforos Angelos, Mitrofanis Kritopoulos and countless less well-known individuals ${ }^{16}$ ) to the activities of Catholic missionaries (Jesuits and Capuchins) in the Levant ${ }^{17}$ or the initiatives of diplomats and their entourages, as in the case of the French ambassador at the Porte (1670-79) Marquis de Nointel and the inquiries he conducted with the help of the French consular network concerning the Eastern Churches' positions on the Eucharist. ${ }^{18}$ Both Catholics and Protestants invoked the testimony of the ancient Churches of the East and attempted to instrumentalize it in their own confessional confrontation, a process that had reciprocal effects, in the sense of a reconfiguration of their epistemic and rhetorical arsenal, producing knowledge transfers on both Western and Eastern confessions. It is this reciprocity, inherent in the notion of interconfessionality, that attracts attention from the viewpoint of the history of knowledge.

On the other hand, the understanding of figures and topics that was hitherto restricted under the heading of 'conversion', could profit from an examination through the lens of transconfessionality, perceived as a form of communication in which the participants do not necessarily speak out of explicit confessional standpoints. Consequently, 'transconfessional' denotes a conscious reaching beyond confessional borders that may follow various motives and may be expressed

16 S. Saracino, 'Griechisch-orthodoxe Almosenfahrer im Heiligen Römischen Reich und ihre wissensgeschichtliche Bedeutung (1650-1750)', in M. Friedrich and J. Schilling (ed.), Praktiken frühneuzeitlicher Historiographie [Cultures and Practices of Knowledge in History/Wissenskulturen und ihre Praktiken, 2] (Berlin-Boston 2019) 141-73.

17 N. Papaïliaki, ‘Des schismatiques et des orthodoxes : action missionnaire française et unité de l'Église en Grèce aux XVIIe et XVIIIe siècles', in M.-H. Blanchet and Fr. Gabriel (eds), Réduire le Schisme? Ecclésiologies et Politiques de l'Union entre Orient et Occident (XIIIe-XVIIIe siècle) (Paris 2013) 303-12, here p. 307; N. Papaïliaki, 'Conflits et coexistences. Les relations des missionnaires français avec les ecclésiastiques et les laïcs grecs au XVIIe siècle', in S. Eyezo'o and J.-Fr. Zorn (eds), Concurrences en Mission. Propagandes, conflits, coexistences (XVIe-XXe siècles), Actes du XXXIe Colloque du CREDIC (Paris 2011) 65-78.

18 A. Hamilton, 'From East to West: Jansenists, Orientalists and the Eucharistic Controversy', in W. Otten, A. Vanderjagt and Hent de Vries (eds), How the West was Won: Essays on Literary Imagination, the Canon, and the Christian Middle Ages for Burcht Pranger (Leiden-Boston 2010) 83-100. 
in different forms, such as referring to common Christian, i.e. pre-confessional, traditions, either to 'irenic' attempts to overcome existing divisions, or in the context of the Republic of Letters. Even in cases that actually match the category of conversion, one may recognize aspects that suggest transconfessional gestures, e.g., when conversion is being invested with claims of pre-confessional Christian commonalities. In such a perspective Patriarch Kyrillos Loukaris' receptiveness towards Calvinism and his quest for an uncorrupted pure Christianity gains nuance. ${ }^{19}$ The same can be said to an extent for certain aspects of the overall Post-Tridentine proselytizing policy of the Catholic Church and its endeavors for Union with the Orthodox Church (establishment of the Greek College of Saint Athanasius at Rome, Uniate Professions of Faith signed by Orthodox hierarchs etc.) and arguments that denied or downgraded the Great Schism.

By focusing rather on personal strategies and the discursive aspects of confessional position-takings, we can also see that contact zones and practices of confessional ambiguity were by no means uncommon among the Greek Orthodox responses to the Confessional Age. The multi-confessional and multi-religious setting of the early modern Levant intensified and multiplied similar ambiguities not only in Ottoman territories (e.g., the coexistence of Orthodox and Catholics in the Aegean Islands and the ambiguous aspects of worship and devotion) ${ }^{20}$, but primarily in Venice (the status and the socio-religious integration of the 'nazione greca' in the city) and throughout the Venetian dominions of the Levant (Cyprus, Crete, Ionian Islands, Peloponnese). ${ }^{21}$

Moreover, an approach to the Greek Orthodox Age of Confessions from the perspective of the history of knowledge may enrich our understanding of central or peripheral confessional subjects of the period. Such agents of knowledge transfer who were hitherto classified simply as converts (e.g. Petros Arkoudios, Leon Allatios, Ioannis Matthaios Karyofyllis), as disguised converts (e.g. Paisios Ligaridis) or persons accused by their contemporaries as being converts (e.g. Zacharias Gerganos, Ioannis Karyofyllis) acquire a special quality as brokers between Orthodoxy and their new-or, supposedly new-denomination. On the other hand, the role of leading Orthodox confessional subjects in confession building

19 G. Hering, Ökumenisches Patriarchat und europäische Politik (1620-1638) (Wiesbaden 1968); O.-V. Olar, La Boutique du Théophile: les relations du patriarche de Constantinople Kyrillos Loukaris (1570-1638) avec la Réforme (Paris 2019).

20 T. Ware, 'Orthodox and Catholics in the Seventeenth Century: Schism or Intercommunion?', in D. Baker (ed.), Schism, Heresy and religious protest (Cambridge 1972) 259-76.

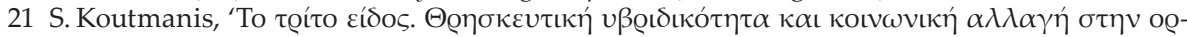

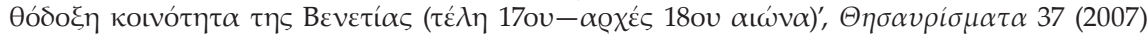
389-420; D. Lappa, 'Religious conversions within the Venetian military milieu (17th and 18th centuries)', Studi Veneziani 67-68 (2013) 183-200; B. Arbel, 'Roman Catholics and Greek Orthodox in Venice's overseas colonies (mid-fifteenth to mid-seventeenth century)', in K. Fukasawa, B. J. Kaplan and P.-Y. Beaurepaire (eds), Religious Interactions in Europe and the Mediterranean World. Coexistence and Dialogue from the Twelfth to the Twentieth Centuries (London-New York 2017) 245-59; C. Santus, Trasgressioni necessarie: Communicatio in sacris, collaborazioni e conflitti tra le comunità cristiane orientali (Levante e Impero ottomano, XVII-XVIII secolo) (Rome 2019). 
and knowledge transfer appears more complex (e.g., the Patriarchs of Jerusalem Dositheos II and his nephew, Chrysanthos Notaras) ${ }^{22}$, since they attempted not simply to define and demarcate Orthodoxy, but at the same time to integrate their Orthodox identity into an unprecedented, novel religious context produced by the challenges of confessionalization.

Furthermore, these attempts to 'confessionalize' Orthodox identity triggered dynamic processes of intra-confessional differentiation producing theological, geographical, cultural, and social varieties and cleavages. Hence, in contrast to the perception of the early modern Greek Orthodox Church as a coherent, insular, and static institution, these varieties within Greek Orthodoxy persisted throughout the eighteenth century. To be sure, stabilization was achieved, a stabilization that could be perceived as ending $a$ Greek Orthodox Age of Confessions e.g., with the proclamation of the Synodal Confession of Faith in 1727, the imposition of stricter boundaries and the reduction of confessional ambiguity with the simultaneous prohibition of communicatio in sacris by the Catholic Church (1729). However, this seemingly settled status of confessional boundaries and identities could be destabilized at any time. A flashpoint regarding the old question of the validity of Catholic baptism and the extent of leniency towards converts to Orthodoxy, sufficed to create a major strife in the 1750s (the Anabaptism issue), uncovering social conflicts that interfered with theological arguments and undermined the accommodationist practices of the Church establishment. ${ }^{23}$

Similar contestations of accommodation characterized the Kollyvadic movement in the last third of the eighteenth century. ${ }^{24}$ In terms of knowledge transfer, both the re-contextualization of Byzantine mystic ('philocalic') spirituality as well as the tacit translation of Jesuit pastoral literature belong to an orchestrated effort to re-negotiate Orthodoxy, its 'tradition' and its boundaries and to claim an instrumental role in a new configuration. Whereas the Confessions of Faith composed by leading Kollyvades pertain rather to intra-Orthodox, and even individual games of power and influence (although as zealots they were accused of Calvinism), their gradual addressing of larger audiences and their promotion of certain goals akin to the confessionalization program (e.g. catechizing and disciplining the laity, criticizing popular superstition) makes them part of a broader context.

22 Kontouma, 'Recherches sur Dosithée II de Jérusalem', Annuaire EPRE-SH 124 (2015-16) 207-218.

23 T. Ware, Eustratios Argenti. A Study of the Greek Church under Turkish Rule (Oxford 1964); D. Wendebourg, 'Taufe und Oikonomia. Zur Frage der Wiedertaufe in der Orthodoxen Kirche', in D. Wendebourg (ed.), Die eine Christenheit auf Erden. Aufsätze zur Kirchen- und Ökumenengeschichte (Tübingen 2000) 23-46.

24 I. Zelepos, Orthodoxe Eiferer im osmanischen Südosteuropa. Die Kollyvadenbewegung (1750-1820) und ihr Beitrag zu den Auseinandersetzungen um Tradition, Aufklärung und Identität (Wiesbaden 2012); S. D. Petmezas, 'On the formation of an ideological faction in the Greek Orthodox Church in the second half of the eighteenth century: the Kollyvades', Bulletin de correspondance hellénique moderne et contemporain, 2 | 2020. http://journals.openedition.org/bchmc/416; DOI: https://doi.org/10.4000/bchmc.416. 
The present volume comprises papers presented in two workshops organized by the research project 'Transfer and overlapping. Knowledge configuration patterns in the era of the Greek homines novi of the Ottoman Empire (1641-1730)' ['Transfer und Überlagerung. Wissenskonfigurationen in der Zeit der griechischen homines novi im Osmanischen Reich (1641-1730)'] in December 2017 and May $2018^{25}$, and draws on both research desiderata addressed above, i.e., of expanding the confessionalization paradigm in both geographical and methodological terms. The articles of the volume thus examine Confessionalization as opening up a field of inter-confessional communication and conflict, negotiation and modification of knowledge; interpersonal networks and networks of books, genres and discourses in motion; materialities and medialities of transfer; accommodation strategies and institution-building processes in the Greek Orthodox Church; the role of confessionally motivated negation both as an obstacle and as a form of knowledge transfer; fluent confessional identities and trans-confessional discourses in clerical milieus. They are grouped in three thematic-methodical sections. The first (Confessional Brokers) focuses on certain protagonists of interconfessional communication in the seventeenth and eighteenth centuries such as the 'Calvinist Patriarch' Kyrillos Loukaris, whose life marks more or less a turning point in the Orthodox responses to the Confessional Age (Olar) or Greek Orthodox students and travelers in the German lands (Pissis, Saracino). The second section (Confessional Ambiguities) highlights the fluidity and hybridity of confessional identities on the margins between Orthodox and Catholic confessions in Venice (Sarris, Cerasoli) and shows the ambiguous coping with confessional borders by Greek Orthodox prelates in Russia (Chrissidis) or Smyrna (Papailiaki). The articles of the third section (Between Akribeia and Oikonomia) deal with the problem of handling confessional transfers and their range and limits not only in theological contexts such as the Eucharistic Debate (Tudorie), but also in adjusting Orthodox policies in matters of worship (Kontouma, Zelepos), ecclesiology (Makrides) and canon law (Stamatopoulos). In place of summarizing conclusions, the volume is rounded off by a short comment from the Ottomanist standpoint (Krstić) as a response to the volume's concept and the case studies presented in the three sections. Finally, we wish to express our thanks to Flippa Pavlidou and Nikos Kaissas for their assistance in organizing the workshops and in preparing this volume for publication. Although this goes actually without saying, we wish to thank also Kristiane Hasselmann for her constant support.

25 'Confessionalization and/as Knowledge Transfer in Eastern Christianity' (Berlin, 15.-16.12.2017) (http://www.sfb-episteme.de/Listen_Read_Watch/berichte/workshop_c06_confessionalization/ index.html), as well as 'Konfessionalisierungsprozesse im Osmanischen Reich' (Berlin, 16.05.2018) (http://www.sfb-episteme.de/veranstaltungen/Vorschau/2018/c06-

konfessionalisierungsprozesse.html). 


\section{Bibliography}

Anastassiadis T., 'Eastern Orthodoxy. An histoire croisée and connected history approach', Bulletin de correspondance hellénique moderne et contemporain, 2 (2020). http:// journals.openedition.org/bchmc/463; DOI: https://doi.org/10.4000/bchmc.463.

Arbel B., 'Roman Catholics and Greek Orthodox in Venice's overseas colonies (mid-fifteenth to mid-seventeenth century)', in K. Fukasawa, B. J. Kaplan and P.-Y. Beaurepaire (eds), Religious Interactions in Europe and the Mediterranean World. Coexistence and Dialogue from the Twelfth to the Twentieth Centuries (London-New York 2017) 245-59.

Benin St. D., The Footprints of God: Divine Accommodation in Jewish and Christian Thought (New York 1993).

Brockmann Th. and D. J. Weiß (eds), Das Konfessionalisierungsparadigma. Leistungen, Probleme, Grenzen (Münster 2013).

Brüning A., 'Confessionalization in the Slavia Orthodoxa (Belorussia, Ukraine, Russia)?-Potentials and Limits of a Western Historiographical Concept', in Th. Bremer (ed.), Religion and Conceptual Boundary in Central and Eastern Europe. Encounters of Faiths (Basingstoke 2008) 66-97.

- 'Die Orthodoxie im konfessionellen Zeitalter: Von der kirchlichen Reform zur Konfessionalisierung-oder nicht? Beobachtungen in universalgeschichtlicher Perspektive', in M.-D. Grigore and Fl. Kührer-Wielach (eds), Orthodoxa Confessio? Konfessionsbildung, Konfessionalisierung und ihre Folgen in der östlichen Christenheit Europas (Göttingen 2018) 45-75.

Chrissidis N. A., 'The World of Eastern Orthodoxy', in H. Scott (ed.), The Oxford Handbook of Early Modern European History, 1350-1750, vol. I. Peoples and Places (OxfordNew York, 2015) 626-51.

Dagron G., 'La règle et l'exception. Analyse de la notion d'économie', in D. Simon (ed.), Religiöse Devianz. Untersuchungen zu sozialen, rechtlichen und theologischen Reaktionen auf religiöse Abweichung im westlichen und östlichen Mittelalter (Frankfurt a.M. 1990) $1-18$.

Dannenberg L., 'Hermeneutik zwischen Theologie und Naturphilosophie: der sensus accomodatus am Beginn des 17. Jahrhunderts', in D. Thouard, Fr. Vollhardt and F. M. Zini (eds), Philologie als Wissensmodell/La philologie comme modèle de savoir [Pluralisierung und Autorität, 20] (Berlin-New York 2010) 261-5.

Grigore M.-D. and Fl. Kührer-Wielach (eds), Orthodoxa Confessio? Konfessionsbildung, Konfessionalisierung und ihre Folgen in der östlichen Christenheit Europas (Göttingen 2018).

Hamilton A., 'From East to West: Jansenists, Orientalists and the Eucharistic Controversy', in W. Otten, A. Vanderjagt and Hent de Vries (eds), How the West was Won: Essays on Literary Imagination, the Canon, and the Christian Middle Ages for Burcht Pranger (Leiden-Boston 2010) 83-100.

Hering G. , Ökumenisches Patriarchat und europäische Politik (1620-1638) (Wiesbaden 1968).

Heyberger B., ‘Pour une « histoire croisée » de l'occidentalisation et de la confessionalisation chez les chrétiens du Proche-Orient', The MIT Electronic Journal of Middle East Studies 3 (2003) 36-49.

Kontouma V., 'La Confession de foi de Dosithée de Jérusalem. Les versions de 1672 et de 1690', in M.-H. Blanchet and Fr. Gabriel (eds), L'Union à l'èpreuve du formulaire. Professions de foi entre églises d'orient et d'occident (XIII $-X V I I I^{\mathrm{e}}$ siècle) (Leuven-Paris-Bristol CT 2016) 341-72. 


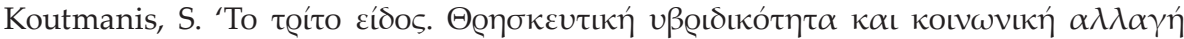

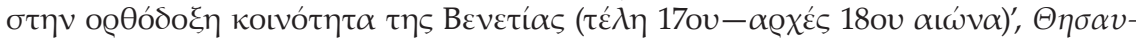

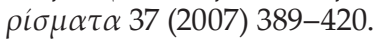

Krstić T., Contested Conversions to Islam. Narratives of Religious Change in the Early Modern Ottoman Empire (Stanford 2011).

- (ed.), Entangled Confessionalizations? Dialogic Perspectives on the Politics of Piety and Community Building in the Ottoman Empire, 15th-18th Centuries (forthcoming).

- 'State and Religion, "Sunnitization" and "Confessionalism" in Süleyman's Time', in P. Fodor (ed.), The Battle for Central Europe (Leiden-Boston 2019) 65-91.

Lappa D., 'Religious conversions within the Venetian military milieu (17th and 18th centuries)', Studi Veneziani 67-68 (2013) 183-200.

Lotz-Heumann U., 'Confessionalization', in A. Bamji, G. H. Janssen and M. Laven (eds), The Ashgate Research Companion to the Counter-Reformation (Surrey-Burlington VT 2013) 33-53.

Makrides V. N., 'Konfessionalisierungsprozesse in der orthodox-christlichen Welt. Ein Periodisierungs- und Systematisierungsversuch', in M.-D. Grigore and Fl. KührerWielach (eds), Orthodoxa Confessio? Konfessionsbildung, Konfessionalisierung und ihre Folgen in der östlichen Christenheit Europas (Göttingen 2018) 77-110.

Meyendorff J., Byzantine Theology. Historical Trends and Doctrinal Themes, 2nd edn (New York 1983).

Olar O., "'A time to speak". The printing activity of Dositheos Notaras, Patriarch of Jerusalem († 1707)', Annales Universitatis Apulensis. Series Historica 15/2 (2011) 35-45.

- La Boutique du Théophile: les relations du patriarche de Constantinople Kyrillos Loukaris (1570-1638) avec la Réforme (Paris 2019).

- 'Les Confessions de Foi de Cyrille Loukaris († 1638)', in M.-H. Blanchet and Fr. Gabriel (eds), L'Union à l'èpreuve du formulaire. Professions de foi entre églises d'orient et d'occident (XIII -XVIII siècle) (Leuven-Paris-Bristol CT 2016) 271-310.

Papaïliaki N., 'Conflits et coexistences. Les relations des missionnaires français avec les ecclésiastiques et les laïcs grecs au XVIIe siècle', in S. Eyezo'o and J.-Fr. Zorn (eds), Concurrences en Mission. Propagandes, conflits, coexistences (XVIe-XXe siècles), Actes du XXXIe Colloque du CREDIC (Paris 2011) 65-78.

- 'Des schismatiques et des orthodoxes : action missionnaire française et unité de l'Église en Grèce aux XVIIe et XVIIIe siècles', in M.-H. Blanchet and Fr. Gabriel (eds), Réduire le Schisme? Ecclésiologies et Politiques de l'Union entre Orient et Occident (XIIIe-XVIIIe siècle) (Paris 2013) 303-12.

Parker Ch. H., 'The Reformation in Global Perspective', History Compass 12 (2014) 924-34.

Pechlivanos M., 'Bibliothoiconomy: Greek homines novi in the Ottoman Tulip Era', in N. Schmidt, N. Pissis and G. Uhlmann (eds), Wissensoikonomien. Ordnung und Transgression vormoderner Kulturen [Episteme in Bewegung: Beiträge zu einer transdisziplinären Wissensgeschichte, 18] (Wiesbaden 2021) 161-77.

Petmezas S. D., 'On the formation of an ideological faction in the Greek Orthodox Church in the second half of the eighteenth century: the Kollyvades', Bulletin de correspondance hellénique moderne et contemporain, 2 | 2020. http://journals.openedition. org/bchmc/416; DOI: https://doi.org/10.4000/bchmc.416.

Pietsch A. and B. Stollberg-Rilinger (eds), Konfessionelle Ambiguität. Uneindeutigkeit und Verstellung als religiöse Praxis in der Frühen Neuzeit [Schriften des Vereins für Reformationsgeschichte, 214] (Gütersloh 2013). 
Richter G., Oikonomia. Der Gebrauch des Wortes Oikonomia im Neuen Testament, bei den Kirchenvätern und in der theologischen Literatur bis ins 20. Jahrhundert [Arbeiten zur Kirchengeschichte, 90] (Berlin-New York 2005).

Russell N., 'From the "Shield of Orthodoxy" to the "Tome of Joy": The Anti-Western Stance of Dositheos of Jerusalem (1641-1707)", in G. E. Demacopoulos and A. Papanicolaou (eds), Orthodox Constructions of the West (New York 2013) 71-82.

Safley Th. M.(ed.), A Companion to Multiconfessionalism in the Early Modern World (LeidenBoston 2011).

Santus C., Trasgressioni necessarie: Communicatio in sacris, collaborazioni e conflitti tra le comunità cristiane orientali (Levante e Impero ottomano, XVII-XVIII secolo) (Rome 2019).

Saracino S., 'Griechisch-orthodoxe Almosenfahrer im Heiligen Römischen Reich und ihre wissensgeschichtliche Bedeutung (1650-1750)', in M. Friedrich and J. Schilling (ed.), Praktiken frühneuzeitlicher Historiographie [Cultures and Practices of Knowledge in History/Wissenskulturen und ihre Praktiken, 2] (Berlin-Boston 2019) 141-73.

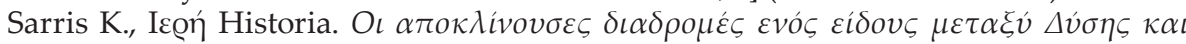

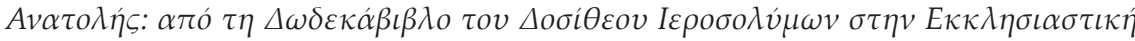

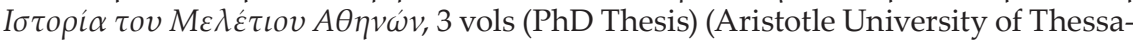
loniki, Thessaloniki 2010).

Terpstra N. (ed.), Global Reformations: Transforming Early Modern Religions, Societies, and Cultures (London-New York 2019).

- 'Reframing Reformation: Framing, Mobilizing, and Transcending Religious Difference in Early Modern Europe' in N. Terpstra (ed.), Reframing Reformation: Understanding Religious Difference in Early Modern Europe (Toronto 2020) 17-28.

Terzioğlu D., 'How to Conceptualize Ottoman Sunnitization: A Historiographical Discussion', Turcica 44 (2012-2013) 301-38.

Greyerz K. von et al. (eds), Interkonfessionalität-Transkonfessionalität-binnenkonfressionelle Pluralität. Neue Forschungen zur Konfessionalisierungsthese [Schriften des Vereins für Reformationsgeschichte, 201] (Gütersloh 2003).

Ware T., Eustratios Argenti. A Study of the Greek Church under Turkish Rule (Oxford 1964).

- 'Orthodox and Catholics in the Seventeenth Century: Schism or Intercommunion?', in D. Baker (ed.), Schism, Heresy and religious protest (Cambridge 1972) 259-76.

Wendebourg D., 'Taufe und Oikonomia. Zur Frage der Wiedertaufe in der Orthodoxen Kirche', in D. Wendebourg (ed.), Die eine Christenheit auf Erden. Aufsätze zur Kirchenund Ökumenengeschichte (Tübingen 2000) 23-46.

Zelepos I., Orthodoxe Eiferer im osmanischen Südosteuropa. Die Kollyvadenbewegung (17501820) und ihr Beitrag zu den Auseinandersetzungen um Tradition, Aufklärung und Identität (Wiesbaden 2012).

Zwierlein C., Imperial Unknowns. The French and British in the Mediterranean, 1650-1750 (Cambridge 2016).

- “'Konfessionalisierung” europäisch, global als epistemischer Prozess. Zu den Folgen der Reformation und zur Methodendiskussion', in Chr. Strohm (ed.), Reformation und Recht. Ein Beitrag zur Kontroverse um die Kulturwirkungen der Reformation (Tübingen 2017) 1-51.

Županov I. G., 'Accommodation', in R. Azria and D. Hervieu-Leger (eds), Dictionnaire des fais religieux (Paris 2010) 1-4. 

I

Confessional Brokers 



\title{
'Io se puotesse riformare la mia Chiesa ...': Patriarch Kyrillos Loukaris and the Protestant 'Public Library' of Constantinople (1628-1636)
}

\author{
Ovidiu Olar, Austrian Academy of Science
}

“"Dis-moi ce que tu lis, je te dirai qui tu es", il est vrai, mais je te connaîtrai mieux si tu me dis ce que tu relis'.

François Mauriac-Mémoires intérieurs (1959).

In the summer of 1642, as he was taking refuge from a violent outburst of plague, the priest Synadinos recounted the major events that marked the town of Serres during his lifetime. The recent execution for high treason of the Constantinopolitan Patriarch Kyrillos Loukaris (1570-1638) was certainly an incident the chronicler could not miss, because it had shocked the Christian world and struck a chord in the faithful who regarded the deceased as their shepherd. 'Alas, what a great misfortune!' exclaimed Synadinos, 'For he was a learned man, wiser than all those fond of learning. ${ }^{1}$

This is neither the first nor the last acknowledgement of Loukaris' erudition by his contemporaries. Matthaios Kigalas, author of a New synopsis of diverse histories from the Creation of the World to the present year, labels the Patriarch as 'the wisest'

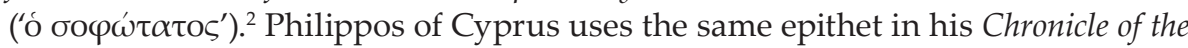
Greek Church. ${ }^{3}$ A seventeenth-century Moldavian translator of Kigalas' New synopsis is even more explicit: for him, the 'elder' Kyrillos is 'most-splendid', 'scholar and learned', 'great and learned'. ${ }^{4}$ Nevertheless, modern scholarship took this erudition at face value and devoted little attention either to Loukaris' formative years or to his lifelong reading habits.

1 P. Odorico et al. (eds), Conseils et mémoires de Synadinos prêtre de Serrès en Macédoine (XVIIe siè-

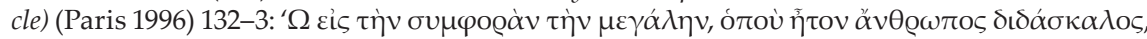

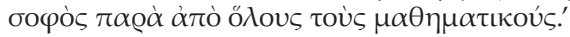

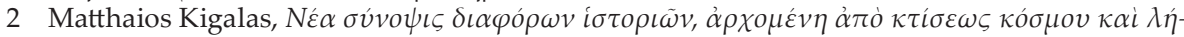
$\gamma o v \sigma \alpha \tilde{\varepsilon} \omega \varsigma \tau \eta \dot{\eta} v \tilde{v} v \dot{\varepsilon} \chi \rho o v i \alpha$... [New synopsis of diverse histories from the Creation of the World to the present year ...] (Venice 1637) 198. See also Anselmo Banduri, Imperium Orientale sive Antiquitates Constantinopolitanae, I (Paris 1711) 217-8.

3 Philippos of Cyprus, Chronicon Ecclesiae Graecae (Franeker 1679) 16-17; see also Banduri, Imperium Orientale, I, 228-9.

4 Biblioteca Academiei Române [= BAR], Ms. rom. 3517, f. 591v: 'Chiril cel prea mundru', 'cel cărtulariu şi învățat', 'bătrânul cel mare şi învățat'. For the manuscript, a chronograph which belongs to the 'Danovici' type, see D. Mihăescu, Cronografele românești (Bucharest 2006) 173-242. 
The reason is twofold. On the one hand, there are neither catalogues nor inventories listing the patriarch's books at any given moment of his eventful life; to put it simply, there are no easy options. ${ }^{5}$ On the other hand, Loukaris' autograph manuscripts-dating from 1598-1626 (not even one of his autograph manuscripts from 1627-1638 has survived) and containing a wide variety of texts, including excerpts, reading notes, and drafts of sermons ${ }^{6}$ - have attracted little interest from theologians, philologists, and historians. ${ }^{7}$ Even though the huge literature on the (in)famous character has been growing continuously and rapidly, only a handful of scholars have ventured inside this fascinating 'workshop'. ${ }^{8}$ Consequently, Georg Hofmann's 1941 plea for an unbiased scientific treatment of Loukaris based on the complete edition of his (oratorical) works remains a desideratum. ${ }^{9}$

The present paper offers a contribution towards filling this gap. On the one hand, it lists the Protestant tracts mentioned in the patriarch's correspondence and tries to identify the rationale behind Loukaris' keen interest in Europe's Reformed Churches. On the other hand, it discusses the efforts made between 1628 and 1636

5 The analysis by Marc D. Lauxtermann of the inventories of eight sixteeenth-century Constantinopolitan private libraries transmitted by Vind. Hist. gr. 98 proves that catalogues can be much more than objective lists of books: M. D. Lauxtermann, “'And many, many more": A Sixteenth-Century Description of Private Libraries in Constantinople, and the Authority of Books', in P. Armstrong (ed.), Authority in Byzantium (Abingdon-New York 2013) 269-84.

6 One is kept in Leiden (Universitaire Bibliotheken Leiden [= UBL], Bibliotheca Publica Graeca [= BPG] 122 [Diktyon (Réseau numérique pour les manuscrits grecs) 76475]), while the others, formerly in the library of the Constantinopolitan Metochion of the Holy Sepulchre, are now in Athens (National Library of Greece [ $=N L G]$, fonds of Metochion Panagiou Tafou [Metochion of the Holy Sepulchre] [= MPT]). For the former: Kyrillos Loukaris, Sermons 1598-1602, ed.

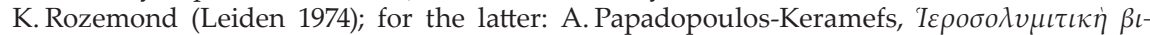
$\beta \lambda \iota 0 \theta \dot{\eta} \kappa \eta$,

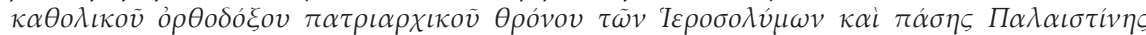

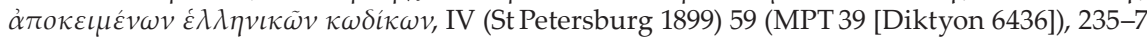
(MPT 262 [Diktyon 6659]), 237-43 (MPT 263 [Diktyon 6660]), 364 (MPT 408 [Diktyon 6805]), 408 (MPT 430 [Diktyon 6827]), 415 (MPT 439 [Diktyon 6836]). Three other seventeenth-century manuscripts (Library of the Patriarchate of Jerusalem, Hierosol. patr. 91, Hierosol. patr. 381, and NLG, MPT 427 [Diktyon 6824]) contain unpublished texts by Loukaris, but are not auto-

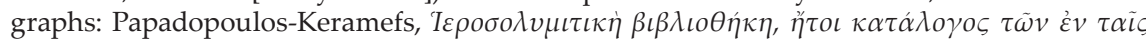

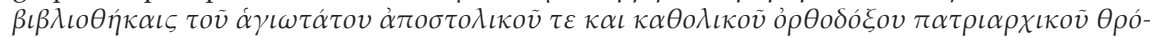

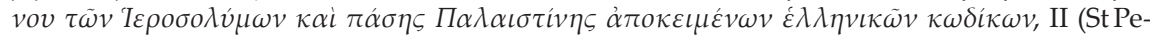
tersburg 1894), 166-7, 512-5 and IV, 406.

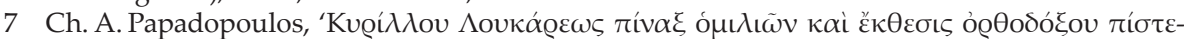

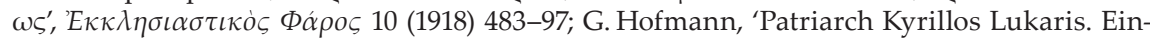
fluss abendländischer Schriften auf seine Predigten', Orientalia Christiana Periodica 7 (1941)

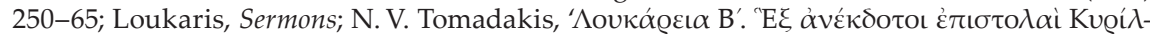

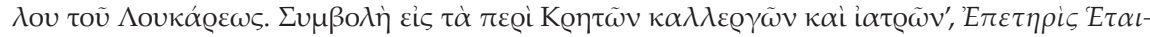

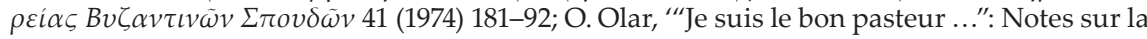
pensée politique de Kyrillos Loukaris', in V. Nosilia and M. Prandoni (eds), Trame controluce. Il patriarca 'protestante' Cirillo Loukaris/Backlighting Plots. The 'Protestant' Patriarch Cyril Loukaris (Florence 2015) 3-30.

8 O. Kresten, 'Review of K. Loukaris, Sermons 1598-1602, ed. K. Rozemond (Leiden 1974)', in Nederlands Archief voor Kerkgeschiedenis 56/2 (1976) 478-81.

9 Hofmann, 'Loukaris', 251. 
by the Calvinist minister Antoine Léger, chaplain of the Dutch embassy in Constantinople, to create a Protestant 'public library' on the shores of Bosporus. For the moment, it is difficult to determine the use (if any) Loukaris or other Eastern Christians made of the items in the library. Yet theirs was a Confessional Age in which the printed book was instrumental in the defining and shaping of the 'True Faith'. A detailed analysis of the inventory of the books that Léger bought in Venice before embarking for the capital of the Ottoman Empire and of the records of the books sent there at his request in the following years 'pour y servir à la propagation de l'Evangile', allows us to better grasp the attempts made by representatives of international Calvinism ${ }^{10}$ to push a reform-minded Loukaris and, with his help, the whole Eastern Christianity towards Reformation.

\section{Prolegomena}

Before we start, some caveats are in order. Firstly, provenance notes can be deceptive. Did the Patriarch translate or commission a Latin translation of the Qur'an (destined, judging by the language, to his Western friends), comparable to the translation of the New Testament in spoken Greek, also authorized by him? ${ }^{11}$ In 1643, the Swedish resident Carl Marin offers a manuscript copy to the Zürich library and says Loukaris did, but we do not know if the latter is responsible for the translation, as the evidence is thin. ${ }^{12}$ Did the patriarch give to Ludwig Camerarius († 1651) a fifteenth-century Greek miscellany of Italian provenance containing texts by classical authors such as Aristotle and Plato? It is possible-Camerarius' collection of letters, now held in Munich, in the Bavarian State Library, includes letters of Loukaris..$^{13}$ However, the provenance note dates from the eighteenth century. ${ }^{14}$

10 M. Prestwich (ed.), International Calvinism, 1541-1715 (Oxford 1985); R. M. Kingdon, 'International Calvinism', in T. A. Brady, H. A. Oberman and J. D. Tracy (eds), Handbook of European History 1400-1600. Late Middle Ages, Renaissance and Reformation, II. Visions, Programs, Outcomes (Leiden-Boston-Köln 1995) 229-47.

11 D. McKinney McNair, 'Kyrillos Loukaris and the Translation of Holy Books: A Latin Koran and a Modern New Testament', in M. F. Arslan and M. V. Bilici (eds), Istanbul tecrübesi. Dinsel ve kültürel farklılıkların birarada yaşaması/The experience of İstanbul. Coexistence of Religious and Cultural Diversities (Istanbul 2010) 456-64.

12 Zentralbibliothek Zürich [= ZB Zürich], Cod. C 199 (Ap. 122), f. II: 'dedico este Alcorano traduzido por l'obra del Reverendissimo Patriarca de Costantinopoli Cyrillo.' Other manuscript copies are known (Landesbibliothek und Murhardsche Bibliothek der Stadt Kassel, Cod. 4o ms. Theol. 57; Cambridge University Library-Mm. IV. 11; Bodleian Library-Arch. Selden B. 4); none mentions Loukaris. See Ó. de la Cruz Palma, La traduccción latina del Corán atribuida al patriarca de Constantinopla Cirilo Lúcaris (1572-1638) (Madrid 2006); P. M. Tommasino, 'Nota bibliográfica. Traduzioni del Corano', Al-Qanțara 31/2 (2010) 647-52; T. E. Burman, 'European Qur'an Translations, 1500-1700', in D. Thomas and J. Chesworth (eds), Christian-Muslim Relations. A Bibliographical History, VI. Western Europe (1500-1600) (Leiden-Boston 2014) 28.

13 Bayerische Staatsbibliothek [= BSB], Cam. 9 [Clm. 10359], n. 219, 220, 222, 224.

14 Erlangen Universitätsbibliothek, Ms. A 04 [Diktyon 14294], IIv: 'E bibliotheca Ludovici Camerarii, qui hunc codicem dono acceperat a patriarcha Constantinopolitano Cyrillo Lucari'. Cf. H. Thurn and O.Stählin (eds), Die griechischen Handschriften der Universitätsbibliothek Erlangen, III/2 (Wiesbaden 1980) 24-8. 
Secondly, Loukaris' ex-libris are not always easy to date. After he became Patriarch of Constantinople in November 1620, Kyrillos marked his ownership on a late-fifteenth to early-sixteenth-century Greek anthology of grammatical and literary works now kept in Athens, in the National Library. Still, it is impossible to say when exactly he acquired it. ${ }^{15}$

A last caveat concerns the relationship between the private library of the patriarch and the library of the Patriarchate. Several signs point towards such a distinction. ${ }^{16}$ In March 1609, as Patriarch of Alexandria, Loukaris accuses archdeacon Maximos the Peloponnesian of stealing manuscripts and printed books belonging to the Church of Alexandria. ${ }^{17}$ In November 1638, the ecumenical Patriarch Kyrillos II Kontaris recovers from the Dutch resident Cornelis Haga, with the help of Ottoman officials, 10 chests 'pieni di libri ereticij' belonging to the deceased Loukaris. ${ }^{18}$ I suspect, though, that Loukaris relied mostly on his private library. This would explain the small number of items related to him in the library of the Patriarchate of Alexandria: one manuscript (out of 538) - an illuminated Archieratikon offered in 1615 by the scribe, Metropolitan Matthaios of Myra ${ }^{19}$-and several printed books. ${ }^{20}$

However, this is not to say that we lack solid data on the topic: even if one leaves aside the hypothetical attributions-no matter how seductive they might be ${ }^{21}-$,

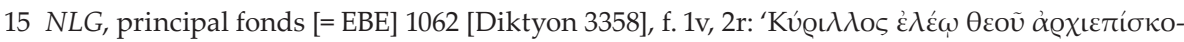

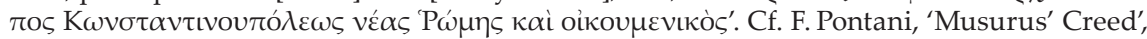
Greek, Roman, and Byzantine Studies 43 (2002-2003) 180-1.

16 See also Lauxtermann, 'Libraries in Constantinople', 278; M.-H. Blanchet, 'Présence et usage de livres au patriarcat de Constantinople durant la seconde moitié du XVe et la première moitié du XVIe siècle', in A. Binggeli, M. Cassin, and M. Detoraki (eds), Bibliothèques grecques dans l'Empire ottoman (Turnhout 2020) 119-44; P. Augustin, 'In aedibus Dn. Legati Angliae Constantinopoli Galatae: Henry Savile, Samuel Slade et les manuscrits de Galata-Péra en 1610', in A. Binggeli, M. Cassin and M. Detoraki (eds), Bibliothèques grecques dans l'Empire ottoman (Turnhout 2020) 225-55.

17 É. Legrand, Bibliographie hellénique ou Description raisonnée des ouvrages publiés en grec par des Grecs au dix-septième siècle, IV (Paris 1896) 256-7 (n. 79-Loukaris to Maximos).

18 In Vienna: Haus-, Hof- und Staatsarchiv, Staatenabteilung. Türkei I-Turcica 114/1638, f. 69r (Johann Rudolf Schmidt to Francesco Ingoli). Kontaris was planning to burn the books publicly.

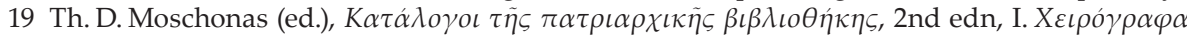
([Salt Lake City] 1965) 77 (n. 115). Giannis Karas linked to Loukaris five more manuscripts

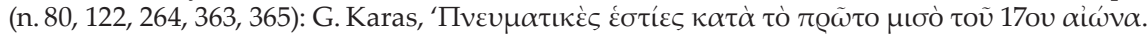

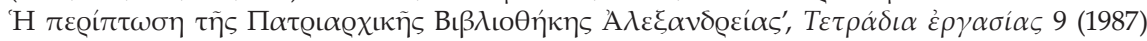

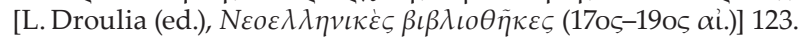

20 According to G. Karas, these are: the Idylls of Theokritos, the Extracts of Stobaeus, the Works of Epiphanius, a concordance of the New Testament, the Comedies of Aristophanes, Philippe de Mornay's De veritate religionis christianae, the Collected works of Plato (Lyon 1590), the Collected works of Isocrates, and a catena of Greek patristic commentaries on the Book of Job

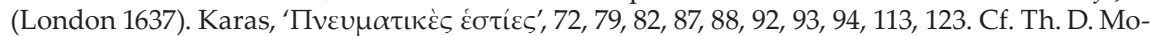

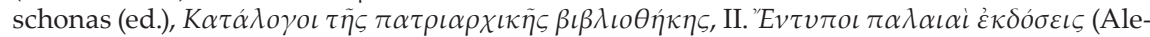
xandria 1946), n. 30, 240, 299, 372, 846, 1183, 1218, 1355 $\beta, 1398$.

21 Owned and annotated by Meletios Pigas, the Greek ms. 461 of Lambeth Palace Library might have been a gift from Loukaris to the Archbishop of Canterbury George Abbot. C. Wright, 
the sources are quite generous. The letters exchanged by the young Loukaris with the famous scholar and Orthodox bishop of Kythera residing in Venice, Maximos Margounios, show that the former had access to the Cretan library of the latter (1589). ${ }^{22}$ The correspondence with the German classical scholars Friedrich Sylburg and David Höschel mentions a 'Roman history' $(1590)^{23}$ and the poem Alexandra by Lycophron of Chalcis, which Isaac Tzetzes had once commented on (1591) ${ }^{24}$ Letters written and received during his first mission in the Polish-Lithuanian commonwealth on behalf of the Patriarch of Alexandria Meletios Pigas mention philosophical tracts such as Aristotle's Organon and Porphyry's Introduction to Aristotle's Categories, as well as the works of Gregory of Nazianzus, Cedrenus, and Thomas Aquinas (1594-early 1598). ${ }^{25}$ An epistle sent from Lviv to Justus Lipsius, in January 1601, expresses appreciation towards the recipient's (unnamed) books. ${ }^{26}$

In addition to the correspondence, Loukaris' 'écrits en vue de la prédication'27albeit methodologically problematic, since we only have access to a written version of an essentially oral genre ${ }^{28}$ - offer precious glimpses of his library. The ones written between 1598 and 1602 show familiarity not only with Basil the Great, John Chrysostom or John of Damascus, but also with Latin theologians old and new such as Augustine, Roberto Bellarmino, Philippus Diez, Cornelio Musso, and Thomas Stapleton (to mention just a few). ${ }^{29}$ The later sermons exhibit an even more diverse range of references, which include Protestant authors such as Calvin, Luther, Girolamo Zanchi († 1590) and Niels Hemmingsen († 1600). ${ }^{30}$

M. Argyrou and Ch. Dendrinos (eds), A Descriptive Catalogue of the Greek Manuscript Collection of Lambeth Palace Library (London 2016) 45-51.

22 Legrand, Bibliographie hellénique, IV, 177-8 (n. 2). Margounios' library was impressive. For a post-mortem inventory of the 48 manuscripts and 138 printed books which he wanted to bequest to the the Sinaitic Metochion of St Catherine at Candia, see Ch. Zampakolas, 'H $\beta \mathrm{t}-$

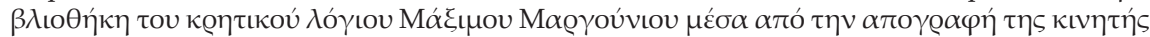

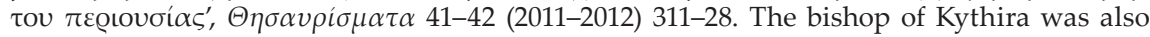
aware of the value of education: in July 1601, he tried to persuade the abbot of Valsamonero Monastery to open a school for ten poor children. P. K. Enepekidis, X

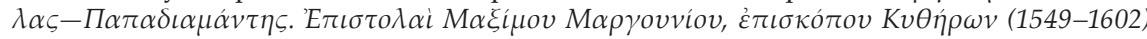
(Athens 1970) 314-6. We do not know whether the plan came to life or not. N. V. Tomadakis,

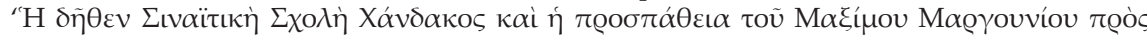

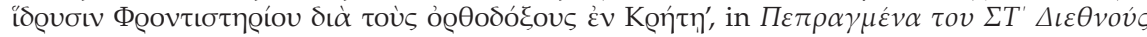

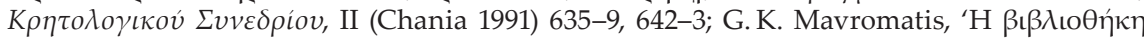

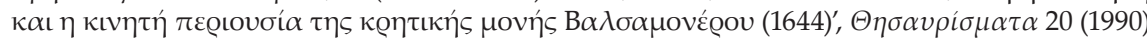
460-1, 473-4.

23 Legrand, Bibliographie hellénique, IV, 198-9 (n. 19).

24 UBL, BPG 122, f. 224r.

25 Legrand, Bibliographie hellénique, IV, 217 (n. 40), 220 (n. 47), 221 (n. 50).

26 J. Lipsius, Epistolae XIV (1601), ed. J. de Landtsheer (Brussels 2006) 81-3 (n. 2964).

27 Expression proposed by Ketje Rozemond: Loukaris, Sermons, 5.

28 Olar, 'Pensée politique', 6; O. Olar, La boutique de Théophile. Les relations du patriarche de Constantinople Kyrillos Loukaris (1570-1638) avec la Réforme (Paris 2019) 84.

29 Loukaris, Sermons, 155-7: 'Index operum a Cyrillo Lucari allatorum'.

30 Hofmann, 'Lukaris'; Olar, 'Pensée politique'. 


\section{'A friend to the Reformed religion'}

One of the first Protestant authors quoted by Loukaris was Calvin. On 16 December 1610, in the written version of a homily to be recited in Cairo, the patriarch cited the former's Institutes of the Christian Religion: 'Two major sacraments are above the rest, the baptism and the communion with this supper ... see Calvin's 4th book of the Institutes, chapter 18, section 19.'31 The quote is not entirely accurate: Calvin claimed that baptism and Eucharist were the only two sacraments, while Loukaris argued that they were the two major holy mysteries out of seven. Yet the patriarch's theological repertoire is impressive: a sermon wrongly attributed to Augustine, Alexander of Hales' Sum of Theology, Bartholomew the Englishman's treatise On the Properties of Things, Aquinas' Opuscula, and the Lenten Sermons of Musso. ${ }^{32}$

From this moment on, the references diversify. In the draft of a sermon delivered on 8 March 1612 in Galata, Loukaris quotes Zanchi's views on reprobation and predestination, as expressed in the treatise On the Nature of God..$^{33}$ The letter sent on 22 September 1613 to the Dutch Remonstrant minister Johannes Wtenbogaert contrasts briefly but aptly the opinions of Jerome, Augustine, and Jacobus Arminius († 1609) on the procession of the Holy Spirit. ${ }^{34}$ The 1617-1619 correspondence with the Leiden-educated Dutch merchant David de Wilhem abounds in references to Protestant books. ${ }^{35}$ Loukaris sent his friend Crusius' Turcograecia, the description of Pierre Bellon's travels in the Levant, a life of St George by Laurentius Surius, an annotated copy of Bellarmino's Christian Doctrine, the sixth volume of Baronio's Ecclesiastical Annals, Meletios Pigas' treatise Against the Jews, and an 'elegant' Italian tract against the Jesuits. ${ }^{36}$ David gave Kyrillos the Acts of the 1611 Hague Conference between the Remonstrants and the Contra-Remonstrants, the 1596 treatise On the Idolatry of the Roman Church by the English Puritan John Rainolds, the 1610 Anti-Bellarminus of the Remonstrant Conradus Vorstius, the works of the 'Lutheran' theologian Leonhard Hutter († 1616), those of the Contra-Remonstrant Franciscus Gomarus ( +1641 ), and the 1563 Heidelberg Catechism. ${ }^{37}$ According to

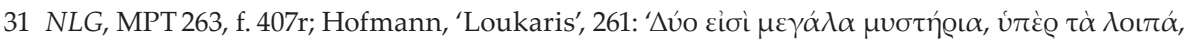

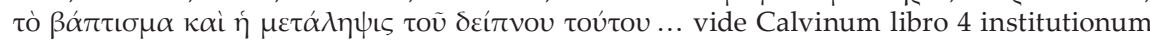
capitulum 18 sectio $19^{\prime}$.

32 NLG, MPT 263, f. 402r, 404r-v, 405r-v, 406r, 407r; Hofmann, 'Loukaris', 253, 255-8.

33 NLG, MPT 262, f. 546r; Hofmann, 'Loukaris', 262.

34 Legrand, Bibliographie hellénique, IV, 295-6 (n. 97). Loukaris says that he received Arminius' Disputationes publicae from Wtenbogaert.

35 UBL, Bibliotheca Publica Latina [= BPL] 26B, f. 5-36; Legrand, Bibliographie hellénique, IV, $313-$

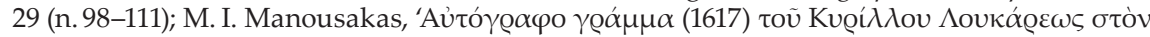

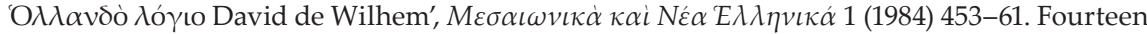
of the letters were recently translated into modern Greek by G. M. Liantas, O П $\alpha \tau \rho \alpha \dot{\alpha} \rho \chi \eta \varsigma$

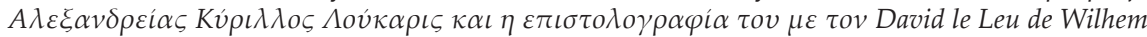

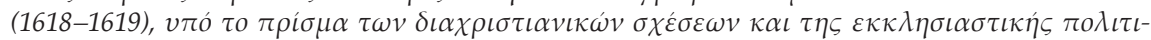
$\kappa \dot{\zeta} \varsigma$ (Thessaloniki 2019).

36 For the annotated catechism, see K. Rozemond, Notes marginales de Cyrille Lucar dans un exemplaire du Grand Catéchisme de Bellarmin (The Hague 1963).

37 We do not know if the Patriarch received the book by King James mentioned on 30 May 1619. 
the patriarch, Rainolds' opinion was correct, the anonymous refutation of Lipsius' treatise on the miracles worked in Halle by a statue of the Virgin with Child was 'very elegant', 38 the dispute between the partisans of Arminius and their adversaries was hard to evaluate, and the assertions of the Heidelberg theologians were 'most-pious and Christian'. On the contrary, the doctrine of the Alkmaar minister Adolphus Tectander Venator ( +1618 ) was 'pestilential'. ${ }^{9}$

Intellectual curiosity left apart-'nil ambio, nil sitio nisi ut semper aliquid discam $^{\prime 40}$-, Loukaris was driven by the desire to reform his superstition-afflicted Church. 'Io se puotesse reformare la mia chiesa lo farei molto volentieri', declared the patriarch with full awareness that the project was unlikely. ${ }^{41} \mathrm{He}$ understood the process as a 'renovation' and 'restitution', not as a conversion; the letters to de Wilhem and a letter to Marc'Antonio de Dominis from September 1618 confirm it. ${ }^{42}$ Still, given this pronounced interest in Protestant theology and the talk about reform, one may understand rather easily how an English traveller to Egypt like George Sandys could have taken Loukaris for 'a friend to the reformed religion'. ${ }^{43}$ Both friends - the British ambassador Sir Thomas Roe-and foes-the French ambassador de Césy-shared the belief that the patriarch was a 'direct' Calvinist, and this all the more so as Loukaris continued the quest for Protestant books. In January 1626, for example, he asked Mitrofanis Kritopoulos, whom he had sent to England to study theology, to procure him books by Johann Wigand († 1587), Hutter and others; the patriarch already had the Lutheran Formula of Concord. ${ }^{44}$

Seizing the opportunity-Loukaris was a particularly precious political commodity-the Dutch resident to Constantinople Cornelis Haga tried immediately to fuel the patriarch's intellectual interests. As early as 1612, at Haga's suggestion,

38 Petrus Denaisius, Dissertatio de idolo Hallensi ... (Heidelberg 1605). It was a reaction to Justus Lipsius' Diva Virgo Hallensi (Antwerp 1604). Loukaris thought Lipsius died as Protestant, until de Wilhem proved him wrong.

39 The book in question was probably: Adolphus Tectander Venator (de Jager), Theologia vera et mera lactentium et infantium in Christo (publ. widow of Jacob de Meester, Alkmaar 1617).

40 Legrand, Bibliographie hellénique, IV, 314.

41 Ibid., 326.

42 Ibid., 329-40 (n. 112). De Dominis had sent to Loukaris the first volume of his De Republica ecclesiastica (publ. John Bill, London 1617), which the Patriarch found to his liking. For details, see Olar, La boutique de Théophile, 116-24.

43 G. Sandys, A Relation of a Iourney [sic] begun An: Dom: 1610 ... (London 1615) 115; O. V. Volkoff (ed.), Voyages en Egypte des années 1611 et 1612. George Sandys-William Lithgow (Cairo 1973) 90 [110].

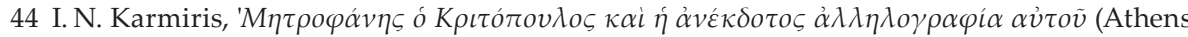
1937) 180-181: Est quidem Doctor nomine Johannes Wigandus, is integrum novum Testamentum cum summariis singulorum capitum in unum congessit volumen. Hunc librum olim semel vidi in manibus cuiusdam Germani. Titulum eiusdem libri oblitus sum. Tu inquire et cum inveneris, mihi eme. Quot e Germanis libros habeo mecum, sunt hi: Concordiam, Chemnitii opera; Huteri si poteris et aliorum Doctorum scripta mihi emere, gratissimum mihi facies [...]'. With regards to Wigand, Loukaris might refer to his $\Sigma \hat{v} v \tau \alpha \gamma \mu \alpha$ (publ. Johannes Oporinus, Basel 1558); Concordia. Pia et unanimi consensu repetita Confessio fidei E doctrinae Electorum, Principum, et Ordinum Imperii ... had been published in Leipzig, in 1584. 
the Dutch States-General sent to Loukaris 'diverse unbound books'. In addition to editions of Greek and Latin Church Fathers such as Basil, Origen, Cyril of Alexandria, Tertullian, Clement of Alexandria, Isidore of Seville, Epiphanius of Salamis, Hilary of Poitiers, and Gregory of Nazianzus, the patriarch received a copy of the 1597 Greek Bible edited by François du Jon (Franciscus Junius). He also received the works of major Protestant theologians; in addition to Calvin and Zanchi, who Loukaris already knew, one may find Philip Melanchton († 1560), Wolfgang Musculus († 1563), Hemmingsen, Peter Martyr Vermigli († 1562), David Pareus († 1622) and William Perkins († 1602). Even if one judges by names and titles only-for example, the Loci communes by Melanchton, Musculus and Martyr-the selection criterion is easily discernible: the patriarch was offered a selective fundamental bibliography of 'classical' and 'protestant' Christian theology.

Opera Melanthonis (32.10); Zanchi's books (25.00); Loci communes Musculi (4.10); Hemmingii opuscula theologica (10.10); Loci communes Martiris (7.15); Pareus' books (14.50); Theologica Perkinsii (8.00); Opera Baselii (13.00); Opera Origines (15.00); Opera Cirilli (13.10); Opera Tertulliani (13.10); Opera Clementis Alexandrini (10.00); Opera S. Isidori (10.10); Opera Epiphanii (5.10); Opera Hilarii (5.10); Opera Nasianseni (8.00); Biblia Graeca Junii (12.00); Eleven books of Calvin in folio (45.00); Marcator's Atlas bound in red velvet and tooled in gold (96.00). Total: $350.00 .{ }^{45}$

Once Loukaris became Patriarch of Constantinople, in November 1620, Cornelis Haga redoubled his efforts to bring him and his Church closer to the Reformation. In 1627, he even convinced the Genevan Company of Pastors to send to the Ottoman capital a minister with a good knowledge of Greek, Hebrew, and Italian capable of taking advantage of Loukaris' alleged Calvinism. In September 1628, Antoine Léger landed on the shores of Bosporus. ${ }^{46}$

45 K. Heeringa (ed.), Bronnen tot de geschiedenis van den Levantschen handel, I/1. 1590-1610 (The Hague 1910) 271. The expensive Gerardus Mercator's Atlas and two globes (terrestrial and celestial) by Willem Jansen Blaeu were most probably a gift for the Sultan. Loukaris will receive two globes from David de Wilhem (Legrand, Bibliographie hellénique, IV, 329).

46 S. Baud-Bovy, 'Antoine Léger, pasteur aux vallées vaudoises du Piémont et son séjour à Constantinople. D'après une correspondance inédite 1622-1631', Revue d'histoire suisse 24/2 (1944) 193-219; A. de Lange, 'Antoine Léger, un "internazionalista" calvinista del Seicento', Bollettino della Società di Studi Valdesi 181 (1997) [S. Peyronel-Rambaldi (ed.), Circolazione di uomini e dell'idee tra Italia ed Europa nell'età della Controriforma] 203-32; A. de Lange, 'De Waldenzenpredikant Antoine Léger en de patriarch Cyrillus Lukaris. Calvinisme en Griekse orthodoxie in de eerste helft van de zeventiende eeuw', Documentatieblad voor de Geschiedenis van de Nederlandse Zending en Overzeese Kerken 6/1 (1999) 1-19; A. de Lange, 'Antoine Léger (1596-1661). Das Leben eines Waldenserpfarrers zwischen Konstantinopel und Genf', in A. Flick and A. de Lange (eds), Von Berlin bis Konstantinopel. Eine Aufsatzsammlung zur Geschichte der Hugenotten und Waldenser (Bad Karlshafen 2001) 119-67; A. de Lange, 'Il ruolo del pastore calvinista Antoine Léger nella genesi e redazione della confessione di fede del patriarca ortodosso Cirillo Loukaris (1629-1633)', in V. Nosilia and M. Prandoni (eds), Trame controluce. Il patriarca 'protestante' Cirillo Loukaris/Backlighting Plots. The 'Protestant' Patriarch Cyril Loukaris (Florence 2015) 119-34. 


\section{'Nostre bibliothèque publique'}

Until his departure, in August 1636, the minister showed no sign of fatigue. He played a major role in the redaction of Loukaris' famous Confession, ${ }^{47}$ and was also instrumental in bringing about the translation of the New Testament into vernacular Greek. ${ }^{48}$ Several other ventures failed, such as the creation of a Protestant colony in Moldavia. ${ }^{49}$ Still, the range of the plans Léger was in charge of is striking: ${ }^{50}$ establishment in Constantinople of a Reformed school, ${ }^{51}$ writing of a catechism in spoken Greek (something that Loukaris heralded already in March 1618 ${ }^{52}$ ), dissemination of the Belgic Confession in Jacobus Revius' Greek version ${ }^{53}$ and its translation into spoken Greek. ${ }^{54}$

A 'public library' was the backbone of the enterprise. Léger speaks for the first time about it in a letter sent from Venice to Pieter van Brederode, ambassador of the Dutch States General in Basel, in August 1628. Learning from a very disappointed Anthonis Piscator, his predecessor as preacher deserving the chapel of the Dutch embassy in Constantinople, that he would not find any books there,

47 O. Olar, 'Les confessions de foi de Cyrille Loukaris († 1638)', in M.-H. Blanchet and F. Gabriel (eds), L'Union à l'épreuve du formulaire. Professions de foi entre Églises d'Orient et d'Occident (XIIIeXVIIIe siècle) (Louvain-Paris-Bristol 2016) 271-310.

48 O. Olar, '«Un trésor enfoui»: Kyrillos Loukaris et le Nouveau Testament en grec publié à Genève en 1638 à travers les lettres d'Antoine Léger', Cahiers du monde russe 58/3 (2017) [P. Bushkovitch, N. A. Chrissidis and R. G. Păun (eds), Les terres de l'orthodoxie au XVIIe siècle] 341-70. Léger also advocated the translation (and edition) in spoken Greek of the 'premiers rudimens de pieté comme 1'Oraison Dominicale, le symbole de Nicee ordinaire en l'Eglise Grecque avec le Decalogue qui y est presque incognu au peuple'. UBL, BPL 2211C, f. 50-2 (n. 27-Léger to André Rivet, Saint-Jean, 26 March 1638).

49 Baud-Bovy, 'Antoine Léger', 213-5; A. Pippidi, 'Diplomaţie şi ortodoxie: Moldova în proiectele propagandei calvine (1630)', in O. Cristea, P. Zahariuc and G. Lazăr (eds), Aut viam inveniam aut faciam. In honorem Ştefan Andreescu (Iaşi 2012) 349-66.

50 G. Hering, Ökumenisches Patriarchat und europäische Politik 1620-1638 (Wiesbaden 1968) $176 \mathrm{ff}$.

51 Legrand, Bibliographie hellénique, IV, 380-2 (n. 133-Léger to the Genevan Company of Pastors, 21/31 March 1629), 382-4 (n. 134-Haga to the Genevan Company of Pastors, 12 Mai 1629), 393-7 (n. 139-the Haarlem pastor Daniel Souterius to Léger, 18 September 1630).

52 Ibid., 325.

53 V. Tsakiris, "The "Ecclesiarum Belgicarum Confessio" and the Attempted "Calvinisation" of the Orthodox Church under Patriarch Cyril Loukaris', The Journal of Ecclesiastical History 63/3

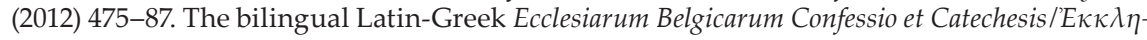

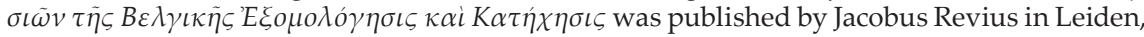
in 1623; it included the Heidelberg Catechism in Sylburg's 1567 translation and the Belgic Confession in Revius' rendition. In 1627, Festus Hommius sent a copy to Loukaris, who 'liked it very much.' BSB, Cam. 9 [Clm. 10359], n. 219; S. A. Gabbema (ed.), Illustrium et clarorum virorum epistolae ... selectiores ... (Harlingen am Wattenmeer 1669) 755-8. The 1627 revised edition was reedited several times.

54 Bibliothèque de Genève [= BGE], Ami Lullin 54, n. 64 (Léger to Bénédict Turrettini, 7/17 February 1629); Staatsarchiv des Kantons Zürich [= StAZH], E_II_389, p.465-7 (Léger to Johann Jakob Breitinger, 12 December 1629). In January 1630, the translation was ready. BGE, Ami Lullin 54, n. 78 (Léger to Turrettini), 80 (Léger to Turrettini, 20/30 March 1630); UBL, BPL 2211C, f. 6-7 (Léger to André Rivet, 12 August 1630). Once returned at home, Léger disclosed the identity of one of the translators: Philippos of Cyprus. Ibid., f. 50-1, 52v. 
Léger decided to buy 'quelques-uns des plus utiles, où moins mauvais' available on the market. With the help of Volkerus van Oosterwyck, chaplain of the Dutch ambassador in Venice, and Daniel Nijs, Dutch merchant, collector, and art dealer living in Venice, he managed to amass some thirty volumes. Hopefully, wrote Léger, the books could constitute 'un petit commencement de Bibliothèque stable pour l'usage des pasteurs et de l'Eglise, que Messeigneurs les Estats nourrissent et protègent en la maison de Monsieur Leur Ambassadeur à Constantinople..55

Did Léger take the Bodleian library as model? We cannot tell for sure, as it was hardly a match: inaugurated in 1602, the Bodleian already counted thousands of manuscripts and printed books. Nevertheless, its ground breaking 1620 catalogue, which was intended to serve as example for both libraries and museums, sits among the items bought in Venice. ${ }^{56}$ Camillo Camilli's additional five cantos to Tasso's epic Jerusalem Delivered also made the list-did Léger fancy himself as a crusader ${ }^{27}$ Whatever the case, he did try to procure everything that could facilitate his mission.

First are the Bibles-one in Hebrew and one in Greek-, the alphabetical list of words in the Vulgate by Franciscus Lucas of Bruges, and Johannes Ferus' comments on the Gospel of St Matthew. ${ }^{58}$ Liturgical books follow-a Greek Orologion and the Roman breviary-, with an Eirmologion coming up several entries later. Yet the core consists of reference works in all shape and sizes: Domenico Nani Mirabelli's Polyanthea in Josephus Langius' revision; ${ }^{59}$ Guillaume Budé's seminal Commentaries on the Greek Language and Passage from Hellenism to Christianity; ${ }^{60}$ a Greek-Latin Dictionary; $; 1$ Ambrogio Teseo's Introduction to the Chaldean Language, Syriac, and Armenian, and Ten Other Tongues; ${ }^{62}$ Johannes Meursius' glossary of Byzantine Greek, ${ }^{63}$ the often expanded collection of Church councils compiled by Bar-

55 BGE, Ami Lullin 54, n. 55. The letter to van Brederode (in copy) includes the list of the books, with their price (174.9 livres).

56 Thomas James, Catalogus universalis librorum in Bibliotheca Bodleiana omnium librorum, linguarum, E scientiarum genere refertissimâ, sic compositus; ut non solum publicis per Europam universam bibliothecis, sed etiam privatis musaeis, alijsque ad catalogum librorum conficiendum usui esse possit (publ. John Lichfield and Jacob Short, Oxford 1620).

57 Camillo Camilli, I cinque canti ... aggiunti al Goffredo del signor Torquato Tasso (publ. Francesco de Franceschi, Venice 1583).

58 Franciscus Lucas, Concordantiae bibliorum sacrorum Vulgatae editionis ... (publ. Balthasar and Jan Moretus, Antwerp 1617); Johannes Ferus, In sacrosanctum Iesu Christi evangelium secundum Matthaeum (publ. Giacomo Piccaglia and Giovanni Maria Leni, Venice 1568).

59 A. M. Blair, Too Much to Know. Managing Scholarly Information before the Modern Age (New Haven 2010) 125-6, 174-88.

60 Guillaume Budé, Commentarii Linguae Graecae (publ. Jodocus Badius, Paris 1529; publ. Robert Estienne, Paris 1548); Guillaume Budé, De transitu Hellenismi ad Christianismum (publ. Robert Estienne, Paris 1534).

61 Johannes Scapula (ed.), Lexicon Graecolatinum (publ. Sebastian Henricpetri, Basel 1579).

62 Teseo Ambrogio degli Albonesi, Introductio in Chaldaicam linguam, Syriacam, atque Armenicam, $\mathcal{E}$ decem alias linguas (publ. Giovanni Maria Simoneta, Pavia 1539).

63 Johannes Meursius, Glossarium graeco-barbarum (publ. Lodewijk Elzevir, Leiden 1614). 
tolomé Carranza de Miranda, future Archbishop of Toledo; ${ }^{64}$ Ambrogio Calepino's best-selling Dictionary; ${ }^{65}$ and Giovanni Botero's Universal Relations. ${ }^{66}$

The intentionality of diversity is equally manifest in the selection of theological works. The 1618 bilingual Greek-Latin edition of Basil of Caesarea and Gavriil of Philadelphia's treatise On the Mysteries represent Eastern Christianity. ${ }^{67}$ Martin Bucer's On the Kingdom of Christ, the bilingual edition of the Heidelberg Catechism and Belgic Confession, Theodore de Bèze's Confession of faith, Martin Chemnitz's Examination of the Council of Trent, Johann Heinrich Alsted's Chronology, and Konrad Dieterich's Dominicalia stand for the Evangelic and Reformed traditions. ${ }^{68}$ As for Catholicism, it is represented-quite randomly-by the Augsburg bilingual Latin-Greek edition of Thomas de Kempis' Imitation of Christ, the first volume of Louis de Granada's Sermons, the Index of prohibited books, and an edition of papal indulgences granted by Sixt V to the Arch-confraternity of the Cord of St Francis. ${ }^{69}$

Léger knew that the selection was far from perfect: some of the books he wanted-for example, Crusius' Turcograecia ${ }^{70}$-were nowhere to be found; others required additional funding. Upon arrival in Constantinople, with the financial support of the States-General and the help of his former professors Bénédict Turrettini (Geneva) and André Rivet (Leiden), the minister pursued relentlessly the goal of obtaining the 'most useful and necessary' books for 'our public library'..$^{71}$ As the Venice route was slow, he proposed an alternative option, which passed through Lyon and Marseille. ${ }^{72}$

64 Published in Venice, in 1546, Bartolomé Carranza de Miranda's Summa conciliorum et pontificum à Petro usque ad Paulum tertium was constantly enlarged until the current pope; it is difficult to identify the edition to which Léger refers.

65 Blair, Too Much to Know, 48, 122-3, 129-30, 178.

66 Giovanni Botero, Le relazioni universali, 2 vols, ed. B. A. Ravioli (Torino 2015).

67 Basil of Caesarea, Opera omnia, quae reperiri potuerunt, ed. Fronton du Duc and Frédéric Morel

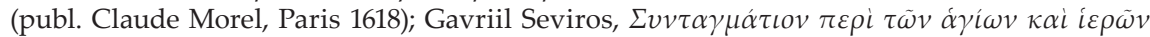
$\mu v \sigma \tau \eta \rho i \omega v$ (publ. Giovanni Antonio Pinelli, Venice 1600).

68 Martin Bucer, De regno Christi Jesu servatoris nostri (publ. Johannes Oporinus, Basel [1557]); Theodore de Bèze, Confessio Christianae fidei, et ejusdem collatio cum papisticis haeresibus (publ. Jean Bonnefoy, Geneva 1560); Martin Chemnitz, Examen Concilii Tridentini, 4 vols (Frankfurt a.M. 1565-1573); Johann Heinrich Alsted, Thesaurus chronologiae (Herborn 1624; Herborn 1628). The Lutheran theologian Konrad Dieterich († 1639) is also known as Cunrad Theodoric; Dominicalia might refer to K. Dieterich, Analysis logica evangeliorum dominicalium ... Pars aestivalis (publ. Nikolaus Hampel, Gießen 1613); ... Pars hyemalis (publ. Nikolaus Hampel, Gießen 1615).

69 Thomas à Kempis, De imitatione Christi Latino-Graecus, ed. Georg Mayr ('typis S. Nicolai', Augsburg 1615); Louis de Granada, Primus tomus Concionum ... (publ. João da Barreira, Lisbon 1573); Bernardo de Sandoval y Rojas, Index librorum prohibitorum et expurgatorum (publ. Jacques Crispin, Geneva: 1619-with a foreword by Bénédict Turrettini). For the Sommario delle indulgenze concesse da Sisto, Léger might have bought the 1599 Mondovì edition (publ. Giovanni Vincenzo Cavalleri).

70 BGE, Ami Lullin 54, n. 70 (Léger to Turrettini, 20 July 1629); Baud-Bovy, 'Antoine Léger', 201.

71 UBL, BPL 2211C, f. 4 (Léger to Rivet, 15/25 December 1628); BGE, Ami Lullin 54, n. 68 (Léger to Turrettini, 2/12 May 1629).

72 Léger to Turrettini: Ibid., n. 63 (7/17 February 1629), 68 (2/12 May 1629), 70 (20 July 1629), 78 (18/28 January 1630). The contacts were the banquier Laurent Pianello in Lyon, the merchant Jean 
Léger's correspondence provides us with the opportunity to reconstruct in some detail the list of the books demanded from friends and collaborators in Basel, Geneva, Zürich, and Leiden. For Loukaris, the minister requested Johann Jakob Ulrich's dark but sympathetic depiction of 'the religion of the Greek Churches', $; 3$ the patriarch received Jean Diodati's Italian translation of the Bible and requested several copies of Diodati's Italian version of the Psalms. ${ }^{74}$ The Dutch ambassador Cornelis Haga was keen of reading histories ancient and new, from Arrian's Circumnavigation of the Euxine to the chronicles of Manasses, Gregoras, Chalkokondyles, and Akropolites, and from de Thou's History of his own time to Vossius' treatise on Greek historiography. ${ }^{75}$ As for the newborn library, Léger focused on the initial objectives of his mission, but tried to adapt to the ever-shifting context.

'For the edification and propagation of the Church', the minister asked constantly for small-format 'catechisms, prayers, confessions of faith', and other similar 'basics' ('rudimens'), not only in Greek and Italian, but also in Spanish: the use of Spanish was wide spread in the area; moreover, Léger provided spiritual assistance to slaves who used it. ${ }^{76}$ For the 'small' library, the accent was on anti-Roman tracts-such as Paolo Sarpi's History of the Council of Trent ${ }^{77}-$, anti-Jesuit polemics,

Guez in Marseille, and Guillaume Guez in Constantinople. For the Pianellos see R. Chartier, 'L'Académie de Lyon au XVIIIe siècle, 1700-1793, étude de sociologie culturelle', in R. Chartier et al. (eds), Nouvelles études lyonnaises [Histoire et civilisation du livre, 2] (Geneva-Paris 1969) 173-4. The Guez brothers were also part of Nicolas Fabri de Peiresc's communication network: P. N. Miller, Peiresc's Mediterranean World (Harvard 2015) passim.

73 ZB Zürich, Thesaurus Hottingerianus, Ms. F. 44, f. 93 (Léger to Adolphe Hottinger, 4 August 1629); in October 1630, it hadn't arrived (ibid., f. 95v). For the book of Johann Jakob Ulrich, De religione Ecclesiarum Graecanicarum, tum vetere, tum hodierna. Disquisitio theologica \& historica (publ. Johann Rudolph Wolf, Zürich 1621), see E. Bryner, ‘Der Zürcher Theologe Johann Jakob Ulrich und seine Konfessionskunde der griechisch-orthodoxen Kirche von 1621', Kirche im Osten 34 (1991) 9-31.

74 BGE, Ami Lullin 54, n. 94 (Léger to Diodati); BGE, Ms. gr. 37-38* (Loukaris to Diodati, 15/25 April 1632); Legrand, Bibliographie hellénique, IV, 400-6 (n. 143).

75 Léger to Rivet: UBL, BPL 2211C, f. 4 (15/25 December 1628); Léger to Turrettini: BGE, Ami Lullin 54, n. 65 (3 March 1629), 70 (20 July 1629), 71 (5/15 September 1629). The books were: Arrian, Ponti Euxini \& Maris Erythraei Periplus, ed. Johann Wilhelm Stuck (publ. Eustache Vignon, Geneva 1577); Hieronymus Wolf, Konrad Clauser and Theodor van der Does (eds), Historiae Byzantinae scriptores tres Graecolatini (publ. Pierre de la Rovière, Geneva 1615); Constantine Manasses, Annales, Graecè ac Latinè, ed. Joannes Meursius (publ. Jan Paets, Leiden 1616); Jacques-Auguste de Thou, Historiarum sui temporis (published in Paris, in 1604, and reedited several times, including in Geneva); Gerardus Vossius, De Historicis Graecis Libri IV (publ. Joannes Maire, Leiden 1624).

76 Léger to Turrettini: BGE, Ami Lullin 54, n. 59 (13 October 1628), 62 (2 January 1629), 63 (7/17 February 1629), 65 (3 March 1629), 68 (2/12 May 1629); Léger to Rivet: UBL, BPL 2211C, f. 4 (15/25 December 1628).

77 BGE, Ami Lullin 54, n. 65 (Léger to Turrettini, 3 March 1629). Smuggled out of Venice, Sarpi's masterpiece was published in London, in 1619, under the anagram 'Pietro Soave Polano'; the polemical subtitle was the doing of the editor, Marc'Antonio de Dominis. G. Cozzi, 'Fra Paolo Sarpi, l'Anglicanesimo e la Historia del Concilio Tridentino', Rivista Storica Italiana 68/4 (1956) 559-619; W. B. Patterson, King James VI and I and the Reunion of Christendom (Cambridge 1997) 246ff. In 1629, it was reedited in Geneva. G. Bonnant, 'Les éditions genevoises de Paolo Sarpi 
and books which formed the canon of Reformed Orthodoxy. ${ }^{78}$ Yet the printing of Loukaris' Confession-a text originally intended for limited and selective audiences-complicated exponentially an already complicated situation. The projects of the patriarch and of his allies came under even more scrutiny, and the conflict with Rome and its proxies escalated.

Anticipating the hostile reactions, Léger urged his correspondents to supply (at the expense of the States-General) potentially useful books. A letter to Bénédict Turrettini from September 1629 is suggestive to this respect:

Je vous prie de nous envoyer au plus tost de toutes les pièces mises en lumière contre eux [that is, the Jesuits], leur Mercure, leur histoire Hospiniana et Luciana, ${ }^{79}$ et de l'histoire delle cose passate tra Paolo V et la serenissima Republica aucunes copies, qui sont d'autant plus de saison à cause de la querelle touchant l'Evesché de Padoue, donné au fils de Duc contre les loix de la République, et encore deux ou trois de la Doctrine et Pratique Romaine en la déposition des Rois $^{80}$ etc., quelque nombre di Relazioni della Religione, ${ }^{81}$ le Turcograecia de Crusius, l'Histoire des Martyrs, ${ }^{82}$ Histoire des Vaudois ${ }^{83}$ et de toutes les bonnes pièces faites pour la conversion des Juifs, entr'autres les livres de Plessis, ${ }^{84}$ Grossius et Christianus Gerson et celui de Raymond de Sebonde, s'il est imprimé tel qu'il la laissé. ${ }^{85}$ En outre Liturgia Anglicana Latinè aut Gallicè et plus grand nombre des petits livrets Italiens acheminés en

au XVIIe et au XVIIIe siècle', in L. Monnier (ed.), Genève et l'Italie (Geneva 1969) 201-28; M. Viallon, 'Les éditions de l'Histoire du Concile de Trente de Paolo Sarpi', in D. Montoliou (ed.), Le livre italien hors d'Italie au XVIIe siècle (Toulouse 2011) 73-90. In May 1629, Léger also requests Paolo Sarpi's Historia particolare delle cose passate tra'l Sommo Pontefice Paolo V e la Serenissima Republica di Venetia (Geneva 1624). BGE, Ami Lullin 54, n. 68.

78 In December 1628, Léger asks André Rivet for his Sommaire et abrégé des controverses de nostre temps touchant la Religion (La Rochelle 1608) and the Criticus sacer (Heidelberg 1612): UBL, BPL 2211C, f. 4. Since February 1629, he constantly requests from Turrettini the [Jacques Godefroy (ed.)], Le Mercure Iesuite: ou Recueil des pieces, concernants le progrés des Iesuites, leurs Escrits $\mathcal{E}$ Differents ... (publ. Pierre Aubert, Geneva 1626). BGE, Ami Lullin 54, n. 63, 65, 68, 70.

79 Rudolf Hospinian, Historia iesuitica ... (publ. Johann Rudolph Wolf, Zürich 1619); Ludovicus Lucius, Historia Jesuitica ... (publ. Johann Jakob Genath, Basel 1627).

80 Recueil des pieces concernants la doctrine romaine touchant la deposition des Rois $\mathcal{E}$ Princes par le Pape ... (publ. Pierre Chouet, Geneva 1627) - collection attributed to Bénédict Turrettini.

81 Relatione dello stato della religione ... ([publ. Pierre Aubert, Geneva] 1625) - Italian version of Sir Edwin Sandys' 1605 Relation of the State of Religion, with notes by Paolo Sarpi.

82 See also BGE, Ami Lullin 54, n. 70.

83 Jean-Paul Perrin, Histoire des Vaudois (publ. Pierre and Jacques Chouët, Geneva 1619); Léger bought it in Geneva. See also BGE, Ami Lullin 54, n. 70.

84 Philippe de Mornay had written an Advertissement aux Juifs sur la venue du Messie (publ. Thomas Portau, Saumur 1607), but Léger might refer to de Mornay, De veritate religionis Christianae ... (publ. Christophe Plantin, Antwerp 1583). In July 1629, the minister had also requested de Mornay's Mysterium iniquitatis seu, Historia Papatus ... (publ. Thomas Portau, Saumur 1611). BGE, Ami Lullin 54, n. 70.

85 Christian Gerson, Der Jüden Thalmud (publ. Vogt, Goßlar 1607). 'Raymond de Sebonde' is Ramón Martí; Léger probably knew that the Basel Hebraist Johannes Buxtorf had a manuscript copy of the anti-Jewish Pugio fidei. For the plans to edit the text, see S. G. Burnett, From 
la balle qu'entendons estre à Smirne, Criticus Riveti ${ }^{86}$ Cocus et Jamesius de Corruptione Patrum, ${ }^{87}$ Historia del Concilio Tridentino, Ochino del Purgatorio, ${ }^{88}$ Taxe de la Chancellerie et Ponitentia, ${ }^{89}$ Catechesis Graecolatina, Synagoga Judai$c a{ }^{90}$ Préjugés de Cameron. ${ }^{91} \mathrm{Il}$ seroit bon aussi que nous essions un choix de quelques passages des Pères Grecs les plus formels pour confirmer la dite

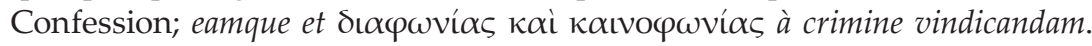
J'en ay quelque nombre, mais si vous en remontrez quelqu'un fort exprès, je vous prie de nous l'indiquer. Et si voyez que l'orthodoxus consensus symphonia Polani, ${ }^{92}$ Vogelius, ${ }^{93}$ ou autre tel recueil contiene quelque chose à propos sur ces matières, je remets à vostre prudence de l'adjouster aux autres si elle le trouve bon. ${ }^{.94}$

The list included many anti-Jesuit tracts: the missionaries of the Society of Jesus were long-term enemies of Loukaris. The patriarch had them expelled from Constantinople in early 1628 , but the suppression of the mission had been temporary. ${ }^{95}$ Given the animosity, fuelled by Léger's arrival, all books depicting the Jesuits in strong colours came in handy. There were also authors-Sarpi, for example, whose

Christian Hebraism to Jewish Studies. Johannes Buxtorf (1564-1629) and Hebrew Learning in the Seventeenth Century (Leiden-New York-Köln 1996) 95-8.

86 Probably the 1626 revised edition: André Rivet, Criticus sacer (publ. Pierre Chouët, Geneva 1626). See also supra, footnote 78.

87 Thomas James, A Treatise of the Corruption of Scripture, Councels, and Fathers ... (publ. Humphrey Lownes, London 1611); Robert Cooke, Censura quorundam scriptorum, quae sub nominibus sanctorum $\mathcal{E}$ veterum auctorum, à Pontificijs passim in eorum scriptis ... citari solent (publ. William Barret, London 1614).

88 Bernardino Ochino, Dialogo del Purgatorio ([publ. Andreas and Jakob Gessner, Zürich] 1556).

89 Taxae cancellariae apostolicae et taxae sacrae penitentiariae apostolicae, with several editions and translations.

90 Johannes Buxtorf, Synagoga Judaica (publ. Wilhelm Anton, Hanau 1604). Léger also requested Johannes Buxtorf, De Abbreviaturis Hebraicis (publ. Konrad Waldkirch and Ludwig König, Basel 1613). BGE, Ami Lullin 54, n. 70.

91 John Cameron, Traicte auquel sont examinez les prejugez de ceux de l'Eglise Romaine, contre la Religion Reformee (publ. Jean Hebert, La Rochelle 1617). See also BGE, Ami Lullin 54, n. 70.

92 Amandus Polanus von Polansdorf, Symphonia Catholica seu Consensus Catholicus et Orthodoxus dogmarum hodiernae Ecclesiae... (publ. Conrad Waldkirch, Basel 1607).

93 Matthäus Vogel, Tesaurus theologicus ... (publ. Georg Gruppenbach, Tübingen 1592).

94 BGE, Ami Lullin 54, n. 71; see also ibid., n. 73 (12 October 1629). In November 1629 (ibid., n. 75), Léger asks again for books, such as Bénédict Turrettini's Sei homilie sopra le parole di Iesu Christo, Luc. XII. v. 5. 6. etc. Non temiate coloro che possono ucidere il corpo ... (publ. Pierre Aubert, Geneva 1623); some of Peter Martyr Vermigli's works; Johann Heinrich Alsted's De manducatione spirituali, transsubstantiatione, sacrificio missae dissertatio. De Ecclesia eiúsque partibus E proprietatibus tractatus adversus Bellarmini, et Becani, E aliorum Pontificiorum errores ... (publ. Matthieu Berjon, Geneva 1630); the [Anonymous], Sommario della religione Christiana (ante 1598), permanently recorded in the Index; and Pierre du Moulin's Bouclier de la foy, ou Defense de la Confession de foy des Eglises reformees du Royaume de France ... (publ. Pierre Aubert, Geneva 1630).

95 A. Ruiu, 'Conflicting Visions of the Jesuit Missions to the Ottoman Empire, 1609-1628', Journal of Jesuit Studies 1/2 (2014) 260-80. 
History Loukaris had received from Sir Thomas Roe ${ }^{96}-$, who expressed critical views of Rome's practices. Jean Crespin's History of the Martyrs depicted the members of the Reformed Church as true Christians ready to give their life for the 'True Church. ${ }^{97}$ As for the Reformed patristic guides, they provided an alternative to the vitiated Catholic canon of Councils and Fathers. ${ }^{98}$ Endorsing Loukaris' Confession of faith, the manuals of Scultetus, Polanus, and Rivet might have motivated his co-religionists to read the unadulterated Scriptures and the 'true' founding theologians, while helping them sort the authentic texts from the falsely attributed and corrupted ones. ${ }^{99}$

In April 1630, Turrettini sent some of the requested volumes: the Byzantine historians and Arrian's Circumnavigation for Haga, Alsted's Treatise on the Church, Sarpi's History of the Council of Trent (two copies), and two anti-Jesuit tracts. ${ }^{100}$ A couple of months later, the books from the Netherlands arrived: the library had finally taken shape. ${ }^{101}$

\section{'Non Africa sola monstrorum ferax ...' ${ }^{102}$}

How exactly were the books used? An answer to this question is certainly not easy to provide. Nevertheless, some points can be made. First, we know that the translator of the New Testament in 'simple' Greek, Maximos Rodios of Kallipoli, lodged with the Dutch ambassador for the entire duration of the translation process; we also know that he chose Diodati's Italian version of the Bible as model for his own work. ${ }^{103}$ The library assembled by Léger, which included biblical materials and

96 British National Archives [= NA], SP 97/11, f. 115r (Loukaris to Roe, 14/24 October 1625).

97 J. Tucker, The Construction of Reformed Identity in Jean Crespin's Livre des Martyrs (London 2017).

98 For an overview, see I. Backus, 'Reformed Orthodoxy and Patristic Tradition', in H. J. Selderhuis (ed.), A Companion to Reformed Orthodoxy (Leiden-Boston 2013) 91-117.

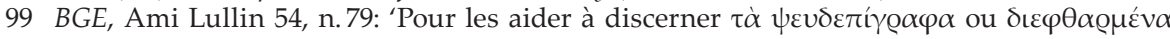
nous aurions besoin du Criticus de Rivet, de Cocus et Jamesius et de la Medulla Patrum de Scultet, et de Bellarmin de scriptoribus de l'impression de Cardon 1613 ou autre, s'il y en a quelqu'une meilleure' (Léger to Turrettini, 6/16 February 1630). The letter introduces Abraham Scultetus, Medulla theologiae Patrum ..., 4 vols (publ. Michael Forster, Amberg 15981613) and, as negative example, Roberto Bellarmino, De scriptoribus ecclesiasticis ... (publ. Horace Cardon, Leiden 1613).

100 BGE, Ami Lullin 54, n. 97bis (total cost 39.6 livres). The anti-Jesuit tracts are du Moulin's Bouclier de la foy and Godefroy's Le Mercure Iesuite. The package was delivered by Paul Viet, in October. Ibid., n. 89, 90.

101 Ibid., n. 85 (Léger to Turrettini, 5/15 June 1630); UBL, BPL 2211C, f. 6-7 (Léger to Rivet, 12 August 1630).

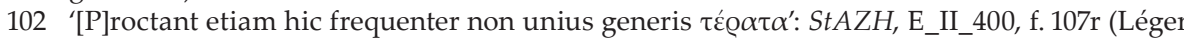
to Breitinger, 5 April 1633). See also BGE, Ami Lullin 54, n. 73 (Léger to Turrettini, 12 October 1629).

103 Ibid., n. 70 (Léger to Turrettini, 20 July 1629); Baud-Bovy, 'Antoine Léger', 207-8; K. Papoulidis, Problèmes de traduction et d'interprétation du Nouveau Testament en grec moderne: le cas de Maxime de Gallipoli (1638) (Thessaloniki 2004) 43-4, 99-103, 110-1. 
dictionaries, might have been helpful, at least during the revision phase (March 1630-1633). ${ }^{104}$

Furthermore, as the publication of Loukaris' Confession stirred up strong emotions all across Europe, Léger compiled a brief patristic florilegium in support of the allegations made by the patriarch in his concise text. We saw him displaying his intentions to Turrettini and demanding books which could facilitate the task. As the minister finished the compilation-in December 1631, he sent it to Loukaris $^{105}$-, it is safe to assume that the request was received favourably.

The same can be said about the demands for the Greek version of Jacques Cappel's Catechism. ${ }^{106}$ Initially, Léger asked for copies because he thought they could introduce to the Greek-speaking Christians the Reformed confession in its 1559 French form; for example, he offers one to the Patriarch Theofanis of Jerusalem. ${ }^{107}$ When he lost his hope that Loukaris will write a Protestant catechism in spoken language, the minister started to look for 'locals' able to do it. As Léger intended to provide them 'a part of the materials', catechisms such as the ones by Calvin and Cappel were needed. ${ }^{108}$ The plan seems to have worked: a catechism in spoken Greek was produced, 'mostly based on the one by Cappel'. ${ }^{109}$

The focus on confessions and catechisms brings however to light an unintentional but paramount flaw of the library: the lack of an 'Eastern' audience. Léger requires persistently catechisms and confessions of faith. ${ }^{110} \mathrm{He}$ offers left and right printed and even manuscript copies (crafted on spot) of the Greek version of the Heidelberg Catechism and of the Belgic Confession-for example, to the 'doctor-philosopher' Georgios Koressios of Chios-; he advocates a translation of the Belgic Confession into spoken Greek and its publication; once this translation is finished, he disseminates manuscript copies. ${ }^{111}$ This acute sense of urgency was fuelled by

104 In July 1629, Léger speaks about adding scholia containing the opinions of the Church Fathers 'que nous pouvons trouver ici'. BGE, Ami Lullin 54, n. 70.

105 Legrand, Bibliographie hellénique, IV, 397-8 (n. 140).

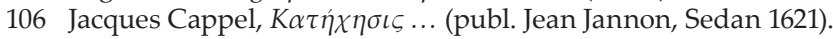

107 UBL, BPL 2211C, f. 9-10 (Léger to Rivet, 23 December 1631).

108 Léger to Turrettini: BGE, Ami Lullin 54, n. 77 (12/22 December 1629), 78 (18/28 January 1630), 80 (20/30 March 1630). Calvin's Catechism had been translated into Greek by Henri Estienne, first from French (1551), then from Latin (1563): J. Calvin, $\Sigma \tau o \iota \chi \varepsilon i \omega \sigma \iota \varsigma \tau \tilde{\eta} \varsigma$ X $\iota \iota \tau \iota \alpha v \tilde{\omega} v$

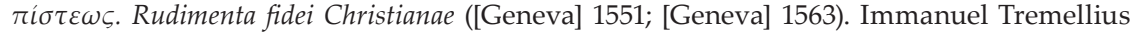
translated it into Hebrew; a Hebrew-Greek edition was published in 1551 and a trilingual Hebrew-Greek-Latin one in 1591. It is important to note that Luther's Small Catechism, althought available in Greek, in bilingual and multilingual editions, is not mentioned.

109 Léger to Rivet: UBL, BPL 2211C, f. 56 (2 July 1640), 57-8 (31 May 1641), 71-2 (28 April 1646).

110 Supra, footnote 76. See also BGE, Ami Lullin 54, n. 73 (Léger to Turrettini, 12 October 1629), 77. Léger also asked Turrettini to send copies of the catechism by Agostino Grosso. Ibid., n. 63,75 .

111 Léger to Turrettini: Ibid., n. 70 (20 July 1629), 80 (20/30 March 1630), 89 (12 October 1630); UBL, BPL 2211C, f. 6-7 (Léger to Rivet, 12 August 1630); StAZH, E_II_395, p. 137-8 (Léger to Breitinger, 30 November 1630). In the summer of 1630, Léger receives from the Netherlands two hundred copies of Revius' 1627 Greek edition of the Confessio Belgica. BGE, Ami Lullin 54, n. 88. For details on the dissemination, see Tsakiris, 'The "Ecclesiarum Belgicarum Confessio".' 
the intensification of Roman missionary activities in the Levant. In December 1631, Léger warned Rivet that the new French ambassador-de Marcheville ${ }^{112}$-brought to Constantinople copies of a newly Paris-printed catechism in spoken Greek and Italian. ${ }^{113}$ In the same letter, he informed his correspondent that a printing press had just been installed in the French embassy. ${ }^{114}$ But this was just a side of the coin. The other side is Léger's certainty that Christianity was in great danger in the East.

The words used by the minister to depict the state of the Greek Church are indicative of his mindset: 'ténèbres', 'barbarie', 'ignorance', 'superstition', 'abus', 'monstres'.115 Léger saw himself at the heart of a combat between light and darkness, good and evil, right and wrong. In this scenario, unrestricted access to the 'pure' Word of God and education played a vital role. The Eastern Christians were 'sick'. They had no use for sophisticated theological tracts. Proper remedies were needed: translations of the 'basics' and catechisms.

The double standard becomes obvious when we compare the cases of the two named users of the Protestant 'public library'. The first is a certain Nicolas Melchior Dominic, who was in the service of the Venetian bailo. After several discussions which excited the curiosity of his dialogue partner, Léger borrowed him books by Peter Martyr Vermigli and Calvin, as well as Daniel Chamier's body of controversies against the Roman Church. ${ }^{116}$ The second is 'a person from Ainos', designated

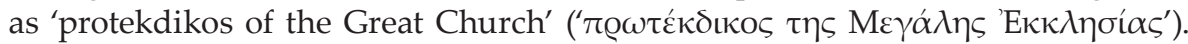
For several months, Léger was in close contact with him. Seeing his interest in Reformed theology and having Cornelis Haga approval, he offered him a copy of the 1627 Greek version of the Belgic Confession, together with other 'confessions, catechisms, and liturgies'. ${ }^{117}$ In short, while the bailo's employee receives theological tracts, the Ainos anonymous only gets the 'basics'.

Léger dismisses the character rather quickly. He does not disclose the nature of their relationship, although he does emphasize his role in convincing the man to write against the doctrine of Purgatory. A couple of particulars show, however,

112 A. Hamilton, “"To Divest the East of all its Manuscripts and all its Rarities”. The Unfortunate Embassy of Henri Gournay de Marcheville', in A. Hamilton, M. H. van den Boogert and B. Westerweel (eds), The Republic of Letters and the Levant (Leiden-Boston 2005) 123-50.

113 UBL, BPL 2211C, f. 9-10 (Léger to Rivet, 23 December 1631). Such a catechism was published in Rome, in 1628. Legrand, Bibliographie hellénique, I, 257 (n. 179). Leonardos Philaras' 1616 translation in spoken Greek of Bellarmino's 'great' catechism was reedited in Paris, in 1633. Ibid., 309-15 (n. 223). For an overview, see N. Papaïliaki-Gamelon, 'Livres de catéchismes et pratiques scolaires des missionaries français en Grèce au XVIIe siècle', in H. Didier and M. Larcher (eds), Pédagogies missionnaires. Traduire Transmettre Transculturer (Paris 2012) 137-46.

114 In 1628, Père Joseph, Richelieu's 'éminence grise', had asked the Congregation de propaganda fide to allow the Capuchins of Constantinople to install a printing press in the French embassy. L. Dedouvres, Le père Joseph polémiste. Ses premiers écrits (1623-1626) (Paris 1895) 447. As far as we know, the request was denied.

115 BGE, Ami Lullin 54, n. 64, 67, 73; UBL, BPL 2211C, f. 9-10.

116 BGE, Ami Lullin 54, n. 80. Daniel Chamier, Panstratia Catholica, sive Controversiarum de religione Pontificios corpus, 4 vols (publ. de la Rovière, Geneva 1626).

117 BGE, Ami Lullin 54, n. 88 (Léger to Turrettini, 4 August 1630). 
that there was more to the story than meets the eye: with permission from the ecclesiastical authorities-Loukaris included-, the mysterious individual kept a school in his house and did not charge for his teaching; he was also a satirical poet who used mockery to ridicule the 'enormous' vices of the clergy and of the monks.

Based on these clues, we can safely establish an identity: Léger's unnamed 'person'

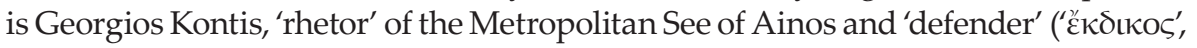
i.e. laic representative in legal and judicial matters) of the Great Church. ${ }^{118} \mathrm{He}$ was a respected scribe, writer, and preacher who belonged to Loukaris' network. As for the motive behind his association with Léger, it is disclosed by a note on a (lost) manuscript dated May 1630: Kontis was involved in the translation into vernacular of the New Testament, being even persecuted by members of the high clergy. ${ }^{119}$

These details are important. The rhetor did not meet Léger's high standards: he was not ready for 'the pure doctrine of truth'. Yet this was the minister's point of view. Kontis' co-religionists - not only the 'ignorant', but even the better-informed ones-had a completely different perspective: to them the Protestant Reformation was suspect, far more suspect than the Roman Catholicism. ${ }^{120}$

Aware of the situation and disappointed both by Loukaris, who was not as active as he could have been, and by the leaders of the Reformed Churches, who did not assist more the Constantinopolitan mission, Léger decided to narrow his focus and pursue two lines of action. Irrespective of the setbacks, the Temple of God had to be rebuilt. ${ }^{121}$ On the one hand, he tried to rally support for the printing of the translations into 'common' Greek which were already completed.

Monsieur le Patriarche Cyrille et ses amis promettent beaucoup, mais ils n'ont effectué jusqu'à présent ce qui se pouvoit avec facilité, comme l'establissement des escholes, un catéchisme vulgaire, choix de personnes plus capables et moins vitieuses aux charges ecclésiastiques. Tout y va au plus offrant. Ceste nation donc estant sous multitude de mercenaires, en effect un

118 In notes on three manuscripts from the collection of Sir Thomas Roe, Georgios presents

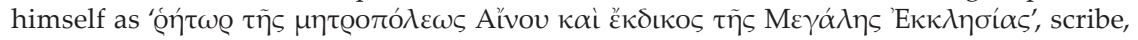
translator (from classical to 'common' Greek), and author, and tells us that his father,

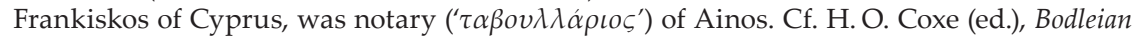
Library. Quarto Catalogues, I. Greek Manuscripts (Oxford 1969) col. 460-4 (n. 4-5, 8). For de-

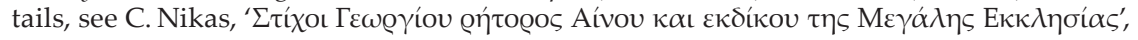

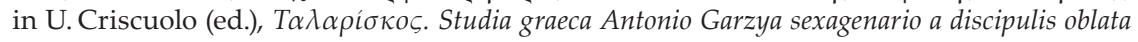
(Naples 1987) 415-56.

119 E. de Muralt (ed.), Catalogue des manuscrits grecs de la Bibliothèque Impériale publique (St Peters-

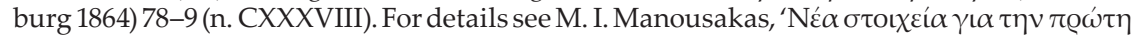

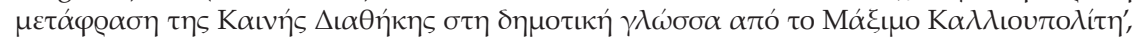

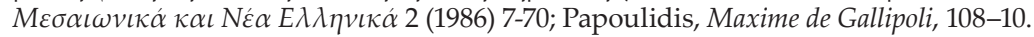

120 UBL, BPL 2211C, f. 15-16 (Léger to Rivet, 12 November 1632). The best illustrative example is the response given by Gerasimos Spartaliotis, the Patriarch of Alexandria, to the letter in which Léger presented his projects: Legrand, Bibliographie hellénique, IV, 385-9 (n. 136-8 July 1629).

121 UBL, BPL 2211C, f. 40-2 (Léger to Rivet, 12 January 1637): 'les matériaux que j'avoy pu ramasser et préparer pour y rebastir le temple de Dieu'. 
grand troupeau de brebis esparses, presque sans pasteur, ce sera un œuvre, comme je croy, grandement utile de leur faire entendre la voix du grand Pasteur, qui comme nous voyons en Ezekiel supplée au défaut des inferieurs. ${ }^{122}$

On the other hand, Léger intensified his anti-Roman campaign and his catechetical activity, directed increasingly towards the Western Europeans, residents and captives alike. ${ }^{123}$

The list of the books shipped from Geneva to Constantinople in May 1635 mirrors the new tactic. ${ }^{124}$ Geneva's Venerable Company of Pastors sent a couple of apologetic works: two copies of Philippe du Mornay's Truth of the Christian Religion against Atheists, Epicureans, Pagans, and Jews and two copies of Hugo Grotius' Truth of the Christian Religion. ${ }^{125}$ It sent as well several polemical tracts: two copies of the ecclesiastical history of Pierre Viret, ${ }^{126}$ two copies of the refutation by Niccolò Balbani of a treatise on the Mass by Antonio Possevino, ${ }^{127}$ four copies of Scipione Lentulo's response to another piece by Possevino, ${ }_{1}^{128}$ four copies of Sir Edwin Sandys' Relation of the State of Religion (annotated by Sarpi), two copies of Charles Drelincourt's Summary of the errors of the Roman Catholic Church, ${ }^{129}$ and 16 copies of the Short treatise of Turrettini which 'proved' the necessity to leave the Roman Church. ${ }^{130}$

Turrettini was also present with ten copies of his Sermons on the verse from the Gospel of Luke which says 'Be not afraid of them that kill the body', ten copies of his Sermons on the first chapter of the Epistle to the Romans, and ten copies of his Prayers. ${ }^{131}$ Yet most of the entries are related to the Bible and to pastoral tools

122 Ibid., f. 15-16.

123 The comparison with the East India case is interesting. Y. Thianto, The Way to Heaven. Catechisms and Sermons in the Establishment of the Dutch Reformed Church in the East Indies (Eugene OR 2014).

124 BGE, Ami Lullin 54, n. 97 (total price 211.7 livres; it included the binding of the books, the transport to Lyon and the customs duty).

125 Philippe du Mornay, De veritate religionis christianae (publ. Cristophe Plantin, Leiden 1583); Hugo Grotius, De veritate religionis Christianae (publ. Joannis Maire, Leiden 1629). Both books were frequently reprinted.

126 Pierre Viret, De fatti de veri successori di Giesu Christo et de suoi Apostoli, et de gli Apostati della Chiesa Papale ... (publ. Giovan Luigi Paschale, [Geneva] 1556).

127 Niccolò Balbani, Trattato primo delle risposte fatte ad un libretto di Messer Antonio Possevino della Messa ... (publ. Olivier Fordrin, [Geneva] 1564).

128 [Scipione Lentulo], Brevi risposte ad un certo scritto, che Antonio Possevino mandò à i fedeli, c'habitano ne le Valli di Lucerna ... fatte per un Ministro delle dette Valli [publ. Oliviero Fordrino, Genova 1564].

129 Charles Drelincourt, Abbregé des controverses, ou Sommaire des erreurs de nostre temps ... (publ. Pierre Aubert, Geneva 1625). The alternative would be Rivet's Sommaire et abrégé des controverses ... (publ. heirs of Hierosme Haultin, La Rochelle 1608), but the list says 'Abbregé des controverses'.

130 [Bénédict Turrettini], Breve trattato nel quale la necessita d'uscir della chiesa Papistica Romana, à chi conosce l'Evangelio, è dimostrata (publ. Pierre Aubert, [Geneva] 1626). Cf. S. Maghenzani, ‘Polemica antinicodemitica e progettualità politica dei lucchesi di Ginevra. Il "Breve trattato" di Benedetto Turrettini (1626)', Schifanoia 40-41 (2011) [2012] 127-45.

131 Neither the 'Preghiere' nor the 'Homilie sopra Rom. 1' are known. See W. A. McComish, The 
such as confessions and catechisms. There are three complete Bibles (one Greek and two Italian), eighteen New Testaments (twelve Greek and six Italian), seven Psalms in Italian, fifty confessions of faith in Italian, fifty catechisms in Spanish, and one hundred 'Italian Alphabets'. Judging by the language and by the nature of the texts, the intended recipients of the educational and pastoral efforts were rather the European slaves than the Eastern Christians. ${ }^{132}$

The books arrived in May $1636 .{ }^{133}$ Only a couple of months later, Léger returned to his homeland. His departure, and especially Loukaris' execution by the Ottomans, in 1638, marked the beginning of the end of the Protestant 'public library'. The new minister attached to the Dutch embassy, David Sartoris, died only one year after his arrival in Constantinople, without being able to carry forward the work of his tenacious predecessor. ${ }^{134}$ Cornelis Haga terminated his long diplomatic career in 1639; his nephew, Hendrik Cops, succeeded him as 'chargé d'affaires' and took interest in ecclesiastical matters, but since Loukaris' death the situation had changed dramatically. ${ }^{135}$ The patriarch had been right all along with respect to the reformation of the Eastern Church: 'iddio sa che tractatur de impossibili.'

\section{Conclusions}

The history of Early Modern Eastern Christianity is a topic that still requires thorough research. Dominated by the remarkable personality of the 'Calvinist' Kyrillos Loukaris, the period is often depicted indiscriminately and in a simplistic manner in terms of a 'struggle of preponderance' between two institutions with declared ecumenical vocation-the Church of Rome and the Church of Constantinople. The former fought against Protestantism and tried to force a re-Union of all Christians afflicted by 'schism'. The latter struggled to survive under Ottoman domination and either allied with Rome or conversed with the Reformed Churches. As for the 'Christ's Churches purely reformed'136, they did seek ideological and political allies

Epigones. A study of the theology of the Genevan Academy at the time of the Synod of Dort, with special reference to Giovanni Diodati (Allison Park PA 1989) 37-9.

132 The biblical texts in Italian were probably those translated by Giovanni Diodati: the 1608 Bible, the 1608 New Testament, and the 1631 Psalms (publ. Pierre Aubert, Geneva; another edition conceals the place of publication and the publisher): McComish, The Epigones, 6, 11-12. 'Forma di orationi e Catechismo in spagnuolo' alludes to the Spanish version of XX. Salmi di David ... La forma de l'orationi Ecclesiastiche... Catechismo per ammaestrare i fanciulli ne la vera e sincera dottrina Christiana (publ. Jean Crespin, [Geneva] 1554-with a foreword by Calvin). The Italian 'Alfabeti' might refer to Juan de Valdés' Alphabeto Christiano, translated by Marcantonio Magno and published in Venice, in 1545. Juan de Valdés, Alfabeto cristiano, ed. M. Firpo (Torino 1994). As for the Italian Confession, it might be the Confessione di fede fatta di comun consentimento da le Chiese che sono disperse per la Francia ... (publ. Jacques Bourgeois, [Geneva] 1561).

133 BGE, Ami Lullin 54, n. 97.

134 For Sartoris' appointment, see Legrand, Bibliographie hellénique, IV, 424-6 (n. 153). Léger had high hopes of him. UBL, BPL 2211C, f. 40-2.

135 Olar, La boutique de Théophile, 262-3, 314-21.

136 P. Benedict, Christ's Churches Purely Reformed. A Social History of Calvinism (New HavenLondon 2002). 
against Roman Catholicism, but confined themselves to the sporadic and illusory pursuit of a theological accord with high-ranked ecclesiastical representatives of the 'Great Church'. However, the archival material tells another story, by far more nuanced, and, as a direct consequence, more dynamic and interesting.

On one hand, Rome's opinions on the Levantine religious issues were not monolithic. On the other hand, Loukaris' ‘Calvinism' needs to be closely examined. The patriarch was for a long time in good terms with the Latin Church-in 1608, he recognized the Pope's primacy, while in 1625 he agreed to open negotiations with regard to a Union. The negotiations failed, but the failure was not due to Loukaris' 'heretic' stance. As for 'international Calvinism', we should not underestimate the efforts made during the times of Loukaris by its proponents to educate the Eastern Christians in the spirit of 'the true Word of God'.

This early-seventeenth-century 'attempted "Calvinisation" of the Orthodox Church'-as Vasilios Tsakiris has termed it ${ }^{137}$ - fits well in the 'confessionalization' paradigm. Born in the Pays de Vaud-a religious 'battleground'138 - and educated in Geneva, Antoine Léger did his best to 'spread the Gospel' among the Greek-speaking Christians. His aims correspond to the confession-building 'methods' detected by Wolfgang Reinhard: encapsulation of the 'pure faith' in a confession; dissemination and enforcement of the purified norms; controlled use of the printing press; instruction; social disciplining; control of the rites and of the language. ${ }^{139}$ Léger was on a mission assigned by a confessionalized Church.

Of course, most decisions depended on his superiors in Geneva and Leiden, and, even more so, on Loukaris. Everybody agreed, however, that the foundation of a 'public library' in Constantinople was vital. Taking advantage of Loukaris' Protestant affinities, Cornelis Haga and his minister obtained funding from the States-General and, with the help of the Genevan pastors and professors-whose daily lives 'were filled with books' ${ }^{\prime 140}$-, amassed dozens of volumes in the Dutch embassy. The endeavour was unprecedented. ${ }^{141}$ It was also immune to nuance: authors like Sarpi, who advocated a moderate approach to religion, become weapons in a confessional 'Cold War'. ${ }^{142}$

137 Tsakiris, 'The "Ecclesiarum Belgicarum Confessio"'. See also Hering, Ökumenisches Patriarchat und europäische Politik.

138 M. W. Bruening, Calvinism's First Battleground. Conflict and Reform in the Pays de Vaud, 1528 1559 (Dordrecht 2004).

139 W. Reinhard, 'Pressures towards Confessionalization? Prolegomena to a Theory of the Confessional Age', in C. Scott Dixon (ed.), The German Reformation. The Essential Readings (Oxford 1999) 169-92.

140 S. M. Manetsch, Calvin's Company of Pastors. Pastoral Care and the Emerging Reformed Church, 1536-1609 (Oxford 2013) 221-54.

141 For a later example, see R. Clogg, 'The Library of the Levant Company's Factory in Smyrna (1805)', 'O 'E $\rho \alpha v l \sigma \tau \eta \bar{s} 11$ (1974) 112-24.

142 N. Constantinidou, Responses to Religious Division, c. 1580-1620. Public and Private, Divine and Temporal (Leiden-Boston 2017). 
Although the library did not last long, its evolution allows us to understand better the complicated relationship between the 'Calvinist' patriarch of Constantinople and the Reform. Several of Loukaris' initiatives could fit roughly in the schema coined by Reinhard: preaching in vernacular, improvement of the education, foundation of a printing press, and religious polemics. In many cases, the patriarch and his Reformed allies worked closely together. In 1632, Loukaris addressed the Genevan pastors as 'fratelli miei in Christo', which, given the context, would qualify him as remote member of the 'transnational brotherhood of the godly' studied by Ole Peter Grell. ${ }^{143}$ Yet, if he was a 'brethren', he was one with many differences. Léger constantly complained about the patriarch's ambivalent attitude towards all Reformed initiatives. A friend turned bitter foe played down both dissimilarities and similarities quoting from Juvenal: 'Graeculus esuriens.' ${ }^{144}$ But Loukaris was no opportunist. He was a worker in the vineyard of the Lord and he truly followed a confession-building project. ${ }^{145}$ He just had a Reformation agenda of his own.

\section{Appendix I}

Books sent to Constantinople, 1628-1636

The following inventory is based on three lists of books compiled by Antoine Léger (BGE, Ami Lullin 54, n. 55, 97, 97bis) and on Léger's correspondance. An edition of the latter will undoubtedly expand the record.

Some titles could not be identified ('des pieces que nous avons de Martyr, Calvin ...', 'une bible Hebraique' 'Biblia $\tau \tilde{\omega} v$ o', 'Testamens Grecs', 'Homilie del sig. Turrettino sopra Rom. 1', 'Preghiere del s. ${ }^{r}$ Turrettino', 'Biblia Graeca'). In several other cases, it was difficult to determine the exact edition ('Horologium Graeco-

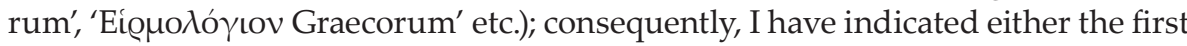
edition or, when available, the last Venetian or Genevan edition.

Albonesi T. A. degli, Introductio in Chaldaicam linguam, Syriacam, atque Armenicam, $\mathcal{E}$ decem alias linguas (Pavia 1539).

Alsted J. H., Thesaurus chronologiae (Herborn 1624; Herborn 1628).

- De manducatione spirituali, transsubstantiatione, sacrificio missae dissertatio. De Ecclesia eiúsque partibus \& proprietatibus tractatus adversus Bellarmini, et Becani, E aliorum Pontificiorum errores ... (Geneva 1630).

[Anonymous], Confessione di fede fatta di comun consentimento da le Chiese che sono disperse per la Francia ... ([Geneva] 1561).

143 BGE, Ms. gr. 37-38* (Loukaris to Diodati, 15/25 April 1632). O. P. Grell, Brethren in Christ. A Calvinist Network in Reformation Europe (Cambridge 2011).

144 M. Prandoni, 'Graeculus o optimus vir? Quel che resta di Loukaris nella Repubblica delle Lettere e nel calvinismo: la disputa teologica tra Ugo Grozio e André Rivét (1642-1646)', in V.Nosilia and M. Prandoni (eds), Trame controluce. Il patriarca 'protestante' Cirillo Loukaris/Backlighting Plots. The 'Protestant' Patriarch Cyril Loukaris (Florence 2015) 152.

145 S. H. Hendrix, Recultivating the Vineyard. The Reformation Agendas of Christianization (Louisville KY-London 2004). 
[Anonymous], Breviarium Romanum (Rome 1568).

Arrian, Ponti Euxini \& Maris Erythraei Periplus, ed. J. W. Stuck (Geneva 1577).

Balbani N., Trattato primo delle risposte fatte ad un libretto di Messer Antonio Possevino della Messa ... ([Geneva] 1564).

Basil of Caesarea, Sancti patris nostri Basilii Magni Caesareae Cappadociae archiepiscopi Opera omnia, quae reperiri potuerunt, ed. Fronton du Duc and Frédéric Morel (Paris 1618).

Bèze T. de, Confessio Christianae fidei, et ejusdem collatio cum papisticis haeresibus (Geneva 1560).

Botero G., Le relationi universali (Venice 1618).

Bucer M., De regno Christi Jesu servatoris nostri (Basel [1557]).

Budé G., Commentarii Linguae Graecae (Paris 1529; Paris 1548).

- De transitu Hellenismi ad Christianismum (Paris 1534).

Calepino A., Dictionarium undecim linguarum, 2 vols (Basel 1616).

Camilli C., I cinque canti di ... aggiunti al Goffredo del signor Torquato Tasso (Venice 1583).

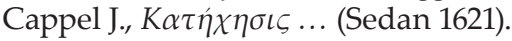

Carranza de Miranda B., Summa conciliorum et pontificum à Petro usque ad Paulum tertium (Venice 1546).

Chamier D., Panstratia Catholica, sive Controversiarum de religione Pontificios corpus, 4 vols (Geneva 1626).

Chemnitz M., Examen Concilii Tridentini, 4 vols (Frankfurt a.M. 1565-1573).

Confraternita del Cordone di S. Francesco $<$ Mondovì, Sommario delle indulgenze concesse da Sisto quinto, et da diversi altri pontefici alli frati minori, et dall'istesso Sisto all'archiconfraternità de Cordigeri fondata nella chiesa di S. Francesco ad Assisi, concesse, et applicate per aggregatione alla Confraternità dello istesso titolo eretta nella chiesa di S. Francesco de FF. minori conventuali di Mondovì (Mondovì 1599).

David, XX. Salmi di David ... La forma de l'orationi Ecclesiastiche ... Catechismo per ammaestrare i fanciulli ne la vera e sincera dottrina Christiana ([Geneva] 1554).

Diodati G. (ed.), La Sacra Bibbia (Geneva 1608).

- (ed.), Il Nuovo Testamento del Signor nostro Iesu Cristo ([Geneva] 1608).

- (ed.), I Sacri Salmi (Geneva 1631).

Drelincourt Ch., Abbregé des controverses, ou Sommaire des erreurs de nostre temps... (Geneva 1625).

Ferus J., In sacrosanctum Iesu Christi evangelium secundum Matthaeum (Venice 1568).

Granada L. de, Primus tomus Concionum ... (Lisbon 1573).

Grotius H., De veritate religionis Christianae (Leiden 1629).

[Godefroy J. (ed.)], Le Mercure Iesuite: ou Recueil des pieces, concernants le progrés des Iesuites, leurs Escrits \& Differents ... (Geneva 1626).

James T., Catalogus universalis librorum in Bibliotheca Bodleiana omnium librorum, linguarum, E scientiarum genere refertissimâ, sic compositus; ut non solum publicis per Europam universam bibliothecis, sed etiam privatis musaeis, alijsque ad catalogum librorum conficiendum usui esse possit (Oxford 1620).

Kempis T. à, De imitatione Christi Latino-Graecus, ed. Georg Mayr (Augsburg 1615).

Lange J. (ed.), Polyanthea nova (Lyon 1604).

[Lentulo Scipione], Brevi risposte ad un certo scritto, che Antonio Possevino mandò à i fedeli, c'habitano ne le Valli di Lucerna ... fatte per un Ministro delle dette Valli [Genova 1564].

Lucas F., Concordantiae bibliorum sacrorum Vulgatae editionis ... (Antwerp 1617).

Meursius J., Glossarium graeco-barbarum (Leiden 1614). 
Mornay P. du, De veritate religionis christianae (Leiden 1583)

Moulin P. du, Bouclier de la foy, ou Defense de la Confession de foy des Eglises reformees du Royaume de France ... (Geneva 1630).

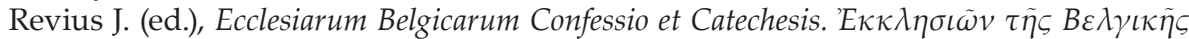

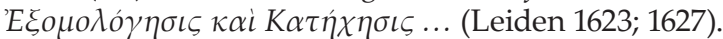

B. de Sandoval y Rojas, Index librorum prohibitorum et expurgatorum (Geneva 1619).

Sandys E., Relatione dello stato della religione ... ([Geneva] 1625).

[Sarpi P. (Pietro Soave Polano)], Historia del Concilio Tridentino (Geneva 1629).

Scapula J. (ed.), Lexicon Graecolatinum (Basel 1579).

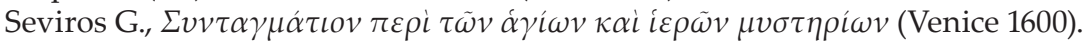

Theodoric C., Analysis logica evangeliorum dominicalium ... Pars aestivalis (Gießen 1613).

- Analysis logica evangeliorum dominicalium ... Pars hyemalis (Gießen 1615).

Turrettini B., Sei homilie sopra le parole di Iesu Christo, Luc. XII. v. 5. 6. etc. Non temiate coloro che possono ucidere il corpo ... (Geneva 1623).

[-], Breve trattato nel quale la necessita d'uscir della chiesa Papistica Romana, à chi conosce l'Evangelio, è dimostrata ([Geneva:] 1626).

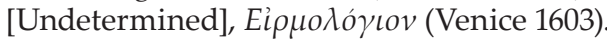

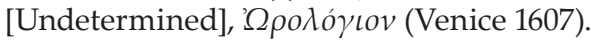

Valdés Juan de, Alphabeto Christiano (Venice 1545) [ed. M. Firpo (Torino 1994)].

Viret P., De fatti de veri successori di Giesu Christo et de suoi Apostoli, et de gli Apostati della Chiesa Papale ...([Geneva] 1556).

Wolf H., Clauser K., and Does T. van der (eds), Historiae Byzantinae scriptores tres Graecolatini (Geneva 1615).

\section{Appendix II}

Other books requested by Antoine Léger for the 'public library' in Constantinople, 1628-1636

The following inventory is based on Léger's (soon-to-be-published) correspondence. Some titles could not be identified ('Grossius' etc.). In several other cases, it was difficult to determine the exact edition; consequently, I have indicated either the first edition or, when available, the last Venetian or Genevan edition.

[Anonymous], Sommario della religion Christiana, raccolto in dieci libri, ne' quali si tratta di tutti gli articoli della fede, second la pura parola di Dio (Roma: Paolo Gigliadoro 1590) [both place of edition and publisher are fictitious; the book was probably published in Geneva].

[Anonymous], Taxae cancellariae apostolicae et taxae sacrae pœnitentiariae apostolicae... (Rome 1514).

Bellarmino R., De scriptoribus ecclesiasticis ... (Leiden 1613).

Buxtorf J., Synagoga Judaica (Hanau 1604).

- De Abbreviaturis Hebraicis (Basel 1613).

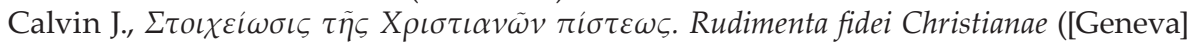
1551; [Geneva] 1563).

Cameron J., Traicte auquel sont examinez les prejugez de ceux de l'Eglise Romaine, contre la Religion Reformee (La Rochelle 1617). 
Cooke R., Censura quorundam scriptorum, quae sub nominibus sanctorum $\mathcal{E}$ veterum auctorum, à Pontificijs passim in eorum scriptis ... citari solent (London 1614).

Crusius M., Turcograecia (Basel 1584).

Gerson C., Der Jüden Thalmud (Goßlar 1607).

Hospinian R., Historia iesuitica ... (Zürich 1619).

James T., A Treatise of the Corruption of Scripture, Councels, and Fathers ... (London 1611).

Lucius L., Historia Jesuitica ... (Basel 1627).

Manasses C., Annales, Graecè ac Latinè, ed. J. Meursius (Leiden 1616).

Mornay P. de, Advertissement aux Juifs sur la venue du Messie (Saumur 1607).

- Mysterium iniquitatis seu, Historia Papatus ... (Saumur 1611).

Ochino B., Dialogo del Purgatorio ([Zürich] 1556).

Perrin J.-P., Histoire des Vaudois (Geneva 1619).

Polansdorf A. Polanus von, Symphonia Catholica seu Consensus Catholicus et Orthodoxus dogmarum hodiernae Ecclesiae... (Basel 1607).

Rivet A, Sommaire et abrégé des controverses de nostre temps touchant la Religion (La Rochelle 1608).

- Criticus sacer [1612] (Heidelberg 1612; Geneva 1626).

[Sarpi P.], Historia particolare delle cose passate tra'l Sommo Pontefice Paolo Ve la Serenissima Republica di Venetia (Geneva 1624).

Scultetus A., Medulla theologiae Patrum ..., 4 vols (Amberg 1598-1613).

Thou J.-A. de, Historiarum sui temporis (Paris 1604).

[Turrettini B.], Recueil des pieces concernants la doctrine romaine touchant la deposition des Rois \& Princes par le Pape ... (Geneva 1627).

Ulrich J. J., De religione Ecclesiarum Graecanicarum, tum vetere, tum hodierna. Disquisitio theologica \& historica (Zürich 1621).

Vogel M., Tesaurus theologicus ... (Tübingen 1592).

Vossius G., De Historicis Graecis Libri IV (Leiden 1624).

\section{Bibliography}

Archives/Manuscripts

Athens, National Library of Greece [= NLG], principal fonds [= EBE] 1062 [Diktyon 3358].

Athens, National Library of Greece [= NLG], fonds of Metochion Panagiou Tafou [Metochion of the Holy Sepulchre] [= MPT] 262 [Diktyon 6659], 263 [Diktyon 6660].

Bucharest, Biblioteca Academiei Române [= BAR], Ms. rom. 3517.

Erlangen, Erlangen Universitätsbibliothek, Ms. A 04 [Diktyon 14294].

Geneva, Bibliothèque de Genève [= BGE], Ami Lullin 54 .

Leiden, Universitaire Bibliotheken Leiden [= UBL], Bibliotheca Publica Graeca [= BPG] 122 [Diktyon 76475].

Leiden, Universitaire Bibliotheken Leiden $[=U B L]$, Bibliotheca Publica Latina [= BPL] 26B, 2211C.

Munich, Bayerische Staatsbibliothek [= BSB], Cam. 9 [Clm. 10359], n. 219, 220, 222, 224.

Vienna, Haus-, Hof- und Staatsarchiv, Staatenabteilung. Türkei I-Turcica 114/1638.

Zürich, Staatsarchiv des Kantons Zürich [= StAZH], E_II_389, 395, 400

Zürich, Zentralbibliothek Zürich [= ZB Zürich], Cod. C 199 (Ap. 122).

Zürich, Zentralbibliothek Zürich [= ZB Zürich], Thesaurus Hottingerianus, Ms F. 44. 


\section{Literature}

Augustin P., 'In aedibus Dn. Legati Angliae Constantinopoli Galatae: Henry Savile, Samuel Slade et les manuscrits de Galata-Péra en 1610', in A. Binggeli, M. Cassin and M. Detoraki (eds), Bibliothèques grecques dans l'Empire ottoman (Turnhout 2020) 225-55.

Backus I., 'Reformed Orthodoxy and Patristic Tradition', in H. J. Selderhuis (ed.), A Companion to Reformed Orthodoxy (Leiden-Boston 2013) 91-117.

Banduri A., Imperium Orientale sive Antiquitates Constantinopolitanae, I (Paris 1711).

Baud-Bovy S., 'Antoine Léger, pasteur aux vallées vaudoises du Piémont et son séjour à Constantinople. D'après une correspondance inédite 1622-1631', Revue d'histoire suisse 24/2 (1944) 193-219.

Benedict P., Christ's Churches Purely Reformed. A Social History of Calvinism (New Haven-London 2002).

Blair A. M., Too Much to Know. Managing Scholarly Information before the Modern Age (New Haven 2010).

Blanchet M.-H., 'Présence et usage de livres au patriarcat de Constantinople durant la seconde moitié du XVe et la première moitié du XVIe siècle', in A. Binggeli, M. Cassin, and M. Detoraki (eds), Bibliothèques grecques dans l'Empire ottoman (Turnhout 2020) 119-44.

Bonnant G., 'Les éditions genevoises de Paolo Sarpi au XVIIe et au XVIIIe siècle', in L. Monnier (ed.), Genève et l'Italie (Geneva 1969) 201-28.

Botero G., Le relazioni universali, 2 vols, ed. B. A. Ravioli (Torino 2015).

Bruening M.W., Calvinism's First Battleground. Conflict and Reform in the Pays de Vaud, 1528-1559 (Dordrecht 2004).

Bryner E., 'Der Zürcher Theologe Johann Jakob Ulrich und seine Konfessionskunde der griechisch-orthodoxen Kirche von 1621', Kirche im Osten 34 (1991) 9-31.

Burman T. E., 'European Qur'an Translations, 1500-1700', in D. Thomas and J. Chesworth (eds), Christian-Muslim Relations. A Bibliographical History, VI. Western Europe (1500-1600) (Leiden-Boston 2014) 25-38.

Burnett S. G., From Christian Hebraism to Jewish Studies. Johannes Buxtorf (1564-1629) and Hebrew Learning in the Seventeenth Century (Leiden-NewYork-Köln 1996).

Chartier R., 'L'Académie de Lyon au XVIIIe siècle, 1700-1793, étude de sociologie culturelle', in R. Chartier et al.(eds), Nouvelles études lyonnaises [Histoire et civilisation du livre, 2] (Geneva-Paris 1969) 131-250.

Clogg R., 'The Library of the Levant Company's Factory in Smyrna (1805)', 'O 'E $\rho \alpha v l^{-}$ $\sigma \tau \eta \dot{s} 11$ (1974) 112-24.

Constantinidou N., Responses to Religious Division, c. 1580-1620. Public and Private, Divine and Temporal (Leiden-Boston 2017).

Coxe H. O. (ed.), Bodleian Library. Quarto Catalogues, I. Greek Manuscripts (Oxford 1969).

Cozzi G., 'Fra Paolo Sarpi, l'Anglicanesimo e la Historia del Concilio Tridentino', Rivista Storica Italiana 68/4 (1956) 559-619.

Cruz Palma Ó. de la, La traduccción latina del Corán atribuida al patriarca de Constantinopla Cirilo Lúcaris (1572-1638) (Madrid 2006).

Dedouvres L., Le père Joseph polémiste. Ses premiers écrits (1623-1626) (Paris 1895).

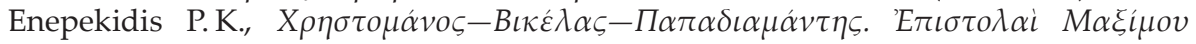

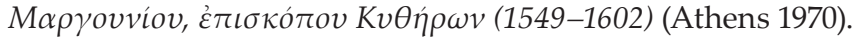

Gabbema S. A. (ed.), Illustrium et clarorum virorum epistolae ... selectiores ... (Harlingen am Wattenmeer 1669). 
Grell O. P., Brethren in Christ. A Calvinist Network in Reformation Europe (Cambridge 2011).

Hamilton A., “"To Divest the East of all its Manuscripts and all its Rarities". The Unfortunate Embassy of Henri Gournay de Marcheville', in A. Hamilton, M. H. van den Boogert and B. Westerweel (eds), The Republic of Letters and the Levant (Leiden-Boston 2005) 123-50.

Heeringa K. (ed.), Bronnen tot de geschiedenis van den Levantschen handel, I/1.1590-1610 (The Hague 1910).

Hendrix S.H., Recultivating the Vineyard. The Reformation Agendas of Christianization (Louisville KY-London 2004).

Hering G., Ökumenisches Patriarchat und europäische Politik 1620-1638 (Wiesbaden 1968).

Hofmann G., ‘Patriarch Kyrillos Lukaris. Einfluss abendländischer Schriften auf seine Predigten', Orientalia Christiana Periodica 7 (1941) 250-65.

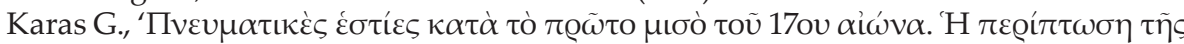

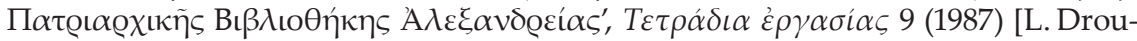

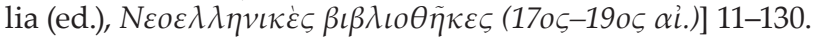

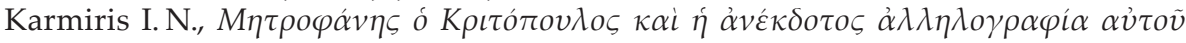
(Athens 1937).

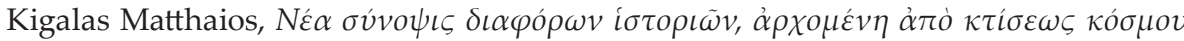

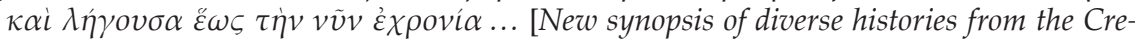
ation of the World to the present year ...] (Venice 1637).

Kingdon R. M., 'International Calvinism', in T. A. Brady, H. A. Oberman, and J. D. Tracy (ed.), Handbook of European History 1400-1600. Late Middle Ages, Renaissance and Reformation, II. Visions, Programs, Outcomes (Leiden-Boston-Köln 1995) 229-47.

Kresten O., 'Review of K. Loukaris, Sermons 1598-1602, ed. K. Rozemond (Leiden 1974)', in Nederlands Archief voor Kerkgeschiedenis 56/2 (1976) 478-81.

Lange A. de, 'Antoine Léger, un "internazionalista" calvinista del Seicento', Bollettino della Società di Studi Valdesi 181 (1997) [S. Peyronel-Rambaldi (ed.), Circolazione di uomini e dell'idee tra Italia ed Europa nell'età della Controriforma] 203-32.

- 'De Waldenzenpredikant Antoine Léger en de patriarch Cyrillus Lukaris. Calvinisme en Griekse orthodoxie in de eerste helft van de zeventiende eeuw', Documentatieblad voor de Geschiedenis van de Nederlandse Zending en Overzeese Kerken6/1 (1999) 1-19.

- 'Antoine Léger (1596-1661). Das Leben eines Waldenserpfarrers zwischen Konstantinopel und Genf', in A. Flick and A. de Lange (eds), Von Berlin bis Konstantinopel. Eine Aufsatzsammlung zur Geschichte der Hugenotten und Waldenser (Bad Karlshafen 2001) 119-67.

- 'Il ruolo del pastore calvinista Antoine Léger nella genesi e redazione della confessione di fede del patriarca ortodosso Cirillo Loukaris (1629-1633)', in V. Nosilia and M. Prandoni (eds), Trame controluce. Il patriarca 'protestante' Cirillo Loukaris/Backlighting Plots. The 'Protestant' Patriarch Cyril Loukaris (Florence 2015) 119-34.

Lauxtermann M. D., “And many, many more”: A Sixteenth-Century Description of Private Libraries in Constantinople, and the Authority of Books', in P. Armstrong (ed.), Authority in Byzantium (Abingdon-New York 2013) 269-84.

Legrand É., Bibliographie hellénique ou Description raisonnée des ouvrages publiés en grec par des Grecs au dix-septième siècle, I (Paris 1894).

- Bibliographie hellénique ou Description raisonnée des ouvrages publiés en grec par des Grecs au dix-septième siècle, IV (Paris 1896). 


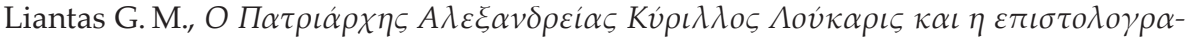

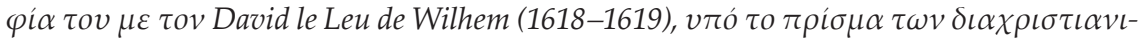

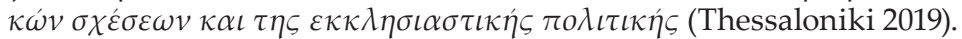

Lipsius J., Epistolae XIV (1601), ed. J. de Landtsheer (Brussels 2006).

Loukaris K., Sermons 1598-1602, ed. K. Rozemond (Leiden 1974).

Maghenzani S., 'Polemica antinicodemitica e progettualità politica dei lucchesi di Ginevra. Il "Breve trattato" di Benedetto Turrettini (1626)', Schifanoia 40-41 (2011) [2012] 127-45.

Manetsch S. M., Calvin's Company of Pastors. Pastoral Care and the Emerging Reformed Church, 1536-1609 (Oxford 2013).

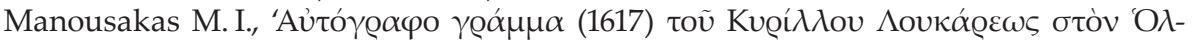

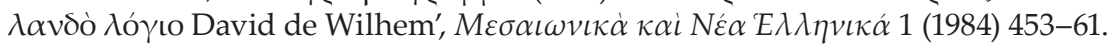

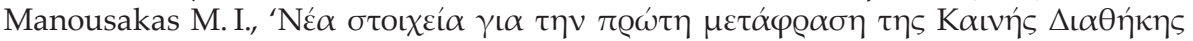

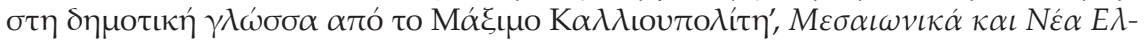
$\lambda \eta v \iota \kappa \alpha ́ 2$ (1986) 7-70.

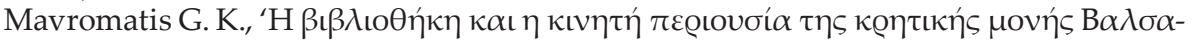

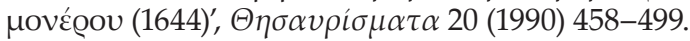

McComish W. A., The Epigones. A study of the theology of the Genevan Academy at the time of the Synod of Dort, with special reference to Giovanni Diodati (Allison Park PA 1989).

McKinney McNair D., 'Kyrillos Loukaris and the Translation of Holy Books: A Latin Koran and a Modern New Testament', in M. F. Arslan and M. V. Bilici (ed.), İstanbul tecrübesi. Dinsel ve kültürel farklllklarm birarada yaşamasl/ The experience of İstanbul. Coexistence of Religious and Cultural Diversities (Istanbul 2010) 456-64.

Mihăescu D., Cronografele românești (Bucharest 2006).

Miller P. N., Peiresc's Mediterranean World (Harvard 2015).

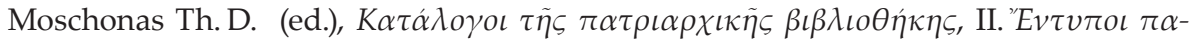
$\lambda \alpha \iota \alpha i$ è $\delta \delta ́ \sigma \varepsilon \iota \varsigma$ (Alexandria 1946).

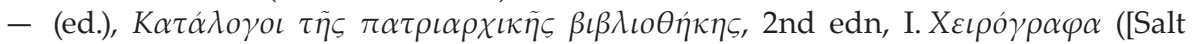
Lake City] 1965).

Muralt E. de (ed.), Catalogue des manuscrits grecs de la Bibliothèque Impériale publique (St Petersburg 1864).

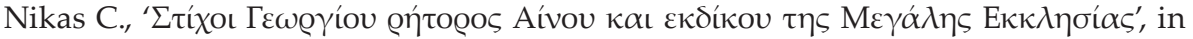

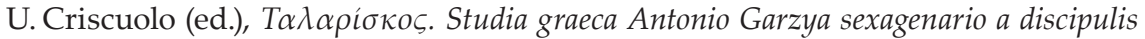
oblata (Naples 1987) 415-56.

Odorico P. et al. (eds), Conseils et mémoires de Synadinos prêtre de Serrès en Macédoine (XVIIe siècle) (Paris 1996).

Olar O., '«Je suis le bon pasteur ...»: Notes sur la pensée politique de Kyrillos Loukaris', in V. Nosilia and M. Prandoni (eds), Trame controluce. Il patriarca 'protestante' Cirillo Loukaris/Backlighting Plots. The 'Protestant' Patriarch Cyril Loukaris (Florence 2015) 3-30.

- 'Les confessions de foi de Cyrille Loukaris († 1638)', in M.-H. Blanchet and F. Gabriel (eds), L'Union à l'épreuve du formulaire. Professions de foi entre Églises d'Orient et d'Occident (XIIIe-XVIIIe siècle) (Louvain-Paris-Bristol 2016) 271-310.

- '«Un trésor enfoui»: Kyrillos Loukaris et le Nouveau Testament en grec publié à Genève en 1638 à travers les lettres d'Antoine Léger', Cahiers du monde russe 58/3 (2017) [P. Bushkovitch, N. A. Chrissidis and R. G. Păun (eds), Les terres de l'orthodoxie au XVIIe siècle] 341-70. 
- La boutique de Théophile. Les relations du patriarche de Constantinople Kyrillos Loukaris (1570-1638) avec la Réforme (Paris 2019).

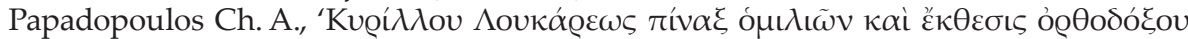

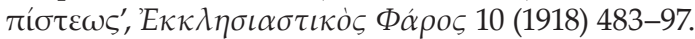

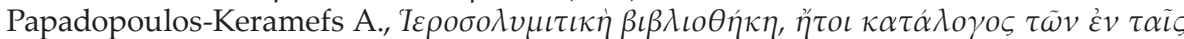

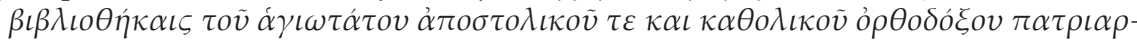

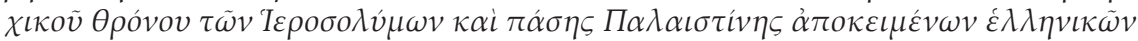
$\kappa \omega \delta i \kappa \omega v$, II (St Petersburg 1894).

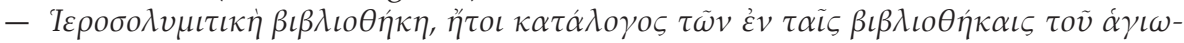

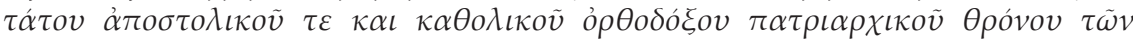

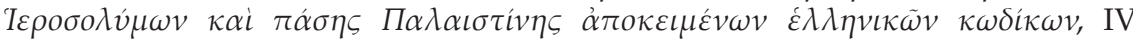
(St Petersburg 1899).

Papaïliaki-Gamelon N., 'Livres de catéchismes et pratiques scolaires des missionaries français en Grèce au XVIIe siècle', in H. Didier and M. Larcher (eds), Pédagogies missionnaires. Traduire Transmettre Transculturer (Paris 2012) 137-46.

Papoulidis K., Problèmes de traduction et d'interprétation du Nouveau Testament en grec moderne: le cas de Maxime de Gallipoli (1638) (Thessaloniki 2004).

Patterson W. B., King James VI and I and the Reunion of Christendom (Cambridge 1997).

Philippos of Cyprus, Chronicon Ecclesiae Graecae (Franeker 1679).

Pippidi A., 'Diplomație şi ortodoxie: Moldova în proiectele propagandei calvine (1630)', in O. Cristea, P. Zahariuc and G. Lazăr (eds), Aut viam inveniam aut faciam. In honorem Ştefan Andreescu (Iaşi 2012) 349-66.

Pontani F., 'Musurus' Creed', Greek, Roman, and Byzantine Studies 43 (2002-2003) 175-213.

Prandoni M., 'Graeculus o optimus vir? Quel che resta di Loukaris nella Repubblica delle Lettere e nel calvinismo: la disputa teologica tra Ugo Grozio e André Rivét (1642-1646)', in V. Nosilia and M. Prandoni (eds), Trame controluce. Il patriarca 'protestante' Cirillo Loukaris/Backlighting Plots. The 'Protestant' Patriarch Cyril Loukaris (Florence 2015) 151-166.

Prestwich M. (ed.), International Calvinism, 1541-1715 (Oxford 1985).

Reinhard W., 'Pressures towards Confessionalization? Prolegomena to a Theory of the Confessional Age', in C. Scott Dixon (ed.), The German Reformation. The Essential Readings (Oxford 1999) 169-92.

Rozemond K., Notes marginales de Cyrille Lucar dans un exemplaire du Grand Catéchisme de Bellarmin (The Hague 1963).

Ruiu A., 'Conflicting Visions of the Jesuit Missions to the Ottoman Empire, 1609-1628', Journal of Jesuit Studies 1/2 (2014) 260-80.

Sandys G., A Relation of a Iourney [sic] begun An: Dom: 1610 ... (London 1615).

Thianto Y., The Way to Heaven. Catechisms and Sermons in the Establishment of the Dutch Reformed Church in the East Indies (Eugene OR 2014).

Thurn H. and Stählin O. (eds), Die griechischen Handschriften der Universitätsbibliothek Erlangen, III/2 (Wiesbaden 1980).

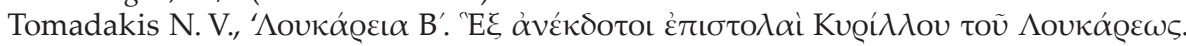

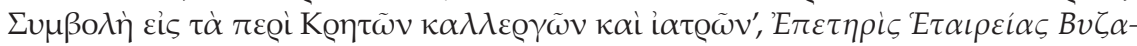

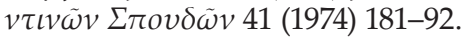

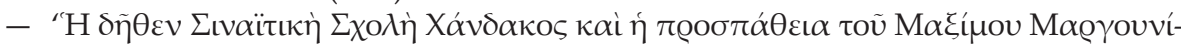

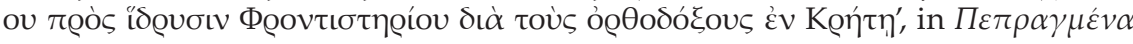

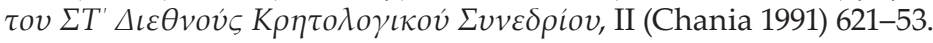


Tommasino P. M., ‘Nota bibliográfica. Traduzioni del Corano', Al-Qanțara 31/2 (2010) 647-52.

Tsakiris V., "The "Ecclesiarum Belgicarum Confessio" and the Attempted "Calvinisation" of the Orthodox Churchunder Patriarch Cyril Loukaris', The Journal of Ecclesiastical History 63/3 (2012) 475-87.

Tucker J., The Construction of Reformed Identity in Jean Crespin's Livre des Martyrs (London 2017).

Viallon M., 'Les éditions de 1'Histoire du Concile de Trente de Paolo Sarpi', in D. Montoliou (ed.), Le livre italien hors d'Italie au XVIIe siècle (Toulouse 2011) 73-90.

Volkoff O. V. (ed.), Voyages en Egypte des années 1611 et 1612. George Sandys-William Lithgow (Cairo 1973).

Wright C., Argyrou M. and Dendrinos Ch. (eds), A Descriptive Catalogue of the Greek Manuscript Collection of Lambeth Palace Library (London 2016).

Zampakolas Ch., 'H $\beta \iota \beta \lambda เ$

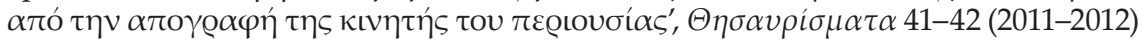
311-28. 


\title{
Zacharias Gerganos in Wittenberg: New Findings and Considerations
}

\author{
Nikolas Pissis, Freie Universität Berlin
}

Communication between German Lutherans and Greek Orthodox in the Confessional Age generated neither particularly fruitful theological exchanges nor spectacular institutional rapprochements. Even the most distinguished of pertinent contacts, such as the correspondence between the Tübingen theologians and the Patriarch of Constantinople Ieremias II between 1573-1581 or the founding of the Collegium Orientale in Halle at the beginning of the eighteenth century produced no lasting results. As Steven Runciman aptly put it:

It is difficult to see how any real union between the Orthodox and Lutheran Churches could have been achieved. The Lutherans had not rid themselves of the superstitions of Rome in order to unite with a Church whose devotion to saints and images and monastic vows must have seemed quite as idolatrous. To the Orthodox the Lutherans seemed to combine certain Roman errors with an unsound evangelism and a regrettable taste for iconoclasm. The chief common-ground was a mutual dislike of the Papacy; and that was hardly a sufficient bond. ${ }^{1}$

And yet, from the point of view of a history of knowledge that seeks to trace movements of knowledge in latent, less manifest forms or in seemingly static historical situations, these ill-fated instances of cultural communication provide cases in point. Confessionalization treated primarily not as an all-encompassing social phenomenon, but as an epistemic process, i.e. stemming out of the need to provide authoritative answers to questions not hitherto asked, forms the context of such communication regardless of its eventual success. ${ }^{2}$ Viewed in these terms, clashes of mind and cultural misunderstandings such as those that characterize the Tübingen-Constantinople correspondence of the 1570s deserve special attention.

1 St. Runciman, The Great Church in Captivity. A Study of the Patriarchate of Constantinople from the Eve of the Turkish Conquest to the Greek War of Independence (Cambridge 1968) 257; cf. G. Hering, 'Orthodoxie und Protestantismus', in M. A. Stassinopoulou (ed.), Nostos. Gesammelte Schriften zur südosteuropäischen Geschichte (Frankfurt a.M. 1995) 73-130, here 130.

2 C. A. Zwierlein, 'Konfessionalisierung europäisch, global als epistemischer Prozess. Zu den Folgen der Reformation und zur Methodendiskussion', in Ch. Strohm (ed.), Reformation und Recht. Ein Beitrag zur Kontroverse um die Kulturwirkungen der Reformation (Tübingen 2017) 1-51; C. A. Zwierlein, Imperial Unknowns. The French and British in the Mediterranean, 1650-1750 (Cambridge 2016) 120, 124, 138. 
The Patriarch Ieremias and his assistants famously replied to the Lutheran correspondents under the constant pressure of the chaplain of the Imperial Habsburg embassy in Constantinople, Stephan Gerlach, with extensive patristic quotations, without really engaging in a genuine dialogue on the theological issues of the debate. ${ }^{3}$ This choice has been interpreted either as a sign of traditionalism and a lack of theological method and reflection; ${ }^{4}$ or as a genuine Orthodox, apophatic reply: an uncorrupted expression of a truly Orthodox standpoint. ${ }^{5}$ What is possibly underplayed in both of these views is that avoiding a direct answer or declining an interpretative proposal does not bring one back to the previous state of mind, as if the question had never been posed or heard. ${ }^{6}$ Similarly, repeating an old truth in a new, radically altered, context implies precisely a subtle, tacit movement of knowledge. The term 'iteration', in the sense of a combination of (and tension between) repetition and change describes this modality. ${ }^{7}$

The effects and the products of the cultural and epistemic encounter of Eastern and Western churches, such as the works of Zacharias Gerganos, that will be discussed in this paper, have usually been seen from an Orthodox viewpoint as regrettable if not embarrassing instances of an alienation of Orthodox consciousness. In the case of Gerganos, his main scholar, Asterios Argyriou, talks about a sly, treacherous alienation ('aliénation lavée et sournoise'), since it comes up disguised under an Orthodox cover. ${ }^{8}$ Elements of Western theology are thought to have 'crept into the theology of all Eastern Churches'. ${ }^{9}$ Using the mineralogical term of Oswald Spengler adopted by Georges Florovsky, this is described as a pseudomorphosis of

3 D. Wendebourg, Reformation und Orthodoxie. Der ökumenische Briefwechsel zwischen der Leitung der Württembergischen Kirche und Patriarch Jeremias II. von Konstantinopel in den Jahren 15731581 (Göttingen 1986); D. Wendebourg, 'Reformation und Orthodoxie. Das erste ökumenische Gespräch zwischen der evangelisch-lutherischen und der griechischen Kirche (1574-1581)', in D. Wendebourg, Die eine Christenheit auf Erde. Aufsätze zur Kirchen- und Ökumenegeschichte (Tübingen 2000) 95-115; V. N. Makrides, ‘Ohne Luther. Einige Überlegungen zum Fehlen eines Reformators im Orthodoxen Christentum', in H. Medick and P. Schmidt (eds), Luther zwischen den Kulturen. Zeitgenossenschaft-Weltwirkung (Göttingen 2004) 318-36, here 329-34.

4 G. Podskalsky, Griechische Theologie in der Zeit der Türkenherrschaft (1453-1821). Die Orthodoxie im Spannungsfeld der nachreformatorischen Konfessionen des Westens (Munich 1988) 109-14; G. Podskalsky, 'Die Kritik der lutherischen Theologie in der griechischen Orthodoxie vom 16. Jahrhundert bis in unsere Zeit-Ein geschichtlicher Überblick', Catholica 22 (1968) 193-206, here 200.

5 Chr. Yannaras, Orthodoxy and the West, transl. P. Chamberas and N. Russell (Brookline MA 2006) 71-4.

6 Wendebourg, Reformation, 402-4.

7 E. Cancik-Kirschbaum and A. Traninger, 'Institution-Iteration-Transfer. Zur Einführung', in eaed. (eds), Wissen in Bewegung. Institution-Iteration-Transfer [Episteme in Bewegung 1] (Wiesbaden 2015) 1-13.

8 A. Argyriou, 'Zacharie Gerganos et Jean-Mattheiu Caryophyllos: Un cas typique d'aliénation

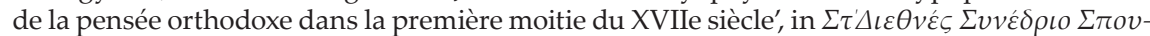

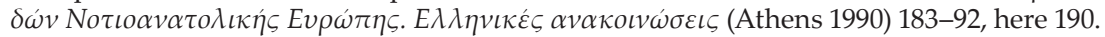

9 A. Despotis, 'Orthodox biblical exegesis in the early modern world (1450-1750)', in E. Cameron (ed.), The New Cambridge History of the Bible, III. From 1450 to 1750 (Cambridge 2016) 518-31, here 521 . This goes along with denying the significance of such an impact since 'these tenden- 
Eastern Christianity: the engagement with questions, terms and forms that were alien to its very nature, to its essence, or to its 'genius' in Florovsky's expression. ${ }^{10}$ However, the reading of these phenomena as a historical tragedy renders pointless the questions history of knowledge would be interested in: What kind of selective transfers are to be traced, which elements are adopted and which not and why, how has Orthodox dogma been demarcated and shaped, how are obvious alterations accommodated, what is the role of communicative contexts, of discursive practices, institutional constraints, personal agendas and political motivations?

Even if the mutual disillusionment of Lutherans and Orthodox regarding a potential union seems inescapable, initially both sides invested sincere hopes in each other. Apart from the political aspect that touches upon the series of Ottoman-Habsburg wars, ${ }^{11}$ the Lutherans searched in the imagined uncorrupted Christianity of the East for a source of legitimation and especially of arguments against the Catholics' accusations of novelties, heresies, and schism. ${ }^{12}$ The Orthodox, for their part, were pleasantly surprised to learn that 'Latin' Christianity no longer formed a unity under the Pope's primacy, but included a number of potential allies. Access to the Western world of learning and printing or to political and financial support would not necessarily entail being exposed to dogmatic concessions towards the Pope. Since the time of the Tübingen-Constantinople-correspondence and the various grecophile activities of Martin Crusius, numerous Greek ecclesiastics visited the Protestant German lands, either for alms-seeking or/and for educational purposes. ${ }^{13}$

cies [...] were vehemently condemned by the majority of Greek exegetes under Ottoman rule as well as by the Greek people and clergy', ibid., 527 .

10 G. Florovskij, 'Westliche Einflüsse in der russichen Theologie', Kyrios 2 (1937) 1-22, here 9, 12; cf. D. Wendebourg, 'Pseudomorphosis, ein theologisches Urteil als Axiom der kirchen- und theologiegeschichtlichen Forschung', in D. Wendebourg, Die eine Christenheit auf Erde. Aufsätze zur Kirchen- und Ökumenegeschichte (Tübingen 2000) 70-94.; K. Chr. Felmy, 'Die orthodoxe Theologie in der Begegnung mit westlichen Einflüssen. Zur Auseinandersetzung um die Theorie der westlichen Pseudomorphose der Orthodoxie', Ostkirchliche Studien 59 (2010) 8-27, here 9,12 .

11 D. Wendebourg, 'Standen politische Motive hinter dem Briefwechsel zwischen der Tübinger Theologischen Fakultät und Patriarch Jeremias II.?', Jahrbuch der Österreichischen Byzantinistik 32/6 (1982) 125-33.

12 A. Schunka, 'Orientinteressen und protestantische Einheit in der Frühen Neuzeit', in Y. Köse (ed.), Şehrâyîn. Die Welt der Osmanen, die Osmanen in der Welt. Wahrnehmungen, Begegnungen und Abgrenzungen. FS Hans Georg Majer (Wiesbaden 2012) 319-36, here 322, 327; St. Saracino, 'Griechisch-orthodoxe Almosenfahrer im Heiligen Römischen Reich und ihre wissensgeschichtliche Bedeutung (1650-1750)', in M. Friedrich and J. Schilling (eds), Praktiken frühneuzeitlicher Historiographie (Berlin 2019) 141-73; A. Ben-Tov, Lutheran Humanists and Greek Antiquity. Melanchthonian Scholarship between Universal History and Pedagogy (Leiden 2009) 116, 131.

13 G. Podskalsky, 'Die Deutschlandreise des Metrophanes Kritopulos (1624-1627) im Rahmen der deutsch-griechischen Beziehungen im 17. Jahrhundert', in E. Konstantinou (ed.), Nürnberg und das Griechentum: Geschichte und Gegenwart (Frankfurt a.M. 2003) 93-106; U. Moennig, ‘On Martin Crusius' Collection of Greek Vernacular and Religious Books', Byzantine and Modern Greek Studies 21 (1997) 40-78; R. Collis, 'Reconstructing the Ottoman Greek World: Early Mod- 
Existing research literature on Zacharias Gerganos provides sparse and contradictory information. ${ }^{14}$ The new findings that will be presented here-unknown published works of Gerganos-do not fill the many lacunae of his biography. According to his own testimony he was born in Arta, studied in Rome before-taking advantage of a scholarship from the Elector of Saxony, Johann Georg-he moved to the 'Zion' of Lutheranism, Wittenberg, ${ }^{15}$ probably in 1618. There he stayed until 1622, attending courses in 'disciplina theologica et humana' and perhaps also in natural philosophy, before returning to his native town. Out of the thin evidence on his subsequent fate, one could distill as the more probable version that he was invested with ecclesiastical officia under the metropolitan of Nafpaktos and Arta Gavriil, his patron, before 1626. Later he must have been elected bishop in one of the bishoprics of this metropolis, and he must have died around the winter of 1630/31. ${ }^{16}$

Gerganos' sojourn in Wittenberg, his activity there and the reaction it provoked belong to the context of the 1620s, a context determined by an escalation of the confessional confrontations in different fronts: The Thirty Years' War that had begun 1618 as the Bohemian war, the founding of the Congregatio de Propaganda Fide in 1622 and the affair of Loukaris only begin to mark out this context. Wittenberg in the early seventeenth century was one of the strongholds of 'Lutheran Orthodoxy'. Long reproached as unworthy epigones of Luther and Melanchthon and as 'narrow-minded confessionalists,'17 the theologians of this period fare better in contemporary research. ${ }^{18}$ Doctrinal theology, ecclesiology, biblical exegesis raised to a 'highly refined science, ${ }^{19}$ but no less so controversial dissociation from Catholicism, Calvinism and also Socinianism constituted the main focus of Wittenberg's theological faculty, the renowned Leucorea.

Of the several traces of Gerganos' activity in Wittenberg left in print, some are well-known, while others are hitherto unnoticed and absent from the standard

ern Ethnography in the Household of Martin Crusius', Renaissance Quarterly 72 (2019) 178-93; Ben Tov, Lutheran Humanists, 113-18.

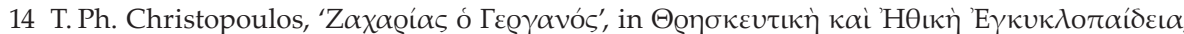

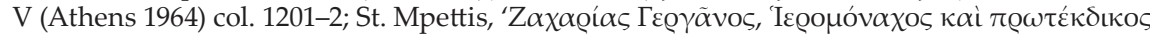

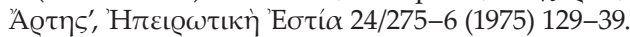

15 A. Ligniez, Das Wittenbergische Zion. Konstruktion von Heilsgeschichte in frühneuzeitlichen Jubelpredigten (Leipzig 2013).

16 V. Tsakiris, Die gedruckten griechischen Beichtbücher zur Zeit der Türkenherrschaft. Ihr kirchenpolitischer Entstehungszusammenhang und ihre Quellen (Berlin and New York 2009) 56 (mention of Gerganos' death in a letter of Neophytos Rodinos from March 1631).

17 K. Appold, 'Academic Life and Teaching in Post-Reformation Lutheranism', in R. Kolb (ed.), Lutheran Ecclesiastical Culture 1550-1675 (Leiden and Boston 2008) 65-115, here 66.

18 K. Appold, Orthodoxie als Konsensbildung. Das theologische Disputationswesen an der Universität Wittenberg zwischen 1570 und 1710 (Tübingen 2004); D. Bohnert, Wittenberger Universitätstheologie im frühen 17. Jahrhundert: eine Fallstudie zu Friedrich Balduin (1575-1627) (Tübingen 2017) 37-57.

19 Appold, 'Academic Life', 103. 
bibliographies. The first group consists of a New Testament edition ${ }^{20}$ and of Gerganos' Christian Catechism, ${ }^{21}$ both published in Wittenberg in 1622. The second comprises a treatise on the differences between Catholics and Orthodox, published in Wittenberg in 1618 in Latin and vernacular Greek as Dissertation 22 / Manual on Certain Controversies between Papists and Greeks. ${ }^{23}$ To these are added a Consolatory Sermon (1622) ${ }^{24}$ in the same idiosyncratic vernacular Greek as the Manual and the Catechism, Gerganos' participation as a respondent to a Latin disputation under professor Friedrich Balduin concerning the Pope's primacy (1622), ${ }^{25}$ as well as Latin and Greek epigrams Gerganos contributed to a dissertation in astronomy $(1620)^{26}$ and to an occasional celebratory publication (1620) respectively. ${ }^{27}$

Still, the available information on Gerganos appears full of riddles. His name is often given mistakenly as 'Gergános', although all his own self-references in manuscript and print form and most of his contemporaries follow the oxytone form 'Gerganós'. It was probably the Latin form 'Gerganus' that led to this confusion. ${ }^{28}$ There is also the peculiarity that Gerganos signs as a native of Arta (in Western mainland Greece) in the Greek front pages, prefaces and dedication letters of his works and as descending from Ithaca in the Latin ones. ${ }^{29}$ Whether this points to an additional ancestral line or serves simply to inspire connotations and links to Homeric topoi (which are readily taken over in the Greek and Latin epigrams

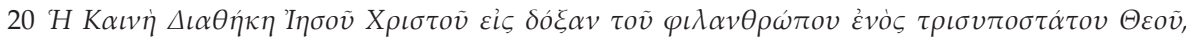

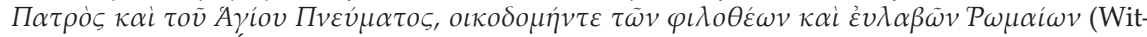
tenberg 1622), see É. Legrand, Bibliographie hellénique ou description raisonnée des ouvrages publiés par les Grecs au XVIIe siècle, I (Paris 1894) $155 f$.

21 Z. Gerganos, X

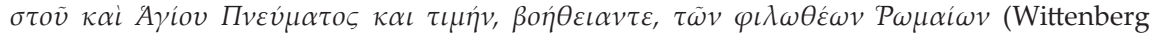
1622), see Legrand, Bibliographie, I, 159-70.

22 Z. Gerganos, Dissertatio de controversiis quae inter Papistas et Graecos agitantur: In qua utriusque Partiis argumenta breviter et candidè proponuntur; Antagonistarum autem Paralogismi dextrè refutantur (Wittenberg 1618).

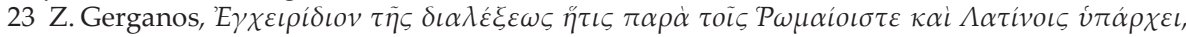

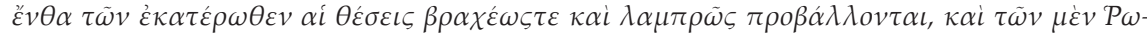

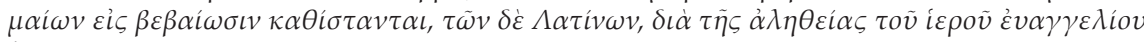

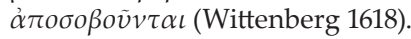

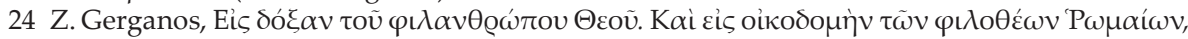

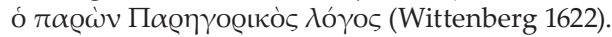

25 Fr. Balduin, Disputatio Ordinaria de Primatu Papae ecclesiastico Exercitii publici gratia proposita in inclyta Academia Wittebergensi ... respondente Zacharia Gergano Ithacensi N. Graeco. Habebitur oùv $\theta \varepsilon \tilde{\omega}$ horis locoque solitis a. d. 5. April (Wittenberg 1622).

26 J. Müller, Uranologia hoc est Dissertatio Physica de Coelo (Wittenberg 1622).

27 Calendae Nuptiales Avorum Prosapia nobilissimi ... (Wittenberg 1620). (Wedding of Margrave Johann Reibold and Anna Maria von Gabelentz). For all the above prints and the extant copies see in VD 17 (Verzeichnis der im deutschen Sprachraum erschienen Drucke des 17. Jahrhunderts) under 'Gerganus': http://www.vd17.de.

28 Only Erasmus Schmidt, professor of Greek and Mathematics in Wittenberg, calls him 'Gergános' in a Greek epigram in his honor, perhaps for reasons of metric (Jakob Martini and Johannes Campanus in similar epigrams call him 'Gerganós').

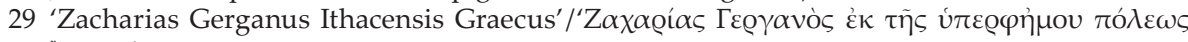
'Aoтns'. 
of his German friends) is not evident. Nonetheless, this can be understood in its symbolic dimension, as an oscillation between distinct communicative contexts and corresponding images of the self. Further, one can only speculate about the circumstances under which he left Rome and found his way to Wittenberg. A putative invitation by Prince Johann Georg is not recorded. More significant is the fact that he is not recorded in the registration books among the students of the faculty. ${ }^{30}$ This was likely due to confessional limitations, ${ }^{31}$ since Gerganos did not convert. As a rule, Princely scholarships covered four years of studies, ${ }^{32}$ which would fit with Gerganos' stay from 1618 to 1622 . In 1618 he is already 'alumnus Serenissimi Electoris Saxoniae', as he signs the Dissertation. However, in his dedication letter to the Elector in the Catechism (1622) he expresses gratitude for the biennial scholarship he was awarded. If this is accurate, there is no positive information about his revenues until at least spring 1622. We can only speculate as well that he was lodged at the 'Augusteum', the low-cost dormitory for scholarship students, where free meals were provided ('Gemeiner Tisch'). ${ }^{33}$ An archival piece, a letter by Gerganos and a certain Venediktos, a Cretan monk of the Holy Sepulchre, to the eminent Lutheran theologian Johann Gerhard in Jena, ${ }^{34}$ sent from Weimar expressing their gratitude for his assistance, is undated and apparently written by Venediktos. Not much more is known about two companions of Gerganos, Nikiforos from Thessaloniki, ex-bishop of Ierissos and a priest named Dimitrios from Agia (in Thessaly), mentioned by Gerganos in all his printed works in Wittenberg. ${ }^{35}$ Equally dubious is a later election to the metropolitan throne of Ioannina or Nafpaktos/Arta. It was in all likelihood later Protestant authors who conferred the title on him posthumously in order to enhance his status. ${ }^{36}$

30 D. Bohnert and M. Wried, Theologiae Alumni Vitebergenses (TAV). Die graduierten Absolventen der Wittenberger Theologischen Fakultät (1502-1648) (Leipzig 2020). Cf. https://www.civ-online. org/de/service/startseite/; http://digital.bibliothek.uni-halle.de/hd/content/titleinfo/2525576. I thank Dr. Daniel Bohnert and Mario Aschoff for their kind advices.

31 Bohnert, Universitätstheologie, 39.

32 Appold, 'Academic Life', 90.

33 Appold, 'Academic Life', 90.

34 St. Saracino, 'Leon Allatios' Entführung der Bibliotheca Palatina und weitere Selbstzeugnisse von Griechen über den Dreißigjährigen Krieg', Daphnis 47 (2019) 158-89, here 161f. The document is kept in: Nachlass Johann Ernst Gerhard, FB Gotha, Chart. A 600, f.345. I thank Dr. Stefano Saracino for sharing the document. On Gerhard, see G. K. Fuegge, Johann Gerhard (1582-1637) and the Conceptualization of Theologia at the Threshold of the 'Age of Orthodoxy'. The Making of the Theologian (Göttingen 2018).

35 At least Nikiforos is indeed recorded as bishop of Ierissos in 1622, M. I. Gedeon, П $\alpha \tau \rho \iota \alpha \rho-$

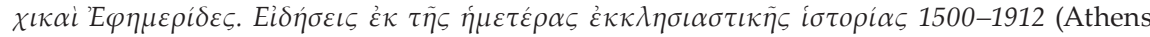
1935-1938) 521. In the New Testament edition, the two Greeks are named on the title page as financiers of the printing; in the Catechism as supporters of Gerganos and in the Consolatory Sermon as the ones who prompted Gerganos to compose it. According to the latter they were both deprived of their children by the Ottomans. Whether this refers to devshirme, kidnapping or simple conversion is not made clear. Nikiforos is said to have rescued his son and to have brought him to Wallachia, where the son died. $4 \mathrm{f}$.

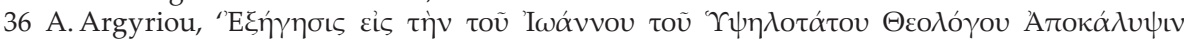


Finally, a last riddle concerns his actual level of education. It is obvious that he never attended a Greek school; his mastery of Greek grammar and orthography is rudimentary. His studies in Rome and Wittenberg, by contrast, indicate a solid training in Latin. He acknowledges as much himself when pointing to the paradox of his Greek (Orthodox) faith and Latin tongue (see below). His printed Latin texts are indeed faultless, but they could have been corrected by his German associates. Mastery of German was not a prerequisite for his studies in Wittenberg. Erasmus Schmidt (1570-1637), professor of Greek literature and Mathematics and one of Gerganos' instructors in Wittenberg, attached a prefatory statement in Greek and Latin to the vernacular Greek edition of Gerganos' Manual, informing the lenient reader that the 'mixobarbarous' language of the treatise is due to the author's choice and desire in favor of his compatriots and not to an alleged incapacity of the Wittenberg scholars to notice and correct its countless barbarisms. Schmidt had published a seminal work on the dialects of Greek, ${ }^{37}$ but his treatise does not indicate a mastery of the 'mixobarbarous' as well. At any rate he was a proponent of Reuchlin's pronunciation of Greek, i.e., the 'Modern Greek' pronunciation. One would probably not go far wrong to suppose that Schmidt contributed to the archaic Greek epigram Gerganos provided to the Calendae-publication in 1620.

Schmidt was in all likelihood also the actual editor of the New Testament; on

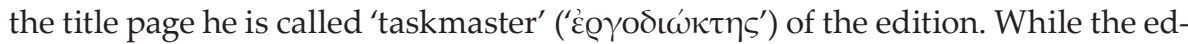
iting of the biblical text was thus only nominally attributed to the linguistically illequipped student, ${ }^{38}$ with Gerganos' Catechism, to quote Gerhard Podskalsky, 'for the first time we encounter Protestant-inspired teachings by a Greek put in print for a Greek audience. ${ }^{39}$ Nevertheless, a few adjustments concerning its confessional outlook are in order. To be sure, apart from adopting a Western confessional genre, which had little in common with earlier Byzantine instructive writings, ${ }^{40}$ he borrowed more than form and style from Lutheran models. Catechisms in Greek were common during the Confessional Age and Lutheran universities like Wittenberg were the main sites of their production. Alongside language teaching, indeed, they served propagandistic goals, primarily in the sense of demonstrating a linkage to the Christian origins and less in considering possible Greek readers-that is, Greek readers able to read the scholarly Attic Greek of the German

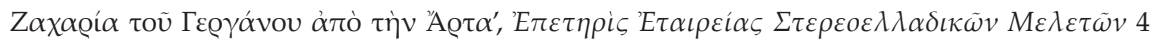
(1973) 367-400, here 370.

37 E. Schmidt, Tractatus de dialectis Graecorum principalibus, quae sunt in parte $\lambda \varepsilon ́ \xi \varepsilon \omega \varsigma$ (Wittenberg 1604).

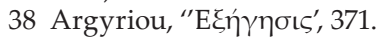

39 Podskalsky, Griechische Theologie, 160 (my translation).

40 R. Flogaus, Die griechischsprachige katechetische Literatur des 16. und 17. Jahrhunderts. Historische Einführung und Beschreibung ausgewählter reformatorischer Werke (Habilitation) (HU, Berlin

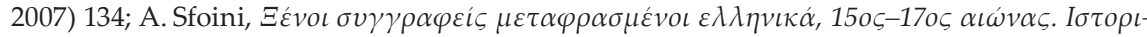
$\kappa \dot{~ \pi \rho о \sigma \varepsilon ́ \gamma \gamma \iota \sigma \eta ~ \tau o v ~ \varepsilon \lambda \lambda \eta v \iota \kappa o v ́ ~ \mu \varepsilon \tau \alpha \varphi \rho \alpha \sigma \tau \iota к о v ́ ~ \varphi \alpha \iota v o \mu \varepsilon ́ v o v ~(A t h e n s ~ 2003) ~ 59-61 . ~ F o r ~ f u r t h e r ~}$ bibliography on early modern catechisms, see the paper of Kostas Sarris in this volume. 
theologians. ${ }^{41}$ However, Gerganos' text is not a Lutheran Catechism rendered in vernacular Greek. An unbiased reading of the book, especially of its latter parts, does not justify such an exaggeration. In the main controversial points, it follows the demarcating lines of Orthodox positions with a fierce polemic outlook against Rome and the Papacy. It is true that the insistence on the preeminence of the Scripture in the introductory chapter, as well as on the need of the lay people to read it themselves, since the Scripture is its own exegete ${ }^{42}$, constitute obvious transfers from Lutheran theology. Nevertheless, they do not violate Orthodox dogma and with some good will (which was definitely lacking on all sides) they could be understood as efforts to accommodate Luther's core message-the return to the Scripture and to an idealized pure Christianity of the early Church-within an Orthodox dogmatic framework. Despite Ieremias' disapproval of his Lutheran correspondents' deprecation of Church tradition, the Orthodox Church had not yet developed a conclusive position towards the sola scriptura principle. ${ }^{43}$ Besides, Gerganos hastens to add that the Church Fathers are (in contrast to the Pope) legitimate exegetes; ${ }^{44}$ an opinion that itself was not necessarily discordant with Luther's exegetical principles. ${ }^{45}$ In any case it may be true that Orthodox theology was accustomed to relying primarily on patristic references both in defining dogma and in exegesis. Nevertheless, to regard patristic vs. biblical quotations as markers for an Orthodox or Protestant 'spirit', is perhaps to project concepts of twentieth-century Orthodox theologians back onto the Confessional Age.

On the other hand, the Orthodox markers, which increase from chapter to chapter alongside the patristic quotations, cannot always be reconciled with Lutheran principles: e.g. Gerganos' negation of the Filioque, his insistence on justification through good works additionally to faith or the defense of the veneration of the saints. Whereas the latter issue was not a particularly contested one, since it could be classified under the 'things indifferent' (adiaphora) to Lutherans, ${ }^{46}$ the case of the former two was quite the opposite. As a matter of fact, during Gerganos' stay in Wittenberg (March 1619), professor Friedrich Balduin held a disputation on the Procession of the Holy Spirit from the Father and the Son which explicitly refuted

41 Flogaus, Die griechischsprachige katechetische Literatur, 115-20, 131-4; Hering, 'Orthodoxie', 84.

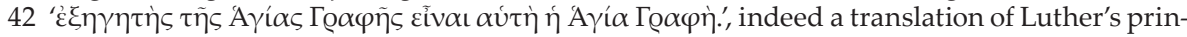
ciple: Scriptura sacra sui ipsius interpres, Gerganos, X

43 A. Tsalampouni, 'Sola scriptura. A Greek-Orthodox Perspective', in St. Alkier (ed.), Sola scriptura 1517-2017. Rekonstruktionen-Kritiken-Transformationen-Performanzen (Tübingen 2019) 343-58.

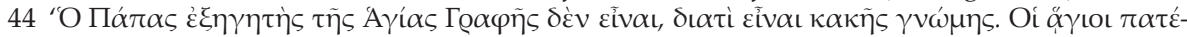

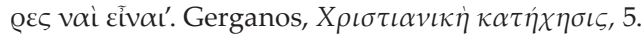

45 W. Mostert, 'Scriptura sacra sui ipsius interpres. Bemerkungen zum Verständnis der Heiligen Schrift durch Luther', Lutherjahrbuch 46 (1979) 60-95; D. Bohnert, 'Dogmatische oder biblische Bibelauslegung? Zur exegetischen und homiletischen Applikation des Schriftprinzips in der Wittenberger Universitätstheologie des frühen 17. Jahrhunderts', in St. Alkier (ed.), Sola scriptura 1517-2017. Rekonstruktionen-Kritiken-Transformationen-Performanzen (Tübingen 2019) 141-61.

46 M. Greengrass, The Longman Companion to the European Reformation, c. 1500-1618 (London and New York 1998) 241. 
the views of the 'Graeci recentiores'. ${ }^{47}$ In the next year (November 1620) he held a further disputation defending the Lutheran view on the limited significance of good works for salvation. ${ }^{48}$ Other statements in Gerganos' Catechism build on the common front of Orthodox and Lutherans against Rome, such as the communion 'in both kinds', the repudiation of the Purgatory and of the Papal Primacy, and last

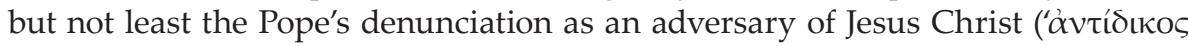

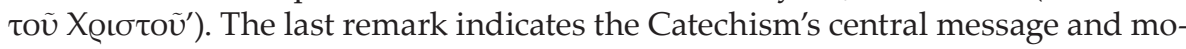
tive, a motive declared on the title page: to be a nail in the Pope's eye. ${ }^{49}$

In short, an interpretation of Gerganos' Catechism as 'more Lutheran than Orthodox, ${ }^{50}$ or a blend of Lutheran and Orthodox doctrines, ${ }^{51}$ designed to serve alleged missionary goals of the Wittenberg Lutherans in the Greek East ${ }^{52}$ is hardly convincing. We will return to the problematic of dealing with 'Lutheran' and 'Orthodox' in an essentialist sense in the concluding passages. In any case, the epigrams of the Wittenberg professors accompanying the Catechism, which praise Gerganos for illuminating his compatriots and call for the book to be distributed in the whole of Greece, testify rather to their anti-Catholic anxieties than some dubious Lutheran missionary projects in seventeenth-century Ottoman Empire. Gerganos' declaration to have left Rome and returned to Greece with an uncontaminated faith ('salve et incontaminata fide in Graeciam rediturus') and to a greater extent the anticipation that the 'Franks', that is, the 'Heretic-Schismatic-Papists' would react fiercely to his book, are more helpful for determining the publication's scope. Actually, Podskalsky's hypothesis that it might have been written as a response to the vernacular Greek edition of Bellarmini's Dottrina Christiana (1616) is plausible, even if we lack substantial evidence. ${ }^{53}$

Thus, it is less the dogmatic content of the book that caused its perhaps undeserved prominence in the seventeenth century, than the context of its appearance. The scandal it caused and the reaction it provoked among the Congregatio de Propaganda Fide had to do with the latter's state of alarm and its belief that it was fighting against a heretical Hydra with many heads but a single objective. As early as 1624 it was wrongly deemed either a work of Loukaris himself, an initiative of his, or was at least taken for granted that Loukaris had planned its mass circulation among the faithful. In the crucial council of November 1627, when the strategy against Loukaris was definitively drawn, measures pertaining to Gerganos'

47 Fr. Balduin, Disputationum theologicarum dodecas (Wittenberg 1619) (Disp. XI.: Disputatio de Processione Spiritus Sancti a Patre \& Filio [...] proposita ab Adriano Stoderto).

48 Fr. Balduin, Disputatio ordinaria de meritis bonorum operum ... respondente M. Levino Pouchenio, Regiomontano Borusso (Wittenberg 1620).

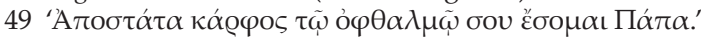

50 Runciman, The Great Church, 258.

51 Podskalsky, Griechische Theologie, 161.

52 Argyriou, 'Zacharie Gerganos et Jean-Mattheiu Caryophyllos', 187f., 191.

53 Podskalsky, Griechische Theologie, 161. The short version had been published in 1602 in translation by Ioannis Matthaios Karyofyllis and the large one in 1616, translated by Leonardos Philaras. See Tsakiris, Die gedruckten griechischen Beichtbücher, $193 \mathrm{f}$. 
Catechism had a prominent place. ${ }^{54}$ The Refutation composed by Ioannis Matthaios Karyofyllis ${ }^{55}$ and published in 1631 goes back to the decisions of this council-it is through this polemic that the name and the echo of Gerganos survived in the following decades. Karyofyllis' witticisms, ${ }^{56}$ are indeed inventive, but his critique is not always fair, e.g. his remarks on the Eucharist, where he distorts Gerganos' basically anti-Calvinist position (the real presence of Christ in flesh and blood) in order to prove his heresy. ${ }^{57}$ It seems that this indirect, refracted reception determined not only the opinions of later Catholic and Protestant authors of the eighteenth century, ${ }^{58}$ who had at their disposal only Karyofyllis' work, but also those of modern research, which tends to take a Protestant conspiracy and especially Gerganos' involvement with Loukaris for granted. ${ }^{59}$

Leaving aside the fact that Calvinists and Lutherans formed a single 'Luthero-Calvinist' block perhaps only in the eyes of the Propaganda fide and that no personal connections of Loukaris to Wittenberg are recorded, there is indeed evidence that Gerganos had no direct link to his supposed mentor as late as 1630. A recommendation letter by the Dutch ambassador Cornelis Haga addressed to the chaplain of the Dutch embassy Antoine Léger and carried by 'Sachario Gergiant, episcopo d'Etholia' contained instructions to enable the latter's access to an audience with Loukaris in Constantinople. ${ }^{60}$ That Gerganos counts Loukaris among the Orthodox martyrs in his 1622 preface to the Commentary on the Revelation neither implies their acquaintance nor Gerganos' Protestant tendencies. As indeed most of Loukaris' adherents, he probably supported the fierce opponent of the Jesuits and the pro-Catholic Orthodox prelates, not Loukaris' Calvinism.

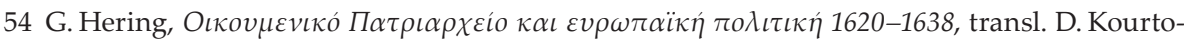
vik (Athens 1992) 115f., 137f., 164; O.-V. Olar, La Boutique du Théophile: les relations du patriarche de Constantinople Kyrillos Loukaris (1570-1638) avec la Réforme (Paris 2019) 167, 174.

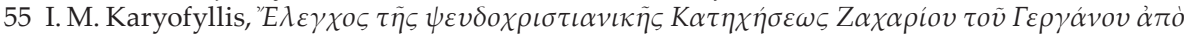
$\tau \eta \dot{v}$ 'A $\rho \tau \eta v / R e f u t a t i o$ Pseudochristianae Catechesis editae a Zacharia Gergano Graeco (Rome 1631); Flogaus, Die griechischsprachige katechetische Literatur, 32-5; Z. N. Tsirpanlis, 'Oi $\dot{\varepsilon} \lambda \lambda \eta v \iota k \dot{\varsigma} \varsigma \dot{\varepsilon} \kappa-$

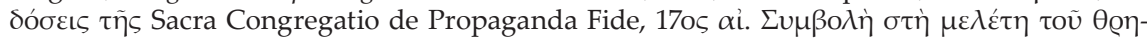

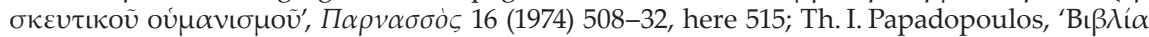

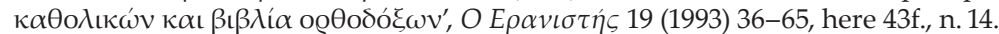

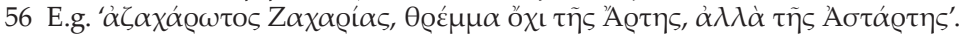

57 Karyofyllis, ’E $\lambda \varepsilon \gamma \chi 0 \varsigma, 119-37$.

58 M. Le Quien, Oriens Christianus, II (Paris 1740) 202; J. M. Heinnecius (Heinecke), Eigentliche und wahrhafftige Abbildung der alten und neuen Griechischen Kirche (Leipzig 1711) 229.

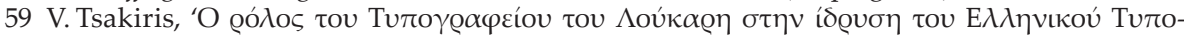

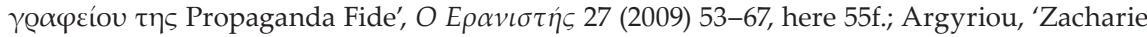
Gerganos et Jean-Mattheiu Caryophyllos', 19.

60 É. Legrand, Bibliographie hellénique ou description raisonnée des ouvrages publiés par les Grecs au XVIIe siècle, IV (Paris 1896) 392f.; Runciman, The Great Church, 272, n. 1, remarks correctly that there is no proof and not much probability that Gerganos was acquainted with Loukaris. Cf.

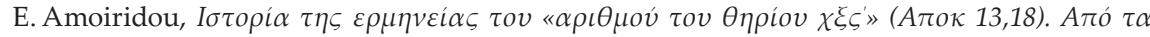

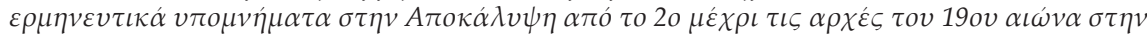

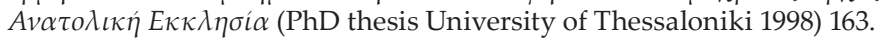


A comparison with the Confession of Faith composed in 1625 in Helmstedt by Mitrofanis Kritopoulos, ${ }^{61}$ who was certainly connected to Loukaris, is perhaps useful. Kritopoulos visited Wittenberg in July 1625, a few years after Zacharias had left it and engaged with more or less the same interlocutors such as Erasmus Schmidt and Jakob Martini, former professor of Logic and Metaphysic who had become Professor of Theology in 1623. Kritopoulos' Confession did not provoke the same kind of controversy as Gerganos' Catechism, not so much because it is indeed much more dispassionate and cautious, tempering the anti-papal polemic and eschewing any traces of Protestant teachings-after all it does attack the Pope and Rome-but mainly because it was published as late as 1661, so to speak post festum, long after the death of both the author and Loukaris. This was due to the plague catastrophe that inflicted Helmstedt immediately after Kritopoulos's departure from the town, not to the alleged displeasure of the Helmstedt theologians with the Confession. Besides, the contexts of the two contemporary works is not identical. Helmstedt was, in contrast to militant Wittenberg, a center of Irenic Protestantism and Georg Calixt, ${ }^{62}$ who hosted Kritopoulos in Helmstedt and prompted him to write the Confession, was the driving force behind the project of a unification of the rival Christian confessions. It is the same conciliatory spirit that permeates the preface of Herman Conring, a disciple of Calixt, to the edition of 1661. The conflict between the rigorous Lutheranism of the Wittenberg faculty and Helmstedt's moderate variant lasted for decades. It is doubtful whether Kritopou-

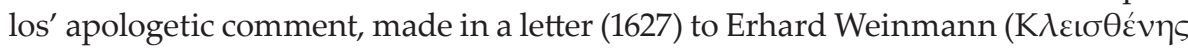

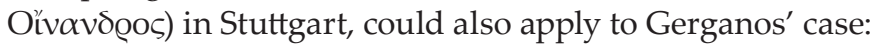

You must know that I could have published only those chapters which show our agreement with each other. But this would make the Papists suspect that we had secretly arranged to do just this. So it is better that some disagreements should appear as well. For when they see our agreement on the more essential points, they will know that the others can easily be healed. ${ }^{63}$

It would seem that Gerganos lacked Kritopoulos' prudence and sophistication. His overall theological reflections in the Catechism and in his further works do

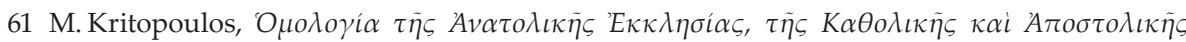
(Helmsetdt 1661); C. Davey, Pioneer for Unity. Metrophanes Kritopoulos (1589-1639) and Relations between the Orthodox, Roman Catholic and Reformed Churches (London 1987) 159-88; E. Hammerschmidt, 'Die Kirche in der Bekenntnisschrift des Metrophanes Kritopoulos', Kirche im Osten 6 (1963) 9-15.

62 J. Wallmann, 'Zwischen Reformation und Humanismus. Eigenart und Wirkungen Helmstedter Theologie unter besonderer Berücksichtigung Georg Calixts', Zeitschrift für Theologie und Kirche 74 (1977) 344-70; Podskalsky, 'Deutschlandreise', 98; Schunka, 'Orientinteressen', 3266.

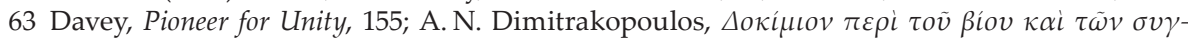

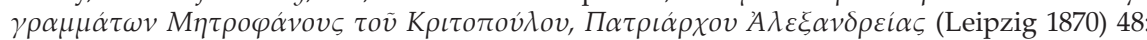

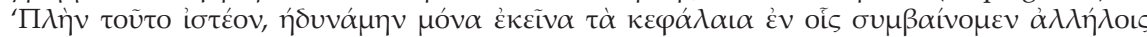

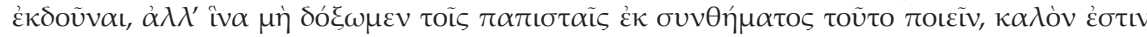

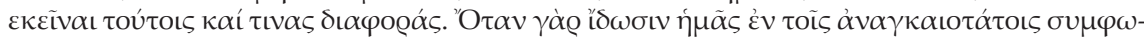

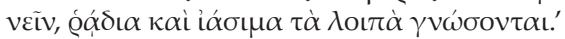




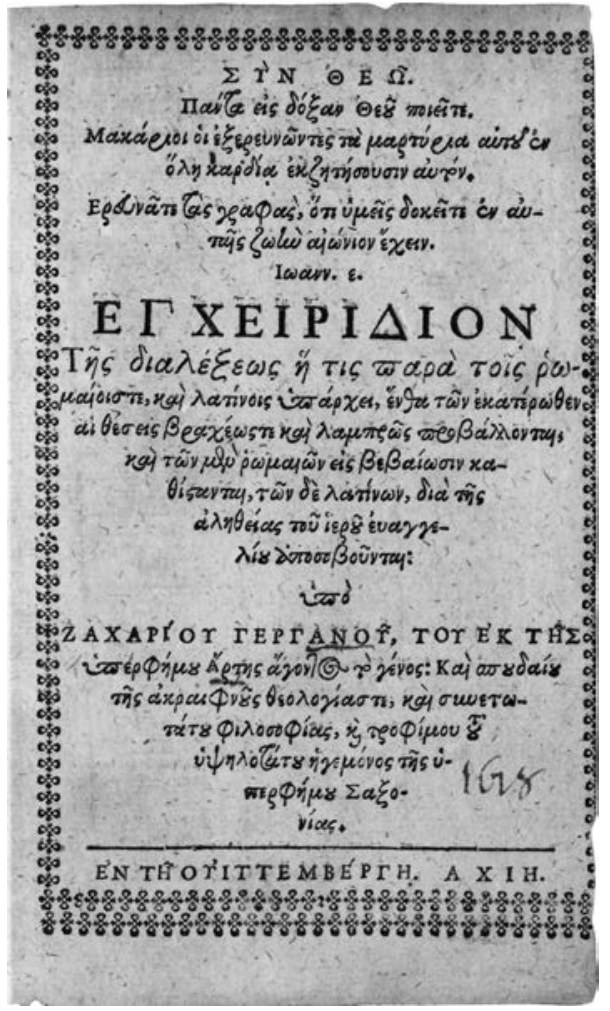

Fig. 1: Zacharias Gerganos, Encheiridion tis dialexeos ..., Wittenberg 1618

(Thüringer Universitäts- und Landesbibliothek, Jena). not really attain a high level of sophistication, even if the scorn of his confessional adversaries is prejudiced. In any case, it is not surprising that Erasmus Schmidt, who got to know both of them, noted in his private papers during Kritopoulos' sojourn in Wittenberg on the 10 July 1625: 'Of all those who have come to us from Greece, he is the most learned I have seen and heard. ${ }^{\prime 64}$ It seems likely that Gerganos' fierce anti-papal stance as stated in the dedication letter to the Elector, as well as in the Latin preface to the Catechism, constituted sufficient common ground to allow it to be approved for publication. In the words of the dean Balthasar Meisner and the professors of the faculty: Tractatum hunc theologicum, quem Zacharias Gerganus, Ithacensis Graecus, nostrae Academiae alumnus, in gratiam suorum popularium mixto-barbara hodiernorum Graecorum lingua conscripsit, legimus quo ad materialia approbavimus, ipsumque typis exscribi permisimus.

However, even before the publication of the Catechism Gerganos had already proven his credentials with his Dissertation on certain controversies between Catholics and Orthodox

(Latins and Greeks). ${ }^{65}$ In spite of its title, it is almost certain that this does not represent a formal dissertation for obtaining an academic grade, since all otherwise expected information is absent from the title page. ${ }^{66}$ It must be understood as a treatise-a manual, Encheiridion in the Greek edition-that focuses upon four contested issues: St. Peter's primacy amid the Apostles, the Pope's claim to

64 Davey, Pioneer for Unity, 191; Dimitrakopoulos, Aokílov, 14: 'omnium, quos ego quidem ex Graecia ad nos profeto vidi et audivi, doctissimus.'

65 The printing was funded by an eminent architect, sculptor and poet at the Saxonian court, the Italian convert Giovanni Maria Nosseri (1544-1620). A dedication letter in Latin addressed to Nosseri accompanies the Greek edition.

66 H. Marti, 'Dissertation', in Historisches Wörterbuch der Rhetorik, ed. G. Ueding, II (Tübingen 1994) col. 880-4; M. Gindhart et al., 'Einleitung', in Frühneuzeitliche Disputationen. Polyvalente Produktionsapparate gelehrten Wissens (Cologne-Weimar-Wien 2016) 7-24, here 9. 
be head of the Church, the Purgatory and the Eucharist. Each point is introduced through general remarks, followed by brief statements of the Papist

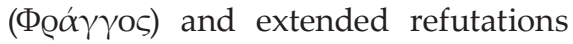

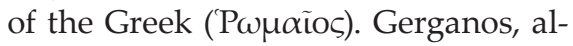

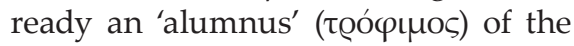
Elector and a student of Theology and Philosophy, calls his work a 'compendium', its Greek edition composed for the sake of Greek students studying the liberal arts. It is to the latter, those sailing on the sea of learning, that a poem extracted from the Gymnasmata linguae graecae of Matthaeus Dresser is addressed, concluding the Latin and the Greek editions. Gerganos already displays some knowledge of Hebraic as well as logic (syllogisms). Particularly interesting are his remarks on the problem of referring to the Fathers or to the Scripture alone: When the case is manifest in Scripture, there is no need to consult the Fathers; their opinion is required only in the case of passages hard to interpret. ${ }^{67} \mathrm{Howev}-$ er, the Fathers Gerganos quotes in the Dissertation are not only Eastern ones

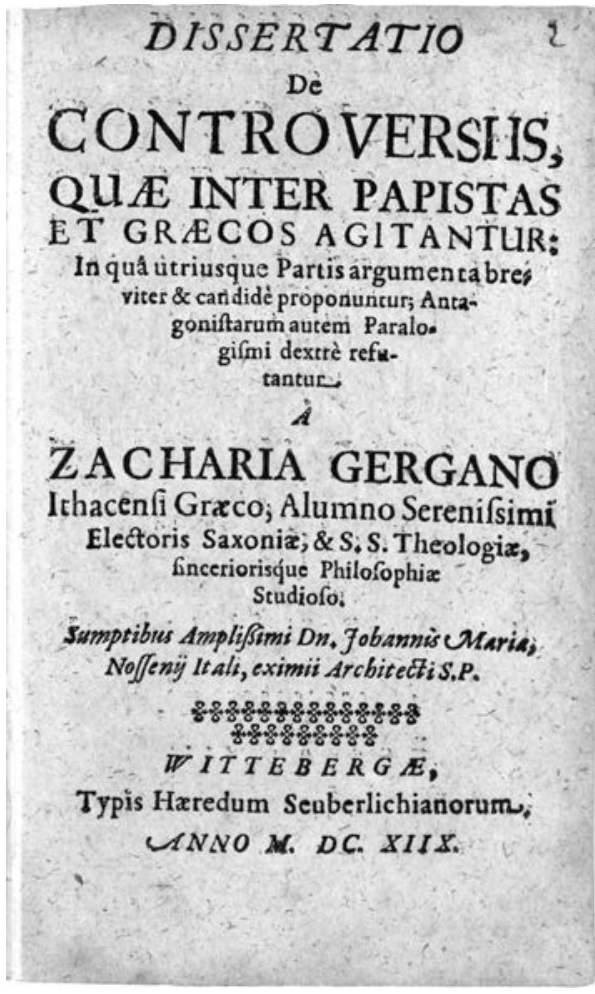

Fig. 2: Zacharias Gerganos, Dissertatio de controversiis ..., Wittenberg 1618

(Thüringer Universitäts- und Landesbibliothek, Jena). such as John Chrysostom, Gregory of

Nazianzus or John of Damascus, but also Latins ${ }^{68}$ such as 'eloquentissimus ille vir Dei Ambrosius' and especially 'magnus ille in divinis scriptis et augustus Pater Augustinus'.69 One may further notice certain formulations that point to the distinct addressees of the two versions, e.g. on the Last Supper, which 'we' ('nos Orthodoxi' added in the Latin one) call 'Mystic Supper'.70

Without doubt, it was on the basis of this work that Gerganos participated in the disputation on the Papal Primacy as a respondent at the side of the praeses et autor Friedrich Balduin. It was not unusual in early modern disputations to be composed by either the praeses or the respondens alone, but as a rule they were joint

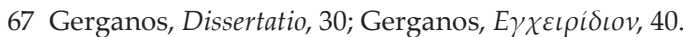

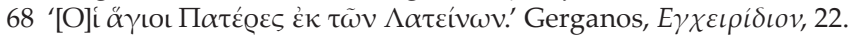

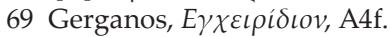

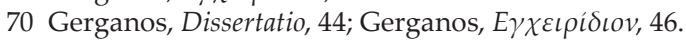


works. ${ }^{71}$ Whether Gerganos' part was indeed that prominent is doubtful, even if the Latin epigrams by the Wittenberg professors accompanying the disputation in print attest (in advance) to his brilliant performance. In any case, certain arguments of the Dissertation and Disputation appear to have informed the antipapal chapters of the Catechism, e.g., on the position of St. Peter as a vicarius Christi, or the interpretation of Matth 16:18 ('tu es petrus et super hanc petram aedificabo ecclesiam meam') and especially in calling its usage by Jesus 'metaphorical'. ${ }^{72}$

A more fundamental, albeit less obvious, aspect of knowledge transfer concerns Gerganos' confessional mental mapping. All his works address in their respective prefaces the Orthodox world as an imagined confessional unity. However, one may observe a gradual formation of this image. In 1618, the Dissertation refers only to the four Patriarchs of the Orthodox Church and the Manual adds the prelates, the monks, the archons and all the Faithful. Four years later, in 1622, in the Catechism and the Consolational Sermon Gerganos draws the outlines of a hierarchically structured community in faith: first, the Orthodox monarchs-the Muscovite tsar and the Georgian king-then the four patriarchs of the Eastern Church, ${ }^{73}$ followed by the princes of Wallachia and Moldavia, the metropolitans, bishops, priest-monks, abbots, priests, hierodiacons, monks as well as the laity of a geographical unity starting with Constantinople but comprising Greek, Slavic and Arab Orthodoxy, from Albania and Serbia to Trebizond, Egypt and Cyprus. This was not a self-evident, supposedly unaltered medieval image and concept, but one shaped by and formulated in the new context of the Confessional Age. The Western, especially Protestant perception of the Eastern Church as a distinct confession in a world of confessions had a crucial impact on its self-awareness both in terms of confessional contents and of Orthodoxy as a confessional block. ${ }^{74}$ It is out of this thinking in confessional blocks that Gerganos accuses the Pope of having ordered the murder of Prince Michael the Brave of Wallachia (1601) and of having instigated the Poles against the Muscovites (during the Muscovite 'Time of Troubles'). ${ }^{75}$

At the same time, this proclaimed Orthodox identity only complements a distinct Greek one that Gerganos operates with, especially when he presents himself to the German literati. Gerganos' laments about the double loss of wisdom and

71 H. Marti, 'Disputation', in Historisches Wörterbuch der Rhetorik, ed. G. Ueding, II (Tübingen 1994) col. 866-80. The actual communicative aspect of the disputation cannot be captured by the printed theses. See Appold, Orthodoxie, 55-60, 80-4 and passim for the importance of disputations as the central praxis of Wittenberg theology. On the disputations of Friedrich Balduin see Bohnert, Wittenberger Universitätstheologie, 163-8.

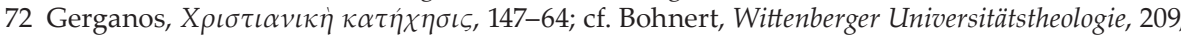
264f.; Bohnert, 'Dogmatische', 153f.

73 Gerganos' omission of the Muscovite Patriarch is not exceptional. Cf. N. Pissis, 'The Image of the Moscow Patriarchate in the Eastern Church: Status and Legitimacy', in K. M. Kain and D. Goldfrank (eds), Russia's Early Modern Orthodox Patriarchate, vol. 1: Foundations and Mitred Royalty, 1589-1647 (Washington and London 2020) 49-70.

74 Zwierlein, Imperial Unknowns, 124; N. Pissis, Russland in den politischen Vorstellungen der griechischen Kulturwelt (Göttingen 2020) 93-6.

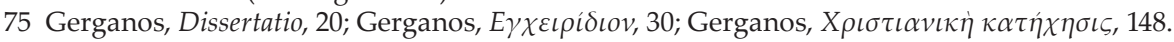


empire and about the decline of education in the sites of its former glory, especially in Athens, echo those of Theodosios Zygomalas addressed to Martin Crusius and indeed those of scores of Greek students in early modern Western courts and academies. However, regardless of communicative contexts, Gerganos' standard frame of reference in all his Latin and Greek writings, 'gens nostra Graeca' $/ \gamma \dot{\varepsilon}$ vos $\tau \tilde{\omega} v$ P $\mathrm{P} \omega \mu \alpha i \omega v^{\prime}$ ', retains an ambiguity that is incompatible with a modern neat separation of confessional and ethnic identities. In the preface to the Consolatory Sermon, he presents bishop Nikiforos and priest Dimitrios as being of Orthodox faith and of Greek (Roman) homeland. ${ }^{76}$ Nonetheless, confessional and ethnic/linguistic identifications overlap when he apologizes to the reader of the Commentary to the Revelation for his poor language, since despite being a Greek Orthodox in faith, he is a Latin in tongue, i.e., education. ${ }^{77}$ A special mention should be made of his reference, in the Latin dedicatory epistle of the Manual, to 'us, the modern Greeks' ('lingua, qua nos moderni Graeci utimus'), one of the earliest of its kind. ${ }^{78}$ If the self-references of the 'Ithacensis Graecus' recall the topoi of Greek learning and its decline, those of the 'noble of Arta' carry connotations equally relevant to the Lutheran milieu. The destiny of the Greek people is modelled upon that of the Jewish Chosen People. ${ }^{79}$ Although positioning the Empire, the Church or the own people in the center of the providential plan was as standard for Byzantine as it was for post-Byzantine theology of history, this constituted an affinity, an overlapping with contemporary notions of Chosen Peoples, abundant in Protestant Europe and no less so in German Lutheranism. ${ }^{80}$

It is in his Consolatory Sermon, where he addresses the 'sympatriotas meos', that this spirit acquires a central place. The text deals with the problem of theodicy, of God's permitting of evil; in the Greek case the urgent challenge posed by the rule of the Infidels over the Faithful. In his Latin dedication letter to members of the Saxonian courtly elite, Gerganos marks out the theological extract of the oration: God is not the originator of evil. He does not delight in men's sins. He permits the existence of evil and the sufferings of men in order to punish their ungratefulness and to test their faith. The Greeks' sufferings constitute an example for other peoples ('ut per Gentis nostrae Graecae, exemplum alias Gentes corrigeret'). This is the standard answer to the challenges of theodicy not only in the Greek Church under Ottoman rule, according to Heb 12, 6 ('because the Lord disciplines the one he loves, and he

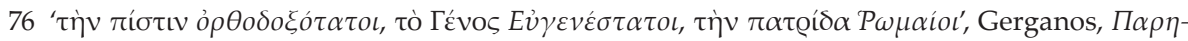

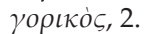

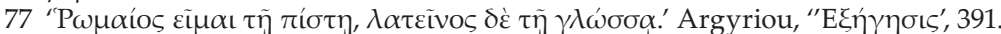

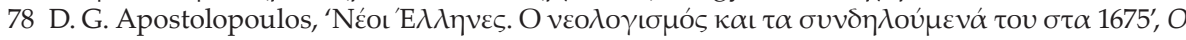

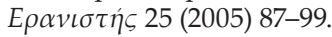

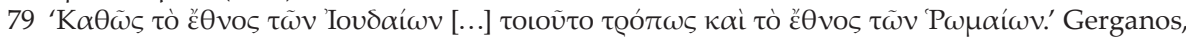

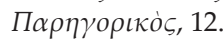

80 A. Mosser (ed.), Gottes auserwählte Völker. Erwählungsvorstellungen und kollektive Selbstfindung in der Geschichte (Frankfurt a.M. 2001). For the Germans as the Chosen People (due to the Reformation), see V. Leppin, Antichrist und Jüngster Tag. Das Profil apokalyptischer Flugschriftenpublizistik im deutschen Luthertum 1548-1618 (Gütersloh 1999) $235 \mathrm{f}$. 
chastens everyone he accepts as his son') and Rev 3, 19 ('Those whom I love I rebuke and discipline'), but of monotheistic religions in general. Gerganos' consolation unfolds across familiar arguments: we have lost the earthly kingdom only to receive the heavenly one; let the Papists rejoice on their earthly power, blessed are the persecuted; besides, the Turks torment only bodies, not the souls of the Faithful etc.

However, despite the commonplaces, the Sermon is of particular interest with regard to knowledge transfers from Lutheran literature. It seems that a key experience of Gerganos, and perhaps the decisive influence in his Wittenberg years, was his acquaintance with the Lutheran theology of history and apocalypticism, especially with regard to its unmasking of the Pope as the Antichrist. In the Sermon one encounters, next to this identification, the definition of the crucial event that signified the Antichrist's appearance in salvation history as well as the original sin that led to the Greeks' captivity under the Ottomans: the recognition of the Papal Primacy by the tyrannical emperor Phocas (602-610) granted to Pope Boniface III (607). For Gerganos, this must have been a moment of revelation. He highlights it in the Latin dedications and prefaces of both the Catechism and the Sermon and repeats it twice in the Sermon's Greek text: 'We have lost our Kingdom because the unlawful emperor Phocas bowed to the unlawful Pope. ${ }^{81}$ It might be that he first came across this discovery during the Disputation, where it is quoted in Chapter XVI as the foundation moment of the Papal primacy. ${ }^{82}$ That Gerganos was probably not the author of this passage is indicated by the fact that in both the Disputation and the Sermon it is followed by a reference to the Union Council of Ferrara/Florence (1438/1439). Nevertheless, while the Disputation gives the name of the Byzantine emperor attending the Council correctly as John Palaeologus, the Sermon confuses him with his father Manuel Palaeologus, whom it calls Emmanuel. ${ }^{83}$ Balduin had already referred to the Phocas-Boniface ominous association in his work De Antichristo (1607) ${ }^{84}$ which Gerganos might well have consulted.

Ioannis Matthaios Karyofyllis was actually accurate when in his attack on Gerganos he ascribed the latter's acquaintance with this argument to the reading of Protestant authors and not of Byzantine ones. ${ }^{85} \mathrm{He}$ was equally right in tracing the antinomies in Gerganos' argumentation: Was the Phocas argument merely an

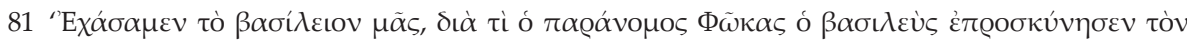

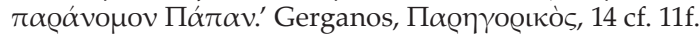

82 Balduin, Disputatio, ch. XVI: 'Bonifatii rogatu Phocas constituit, sedem Romanae et Apostolicae ecclesiae caput esse omnium Ecclesiarum'.

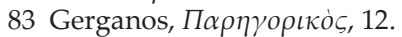

84 Fr. Balduin, Diatribe theologica de Antichristo in qua Papicolarum fabulae de utopico Antichristo ex immotis scripturarum divinarum oraculis, et subsecuto infalibili temporum eventu sufficienter refutantur (Wittenberg 1607) 29.

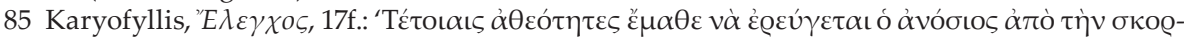

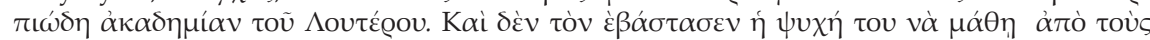

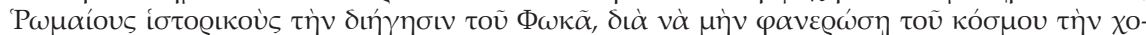

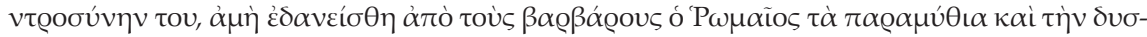

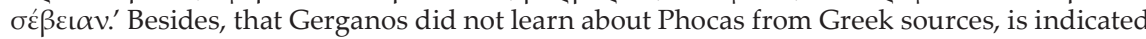
by the fact that he calls him Phócas instead of Phocás. 
excuse? Was it the sins of the kings and emperors or the faithlessness of the people that caused God's anger and chastisement, in the Old Testament as well as in the history of the Church?

The identification of Phocas as the actual creator of the Antichrist institution of the Papacy goes back to Luther himself. It later became a standard argument of Lutheran church historiography including the seminal Magdeburg Centuries the Disputation refers to. ${ }^{86}$ Its additional advantage of structuring time by locating the emergence of both heads of the double-headed Antichrist, Pope and Mohamed, or Papacy and Islam, at around the same time (the early seventh century) made it especially plausible. Greek exegetical commentaries of the Revelation in the eighteenth century readily adopted it. In the 1620s, among Gerganos' contemporaries, Christoforos Angelos dated the Apostasy of the Pope to the reign of Phocas, ${ }^{87}$ in doing so following the main currents of English apocalyptic literature, which also appropriated the argument.

Much more peculiar is an additional argument of Gerganos, presumably also inspired by readings in Wittenberg. In refuting Catholic accusations of the Greeks having been enslaved because of their separation from Rome, he argues once again in terms of confessional blocks. He lists the kingdoms the Papists had themselves lost after the Reformation such as England, Denmark, Sweden etc., which were 'of a different faith' in Gerganos' cautious formulation. This was a familiar argument, invoked in several variants by seminal Orthodox churchmen before and after Gerganos like the Patriarchs Meletios Pigas of Alexandria and Dositheos II of Jerusalem. But Gerganos goes on (admittedly contradicting his own hitherto argumentation) to downgrade the fall of Byzantium: 'We have lost our kingdom, which was the Third Monarchy, before Jesus Christ. The Hagarens received the Kingdom from the Franks, thus it is the Papists whose faith is corrupted!'s8 The standard Christian identification of the Roman/Byzantine Empire with the Fourth Empire in the Book of Daniel (Dan 2 and 7) ${ }^{89}$ was still self-evident for Greek (that is: Romans, 'Rhomaioi') scholars of the seventeenth century. But for Gerganos the ambiguities of pre-national collective identifications reserved an apparently pleasant realization: If the Latin books he may have consulted, e.g. Johan Sleidan's De

86 H. Preuß, Die Vorstellungen vom Antichrist im späteren Mittelalter, bei Luther und in der konfessionellen Polemik (Leipzig 1906) 159, 194f., 226f., 234-7, $245 \mathrm{f}$.

87 K. Garitsis, O X held a prominent place in Calvinist writings, especially in Johan Alsted's Cursus (1620) and Diatribe (1627) as a landmark in the periodization of Church history: H. Hotson, Paradise Postponed. Johann Heinrich Alsted and the Birth of Calvinist Millenarianism (Dordrecht 2000) 87-9.

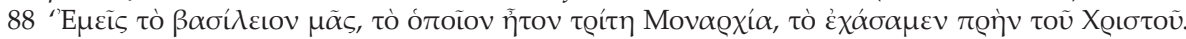

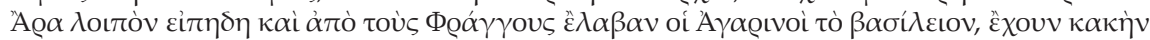

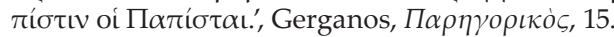

89 G. Podskalsky, Byzantinische Reichseschatologie. Die Periodisierung der Weltgeschichte in den Vier Grossreichen (Daniel 2 und 7) und dem Tausendjährigen Friedensreiche (Apok. 20). Eine motivgeschichtliche Untersuchung (Munich 1972). 
quator summis imperiis (1559) ${ }^{90}$ or indeed any Lutheran manual near at hand, referred to the Third Monarchy, the Monarchy of Alexander and his successors, as 'Monarchia Graeca' or 'Monarchia Graecorum', wasn't it plausible for the Graeci, the 'filotheoi Rhomaioi', to claim it and reverse the mockery of the Papists?

That is, both the traditional consolatory argument about God testing his beloved people as well as odd sophistries serve the same objective as the Catechism: to arm the Orthodox with arguments for replying to Catholic missionaries:

What can you answer [to the Third-Monarchy-argument, N.P.], you adorer of the Pope? You keep silent! [...] When a Papist tells you that you lost your kingdom because your faith is false, answer him: We do not err; and for these sufferings and torments God will award us His Kingdom in the afterlife. But you, heretic, are lying like the Devil and you err as the damned schismatic you are! Get thee hence, Satan and do not scandalize me! The Kingdom of God lies not in [earthly] glories and kingdoms, but in the Orthodox faith. ${ }^{91}$

As a matter of fact, it is the last work of Gerganos, which, once more according to Podskalsky, bears clearer traces of Protestant teachings: The Commentary on the Revelation of John, probably composed after his return to his native Arta during the year $1622 .{ }^{92}$ His autograph (Bodl. Laudanus gr. 77) (33 $^{3}$ survives in Oxford, where it ended up as part of the manuscript collection of the Archbishop of Canterbury and Chancellor of the Oxford University William Laud (1573-1645). Whether it was sent by Gerga-

90 I. Sleidanus, De quatuor summis imperiis libri tres (Leiden 1631 [1556]) 5 and passim; cf. M. Pohlig, Zwischen Gelehrsamkeit und konfessioneller Identitätsstiftung. Lutherische Kirchen- und Universalgeschichtsschreibung 1546-1617 (Tübingen 2007) 161-75.

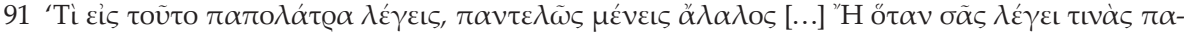

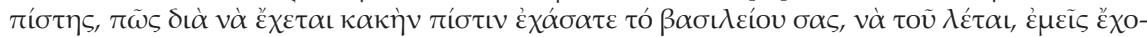

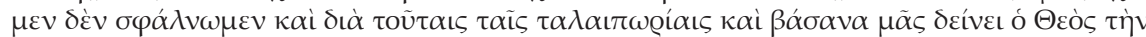

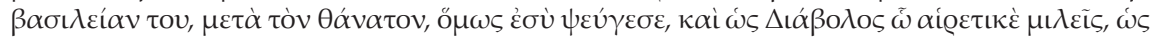

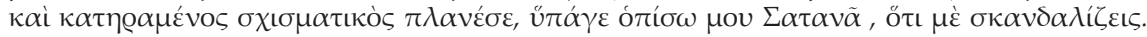

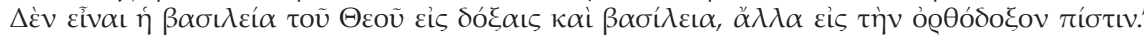

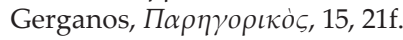

92 Since Gerganos must have had the Commentary of Maximos the Peloponnesian from the start at his disposal, Argyriou's conclusion that he started composing his own Commentary in Arta (the possibility that he carried it with him through all the years or that he accessed it while in Wittenberg is minimal) is reasonable. If the reference (in the preface) to the sufferings of patriarch Kyrillos Loukaris concerns the period of his dethronement and exile in 1622 (April to October) and if the reference to the ten sultans (Chapter 2) includes (beginning with Mehmed II) the reigning Osman II, who was murdered in May, 20 1622, Argyriou is right in dating the start of Gerganos' work to before the end of May 1622. However, we have to take into account that if he was indeed present at the Disputation with Friedrich Balduin, in April, 8 he was still in Wittenberg,

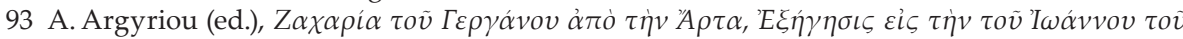

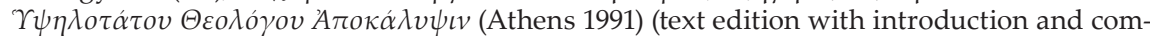
ments); A. Argyriou, Les exégèses grecques de l'Apocalypse à l'époque turque (1453-1821). Esquisse d'une histoire des courants idéologiques au sein du peuple grec asservi (Thessaloniki 1982) 158-218;

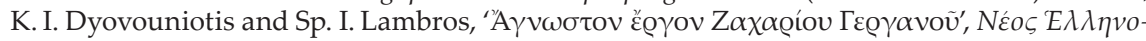
$\mu \nu \eta \dot{\mu} \omega v 15$ (1921) 127-31. 
nos to Nikodimos Metaxas, the person responsible for the printing house design of Loukaris, with the explicit purpose of being put in print, or Gerganos had simply obtained and read the Apostasy of Christoforos Angelos (London 1624) ${ }^{94}$ and decided in 1626 (his dedicatory epistle bears the date 20 August 1626) to revise and send his manuscript to London in order to be printed at the same printing house, is not clear, since we lack any pertinent information. William Laud, who acquired it in 1633, was on the one hand a natural address for the manuscript on account of his relations to the Orthodox Church. On the other hand, however, his opposition to confessional radicalism and especially to the virulent Papal Antichrist thesis (he licensed no books referring to the Pope as Antichrist) ${ }^{95}$ would make him less favorable to the works' stance and to a publication project, provided that he could gain access to its content.

The renewed interest in the Last Book of the New Testament in the early modern times forms part of what Caspar von Greyerz has called the 'confessionalization of apocalypticism'. ${ }^{96}$ In this context the different confessions displayed distinct attitudes towards its meaning and message, attitudes that implied also different temporalities: In terms of salvation history the Protestants, and especially the Lutherans, lived, as has been aptly observed, later than their Catholic contemporaries. ${ }^{97}$ Luther's 'unmasking' of the Pope, i.e. the institution of the papacy, as the Antichrist proper, and thus the realization that the unfolding of the apocalyptic script, the final countdown, had already begun, became a genuine Lutheran 'article of faith', practically undisputed until the mid-seventeenth century. ${ }^{98}$ Wittenberg was one of the main centers of this agitation. The hundred-year-anniversary of the Reformation in 1617, where Gerganos' later acquaintance Jacob Martini held an anti-papal speech, was marked by a unique

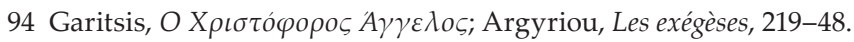

95 R. Zaller, The Discourse of Legitimacy in Early Modern England (Stanford 2007) 221f.

96 K. von Greyerz, 'Die Konfessionalisierung der Apokalyptik', in U. Fink and A. Schindler (eds), Zeitstruktur und Apokalyptik. Interdisziplinäre Betrachtungen zur Jahrtausendwende (Zurich 1999) 163-79. This can be understood both in the sense of an overwhelming presence of apocalyptic imagery and language in confessional polemics, which von Greyerz stresses, as well as the preponderance of confessional imperatives in apocalyptic exegesis.

97 A. Seifert, Der Rückzug der biblischen Prophetie von der Neueren Geschichte. Studien zur Geschichte der Reichstheologie des frühneuzeitlichen deutschen Protestantismus (Cologne and Wien 1990) 8; M. Pohlig 'Exegese und Historiographie. Lutherische Apokalypsekommentare als Kirchengeschichtsschreibung (1530-1618)', in Th. Kaufmann et al. (eds), Frühneuzeitliche Konfessionskulturen (Gütersloh 2008) 289-317.

98 Leppin, Antichrist, 45-50, 229, on apocalypticism as a 'movens' of Lutheran confessionalization 284; Pohlig 'Exegese und Historiographie', 289: Th. Kaufmann, 'Apokalyptische Deutung und politisches Denken im lutherischen Protestantismus in der Mitte des 16. Jahrhunderts', in A. Brendecke et al. (eds), Die Autorität der Zeit in der Frühen Neuzeit (Berlin 2007) 411-53, here 416f.; I. Richardsen-Friedrich, Antichrist-Polemik in der Zeit der Reformation und der Glaubenskämpfe bis Anfang des 17. Jahrhunderts. Argumentation, Form und Funktion (Frankfurt a.M. 2003) 141-9, 262-9; H.-J. Schönstädt, Antichrist, Weltheilsgeschehen und Gottes Werkzeug. Römische Kirche, Reformation und Luther im Spiegel des Reformationsjubiläums 1617 (Wiesbaden 1978) 106-34; Pohlig, Zwischen Gelehrsamkeit, 462. 
apocalyptic excitement. ${ }^{99}$ The instructions of the Elector Johann Georg for the anniversary particularly stressed the Papal Antichrist topos. ${ }^{100}$

All told, the significance of apocalypticism for the construction of Lutheran confessional identity that was pursued by Lutheran clerical elites can be hardly overstated. ${ }^{101}$ This proved to be the most attractive aspect of Lutheranism for the Greek Orthodox in terms of knowledge transfers. Apocalypticism, in particular the historical exegesis of the Revelation and the centrality of the Antichrist theme, constituted the most telling and most enduring affinity between Lutherans and Greek Orthodox, an affinity that was based on the mutual self-understanding and self-profiling of both confessional communities as a revival of the Early Church, the suffering Church of saints and martyrs. Besides, Lutheran and Greek Orthodox apocalyptic literatures shared the aversion towards millenarianism. The earliest pertinent transfers, though, are to be found in the field of art history. Scenes of the Revelation became a prominent topic in Orthodox iconography only in the Confessional Age as a result of the same process that initiated the apocalyptic commentaries. The wall paintings in the Athonite monastery Dionysiou (mid-sixteenth or early seventeenth century) derive their motives from the models of wood engravings of Hans Holbein the Younger and Lucas Cranach the Elder, and adapt their antipapal confessional propaganda. ${ }^{102}$ Similarly, Greek commentaries of the Revelation of John from the early seventeenth to the late nineteenth century owe a large part of their exegetical strategies, historical arguments and identifications to early modern Lutheran exegesis.

The modalities of this transfer, however, are far from plain and unambiguous. Instead, they represent an exemplary instance of the modalities of iteration and accommodation. It is true that the Lutheran concept of the Papal Antichrist inspired and guided Gerganos in the composition of his text-a text belonging to a novel, confessional genre. Nevertheless, Gerganos' work is based almost exclusively on the Commentary of the Revelation composed by Maximos the Peloponnesian up to two decades previously. He does not even use the original text of the Revelation, but only Maximos' vernacular translation. Maximos' commentary is itself a paraphrasis of the Byzantine commentaries of Andrew of Caesarea (563-637) and Arethas of Caesarea (c. 860-c. 939), the second itself being practically a reformulation of the first. Maximos adds only minor comments of his own and refuses any speculation about the fulfillment of the prophecies in his time or in the near future.

99 Th. Kaufmann, Geschichte der Reformation in Deutschland (Berlin 2009) 727-34; Schönstädt, Antichrist, 23f.

100 Bohnert, 'Dogmatische', 143, n. 7. For the increase in apocalyptic pamphlets in the Lutheran lands after 1610, see Leppin, Antichrist, 53, 291.

101 Leppin, Antichrist, 52, 281; Pohlig, Zwischen Gelehrsamkeit, 35-42.

102 L. H. Heydenreich, 'Der Apokalypsen-Zyklus im Athosgebiet und seine Beziehungen zur deutschen Bibelillustration der Reformation', Zeitschrift für Kunstgeschichte 8 (1939) 1-40;

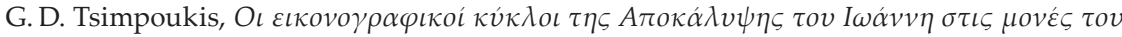
Ayíov Opovs (PhD Thesis) (National and Kapodistrian University of Athens, Athens 2012) 24-9, 319-21. 
But it is precisely this silence-in keeping with his Byzantine models-that in the context of its creation represents an unmistakable statement. Whether or not the commentary was written as a direct refutation of the views of Maximos' adversary Dionysios Filosofos or Skylosofos and his apocalyptically inspired revolts (in 1600 and 1611), ${ }_{1}^{103}$ the message of Maximos' work and probably its motivation consisted in the negation of any political actualization of the Revelation.

Although Gerganos takes over the structure and much of the exegetical text of Maximos, his approach is significantly different. He does speculate about the present and future identification of the apocalyptic figures and he at least partially advocates for a historical reading. The Revelation of John talks about the sufferings and the endurance of Gerganos' Greek Orthodox contemporaries, as for Lutheran exegetes it foretold the emergence of the Lutheran confessional community. ${ }^{104}$ The tone and the message of his Commentary, as in the Sermon, is a consolatory one: 'here the sufferings, there the award'. ${ }^{105}$ Gerganos more than once refers to his contemporary Ottoman context, e.g. to the overthrow and the execution of Sultan Osman II in $1622,{ }^{106}$ or to more or less constant features of the framework such as conversion to Islam and the so-called Crypto-Christians or the debasement of coinage. At Rev 2:10, when commenting on the 'ten days of tribulation', Gerganos identifies them with the ten Ottoman sultans from Mehmed the Conqueror to Osman II and deduces a proximate (though not calculated) Ottoman collapse. ${ }^{107}$ Gerganos' horizon of expectations does not seem to allow for an imperial restoration after Ottoman doom, as was the case in oracular tradition and in later exegesis. The imminent end of the sufferings and sorrows is a transcendent one; it is the End of Days:

'the pure and holy prayers of the Orthodox, taken by the holy angels to the [...] Living God; and they beg him together with the saints to bring the End of the World soon, so that the Orthodox will be freed from the Infidels' hands.' ${ }^{\prime 08}$

103 E. Gara, 'Prophecy, Rebellion, Suppression: Revisiting the Revolt of Dionysios the Philosopher in 1611', in Gr. Salinero et al. (eds), Paradigmes rebelles. Pratiques et cultures de la désobéissance à l'époque moderne (Brussels 2018) 335-63. Most likely, according to a scriber's note on the now missing Codex 605 of the Iviron monastery, Maximos composed his Commentary while in Alexandria (1598-1601). In earlier publications Argyriou opted for a dating

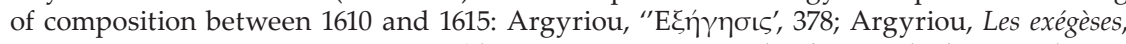

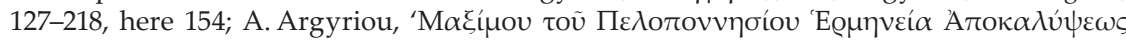

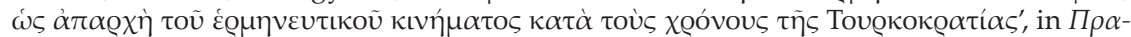

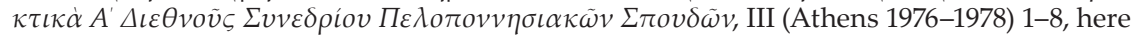
5; Argyriou, 'La Bible dans l'Orthodoxie grecque du XVII siècle', Revue des Sciences Reli-

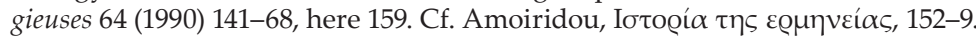

104 Pohlig, 'Exegese und Historiographie', 317.

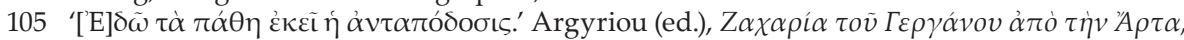

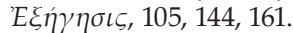

106 This indicates that this part of the Commentary was definitely composed after May 1622.

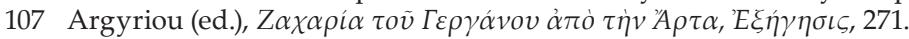

108 Ibid. 
Gerganos is convinced that his own days are the last. While Maximos cautiously formulates 'At the End, when the Antichrist appears ${ }^{109}$, this is rendered by Gerganos as 'At the End, which is now, when [i.e., since] the Antichrist is present'.110 However, the belief in the imminence of the End should not be interpreted in terms of a supposed pervasive apocalyptic anxiety or a distinct 'apocalyptical mentality'. One should rather take into account an interpretation of apocalypticism, and apocalyptic exegesis in particular, as a largely self-referential discourse instead of a mere discourse of crisis and not overstate the practical consequences of apocalyptic interpretations. ${ }^{111}$ The lack of exegetic consistency and the at times contradictory historical interpretations, a feature of Lutheran commentaries as well, fit into this understanding of apocalyptic exegesis. ${ }^{112}$

This becomes evident in the treatment of the papacy as an Antichrist institution, which despite the polemic stance, comes out in a rather confusing manner. Both beasts in Rev 13 represent different shapes of the Devil, while the Latin heretics together with the Jews and the Moslems are simply his instruments for torturing the Faithful. ${ }^{113}$ Gerganos consciously avoids attaching the term Antichrist to the Pope-whenever Arethas and Maximos talk of the future Antichrist, he frequently prefers to refer to the Devil and the Heretics (the Latins) ${ }^{114}$ and to avoid, as much as possible, the term Antichrist, which does not as such appear in the Book of Revelation anyway. The interpretation of the notorious number of the beast constitutes a revealing example of the significance of iteration as the movement of knowledge. Gerganos jubilantly quotes the beast's name 'Lateinos' (numerical value of $\Lambda \alpha \tau \varepsilon \tilde{\varepsilon}$ vos in the Greek alphabet amounts to 666) - an interpretation going back to the Church Fathers Irenaeus and Hippolytus, as referring to the Roman Empire, i.e. the still pagan Rome before Constantine's Conversion. He adopts the deciphering from Maximos and in his reading-as in Lutheran readings-this is further proof of the satanic quality of the Papacy. The new context provides the old interpretation with an entirely different meaning. However, Gerganos' reluctance to overstate his argument, a reluctance evident in the hesitant use of the Antichrist label, led him to cross out the 'Lateinos'-passage in his manuscript with publication in mind. Still, he did not modify or remove his explicit identification of the Pope with the 'red beast' in Rev 17:3. ${ }^{115}$

Neither does he follow consistently the Lutheran (precisely, Melanchthonian) concept of the dual Antichrist, Papacy and Islam or Pope and Mohammed/Sultan, which would become standard for later Greek exegetes. In the dedication

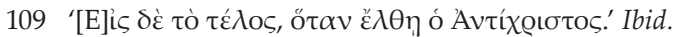

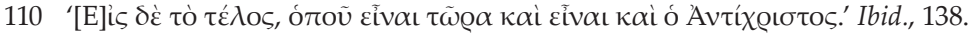

111 Pohlig, Zwischen Gelehrsamkeit, 463; Pohlig, 'Exegese', 292-4; Leppin, Antichrist, 44, 85f., 168, 262f., 278; Kaufmann, 'Apokalyptische Deutung', 418.

112 Pohlig 'Exegese und Historiographie', 315f.

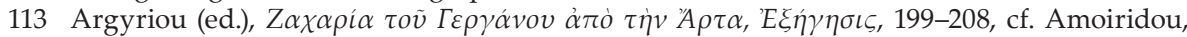

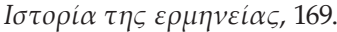

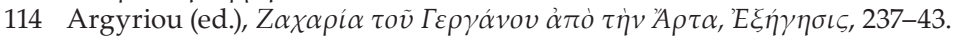

115 Ibid., 237. 
of his Manual to Nosseri (1618) he had reproached the two evils which the Devil unleashed against the Church: the Hagarens and the Papists, who tortured the Faithful through violence and through fraud respectively. ${ }^{116}$ In the Commentary his reference to the 'Hagarens' as evil forces is only passing, he identifies the apocalyptic peoples Gog and Magog (Rev 20:8) with the Hagarens and Tatars (269f) a standard interpretation. But then, in Rev 20: 9-10 they land in the 'lake of fire and brimstone' together with their (false) prophet Mohammed and the 'beast of Rome', the Pope. ${ }^{117}$

How are the transfers from Lutheran exegetical models in Gerganos' Commentary to be assessed? On the one hand he must reject the Lutheran principle he had accepted in his Catechism, that the Holy Scripture provides its own interpretation. The Revelation is, he warns, dark and hard to comprehend. The laymen need instruction. However, Luther had to admit as much himself in his preface to an edition of the Revelation. ${ }^{118}$ A quote from Jerome's epistles in the dedication letter of Gerganos ${ }^{119}$ is identical with the one in Luther's preface to the Revelation, as Evangelia Amoiridou has noticed. ${ }^{120}$ Gerganos certainly did not pattern himself on a single Lutheran commentary, although one cannot exclude the possibility of his having at his disposal his teachers, Friedrich Balduin's, De Antichristo or a commentary such as David Chytraeus' influential Explicatio Apocalypsis, which includes among other matches, Emperor Phocas, the 'Lateinos'-deciphering or the peculiar interpretation of the sun turning black and the moon as blood (Rev 6:12) as well as the overall spiritual interpretive framework blended with historical exegesis. ${ }^{121}$

On the other hand, in Gerganos' Commentary the Protestants constitute the third force of evil-doers: the schismatics (reversion of the usual argument) or those

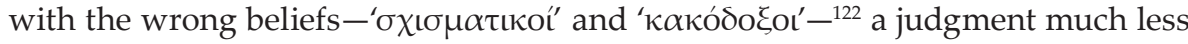
prominent and much less severe than the one on Latin and Moslems, but nevertheless an unmistakable distancing from their teachings. Furthermore, Gerganos'

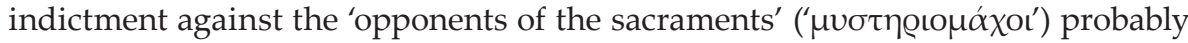
refers to the Calvinists and their Eucharist theology. ${ }^{123}$

Traces of knowledge transfer beyond the field of exegesis concern frequent references by Gerganos to natural philosophy, physical explications of apocalyptic images such as those on smoke, digestion, chemistry, meteorology or to the corre-

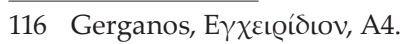

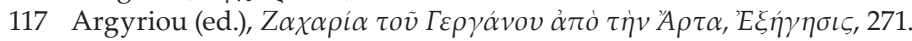

118 Pohlig, 'Exegese und Historiographie', 292.

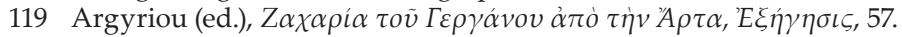

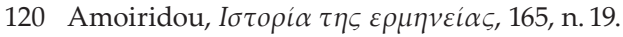

121 D. Chytraeus, Explicatio Apocalypsis Ioannis perspicua et brevis (Wittenberg 1564) 273. Cf. I. Backus, Reformation Readings of the Apocalypse. Geneva, Zurich, Wittenberg (Oxford 2000) 113-29.

122 To call the Catholics 'heretics' and the Protestants 'schismatics' constitutes a reversal of the standard Catholic usage (Heretics for the Protestants, Schismatics for the Eastern Orthodox).

123 Argyriou's conclusion that this cannot refer to the Protestants does not distinguish be-

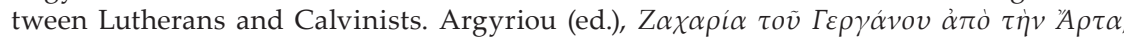

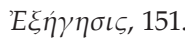


spondence of microcosm and macrocosm. ${ }^{124}$ One may recall Gerganos' contribution to the astronomical dissertation 1622 as well as the overall presence of astronomy in the Wittenberg curricula, with the result that astronomy's 'fruits frequently appear in theology of the period.'125 The same goes for Hebrew studies. They too may be traced in the Commentary, although he may have adopted the etymologies and explications of Hebrew words ${ }^{126}$ from Lutheran exegetes, such as Chytraeus.

Thus, the cardinal features adopted from Lutheran apocalypticism in Gerganos' Commentary consist in its temporalities (the impeding End), in the partial employment of historical application and, certainly, the demonization of confessional adversaries. On the other hand, the solipsistic view, the central role attributed to one's own confessional community constitutes a shared quality of Lutheran and Greek Orthodox apocalyptic imagination, rather than a transfer proper. However, it is certainly no coincidence that one encounters these elements in texts of Greek contemporaries of Gerganos in the 1620s. Christoforos Angelos and his identification of the Pope with the Apostate of the Revelation (he reserves the Antichrist label for Mohammed alone $)^{127}$ has already been mentioned. Mitrofanis Kritopoulos refers in the concluding chapter of his Confession (on the present state of the Eastern Church) to Mohammed as the Antichrist, the son of perdition who subjugated the Eastern Church. ${ }^{128}$ In his Grammar of Vernacular Greek (1627) he espouses the view that the Revelation of John describes the destinies of the Orthodox and their Churches. ${ }^{129}$ Kritopoulos is said to have composed also a Commentary on the Revelation that is no longer extant. ${ }^{130}$ Finally, Loukaris himself, had in 1618 referred to the papacy as the force of the Antichrist in a letter to Marco Antonio de Dominis, the ex-bishop of Split turned ferocious opponent of the Roman Chruch. ${ }^{131}$ There is no positive evidence on the circulation of Zacharias Gerganos' Commentary-Argyriou maintained that a century later, Anastasios Gordios, author of the most influential apocalyptic interpretation, must have read it, together with the commentaries of Maximos and Christoforos Angelos, but this is more than dubious. ${ }^{132}$ Be that as it may, Zacharias' work opens up a tradition of apocalypticism that will endure in Greek Orthodoxy up to the late nineteenth century.

124 Ibid., 66, 94, 168, 172f., 260.

125 Appold, 'Academic Life', 100.

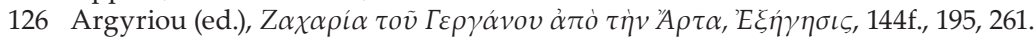

127 Garitsis, O X

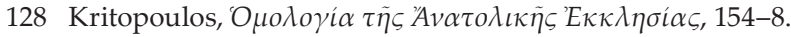

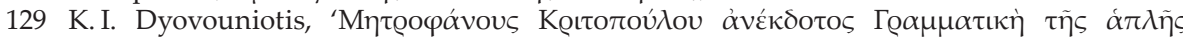

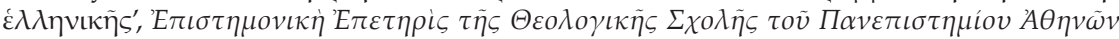
10 (1926) 97-123, here 122.

130 Argyriou, 'La Bible dans l'Orthodoxie', 162 but without a source reference.

131 Legrand, Bibliographie, IV, 329-40.

132 Argyriou, Les exégèses, 167, 305-54 (on Gordios); Podskalsky, Reichseschatologie, 63f.;

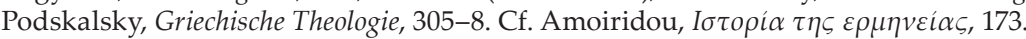


The works of Zacharias Gerganos as well as the context of his relations to the Wittenberg Lutherans neatly fit the label 'interconfessional'. It is in his quality as Greek Orthodox, not as Lutheran convert or an advocate of irenicism that he engaged in communication and exchange with his Lutheran interlocutors, both in presenting to them the differences between the Catholic and Orthodox Churches and in utilizing the Wittenberg press in order to address his fellow Greek Orthodox with a polemic as well as a consolatory message. This interconfessional communication can indeed be understood as having a reciprocal impact: on the one hand in fostering the Lutherans' arguments about the Greek Church being hostile to the Pope and in providing them with a convenient summary of Orthodox controversialist views; on the other hand, in transferring and accommodating in an Orthodox framework, elements of contemporary Lutheran theology and polemic.

However, what should complement such a reading is the contextual character of the confessional identities. Zacharias Gerganos belonged to those mobile actors (he called himself a 'peregrinus' ${ }^{\prime 33}$ ) of the Confessional Age who were acquainted with more than one of the opposing confessions and their argumentative arsenals ${ }^{134}$ and who positioned themselves consciously on this contested field. The dimensions (and the dialectics) of perceiving and representing the self and being perceived or ascribed an image by others-what German literature calls 'Selbst- und Fremdbeschreibung'-in the shaping of such a confessional profile can hardly be overstated. Gerganos was neither a weak-willed instrument of Lutheran propaganda, nor the selfless witness and servant of the Orthodox cause that he describes himself as being. Thus, the knowledge transfers that make up his work cannot be understood simply as compliance to the dictates of his Lutheran academic milieu (however 'indirect'135). Similarly, the Lutheran professors of Wittenberg could project on Gerganos notions of the Ecclesia Graeca and its fate that had a reassuring function for their own academic and confessional identities. An understanding of confessionalization processes as an epistemic phenomenon implies a recognition of the performative character of confessionalist discourses. In this sense, Gerganos operated in an epistemic field which was at the same time preset and in the making and it was in such a field that he endeavored to accommodate his own aspirations as well as the expectations of his hosts and to shape a confessional profile.

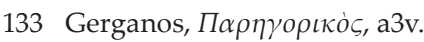

134 K. Bremer, 'Konversionalisierung statt Konfessionalisierung? Bekehrung, Bekenntnis und das Politische in der Frühen Neuzeit', in H. Jaumann (ed.), Diskurse der Gelehrtenkultur in der Frühen Neuzeit. Ein Handbuch (Berlin and New York 2010) 369-408, here 397f.

135 Podskalsky's comment (Griechische Theologie, 161, n. 665) is particularly puzzling: 'Überhaupt stellt sich die Frage, wieweit dem Schreiber [Gerganos N.P.] bei diesen Werken die Feder "geführt wurde", wenn auch indirekt von seinem Studienmilieu.' 


\section{Bibliography}

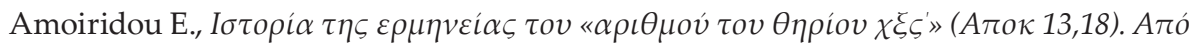

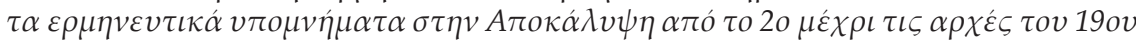

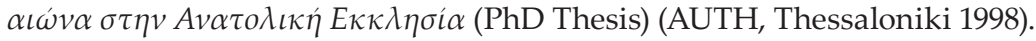

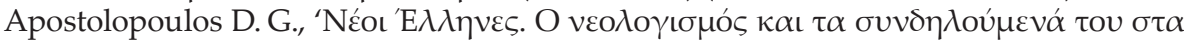

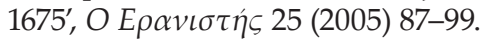

Appold K., Orthodoxie als Konsensbildung. Das theologische Disputationswesen an der Universität Wittenberg zwischen 1570 und 1710 (Tübingen 2004).

- 'Academic Life and Teaching in Post-Reformation Lutheranism', in R. Kolb (ed.), Lutheran Ecclesiastical Culture 1550-1675 (Leiden-Boston 2008) 65-115.

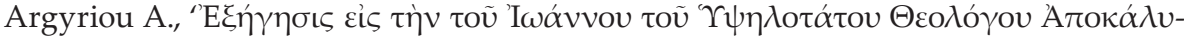

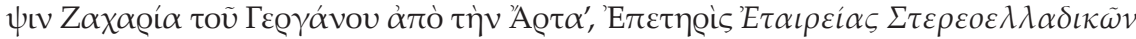

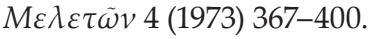

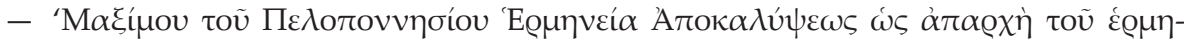

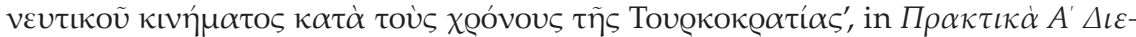

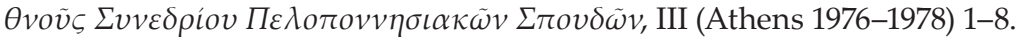

- Les exégèses grecques de l'A pocalypse à l'époque turque (1453-1821). Esquisse d'une histoire des courants idéologiques au sein du peuple grec asservi (Thessaloniki 1982).

- 'La Bible dans l'Orthodoxie grecque du XVII siècle', Revue des Sciences Religieuses 64 (1990) 141-68.

- 'Zacharie Gerganos et Jean-Mattheiu Caryophyllos: Un cas typique d'aliénation de

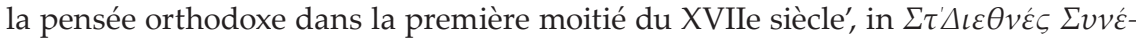

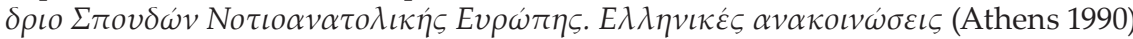
183-92.

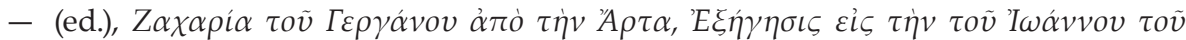

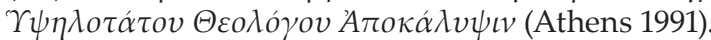

Backus I., Reformation Readings of the Apocalypse. Geneva, Zurich, Wittenberg (Oxford 2000).

Balduin Fr., Diatribe theologica de Antichristo in qua Papicolarum fabulae de utopico Antichristo ex immotis scripturarum divinarum oraculis, et subsecuto infalibili temporum eventu sufficienter refutantur (Wittenberg 1607).

- Disputationum theologicarum dodecas (Wittenberg 1619).

- Disputatio ordinaria de meritis bonorum operum ... respondente M. Levino Pouchenio, Regiomontano Borusso (Wittenberg 1620).

- Disputatio Ordinaria de Primatu Papae ecclesiastico Exercitii publici gratia proposita in inclyta Academia Wittebergensi ... respondente Zacharia Gergano Ithacensi N. Graeco. Habebitur oùv $\theta \varepsilon \tilde{\omega}$ horis locoque solitis a. d. 5. April (Wittenberg 1622).

Ben-Tov A., Lutheran Humanists and Greek Antiquity. Melanchthonian Scholarship between Universal History and Pedagogy (Leiden 2009).

Bohnert D., Wittenberger Universitätstheologie im frühen 17. Jahrhundert: eine Fallstudie zu Friedrich Balduin (1575-1627) (Tübingen 2017).

- 'Dogmatische oder biblische Bibelauslegung? Zur exegetischen und homiletischen Applikation des Schriftprinzips in der Wittenberger Universitätstheologie des frühen 17. Jahrhunderts', in St. Alkier (ed.), Sola scriptura 1517-2017. Rekonstruktionen-Kritiken - Transformationen - Performanzen (Tübingen 2019) 141-61.

- and Wried M., Theologiae Alumni Vitebergenses (TAV). Die graduierten Absolventen der Wittenberger Theologischen Fakultät (1502-1648) (Leipzig 2020). 
Bremer K., 'Konversionalisierung statt Konfessionalisierung? Bekehrung, Bekenntnis und das Politische in der Frühen Neuzeit', in H. Jaumann (ed.), Diskurse der Gelehrtenkultur in der Frühen Neuzeit. Ein Handbuch (Berlin-New York 2010) 369-408.

Calendae Nuptiales Avorum Prosapia nobilissimi ... (Wittenberg 1620).

Cancik-Kirschbaum E. and Traninger A., 'Institution-Iteration-Transfer. Zur Einführung', in E. Cancik-Kirschbaum and A. Traninger (eds), Wissen in Bewegung. Institution-Iteration-Transfer [Episteme in Bewegung 1] (Wiesbaden 2015) 1-13.

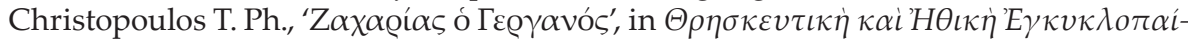
$\delta \varepsilon \iota \alpha, \mathrm{V}$ (Athens 1964) col. 1201-2.

Chytraeus D., Explicatio Apocalypsis Ioannis perspicua et brevis (Wittenberg 1564).

Collis R., 'Reconstructing the Ottoman Greek World: Early Modern Ethnography in the Household of Martin Crusius', Renaissance Quarterly 72 (2019) 178-93.

Davey C., Pioneer for Unity. Metrophanes Kritopoulos (1589-1639) and Relations between the Orthodox, Roman Catholic and Reformed Churches (London 1987).

Despotis A., 'Orthodox biblical exegesis in the early modern world (1450-1750)', in E. Cameron (ed.), The New Cambridge History of the Bible, III. From 1450 to 1750 (Cambridge 2016) 518-31.

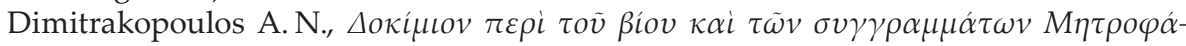

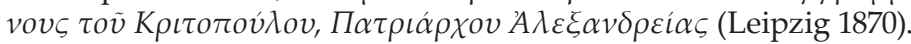

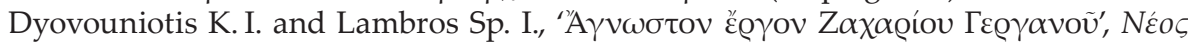

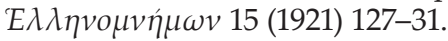

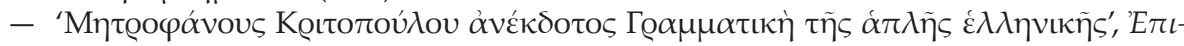

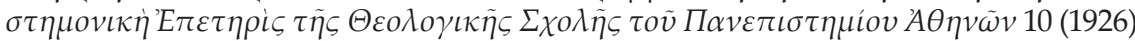
97-123.

Felmy K. Chr., 'Die orthodoxe Theologie in der Begegnung mit westlichen Einflüssen. Zur Auseinandersetzung um die Theorie der westlichen Pseudomorphose der Orthodoxie', Ostkirchliche Studien 59 (2010) 8-27.

Flogaus R., Die griechischsprachige katechetische Literatur des 16. und 17. Jahrhunderts. Historische Einführung und Beschreibung ausgewählter reformatorischer Werke (Habilitation) (HU, Berlin 2007).

Florovskij G., 'Westliche Einflüsse in der russichen Theologie', Kyrios 2 (1937) 1-22.

Fuegge G. K., Johann Gerhard (1582-1637) and the Conceptualization of Theologia at the Threshold of the 'Age of Orthodoxy'. The Making of the Theologian (Göttingen 2018).

Gara E., 'Prophecy, Rebellion, Suppression: Revisiting the Revolt of Dionysios the Philosopher in 1611', in Gr. Salinero et al. (eds), Paradigmes rebelles. Pratiques et cultures de la désobéissance à l'époque moderne (Brussels 2018) 335-63.

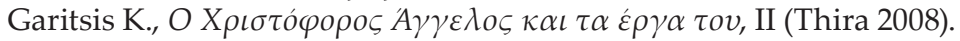

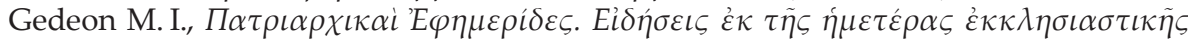

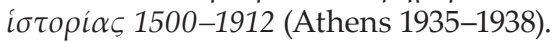

Gerganos Z., Dissertatio de controversiis quae inter Papistas et Graecos agitantur: In qua utriusque Partiis argumenta breviter et candidè proponuntur; Antagonistarum autem Paralogismi dextrè refutantur (Wittenberg 1618).

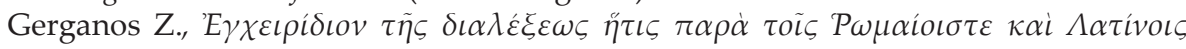

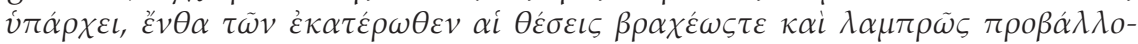

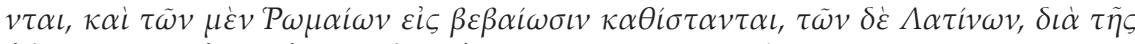

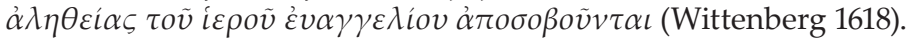




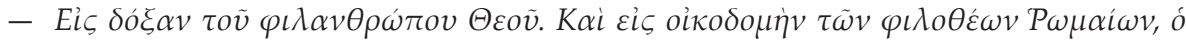

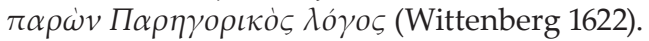

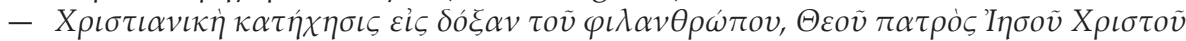

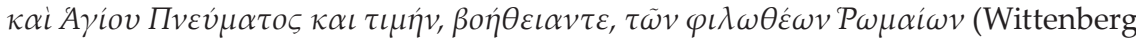
1622).

Gindhart M. et al., 'Einleitung', in Frühneuzeitliche Disputationen. Polyvalente Produktionsapparate gelehrten Wissens (Cologne-Weimar-Wien 2016) 7-24.

Greengrass M., The Longman Companion to the European Reformation, c. 1500-1618 (London-New York 1998).

Greyerz K. von, 'Die Konfessionalisierung der Apokalyptik', in U. Fink and A. Schindler (eds), Zeitstruktur und Apokalyptik. Interdisziplinäre Betrachtungen zur Jahrtausendwende (Zurich 1999) 163-79.

Hammerschmidt E., 'Die Kirche in der Bekenntnisschrift des Metrophanes Kritopoulos', Kirche im Osten 6 (1963) 9-15.

Heinnecius (Heinecke) J. M., Eigentliche und wahrhafftige Abbildung der alten und neuen Griechischen Kirche (Leipzig 1711).

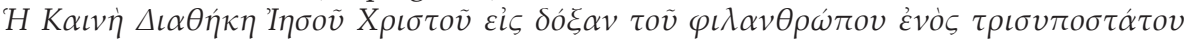

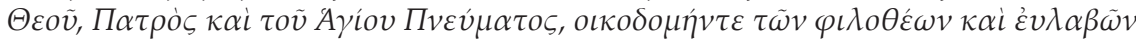

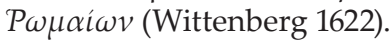

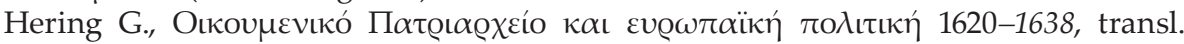
D. Kourtovik (Athens 1992).

- 'Orthodoxie und Protestantismus', in M. A. Stassinopoulou (ed.), Nostos. Gesammelte Schriften zur südosteuropäischen Geschichte (Frankfurt a.M. 1995) 73-130.

Heydenreich L. H., ‘Der Apokalypsen-Zyklus im Athosgebiet und seine Beziehungen zur deutschen Bibelillustration der Reformation', Zeitschrift für Kunstgeschichte 8 (1939) 1-40.

Hotson H., Paradise Postponed. Johann Heinrich Alsted and the Birth of Calvinist Millenarianism (Dordrecht 2000).

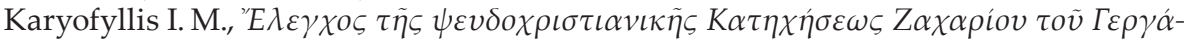
vov ảmò $\tau \eta \dot{v}$ 'A $\rho \tau \eta v / R e f u t a t i o$ Pseudochristianae Catechesis editae a zacharia Gergano Graeco (Rome 1631).

Kaufmann Th., 'Apokalyptische Deutung und politisches Denken im lutherischen Protestantismus in der Mitte des 16. Jahrhunderts', in A. Brendecke et al. (eds), Die Autorität der Zeit in der Frühen Neuzeit (Berlin 2007) 411-53.

- Geschichte der Reformation in Deutschland (Berlin 2009).

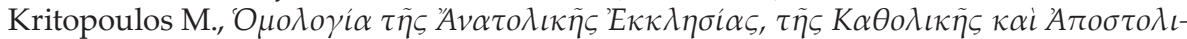
$\kappa \tilde{\eta} \varsigma$ (Helmstedt 1661).

Legrand É., Bibliographie hellénique ou description raisonnée des ouvrages publiés par les Grecs au XVIIe siècle, 5 vols (Paris 1894-1903).

Leppin V., Antichrist und Jüngster Tag. Das Profil apokalyptischer Flugschriftenpublizistik im deutschen Luthertum 1548-1618 (Gütersloh 1999).

Le Quien M., Oriens Christianus, II (Paris 1740).

Ligniez A., Das Wittenbergische Zion. Konstruktion von Heilsgeschichte in frühneuzeitlichen Jubelpredigten (Leipzig 2013).

Makrides V. N., ‘Ohne Luther. Einige Überlegungen zum Fehlen eines Reformators im Orthodoxen Christentum', in H. Medick and P. Schmidt (eds), Luther zwischen den Kulturen. Zeitgenossenschaft-Weltwirkung (Göttingen 2004) 318-36. 
Marti H., 'Disputation', in Historisches Wörterbuch der Rhetorik, ed. G. Ueding, II (Tübingen 1994) col. 866-80.

- 'Dissertation', in Historisches Wörterbuch der Rhetorik, ed. G. Ueding, II (Tübingen 1994) col. 880-4.

Moennig U., 'On Martin Crusius' Collection of Greek Vernacular and Religious Books', Byzantine and Modern Greek Studies 21 (1997) 40-78.

Mosser A. (ed.), Gottes auserwählte Völker. Erwählungsvorstellungen und kollektive Selbstfindung in der Geschichte (Frankfurt a.M. 2001).

Mostert W.,'Scriptura sacra sui ipsius interpres. Bemerkungen zum Verständnis der Heiligen Schrift durch Luther', Lutherjahrbuch 46 (1979) 60-95.

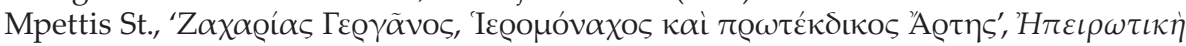

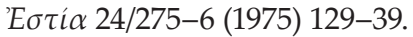

Müller J., Uranologia hoc est Dissertatio Physica de Coelo (Wittenberg 1622).

Olar O.-V., La Boutique du Théophile : les relations du patriarche de Constantinople Kyrillos Loukaris (1570-1638) avec la Réforme (Paris 2019).

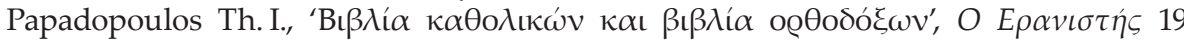
(1993) 36-65.

Pissis N., 'The Image of the Moscow Patriarchate in the Eastern Church: Status and Legitimacy', in K. M. Kain and D. Goldfrank (eds), Russia's Early Modern Orthodox Patriarchate, I. Foundations and Mitred Royalty, 1589-1647 (Washington-London 2020) 49-70.

- Russland in den politischen Vorstellungen der griechischen Kulturwelt (Göttingen 2020).

Podskalsky G., 'Die Kritik der lutherischen Theologie in der griechischen Orthodoxie vom 16. Jahrhundert bis in unsere Zeit- Ein geschichtlicher Überblick', Catholica 22 (1968) 193-206.

- Byzantinische Reichseschatologie. Die Periodisierung der Weltgeschichte in den Vier Grossreichen (Daniel 2 und 7) und dem Tausendjährigen Friedensreiche (Apok. 20). Eine motivgeschichtliche Untersuchung (Munich 1972).

- Griechische Theologie in der Zeit der Türkenherrschaft (1453-1821). Die Orthodoxie im Spannungsfeld der nachreformatorischen Konfessionen des Westens (Munich 1988).

- 'Die Deutschlandreise des Metrophanes Kritopulos (1624-1627) im Rahmen der deutsch-griechischen Beziehungen im 17. Jahrhundert', in E. Konstantinou (ed.), Nürnberg und das Griechentum: Geschichte und Gegenwart (Frankfurt a.M. 2003) 93106.

Pohlig M., Zwischen Gelehrsamkeit und konfessioneller Identitätsstiftung. Lutherische Kirchen- und Universalgeschichtsschreibung 1546-1617 (Tübingen 2007).

- 'Exegese und Historiographie. Lutherische Apokalypsekommentare als Kirchengeschichtsschreibung (1530-1618)', in Th. Kaufmann et al. (eds), Frühneuzeitliche Konfessionskulturen (Gütersloh 2008) 289-317.

Preuß H., Die Vorstellungen vom Antichrist im späteren Mittelalter, bei Luther und in der konfessionellen Polemik (Leipzig 1906).

Richardsen-Friedrich I., Antichrist-Polemik in der Zeit der Reformation und der Glaubenskämpfe bis Anfang des 17. Jahrhunderts. Argumentation, Form und Funktion (Frankfurt a.M. 2003).

Runciman St., The Great Church in Captivity. A Study of the Patriarchate of Constantinople from the Eve of the Turkish Conquest to the Greek War of Independence (Cambridge 1968). 
Saracino St., 'Leon Allatios' Entführung der Bibliotheca Palatina und weitere Selbstzeugnisse von Griechen über den Dreißigjährigen Krieg', Daphnis 47 (2019) 158-89.

- 'Griechisch-orthodoxe Almosenfahrer im Heiligen Römischen Reich und ihre wissensgeschichtliche Bedeutung (1650-1750)', in M. Friedrich and J. Schilling (eds), Praktiken frühneuzeitlicher Historiographie (Berlin 2019) 141-73.

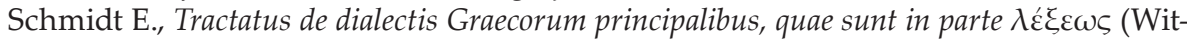
tenberg 1604).

Schönstädt H.-J., Antichrist, Weltheilsgeschehen und Gottes Werkzeug. Römische Kirche, Reformation und Luther im Spiegel des Reformationsjubiläums 1617 (Wiesbaden 1978).

Schunka A., 'Orientinteressen und protestantische Einheit in der Frühen Neuzeit', in Y. Köse (ed.), Şehrâyîn. Die Welt der Osmanen, die Osmanen in der Welt. Wahrnehmungen, Begegnungen und Abgrenzungen. FS Hans Georg Majer (Wiesbaden 2012) 319-36.

Seifert A., Der Rückzug der biblischen Prophetie von der Neueren Geschichte. Studien zur Geschichte der Reichstheologie des frühneuzeitlichen deutschen Protestantismus (CologneVienna 1990).

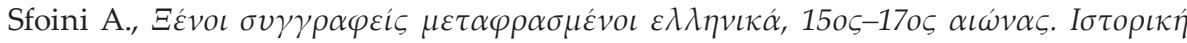

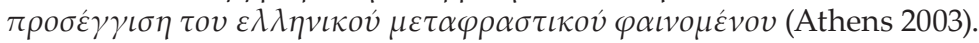

Sleidanus I., De quatuor summis imperiis libri tres (Leiden 1631 [1556]).

Tsakiris V., Die gedruckten griechischen Beichtbücher zur Zeit der Türkenherrschaft. Ihr kirchenpolitischer Entstehungszusammenhang und ihre Quellen (Berlin-New York 2009).

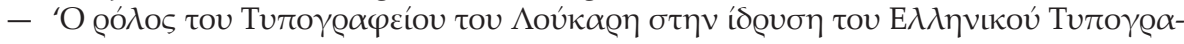

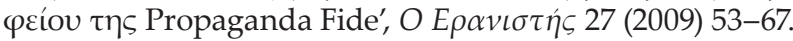

Tsalampouni A., 'Sola scriptura. A Greek-Orthodox Perspective', in St. Alkier (ed.), Sola scriptura 1517-2017. Rekonstruktionen-Kritiken-Transformationen-Performanzen (Tübingen 2019) 343-58.

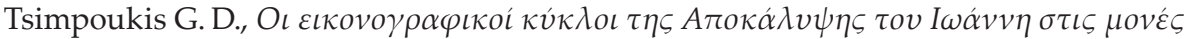

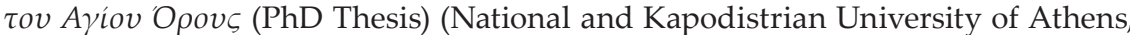
Athens 2012).

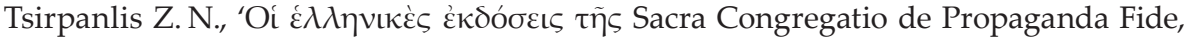

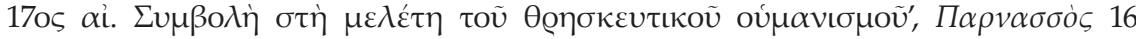
(1974) 508-32.

Wallmann J., 'Zwischen Reformation und Humanismus. Eigenart und Wirkungen Helmstedter Theologie unter besonderer Berücksichtigung Georg Calixts', Zeitschrift für Theologie und Kirche 74 (1977) 344-70.

Wendebourg D., 'Standen politische Motive hinter dem Briefwechsel zwischen der Tübinger Theologischen Fakultät und Patriarch Jeremias II.?', Jahrbuch der Österreichischen Byzantinistik 32/6 (1982) 125-33.

- Reformation und Orthodoxie. Der ökumenische Briefwechsel zwischen der Leitung der Württembergischen Kirche und Patriarch Jeremias II. von Konstantinopel in den Jahren 1573-1581 (Göttingen 1986).

- 'Reformation und Orthodoxie. Das erste ökumenische Gespräch zwischen der evangelisch-lutherischen und der griechischen Kirche (1574-1581)', in D. Wendebourg., Die eine Christenheit auf Erde. Aufsätze zur Kirchen- und Ökumenegeschichte (Tübingen 2000) 95-115.

- 'Pseudomorphosis, ein theologisches Urteil als Axiom der kirchen- und theologiegeschichtlichen Forschung', in D. Wendebourg., Die eine Christenheit auf Erde. Aufsätze zur Kirchen- und Ökumenegeschichte (Tübingen 2000) 70-94. 
Yannaras Chr., Orthodoxy and the West, transl. P. Chamberas and N. Russell (Brookline MA 2006).

Zaller R., The Discourse of Legitimacy in Early Modern England (Stanford 2007).

Zwierlein C. A., Imperial Unknowns. The French and British in the Mediterranean, 16501750 (Cambridge 2016).

- 'Konfessionalisierung europäisch, global als epistemischer Prozess. Zu den Folgen der Reformation und zur Methodendiskussion', in Ch. Strohm (ed.), Reformation und Recht. Ein Beitrag zur Kontroverse um die Kulturwirkungen der Reformation (Tübingen 2017) 1-51. 



\title{
Greek Orthodox Alms Collectors from the Ottoman Empire in the Holy Roman Empire: Extreme Mobility and Confessionalized Communication
}

\author{
Stefano Saracino, Jena / Munich
}

On the roads of the Holy Roman Empire, whose deplorable conditions are often lamented by early modern commentators, one may imagine a wide array of travellers: merchants, pilgrims, journeymen, beggars, messengers from the courts, stagecoaches (being part of the emerging postal services), or noblemen on their 'Grand Tour', to name just some types. ${ }^{1}$ The present article intends to add a further figure to our image of early modern far-distance travellers in the German territories (the extension of the Holy Roman Empire, in length as well as in width, was about nine hundred kilometres and could be crossed in a thirty-day's journey): Greek-Orthodox alms collectors from the Ottoman Empire (or from the Venetian 'stato da mar'), who mostly (but not always) were clergymen, like priests, monks, abbots, and in some cases even metropolitans. Despite their origin from remote spaces, the presence of these migrants may not have been as rare as could be expected. The overwhelming majority of the fifty-nine Greek guests who between 1579 and 1606 visited the Greek scholar and self-proclaimed philhellene in Tübingen (in the duchy of Württemberg) Martin Crusius (1526-1607) belonged to this migration type. $^{2}$ To this number can be added a further forty cases of alms-collectors from the times of Crusius until the second half of the eighteenth century, which I was able to identify in archival records from a variety of places (see Appendix). Helpful are also previous case studies on wandering Greek clergymen who collected alms and provoked normative and legal conflicts during the eighteenth century. ${ }^{3}$

1 H. T. Gräf and R. Pröve, Wege ins Ungewisse. Reisen in der Frühen Neuzeit 1500-1800 (Frankfurt a. M. 1997); W. Behringer, Im Zeichen des Merkur. Reichspost und Kommunikationsrevolution in der Frühen Neuzeit (Göttingen 2002).

2 This number is the result of a meticulous inquiry by Ulrich Moennig, who has specified the general (probably exaggerated) assumption of Nikos Panagiotakis, who speaks of over one hundred Greek guests in the house of Crusius: U. Moennig, 'On Martinus Crusius's collection of Greek vernacular and religious books', Byzantine and Modern Greek Studies 21 (1997) 40-78, 72-5; N. Panagiotakis, 'Griechische Musiker im Deutschland des 16. Jahrhunderts', in H. Eideneier (ed.), Graeca recentiora in Germania. Deutsch-griechische Kulturbeziehungen vom 15. bis 19. Jahrhundert [Wolfenbütteler Forschungen 59] (Wiesbaden 1994) 137-47, 141.

3 On a network of alms collectors using forged credential letters in the 1720s-1730s, connected with the names of Serafeim of Mytilene, Athanasios Pavlos, Athanasios Dorostamos and

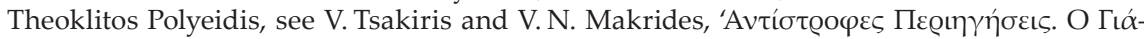

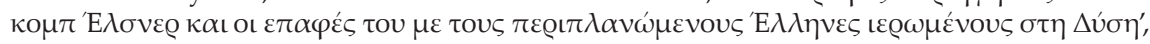


The present article, however, will not be concerned with the diachronic development of the immigration of Greek-Orthodox alms collectors into the Holy Roman Empire, which may be connected generally to the development over time

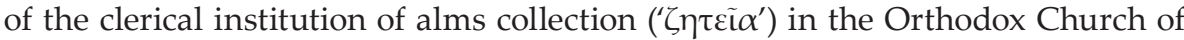
the Ottoman Empire, and which our migrants were part of; i.e. the movement of persons legitimized by official credential letters for the purpose of collecting alms. ${ }^{4}$ Though this is an interesting question in its own right, the fragmentary and casual character of the archival records used for this study do not allow general conclusions on this topic. Nor will questions of the legality or illegality of the actors involved be addressed. It often happened that their credential letters and charitable practices aroused suspicion in the eyes of their hosts and interlocutors in the Holy Roman Empire. ${ }^{5}$ As Tsakiris and Makrides have shown, individuals probably using forged documents and false identities (like Athanasios Pavlos, Athanasios Dorostamos and Theoklitos Polyeidis) were at the same time accredited and even prestigious representatives of the Orthodox Church; they may have justified these illegal and unethical means through their charitable and sometimes political ends. ${ }^{6}$ On the other hand, normative conflicts of this kind may have been constructed by members of the host societies-by clergymen or scholars-for the sake of their own confessional or epistemic agendas. For instance, Johann Michael Heineccius (1674-1722), who was chief pastor at the Marienkirche in Halle and represented Lutheran orthodoxy in town, in his monumental treatise of 1711 warns the reader that the wandering Greeks are prepared to do and witness anything, that might promote their chief aim of collecting alms. But in this

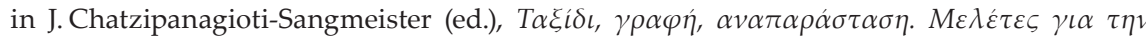

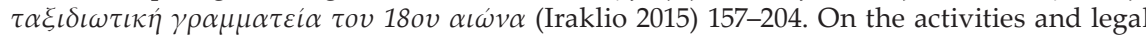
conflicts provoked by a monk from Sinai Monastery called Ioannikios and a Cretan monk called Jeremias, who collected alms in the Hungarian territories of the Habsburgs in the 1760s see C. Chotzakoglou and C. Gastgeber, 'Griechische Mönche in Ungarn. Zwei Dokumente aus dem 18. Jahrhundert über das Sammeln von Almosen und den Einfluß der Unierten am

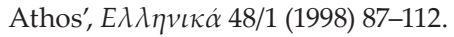

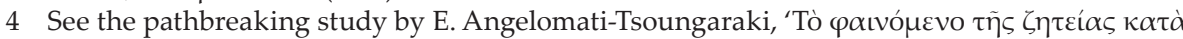

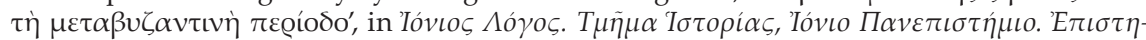

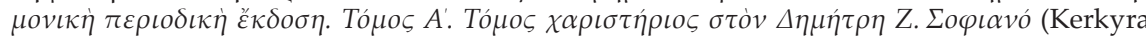
2007) 247-93. On the activities in this field by the Patriarchate of Jerusalem, see P. Stathi, X $\rho \dot{v}$ -

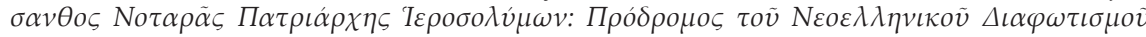
(Athens 1999) 129-38.

5 Martinus Crusius had already complained to Theodosios Zygomalas, his correspondent in Constantinople, about the obviously manipulated or forged documents presented to him by

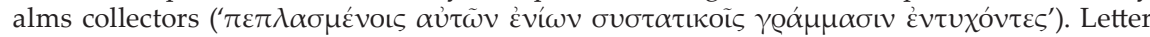
to Zygomalas, 1 July 1600, in Universitätsbibliothek Tübingen, Mh 466-1-9 [= Crusius, Diarium], VIII, f. 210-4, 211f.

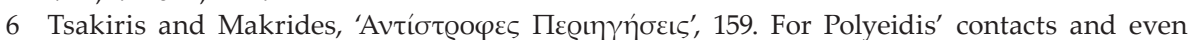
friendship with the eminent scholar and theologian Evgenios Voulgaris, which were established after his return from Europe and Russia on Mount Athos around 1756, see P. M. Kitromilides, 'Athos and the Enlightenment', in A. Bryer and M. Cunningham (eds), Mount Athos and Byzantine Monasticism. Papers from the Twenty-eighth Spring Symposium of Byzantine Studies (Aldershot 1996) 257-72, $268 f$. 
period Heineccius had also come into conflict with the Halle Pietists led by August Hermann Francke (1663-1727), and criticized their missionary engagement for the revival of true Christian faith among the Greeks in the Ottoman Empire, and generally the post-confessional open-mindedness of some of its protagonists towards Greek Orthodoxy. ${ }^{7}$

The main purposes of this article will be twofold: I) to reconstruct the high mobility of the alms collectors from the Southeast, the factors predetermining their mobility and the practical aspects of their collections, and II) to analyse their role in interconfessional dialogues with (erudite) members of host societies, i.e. the communication and transfer of knowledge focused on the confessio Graeca, which was imagined by their interlocutors to be a homogeneous and stable block in accordance with the evolving confessions in the Empire (Catholic, Lutheran, Calvinist).

The aim here is thus to reappraise, with reference to the cases of alms collectors, the importance of migration and mobility for the study of the relationships between Greek Orthodoxy and the (Latin) confessions of the West in the early modern period. In this effort I will follow a path already paved by the studies of Moennig, Makrides and Tsakiris cited in this chapter. ${ }^{8}$ The case of alms collectors is also informative for an enquiry into processes of knowledge transfer (of confessionally relevant knowledge) that Greek migrants were involved in during their stay in the Holy Roman Empire. ${ }^{9}$ In addition to the corpus of alms collectors, whose existence is attested because they applied for passports at the imperial chancery in Vienna,

7 See the chapter 'Die mündlichen Erzehlungen der reisenden Griechen sind selten gewiß' in J. M. Heineccius, Eigentliche und wahrhafftige Abbildung der alten und neuen Griechischen Kirche, ihrer Historie, Glaubens-Lehren und Kirchen-Gebräuchen (Leipzig 1711) 225f: “Denn Armuth treibet sie zum betteln, und bey diesem elenden Handwerck lernen sie gemeiniglich alle die Qualitäten, die sonst denen Bettlern eigen sind. Man hat wahrgenommen, daß sie um eines Allmosens willen, sich wenig Gewissens machen, einem jedweden etwas vorzureden, wie ers gern höret. Offt haben die, so bey den Papisten die Florentinische Union angenommen, dieselbe bey den Evangelischen mit grossem Eifer verworffen, anderer leichtsinnigen Veränderungen zu geschweigen." For Halle Pietism and its relationship to the Confessio Graeca, see U. Moennig, 'Die griechischen Studenten am Hallenser Collegium orientale theologicum', in J. Wallmann and U. Sträter (eds), Halle und Osteuropa. Zur europäischen Ausstrahlung des hallischen Pietismus [Hallesche Forschungen, 1] (Halle 1998) 299-329; V. N. Makrides (ed.), A Á́-

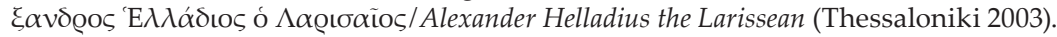

8 Compare also D. Wendebourg, Reformation und Orthodoxie. Der ökumenische Briefwechsel zwischen der Leitung der Württembergischen Kirche und Patriarch Jeremias II. von Konstantinopel in den Jahren 1573-1581 [Forschungen zur Kirchen- und Dogmengeschichte, 37] (Göttingen 1986); G. Podskalsky, Griechische Theologie in der Zeit der Türkenherrschaft (1453-1821). Die Orthodoxie im Spannungsfeld der nachreformatorischen Konfessionen des Westens (München 1988); R. Calis, 'Reconstructing the Ottoman Greek World: Early Modern Ethnography in the Household of Martin Crusius', Renaissance Quarterly 72 (2019) 148-93.

9 For the importance of knowledge transfer for early modern processes of confessionalization, see C. Zwierlein, 'Konfessionalisierung europäisch, global als epistemischer Prozess. Zu den Folgen der Reformation und zur Methodendiskussion', in C. Strohm (ed.), Reformation und Recht. Ein Beitrag zur Kontroverse um die Kulturwirkungen der Reformation (Tübingen 2017) 1-51. For the transfer and the network of knowledge at the court of the principality of Wallachia, see K. Sarris, N. Pissis and M. Pechlivanos, 'Accumulating Cultural Capital: Intellectual Net- 
what follows is based mainly on well documented cases of alms collectors from the late sixteenth century (Crusius' guests), from the late seventeenth century (based on information from a notebook kept by the scholar from Nuremberg Christoph Arnold, 1627-1685, and on the journal Monatliche Unterredungen edited by the scholar from Gotha Wilhelm Ernst Tentzel, 1659-1707) and from the 1720s-1730s (the aforementioned network of Pavlos-Dorostamos-Polyeidis).

\section{A 'Grand Tour' for Charitable Ends:}

\section{Practical Aspects of 'ziteies' in the Holy Roman Empire}

Apart from the testimony given by Crusius for the immigration of over fifty alms collectors between 1579 and 1606, the sample of cases listed in the appendix for the following decades and centuries shows that there was a constant influx of members of this migration regime into the German territories. Even during the Thirty Years' War (1618-1648), which increased the risks of travelling considerably, several cases are attested to in the sources. ${ }^{10}$ Seven persons applied for a passport in Vienna during the war (among them two metropolitans from Ohrid and a metropolitan from the island of Lefkada, whose stay in the Calvinist town of Marburg is attested also for the year 1648). The Metropolitan Nathanail from Lefkada, who according to the imperial chancery in Vienna, had declared himself a Uniate in 1638, ten years later produced for his Calvinist hosts in Marburg a written testimony in which he attested that the confession of the 'Calvinist' patriarch Kyrillos Loukaris was valid for the Greek Church. ${ }^{11}$ After an incident with Christian pirates on the island of Lefkada, Nathanail had fallen into disfavour with the Ottoman authorities and was now collecting money for his ransom. In 1628 an archimandrite from Constantinople named Efthymios collected alms for the foundation of a school and a printing press on Mount Athos. ${ }^{12}$ In the same year as Efthymios

works and Political Power of the Mavrokordatos Dynasty (1641-1730)', in D. Stamatopoulos (ed.), Power Networks in the Imperial and Post-Imperial Balkans (18th to 20th c.) (forthcoming).

10 For Greek travellers in the Holy Roman Empire during the Thirty Years' War, see S. Saracino, 'Leon Allatios' Entführung der Bibliotheca Palatina und weitere Selbstzeugnisse von Griechen über den Dreißigjährigen Krieg. Narrativen des Krieges und deren wissensgeschichtliche Bedeutung', Daphnis 47 (2019) 158-89.

11 Nathanail even stated that he had been made bishop by Loukaris: '[E]st autographum, quod anno priore 1648 mense Augusto eidem Parenti meo reliquit Nathanael Archiepiscopus Leucados \& S. Maurae, in quo pariter Confessionem Cyrilli Lucaris (ut in apographo vides) magno cum zelo approbat, a quo Archiepiscopus erat Anno 1624. d. 8. Augusti ordinatus' (Letter from Samuel Andreae in Marburg to Wilhelm Ernst Tentzel in Gotha, 5 September 1696, printed in W. E. Tentzel (ed.), Monatliche Unterredungen (Leipzig 1697) 483). In his application for a passport, he is described as 'Nathanaellus Achiepiscopus S. ${ }^{\text {tae }}$ Maurae natione Graecus, sacris tamen Romano-Catholice Ecclesiae institutis initiatus locupletis authoritatis ac fidei testimonijs nos edoceri curavit.' Haus-, Hof- und Staatsarchiv Wien [= HHStA], RHR, Grat Feud, Patentes und Steckbriefe, 3-14. Sunar Henny: 'Nathanael of Leukas and the Hottinger Circle: The Wanderings of a Seventeenth-Century Archbishop', International Journal of the Classical Tradition 27 (2020), 449-472.

12 Ibid., 1-172: "Euthimio Constantinopolitano Grande Archimandritta della Chiesa Orientale cioè Generale dell ordine di San Basilio Grande, che desiderando fundar un collegio per li 
(1628), the Metropolitan of Ohrid Porfyrios (who signed his petition for a passport with green ink as 'The Patriarch of Ohrid Porfyrios' ['O П $\alpha \tau \varrho \iota \alpha ́ \varrho \chi \eta \varsigma ~ A \chi \varrho เ \delta \tilde{\omega} v$

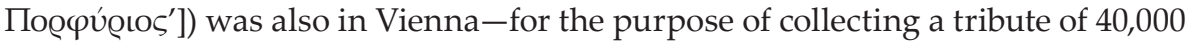
'aurei' (florin, probably). ${ }^{13}$

Further reasons for clerical fundraising mentioned in the credential letters or other documents used by alms collectors in the Holy Roman Empire, are the reduction of the debts of ecclesiastical institutions towards the Ottoman state, the nomination tax for high ecclesiastical offices, the release of monks taken as hostages because of the payment default of their host institutions (or because of other forms of misbehaviour), and fundraising for the liberation of Christian slaves and captives who had been captured in wars (e.g. the Second Morean War of 17141718) or by corsairs and pirates. ${ }^{14}$

Yet laymen also appeared in person at the imperial chancery in Vienna and (strikingly often) in Tübingen as visitors of Crusius. In most cases they collected the ransom for their own liberation or that of their relatives and were part of the sophisticated bilateral system of ransoming war prisoners and captives of pirates and corsairs that flourished between the Christian and Muslim states in the Mediterranean as well as along the Habsburg-Ottoman frontier in Hungary. ${ }^{15}$ Occasionally, however, we also find other motivations, as in the 1659 case of a merchant from Naxos ('Ioannem Antonium Nationis Graecae ex Insula Archipelagi de Axia'), who had suffered shipwreck and financial ruin. The merchant

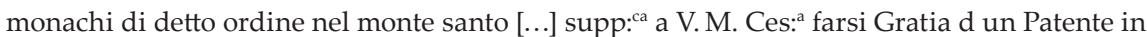
Ott: ${ }^{\text {ma }}$ forma in pergamino, per poter sicuramente domandar aiuto et favore da tutti i Principi, Vescovi, Abbati, et altri, non solo per il Sacro Romano Imperio, ma anco per altri Regni et Provincie per fabricar detto Collegio."

13 Ibid., 3-88.

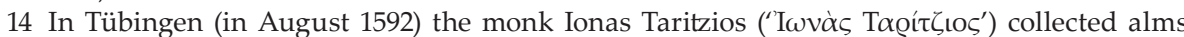
because his monastery of Agia Triada in the province of Kyzikos had accumulated depts ('ő $\tau \mathrm{L}$

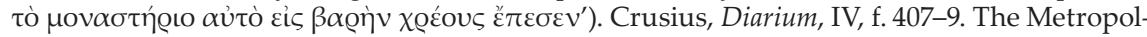
itan of Ohrid Gavriil, who visited Crusius (in August 1587) with a retinue of twelve persons, had to collect sixteen thousand ducats he had agreed on with the Ottomans as a nomination tax. Ibid., III, f. 602. In Gotha (in August 1693) the provost of the monasteries of Evvoia Mitrophanis Tzitzilianos collected the ransom (four thousand thalers) for several monks taken as hostages because of their debts towards the Ottoman state. Tentzel (ed.), Monatliche Unterredungen, 1693, 631. The effort of the Orthodox Church in the liberation of captives from the Second Morean War is indicated (among others) as reason for the collections of the network

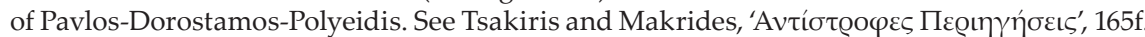

15 K. Teply, 'Vom Los osmanischer Gefangener aus dem Großen Türkenkrieg 1683-1699', Südostforschungen 32 (1973) 33-72; G. Pálffy, 'Ransom Slavery along the Ottoman-Hungarian Frontier in the Sixteenth and Seventeenth Centuries', in G. Dávid and P. Foder (eds), Ransom Slavery Along the Ottoman Borders. Early Fifteenth-Early Eighteenth Centuries (Leiden 2007) 35-84; E. Pauli, Triumph der Barmherzigkeit. Die Befreiung christlicher Gefangener aus muslimisch dominierten Ländern durch den österreichischen Trinitarierorden (1690-1783) (Göttingen 2016); M. Ressel, 'The North-European Way of Ransoming. Explorations into an unknown dimension of the Early Modern Welfare State', Historical Social Research 35/4 (2010) [C. Zwierlein, R. Graf and M. Ressel (eds), The Production of Human Security in Premodern and Contemporary History] 125-47. 
had a powerful advocate in Vienna, as in the past he had been the servant of the former Habsburg ambassador at the Porte, Johann Rudolf Schmid Freiherr von Schwarzenhorn (1590-1667), whose contribution to the deposition and execution of Patriarch Loukaris in 1638 had been crucial. ${ }^{16}$

Clerics also went to Europe for 'private' reasons, with the intention of helping relatives who were suffering bondage as slaves or captives in the Ottoman Empire-though Crusius voiced suspicion that some of them were only pretending to help their beloved in order to evoke sympathy while in fact working for the fundraising of the Orthodox Church. ${ }^{17}$

In the Crusius' records the share of clergymen (and of their servants) among his Greek visitors is already considerable. But in the cases recorded for the seventeenth and eighteenth centuries, this share becomes overwhelming (thirty-five of the forty one recorded persons). Most individuals were between twenty-five and fifty years old, hence in the age best suited for making protracted and exhausting journeys all over Europe. ${ }^{18}$ They arrived in the German territories (and other European territories) by following two different routes: either by sea via port towns in Italy (like Venice, Naples or Ancona) as well as in Holland and England or by land following the continental (trade) routes over the Balkans and Hungary, or by passing the Danubian principalities and into Russian or Polish territory before arriving in the Holy Roman Empire. Several of Crusius' Greek interlocutors in Tübingen attested to prior stays in the Kingdom of Poland or in the Tsardom of Russia (perhaps they had come from this direction because they had to avoid the Hungarian territories, where from 1593 to 1606 the Habsburg-Ottoman-War took place). Both the alms collectors who visited Christoph Arnold in Nuremberg in the 1670s, who filled a notebook with the information about his Greek guests, and the members of the network of Pavlos-Dorostamos-Polyeidis in the 1720s-1730s used

16 A recommendation by Schwarzenhorn is included in the petition of Ioannis from Naxos, dated 20 December 1659. HHStA, RHR, Grat Feud Patentes und Steckbriefe 1-20. For the deposition of Loukaris and the role played by Schwarzenhorn see G. Hering, Ökumenisches Patriarchat und europäische Politik: 1620-1638 (Wiesbaden 1968) 306-8, 311, 315.

17 A certain Dimitrios Protopapas from Larissa and his companion Pankalos from Corfu ('Pancalus Corcyrensis') in October 1589 were gathering money for the liberation of Dimitrios' relatives, but Crusius believed that they supported the project of Patriarch Ieremias II 'Tranos' to refurbish his residence in Constantinople: 'stipem colligebat [...] uxor, \& 3 liberi eius, essent oppignorati a Turcis: donec ipse 1000 Ducatos absolveret. Ego vero credo, ut Patriarcha

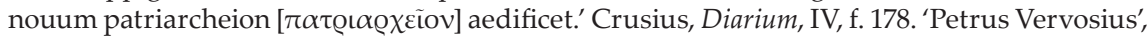
a presbyter from Sitia, in 1669 collected the ransom for his two brothers, who had been deported to Tunis and made galley slaves (presumably during the Cretan War, 1645-1669). See Stadtbibliothek Nürnberg, Amb. 98, $4^{\circ}$ MS [= Arnold, Notebook], f. 5.

18 If they were younger or older and had past their prime age, the sources described their age as exceptional. Crusius judged the sixty-one-year-old 'Nicolaus Stephani' from Ioannina, who had been captured by pirates, to be an old man ('miser, senex, canus, annorum 61.'). M. Crusius, Annalium Svevicorum Dodecastertia (Frankfurt a.M. 1596) 823. Petros Fokas, who was only twenty years old, is described as 'adolescens Graecus, nondum 20. annorum.' Ibid., 834. The presbyter from Sitia (Crete) 'Petrus Vervosius', who visited Arnold in November 1669, was sixty-seven years old ('seines Alters nunmehr 67 Jahre'). Arnold, Notebook, f. 3. 
routes passing through Hungary and stayed in the Habsburg capital Vienna. At any rate, the mobility of the members of this migratory regime was not linear in form (from A to B), having the character of tours crisscrossing territories of Eastern, Central and Western Europe. With regard to extension in space, the differing itineraries noted by Crusius in his diary for the following two alms collectors are probably quite typical:

The priest Dimitrios from Thessaloniki, who stayed in Tübingen in November 1593 and gathered money for the liberation of his sons, had travelled on the following itinerary: 'Itinerarium Demetrii: Thessalonica, B $\lambda \alpha \chi i ́ \alpha$ [Wallachia], $\pi 0 \gamma \delta \alpha v i ́ \alpha$

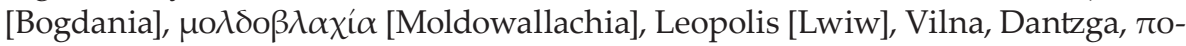

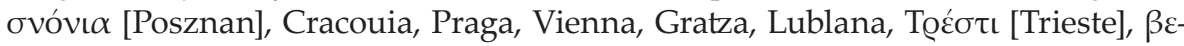

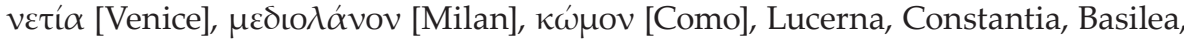
Freiburgum, Augspurgum, Ulma, Tybinga. ${ }^{\prime 19}$

The monk Symeon from the monastery of Agia Paraskevi (near Himara) in July 1597 not only shared with Crusius his travel itinerary, but also the duration of some of his stops 'en route': 'Constantinopolis, Walachia, Transylvania, Polonia, Liopoli, Russia, Moscouia [...] Polonia, Prußia. Inde per marem in Angliam, Londinum, hinc in Holandiam, et ascesus per Rhenum, ac Spiram. Leopoli 1 annum, in Moscovia 9 menses, in Transylvania 3 menses, in Anglia circ. 6 M.' ${ }^{20}$ According to the testimony of Wilhelm Ernst Tentzel, Mitrofanis Tzitzilianos, the abbot from Evvoia, had visited England and Holland, and afterwards had travelled along the rivers Rhine and Main to Frankfurt and then to Gotha. ${ }^{21}$

Most of these charitable actors mentioned stops in capitals and residential cities of various European countries and kingdoms. A typical feature of this migration regime therefore seems to be a high degree of mobility that was seldom in this time and required that a number of difficult preconditions be met (in way comparable to the high mobility of noblemen on their Grand Tour or of long-distance merchants). We have to bear in mind that in early modernity travelling posed challenges very different to the present day, in terms of economy, logistic, transportation and physical effort. Three requirements predetermining the high mobility of Greek alms collectors are analysed in what follows: 1) to provide themselves with passports, letters of safe conduct and other testimonials by political and ecclesiastical authorities of their home as well of their host countries, 2) to have at

19 Crusius, Diarium, IV, f. 627.

20 Ibid., VI, f. 501.

21 '[M]it Engländischen Schiffen nach London kommen zu Oxfurt und Cambridge gewesen hierauff in Holland gereiset [...] und zu Wasser biß nach Franckfurt am Mayn geschiffet von da er weiter durch Teutschland reiset.' Tentzel (ed.), Monatliche Unterredungen, 1693, 631. The charity of Orthodox principalities and courts like Wallachia and Russia was also a favourite

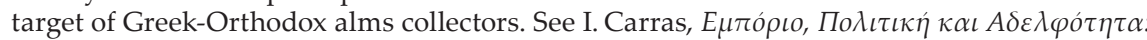

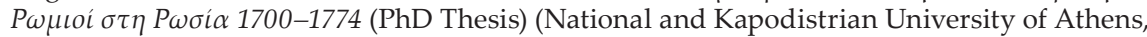
Athens 2010), 427-49; I. Carras, 'Orthodoxe Kirche, Wohltätigkeit und Handelsaustausch: Kaufleute und Almosensammler entlang der osmanisch-russischen Grenze im 18. Jahrhundert', in: Erfurter Vorträge zur Kulturgeschichte des Orthodoxen Christentums 19 (2020). 
their disposal sufficient money (and in the case of alms collectors, to support their budget with constant revenues from the collection of alms), 3) to travel in groups, i.e. to be accompanied by fellow travellers or even by servants and interpreters. ${ }^{22}$

The alms collectors usually possessed credential letters they had received from their host institutions in the Ottoman Empire (issued by the Patriarch of Constantinople or other patriarchs, by metropolitans and abbots). ${ }^{23}$ But of equal (or even greater) importance in terms of mobility were credential letters given to them by political authorities in the host lands or by the ambassadors of European powers in Constantinople. ${ }^{24}$ Certificates of this kind also attest to the whereabouts of the migrating Greeks in the Holy Roman Empire. Unsurprisingly, the residential city of the Habsburg emperors-usually Vienna, but in Crusius' days Prague-had a great appeal, as in addition to the generous alms distributed to them in this place imperial passports could guarantee their legitimation all over the empire. Crusius' guests, for instance, showed credential letters issued by the Emperor Rudolph II, by his confident Count Paul Sixt III Trautson or by the court physician Petrus Moravius. ${ }^{25}$ Numerous alms collectors are attested only because they applied for a passport in Vienna (see Appendix). In addition, the monk Athanasios Pavlos (who declared to be from the Iviron Monastery and in the same time to be Vicar General of the Holy Sepulchre in Jerusalem) possessed an imperial passport ('einen Kayserl. Paß oder Patent, welches d. 27. Octobr. 1730 auf Ordre des HofKriegs-Raths in der Canzley zu Wien sey gegeben worden'), which was thought to be a forgery. ${ }^{26}$ Other migrating alms collectors presented commendatory letters

22 For the difficulties of travelling, see footnote 1 . The provision with both money and credential letters is addressed in the lemma on 'Reisen' in Johann Heinrich Zedler's encyclopedia. See J.H. Zedler, Großes vollständiges Universal-Lexikon aller Wissenschaften und Künste, XXXI (Leipzig 1742) 367-80.

23 For the typical features of the credential letters see the example of the letter from 7 January 1759 issued by the Patriarch of Constantinople Serafeim II for the layman Georgios from Arta, whose brothers had been captured by 'Albanians', discussed in H. Hunger, 'Ein griechischer Patriarchen-Geleitbrief des 18. Jahrhunderts, Neuerwerbung der Österreichischen Nationalbibliothek: Suppl. gr. 188', Jahrbuch der Österreichischen Byzantinischen Gesellschaft 6 (1957) 145-9.

24 Athanasios Dorostamos possessed credential letters issued by the English ambassador in Constantinople Everard Fawkener, by the Dutch ambassador in Constantinople Cornelis Calkoen, and by the Russian ambassador in Paris Prince Antiochus Kantemir, dated 27 September 1739, 2 December 1739 and 1 November 1740. J. Elßner, Fortsetzung der Neuesten Beschreibung derer Griechischen Christen in der Türkey (Berlin 1747) 46-51.

25 Examples include the monk from Iviron Monastery Daniil Palaiologos in September 1585 (by Rudolph II), Petros Fokas in November 1590 (from Rudolph II and Elisabeth from Habsburg), Stefanos Laskaris in January 1589 (from Paul Sixt III Trautson) and the Metropolitan of Ohrid Gavriil in August 1587 (from Petrus Moravius). See Crusius, Annalium, 794, 802-4; Crusius, Diarium, IV, f. 116, 282-7.

26 Athanasios Pavlos, who was condemned and hanged in the town of Herzogenbusch in North Brabant in August 1736, had declared himslelf to be 'ein Priester der Griechischen Kirche aus dem Convent Ivirum, auf dem Berge Athos, bekleidet mit der Würde eines Archimandriten, und Vicarius Generalis des heiligen Stuhls zu Jerusalem.' Elßner, Fortsetzung, 22. For the imperial passport, see ibid., 36 . 
attesting to their sojourns at the courts in Rome, Venice, London or Warsaw. In the Holy Roman Empire they also visited the courts of the electors ('Kurfürsten'), of important duchies as well as free imperial cities, where they not only begged for alms, but asked to be provided with further credential letters. ${ }^{27}$ This ability to accumulate credential letters and passports gave them an important advantage compared to less mobile residents or travellers in the German territories as it increased the legitimacy of their practices considerably.

For the clergymen from the Ottoman Empire performing fundraising-campaigns in distant European territories, the planning of the itineraries and of other travel modalities began already at home. The Bishop of Samos, Iosif Georgeirinis, who sojourned in England in 1678, provides us with insights into preparatory measures of this kind. According to his testimony the monasteries on Mount Athos would operate 'ziteies' in the following way:

As for the maintenance of these Monasteries, though their Lands be sufficient to feed them, and their Mountain furnish them with Wine enough to drink; yet as the matter is order'd, they commonly want Money to pay their Haratch, or yearly Tribute [...] So that every year they select some of their Caloirs [i.e. monks] to go abroad, and beg the Charity of Christian People, towards the relief of the respective Monastery. And these are always by two and two together. And the Monasteries agree before-hand to what particular places they will send their respective Emissaries, who continue ordinarily two or three years in their perambulation. At their coming home, the Money is delivered to the Skenaphylax [sic], or the Steward of the Monastery; for it is against the Rule of their Order, to meddle with Money. ${ }^{28}$

Apart from arrangements concerning the size of travelling groups ('two and two together'), which itinerary the travellers had to follow, how long they should stay away from their host institution, and how they had to deliver the collected money, clearly they also had to be provided with money right from the start, as they had to meet high costs for transportation and accommodation.

But what do we know about the quantity of revenues the alms collectors handled in the German territories? Only scattered references on this topic can be found in the sources, which nonetheless are highly informative. Daniil Kastrisios, for instance, who reported to Christoph Arnold that he was collecting money for

27 Among Crusius' guests, for example, held certificates signed by Ernst, the Archbishop and Elector of Cologne (Daniil Palaiologos), the Duke of Bavaria Wilhelm V (Andreas Laskarefs), the Elector of Trier (Stamatios Donatos) and by the Elector of Brandenburg-Preußen (Pavlos from Thessaloniki); see M. Crusius, Turcograecia (Basel 1584) 189; Crusius, Annalium, 794; Crusius, Diarium, II, f. 529f.; VI, f. 517f.

28 I. Georgeirinis, A description of the present state of Samos, Nicaria, Patmos and Mount Athos (London 1678) 98f. The Jesuit Father Francois Richard reported in 1669 that almost half of the seven thousand monks on Mount Athos were absent because of journeys to the dependencies (' $\mu \varepsilon \tau$ tó $\chi\left\llcorner\alpha^{\prime}\right)$ of the monasteries or activities as alms collectors. G. Hofmann, 'Die Jesuiten und der Athos', Archivum Historicum Societatis Iesu 8 (1939) 3-33, especially p. 15. 
the liberation of monks from the Iviron Monastery who had been deported by the Ottomans from the island of Patmos (!) because they had helped the Venetians (probably during the Venetian-Ottoman, Cretan War of 1645-1669), had received great sums at the English court but also at the courts of different German electors (in Berlin, in Dresden and in Heidelberg). ${ }^{29}$ The Prince of York (the future King James II) had given him twenty pounds sterling, the Elector of Brandenburg-Prussia Friedrich Wilhelm sixty Reichsthalers, his wife Dorothea thirty Reichsthalers, the elector of Saxony Johann Georg II fifty Reichsthalers. He furthermore reported that he already had transferred two thousand Reichsthalers to the Ottoman Empire, probably with the help of Greek merchants from Smyrna he had visited in Amsterdam..$^{30}$ Thomas Palaiologos, the son of a renegade who had been the Ottoman governor of Macedonia, visited Crusius in July 1591 and shared with him his experience that princes and bishops ('Principes \& Episcopi') were more generous giving amounts between fifteen and fifty florins (guilders), whereas the cities' magistrates ('civitates') usually only gave amounts between one and three florins. ${ }^{31}$

Also, extremely informative is an entry in Crusius' diary consisting of an excerpt from the account books presented to him by another alms collector named

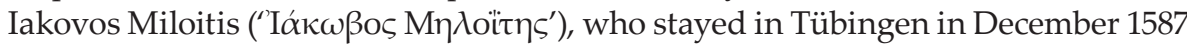
and required a sum of eight hundred thalers (or 40,000 aspers, namely akçe). Between June and September 1587 Miloitis' had collected money in residential cities, small towns and villages of central Germany: one thaler in the School (University?) of Wittenberg, twenty-eight 'Groschen' from the Church of St Jacob in Einbeck (southern Lower Saxony), one thaler from the university of Erfurt, two thalers from the town of Eschwege, four thalers while collecting in front of the church of Eschwege, five cubits of cloth from the church of Holy Mary in Boyneburg, six 'Reichsthalers' from the Landgrave of Hessen-Kassel Wilhelm IV, two florins from the city of Kassel, fifteen thalers from the elector of Saxony Christian I and further four

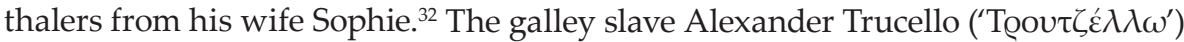
from Cyprus, who was an eyewitness of the battle of Lepanto (7 October 1571) and was able to escape after this battle into Venetian territory, was allowed on 16 April 1582 to collect 3.5 florins infront of the door of the church of St George in Tübingen

29 From Kastrisios' narration it remains unclear how the monks from the Iviron Monastery were involved in the events on the island of Patmos. See Arnold's report about Kastrisios mission for the churchwarden of Nuremberg, 26 March 1670. Arnold, Notebook, f. 3-6, especially f. 4.

30 For alms given to him in London, Berlin and Dresden, see ibid., f. 40f. 'Er bekante mir, daß er allbereits, von den gesamleten Geldern, bey 2000 Rthl nach Haus per Wechsel übermacht.' Ibid., f. 41. Kastrisios had celebrated the Easter mass for Greek merchants in Amsterdam: 'Zu Amsterdam hat er, am Osterfest, bey den Griechen den Gottesdienst verrichtet; allda 20. bis 30. Diener, welche von 4. oder 5. reichen, griechischen Kaufleuten, so zu Smyrna wohnen, daselbst gehalten werden: denn die übrigen Handelsleute zu Smyrna sind meistentheils Engelländer und Holländer, welche die Smyrnafahrer genennet werden.' Ibid., f. 42.

31 Crusius, Diarium, IV, f. 318.

32 Ibid., III, f. 653. 
and received further alms from the Principal of the University (one florin), from the Faculty of Arts (two florins) and from Crusius (one florin). ${ }^{33}$

One of the pieces of incriminating evidence arising from the interrogation of Athanasios Pavlos by the criminal court of Herzogenbusch in 1736 was the fact that the suspect possessed account books ('zweyen bey ihm gefundenen Collecten-Bücherchen') attesting to having earned many thousands of guilders but was unable to indicate where he had sent the money to or what he had done with it. ${ }^{34} \mathrm{~A}$ file recently discovered by the author of this article concerning the investigation against Athanasios Dorostamos in the Duchy of Württemberg from January 1738 shows that the sums indicated by Pavlos in Brabant were not at all exaggerated. According to the testimony given by Dorostamos, who had been arrested in Stuttgart, between February 1736 and November 1737 he managed to collect in the German territories alms amounting to almost 2000 florins. ${ }^{35}$

The business of Greek alms collectors hence seems to have been a highly lucrative one. Yet this presented them with a practical problem arising from the almost Babylonian chaos of currencies used in the myriad small states and territories of the Holy Roman Empire. ${ }^{36}$ As analysed above, the collectors carried manifold currencies with them and had to take care that the money did not lose its value when transferring it over the boarders of states and Empires. To carry greater sums of money (i.e. of gold and silver coins) was disadvantageous and risky in early modernity. Hence money was transferred (with the help of merchants) by bills of exchange ('Wechsel'). Several of our wandering Greeks mention the use of this financial tool, e.g. Daniil Kastrisios with regard to Christoph Arnold and Athanasios Dorostamos with regard to the Calvinist consistorial councillor in Berlin, Jacob Elßner (1692-1750). ${ }^{37}$ In the best case scenario, they even sought to increase value

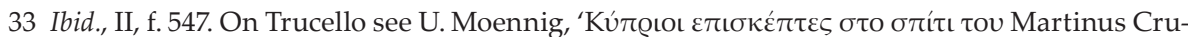

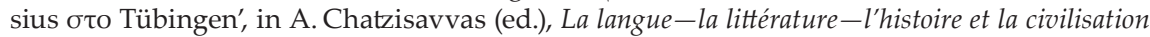
chypriotes (Besançon 1995) 260-80.

34 Elßner, Fortsetzung, 36.

35 Breslau 15 fl. (from the church); Frankfurt (Oder) $30 \mathrm{fl}$. (from the church and the university); Berlin $75 \mathrm{fl}$. (Calvinist church), $75 \mathrm{fl}$. (university), $15 \mathrm{fl}$. (Lutheran church), $30 \mathrm{fl}$. (queen), $30 \mathrm{fl}$. (D. E. Jablonski), Hamburg 150 fl. (J. C. Wolff, church, magistrate); Magdeburg 75 fl. (church); Leipzig 50 fl.; Halle/Saale 24 fl. (from the professors); Dresden 150 fl. (king), 22 fl. (V. E. Löscher and Lutheran church), 40 fl. (Calvinist church); Chemnitz 30 fl. (magistrate); Altenburg $150 \mathrm{fl}$;; Bayreuth $75 \mathrm{fl}$. (from the margrave); Ansbach $28 \mathrm{fl}$. (from the margrave); Nuremberg $100 \mathrm{fl}$. (magistrate); Augsburg 200 fl. (Lutheran church); Mannheim 200 fl. (from the elector); Darmstadt 200 fl.; Gießen 50 fl.; Frankfurt am Main 46 fl. See the file with the interrogation of Dorostamos: Hauptstaatsarchiv Stuttgart [= HSTAS], A 202, Bü 1692, document Nr. 6.

36 Zedler advises travellers on this point: 'Mache dir, vornemlich, ehe du in ein Land gehest, die Müntzen derselben Provinz bekannt, und laß sie dir von Kaufleuten, die deine guten Freunde sind, erklären. Denn sonst lernest du dieselben gewiß in der Fremde mit deinem Schaden kennen.' Zedler, Universal-Lexikon, XXXI, 368.

37 '[D]urch Wechsler unmittelbar an den Patriarchen nach Constantinopel übermacht.' Elßner, Fortsetzung, 3. According to his interrogation in Stuttgart he had send one thousand five hundred florins, as well as a golden watch and two silver watches with the help of the merchant Nicolas Turnowitz in Leipzig to the Patriarche in Constantinople. 
by investing money in precious commodities: Kastrisios reported that in Danzig he had invested five hundred Reichsthalers in rosaries made of amber, which he intended to sell to the Catholics in Italy. ${ }^{38}$ In Leipzig the aforementioned Miloitis had purchased twenty copies of a Greek print of the New Testament for 5.5 thalers, which he intended to send to his wife in Constantinople, hoping thereby to quadruplicate the value (by selling each copy for one thaler). ${ }^{39}$

In order to reduce the risk of falling victim to robbers (or to other adversities) early modern travellers avoided uninhabited regions and joined together in travelling groups. ${ }^{40}$ For this purpose, in the eighteenth century Greek merchants who travelled outside the Ottoman Empire formed larger groups (horse treks and caravans) and were sometimes armed. ${ }^{41}$ By contrast, our alms collectors often travelled alone or in very small groups consisting of only two or three persons. Furthermore, it was inevitable for them to carry larger sums of money with them (at least in parts of their journeys). Unsurprisingly, some of them were robbed on the road, as was the case with the aforementioned Iakovos Miloitis, whose treacherous servant (a native from Magdeburg) had prepared an ambush with an accomplice in a forest near Weißensee (Thüringen), depriving him of a sum of forty thalers as well as of his horse and coach and almost beating him to death. ${ }^{42}$ In the 1730 s Athanasios Dorostamos reported to his host, the Calvinist consistorial councillor in Berlin Jacob Elßner, that his entourage composed of three persons had been attacked by robbers in the border zone between Wallachia and Transylvania, one of them being shot dead, the other two being robbed..$^{43}$ On their extensive and long-standing journeys alms collectors were occasionally accompanied by staff, such as servants or interpreters, some of whom already had entered into their service in the Ottoman Empire. Others were employed during or shortly before the stay in the Holy Roman Empire, as their German, Polish or Italian origins reveal. ${ }^{44}$ An exception

38 '[F]ür 500 R[eichs]th[a]ler, zu Dantzig, Paternoster eingekauft, so von Bernsteinen gemacht: Solche nun grosses Geld, bey grossen Herren in Welschland (die sehr viel davon halten) wieder hinaus zu bringen.' Arnold, Notebook, f. 42.

39 Crusius, Diarium, III, f. 641 f.

40 Gräf and Pröve, Wege ins Ungewisse, 193-243.

41 For Greek merchants from the Ottoman Empire trading in the Habsburg lands and especially

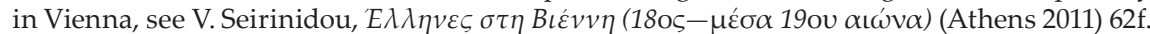

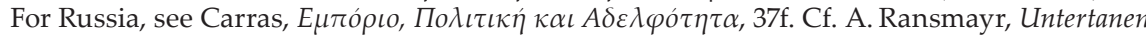
des Sultans oder des Kaisers. Struktur und Organisationsform der beiden Wiener griechischen Gemeinden von den Anfängen im 18. Jahrhundert bis 1918 (Vienna 2018).

42 The description of this episode, which occurred on 12 July 1587, can be found in Crusius, Diarium, III, f. 647.

43 J. Elßner, Neueste Beschreibung derer Griechischen Christen in der Türkey (Berlin 1737) 8.

44 Crusius is again a precious source of information on the travelling companions of those who collected alms in Tübingen: The uncle and nephew Lukas and Andreas Argyros from Santorini had an interpreter from Leipzig called Johann Friedrich Weidner (Crusius, Turcograecia, 206). Filippos Mavrikios travelled with an Italian servant ('cum famulo italo') (Crusius, Annalium, 794). Iakovos Miloitis travelled with a servant from Erfurt called Joachim Christ (Crusius, Diarium, III, f. 651). Nikolaos Rallis had an interpreter from Carinthia ('Lamberto Rauensteinero ex op[pido]. S. Viti in Karinthia', ibid., IV, f. 48). 
is the case of the Metropolitan of Ohrid Gavriil, who travelled through Germany with an entourage counting twelve persons, three coaches and twelve horses, among them an Italian tailor, a Polish horse groom, three German coachmen and a German interpreter. ${ }^{45}$ His pompous entourage did not fail to make a deep impression on the observers of the host society. Whereas the Greek guests of Crusius usually had to present themselves at the gatekeepers of the town and were informed by them where they could find the humanist, or were escorted by them to his house, in the case of Metropolitan Gavriil it was Crusius with his son Urban and other dignitaries of Tübingen who waited upon the Greek prelate at the 'Lustenauer Tor' when he made his entry on 31 August 1587 (it is even reported that Crusius greeted him with reverence and kissed the hand of the prelate). ${ }^{46}$

As a person of high estate, Metropolitan Gavriil travelled with large coaches driven by four horses each. But other, humbler alms collectors also used coaches as means of transportation. The aforementioned Iakovos Miloitis was travelling with a small coach ('vehiculum parvum') and one horse when he was robbed in a forest of Thüringen. ${ }^{47}$ Daniil Kastrisios is reported to have travelled (in company of a student) from Emden to Holland with a wagon ('Wagen'), probably with a stagecoach. ${ }^{48}$ Athanasios Pavlos also travelled with a wagon ('Waagen'), with two horses, a servant and an interpreter, though in his case self-fashioning as a person of high estate failed miserably (at least in the town of Northern Brabant, where he was condemned as an impostor and hanged in August 1736). ${ }^{49}$ Many among our perambulating alms collectors probably travelled simply by foot but nonetheless were confronted with expenses for food or accommodation in hostels.

\section{Testing the Confession of Greek Orthodox Migrants and Transferring Confessional Knowledge}

Several examples have been mentioned above showing that the attitudes of Greek Orthodox alms collectors, who in the majority of cases were clergymen, were flexible and pragmatic towards confessional matters. What follows is concerned with the interconfessional dialogues and communications the Greek migrants were involved in, the questions on confessional matters addressed to them by German

45 Crusius, Annalium, 803; Crusius, Diarium, III, f. 590f, 614.

46 Ibid., III, f. $589 f$.

47 Crusius, Annalium, 803.

48 In 1679 Arnold noted in his notebook rumours about Kastrisios' journey to Holland and of his attempt to rob the student in his company and take his two hundred thalers. See the note on 'D. Castrensii mala fides': “daß dieser Castrensius 2. od. 3. Meilen vor Emden [...], als in seiner Himbreise nach Holland begriffen, sich mit einem Studioso der auch mit 200. Rthalern nach Holland daselbst, zu streben gewolt, vor der Abreise bekant gemacht: als sie nun beede reisfertig gewest, und auf den Wagen so lang noch warten müssen, habe d Castrensius jenem Studioso eine kleine Spatzirreise, ausser dem Thor so lang angebotten [...] in Meinung, als ob er alles Geld bey sich hatte, mit seinem Stock einen Schmeiß über das Genick gegeben, davon er aber umgefallen, stets ihm zu geben versprochen, was er bey sich habe." (Arnold, Notebook, f. 16)

49 Eliner, Fortsetzung, 36f., especially p. 42. 
learned men (like Crusius in Tübingen, Arnold in Nuremberg, Tentzel in Gotha or Elßner in Berlin), who represented or were commissioned by local ecclesiastical and political authorities. There were many reasons for the migrants to act carefully and tactfully in this regard. This was a necessity resulting from their continuous crossing of political and religious/confessional borders-something intensified by the political reality of the Holy Roman Empire, consisting as it did of numerous political entities (many of them being microstates) and to the plurality of confessional groups living there border to border or even coexisting in one territory. ${ }^{50}$ To be aware of the confessional demarcation lines, to be able to adapt to the confessional horizon of each individual group, and to act in a diplomatic way were imperative for them and their enterprise. Crusius reports that his first Greek guest in Tübingen (in February 1579), the illiterate Stamatios Donatos, who had been taken captive during the War of Cyprus (1570-1573) and needed two hundred-fifty ducats for his liberation, knew the differences between Lutherans, Catholics, Anabaptists, Calvinists and Antitrinitarians. ${ }^{51}$ Moreover, the alms collectors came to the German territories primarily as economic agents, as members of a charitable economy, and not as advocates of their confession. Their counterparts on the other hand could follow own confessional interests and exploit the migrants' testimonies or speech acts for their agendas.

The (sometimes insincere) pragmatism of both Greek Orthodox migrants and German hosts can be illustrated with the example of the interaction in August 1693 between the alms collector Mitrofanis Tzitzilianos from Evvoia and the courtier and scholar from Gotha Wilhelm Ernst Tentzel. Apart from examining the credential letter the Greek presented in Gotha-signed by the Patriarch of Constantinople Kallinikos II and a further nine metropolitans, whose authenticity was analysed by comparing it with similar ecclesiastical documents edited by Martin Crusius in his monumental Turcograecia (Basel 1584)-Tentzel addressed several questions on confessional matters to Tzitzilianos (e.g. the Eucharist and the Catholic dogma of Transubstantiation). ${ }^{52}$ He also implemented a procedure that can be called as 'test of confession', which was based on the confrontation of the Greek migrant with confessionally controversial texts. Arnold had used this method, too, and had confronted his Greek guests with texts attesting to a supposed vicinity or harmony between the Eastern Church and the Roman-Catholic Church. Tentzel explicitly imitated Arnold's method.$^{53}$ In Nuremberg he had presented the memoirs

50 For the impact of the political and confessional plurality in the Holy Roman Empire from the perspective of cultural history, see P. Hartmann, Kulturgeschichte des Heiligen Römischen Reiches (1648-1806). Verfassung, Religion, Kultur (Wien-Köln-Graz 2001).

51 'Nouerat, in terris nostris Lutheranos esse \& Papistas, \& Anabatistas, \& Caluinistas et Antitrinitarios. Nec scribere, nec legere, sciebat.' Crusius, Turcograecia, 189.

52 See the description of Tzitzilianos' credential letter and the confrontation with examples from Crusius' Turcograecia as well as the description of the questions and answers from the discussion between Tzitzilianos and Tentzel in Tentzel (ed.), Monatliche Unterredungen, 1693, 631-6.

53 'Den Discours selbst mit diesem Griechen [with Tzitzilianos] richteten unsere Herren ein nach der Methode, die der Herr Arnoldus zu Nürnberg mit dem Joasapho Logotheta gehal- 
of Sylvestros Syropoulos on the council of Ferrara-Florence (1438-1439) to an erudite monk from Kalamata named 'Joasaph Logotheta' (in October 1665) and also to an illiterate presbyter from Sitia called 'Petrus Vervosius' (in November 1669), who was unskilled in any foreign language except vernacular Greek. ${ }^{54}$ Arnold's method was a kind of security measure intended to help the Lutheran confessional regime in Nuremberg to detect whether the alms seekers were 'authentic' Greek Orthodox or Uniates. Some of Crusius' guests also made statements in passing about the Union of Ferrara and Florence that were intended to flatter Lutheran ears. ${ }^{55}$

The advantage of Tentzel's refined method was that it could even evoke differentiations concerning the attitudes of Greeks towards the differing Protestant confessions. The Lutheran hosts in Gotha were satisfied when their guest was confronted with the pro-Calvinist Confessio fidei (Geneva 1629) of Patriarch Kyrillos Loukaris as well as with the more moderate (and supposedly pro-Lutheran) confession of Mitrofanis Kritopoulos (first published posthumously in Helmstedt in 1661) while Tzitzilianos took the side of the latter and condemned the former. ${ }^{56}$ Not to his own detriment but definitely damaging to the reputation of later Greek migrants, was the news of the positive attitude of Tzitzilianos' towards Loukaris, which he was supposed to have exhibited during his stay later in the same year (1693) in the Calvinist town of Marburg. Samuel Andreae, a theologian from this

ten und in seiner Epistel an Herrn D. Veiel zu Ulm (welche dieser seiner Defension contra Allatium vorgesetzet) mit vielen gelehrten Annotationen beschrieben hat.' Ibid., 635.

54 'Vervosius' had reacted in the following way: "Dessen eigentliche Meinung zu erforschen, ob er vielleicht ein Römischer, so genannter Scismas Griech were, oder den Pabst zu Rom für einen Schismatischen hielte; bediente ich mich dieses Vortheils und legte ihm Historien Concilii Florentini, wie solche D. Rob. Creygthon deß jetzigen Königes in Engelland Sacellany, Grece et Latine edirt, vor: Und lobte ihm solches Concilium auf das allerbeste, als die Vereinigung der Orientalischen mit der Ocidentalischen Kirche, das ist, der Griechischen mit der Römischen. Allein er fing alsobald an, solches zu verpfujen ernstlich dem selben zu widersprechen." (Arnold, report to the churchwarden, 17 November 1669-Arnold, Notebook, f. 3) For Arnold's confrontation of 'Joasaph Logotheta' with the same text, see Arnold's letter to Elias Vejel, 10 March 1666, printed in E. Vejel, Defensio Exercitationis Historico-Theologicae de Ecclesia Graecanica Hodierna (Frankfurt a.M. 1666) [7f.].

55 In May 1599 during his stay in Tübingen, Metropolitan Athanasios I of Ohrid, who was gathering money and soldiers for a planned rebellion against the 'Turks' in the territory of his di-

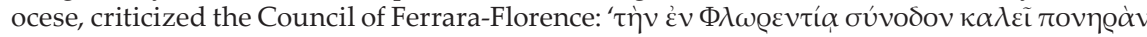

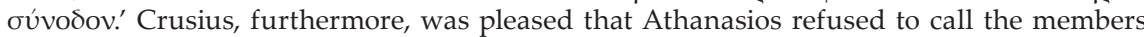

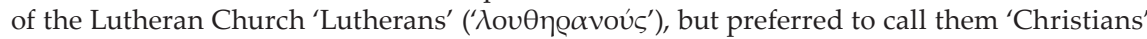

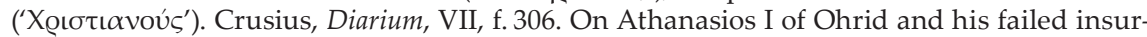
rection in the territory of Himara in the summer of 1596, see P. Bartl, Der Westbalkan zwischen spanischer Monarchie und Osmanischem Reich. Zur Türkenkriegsproblematik an der Wende vom 16. zum 17. Jahrhundert (Wiesbaden 1974) 124-31.

56 Man zeigete ihm des Cyrilli Lucaris, Patriarchs zu Constantinopel Confession, wie sie in Holland an. 1645 [...] gedruckt worden; man zeigete ihm auch des Metrophanis Critopuli Confession, welche Ioannes Horneius zu Helmstädt an. 1661 heraus gegeben: des Metrophanis seine approbirte er als dem Glauben der wahren Griechen gantz conform, des Cyrilli seine aber verwarff er als gar zu sehr nach der Reformirten hypothesibus eingerichtet. (Tentzel (ed.), Monatliche Unterredungen, 1693, 637.) 
town, in a letter from 5 September 1696 had informed Tentzel as editor of the Monatliche Unterredungen that he possessed several written testimonies of migrating Greeks proving that Loukaris' confession of faith corresponded to the dogma of their Church-among them also a written document by Tentzel's former guest, Tzitzilianos. For Tentzel the matter had become clear. The wandering Greeks trimmed their sails to the (confessional) wind that was blowing in the territory they were passing through:

Ich habe bey der subscription Metrophanis Tzitziliani noch was zu erinnern erwiederte Mecoenas. Als dieser Archimandrit an. 1693 bey uns war verwarff er des Cyrilli Lucaris Confession, als gar zu sehr nach der Reformirten hypothesibus eingerichtet [...] wie kommts denn daß er zu Marpurg eben dieselbe Confession approbiret hat? Dazu weiß ich nichts anders zu sagen war Tulli Gegenantwort als daß Metrophanes einer von denen unbeständigen Griechen gewesen zu seyn scheinet/die den Leuten nach dem Munde schwatzen. Wenn sie bey den Lutheranern sind so reden sie wie es dieselben gerne hören: Sind sie aber bey den Reformirten so pflegen sie sich deren hypothesibus auch $\mathrm{zu}$ accomodiren. ${ }^{57}$

Tzitzilianos' case was made public in Tentzel's journal, and several scholars commenting on the 'confession of the Greeks' in the eighteenth century were familiar with the incident from Gotha. ${ }^{58}$

Thus far we have examined the involvement of migrants in 'tests of confession' of scholars who were supporting indirectly or even acting in the name of ecclesiastical authorities. These agents, however, also had a scholarly interest in matters concerning the dogmas, traditions and confessional cultures of Eastern Churches. As 'armchair orientalists' (Mulsow) their encounter with Greek migrants offered them exceptional possibilities of accumulating or verifying knowledge about the 'confessio Graeca' as well as about other related matters, like the Greek language, the topography of Greece, but also the other languages and cultures present in the Ottoman Empire. ${ }^{59}$ Eideneier, Moennig and Toufexis have analysed the importance of the communication with Greek migrants for Martin Crusius' study of the Modern Greek language and their role in making available for him linguistic knowledge (vocabulary, printed texts, specimens of handwriting, reading literary

57 Ibid., 1697, 495. Cf. the autographs of four Greek migrants with sympathies for Loukaris, which were sent by Andreae to Tentzel. Forschungsbibliothek Gotha, Chart. B 200, fol. 31r-37v.

58 Apart from Heineccius (Heineccius, Wahrhaftige Abbildung, part I, 226), for instance, Johann Fecht. See J. Fecht, Kurtze Nachricht von der Religion der heutigen Griechen (Rostock-Leipzig 1713) 94.

59 M. Mulsow, 'Global Intellectual History and the Dynamics of Religion', in C. Bochinger and J. Rüpke (eds), Dynamics of Religion: Past and Present (Berlin-Princeton 2017) 251-72; S. Saracino, ‘Griechisch-orthodoxe Almosenfahrer im Heiligen Römischen Reich und ihre wissensgeschichtliche Bedeutung (1650-1750)', in M. Friedrich and J. Schilling (eds), Praktiken frühneuzeitlicher Historiographie [Cultures and Practices of Knowledge in History, 2] (Berlin-Boston 2019) 141-73. 


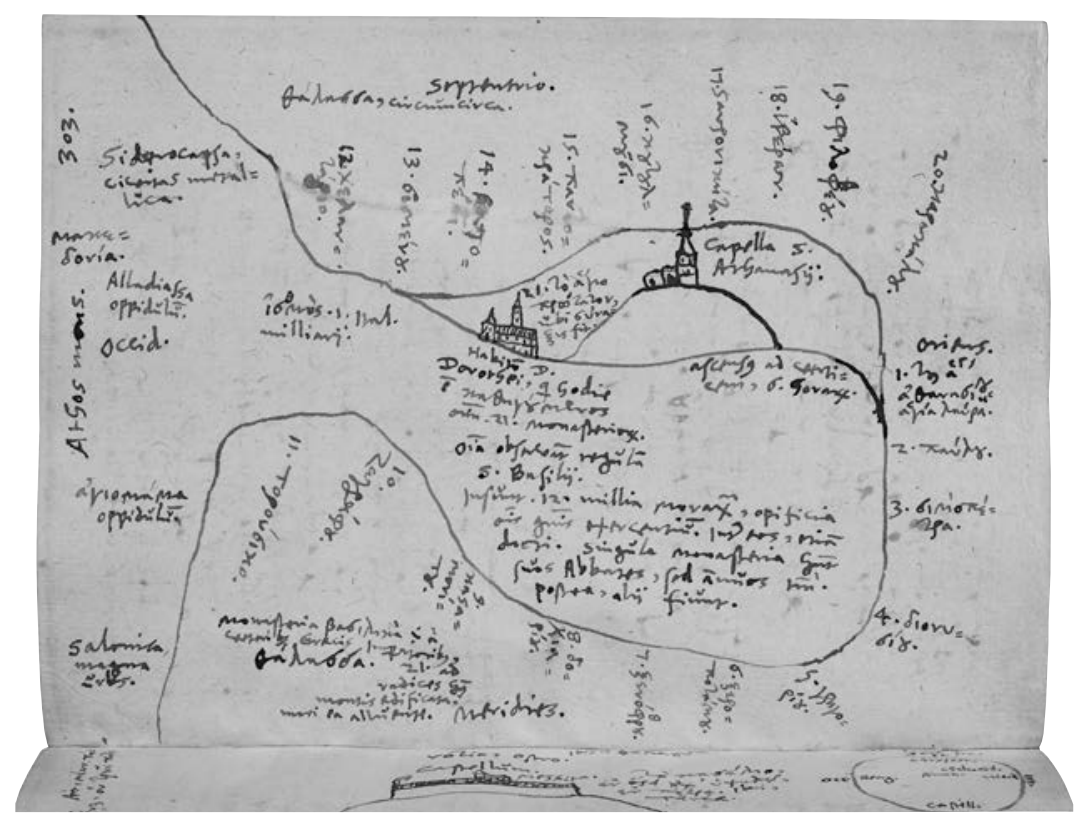

Fig. 3: Handwritten map of Mount Athos from Martin Crusius' Diary, which was made with the help of the monk Daniil Palaiologos

texts aloud).$^{60}$ Almost all of them were alms collectors. But these migrants also provided Crusius with 'ethnographical' and geographical knowledge, sometimes entangled with confessional perspectives. ${ }^{61}$ Insightful in this regard is the case of the monk Daniil Palaiologos, a native of Athens and the steward ('oikovónos') of the Iviron Monastery on Mount Athos, who was collecting funds for the liberation of some of his fellow monks. During his stay in Tübingen in September 1585 he shared with Crusius his 'cognitive map' of the Athos Peninsula and of the location of its twenty monasteries. Based on this knowledge Crusius produced a handwritten (rudimentary) map of Athos. (Fig. 3). The map lists and also localizes the twenty monasteries on Mount Athos. ${ }^{62}$

60 Moennig, 'Martinus Crusius's collection'; H. Eideneier, 'Von der Handschrift zum Druck. Martinus Crusius und David Höschel als Sammler griechischer Venezianer Volksdrucke des 16. Jahrhunderts', in H. Eideneier (ed.), Graeca recentiora in Germania. Deutsch-griechische Kulturbeziehungen vom 15. bis 19. Jahrhundert [Wolfenbütteler Forschungen 59] (Wiesbaden 1994) 93-111; P. Toufexis, Das Alphabetum vulgaris linguae graecae des deutschen Humanisten Martin Crusius (1526-1607). Ein Beitrag zur Erforschung der mündlichen griechischen Sprache im 16. Jh. (Köln 2005).

61 Thoroughly in Calis, 'Reconstructing the Ottoman Greek World'.

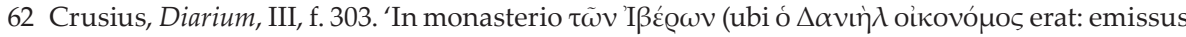

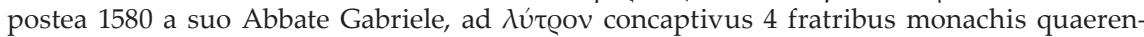
dum)'. Ibid., fol. 304. For the concept of 'cognitive map' indicating the subjective spatial knowl- 
The German learned men structured their colloquies with Greek alms collectors according to a specific set or catalogue of standardized questions (concerning the council of Ferrara-Florence, the confession of faith of Kyrillos Loukaris, the number of canonized church councils, the number of sacraments, the dogma of transubstantiation etc.). Christoph Arnold recorded the knowledge made available to him in the course of interrogations of Greek migrants in a specific notebook. He organized this knowledge in his notebook by annotating 'lemmata' at the margin-an epistemic procedure rooted in the excerpting practices taught in early modern universities. ${ }^{63}$ In passages from this 'handwritten encyclopaedia' of Arnold, which were produced on the basis of his communication with Daniil Kastrisios, we find 'lemmata' like the following: 'Castrensum familia' (outlining his family background), 'Monasterium $\tau \tilde{\omega} \nu$ 'I $\beta \eta j \varrho \omega \nu$ ['of Iviron']' (with information on this monastic institution), 'Metalla in Pathmo' (describing the resources of metals in the island of Patmos), 'Confessio Cyrilli Lucaris' (with statements on the issue of Lukaris' faith) or 'Parochiae XIV. Constantinopolitanae' (with information about the fourteen parishes of Constantinople).

In addition to Crusius' works, Arnold's notebook, and Tentzels' journal, the Calvinist theologian from Berlin Jacob Elßner also attests to how the colloquies with Greek alms collectors could be at the root of research or book publications by German learned men on the subject of Greek Orthodoxy, and how colloquies with Greeks were transformed into books. Elßner's treatise Neueste Beschreibung derer Griechischen Christen in der Türkey (1737) already mentions on the title page the pivotal contribution of his guest Dorostamos, presenting him as co-author ('Aus glaubwürdiger Erzehlung Herrn Athanasius Dorostamus, Archimandriten des Patriarchen zu Constantinopel'). It furthermore contains a portrait of the Greek clergyman (Fig. 4). Also Dorostamos seems to have shared Elßner's point of view that he had contributed an essential part of it, for during his interrogation in Stuttgart he stated that during his longer stay in Berlin (caused by an illness) he had 'helped Mr Elßner in his house in writing his book on the Greek Church.'64

Concerning the supposedly scandalous (Catholic) dogma of transubstantiation, Elßner was satisfied to note the long and voluminous beard of the archimandrite, in which crumbs of the consecrated bread could get stuck during the liturgy. Hence, Elßner concluded, the Greeks could not take Transubstantiation literally, something which Calvinists and Lutherans alike completely rejected, though the Lutherans did recognize a real presence of Christ's body and blood in the Eucharist. ${ }^{65}$ As trivial as

edge or experience of a certain space by an individual, see R. Downs and D. Stea, Kognitive Karten: Die Welt in unseren Köpfen (New York 1982).

63 Concerning the excerpting notebooks of the 'orientalist' and Professor for Greek and Hebrew at the Gymnasium of Hamburg, Johann Christoph Wolf, see M. Mulsow, Prekäres Wissen. Eine andere Ideengeschichte der Frühen Neuzeit (Frankfurt a.M. 2012) 367-403.

64 '[I]l avoit aidé à M.r Elsner dans sa propre maison à faire le livre de l'Histoire de l'Eglise Greque'. HSTAS, A 202, Bü 1692, document Nr. 6.

65 'E]s kann auch so genau nicht zugehen, daß nicht einige Brodsamen vom heiligen Brod, einige Tropfen vom heiligen Wein in dem ansehnlichen Ober- und Unterbart derer Griechen, 


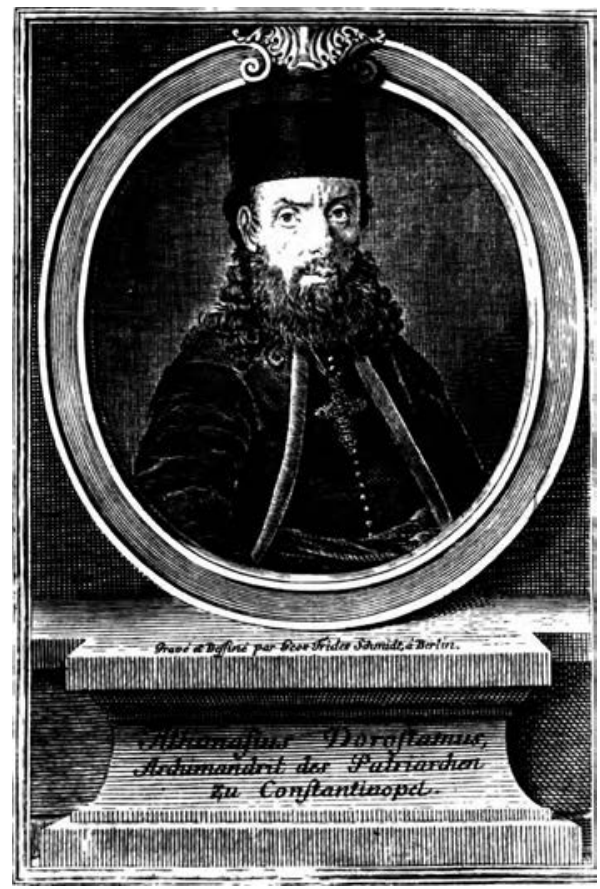

Fig. 4: Engraving with a portrait of Athanasius Dorostamus from Elßner's Neueste ‘Beschreibung derer Griechischen Christen in der Türkey’ (1737)

this method of generating knowledge may be, it does illustrate the deep impression a Greek clergyman could make from up close on 'specialists' like Elßner. ${ }^{66}$

If Greek migrants were opportunistic in adapting to the confessional outlook of the host societies, scholars like Crusius, Arnold, Tentzel and Elßner were at the same time eager to make them fit perfectly into their imaginations, converting them into living witnesses of an 'authentic Greek confession' compatible with Lutheranism or Calvinism. How did the migrants react to the virulent situation of

derer Priester vornehmlich welche das Brod in die Hand, und den Kelch mit dem Wein bekommen, hangen bleiben.' Elßner, Neueste Beschreibung, 234.

66 See also the description of the beards and robes of Polyeidis and Pavlos by the chancery of the the southern German county of Hohenlohe-Kirchberg from 2 October 1731 (I thank Tobias Graf for indicating this source to me): "Der Erste, so Ein Abbt, nennet Sich Theocletus Polyades u. Sein compagnon P. Athanasius Paulus. Beyde Schwarze Stark bärtige denen Juden nicht ohnähnliche Leuthe. Jener träget Einen langen Talar von violet-gewäßertem SeydenMoor, roth doupliret; das Unterkleyd ist auch blau mit einen rothen escarpe gebunden; die unter dem habende Müze ist von gleichem Grunde, wie das Obergewandt und an Einem rothen Band führet Er Ein wohl abhangend. schlecht Silbernes Creuz. Der Pater ist mit Einem Schwarzen Seydenen habit biß um die Füße bekleydet und das Untergewand auch blau. Beyde sindt von mitteln Jahren." (Hohenlohe Zentralarchiv Neuenstein, Ki 10, Nr. 25, Lit. A-41.) 
confessional competition experienced in the Holy Roman Empire and to the manipulative treatment they experienced by German learned men? The approach of accommodation, for instance, of making anti-Catholic statements to Lutheran or Calvinist audiences, has been treated at length. Moreover, it has been described as a typical feature of the migration regime of Greek Orthodox alms collectors from the Ottoman Empire, with their high-grade mobility, to be reliant on support from (elite) members of the host societies. Their assistance for migrants, their supply with money, recommendatory letters and information, was decisive for the success of their specific enterprise. In this light, the disposition to accommodate their statements about Greek Orthodoxy to the outlook of their Protestant counterparts seems, to a certain extent to, have been born out of necessity.

The opposite approach of following a confrontational strategy, of intentionally distinguishing one's confession from the encountered confessional regime in the host territory, is even of greater interest, although it rarely arises. The Metropolitan of Ohrid Gavriil, who had entered Tübingen with a large entourage in August 1587, simply prohibited questions about religious matters from being addressed to him. ${ }^{67}$ With his performance the Metropolitan obviously tried to style himself as high ranking noble- and clergyman and intended to raise the solidarity of his aristocratic peers in the Holy Roman Empire. A similar form of self-fashioning can also be observed in several other of Crusius' guests, who claimed to be descendants of Byzantine imperial families (e.g. in July 1591 Thomas Palaiologos claimed to be the great-grandchild of the brother of Konstantinos XI Palaiologos, the last Byzantine emperor) ${ }^{68}$ In the case of those whose high rank was recognized and accredited, the members of the host societies were willing to tolerate their peculiar confessional traditions and pious practices. Metropolitan Gavriil and other clergymen in his entourage are said to have been fasting (a religious practice not recognized by Lutherans), for which reason it was arranged that they should be served in the hostel in Tübingen with fish, crabs, soup, vegetables and bread rolls for supper. ${ }^{69}$

In his interconfessional communication with German learned men, the alms collector Theoklitos Polyeidis, member of the notorious network connected to Athanasios Pavlos and Athanasios Dorostamos, seems to have been abounding in self-confidence. The director of the 'Gymnasium illustre' in Gotha Johann Stuß (1686-1775) reports that he had addressed a catalogue of eighteen questions of mostly confessional contents to Polyeidis, who sojourned in Gotha in December of 1732 and was eager to gain access to the Ernestinian court. ${ }^{70}$ Stuß, as representative of the then

67 '[C]olloquens de varijs rebus: sed nihil admodum de Religione conferre Patriarcha volebat.' Crusius, Annalium, 803.

68 Thomas Palaiologos had fled from the Ottoman Empire because of his conversion to the Christian faith. He was the son of a Muslim convert called Mehmed Bei, who is said to have been the Ottoman governor of Macedonia. See the long entry about his imperial genealogy by the hand of Palaiologos in Crusius, Diarium, III, f. 319-25.

69 'Illi tres, et alii Ecclesiastici viri carne non vescuntur. Ergo eis pisces, cancri, iuscula, olus, pastilli etc. apposita fuerunt'. Ibid., III, f. 590.

70 Stuß' report about his encounter with Polyeidis was presented by him in a speech delivered 
rather old-fashioned confessional regime of Gotha, describes the feature of Poly-

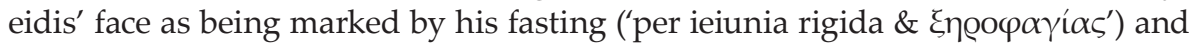
contrasts the hard fasting discipline of Greek clergymen to the gluttony of Catholic monks and priests. One of the eighteen questions concerned the 'abuse' committed by the Eastern Church in giving the Holy Communion to new-borns after baptism ('an abusus ille, quo infantibus statim post baptismum etiam eucharistia porrigatur, hodieque in ecclesia Greca vigeat?'). ${ }^{71}$ Polyeidis' answered that this was not an abuse but an ancient practice of the church ('hunc abusum non esse, sed antiquam ecclesiae praxin'), quoting from the Gospel of John 6: 53 ('unless you eat the flesh of the Son of Man and drink his blood, you have no life in you'). Hence, it seems that Polyeidis' negotiated confessional matters regardless of the consequences for his enterprise as an alms collector. It seems paradoxical that Polyeidis, who was accused by Athanasios Pavlos of being the mastermind of their network and the protagonist in forging credential letters, did not act in an opportunistic way but rather preferred to 'fight' without hesitation for his confession. ${ }^{72}$ That Polyeidis felt no necessity to accommodate and to flatter in the way his predecessors did, at least during his stay in Gotha, permits different conclusions. On one hand it could be interpreted as evidence for the fact that itinerant Greek clergymen in the eighteenth century reflected the consolidated confessional identity of their Church, which had made efforts to be 'confessionalize' e.g. under the Patriarch of Jerusalem Dositheos II (r. 1669-1707). On the other hand, Polyeidis may represent the case of an alms collector who, after his long-lasting stay in the German territories, possessed a standing and a reputation that allowed him to act more offensively in confessional debates. ${ }^{73}$

Of course nonetheless he was vulnerable to the accusation of using forged documents, and after the condemnation of Athanasios Pavlos in August 1736 it is reported that he was temporarily arrested in the town of Wiesbaden until he could be discharged by the Metropolitan of Karlowitz Vikentije Jovanović (m. 1731-1737). ${ }^{74}$

on 27 July 1733 during the celebration of the aniversary of the 'Gymnasium illustre' in Gotha. J. Stuß, Observationes selectas de Ecclesiae Graecae sub imperio Turcico statu hodierno exhibet, simulque ad solemnem panegyrin sub auspicia lustrationis anniverariae illustris Gymnasii Gothani celebrandam (Gotha 1733).

71 Ibid., 5.

72 Athanasios Pavlos testified to the criminal court of Herzogenbusch that it was Polyeidis who had suggested manipulating the credential letters of the patriarch Paisios II: "Daß in seinem Original-Patent nicht geschrieben, daß er zu Lösung der Sclaven collectiren solle, sondern nur allein zum Aufbringen des Tributs, welchen die Kirche jährlich an dem Sultan bezahlen müsse; daß aber oben gemeldeter Theoclitus Polidies ihm bekandt gemacht, daß das Wort Tribut geändert, und in die Stelle gesetzt wäre zur Lösung 8800 Sclaven, unter dem Vorwand, daß, wann das Wort Tribut darinnen bleibe, die Collecte bey fremden Nationen nicht viel einbringen würde." (Elßner, Fortsetzung, 27)

73 Polyeidis later became the first priest of the Greek Orthodox community of the Holy Trinity in Leipzig founded in 1743, see F.-T. Suppé, 'In Sachsen auf Heimatboden. Zur Geschichte der griechischen Gemeinde in Leipzig', in G. S. Henrich (ed.), Evgenios Vulgaris und die Neugriechische Aufklärung in Leipzig (Leipzig 2002) 13-46, 17 .

74 J. G. Heinsius, Unpartheyische Kirchen-Historie Alten und Neuen Testaments ... Dritter Theil in welchem die Geschichte vom Jahr nach Christi Geburt 1730 bis 1750 enthalten sind (Jena 1754) 585: 
In his colloquy with Stuß in Gotha, on the crucial tenth question of whether their shared hostility to the dogma of the Roman-Catholics could bring about a future cooperation of Lutherans and Greek Orthodox, he answered in a diplomatic but also resolute manner: Although many differences between these two groups were

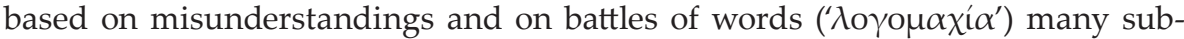
stantial and insuperable differences still remained. At this point in the dialogue with Stuß, he had referred to the famous correspondence between Patriarch Ieremias II and the theologians of Tübingen, who had been assisted by the expert for Greek language and culture Martin Crusius, a correspondence which had been interrupted by the Patriarch in 1581. Polyeidis even produced a copy of the printed edition of this correspondence (Wittenberg 1584), which he had received as a gift during his stay in Tübingen. ${ }^{75}$ More than 120 years after the death of Crusius, who had made an important contribution to shaping the communication between Greek Orthodox migrants and members of the host societies in the Holy Roman Empire, Tübingen still had an appeal for alms collectors like Polyeidis. However, it can be assumed that he also invoked the correspondence between Tübingen and Constantinople to strengthen the cooperative spirit between Lutherans and Greek-Orthodox during his stay in Protestant lands.

\section{Conclusions: Alms Collectors as 'Confessionalized' Actors?}

In the terms of 'confessionalization', as Cornel Zwierlein has re-defined it, as a phenomenon of transfer of knowledge and of communication ('als das Fragen-Stellen- und Fragen-Beantworten-Können-Müssen'),, ${ }^{76}$ Greek Orthodox alms collectors were 'confessionalized' actors. At least during their stay in the 'confessionalized' territories of the Holy Roman Empire, questions of a confessional nature were constantly posed to them which they had to be able to answer. This ability was one important precondition for their mobility and for the success of their economic-charitable enterprise. To refuse to answer questions, to deny communication of one's confession, as the Metropolitan of Ohrid Gavriil did in Tübingen, was

\footnotetext{
"Man hat vorgeben wollen, daß er [Polyeidis] keinesweges um Allmosen zu sammlen, sondern als ein Prälat, in seinen eigenen Angelegenheiten, in diese Gegenden gekommen sey. Allein wir haben Nachrichten, daß er allerdings Collecten in Deutschland zu Erlösung christlicher Sclaven gesammlet, und mit authentischen Urkunden von den Griechischen Patriarchen und Erzbischoffen versehen gewesen. Man hatte ihn so gar an einigen Orten mit einem gewissen Betrüger vermenget, und ihn in schweren Verdacht gezogen, als seine Ehre durch die öffentliche Bekanntmachung eines Briefes gerettet wurde, den der Erzbischof zu Carlowitz an den Herrn Inspector Hellmund zu Wißbaden von A. 1736 geschrieben. Er meldet darinne, Theocletus sey angekommen, und man bedanke sich vor die überschickten Allmosen."

75 '[R]esp. controuersias plerasque Graecorum cum euangelicis nonnisi logomachias esse. Graecos autem ab iis, quae per canones conciliorum, \& patrum orthodoxorum auctoritatem confirmata sint, abire non posse: vti \& patriarcha HIEREMIAS theologicis Tubingensibus demonstrarit in Actis E scriptis reciprocis Wittebergae 1584. editis, quae, Tubingae sibi donata, proferebat.' Stuß, Oratio, 5. For the correspondence between the Lutheran theologians from Tübingen and Ieremias II between 1573 and 1581, see Wendebourg, Reformation und Orthodoxie.

76 Zwierlein, 'Konfessionalisierung', 9.
} 
rather the exception. Most of the actors analysed in this study consented to give loquacious answers, while often accommodating the confessional perspective of the counterpart and dissimulating their own confessional identity.

But can they be described as 'confessional actors' according to the concept of confessionalization in its older and stricter meaning, as developed by Heinz Schilling and Wolfgang Reinhard in the 1980s, i.e. as a process of disciplining believer-subjects that was pursued by political authorities in the decades and centuries after the Reformation? The confessional communication with the Greek Orthodox that Martin Crusius was involved in, whether in his official correspondence with Patriarch Ieremias II in Constantinople (1573-1581) or concerning migrating Greeks making their courtesy visit in Tübingen, always had a semi-political character. ${ }^{77}$ Crusius' studies of the Greek language, confession and culture coincide with a period when Lutheranism in Württemberg and in the Holy Roman Empire generally was demarcating itself from Calvinism, as part of the protracted process of verbalizing and implementing the Formula of Concord (1577). The philhellene from Tübingen did not fail to inform his territorial sovereign in Stuttgart about the visit of Greek alms collectors (especially those of higher rank). ${ }^{78}$ The court in Stuttgart, furthermore, was eager to directly intervene in confessionally delicate issues, e.g. when Greek guests petitioned to be baptized in Tübingen and to convert to the Lutheran faith. This applies to the (exceptional) case of Mohammed/ Kosmas Papadatos from Arta, a fugitive janissary who was born in the Orthodox faith but as a child had been recruited for the Ottoman elite squad and converted

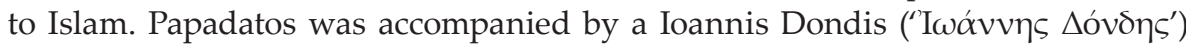
from Chania (Crete), who was his interpreter. ${ }^{79}$ Despite the sceptical reactions of Crusius' colleagues Jacob Andreae and Jacob Heerbrandt-they thought that the conversion of a former Greek Orthodox and Muslim convert would awaken bad memories of Catholic proselytism and would discredit the Lutherans in Tübingen in front of Patriarch Ieremias II-the Duke decreed that Papadatos should be accommodated at his costs in the students' house ('Burse') and receive catechetical tuition by Crusius personally. ${ }^{80}$ After his thorough instruction into the principles

77 For the political dimension of the correspondence between Tübingen and Constantinople and for the role played in it by duke Ludwig and his court chaplain Lukas Osiander, alongside the theologians and university professors Jacob Andreae and Jacob Heerbrand, see Wendebourg, Reformation und Orthodoxie, 108-11.

78 Concerning the visit of the Metropolitan of Ohrid Gavriil, see Crusius' letter to duke Ludwig, 1 September 1587. Crusius, Diarium, III, f. 593-5.

79 Immediately after their arrival they brought forward the motion that Mohamed/Kosmas may be baptized in Tübingen. Ibid., III, f. 512. The records connected to the episode of Papadatos' baptism fill over seventy pages of Crusius' diary (ibid., III, f. 512-88). For the conversion and baptism of Muslims in the Holy Roman Empire, see M. Friedrich, 'Türkentaufen. Zur theologischen Problematik und geistlichen Deutung der Konversion von Muslimen im Alten Reich', in A. Schunka (ed.), Orientbegegnungen deutscher Protestanten in der Frühen Neuzeit [Zeitsprünge. Forschungen zur Frühen Neuzeit 16/1] (Frankfurt a.M. 2014) 47-74.

80 For the sceptical reactions of Andreae, Heerbrand and Osianders, see Crusius, Diarium, III, f. 516. They feared 'quo Patriarcha Hieremia nostrae Religioni resistere, Papistae nobis insul- 
of Christian (Lutheran) faith, Papadatos was finally baptized on 20 of August 1587 in Tübingen. ${ }^{81}$ Other scholars interacting with Greek clergymen in the seventeenth and eighteenth centuries also communicated reports about these migrants to their ecclesiastical authorities (like Arnold in Nuremberg) or were themselves members of the ecclesiastical regime (like the consistorial councillor Elßner in Berlin).

Apart from the soft means (demanding answers to confessional questions) and hard means (catechizing and converting individuals) of confessionalization, this paper has dealt primarily with processes of knowledge transfer between Greek Orthodox alms collectors and scholars in the Holy Roman Empire. At first glance this transfer seems to have been contaminated by an interest-driven behaviour of both sides, by opportunism, flattery and accommodation. As Heineccius warned his reader, the wandering Greeks were ready to do and witness everything that might further their chief aim of collecting alms. But this is only one side of the coin. This transfer of knowledge represented a great opportunity for both sides to learn about the confession of the other. It was stabilized (and institutionalized) by the constant influx of alms collectors and the willingness of the host societies to support them. In return for the willingness of Greek migrants to provide their hosts with information, to answer their confessional questions and aporias, to supply them with Greek texts and manuscripts, scholars like Crusius, Arnold, Tentzel, Stuß and Elßner were ready to offer them their unrestricted support (money, information and intervention before political and ecclesiastical authorities). The mutual exchange of material and immaterial goods, of caritas and episteme, of alms and knowledge, finally becomes apparent as the real motor of the migratory regime that has been analysed in this survey. ${ }^{82}$ Recalling the self-confident and confrontational behaviour in confessional matters displayed by Metropolitan Gavriil (1587) and Theoklitos Polyeidis (1732) we may assume that sufficient bargaining spaces were conceded to migrants by the host societies, and that they were enabled to preserve their religious and cultural identities, an indispensable condition for successful migration in early modernity-as it still is today. ${ }^{83}$

tare.' Ibid., III, fol. 516. Information had reached the court in Stuttgart that Mohamed/Kosmas was completely unfamiliar with the Christian faith ('dermaßen noch so rudis befunden, das er auch das pater noster nit wol erzelen khönte'). Letter from Duke Ludwig to Crusius, 8 July 1587. Ibid., III, f. 519.

81 See the copies of the letters by Duke Ludwig from 8 July and 3 August 1587. Ibid., III, f. 519f., 544-6.

82 Sometimes German scholars supported Greek alms collectors on condition that they would give their share later on, after their return to their homelands. Crusius' complains to Zygomalas in Constantinople about the fact that many of the former Greek guests he had supported warmheartedly in Tübingen, did not keep their promise to send him books or manuscripts

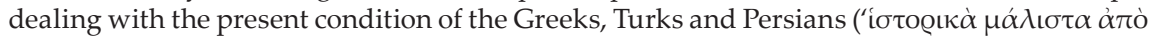

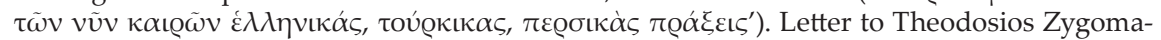
las, 1 Juli 1600. Crusius, Diarium, VIII, f. 210-4, 212.

83 A.Schunka, 'Normsetzung und Normverletzung in Einwanderungsgesellschaften der Frühen Neuzeit', in K. P. Krauss (ed.), Normsetzung und Normverletzung. Alltägliche Lebenswelten im Königreich Ungarn des 18. Jahrhunderts (Stuttgart 2015) 29-55. 


\section{Appendix}

Alms collectors from the Ottoman Empire and the Venetian 'stato da mar' with places of origin and of attested sojourns in the Holy Roman Empire ${ }^{84}$

\begin{tabular}{|c|c|c|c|c|}
\hline Name & Date & Place of origin & Destination & Sources \\
\hline $\begin{array}{l}\text { 1. Joasaph } \\
\text { 2. Molitus }\end{array}$ & 1606 & $\begin{array}{l}\text { St Catherine's } \\
\text { Monastery } \\
\text { (Sinai) }\end{array}$ & Vienna & $\begin{array}{l}\text { HHStA, RHR, Grat Feud } \\
\text { Patentes und Steckbriefe, } \\
\text { 2-107 }\end{array}$ \\
\hline $\begin{array}{l}\text { 3. Anastasius } \\
\text { de Moscha } \\
\text { 'Graecus' }\end{array}$ & 1607 & no information & Vienna & $\begin{array}{l}\text { HHStA, RHR, Grat Feud } \\
\text { Patentes und Steckbriefe, } \\
4-6\end{array}$ \\
\hline $\begin{array}{l}\text { 4. Hieremias } \\
\text { 5. Parthenius }\end{array}$ & 1616 & $\begin{array}{l}\text { Iviron Monaste- } \\
\text { ry (Athos) }\end{array}$ & Vienna & $\begin{array}{l}\text { HHStA, RHR, Grat Feud } \\
\text { Patentes und Steckbriefe, } \\
1-41\end{array}$ \\
\hline $\begin{array}{l}\text { 6. Andreas Thes- } \\
\text { salonicensis }\end{array}$ & 1622 & Thessaloniki & Vienna & $\begin{array}{l}\text { HHStA, RHR, Grat Feud } \\
\text { Patentes und Steckbriefe, } \\
2-4\end{array}$ \\
\hline $\begin{array}{l}\text { 7. Paleologus } \\
\text { Porphyrius, } \\
\text { Metropolitan } \\
\text { of Ohrid } \\
\text { 8. Jeremias, } \\
\text { Metropolitan } \\
\text { of Durazzo } \\
\end{array}$ & 1628 & Ohrid, Durazzo & Vienna & $\begin{array}{l}\text { HHStA, RHR, Grat Feud } \\
\text { Patentes und Steckbriefe, } \\
\text { 3-88 }\end{array}$ \\
\hline 9. Euthimius & $\begin{array}{l}1628 \\
1630\end{array}$ & Constantinople & Vienna & $\begin{array}{l}\text { HHStA, RHR, Grat Feud } \\
\text { Patentes und Steckbriefe, } \\
1-172 / 173\end{array}$ \\
\hline $\begin{array}{l}\text { 10. Abraham, } \\
\text { Metropolitan } \\
\text { of Ohrid }\end{array}$ & 1629 & Ohrid & Vienna & $\begin{array}{l}\text { HHSt } A, \text { RHR, Grat Feud } \\
\text { Patentes und Steckbriefe, } \\
1-20\end{array}$ \\
\hline $\begin{array}{l}\text { 11. Panagio- } \\
\text { ta Phocas } \\
\text { Canci ('civis } \\
\text { Melenicensis } \\
\text { Graecus') }\end{array}$ & 1630 & Meleniko & Vienna & $\begin{array}{l}\text { HHStA, RHR, Grat Feud } \\
\text { Patentes und Steckbriefe, } \\
\text { 3-92 }\end{array}$ \\
\hline $\begin{array}{l}\text { 12. Nathanael, } \\
\text { Metropolitan } \\
\text { of St Maura } \\
\text { ('natione Grae- } \\
\text { cus') }\end{array}$ & 1638 & Lefkada & Vienna & $\begin{array}{l}\text { HHStA, RHR, Grat Feud } \\
\text { Patentes und Steckbriefe, } \\
\text { 3-14 } \\
\text { Tentzel } 1697\end{array}$ \\
\hline
\end{tabular}

84 The names listed in the first column are spelled in the (mostly Latinized) form of the Greek names of alms collectors as it is used in the archive's sources listed in the last column. 


\begin{tabular}{|c|c|c|c|c|}
\hline Name & Date & Place of origin & Destination & Sources \\
\hline $\begin{array}{l}\text { 13. Ioannes Anto- } \\
\text { nius }\end{array}$ & 1659 & Naxos & Vienna & $\begin{array}{l}\text { HHStA, RHR, Grat Feud } \\
\text { Patentes und Steckbriefe, } \\
1-20\end{array}$ \\
\hline $\begin{array}{l}\text { 14. Joasaph Logo- } \\
\text { theta }\end{array}$ & 1665 & Kalamata & Nuremberg & Arnold 1666 \\
\hline $\begin{array}{l}\text { 15. Petrus Vervo- } \\
\text { sius }\end{array}$ & 1669 & Sitia (Crete) & Nuremberg & $\begin{array}{l}\text { Arnold, StB Nürnberg, } \\
\text { Amb. } 98,4^{\circ} \mathrm{MS}\end{array}$ \\
\hline 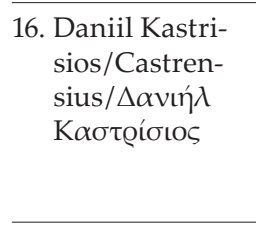 & $\begin{array}{l}1670, \\
1672\end{array}$ & $\begin{array}{l}\text { Iviron Monas- } \\
\text { tery (Athos), } \\
\text { Patmos }\end{array}$ & $\begin{array}{l}\text { Hungary, Vien- } \\
\text { na, Nuremberg, } \\
\text { Leipzig, Hildes- } \\
\text { heim, Berlin, } \\
\text { Heidelberg, } \\
\text { Dresden }\end{array}$ & $\begin{array}{l}\text { Arnold, StB Nürnberg, } \\
\text { Amb. } 98,4^{\circ} \mathrm{MS} \\
\text { Hillarius } 1687\end{array}$ \\
\hline $\begin{array}{l}\text { 17. Athanasius } \\
\text { (the Macedoni- } \\
\text { an) } \\
\text { 18. Georgius } \\
\text { Philippinus }\end{array}$ & 1673 & $\begin{array}{l}\text { Iviron Monas- } \\
\text { tery (Athos), } \\
\text { Constantinople }\end{array}$ & $\begin{array}{l}\text { Nuremberg, } \\
\text { Regensburg, } \\
\text { Augsburg, Ulm, } \\
\text { Nördlingen, } \\
\text { Wien, Leipzig }\end{array}$ & $\begin{array}{l}\text { Arnold, StB Nürnberg, } \\
\text { Amb. } 98,4^{\circ} \text { MS } \\
\text { Hillarius } 1687\end{array}$ \\
\hline $\begin{array}{l}\text { 19. Franciscus } \\
\text { Polani }\end{array}$ & 1686 & Crete & Marburg & Tentzel 1697 \\
\hline $\begin{array}{l}\text { 20. Metrophanes } \\
\text { Tzitzilianos }\end{array}$ & 1693 & Evvoia & Gotha, Marburg & Tentzel 1693 and 1697 \\
\hline 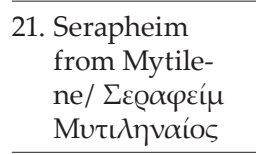 & $1697 / 98$ & $\begin{array}{l}\text { Mytilene, Cons- } \\
\text { tantinople }\end{array}$ & $\begin{array}{l}\text { Vienna, Leipzig, } \\
\text { Halle }\end{array}$ & $\begin{array}{l}\text { Helladius } 1714 \\
\text { Tsakiris and Makrides } \\
2015\end{array}$ \\
\hline $\begin{array}{l}\text { 22. Dionysius Sac- } \\
\text { romonachus }\end{array}$ & 1703 & $\begin{array}{l}\text { Monastery of } \\
\text { St Athanasius } \\
\text { (Thessaly) }\end{array}$ & Gotha & Stuß 1733 \\
\hline $\begin{array}{l}\text { 23. N. Adriani, } \\
\text { Abbas }\end{array}$ & 1705 & no information & Gotha & Stuß 1733 \\
\hline $\begin{array}{l}\text { 24. Abbot from } \\
\text { Philippoi }\end{array}$ & 1713 & $\begin{array}{l}\text { Philippoi } \\
\text { (Macedonia) }\end{array}$ & Rostock & Fecht 1712 \\
\hline 25. Athanasius & 1719 & $\begin{array}{l}\text { St Catherine's } \\
\text { Monastery } \\
\text { (Sinai) }\end{array}$ & Vienna & $\begin{array}{l}\text { OeSt } A, \text { FHKA, SUS RA } \\
186.1 .61-62\end{array}$ \\
\hline $\begin{array}{l}\text { 26. Dionysius } \\
\text { 27. Sebastiano }\end{array}$ & 1721 & $\begin{array}{l}\text { St Catherine's } \\
\text { Monastery } \\
\text { (Sinai) }\end{array}$ & Vienna & $\begin{array}{l}\text { OeStA, FHKA, SUS RA } \\
\text { 186.1.61-62 }\end{array}$ \\
\hline $\begin{array}{l}\text { 28. Paisios, Me- } \\
\text { tropolitan of } \\
\text { Patras }\end{array}$ & $1731 / 33$ & $\begin{array}{l}\text { Patra (Pelopon- } \\
\text { nese) }\end{array}$ & Vienna & $\begin{array}{l}\text { Papadopoulos-Keramefs } \\
1907\end{array}$ \\
\hline
\end{tabular}




\begin{tabular}{|c|c|c|c|c|}
\hline Name & Date & Place of origin & Destination & Sources \\
\hline $\begin{array}{l}\text { 29. Athanasius } \\
\text { Paulus }\end{array}$ & $\begin{array}{l}1731- \\
1736\end{array}$ & $\begin{array}{l}\text { Jerusalem, Ivi- } \\
\text { ron Monastery } \\
\text { (Athos) }\end{array}$ & $\begin{array}{l}\text { Augsburg, } \\
\text { Darmstadt, } \\
\text { Wien, Hungary, } \\
\text { Hohenlohe's } \\
\text { Grafschaft }\end{array}$ & $\begin{array}{l}\text { Rousseau, Confessions } \\
\text { Elßner } 1747 \\
\text { Tsakiris and Makrides } \\
2015\end{array}$ \\
\hline $\begin{array}{l}\text { 30. Athanasius } \\
\text { Dorostamus }\end{array}$ & $\begin{array}{l}1735- \\
1738 \\
1741\end{array}$ & $\begin{array}{l}\text { Constantinople, } \\
\text { Athos }\end{array}$ & $\begin{array}{l}\text { Among others: } \\
\text { Vienna, Berlin, } \\
\text { Leipzig, Gotha, } \\
\text { Erfurt, Weimar, } \\
\text { Hamburg }\end{array}$ & $\begin{array}{l}\text { Elßner 1737, } 1747 \\
\text { Acta Historico-Ecclesiasti- } \\
\text { ca, IX/50, Weimar } 1745 \\
\text { Tsakiris and Makrides } \\
2015\end{array}$ \\
\hline $\begin{array}{l}\text { 31. Theoklitos } \\
\text { Polyeidis }\end{array}$ & $\begin{array}{l}1731- \\
1737\end{array}$ & $\begin{array}{l}\text { Iviron Monaste- } \\
\text { ry (Athos) }\end{array}$ & $\begin{array}{l}\text { Tübingen, } \\
\text { Frankfurt a.M., } \\
\text { Wiesbaden, Kas- } \\
\text { sel, Gotha, Graf- } \\
\text { schaft Nassau- } \\
\text { Dietz, Hamburg, } \\
\text { Berlin, Leipzig, } \\
\text { Hohenlohe's } \\
\text { Grafschaft }\end{array}$ & $\begin{array}{l}\text { Stuß } 1733 \\
\text { Elßner } 1737 \\
\text { Kourilas } 1932 \\
\text { Tsakiris/Makrides } 2015\end{array}$ \\
\hline $\begin{array}{l}\text { 32. Gerasimos } \\
\text { Ablonita }\end{array}$ & 1754 & $\begin{array}{l}\text { Bishop from } \\
\text { Crete }\end{array}$ & $\begin{array}{l}\text { Halle, Heil- } \\
\text { bronn, Hamburg }\end{array}$ & $\begin{array}{l}\text { Stephan Schultz } 1773 \text { and } \\
1776\end{array}$ \\
\hline $\begin{array}{l}\text { 33. Protosyngellos } \\
\text { of Alexandria }\end{array}$ & 1755 & Alexandria & Vienna & AHG, G48, F2 \\
\hline $\begin{array}{l}\text { 34. Georgios from } \\
\text { Arta }\end{array}$ & 1759 & Arta (Epirus) & Vienna (?) & Hunger 1957 \\
\hline $\begin{array}{l}\text { 35. Bulgarian } \\
\text { Eremites }\end{array}$ & 1760 & Bulgaria & Vienna & $A H G, \mathrm{G} 48, \mathrm{~F} 2$ \\
\hline $\begin{array}{l}\text { 36. Protosyngellos } \\
\text { of Antioch }\end{array}$ & 1760 & Antioch & Vienna & $A H G, \mathrm{G} 48, \mathrm{~F} 2$ \\
\hline 37. Gregorio & 1761 & $\begin{array}{l}\text { Great Lavra Mo- } \\
\text { nastery (Athos) }\end{array}$ & Vienna & $A H G, \mathrm{G} 48, \mathrm{~F} 2$ \\
\hline 38. Ioannikios & 1761 & $\begin{array}{l}\text { St Catherine's } \\
\text { Monastery } \\
\text { (Sinai) }\end{array}$ & Hungary & $\begin{array}{l}\text { Chotzakoglou and Gast- } \\
\text { geber } 1998\end{array}$ \\
\hline 39. Jeremias & 1764 & Crete & Hungary & $\begin{array}{l}\text { Chotzakoglou and Gast- } \\
\text { geber } 1998\end{array}$ \\
\hline $\begin{array}{l}\text { 40. Stephanus } \\
\text { Simoni, abbot } \\
\text { of the brothers } \\
\text { of St Anthony }\end{array}$ & 1765 & Syria & Vienna & $\begin{array}{l}\text { HHStA, RHR, Grat Feud } \\
\text { Patentes und Steckbriefe, } \\
4-77\end{array}$ \\
\hline $\begin{array}{l}\text { 41. Monk from } \\
\text { Mount Sinai }\end{array}$ & 1772 & $\begin{array}{l}\text { St Catherine's } \\
\text { Monastery } \\
\text { (Sinai) }\end{array}$ & Vienna & $\begin{array}{l}\text { NÖLA, Nö. Reg., C-Akten } \\
21 \text { (de 1796), Karton } 424\end{array}$ \\
\hline
\end{tabular}




\section{Bibliography}

Archives/Manuscripts

Gotha, Forschungsbibliothek Gotha [= FB Gotha], Chart. B 200, fol. 31r-37v.

Neuenstein, Hohenlohe Zentralarchiv Neuenstein [= HZAN], Ki 10, Nr. 25, Lit. A-41.

Nuremberg, Stadtbibliothek Nürnberg [= StB], Amb. 98, 4 MS. [= Arnold, Notebook]

Sankt Pölten, Niederösterreichisches Landesarchiv [= NÖLA], Nö. Reg., C-Akten 21 (de 1796), Karton 424.

Stuttgart, Hauptstaatsarchiv Stuttgart [= HSTAS], A 202, Bü 1692, document Nr. 6.

Tübingen, Universitätsbibliothek Tübingen, Mh 466-1-9. [= Crusius, Diarium]

Vienna, Archiv der griechisch-orthodoxen Kirchengemeide zum hl. Georg in Wien [= AHG], G48, F2.

Vienna, Haus-, Hof- und Staatsarchiv Wien [= HHStA], RHR, Grat Feud, Patentes und Steckbriefe, Karton 1-4.

Vienna, Österreichisches Staatsarchiv [= OeStA], Finanz- und Hofkammerarchiv [= FHKA], SUS RA 186.1.61-62.

\section{Literature}

Angelomati-Tsoungaraki E., ‘Tò $\varphi \alpha \iota v o ́ \mu \varepsilon v o ~ \tau \tilde{\eta} \varsigma \zeta \eta \tau \varepsilon \dot{\imath} \alpha \varsigma \kappa \alpha \tau \dot{\alpha} \tau \dot{\eta} \mu \varepsilon \tau \alpha \beta v \zeta \alpha v \tau \iota v \eta \dot{\eta} \pi \varepsilon \rho i ́-$

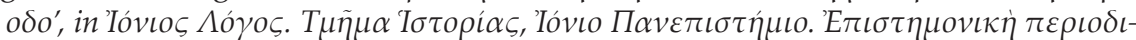

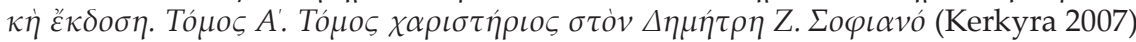
247-93.

Bartl P., Der Westbalkan zwischen spanischer Monarchie und Osmanischem Reich. Zur Türkenkriegsproblematik an der Wende vom 16. zum 17. Jahrhundert (Wiesbaden 1974).

Behringer W., Im Zeichen des Merkur. Reichspost und Kommunikationsrevolution in der Frühen Neuzeit (Göttingen 2002).

Calis R., 'Reconstructing the Ottoman Greek World: Early Modern Ethnography in the Household of Martin Crusius', Renaissance Quarterly 72 (2019) 148-93.

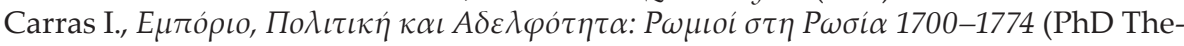
sis) (National and Kapodistrian University of Athens, Athens 2010).

Chotzakoglou C. and Gastgeber C., 'Griechische Mönche in Ungarn. Zwei Dokumente aus dem 18. Jahrhundert über das Sammeln von Almosen und den Einfluß der

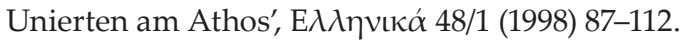

Crusius M., Turcograecia (Basel 1584).

- Annalium Svevicorum Dodecastertia (Frankfurt a.M. 1596).

Downs R. and Stea D., Kognitive Karten: Die Welt in unseren Köpfen (New York 1982).

Eideneier H., 'Von der Handschrift zum Druck. Martinus Crusius und David Höschel als Sammler griechischer Venezianer Volksdrucke des 16. Jahrhunderts', in H. Eideneier (ed.), Graeca recentiora in Germania. Deutsch-griechische Kulturbeziehungen vom 15. bis 19. Jahrhundert [Wolfenbütteler Forschungen 59] (Wiesbaden 1994) 93-111.

Elßner J., Neueste Beschreibung derer Griechischen Christen in der Türkey (Berlin 1737).

- Fortsetzung der Neuesten Beschreibung derer Griechischen Christen in der Türkey (Berlin 1747).

Fecht J., Kurtze Nachricht von der Religion der heutigen Griechen (Rostock-Leipzig 1713).

Friedrich M., 'Türkentaufen. Zur theologischen Problematik und geistlichen Deutung der Konversion von Muslimen im Alten Reich', in A.Schunka (ed.), Orientbegegnungen deutscher Protestanten in der Frühen Neuzeit [Zeitsprünge. Forschungen zur Frühen Neuzeit 16/1] (Frankfurt a.M. 2014) 47-74. 
Georgeirinis I., A description of the present state of Samos, Nicaria, Patmos and Mount Athos (London 1678).

Gräf H. T. and Pröve R., Wege ins Ungewisse. Reisen in der Frühen Neuzeit 1500-1800 (Frankfurt a.M. 1997).

Hartmann P., Kulturgeschichte des Heiligen Römischen Reiches (1648-1806). Verfassung, Religion, Kultur (Wien-Köln-Graz 2001).

Heineccius J. M., Eigentliche und wahrhafftige Abbildung der alten und neuen Griechischen Kirche, ihrer Historie, Glaubens-Lehren und Kirchen-Gebräuchen (Leipzig 1711).

Heinsius J. G., Unpartheyische Kirchen-Historie Alten und Neuen Testaments ... Dritter Theil in welchem die Geschichte vom Jahr nach Christi Geburt 1730 bis 1750 enthalten sind (Jena 1754).

Hering G., Ökumenisches Patriarchat und europäische Politik: 1620-1638 (Wiesbaden 1968).

Hofmann G., 'Die Jesuiten und der Athos', Archivum Historicum Societatis Iesu 8 (1939) 3-33.

Hunger H., 'Ein griechischer Patriarchen-Geleitbrief des 18. Jahrhunderts, Neuerwerbung der Österreichischen Nationalbibliothek: Suppl. gr. 188', Jahrbuch der Österreichischen Byzantinischen Gesellschaft 6 (1957) 145-9.

Kitromilides P. M., 'Athos and the Enlightenment', in A. Bryer and M. Cunningham (eds), Mount Athos and Byzantine Monasticism. Papers from the Twenty-eighth Spring Symposium of Byzantine Studies (Aldershot 1996) 257-72.

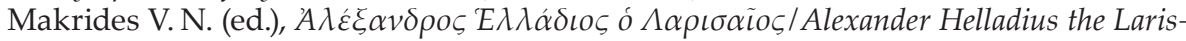
sean (Thessaloniki 2003).

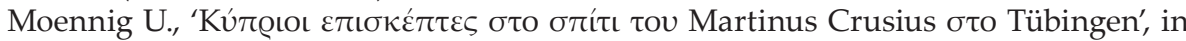
A. Chatzisavvas (ed.), La langue-la littérature-l'histoire et la civilisation chypriotes (Besançon 1995) 260-80.

- 'On Martinus Crusius's collection of Greek vernacular and religious books', Byzantine and Modern Greek Studies 21 (1997) 40-78.

Moennig U., 'Die griechischen Studenten am Hallenser Collegium orientale theologicum', in J. Wallmann and U. Sträter (eds), Halle und Osteuropa. Zur europäischen Ausstrahlung des hallischen Pietismus [Hallesche Forschungen, 1] (Halle 1998) 299-329.

Mulsow M., Preküres Wissen. Eine andere Ideengeschichte der Frühen Neuzeit (Frankfurt a.M. 2012).

- 'Global Intellectual History and the Dynamics of Religion', in C. Bochinger and J. Rüpke (eds), Dynamics of Religion: Past and Present (Berlin-Princeton 2017) 251-72.

Pálffy G., 'Ransom Slavery along the Ottoman-Hungarian Frontier in the Sixteenth and Seventeenth Centuries, in G. Dávid and P. Foder (eds), Ransom Slavery Along the Ottoman Borders. Early Fifteenth-Early Eighteenth Centuries (Leiden 2007) 35-84.

Panagiotakis N., 'Griechische Musiker im Deutschland des 16. Jahrhunderts', in H. Eideneier (ed.), Graeca recentiora in Germania. Deutsch-griechische Kulturbeziehungen vom 15. bis 19. Jahrhundert [Wolfenbütteler Forschungen 59] (Wiesbaden 1994) 137-47.

Pauli E., Triumph der Barmherzigkeit. Die Befreiung christlicher Gefangener aus muslimisch dominierten Ländern durch den österreichischen Trinitarierorden (1690-1783) (Göttingen 2016).

Podskalsky G., Griechische Theologie in der Zeit der Türkenherrschaft (1453-1821). Die Orthodoxie im Spannungsfeld der nachreformatorischen Konfessionen des Westens (München 1988).

Ransmayr A., Untertanen des Sultans oder des Kaisers. Struktur und Organisationsform der beiden Wiener griechischen Gemeinden von den Anfüngen im 18. Jahrhundert bis 1918 (Vienna 2018). 
Ressel M., 'The North-European Way of Ransoming. Explorations into an unknown dimension of the Early Modern Welfare State', Historical Social Research 35/4 (2010) [C. Zwierlein, R. Graf and M. Ressel (eds), The Production of Human Security in Premodern and Contemporary History] 125-47.

Saracino S., ‘Griechisch-orthodoxe Almosenfahrer im Heiligen Römischen Reich und ihre wissensgeschichtliche Bedeutung (1650-1750)', in M. Friedrich and J. Schilling (eds), Praktiken frühneuzeitlicher Historiographie [Cultures and Practices of Knowledge in History, 2] (Berlin-Boston 2019) 141-73.

- 'Leon Allatios' Entführung der Bibliotheca Palatina und weitere Selbstzeugnisse von Griechen über den Dreißigjährigen Krieg. Narrativen des Krieges und deren wissensgeschichtliche Bedeutung', Daphnis 47 (2019) 158-89.

Sarris K., Pissis N. and Pechlivanos M., 'Accumulating Cultural Capital: Intellectual Networks and Political Power of the Mavrokordatos Dynasty (1641-1730)', in D. Stamatopoulos (ed.), Power Networks in the Imperial and Post-Imperial Balkans (18th to 20th c.) (forthcoming).

Schunka A., 'Normsetzung und Normverletzung in Einwanderungsgesellschaften der Frühen Neuzeit', in K. P. Krauss (ed.), Normsetzung und Normverletzung. Alltägliche Lebenswelten im Königreich Ungarn des 18. Jahrhunderts (Stuttgart 2015) 29-55.

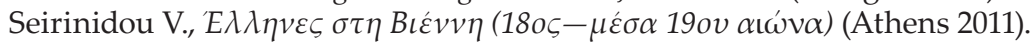

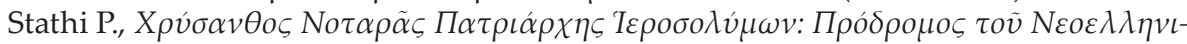

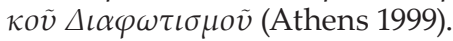

Stuß J., Observationes selectas de Ecclesiae Graecae sub imperio Turcico statu hodierno exhibet, simulque ad solemnem panegyrin sub auspicia lustrationis anniverariae illustris Gymnasii Gothani celebrandam (Gotha 1733).

Suppé F.-T., 'In Sachsen auf Heimatboden. Zur Geschichte der griechischen Gemeinde in Leipzig', in G.S. Henrich (ed.), Evgenios Vulgaris und die Neugriechische Aufklärung in Leipzig (Leipzig 2002) 13-46.

Tentzel W. E. (ed.), Monatliche Unterredungen (Leipzig 1689-1698).

Teply K., 'Vom Los osmanischer Gefangener aus dem Großen Türkenkrieg 1683-1699', Südostforschungen 32 (1973) 33-72.

Toufexis P., Das Alphabetum vulgaris linguae graecae des deutschen Humanisten Martin Crusius (1526-1607). Ein Beitrag zur Erforschung der mündlichen griechischen Sprache im 16. Jh. (Köln 2005).

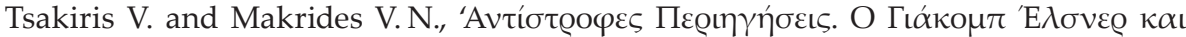

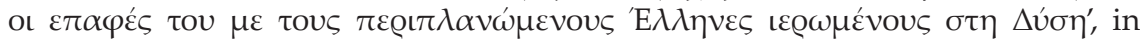

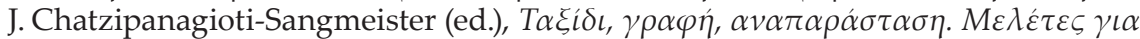
$\tau \eta v \tau \alpha \xi \iota \delta \iota \omega \tau \iota k \dot{~ \gamma \rho \alpha \mu \mu \alpha \tau \varepsilon i ́ \alpha ~ \tau o v ~ 180 v ~ \alpha \iota \omega ́ v \alpha ~(I r a k l i o ~ 2015) ~ 157-204 . ~}$

Vejel E., Defensio Exercitationis Historico-Theologicae de Ecclesia Graecanica Hodierna (Frankfurt a.M. 1666).

Wendebourg D., Reformation und Orthodoxie. Der ökumenische Briefwechsel zwischen der Leitung der Württembergischen Kirche und Patriarch Jeremias II. von Konstantinopel in den Jahren 1573-1581 [Forschungen zur Kirchen- und Dogmengeschichte, 37] (Göttingen 1986).

Zedler J. H., Großes vollständiges Universal-Lexikon aller Wissenschaften und Künste, XXXI (Leipzig 1742).

Zwierlein C., 'Konfessionalisierung europäisch, global als epistemischer Prozess. Zu den Folgen der Reformation und zur Methodendiskussion', in C. Strohm (ed.), Reformation und Recht. Ein Beitrag zur Kontroverse um die Kulturwirkungen der Reformation (Tübingen 2017) 1-51. 
II

Confessional Ambiguities 



\title{
What's Confessionalization got to do with it?

\author{
Indulgences and Education in Seventeenth-Century \\ Eastern Orthodoxy
}

\author{
Nikolaos Chrissidis, Southern Connecticut State University
}

In this essay, I argue that what appear to be confessionalizing elements in Eastern Orthodoxy in the seventeenth century are not easily comparable to the confessionalization programs one finds further to the west of the Orthodox world. Moreover, I contend that some of these elements were actually borrowings and constituted parts of a developing Westernization of Orthodoxy and were therefore a cause of concern for at least some clergymen. Indeed, in the study of early modern Orthodoxy, confessionalization may be less useful than its related notion of transconfessionality. I will try to show that for the seventeenth century (if not for the whole period until the nineteenth century) transconfessionality should be the operative notion of our interpretive efforts in understanding the history of Eastern Orthodoxy. My argument rests on two case studies, those of education and of indulgences ('synchorochartia'), as they pertain to the historical experience of seventeenth-century Eastern Orthodoxy. ${ }^{1}$

Confessionalization has admittedly not fared very well as applied to Eastern Orthodoxy's early modern trajectory. ${ }^{2}$ Scholars have raised several objections. Some have doubted the possibility of confessionalization when church and state

1 For overviews, see P. Bushkovitch, Religion and Society in Russia: The Sixteenth and Seventeenth Centuries (New York 1992); P. Bushkovitch, 'Change and Culture in Early Modern Russia', Kritika: Explorations in Russian and Eurasian History 16/2 (2015) 291-316; N. Chrissidis, 'The World of Eastern Orthodoxy', in H. Scott (ed.), The Oxford Handbook of Early Modern European History, 1350-1750, I. Peoples and Place (Oxford-New York 2015) 626-51; St. Runciman, The Great Church in Captivity: A Study of the Patriarchate of Constantinople from the Eve of the Turkish Conquest to the Greek War of Independence (Cambridge 1968); P. M. Kitromilides, 'Orthodoxy and the West: Reformation to Enlightenment', in M. Angold (ed.), Cambridge History of Christianity, V. Eastern Christianity (Cambridge 2006) 187- 209; S. Petmézas, 'L' organization ecclésiastique sous les Ottomans', in P. Odorico et al. (eds), Conseils et mémoires de Synadinos, prêtre de Serrès en Macédonie (XVIIe siècle) (Paris 1996) 487-569.

2 Interestingly, Heinz Schilling spoke of the confessionalization paradigm in Latin Europe (and thus seems to exclude the Orthodox from this phenomenon). H. Schilling, 'Confessionalization: Historical and Scholarly Perspectives of a Comparative and Interdisciplinary Paradigm', in J. M. Headley, H. J. Hilderbrand and A. J. Papalas (eds), Confessionalization in Europe, 1555-1700. Essays in Honor and Memory of Bodo Nischan (Burlington 2004) 21-35, here p. 26. Further, Schilling also explicitly connected the dualism of church and state (as interrelated forces that did not overpower one another and consequently acted as agents of confessionalization) to Western Europe, whereas in Eastern Orthodox countries this dualism is not 
already share the same confession, as in the case of Russia. Alternatively, others have questioned the presence of confessionalization where the state authority (sultan) and the rulers' religion (Islam) were radically different from the religion of large numbers of the empire's subjects, as was the case in the Ottoman Empire. Further arguments have pointed out that the Orthodox Church was prevented from carrying out proselytism and could not easily and effectively control all aspects of its flock's religious experience. At another level, still other scholars have questioned the extent to which confessionalization is a useful analytical concept in cases in which there was no break in theology, and no radical departure from any doctrinal orthodoxy.

This is not to mean that there have not been at least some advocates for some forms of confessionalization in Eastern Orthodoxy. According to Giorgos Tzedopoulos, for example, the neomartyrs constitute such a case in the Ottoman Empire. ${ }^{3}$ Other scholars have also argued that the case of the Old Believers in the Russian Empire exhibits certain confessionalizing elements. ${ }^{4}$ As Barbara Skinner has shown, some confessionalizing tools were used by both Uniates and Orthodox, but then there was a break in that case, if not in theology, at least in ecclesiology: the Uniates accepted the primacy of the Pope. Serhii Plokhy has made an argument for confessionalizing elements in Cossack-supported policies on religion during the seventeenth-century. ${ }^{5}$

Alfons Brüning has provided one of the most systematic critiques of the applicability of the concept of confessionalization in Orthodoxy, especially in Ruthenia (Ukraine-Belarus' in the early modern period) and in Russia. In general, Brüning seems to think that certain processes and measures (such as in liturgical books, in catechisms, in linguistic reforms, in the reforms instigated by Petro Mohyla's efforts, in education, in visitations, etc.) can be considered attempts at confession-

present, according to him. By extension, only Western Europe was programmed (the term is Schilling's) to a process that in waves led to secularity, modernity and rationality. Ibid., 28.

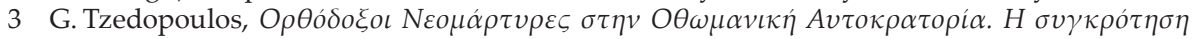

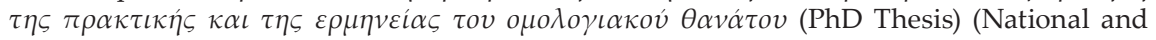
Kapodistrian University of Athens, Athens 2012) 156-7. Tzedopoulos indicates that confessionalization remained incomplete as a program (if it ever was one, I would add) given that policies and practices of controlling knowledge and imposing discipline were not attempted (for example, schooling, sustained use of printed matter, inquisitional methods, etc.). On the other hand, the Church did attempt some other policies such as the short-lived printing press, sermonizing, and also the use of popularized literature. Instead, in the Ottoman context (and here Tzedopoulos follows Tijana Krstic), it was conversion cases that represent the most obvious field in which confessionalization worked. Nevertheless, he argues that the phenomenon of neomartyrs can be seen as part of the Greek Orthodox process of confessionalization: it was part of a defensive discourse which showed Orthodoxy to be vibrant and able to create holy people. It was not meant to oppose political authority (that is, the Ottomans).

4 L. Behrisch, 'Social Discipline in Early Modern Russia. Seventeenth to Nineteenth Centuries', in H.Schilling and L. Behrisch (eds), Institutionen, Instrumente und Akteure sozialer Kontrolle und Disziplinierung im frühneuzeitlichen Europa (Frankfurt 1999) 325-57.

5 B. Skinner, The Western Front of the Eastern Church (Dekalb IL 2009); S. Plokhy, The Cossacks and Religion in Early Modern Ukraine (Oxford 2001). 
alization. However, he still wonders whether this was confession building in the sense of a confessional community. He does not think that confessionalization is readily applicable to Orthodoxy due to its emphasis on liturgical practice rather than doctrinal definition. In fact, he argues that Orthodoxy is neither willing, nor able to form a confession in the Western sense. Brüning also wonders whether the targeted audiences did really absorb the messages and adhere to them. As a result, Brüning has a number of objections to the applicability of confessionalization in the case of Orthodoxy: 1) The state already dominated Orthodoxy in Russia, so the collaboration needed for the social disciplining was lacking; 2) The Russian Orthodox Church was very reluctant to pronounce independently on theological matters until well until the 1680s, when the Eucharist conflict broke out. Even then, there was little independent theological thinking that took place. 3) Russian Orthodoxy had not formulated a clear doctrinal corpus comparable to Western confessions. 4) Even the new type of reformist bishops (like Afanasii Kholmogorskii) of the late seventeenth and early eighteenth centuries were not particularly successful. More recently, Brüning has argued that social disciplining seems to have fared better as a policy, but he seems to attribute this to existing reforming trends rather than to any kind of confessionalizing initiatives from above. ${ }^{6}$

My approach in this essay would seem to be in partial agreement with Liudmilla Charipova's take on confessionalization. ${ }^{7}$ Charipova does not think that we need to be too "purist" in approaching confessionalization in Orthodoxy. She also suggests that Petro Mohyla's reforms can be seen as a form of confessionalizing renewal but wonders whether his efforts were self-defeating, since by incorporating Roman Catholic elements in order to counter the Protestants, Mohyla moved closer to his other religious rivals (the Roman Catholics). On the other hand, Charipova suggests that the student sodalities and the lay confraternities could be seen as efforts at confessionalization. She also argues that the statist aspect of confessionalization is not easily applicable to Poland-Lithuania, thus eventually contending that Mohyla was involved in 'confession building but without confessionalization' (which I take to mean that she does not think that the statist part of it took place). Charipova does not speak of transconfessionality, but she is right that Mohyla

6 A. Brüning, 'Confessionalization in the Slavia Orthodoxa (Belorussia, Ukraine, Russia)?-Potential and Limits of a Western Historiographical Concept', in Th. Bremer (ed.), Religion and the Conceptual Boundary in Central and Eastern Europe. Encounters of Faiths (Basingstoke 2008) 66-97; A. Brüning, 'Social discipline among the Russian Orthodox parish clergy (seventeenth-eighteenth centuries): Normative ideals, and the practice of parish life', Cahiers $d u$ monde russe 58/3 (2017) 303-40. See also M. P. Romaniello, 'Mission Delayed: The Russian Orthodox Church after the Conquest of Kazan', Church History 76/3 (2007) 511-40. Romaniello describes the activities of the Russian Orthodox Church in the newly-conquered territories of Kazan', supported by the state, as involving some confessionalizing measures (for example, on moral discipline) but with rather meager results.

7 L. V. Charipova, 'Orthodox Reform in Seventeenth-Century Kiev: The Evidence of a Library', Journal of Early Modern History 17/3 (2013) 273-308. 
was building a confession. Indeed, Mohyla was involved in what could be called housekeeping in order to keep the inhabitants of the house living in it and not abandoning it. To the extent that he was building faith, schools, rituals, etc., this was indeed confession-building. Nevertheless, I would argue that even Petro Mohyla aimed to build his confession through transconfessionality.

The question of the applicability of confessionalization is further complicated by what can be termed the reactiveness of Orthodoxy in the early modern and even modern periods. In facing other Christian denominations, Orthodoxy does not appear to have set the tone or parameters of the polemical discussion, but rather it has reacted to whatever originated in the West (whether Roman Catholic or Protestant). The general picture, if not all the details, appears fairly clear. In the early modern period Orthodox thinkers were forced to debate or at the very least respond to questions on doctrinal matters (such as transubstantiation or purgatory), papal primacy or the importance of tradition. Far from being the initiators of discussion, they sometimes were very unwilling or reluctant participants in it. This is not to say that Orthodoxy was mute. Rather, it is to say that it usually spoke after being asked. ${ }^{8}$ As for the modern period, I would submit that the jury is still out since we hardly have a religious history of the modern Greek Orthodox Church. Regarding Russian Orthodoxy in the modern period, for example, such reactiveness is clearly evident in the transconfessionality that marked its activities as analyzed by Gregory Freeze. What Freeze describes as the five elements characterizing the history of Russian Orthodoxy in the modern period are in essence reactions to Western trends (whether these trends came from within the empire or from outside of it). These five elements were: 1) The Roman Catholic seminary as a model for Orthodox seminaries; 2) The reform of parish clergy on the basis of Lutheran and Roman Catholic prototypes; 3) Education and the role of women (deaconesses), based on similar trends in Roman Catholicism; 4) Parish reform councils based on foreign models; 5) Pastoral education and training, based on Western models. ${ }^{9}$

Not that confessionalization has had an easy trajectory in Western historiography, either. As scholars have noted, the application of the confessionalization paradigm in Roman Catholicism has necessitated an emphasis on the religious life as lived, a lessening in the emphasis on the collaboration with the state, and also less of an emphasis on modernization. In cases examined regarding Roman Catholicism, it appears that much of the initiative for confessionalizing activities either came from below (the city authorities rather than the central state) or involved attempts by Roman Catholic orders to mold a popular piety in conformity

8 See Chrissidis, 'The World of Eastern Orthodoxy', 638-43. See for example the case of Patriarch Ieremias of Constantinople and the Protestants on the issue of the calendar.

9 Gr. L. Freeze, 'Globalization and Orthodoxy in Imperial Russia', Vestnik Sankt-Peterburgskogo Universiteta 62/1 (2017) 417. Freeze argues for transconfessionality during eighteenth-century Russia, with a decrease during the era of Nicholas I (1825-1855), but a resurgence again in the second half of the nineteenth century. 
with the precepts of the Roman Catholic Church (for example, the devotional literature published for the masses by Jesuits). ${ }^{10}$ Given Orthodoxy's obvious closeness to Roman Catholicism as opposed to Protestant denominations, we may have to take the above insights into consideration.

Scholars of Eastern Orthodox history might be on firmer footing if they were to use as methodological tools the related concepts and offshoots of confessionalization. These are: the concept of transconfessionality, defined as a voluntary opening to the other confessions; interconfessionality, defined as an exchange on more or less equal basis; and, finally, inside pluralism, referring to variants inside a confession. My personal preference is for transconfessionality, because I do not think that the Greeks (or the Russians, for that matter) in the early modern period were operating on a more or less equal basis with other confessions for political and intellectual reasons. ${ }^{11}$ Similarly, I am not yet convinced that the notion of inside pluralism applies effectively in the case of Orthodoxy, since doctrinal matters were not high up on the agenda of issues at the time (the exceptions may be transubstantiation, for a period of time, but not much beyond that and the Kyrillos Loukaris case).

I therefore propose that early modern Orthodoxy is better understood through the concept of transconfessionality. I think of transconfessionality as a more or less voluntary opening to the other confession (especially to Roman Catholicism) but one which (if the phrase may be permitted) was something like a "crypto-interlibrary loan": Orthodoxy openly adopted a number of practices, tools and concepts from Roman Catholicism but it did so all the while thinking about its own protection (always claiming that the borrowing was according to Orthodox tradition, or not a borrowing at all) and in a second-hand fashion (borrowings were first tried by Western Christians). Eventually, of course, this leads scholars back to the somewhat old-fashioned notion of Westernization. ${ }^{12}$ In order to make my case for transconfessionality, I would like to focus on Greeks peddling education and salvation in the seventeenth century, or more precisely, Jesuit scholasticism

10 See the essays by R. Mentzer, 'Fashioning Reformed Identity in Early Modern France', in J. M. Headley, H. J. Hilderbrand and A. J. Papalas (eds), Confessionalization in Europe, 15551700. Essays in Honor and Memory of Bodo Nischan (Burlington 2004) 243-56; L. Lazar, 'The Formation of the Pious Soul: Trans-alpine Demand for Jesuit Devotional Texts, 1548-1615', in ibid., 289-318; also Th. Brady Jr., 'Confessionalization-The Career of a Concept', in ibid., 1-20.

11 Lack of political independence among Balkan Orthodox; lack of intense intellectualization of religious thought and lack of sustained educational system (in both the Balkans and in Russia).

12 In this sense, whatever communication and knowledge transfer seems to have taken place appears to have been predicated on the dominance of the Western patterns of education and theologizing (neo-scholastic Jesuit in the cases of Roman Catholic influences). The Orthodox had to use their opponents' concepts, otherwise there could not have been be any dialogue, nor of course any ability to make use of the latest trends in education or polemics. One could argue that transconfessionality can also refer to academic discussion in which scholars can disagree; also, that confessionalization may in fact be the reason for the knowledge transfer. These are good points, but until we know the ways in which the results of the knowledge transfer were put to use, it is difficult to assign them confessionalizing qualities. 
and indulgences, both in their Orthodox guise. One aspect of my story has to do with education and very little to do with doctrine (at least on the face of it). ${ }^{13}$ The other aspect of my story has to do with salvation practices, the procurement and use of synchorochartia (Orthodox indulgences). I hasten to add that, in theory, the synchorochartia's validity is predicated upon a seemingly non-existing (in Orthodoxy) doctrine, that of purgatory. In some ways, therefore, my effort is an attempt to argue for transconfessionality in both its strictly doctrinal and its wider church-building forms (in the form of creating the educated cadres of the church).

\section{The Case of Education: The Slavo-Greco-Latin Academy in Moscow}

In the early seventeenth-century, then Patriarch of Alexandria Kyrillos Loukaris wrote a dialogue on the issue of Jesuit inroads into the Orthodox East. A veteran of the polemical conflicts that surrounded the Union of Brest (1596), Loukaris used the dialogue to dwell extensively on two topics: the popularity of Jesuit educational institutions and Jesuit-influenced appointments to positions of authority in the Greek Church. Specifically, Loukaris pointed out the success of the Jesuit school on the island of Chios. He also considered the possibility of a future Patriarch who may be an appointee of the Jesuits, in which case overall Orthodox spiritual supervision, educational oversight and preaching would be in the hands of the Jesuits. Indeed, for Loukaris, Jesuit achievements could largely be attributed to preaching and to teaching children for free. Through such free lessons, he argued, they bought the souls and the consciences of their students. ${ }^{14}$ In a 1613 letter to a Dutch correspondent, Loukaris noted that the Jesuit school in Constantinople was immensely popular and wryly added that the Jesuits enjoyed 'as undisputed success as foxes among poultry' in it. Both before and during his tumultuous tenure as Patriarch, Loukaris was impressed and terrified, in equal measure, by Jesuit activities. ${ }^{15}$

Loukaris' assessment was of course polemical and cannot necessarily be accepted at face value. In retrospect, it also sounds rather exaggerated given that in Greek historiography the image persists that it was not Jesuit Aristotelianism, but

13 According to Heinz Schilling, the early modern university was a main agent of modernization, and as such was also a main institution in which the alliance of church and state in the era of confessionalization can be observed at war. On the one hand, the university was an educational institution that was confessionally-based and into which one entered through swearing an oath; on the other hand, it also contributed to the creation of elites with specialized knowledge, and contributed to the development of rational investigation. H. Schilling, ‘Das konfessionelle Europa. Die Konfessionalisierung der europäischen Länder seit Mitte des 16. Jahrhunderts und ihre Folgen für Kirche, Staat, Gesellschaft und Kultur', in J. Bahlcke and A. Strohmeyer (eds), Konfessionalisierung in Ostmitteleuropa: Wirkungen des religiösen Wandels im 16. und 17. Jahrhundert in Staat, Gesellschaft und Kultur (Stuttgart 1999) 18-19.

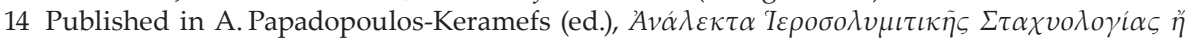

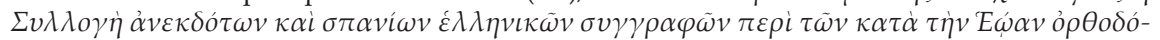

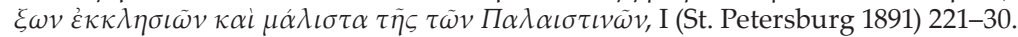

15 Cited in C. Davey, 'Metrophanes Kritopoulos and his Studies at Balliol College', in P. M. Doll (ed.), Anglicanism and Orthodoxy: 300 years after the 'Greek College' in Oxford (Frankfurt a.M.Berlin-New York 2006) 59. 
rather the Padua-influenced Aristotelianism of Theofilos Korydallefs (1570-1645) that dominated the curriculum of Greek (and other Balkan) schools in the seventeenth-century Ottoman Empire. Instead, I will argue that there were at least two (and probably more) varieties of Aristotelianism that were used in school curricula in Greek-run schools of the seventeenth century. My discussion is based on the case of the Leichoudes brothers, Ioannikios and Sofronios, in the Slavo-Greco-Latin Academy of Moscow in the 1680s and 1690s. This discussion is the result of my previous attempt to place the Slavo-Greco-Latin Academy in the overall context of Greek-run education of the early modern period.

During the seventeenth century, Eastern Orthodoxy was faced with the acute intellectual challenge of responding to Roman Catholic and Protestant doctrinal and polemical pronouncements, to educational and missionary activities in its own backyard, not to mention the alternative understandings of the world offered by new scientific trends. ${ }^{16}$ It is still not entirely clear what the Eastern Orthodox responses were, but the general picture is one of reactiveness rather than of initiating the discussion. One direct result of such an intellectual challenge was the Orthodox recognition of the need for formal education. Such education took place in schools established by Roman Catholic or Protestant missionaries in both the Ottoman Empire and among the Orthodox Slavs in Ruthenia and/or by Orthodox initiative (funded by merchants or by brotherhoods, for example). As is well known, many Orthodox students also sought education in the West, such as at the University of Padua, the Cottunian College (1653, also in Padua), the Flanginian School in Venice (1662), and the Saint Athanasius College (Collegio Greco) in Rome (1581), just to name some of these schools. Upon graduation, some of them returned home and set up middle and higher education schools, where they appear to have applied a Jesuit-influenced curriculum, properly revised to avoid doctrinal problems. The result was that education in early modern Orthodoxy exhibited substantial influence, in both form and in content, from Jesuit patterns. ${ }^{17}$

The full extent of such Western (including Jesuit) influence is yet unknown, because we unfortunately lack individual case studies of Greek schools across the Orthodox East for the seventeenth century. ${ }^{18}$ At best, we have the biographies and lists of works by individual teachers, but not more, for the seventeenth and much of the eighteenth century. In Greek historiography, Korydallism, the philosophy of Loukaris' friend and a main collaborator, Theofilos Korydallefs, is assumed to be the dominant educational model. Kleovoulos Tsourkas has suggested that Korydallefs aimed to analyze Aristotle without reference to faith, thus trying to

16 See footnote 8 above.

17 N. Chrissidis, An Academy at the Court of the Tsars: Greek Scholars and Jesuit Education in Early Modern Russia (Dekalb IL 2016) chapters 1 and 5.

18 Even the fundamental work on the princely academies in Moldavia and Wallachia is descriptive rather than analytical in its approach to the curriculum and, in any case, deals primarily with the eighteenth century. See A. Camariano-Cioran, Les Académies princières de Bucarest et de Jassy et leurs professeurs (Thessaloniki 1974). 
separate philosophy from theology. This is usually taken to mean that late sixteenth- and early-seventeenth-century Paduan Aristotelianism, which tended to focus more on a naturalistic interpretation of the world, was transposed to the Greek-speaking intellectual milieux of the seventeenth century through Korydallefs' influence. As such, another scholar has suggested, Korydallism can also be seen as a counter-offensive to the natural philosophy, as propagated by Loukaris' nemesis, the Jesuits. ${ }^{19}$

There is no doubt that Korydallism was influential in Greek schools of the seventeenth and eighteenth centuries, but the extent and purview of such influence remains to be ascertained on the basis of detailed study of school curricula. Moreover, the Slavo-Greco-Latin Academy in Moscow, a school set up and run by the Greek brothers Ioannikios and Sofronios Leichoudes in the Russian capital in 1685, does not appear to have employed Korydallism. As such, the Leichoudian Academy's case can be used as a test for the dominant paradigm.

Padua's Aristotelianism does not appear to have informed the curricular choices of the Leichoudes Brothers in the Slavo-Greco-Latin Academy in Moscow, despite Sofronios' graduation from the famous university. Instead, Ioannikios and Sofronios' emulated their teacher Gerasimos Vlachos and the model of the Cottunian College in Padua; both Vlachos and the College had themselves been under Jesuit educational influence. ${ }^{20}$ Indeed, Leichoudian rhetoric as it appears in the textbooks the two brothers authored or compiled, borrowed directly from Jesuit treatises or followed them indirectly through the influence of Gerasimos Vlachos' rhetoric. The result was that the Leichoudes taught their students and practiced in their own speeches the Baroque rhetoric of the 'grand style'. Moreover, the Leichoudian Academy's philosophy course was squarely based on Jesuit prototypes in respect of both logic and cosmology. The two brothers thus brought to Russia a Greek version of Western education, but the crucial point is that this education was that of Jesuit logicians, natural philosophers and rhetoricians. The West was brought to Russia by the Greeks via Italy.

Korydallism was not necessarily the only version of Aristotelianism taught in Greek-run schools. Rather, there were other versions that may have been somewhat or equally influential, based on the works of Nikolaos Koursoulas and Gerasimos Vlachos, themselves reflecting intensive Jesuit influences. ${ }^{21}$ The Leichoudian opus

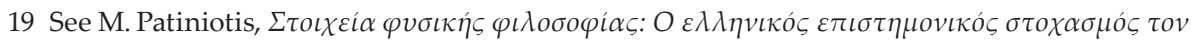

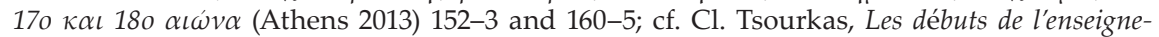
ment philosophique et de la libre pensée dans les Balkans: La vie et l'oeuvre de Théophile Corydalée (1570-1646), 2nd ed. (Thessaloniki 1967), whose approach however may overemphasize the distinction between philosophy and faith in Korydallism: see Linos Benakis' review of Tsourkas' book in 'E $\lambda \lambda \eta v \iota k \alpha$ 23/2 (1970) 309-404.

20 Gerasimos Vlachos was one of the eminent philosophers and theologians in the Greek East

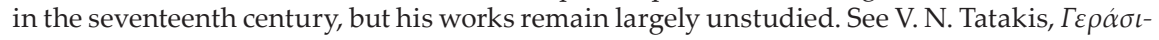

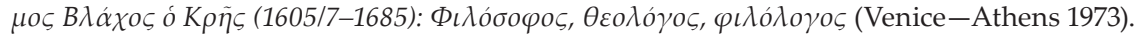

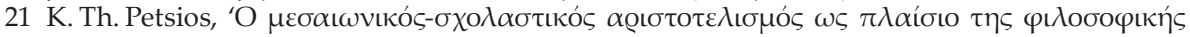

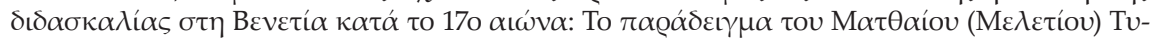


is an example of an Aristotelianism of this type that was much more beholden to Jesuit prototypes. Korydallism constitutes another, different type of Aristotelianism in the Orthodox East, one that appears to have tried to dissociate understanding of the natural world from religious dogma. The first and fairly obvious conclusion is that when discussing education established and run by the Greeks in the seventeenth century, we need to be talking about Aristotelianisms (in the plural), something that for the Renaissance has already been an article of faith since at least the works of Charles Schmitt. ${ }^{22}$ After intensive and focused study of the schools, we may conclude (very much like scholars have done in the case of the Kyiv Mohyla Academy) that early modern Greek school Aristotelianism was eclectic and its varieties were many, depending very much on intellectual proclivities, doctrinal considerations and personal choices imposed by church prohibitions or the fear thereof. ${ }^{23}$ We should remember that we are dealing with schools that straddled the secondary and tertiary education levels, in our terms. Therefore, Aristotelianism's varieties were also connected with conscious choices made by the individual teachers as to what could or should be discussed or included in the classroom teaching, as opposed to expositions in sermons, for example. Jesuit educational influence is obvious to historians of early modern Ukrainian education, but it remains a controversial conclusion that goes against much of modern Greek historiography. Once we ascertain the extent to which Orthodox higher education in the early modern period (both in the Greek Orthodox East and in Eastern Slavic lands) began along Jesuit lines, we then can speak more confidently about what may have been Orthodox and what not in educational activities. In other words, we can begin to consider whether educational activities fit a confessionalizing paradigm. The examples we have so far provide us with tantalizing glimpses of substantial, but not exclusive Jesuit influence, in parallel with other trends of Aristotelianism. To what extent this influence impacted the way in which Orthodoxy was understood and practiced is not yet clear. What is clear is that, in the current state of our knowledge of early modern Greek education, there appears to be no discernible attempt among Greek teachers to create a distinct and unassailable line of Orthodox approach to education in the seventeenth century. Instead, there is adoption of Western trends and presumed adaptation to Orthodox needs. In short, there is Westernization.

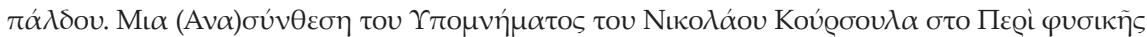

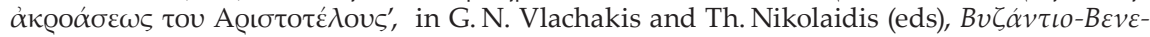

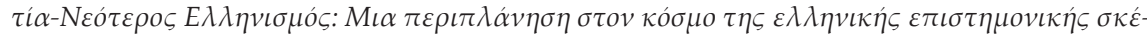

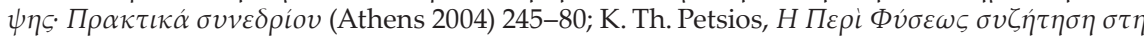

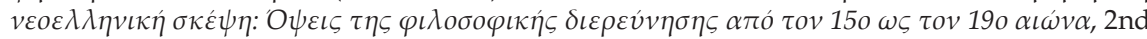

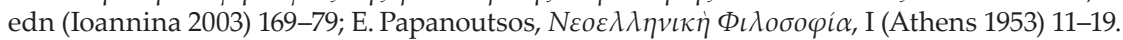

22 Ch. B. Schmitt, Aristotle and the Renaissance (Cambridge MA 1983).

23 For more on this issue, see N. Chrissidis, 'Greek Teachers, Jesuit Curriculum, Russian Students: The Slavo-Greco-Latin Academy of Moscow in Historiographical Perspective', Kyïus'ka Akademiia 10 (2012) 90-116. 


\section{The Case of Eastern Orthodox Indulgences}

Although the phenomenon is little discussed and remains largely unresearched, it is well-known that in the late medieval period Eastern Orthodox prelates began the practice of issuing handwritten (and later, printed) letters of absolution. Believers used these letters as public certificates of repentance and as mnemonic tools to prevent future sinful behavior. For their part, the Patriarchs (their main issuers after an initial period of uncertainty over who could properly issue them) utilized them to enhance their authority as the ultimate arbiters of salvation in this world. The practice had become widespread among the Greeks by the sixteenth century and from there spread to other parts of the Orthodox world. The documents issued were known as 'synchorochartia' ( $\sigma v \gamma \chi \omega \rho \circ \chi \alpha \dot{\alpha} \rho \tau \alpha)$ or 'synchoritiria' $(\sigma v \gamma \chi \omega \rho \eta \tau \eta \dot{\rho} \iota \alpha)$ (documents [lit. papers] of forgiveness) in Greek, and 'razreshitel'nye gramoty' or 'razreshal'nye gramoty' (letters of absolution) in Russian. In this essay, I focus on letters of remission for the living. ${ }^{24}$

The content of such letters appears to have stabilized shortly after their first appearance in print in the middle of the seventeenth century. After the title of the issuing Patriarch or other prelate and the invocation of the 'power of keys' (i.e. the bishop's authority to bind and loose), there comes the absolution for all confessed sins, and of the guilt, of the bond, and of the penance owed for them. Special mention is made of instances of canonical prohibition (curse or anathema) and prior confession to one's spiritual father appears as a prerequisite to absolution. Finally, God is asked to pardon any sin left unconfessed because of forgetfulness and the text ends by invoking the intercession of the Virgin Mary, Apostles and saints. Textually, printed synchorochartia granted to the living exhibit few differences among themselves, the principal variation being in the names of saints or apostles associated with the issuer's patriarchal see. Other variants focused on whether or not there was fulfillment of the penance, or on the lack of mention of certain sins due to forgetfulness or intentionally. ${ }^{25}$ The absence of prescribed devotional use of letters of remission and also the lack of any precise Orthodox theology on them before the mid-seventeenth century probably contributed to the appearance of such variants.

What did these letters offer to Orthodox recipients? The main point is that they offered absolution for all confessed sins, leaving remission for unconfessed ones to God, since in the Orthodox understanding of confession the spiritual father is

24 On indulgences in the Orthodox East, the pioneering and still unsurpassed works are those of

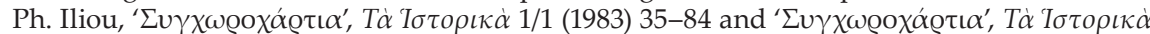

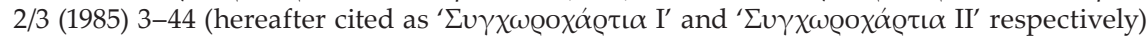
See also N. Chrissidis, 'Edification Through the Memory of Sins: The Practical Uses of Eastern Orthodox Indulgences', Canadian-American Slavic Studies 52/2-3 (2018) 181-92; N. Chrissidis, 'Between Forgiveness and Indulgence: Funerary Prayers of Absolution in Russia', in N. Lupinin, D. Ostrowski and J. B. Spock (eds), The Tapestry of Russian Christianity: Studies in History and Culture [Ohio Slavic Papers 10 and Eastern Christian Studies 2] (Columbus OH 2016) 261-93.

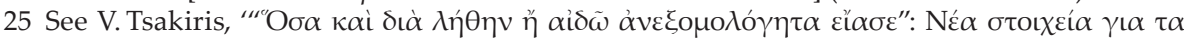

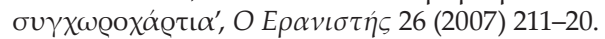


a witness and facilitator of confession, leaving ultimate remission of sins to God. Further, the text dealt with certain serious problems in which a recipient may find himself/herself, such as an anathema or excommunication, a curse (whether parental, priestly or self-inflicted), and the breaking of the sanctity of oath. Thus, synchorochartia must have offered some security regarding forgiveness. Theologically, Eastern Orthodox letters of absolution reflect the emphasis on true contrition and the eagerness to avoid sin in the future, and explicitly emphasize the penitent's willingness and his or her sincere desire to undertake penance. Emphasis on the 'satisfaction' of God is thus largely absent from them, as it is from the Orthodox understanding of the sacrament of confession. ${ }^{26}$

A comparison of Orthodox synchorochartia with Roman Catholic indulgences shows that they were equivalents, and they were certainly offered as such by the Orthodox religious authorities. As is well known, Roman Catholic indulgences either partially reduced the temporal punishment (partial indulgences) or eliminated such temporal punishment altogether (plenary indulgences). ${ }^{27}$ Both Eastern and Western indulgences presupposed confession and the acceptance of penance. Unlike their Western counterparts which dealt with temporal punishment due to sin and specified the extent of reduction of penance, Eastern Orthodox synchorochartia provided absolution of sins committed and confessed, but without explicitly reducing specified penance. In short, they emphasized willingness to do penance but left its completion unspecified. Synchorochartia were often purchased by the believers directly (from clerics) or indirectly (through correspondence) and therefore the extent of penance fulfillment was conveniently left to the individual's conscience.

The granting equivalence between Eastern and Western indulgences (though of course not the theological functionality of the Western ones) was formally proclaimed in the Confession of Faith that the Council of Constantinople issued in 1727. Its article thirteen reads:

26 The theological and canonical literature on repentance and confession in Eastern Orthodoxy

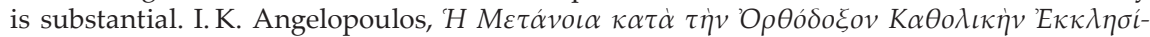

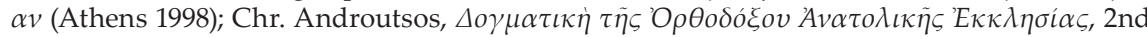

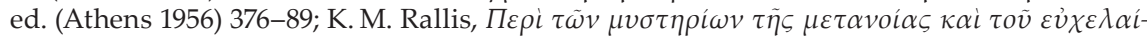

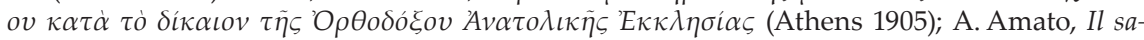
cramento della penitenza nella teologia Greco-Orthodossa. Studi storico-dogmatici (sec. XVI-XX) (Thessaloniki 1982); J. Chryssavgis, Repentance and Confession in the Orthodox Church (Brookline MA 1990); A. Almazov, Tainaia ispoved' v pravoslavnoi vostochnoi tserkvi, 3 vols (Odessa 1894; reprint, Moscow 1995).

27 The literature on Western indulgences is vast: see W. Kent, 'Indulgences', Catholic Encyclopedia, VII (New York 1910), http://www.newadvent.org/cathen/07783a.htm.; Et. Magnin, 'Indulgences', Dictionnaire de Théologie Catholique, VII/2 (Paris 1923) cols 1594-1636; H. Ch. Lea, A History of Auricular Confession and Indulgences in the Latin Church, 3 vols (reprint, New York 1968); and the fundamental N. Paulus, Geschichte des Ablasses im Mittelalter, 3 vols. (Paderborn 1922-1923). More recently, see R. N. Swanson, Indulgences in Late Medieval England: Passports to Paradise? (Cambridge 2007). 
[We confess] that the authority to absolve sins, which when given in writing to the pious the Eastern Church of Christ calls synchorochartia, and the Latins call indulgences, is given by Christ in the Holy Church, and that their use is one of the most salutary refuges. [We confess] that these synchorochartia are given in the whole Catholic Church by all four most holy Patriarchs, of Constantinople, Alexandria, Antioch, and Jerusalem. [We confess] that they are given frugally and with spiritual reproach, and to whom and whenever is appropriate, in the exact manner that the Eastern Church follows in such matters, and not in the manner of the Latins through which develops immeasurable license and misuse, from which [license and misuse] everybody remembers what evils followed in the Western Church. And to say that only the Pope has the exclusive authority to grant such [letters of absolution] is an obvious lie and a result of the absurd innovation of the Latins. ${ }^{28}$

The main point here was not the theology of indulgences but rather papal pretensions to exclusive issuance. In other words, what was an innovation was not the granting of indulgences but rather papal claims to an absolute authority to do so. As is well known, Orthodoxy never fully developed a doctrine of purgatory, no matter how much discussion eventually surrounded the so-called middle condition of the souls. ${ }^{29}$ Despite this unwillingness to formulate related doctrine, at least two Orthodox writers pronounced theologically on indulgences, Patriarch Dositheos of Jerusalem and the monk Nikolaos Koursoulas (ca. 1602-1652). ${ }^{30}$ Most probably echoing (or even copying-the topic requires further study) what appear to be the unpublicized views of the theologian Georgios Koressios from the early seventeenth century, Dositheos asserted that all Patriarchs, bishops and spiritual fathers, not just the Pope, could offer absolution of sins to any believer (not only to their own confessants), and that such documents were official certificates of repentance to be used as mnemonic tools for the avoidance of future sinning. He further suggested that such documents eliminated any penance owed, especially 'if in any occasion it has not been fulfilled', but they presupposed true contrition. ${ }^{31}$ Koursou-

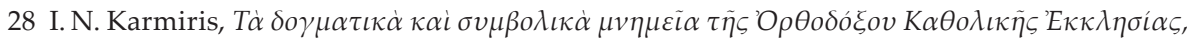
II (Athens 1953) 867-8.

29 J. Meyendorff, Byzantine Theology. Historical Trends and Doctrinal Themes, 2nd edn with revi-

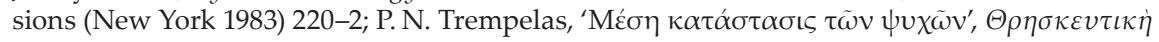

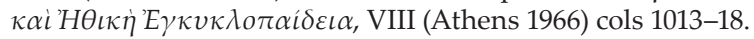

30 On Patriarch Dositheos, see K1.-P. Todt, 'Dositheos II. von Jerusalem', in C. G. Conticello and V. Conticello (eds), La theologie byzantine et sa tradition, II. (XIIIe-XIXe s.) (Turnhout 2002) 659720; G. Podskalsky, Griechische Theologie in der Zeit der Türkenherrschaft, 1453-1821 (München 1988) passim. On Koursoulas, see ibid., 242-4.

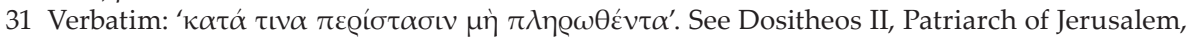

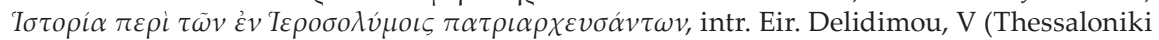
1983) 80-111, especially p. 102-3 (on satisfaction: Dositheos appears to emphasize its medicinal/therapeutic rather than punitive value) and 109-11 (concluding remarks summarizing

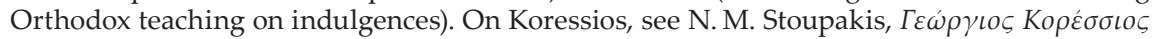

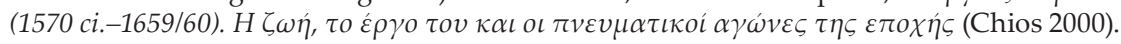


las viewed indulgences as tools of appeal ( $\dot{\varepsilon} v \sigma \tau \tau \iota \kappa \tilde{\omega} \varsigma)$ to a higher authority in the Church that allowed a believer to eliminate penance owed. ${ }^{32}$

Vernacular uses of indulgences echo Dositheos' and Koursoulas' theological understanding of them. For example, in the late sixteenth century, while investigating a dispute between the priest and the parishioners of the Greek brotherhood of Napoli, the agents of the Roman Catholic archbishop discovered practices connected to Eastern indulgences. When they inquired about their use, the Greeks claimed that they used them out of piety and that they also had asked the priest to read them above their head after confession (obviously, I would add, as an attempt to eliminate penance). ${ }^{33}$ In the early eighteenth century, the well-traveled merchant Chatzikyriakis Vourliotis, in a personal letter to the Archbishop Athanasios of Sinai dated 1708, equated imprints of the monastery's seal in individual leaves of paper (colored or not) to synchorochartia in terms of their mnemonic functions: indulgences were physical reminders of past absolution of sin. In short, to the extent that we can tell, the vernacular use of indulgences reflected their theological understanding. ${ }^{34}$ Nevertheless, there remains an important issue: the Greeks starting using them only after their first appearance as a Western practice, and then without any particular specific and spelt-out doctrinal theological understanding of them. There never developed a doctrine on indulgences, although their use was widespread. In short, there was adoption of a Western practice without the accompanying doctrinal basis.

\section{Transconfessionality and Westernization}

Education influenced by Western, Jesuit and other, trends; absolutory practices and accompanying theological understandings borrowed, adopted and adapted from Roman Catholicism and then 'sold' as Orthodox ones. Where do these two cases of Roman Catholic influence on Orthodoxy leave us with regard to education, to indulgences and to confessionalization? Brüning's notion of Orthodoxy's unwillingness and inability to confessionalize goes some way towards explaining the incomplete way through which indulgences were incorporated into Orthodox practice (but not Orthodox doctrine). It also accords well with the apophaticism of Orthodoxy and its reactive character in the early modern period.

But if we adopt a bird's-eye-view, then the following picture appears to emerge. In educational matters, Orthodoxy attempted to focus on the creation of learned theologians and educated functionaries to staff the church and the state (the lat-

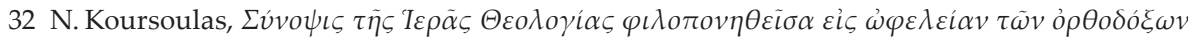
$\varphi \iota \lambda о \mu \alpha \theta \tilde{\omega} v$, ed. S. Ch. Raftanis, II (Zakynthos 1862) 425-6. Koursoulas' theology remained unpublished in the early modern period, but was quite widespread in manuscript form in the seventeenth through the nineteenth centuries: see Iliou, ' $\Sigma v \gamma \chi$

33 C. Nikas, I primi tentativi di latinizzazione dei Greci di Napoli e le prime 'carte assolutorie' orientali in occidente (Napoli 1998) especially p. 54-8 and p. 141ff. for the records of the investigation.

34 On the use of and responses to images, see among others, D. Freedberg, The Power of Images: Studies in the History and Theory of Response (Chicago 1989). 
ter of course only in the Russian Empire, although one finds several graduates of Orthodox schools in high positions of the Ottoman administration). These learned individuals were of course supposed to understand grammar, rhetoric and philosophy. In other words, they were supposed to be sophisticated in order to polemicize and to educate others, and to run state or church affairs. It may therefore be better to focus on tranconfessionality, since it facilitates a greater understanding of Orthodox educational efforts of the early modern period. In the education field, in particular, it would be more fruitful to look at the way in which several trends (Aristotelianisms of Padua, Jesuit Aristotelianisms) infiltrated the East. It was not so much confessionalization, as a series of Aristotelianizations. In the case of indulgences, we ought to consider the extent to which Orthodoxy was adaptive enough to adopt certain practices without openly adopting the necessary doctrinal underpinnings for them (leading to some doctrinal acrobatics, to be sure).

In conclusion, I am offering the following propositions, which may (one hopes) serve as a springboard for further research.

1) If confessionalization is taken to mean the creation and sustaining of separate, distinct and self-contained Churches characterized by distinct doctrines, rituals, spirituality, and everyday life of the believers, then its applicability to early modern Orthodoxy seems doubtful to me.

2) If education is any indication, then Orthodoxy (whether Russian or Greek) in the early modern (and even modern period) was a vast tableau of transconfessionality, not confessionalization.

3) If we end up insisting on the use of confessionalization as a paradigm, and again taking our cue from education, then I would argue that Orthodoxy was involved in a process of confessionalization of the Church, not confessionalization of society. Nevertheless, it was confessionalizing through transconfessionality. ${ }^{35}$ It should be remembered that Reinhard spoke of the confessionalization of the church (not of society, as Schilling did). Perhaps, then, we should be concerned with the extent to which this confessionalization of the Church took place and, in particular, with ascertaining the extent to which transconfessionality tells a better story-or tells the story better.

4) If adopted, transconfessionality may prove to be largely beneficial to historians of Orthodoxy. At least it does not deny Westernization a priori. It tries to assign some history to Orthodoxy, something that is still largely a struggle in the history profession in Greece. Witness, for example, the fact that the history of Orthodoxy is really still primarily written by theologians and clerics, rather than by lay historians, especially in Greece. Finally, transconfessionality is arguably a more neutral term and avoids the judgement inherent in arguments about

35 See Brady Jr., 'Confessionalization-The Career of a Concept', article about the distinction between confessionalization of the church versus confessionalization of society; also see Charipova's argument, referred to above, that Petro Mohyla built a confession without confessionalization. 
the pseudomorphosis of Orthodoxy. ${ }^{36}$ Westernization has normally had a bad reputation in the Orthodox Church. But more recently, especially in Russia, it seems to have elicited certain positive reactions. ${ }^{37}$

5) Transconfessionality also may help us understand certain elements of Orthodox practice that do not render themselves readily to interpretation and explanation, let alone to ascertaining their exact function in Orthodox experience. As regards indulgences and the absence of the purgatory doctrine in Orthodoxy, one may view them as a clear attempt to create a practice comparable to that of the West so as to meet needs of the believers that were otherwise not satisfied. In this sense, we should also remember the work of David Frick, who has pointed out that the Orthodox in essence adopted the tools of their opponents, because they were the necessary ones in their polemical arsenal. ${ }^{38}$

6) One could argue that there is a combined underdevelopment in that Orthodoxy adopted the tools, the theories, and even the liturgical books but somehow still remained separate as a 'confession' due largely to political factors. ${ }^{39}$ The Orthodox adopted the rhetoric, the logic, the Latin formulations in certain rituals ${ }^{40}$ and even (seemingly) doctrinal matters, cleansed appropriately, but we still lack a clear understanding of the resulting forms of Orthodox theology and pious practice. This is at least partly because the period between 1550 and 1700 is the least well-researched period in the intellectual and religious history of the Greeks (except in the case of Loukaris) and of Greek Orthodoxy. Hence, scholars have to grapple with 'peculiar' situations whereby, for example, there is no doctrine of purgatory in Orthodoxy but there is the intermediate condition of the souls. We should not forget that in the absence of an Orthodox emperor forcing it to pronounce this or that way doctrinally, Orthodoxy generally tended to bide its time. Only in the last throes of the Byzantine Empire (when Constantinople frankly was not the center of an empire anymore, but a much

36 G. Florovsky, Collected Works of Georges Florovsky, V. Ways of Russian Theology, ed. R. S. Haugh, translated by R. L. Nichols (Belmont MA 1979); D. Wendebourg, "'Pseudomorphosis"-ein theologisches Urteil als Axiom der kirchen- und theologiegeschichtlichen Forschung', in R. Taft (ed.), The Christian East. Its Institutions and its Thought. A Critical Reflexion. Papers of the International Scholarly Congress for the 75th Anniversary of the Pontifical Oriental Institute Rome, 30 May - 5 June 1993 (Rome 1996) 565-89. English translation in the Greek orthodox Theological Review 42 (1997) 321-42.

37 The hieromonk Petr Meshcherinov, who has translated Johann Arndt's works, has been publicly saying that the westernization of Russian Orthodoxy was a positive development because it gave a jolt to Orthodoxy and it could still be fruitful today. See http://blagovest-info. ru/index.php?ss=2\&s=3\&id=75288.

38 D. A. Frick, 'Sailing to Byzantium: Greek Texts and the Establishment of Authority in Early Modern Muscovy', Harvard Ukrainian Studies 19 (1995) 138-57.

39 See L. Engelstein, 'Combined Underdevelopment: Discipline and the Law in Imperial and Soviet Russia', The American Historical Review 98/2 (1993) 338-53.

40 See for example the case of the adoption of the Latin-influenced indicative form 'I absolve you' in some liturgical books from the early modern period: H. B. Kraienhorst, Buß- und Beichtordnungen des griechischen Euchologions und des slawischen Trebniks in ihrer Entwicklung zwischen Osten und Westen [Das östliche Christentum. Neue Folge, 51] (Würzburg 2003) 342-7. 
diminished city-state) did the Orthodox Church resist imperial authority effectively, and only after it returned to Constantinople. ${ }^{41}$ Transconfessionality, therefore, may also help us deal with the reputed apophaticism of Orthodoxy by better understanding how the reluctance to name and define something in fact does not mean that the Orthodox did not have the concept.

\section{Bibliography}

Almazov A., Tainaia ispoved' v pravoslavnoi vostochnoi tserkvi, 3 vols. (Odessa 1894; reprint, Moscow 1995).

Amato A., Il sacramento della penitenza nella teologia Greco-Orthodossa. Studi storico-dogmatici (sec. XVI-XX) (Thessaloniki 1982).

Androutsos Chr., $\Delta \circ \gamma \mu \alpha \tau \iota \kappa \dot{\eta} \tau \tilde{\eta} \varsigma^{\prime} O \rho \theta o \delta o ́ \xi o v ~ A v \alpha \tau o \lambda \iota \kappa \tilde{\eta} \varsigma^{\prime} E \kappa \kappa \lambda \eta \sigma i \alpha \varsigma$, 2nd ed. (Athens 1956).

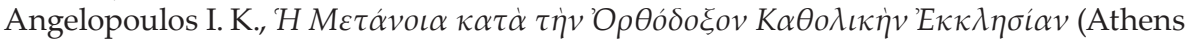
1998).

Angelov D., Imperial Ideology and Political Thought in Byzantium, 1204-1330 (Cambridge 2006).

Behrisch L., 'Social Discipline in Early Modern Russia. Seventeenth to Nineteenth Centuries', in H. Schilling and L. Behrisch (eds), Institutionen, Instrumente und Akteure sozialer Kontrolle und Disziplinierung im frühneuzeitlichen Europa (Frankfurt a.M. 1999) 325-57.

Benakis L., 'review of $\mathrm{Cl}$. Tsourkas, Les débuts de l'enseignement philosophique et de la libre pensée dans les Balkans: La vie et l'oeuvre de Théophile Corydalée (1570-1646), 2nd ed. [Institute for Balkan Studies, 95] (Thessaloniki 1967)', in E $\lambda \lambda \eta v \iota k \dot{\alpha} 23 / 2$ (1970) 309-404.

Brady Jr. Th., 'Confessionalization-The Career of a Concept', in J. M. Headley, H. J. Hilderbrand and A. J. Papalas (eds), Confessionalization in Europe, 1555-1700. Essays in Honor and Memory of Bodo Nischan (Burlington 2004) 1-20.

Brüning A., 'Confessionalization in the Slavia Orthodoxa (Belorussia, Ukraine, Russia)?-Potential and Limits of a Western Historiographical Concept', in Th. Bremer (ed.), Religion and the Conceptual Boundary in Central and Eastern Europe. Encounters of Faiths (Basingstoke 2008) 66-97.

- 'Social discipline among the Russian Orthodox parish clergy (seventeenth-eighteenth centuries): Normative ideals, and the practice of parish life', Cahiers du monde russe 58/3 (2017) 303-40.

Bushkovitch P., Religion and Society in Russia: The Sixteenth and Seventeenth Centuries (New York 1992).

- 'Change and Culture in Early Modern Russia', Kritika: Explorations in Russian and Eurasian History 16/2 (2015) 291-316.

Camariano-Cioran A., Les Académies princières de Bucarest et de Jassy et leurs professeurs (Thessaloniki 1974).

Charipova L. V., 'Orthodox Reform in Seventeenth-Century Kiev: The Evidence of a Library', Journal of Early Modern History 17/3 (2013) 273-308.

Chryssavgis J., Repentance and Confession in the Orthodox Church (Brookline MA 1990).

41 See D. Angelov, Imperial Ideology and Political Thought in Byzantium, 1204-1330 (Cambridge 2006). 
Chrissidis N., 'Greek Teachers, Jesuit Curriculum, Russian Students: The Slavo-Greco-Latin Academy of Moscow in Historiographical Perspective', Kyïus'ka Akademiia 10 (2012) 90-116.

- 'The World of Eastern Orthodoxy', in H. Scott (ed.), The Oxford Handbook of Early Modern European History, 1350-1750, I. Peoples and Place (Oxford-New York 2015) 626-51.

- An Academy at the Court of the Tsars: Greek Scholars and Jesuit Education in Early Modern Russia (Dekalb IL 2016).

- 'Between Forgiveness and Indulgence: Funerary Prayers of Absolution in Russia', in N. Lupinin, D. Ostrowski and J. B. Spock (eds), The Tapestry of Russian Christianity: Studies in History and Culture [Ohio Slavic Papers 10 and Eastern Christian Studies 2] (Columbus OH 2016) 261-93.

- 'Edification Through the Memory of Sins: The Practical Uses of Eastern Orthodox Indulgences', Canadian-American Slavic Studies 52/2-3 (2018) 181-92.

Davey C., 'Metrophanes Kritopoulos and his Studies at Balliol College', in P. M. Doll (ed.), Anglicanism and Orthodoxy: 300 years after the 'Greek College' in Oxford (Frankfurt a.M.-Berlin-New York 2006) 57-77.

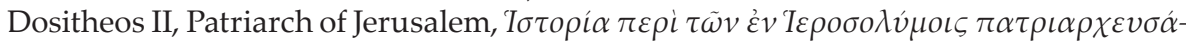
$v \tau \omega v$, intr. Eir. Delidimou, V (Thessaloniki 1983).

Engelstein L., 'Combined Underdevelopment: Discipline and the Law in Imperial and Soviet Russia', The American Historical Review 98/2 (1993) 338-53.

Florovsky G., Collected Works of Georges Florovsky, V. Ways of Russian Theology, ed. R. S. Haugh, translated by R. L. Nichols (Belmont MA 1979).

Freedberg D., The Power of Images: Studies in the History and Theory of Response (Chicago 1989).

Freeze Gr. L., 'Globalization and Orthodoxy in Imperial Russia', Vestnik Sankt-Peterburgskogo Universiteta 62/1 (2017) 4-17.

Frick D. A.,' 'Sailing to Byzantium: Greek Texts and the Establishment of Authority in Early Modern Muscovy', Harvard Ukrainian Studies 19 (1995) 138-57.

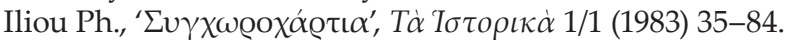

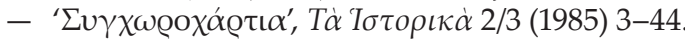

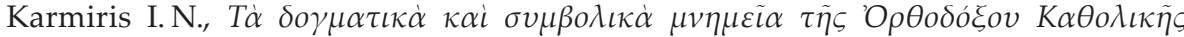

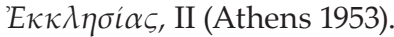

Kitromilides P.M., 'Orthodoxy and the West: Reformation to Enlightenment', in M. Angold (ed.), Cambridge History of Christianity, V. Eastern Christianity (Cambridge 2006) 187-209.

KentW., 'Indulgences', Catholic Encyclopedia, VII(New York1910).http://www.newadvent. org/cathen/07783a.htm.

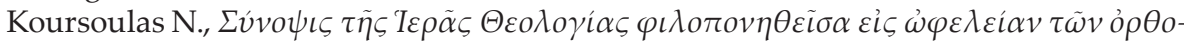
$\delta o ́ \xi \omega v \varphi \iota \lambda o \mu \alpha \theta \tilde{\omega} v$, ed. S. Ch. Raftanis, II (Zakynthos 1862).

Kraienhorst H. B., Buß- und Beichtordnungen des griechischen Euchologions und des slawischen Trebniks in ihrer Entwicklung zwischen Osten und Westen [Das östliche Christentum. Neue Folge, 51] (Würzburg 2003).

Lazar L., 'The Formation of the Pious Soul: Trans-alpine Demand for Jesuit Devotional Texts, 1548-1615', in J. M. Headley, H. J. Hilderbrand and A. J. Papalas (eds), Confessionalization in Europe, 1555-1700. Essays in Honor and Memory of Bodo Nischan (Burlington 2004) 289-318. 
Lea H. Ch., A History of Auricular Confession and Indulgences in the Latin Church, 3 vols (reprint, New York 1968).

Magnin Et., 'Indulgences', Dictionnaire de Théologie Catholique, VII/2 (Paris 1923) col. 1594-1636.

Mentzer R., 'Fashioning Reformed Identity in Early Modern France', in J. M. Headley, H. J. Hilderbrand and A. J. Papalas (eds), Confessionalization in Europe, 1555-1700. Essays in Honor and Memory of Bodo Nischan (Burlington 2004) 243-56.

Meyendorff J., Byzantine Theology. Historical Trends and Doctrinal Themes, 2nd edn with revisions (New York 1983).

Nikas C., I primi tentativi di latinizzazione dei Greci di Napoli e le prime 'carte assolutorie' orientali in occidente (Napoli 1998).

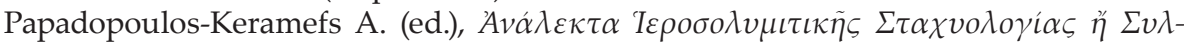

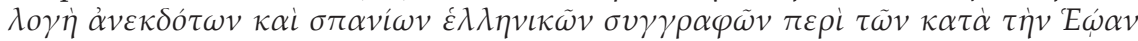

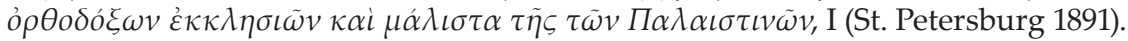

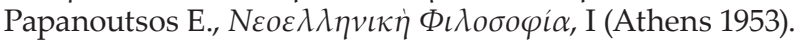

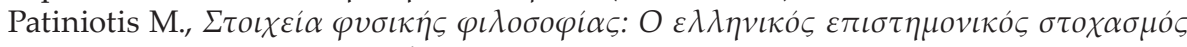

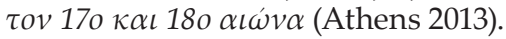

Paulus N., Geschichte des Ablasses im Mittelalter, 3 vols. (Paderborn 1922-1923).

Petmézas S., 'L' organization ecclésiastique sous les Ottomans', in P. Odorico et al. (eds), Conseils et mémoires de Synadinos, prêtre de Serrès en Macédonie (XVIIe siècle) (Paris 1996) 487-569.

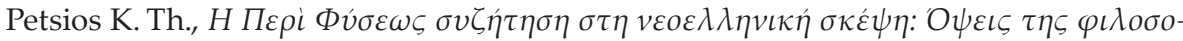

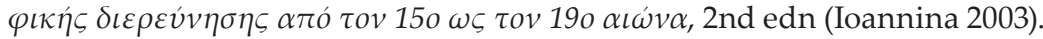

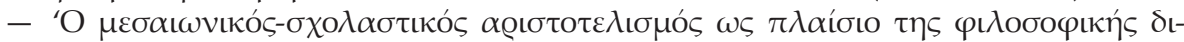

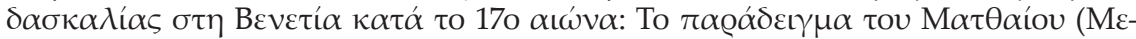

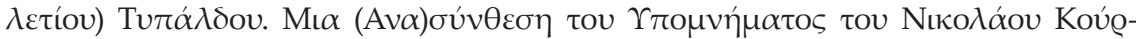

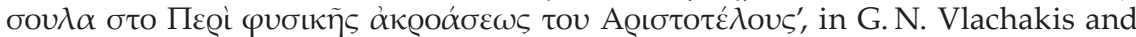

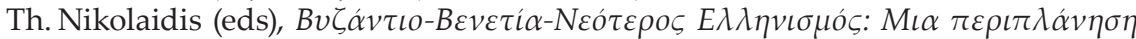

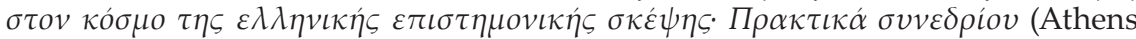
2004) 245-80.

Plokhy S., The Cossacks and Religion in Early Modern Ukraine (Oxford 2001).

Podskalsky G., Griechische Theologie in der Zeit der Türkenherrschaft, 1453-1821 (München 1988).

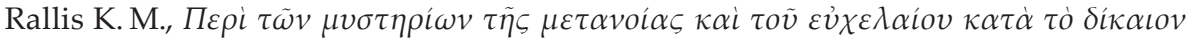
$\tau \tilde{\eta} \varsigma^{\prime} O \rho \theta o \delta o ́ \xi o v ~ A v \alpha \tau o \lambda \iota \kappa \tilde{\eta} \varsigma^{\prime} E \kappa \kappa \lambda \eta \sigma i \alpha \varsigma$ (Athens 1905).

Romaniello M. P., 'Mission Delayed: The Russian Orthodox Church after the Conquest of Kazan', Church History 76/3 (2007) 511-40.

Runciman St., The Great Church in Captivity: A Study of the Patriarchate of Constantinople from the Eve of the Turkish Conquest to the Greek War of Independence (Cambridge 1968).

Schilling H., 'Das konfessionelle Europa. Die Konfessionalisierung der europäischen Länder seit Mitte des 16. Jahrhunderts und ihre Folgen für Kirche, Staat, Gesellschaft und Kultur', in J.Bahlcke and A.Strohmeyer (eds), Konfessionalisierung in Ostmitteleuropa: Wirkungen des religiösen Wandels im 16. und 17. Jahrhundert in Staat, Gesellschaft und Kultur (Stuttgart 1999) 13-62.

Schilling H., 'Confessionalization: Historical and Scholarly Perspectives of a Comparative and Interdisciplinary Paradigm', in J. M. Headley, H. J. Hilderbrand and 
A. J. Papalas (eds), Confessionalization in Europe, 1555-1700. Essays in Honor and Memory of Bodo Nischan (Burlington 2004) 21-35.

Schmitt Ch. B., Aristotle and the Renaissance (Cambridge MA 1983).

Skinner B., The Western Front of the Eastern Church (Dekalb IL 2009).

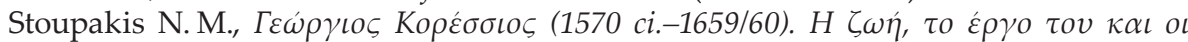

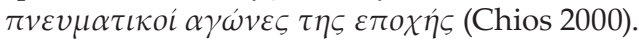

Swanson R. N., Indulgences in Late Medieval England: Passports to Paradise? (Cambridge 2007).

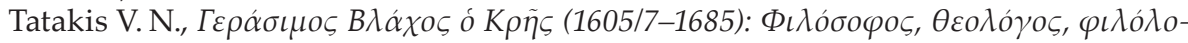

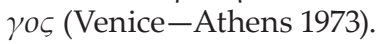

Todt K1-P, 'Dositheos II. von Jerusalem', in C. G. Conticello and V. Conticello (eds), La theologie byzantine et sa tradition, II. (XIIIe-XIXe s.) (Turnhout 2002) 659-720.

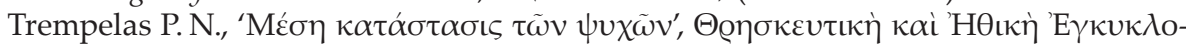
$\pi \alpha i ́ \delta \varepsilon เ \alpha$, VIII (Athens 1966) col. 1013-18.

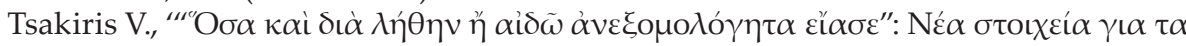

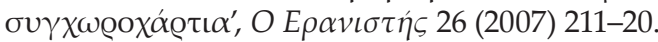

Tsourkas Cl., Les débuts de l'enseignement philosophique et de la libre pensée dans les Balkans: La vie et l'oeuvre de Théophile Corydalée (1570-1646), 2nd ed. [Institute for Balkan Studies, 95] (Thessaloniki 1967).

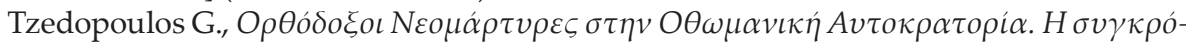

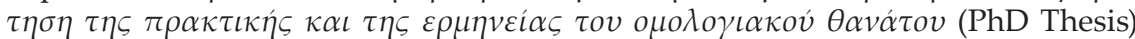
(National and Kapodistrian University of Athens, Athens 2012).

Wendebourg D., "Pseudomorphosis"-ein theologisches Urteil als Axiom der kirchen- und theologiegeschichtlichen Forschung', in R. Taft (ed.), The Christian East. Its Institutions and its Thought. A Critical Reflexion. Papers of the International Scholarly Congress for the 75th Anniversary of the Pontifical Oriental Institute Rome, 30 May-5 June 1993 (Rome 1996) 565-89. [English translation in the Greek orthodox Theological Review 42 (1997) 321-42.] 



\title{
'come una tavola ad uno che si annega in mare'*: The Transfer(s) of a Jesuit Catechism to the Edges of the Greek Confessional Seas
}

\author{
Kostas Sarris, Freie Universität Berlin
}

\section{Introduction}

Early modern Christian catechisms ${ }^{1}$ comprise an integrated system of theological and pastoral knowledge that aims either to instruct the congregants or to introduce its audience into a specific Christian denomination and its principles. Hence, this genre of texts represents a common religious instruction for both pastoral and missionary goals. ${ }^{2}$ On the other hand, 'catechetical knowledge' - so to speakcould be understood as a kind of theological knowledge tied directly to the pastoral ministry, which includes in a broad sense the missionary activity, as well. Notably, its practical orientation makes the catechetical knowledge an essential dimension of the theological knowledge, since it constantly interacts with the social and cultural landscape within which it has been transferred, performed, and practiced. Actually, catechetical knowledge could be described as a distinct field of ongoing dialogue and tension between theology and society; a field traversed by divergent, counterbalancing, rival, but also intertwined dynamics that marked the early modern Age of Confessions. ${ }^{3}$

* Otherwise: 'as a wooden plank for one who is drowning at sea.' Th. Papadopoulos, 'O Bıќ́-

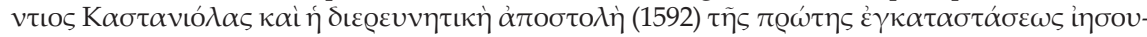

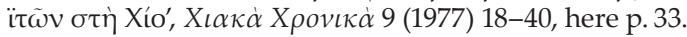

1 A concise presentation of this early modern genre can be found in H.-J. Fraas, W. Grünberg, G. J. Bellinger and P. Hauptmann, 'Katechismus', in Theologische Realenzyklopädie Online (Berlin-Boston 1988) 710-44, https://db.degruyter.com/view/TRE/TRE.17_710_1D; R. Janz, 'Catechisms', in The Oxford Encyclopedia of the Reformation (Oxford 1996), https://www.oxford reference.com/view/10.1093/acref/9780195064933.001.0001/acref-9780195064933-e-0247. Cf. L. Hellinga, 'Catechism', in The Oxford Companion to the Book (Oxford 2010). https://www.oxfordreference.com/view/10.1093/acref/9780198606536.001.0001/acref-9780198606536-e-0930; G. Campbell, 'Catechisms', in The Oxford Dictionary of the Renaissance (Oxford 2003), https:// www.oxfordreference.com/view/10.1093/acref/9780198601753.001.0001/acref-9780198601753e-754. For a penetrating introduction to the topic and the interplay between religious knowledge and early modern Christian identity, see L. P. Wandel, Reading Catechisms, Teaching Religion (Leiden-Boston 2016) indicatively p. 7-36.

2 The devotional aspect of the majority of the catechetical textbooks could also be considered to be part of their pastoral goals.

3 The term 'Age of Confessions', in its plurality, seems to suit better a descriptive-instead of analytical-definition of the period of early modern European history that follows the Reformations of the sixteenth century. For an account of the early modern Confession, see 
Notwithstanding their crucial role in the articulation and the transfer of theological knowledge, early modern catechisms remain relatively unknown to research. ${ }^{4}$ Although many scholars have referred to the sixteenth century as the 'Age of the Catechisms, ${ }^{5}$ and while catechisms have been strongly associated in the historiography of the period with the notion of 'Confessionalization' and its development, ${ }^{6}$ they have not been studied in detail as both meaningful carriers of theological knowledge and as a critical textual space of communication and interaction between confessions and communities. Indeed, a catechism-or, more precisely, a successful one-is the outcome of this negotiation, since it structures, ensures the coherence of, and teaches the corresponding confession as a result of adaptations, compromises, silences, accentuations, additions, or removals, according to the social and cultural setting. Subsequently, contrary to their common, formal, even often simplistic form and content on the surface, catechisms can help uncover many aspects of theological and pastoral knowledge and its modalities of transfer, while they can prove to be acute indicators of the religious and social reality in which they have been written, read or taught.

For the Eastern Church, the early modern catechisms-as a form of comprehensive confessional instruction-represent an imported religious genre. ${ }^{7}$ The first Protestant catechisms rendered into Greek were issued in the early 1550s; a few more were published up to the late 1570s, followed by a single one in $1638 .{ }^{8}$ These translations were in fact chiefly aimed at teaching the Ancient Greek language in conjunction with pastoral instruction in Protestant Europe; they seemed to have

L. P. Wandel, 'Confession', in Th. M. Safley (ed.), A Companion to Multiconfessionalism in the Early Modern World (Leiden-Boston 2011) 23-43.

4 Apart from the pioneering book of Lee Palmer Wandel cited above, concerning the Roman Catholic catechisms and their presence in education in Italy and France, see respectively: K. M. Comerford, 'Clerical Education, Catechesis, and Catholic Confessionalism: Teaching Religion in the Sixteenth and Seventeenth Centuries', in K. M. Comerford and H. M. Pabel (eds), Early Modern Catholicismm. Essays in Honour Off John W. O'Malley, S. J. (Toronto-Buffalo-London 2001) 241-65; K. E. Carter, Creating Catholics: Catechism and Primary Education in Early Modern France (Notre Dame IN 2011).

5 R. Bireley, 'Redefining Catholicism: Trent and beyond', in R. P. Hsia (ed.), The Cambridge History of Christianity, VI. Reform and Expansion 1500-1660 (Cambridge 2007) 145-61, here p. 157.

6 For an overview of the term, see H. Klueting, 'Confessionalization', in Religion Past and Present (2011), http://dx.doi.org/10.1163/1877-5888_rpp_COM_12055; H. Fischer, 'Konfessionalismus', in Theologische Realenzyklopädie, XIX. Kirchenrechtsquellen-Kreuz (Berlin-New York 1990) 426-31.

7 Fraas, Grünberg, Bellinger and Hauptmann, 'Katechismus', 736; Fr.-P. Tebartz-van Elst, E. Schulz, P. Hauptmann and H.-J. Fraas, 'Catechism', in Religion Past and Present (2011), http:// dx.doi.org/10.1163/1877-5888_rpp_COM_11382. Regarding the Byzantine literary genre of $\varepsilon \varrho \omega \tau-\alpha \pi$ many others, see Y. Papadogiannakis, 'Erotapokriseis', in R. S. Bagnall et al. (eds), The Encyclopedia of Ancient History, V. Ec-Ge (Chichester 2013) 2491-3. Cf. P. Ermilov, ‘Towards a Classification of Sources in Byzantine Question-and-Answer Literature', in A. Rigo (ed.), Theologica Minora: The Minor Genres of Byzantine Theological Literature (Turnhout 2013) 110-25.

8 The Christian Catechism by Zacharias Gerganos (Wittenberg 1622) is another story, recounted by Nikolas Pissis in this volume. 
had an extremely limited circulation across the Greek Orthodox populations. ${ }^{9}$ Instead, the majority of the Catholic catechisms set out from the very beginning to either instruct Greek-speaking Roman Catholics in the tenets and the devotional practices of their confession or convert Orthodox congregants to Catholicism. The bibliography mentions-but with no further evidence-that in 1579 Pope Gregory XIII issued a Roman catechism written in vernacular Greek, according to the relevant works by Peter Canisius and Johann Gropper, and that thousands of copies were sent to the Levant. ${ }^{10}$ In the following decades the prominent Catholic catechetical texts (by Peter Canisius and Roberto Bellarmino) were published in Greek alongside several others, brief or more extensive. Some of these catechisms were reissued repeatedly during the seventeenth century, but such publishing activity weakened markedly in the following century. ${ }^{11}$

Although catechisms-and, especially, Catholic catechisms-were circulated among Orthodox populations already from the end of sixteenth century, endorsing the latter's Union with Rome, the Eastern Church did not embrace this

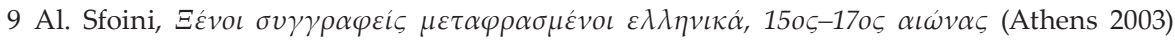
59-64.

10 P. P. Rodotà, Dell'origine, progresso, e stato presente del Rito Greco in Italia, III. Degli Albanesi, Chiese greche moderne, e Collegio Greco in Roma coll'indice di tutta l'opera (Rome 1763) 150. That testimo-

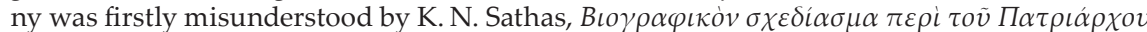
Iepcuiov B' (1572-1594) (Athens 1870) $v \eta^{\prime}$ [58]. A further misunderstanding led to the incorrect assumption that the Roman Catechism (Rome 1566/1567), which had been planned during the Council of Trent and issued by Pope Pius IV, was translated into Greek already in 1576. M. V. Dmitriev, 'Western Christianity and Eastern Orthodoxy', in R. P. Hsia (ed.), The Cambridge History of Christianity, VI. Reform and Expansion 1500-1660 (Cambridge 2007) 321-42, here p. 323. Anyway, no such catechism is documented from the 1570s.

11 In chronological order, these books are: the Catechismus parvus by Émond Auger (Toulouse

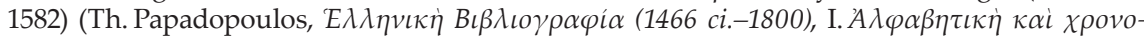

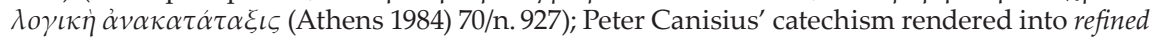
Attic Greek by Georg Mayr for the teaching of Ancient Greek (Ingolstadt 1595 and 1618, Köln 1558 and 1626, Augsburg 1613, Vienna ca 1620, 1657, 1672 and 1718, Dillingen 1621, 1622, 1629, 1654, 1660 and 1707, Sion 1644, Munich 1646 and 1677, Bratislava 1666, Prague 1667 and 1753,

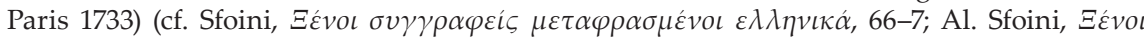

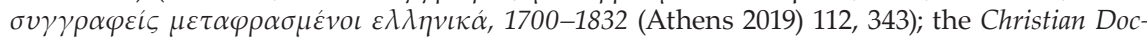
trine by Diego de Ledesma (Rome 1595 and 1604, Venice 1609, 1772, Paris 1657 and 1687) (Papa-

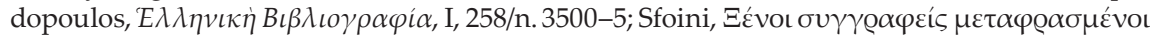

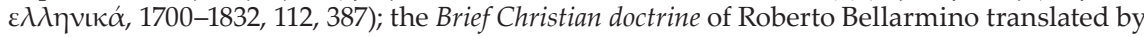
Ioannis-Matthaios Karyofyllis (Rome 1602, 1635, 1637, and by 'Giorgio Perpiniano' in Padua 1695); the extensive Christian doctrine by Bellarmino, translated anonymously in Rome 1603 and later by Leonardos Filaras (Rome 1616, 1635, 1637 and 1715, Paris 1633) (Papadopoulos, 'E $\lambda$ $\lambda \eta v \iota \kappa \eta \dot{~ B \iota \beta \lambda \iota ~}$

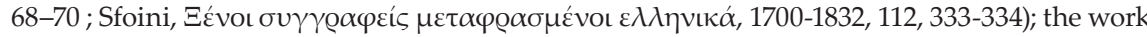
of Petros Arkoudios, Orthodox Christian doctrine (Rome 1628, 1671 and Venice 1682, 1761;) (Pa-

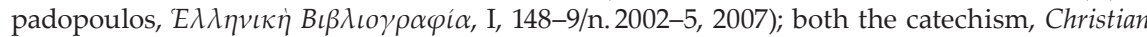
doctrine, and the Orthodox manual of the Romans by Paul de Lagny (Paris 1668) (Papadopoulos,

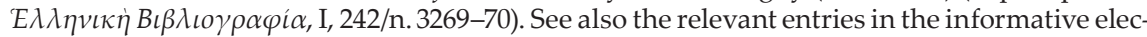
tronic catalogue 'Greek Bibliography of the 19th Century' (now extended to the beginnings of typography), which has been created by the Bibliology Workshop 'Philippos Iliou' (https:// www.benaki.org/index.php?option=com_landings\&view=filippos_iliou\&lang=en). 
religious genre until a century later, and then only in a half-hearted manner. ${ }^{12}$ Unsurprisingly, in the Greek literature the first catechetical books come from Venetian regions: Nikolaos Voulgaris from Corfu was the author of a voluminous Holy Catechesis. Namely Exegesis of the Divine and Holy Liturgy and Examination of the Ordained Men [...] (Venice 1681 and republished in 1694) ${ }^{13}$, while Iosif Doxas from Zakynthos published a similar Holy Catechesis for these who are about to ascend the degree of priesthood (Venice 1695). ${ }^{14}$ It was only after the mid-eighteenth century that the issue of Orthodox catechisms shows some considerable presence in Greek book production; yet even then they were still intended for clerics and scholars-such as Voulgaris' and Doxas' Holy Catechesis - rather than at the common Orthodox flock. ${ }^{15}$

At first glance, this observation may appear surprising, bearing in mind the interplay between the notions of 'confessionalization' and religious 'mission-propagation' on the one hand, and, on the other, the broadening of the concept of confessionalization into a communication process of 'epistemic pressure'-which has

12 The claim that Petro Mohyla's Confessio Orthodoxa (1640) introduced the catechetical genre in Orthodox literature is arguable, since this work derives from another early modern religious genre: the confessions. Fraas, Grünberg, Bellinger and Hauptmann, 'Katechismus', 736; Tebartz-van Elst, Schulz, Hauptmann and Fraas, 'Catechism'. Regarding the divergent meanings of the early modern confession, see C. H. Ratschow, 'Konfession/Konfessionalität', in Theologische Realenzyklopädie, XIX (Berlin-New York 1990) 419-26.

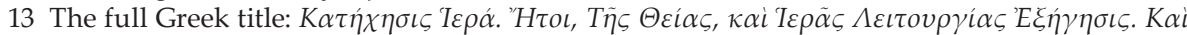

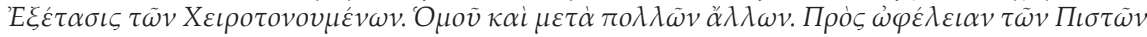

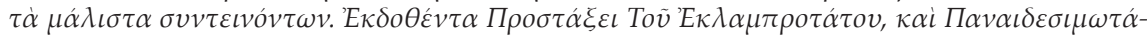

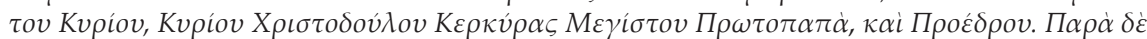

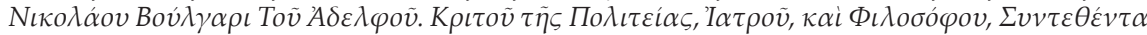
ó

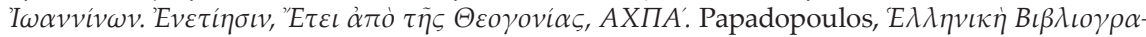
pí $\alpha, \mathrm{I}, 106-7 / \mathrm{n} .1438-40$. A concise but praiseful assessment of this book characterized it as a

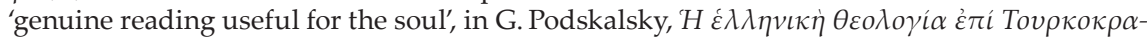

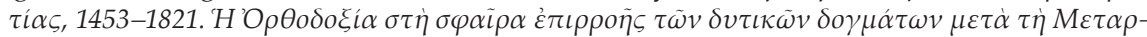
$\rho v \theta \mu \iota \sigma \eta$ (Athens 2005) 356. The life and works of Nikolaos Voulgaris (1634-post 1684) have not

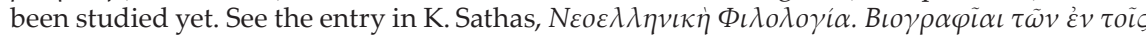

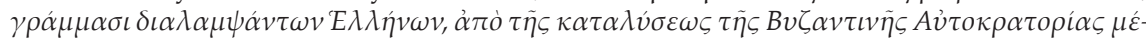
$\chi \rho \iota \tau \tilde{\eta} \varsigma^{\prime} E \lambda \lambda \eta v \iota \kappa \tilde{\eta} \varsigma^{'} E \theta v \varepsilon \gamma \varepsilon \rho \sigma i \alpha \varsigma$ (1453-1821) (Athens 1868) 341-3.

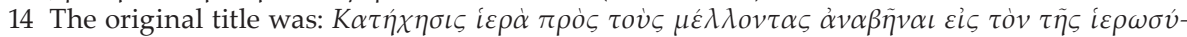

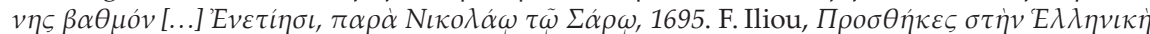

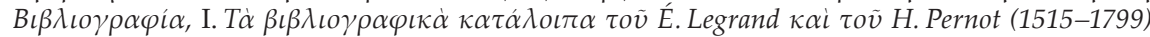
(Athens 1973) 321/n. 110. Aspects of the biography of the bishop Iosif Doxas (1616/1618-before

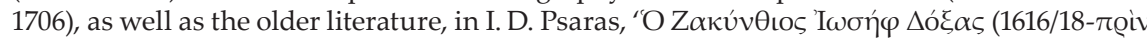

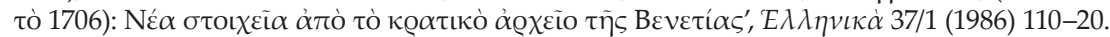

15 Note the widespread Greek translation of the Orthodox Teaching (1765) by the Metropolitan of Moscow, Platon (Levshin), and its publication in 1782 at Leipzig, followed by two immediate reprints in Vienna (1782 and 1783). The translator, Diamantis Korais (the later prominent scholar of the Modern Greek Enlightenment, Adamantios Korais), emphasizes the lack of such a book among the Greeks, while a subsequent editor of the mid-nineteenth century notes its usefulness for teachers and students of higher education. Platon, Metropolitan of Moscow, Orthodox Teaching, namely Synopsis of the Christian Theology, transl. Diamantis Korais (Athens 1836) [3], [5-6]. For a survey of Orthodox catechisms rendered in Greek until the early nine-

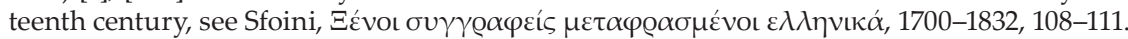


been aptly described as 'das Fragen-Stellen- und das Fragen-Beantworten-Können-Müssen von Fragen, die man vorher so nicht hatte. ${ }^{\prime 16}$ Although authoritative Orthodox Confessions were produced during the seventeenth century (by Petro Mohyla in 1640 and by Patriarch of Jerusalem Dositheos II in 1672), they could hardly respond to catechisms that were in equal terms heterodox and missionary in character, ${ }^{17}$ they might have been doctrinal texts par excellence, but neither of them paid great attention to the pastoral ministry. Actually, if a Greek Orthodox Age of Confessions can be conventionally defined as lasting from the late sixteenth century until the peak marked by the issuing of the Concise and principal exposition of the holy articles and doctrines of the Eastern Christian Church by the Synod of Constantinople under Patriarch Ieremias III in $1727,{ }^{18}$ this Age of Confessions was not marked by Greek Orthodox catechisms. Across the Greek-speaking lands one notices an almost complete absence of this religious genre.

Indeed, the relevant field is dominated by Catholic catechetical textbooks rendered into Greek-most of them into the vernacular. Among them, the brief catechism (on average, twenty small sized pages) written by the Spaniard Jesuit and professor in the Collegio Romano at Rome, Diego de Ledesma (1519-1575) stands out. ${ }^{19}$ The Dottrina Christiana breve per insegnar in pochi giorni et per interrogationi a modo di dialogo, fra il Maestro, e Discepolo (first edition Rome, 1571) holds the distinction of being one of the most widely translated and circulated Catholic catechisms of the early modern period. ${ }^{20}$ The heuristic value of the Greek fortunes of Ledesma's Dottrina Christiana might be presumed to rest on the fact that it constantly circulated among Greek-speaking populations, covering through its republications almost the entire Greek Orthodox Age of Confessions. Specifically, a vernacular

16 '[H]aving to be capable of posing and answering questions of a kind that previously did not exist.' C. A. Zwierlein, “Konfessionalisierung' europäisch, global als epistemischer Prozess. $\mathrm{Zu}$ den Folgen der Reformation und zur Methodendiskussion', in Chr. Strohm (ed.), Reformation und Recht. Ein Beitrag zur Kontroverse um die Kulturwirkungen der Reformation (Tübingen 2017) 1-51, here p. 9.

17 See above, footnote 6 .

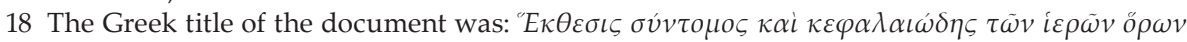

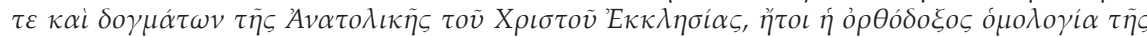

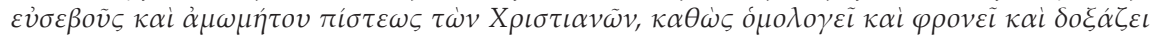

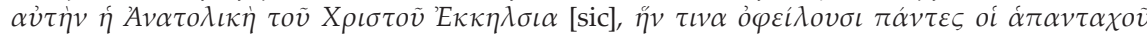

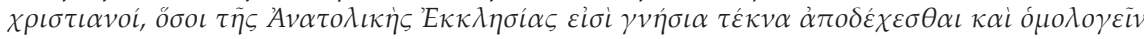

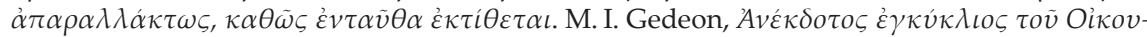

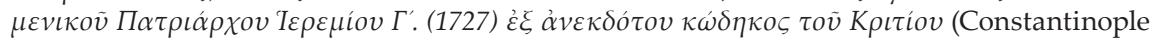
1872) here p. 23.

19 J. M. Belmonte, To give Ornament, Splendor and Perfection: Diego de Ledesma and Sixteenth Century Jesuit Educational Administration (PhD Thesis) (Loyola University Chicago, Chicago IL 2006) 90-2; L. Resines, 'El catecismo de Diego de Ledesma', Archivum Historicum Societatis Iesu 66/132 (1997) 249-74, especially p. 259-60.

20 It was even translated into Wendat, the local indigenous language of the First Nations in New France, Canada. J. Steckley, 'Inventing new words. Father Jean de Brébeuf's Wendat Catechism of 1632', in A. Flüchter and R. Wirbser (eds), Translating Catechisms, Translating Cultures. The Expansion of Catholicism $n$ the Early Modern World (Leiden-Boston 2017) 129-69. 
Greek translation, attributed to the Jesuit Vincenzo Castagnola from Chios, had already been issued in $1595 .^{21}$ The brief translation by Castagnola was well-known and circulated widely, as it is documented in a total of five re-editions (Rome 1604, Venice 1609, Paris 1657 and 1687, Venice 1772). ${ }^{22}$

However, Ledesma's catechism was translated into Greek vernacular once again in the late seventeenth century, albeit without mention of the author's identity and not as an independent edition. In 1686 at Venice, Ioannis Makolas translated from the Latin and published the Roman historical-ethical compilation entitled Justin. ${ }^{23}$ In the last pages of this volume, a second Greek translation of the Dottrina Christiana by Ledesma was published, completed by the Orthodox priest Michail Mitros from Ioannina. According to Alexandra Sfoini, who first made the identification, the Christian Doctrine at the end of the edition of Makolas' Justin is, virtually, 'the translation by Castagnola [...] with some changes and additions by the priest Michail Mitros from Ioannina.' ${ }^{24}$ Yet the case proves to be much more complicated.

In fact, the heuristic value of Ledesma's catechism in Greek lies particularly in the fact that it was translated twice, at the far chronological limits of the Greek Orthodox Age of Confessions (Rome 1595, Venice 1686) and by two totally different agents: a Jesuit missionary and an Orthodox priest. Consequently, the critical study and juxtaposition of the two Greek versions of the Dottrina Christiana by Diego de Ledesma may allow us to delve into the modalities, as well as the historicity of the interconfessional transfer of theological knowledge. The outcome of such a comparison will not simply be a clarification and differentiation of the 'theologoumena' between 'essentials' and 'adiaphora'. ${ }^{25}$ Through the close com-

21 É. Legrand, Bibliographie hellénique ou description raisonnée des ouvrages publiés par des grecs au XVe et XVIe siècles, II (Paris 1885) 226/n. 286.

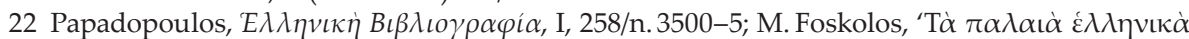

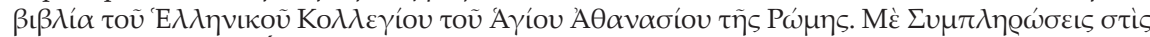

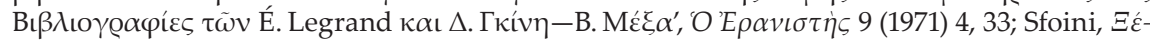

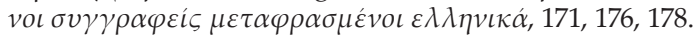

23 Ioannis Makolas, Historical Book called Justin [...] (Venice 1686). Legrand, Bibliographie hellénique

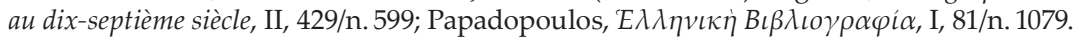

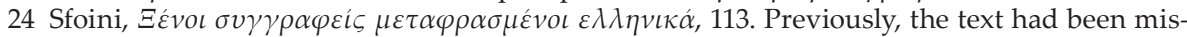
takenly identified with the Brief Christian doctrine by Roberto Bellarmino. K. Kyriakopoulos,

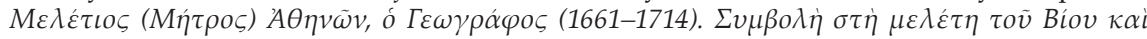

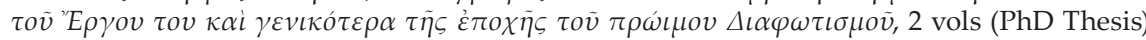
(National and Kapodistrian University of Athens, Athens 1990) 75-7.

25 Regarding this distinction, see R. Heiligenthal and W. Joest, 'Gebot', in Theologische Realenzyklopädie, XII. Gabler-Gesellschaft/Gesellschaft und Christentum V (Berlin-New York 1984) 124-38, here p. 128. The debate about the 'adiaphora'-'things indifferent'-'nonessentials' in Christian soteriology originates in Martin Luther, while it is also situated at the heart of the so-called Rites Controversies in the context of the non-European Catholic missions. I. G. Županov and P. A. Fabre, 'The Rites Controversies in the Early Modern World: An Introduction', in I. G. Županov and P. A. Fabre (eds), The Rites Controversies in the Early Modern World (Leiden-Boston 2018) 1- 26, here p. 11-20; R. Po-chia Hsia, 'Theological Developments in the Non-European World, 1500-1800', in U. L. Lehner, R. A. Muller and A. G. Roeber (eds), The Oxford Handbook of Early Modern Theology, 1600-1800 (Oxford 2016) 11-24, especially p. 20-1. 
parison of translation practices and accommodation methods, valuable inferences can be drawn about both the varied historical context (the conjuncture) that made possible and deployed each translation (defining the modalities of the transfer) and about some crucial aspects of the Greek Orthodox Age of Confessions (related to the historicity of the transfer).

A central dimension of this epistemic transfer is the very notion of translation. In particular, the concept of 'cultural translation' introduced by Peter Burke and Ronnie Po-Chia Hsia includes in its focal research fields the space of religion as it had evolved from the Reformation. ${ }^{26}$ Along similar lines, a group of scholars has recently studied especially the Catholic catechisms of the missionaries outside Europe as a typical double form of cultural translation (literal and metaphorical) aiming at showing the 'glocality' of early modern Catholicism and its fundamental transculturality. ${ }^{27}$ In the case of the Greek translations of Ledesma's catechism, however, the utilization of ideas and analytical tools elaborated or concretized from the point of view of cultural translation (accommodation, adaptation, sayable, translatable, legible, intelligible) and applied to the study of catechisms rendered into non-European languages by Catholic missionaries, should also take into consideration the complex confessional realities of the early modern Levantine historical setting. ${ }^{28}$

This setting could be likened to an array of 'Greek confessional seas', because of its plural, diverse, yet-unformed, but at once uniform and dynamic confessional landscape, set in motion during the Greek Orthodox Age of Confessions not only through the epistemic pressure applied by Western missionaries, diplomats and many others, ${ }^{29}$ but also as a result of a particular historical condition in the early modern Levant that we tend to forget: multiconfessionalism. ${ }^{30}$ Indeed, for the Greek Orthodox Church the multiconfessional setting was not just a longstanding reality (both in the Venetian domains and within the multireligious Ottoman Em-

26 P. Burke and R. Po-Chia Hsia (eds), Cultural Translation in Early Modern Europe (New York 2007). Preferring the literal to the metaphorical, Heinz Schilling and István György Tóth speak instead of 'cultural exchange'. H. Schilling and I. G. Tóth (eds), Cultural Exchange in Early Modern Europe, I. Religion and Cultural Exchange in Europe, 1400-1700 (Cambridge 2006).

27 The contributors to the collective volume A. Flüchter and R. Wirbser (eds), Translating Catechisms, Translating Cultures. The Expansion of Catholicism in the Early Modern World (LeidenBoston 2017).

28 I prefer the geographical and cultural term 'Levant'/'Levantine' as more appropriate, in order to describe both the Ottoman and Venetian territories in the Eastern Mediterranean, from the Adriatic Sea to the Middle East.

29 Zwierlein, "Konfessionalisierung' europäisch, global als epistemischer Prozess', 21-31. This argument has been further elaborated in C. Zwierlein, Imperial Unknowns. The French and British in the Mediterranean, 1650-1750 (Cambridge 2016) 118-42, 163-84.

30 For a definition in its European context: 'Multiconfessionalism, [is] understood here as the legally recognized and politically supported coexistence of two or more confessions in a single polity.' Th. M. Safley, 'Multiconfessionalism: A Brief Introduction', in Th. M. Safley (ed.), A Companion to Multiconfessionalism in the Early Modern World (Leiden-Boston 2011) 1-19, here p. 7. 
pire); ${ }^{31}$ it also represented a probable, future and, most importantly, menacing potentiality, bearing in mind the indifference-at least in principle-of the Sublime Porte to the denominational rivalries of its Christian subjects.

The emphasis on multiconfessional societies as a key result of the European Reformations, which through their plurality shaped the religious landscape of the early modern period, has further strengthened the criticism of 'Confessionalization' in its narrow sense. In fact, multiconfessionalism degrades the historical significance or even challenges the formation itself of the primary outcome of the 'Confessionalization' scheme: the religiously homogenized and totally uniform, early modern 'confessional states'. ${ }^{32}$ Besides, insofar as it concerns our topic, the various aspects introduced by multiconfessionalism shed light on the multiple communication levels of a religious translation within a multiconfessional setting. The act of translation does not simply transfer, reconfigure, and accommodate theological knowledge and its cultural representations in a two-way communication between two specific confessions, but it takes into serious consideration the multiconfessional realities and their dynamics in situ. ${ }^{33}$ Moreover, confessional ambiguities or transconfessional endeavors mostly entail some kind of existing or potential multiconfessionalism.

Indeed, it is no coincidence that both initiatives to render Ledesma's catechism into vernacular Greek were motivated by and addressed (at least initially) to congregants of multiconfessional societies: Vincenzo Castagnola at Chios Island, whereas Michail Mitros in Venice. Castagnola's translation is dated almost to the beginning of the Greek Orthodox Age of Confessions and, as I try to show below, represents an interesting case of a missionary cultural translation aimed initially at the Greek-speaking Roman Catholics of Chios. On the other hand, I argue that Mitros employs the cultural translation as a starting point, so as to propose something confessionally absolutely novel, which comes to interact with the multiconfessional Venice. This transconfessional endeavor, or experiment, is inextricably linked to the Meletios Typaldos affair and his attempt to convert the Orthodox Venetian subjects to Catholicism around 1700-an affair that marked in its own way the end of the Age of Confessions for the Greek Orthodox Church.

\section{The Christian Doctrine by Vincenzo Castagnola}

Twenty-four years after the publication of the Dottrina Christiana breve per insegnar in pochi giorni et per interrogationi a modo di dialogo, fra il Maestro, e Discepolo (Rome, 1571) by the Jesuit professor at the Collegio Romano, Diego de Ledesma, a vernacular Greek translation, attributed to the fellow Jesuit Vincenzo Castagnola from

31 Focusing, of course, here exclusively on the Christian denominations (Orthodox, Armenians, later Catholics) of the Muslim, in all respects, Ottoman state.

32 See the relevant critic in Safley, 'Multiconfessionalism: A Brief Introduction', 9-13.

33 Otherwise, it would be difficult to interpret, for example, the Eucharistic Debate of the seventeenth century in its Greek Orthodox dimension. 
Chios, ${ }^{34}$ was issued in a small size format (in-16). The title of the translation rather follows than copies the original:

Christian Doctrine. In which the Teacher questions, and the Pupil answers. Composed by the father Jacob Ledesma theologian of the society of Jesus, and turned to the Roman language by the father Vincenzo Castagnola of the same society. [...] In Rome, by Luigi Zannetti, 1595. ${ }^{35}$

The second part of the title is identical with the first one, but published in Latin fonts, in so-called Francochiotic. ${ }^{36}$ Correspondingly, the main text is also printed in both Greek and Francochiotic fonts per page and runs to seventy-nine pages. This small book is wellknown and was republished five times (Rome 1604, Venice 1609, Paris 1657 and 1687, Venice 1772). ${ }^{37}$

Like its original, Castagnola's translation has the form of a dialogue, struc-

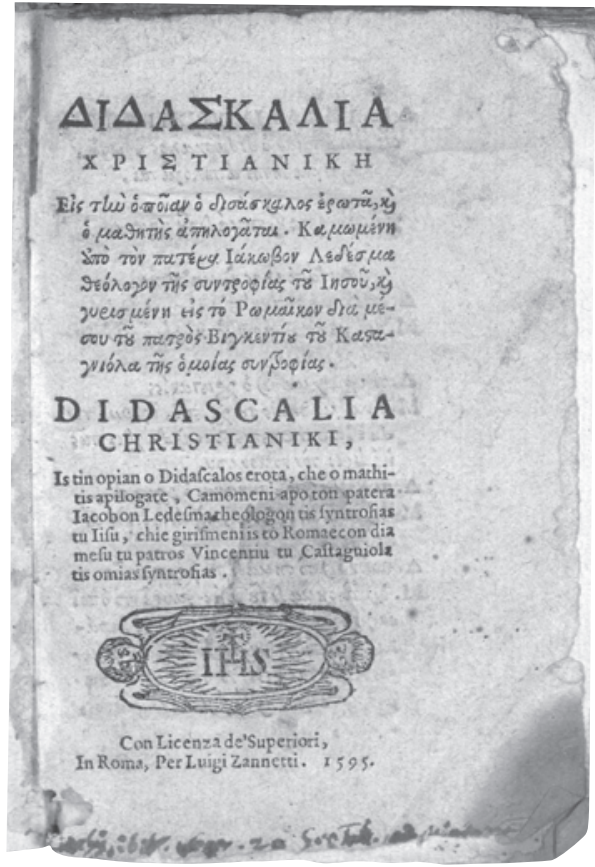

Fig. 5: Diego de Ledesma, Christian Doctrine, transl. Vincenzo Castagnola, Rome 1595 (Jagiellonian Library, Cracow). tured in fifteen thematic sections:

- On the name and sign of the Christian.

- On the purpose and the things that the Christian needs.

- Exegesis of some important articles of the Creed.

- On the second thing that the Christian needs, namely on the hope.

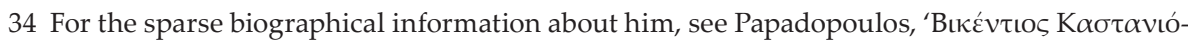
$\lambda \alpha \varsigma^{\prime}, 19-21$.

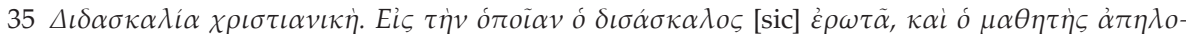

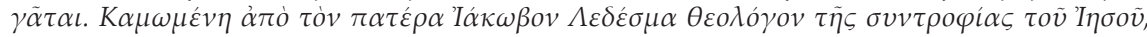

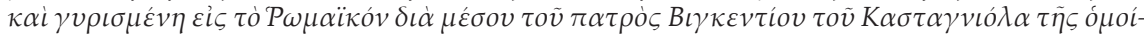

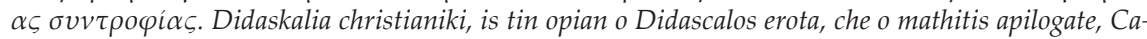
momeni apo ton patera Jacobon Ledesma theologon tis syntrofias tu Iisu, chie girismeni is to Romæcon dia mesu tu patros Vincentiu tu Castagniola tis omias syntrofias. Con Licenza de' Superiori. In Roma, per Luigi Zannetti, 1595. Cf. É. Legrand, Bibliographie hellénique ou description raisonnée des ouvrages publiés par des grecs au XVe et XVI siècles, II (Paris 1885) 226/n. 286.

36 On the Francochiotic fonts and books, see M. Vitti, 'Catechismi in "francochiotica" e il codique vaticano gréco', Orientalia Cristiana periodica 24 (1958) 257-75; and especially M. Foskolos, Ta

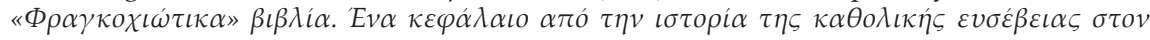
$\varepsilon \lambda \lambda \eta v \iota k o ́ ~ \chi \omega ́ \rho o$ (Thessaloniki 2012), which summarizes the existing literature.

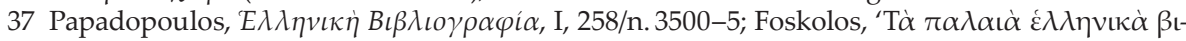

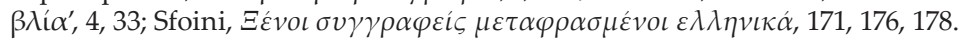


- For other prayers, and entreaties to the saints.

- For the third thing that the Christian needs, which is love.

- On the fourth thing, which is necessary to the Christian, which is good deeds.

- Exegesis of the ten commandments.

- On the five commandments of the Church.

- On the primary sins that are called mortal.

- Against these sins are seven virtues.

- On the seven mysteries of the Holy Church.

- Confession.

- On other good things referred in the Christian Doctrine.

- Prayer. ${ }^{38}$

It is difficult, however, to identify a specific edition of Ledesma's catechism as the original that Castagnola rendered into vernacular Greek.

The catechetical text of Ledesma itself has differences from edition to edition, some of which are secondary, but others are considerable. For example, between the chronologically very close editions of 1589 and 1593 in Rome, apart from secondary variations concerning the format of the text ${ }^{39}$ and the presence or absence of the concluding words 'Amen Iesus'/AAmen Giesú' in some sections, ${ }^{40}$ there are

38 The original headings are:

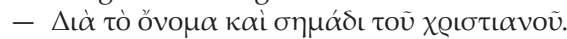

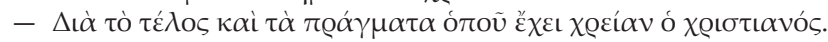

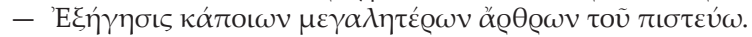

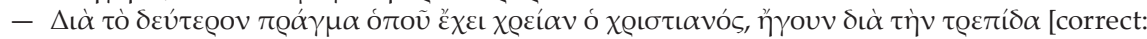
$\dot{\varepsilon} \lambda \pi i \delta \alpha \alpha]$

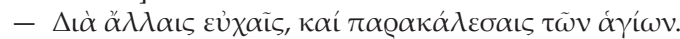

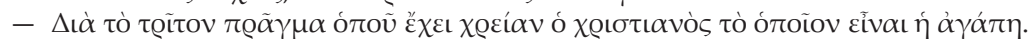

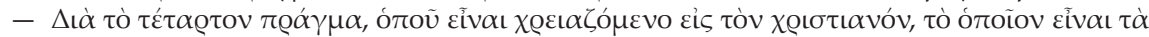
$\kappa \alpha \lambda \dot{\alpha}$ हैo $\gamma \alpha$.

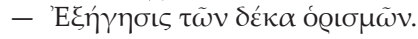

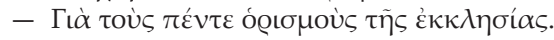

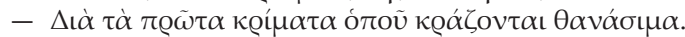

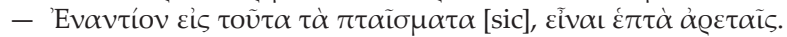

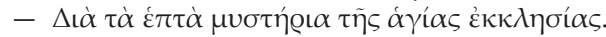

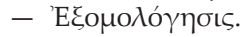

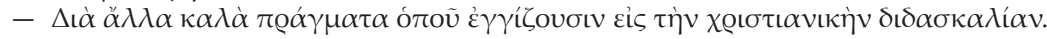

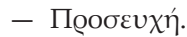

For this study, the third edition has been used which contains the text only in Greek fonts: Vincenzo Castagnola, Christian Doctrine (Venice 1609). Shortly before the publication of this article, the first edition was found, showing no significant variations from that of 1609. Vincenzo Castagnola, Christian Doctrine (Rome 1595). Where there is a citation to the first edition, the year of publication is noted after the title.

39 Diego de Ledesma, Dottrina christiana breve, A modo di Dialogo, fra'l Maestro e'l Discepolo. Composta per il R. P. Iacomo Ledesma Dottor Theologo, della Compagnia di Giesu (Rome 1589) 2-3, 5, 11 passim; Diego de Ledesma, Dottrina christiana, Composta per il R. P. Giacomo Ledesma della Compagnia di Giesu. Di nuovo ristampata, \& diligentemente coretta (Rome 1593) 2-3, 4, 8-9 passim.

40 Ledesma, Dottrina christiana (1589) 5, 6 passim; Ledesma, Dottrina christiana (1593) 4, 5 passim. 
significant differences. ${ }^{41}$ In particular, the part 'Delli Commandamenti della Chiesa' is totally different between the two editions, even regarding the commandments themselves. ${ }^{42}$ Moreover, the edition of 1593 contains a text entitled 'Confiteor' ('I confess') that is absent from the edition of $1589^{43}$ while, in contrast, the older edition concludes with some prayers absent from the later edition. ${ }^{44}$ Last but not least, in the section 'Espositione di alcuni articoli principali del Credo', while the edition of 1593 makes a clear mention on the Filioque, the edition of 1589 remains silent. ${ }^{45}$

The Greek translation by Vincenzo Castagnola combines several published versions of Ledesma's Dottrina Christiana or, probably, follows an edition that was already a result of combining the aforementioned variations. It is striking that Castagnola translated both one of the final prayers at the edition of $1589^{46}$ and the 'Confiteor' text from the edition of $1593 .{ }^{47}$ In any case, even though his translation is closer to Ledesma's later edition (Rome 1593) than to the older one (Rome 1589), ${ }^{48}$ what characterizes Castagnola's endeavor is its conscious selectivity.

This selectivity does not prevent him from providing a broadly literal translation of the original, and from more or less following the division of the Italian text into sections with relevant headings. ${ }^{49}$ Yet many significant discrepancies can be detected-to say nothing of the numerous small and insignificant differences or Castagnola's misunderstandings throughout the translation,,$^{50}$ as well as his attempt to improve the format of the text, ${ }^{51}$ to illustrate terms, ${ }^{52}$ and to reduce the redundancies and repetitions that characterize the original. ${ }^{53}$ There are in fact specific points of the catechism where Castagnola modifies rather than translates Ledesma, in order to adapt its content for the Greek-speaking audience.

41 Besides, the edition of 1593 is presented in its title page as 'diligentemente coretta'.

42 Ledesma, Dottrina christiana (1589) 21-2; Ledesma, Dottrina christiana (1593) 16.

43 Ledesma, Dottrina christiana (1593) 19-20; cf. Ledesma, Dottrina christiana (1589) 25.

44 Ledesma, Dottrina christiana (1589) 31-2; cf. Ledesma, Dottrina christiana (1593) 24.

45 Ledesma, Dottrina christiana (1593) 7 reads: 'Spirito santo [...] il qual procede dal Padre, \& dal Figliuolo, et dà la gratia [...].' Ledesma, Dottrina christiana (1589) 8-9 reads: 'Spirito santo [...] il quale dà la gratia [...].'

46 Castagnola, Christian Doctrine, $\lambda^{\prime}$; Ledesma, Dottrina christiana (1589) 31.

47 Castagnola, Christian Doctrine, $\kappa \gamma^{\prime}-\kappa \delta$; Ledesma, Dottrina christiana (1593) 19-20.

48 E.g. Castagnola's translation of the section 'Delli Commandamenti della Chiesa' corresponds to the edition of 1593, instead of that of 1589. Castagnola, Christian Doctrine, in'; Ledesma, Dottrina christiana (1593) 16; cf. Ledesma, Dottrina christiana (1589) 21-2. Still, the first of the Decalogue follows the version of 1589: Castagnola, Christian Doctrine, to $\tau^{\prime}$; Ledesma, Dottrina christiana (1589) 19; cf. Ledesma, Dottrina christiana (1593) 14.

49 In the last pages, there are some differences in the person of the dialogue who utters specific words, but these differences are without any importance.

50 E.g. Castagnola, Christian Doctrine, $\kappa^{\prime}$; cf. Ledesma, Dottrina christiana (1593) 17.

51 Castagnola, Christian Doctrine, $\zeta^{\prime}, \iota \theta^{\prime}, \kappa \gamma^{\prime}$; cf. Ledesma, Dottrina christiana (1593) 7, 16-17, 19.

52 Castagnola, Christian Doctrine, $\iota^{\prime}-\kappa \beta^{\prime}, \kappa \varepsilon^{\prime}$; cf. Ledesma, Dottrina christiana (1593) 16-18, 21.

53 Castagnola, Christian Doctrine, เo $\tau^{\prime}-\kappa \alpha^{\prime}$; cf. Ledesma, Dottrina christiana (1593) 14-18. 
Hence, he does not hesitate to keep but obscur a clear reference of the Italian original to the papal Primacy, ${ }^{54}$ while choosing not to mention the doctrine of Filioque. ${ }^{55}$ However, the translator appears flexible and inventive in the case of some doctrinal and devotional disputes. When the teacher asks the pupil about the Holy Communion, Castagnola naively changes the Catholic term 'Hostia' ('host') of the

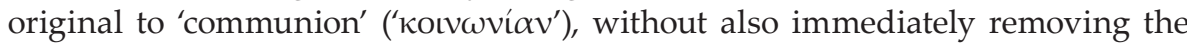

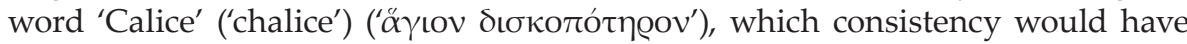
required. ${ }^{56}$ Moreover, the very appellation of the Church is consciously equivocal across the Greek text. Nowhere is this Church called 'Roman' or 'Orthodox'. ${ }^{57}$ Instead, an ambiguous, eclectic form of the Italian catechism is preferred: the 'Santa Madre Chiesa Cattolica' is transformed into 'holy and Catholic Church'. ${ }^{58}$ But the highlight of the ambiguity is found in the doctrine of Purgatory. Although Castagnola expurgates the term 'Purgatorio' from a teacher's question, ${ }^{59}$ he leaves untouched the answer of the pupil that describes exactly this Catholic dogma. ${ }^{60}$ Closely related to the doctrine of the Purgatory is also the catechism's pedantic categorization of sins, which characterizes post-Tridentine Moral Theology ${ }^{61}$ and

54 'Giesu Christo [...] \& il Papa suo Vicario in Terra'. Ledesma, Dottrina christiana (1593) 7; cf. 'ó

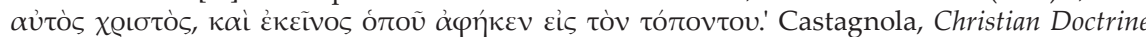
(1595) 14. Noteworthy is the fact that this specific phrase has been completely deleted from the third edition. Castagnola, Christian Doctrine, $\zeta$ '.

55 Ledesma, Dottrina christiana (1593) 7: 'M[aestro]. Credete voi nello Spirito santo. D[iscepolo]. Mesersi, che è vero Dio, e la terza persona della Santissima Trinità, il qual procede dal Padre, e dal Figliuolo, e dà la gratia, e I suoi doni alla Santa Chiesa Cattolica.' Cf. Castagnola, Chris-

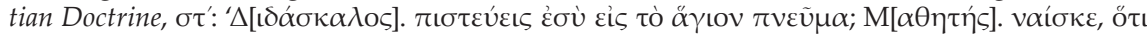

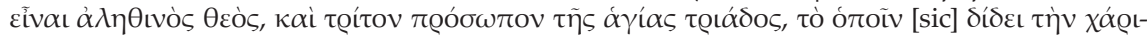

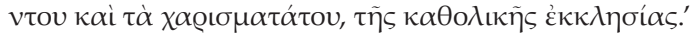

56 Castagnola, Christian Doctrine, $\kappa \delta^{\prime}$; cf. Ledesma, Dottrina christiana (1593) 20. The Greek Orthodox term 'communion' represents, undividedly, the body (i.e. the Catholic 'Hostia') and the blood (i.e. what is contained in the 'Calice') of Christ.

57 Even when Ledesma's text was explicit: 'la santa Chiesa Catolica Romana.' Ledesma, Dottrina christiana (1589) 5.

58 Castagnola, Christian Doctrine, $\gamma^{\prime}$, see also $\zeta^{\prime}$; cf. Ledesma, Dottrina christiana (1593) 4, 7.

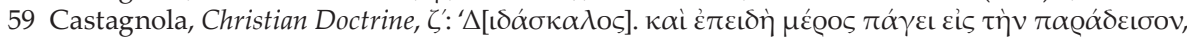

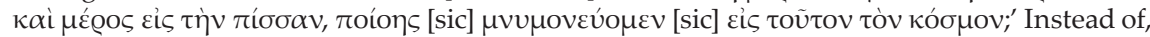
Ledesma, Dottrina christiana (1593) 8: 'M[aestro]. Chi và alle pene del Purgatorio?'.

60 Castagnola, Christian Doctrine, $\zeta^{\prime}-\eta \eta^{\prime} ;$ Ledesma, Dottrina christiana (1593) 8. Cf. the relevant

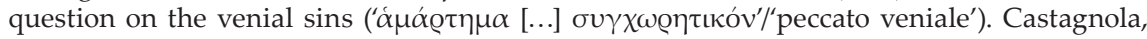
Christian Doctrine, $\kappa^{\prime}-\kappa \alpha^{\prime}$; Ledesma, Dottrina christiana (1593) 17. As regards this Catholic doctrine, see the typical labelling of seventeenth century as 'Le siècle du purgatoire' in the relevant chapter entitled 'Entre le ciel et l'enfer' of M. Vovelle, La Mort et l'Occident de 1300 à nos jours, 2nd edn (Paris 2000) 302-14, here p. 308.

61 On the increasing importance of the Confession and Penitence-and, consequently, of the systematization of the sins-in post-Tridentine Catholic Church, see J. Bossy, 'Moral Arithmetic: Seven Sins into Ten Commandments', in E. Leites (ed.), Conscience and Casuistry in Early Modern Europe (Cambridge 1988) 214-34; W. de Boer, The Conquest of the Soul. Confession, Discipline, and Public Order in Counter-Reformation Milan (Leiden-Boston-Köln 2001); W. de Boer, 'At Heresy's Door: Borromeo, Penance, and Confessional Boundaries in Early Modern Europe', in A. Firey (ed.), A New History of Penance (Leiden-Boston 2008) 343-75; W. D. Myers, 
is translated in full by Castagnola apart from the so-called 'peccata clamantia' (the very serious mortal 'sins that cry to Heaven for Vengeance'/'sins that cry out'). ${ }^{62}$ Lastly, secondary aspects of the Catholic devotional practice have either been Hellenized, as regards the various Catholic surnames of the Holy Mary, which have been replaced by Greek ones, ${ }^{63}$ or simply omitted, like the appropriate fasting days of the week. ${ }^{64}$ Nevertheless, the Catholic doctrinal core of post-Tridentine Jesuit Dottrina christiana by Ledesma remains intact and explicit in its vernacular Greek translation by Vincenzo Castagnola.

As evidenced by the missionary activity of Catholic missionaries (Jesuits and Capuchins, mainly) in the Aegean Sea and the Ottoman Empire during the late sixteenth and seventeenth century, catechisms in the Greek vernacular had multiple functions and a variety of recipients. ${ }^{65}$ First of all, they were the main texts for the pastoral activity of the missionaries among the native Roman Catholic people, ${ }^{66}$ who only speak Greek. ${ }^{67}$ Moreover, these catechisms were used as textbooks in the missionary schools, representing a central part of their educational program. ${ }^{68}$

"Poor, Sinning Folk". Confession and Conscience in Counter-Reformation Germany (Ithaca-London 1996) 107ff.; W. D. Myers, 'From Confession to Reconciliation and Back: Sacramental Penance', in R. F. Bulman and F. J. Parrella (eds), From Trent to Vatican II: Historical and Theological Investigations (Oxford-New York 2006) 241-66, here p. 241-56; cf. P. W. Carey, Confession: Catholics, Repentance, and Forgiveness in America (Oxford-New York 2018) 11-28.

62 The omitted text: 'Li peccati che dimandano vendetta da Dio. Sono quattro. Il primo. Homicidio voluntario. Il secondo. Il nefando peccato di sodomia. Il terzo. La oppressione de poveri. Il quarto. Il defraudar gl'operari della mercede.' Ledesma, Dottrina christiana (1593) 23; cf. Castagnola, Christian Doctrine, $\kappa \eta^{\prime}$. It is worth noting the strongly social dimension of these sins that refer directly to the social and economic relations of the faithful. See, K. Golser, 'Soziale Sünden, die zum Himmel schreien. Eine vergessene, aber anscheinend jetzt wieder aktuelle Kategorie', in A. Bondolfi and H. J. Münk (eds), Theologische Ethik heute. Antworten für eine humane Zukunft-Hans Halter zum 60. Geburtstag (Zürich 1999) 173-88.]

63 Castagnola, Christian Doctrine, เ $\alpha$; Ledesma, Dottrina christiana (1593) 11.

64 Fridays and Saturdays for the Catholics of the catechism, instead of Wednesdays and Fridays for the Orthodox. Ledesma, Dottrina christiana (1593) 16; cf. Castagnola, Christian Doctrine, i $\eta$ '.

65 For a general introduction to the topic, through the lens of the Francochiotic books, see

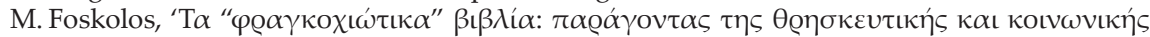

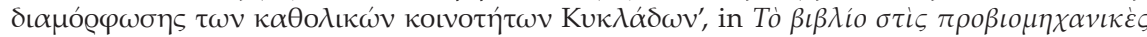

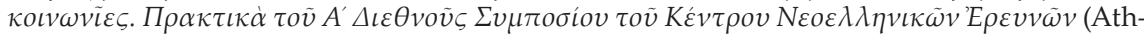
ens 1982) 209-35.

66 The Catholic missions in the Greek-speaking regions primarily settled next to pre-existing Catholic communities, like Chios or in Galata at Constantinople. N. Papaïliaki, 'Des schismatiques et des orthodoxes: action missionnaire française et unité de l'Église en Grèce aux XVIIe et XVIIIe siècles', in M.-H. Blanchet and Fr. Gabriel (eds), Réduire le Schisme ? Ecclésiologies et Politiques de l'Union entre Orient et Occident (XIIIe-XVIIIe siècle) (Paris 2013) 303-12, here p. 307.

67 Apart from the Catholic populations of the Aegean Islands, even the descendants of the Genovese of Galata, the so-called Perot community, used Greek as the everyday language by the seventeenth century. E. R. Dursteler, Venetians in Constantinople. Nation, Identity, and Coexistence in the Early Modern Mediterranean (Baltimore 2006) 141-3.

68 C. Casalini, 'Rise, Character, and Development of Jesuit Education: Teaching the World', in I. G. Županov (ed.), The Oxford Handbook of the Jesuits (Oxford-New York 2019) 153-76, here 
However, the composition of the student population in these schools was mixed: next to the Roman Catholic pupils there were Greek Orthodox, Jews or Armenians, depending on the location of each school. ${ }^{69}$ The case of the newly established (at the end of 1592) Jesuit school at Chios is emblematic. It was aimed at the large Roman Catholic population of Chios but also at the Greek Orthodox majority of the island; ${ }^{70}$ in fact, its popularity among the latter proved particularly high from the very beginning. In 1597, almost half of its two hundred students were Greek Orthodox. ${ }^{71}$

Although the implemented educational program was perceived or presented by the Jesuits as an act of charity and pastoral care for the Catholic congregation, ${ }^{72}$ it actually provided an opportunity to proselytize young Orthodox students, too. In this process the role of catechisms would be introductory but crucial, as in any attempt at proselytization among the Orthodox denomination. ${ }^{73}$ Moreover, catechizing and proselytizing, rather than educating, were the primary goals of the Society of Jesus. In this sense, catechisms represented a very important kind of doctrinal textbooks for the Jesuit missions, since they combined pastoral, instructive and proselytizing functions. The great emphasis put on the catechesis by the Jesuits explains the numerous catechisms, brief or extensive, produced by members of the Society for a wide range of readers (children, students or adults, lay people, or clerics). The variety of the Jesuit catechisms reflects both the personal approach of the writer to the Catholic doctrines and the various local catechetical traditions and particularities. ${ }^{74}$ Thus, the Dottrina christiana breve by Diego de Ledesma (1571) was based on Italian catechetical traditions and, despite its naïve character aiming at children, ${ }^{75}$ dominated in the Italian missions of the Society

p. 154; N. Papaïliaki-Gamelon, 'Livres de catéchismes et pratiques scolaires des missionnaires français en Grèce au XVIIe siècle', in H. Didier and M. Larcher (eds), Pédagogies missionnaires: traduire, transmettre, transculturer. 32e Colloque du CRÉDIC. Lisbonne 30 août-3 septembre 2011 (Paris 2012) 137-46.

69 E.g. see the case of the Jesuit school at Galata. E. Dursteler, 'Education and Identity in Constantinople's Latin Rite community, c. 1600', Renaissance Studies 18/2 (2004) 287-303, here p. 297-8; P. Shore, 'Jesuits in the Orthodox World', in I. G. Županov (ed.), The Oxford Handbook of the Jesuits (Oxford-New York 2019) 318-48, here p. 322-3. Cf. Papaïliaki-Gamelon, 'Livres de catéchismes et pratiques scolaires', 137-46.

70 Cf. Ph. P. Argenti, The Religious Minorities of Chios: Jews and Roman Catholics (Cambridge 1970).

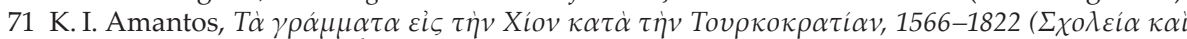

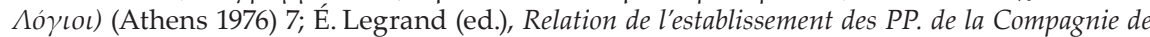
Jésus en Levant (Paris 1869) 9-12.

72 For a good introduction in the vast literature regarding the multilevel relationship between Jesuits and education, see Casalini, 'Teaching the World', 153-76; P. F. Grendler, 'Jesuit Schools in Europe. A Historiographical Essay', Journal of Jesuit Studies 1 (2014) 7-25.

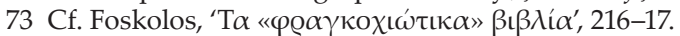

74 Th. Worcester, 'Catechism', in Th. Worcester et al. (eds), The Cambridge Encyclopedia of the Jesuits (New York 2017) 145-6; Grendler, 'Jesuit Schools in Europe', 20-1; Casalini, 'Teaching the World', 154-5.

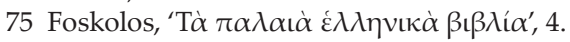


until 1597, when a new Dottrina cristiana breve, written by the Jesuit and Cardinal Roberto Bellarmino, became the main Jesuit catechism. ${ }^{76}$

In such a framework, the translation of Ledesma's Dottrina christiana by Castagnola could not be accidental. On the contrary, it was part of the broader endeavor of Rome and the Society of Jesus to send missionaries to the Greek-speaking Aegean islands and the Ottoman lands. ${ }^{77}$ In particular, during the last two decades of the sixteenth century a confluence of relevant facts can be observed: after the first, ill-fated, Jesuit mission in Constantinople-Galata (1583-1586), the Society took over the direction of the Greek College of Saint Athanasius at Rome in 1591,78 while exactly the next year the Jesuit missionaries sailed to Chios island. There, in 1592, both the first Jesuit residence and the first Jesuit school in the Levant were established..$^{79}$ Consequently, the initiative of Vincenzo Castagnola, a Jesuit, native Roman Catholic from Chios, to translate Ledesma's catechism in vernacular Greek and to publish it in Greek and Francochiotic fonts ${ }^{80}$ in Rome in 1595 was closely related with the Jesuit mission of 1592 and the operation of its school at Chios. ${ }^{81}$

In fact, Castagnola was the leader of that first Jesuit mission at Chios. ${ }^{82} \mathrm{He}$ arrived there, together with the Jesuit F. Simone Bucceri, on 18 September 1592 and in a short time they managed to settle in a small church, called 'Madonna del Trave',

76 Worcester, 'Catechism', 145-6; Grendler, 'Jesuit Schools in Europe', 21.

77 For an overview, see J. Donohue, 'Middle East', in Th. Worcester et al. (eds), The Cambridge Encyclopedia of the Jesuits (New York 2017) 520-1; C. Capizzi, 'Grecia', in Ch. E. O'Neill and J. M. Domínguez (eds), Diccionario Histórico de la Compañía de Jesús. Biográfico-Temático, II. Costa Rossetti-Industrias (Rome-Madrid 2001) 1809-11. For a general historiographical approach, see R. J. Clines, 'The Society of Jesus and the Early Modern Christian Orient', in Jesuit Historiography Online (2016), http://dx.doi.org/10.1163/2468-7723_jho_COM_192582.

78 J. Krajcar, 'The Greek College under the Jesuits for the First Time (1591-1604)', Orientalia

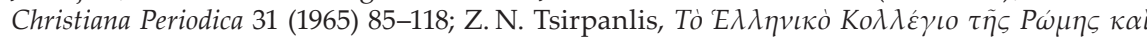

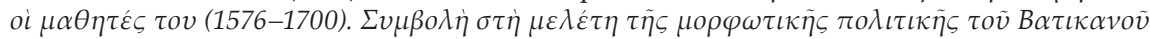
(Thessaloniki 1980) 39-40, 70-4.

79 Capizzi, 'Grecia', 1809. Though, in 1583, the Jesuits had already founded a small school in Galata, it vanished, together with the entire Jesuit mission, in 1586 under the outbreak of a plague epidemic in Constantinople. V. Ruggieri, 'Constantinopoli vista da P. Giulo Mancinelli S. J. (1583-1585)', Revue des études byzantines 60 (2002) 113-31, here p. 113-17; Dursteler, 'Constantinople's Latin Rite community', 295-6; Ch. A. Frazee, Catholics and Sultans. The church and the Ottoman Empire, 1453-1923 (New York 1983) 73-4.

80 It is also noteworthy that the Christian Doctrine by Castagnola is the first known Francochiotic book. Foskolos, 'T $\alpha \ll \varphi \rho \alpha \gamma \kappa о \chi \iota \omega ́ \tau \iota \kappa \alpha » \beta \iota \beta \lambda i ́ \alpha$ ', 210.

81 The hypothesis linking this translation to the presence of Jesuits in Istanbul and the function of their school at Galata is not convincing enough. Papaïliaki-Gamelon, 'Livres de catéchismes et pratiques scolaires', 138. As has been noted above, the first mission at Constantinople in 1583 was short-lived, whereas the Jesuits returned there only in 1609. Dursteler, 'Constantinople's Latin Rite community', 296-7; Dursteler, Venetians in Constantinople, 146; A. Ruiu, 'Conflicting Visions of the Jesuit Missions to the Ottoman Empire, 1609-1628', Journal of Jesuit Studies 1 (2014) 260-80, especially p. 260-7.

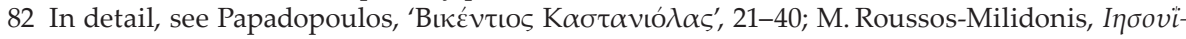

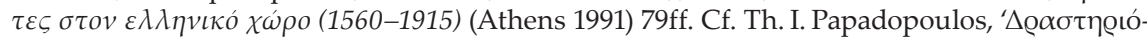

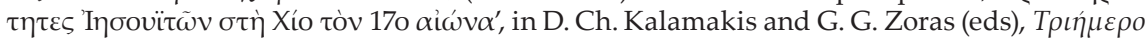


by the agency of the Catholic community of the island and their Bishop, Benedetto Garetto. The two Jesuits immediately started preaching, performing liturgies and hearing confessions, while they catechized their folk. According to Castagnola's correspondence with Claudio Acquaviva, the Superior General of the Society of Jesus in Rome, in early November 1592, they already operated a small school for Catholic pupils and they envisaged a Jesuit college that would gather students from all over the Aegean islands, both Catholics and Orthodox; its ultimate aim would be to prepare the best of them in order to be sent to the Collegio Romano and become members of the Society of Jesus. ${ }^{83}$

On the other hand, the pastoral ministry of the Catholic denomination of the island, being one of the main concerns of post-Tridentine Roman Church, also had absolute priority for the missionaries of the Society of Jesus. Days after his arrival at Chios, in his first letter-report, Castagnola describes the situation of the Catholic flock in the island in dramatic terms: 'Quindi è gran caristia di cose spirituale. Sono qui da $10{ }^{\mathrm{m}}$ cattolici, siccome mi ha detto il vescovo. Sono vessati da Greci e da Turchi e da Iudei et anco alcuni luterani occulti, cosi Francesi come Inglesi. Hanno di bisogno di grande aiuto. ${ }^{84}$ Both catechesis and confession were the first things that the two Jesuits would try: 'Io frattanto non starò in oc[ch]io; insegnerò la dottrina $X^{\text {ana }}$ [Christiana] a tutti e confesserò quanto abbastano le mie forze. ${ }^{85}$ Furthermore, the small church given to them would facilitate their pastoral ministry, ${ }^{86}$ which intertwined with the primary education they offered:

Questi gentil huomini [of the Catholic community] hanno astretto che insegnassimo alli suoi figliuoli qualche poco di lettere et insieme la dottrina christiana, virtù e confessarli; e sono soccursi tanti alla dotrrina christiana, parendo a tutti il nostro modo d'insegnare tanto buono che venghono grandi e piccoli e stanno fuori di chiesa, per non poter capire tutti. ${ }^{87}$

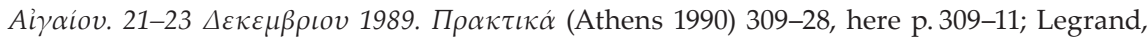
Bibliographie hellénique au XVe et XVI siècles, II, 226.

83 Later, Castagnola resiled from the plan for a Jesuit college at Chios. Papadopoulos, 'Bıкévtıos

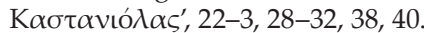

$84 \mathrm{Ibid.,} 27$ (letter of 21..09.1592): 'So it is a great deal of spiritual things. I am here for 10,000 Catholics, as the bishop told me. They are harassed by Greeks and Turks and Jews and by some crypto-Lutherans, both French and English. They need great help.'

85 Ibid., 27 (letter of 21.09.1592): 'In the meantime, I will keep a low profile; I will teach the Christian doctrine to everyone and I will confess as much as I can.'

86 Ibid., 29 (letter of 02.10.1592): 'li exercitar li nostri exercitii, insegnar la dottrina christiana, confessar e comunicare e in tanto hebbi risolutione di costà.' ['to carry out our exercises, to teach the Christian doctrine, to confess and give the Communion and in the meantime to have resolutions from there.'] Cf. ibid., 31 (letter of 17.11.1592).

87 Ibid., 32 (letter of 17.11.1592): 'These gentlemen have arranged for us to teach their children a few letters and at the same time the Christian doctrine, the virtues, and to confess them; and so many have come to listen of the Christian doctrine, our way of teaching appearing so good to everyone that they come, adults and children, and stand outside the church, because it cannot accommodate everybody.' Cf. ibid., 38 (undated report, presumably of 1593). 
Hence, the core of the Jesuit exercises, as described in these letters, was the catechizing, while the quick success of Castagnola's mission at Chios was presented inextricably linked with 'il nostro modo' to teach the Christian doctrine; and this 'modo' referred principally to the use of the spoken language.

In this context, on 17 November 1592, Castagnola informs the Superior General:

Habbiamo traslatato la Dottrina Christiana in greco vulgare, poichè quà non intendeno ne italiano ne greco, latino, essendo quasi persa la disciplina della lingua greca affatto. La recitamo ogni festa alla nostra chiesotta e li pare tanto buono il nostro modo, per non haver giammai inteso la sustansa della nostra fede che già non intesero mai. E grandi e piccolo vengon, e Greci ancora; di modo la vanno copiando li figlioli e mastri per impararla et insegnarla. Le altre Dottrine che sono stampate questi anni passati non servono, perchè non l'intendeno. Non posso exarare a V. P. $^{\text {tà }}$ [Vostra Paternità] il gran frutto che si farà havendo dui migliaia di queste Dottrine stampate.

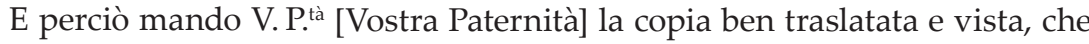
ad ogni modo, per l'amor de Dio, la faccia stampare con caratteri greci e latini; e mandarmi da due millia, cioè mille greche e mille latine, perchè aprirà li occhi a tanti christiani ciecchi, che mai hanno saputo cosa sia legge di Christo; et è tanta necessaria per aiuto de queste anime e servitio di Dio, come una tavola ad uno che si annega in mare. ${ }^{88}$

This is a statement that perfectly reflects both the multiple uses and recipients of a catechetical textbook, as well as the principal reason for its translation.

Having realized that the Catholics of Chios spoke neither ancient Greek, nor Latin, nor even Italian anymore, Castagnola and, presumably, Bucceri decided to render the homonymous Dottrina Christiana by Diego de Ledesma into vernacular Greek. Their initiative turned out to be successful, as their congregation increased remarkably including, in addition to Catholics, Orthodox too ('e Greci ancora'). ${ }^{89}$

88 Ibid., 32-3 (letter of 17.11.1592): 'We have translated the Christian Doctrine into vulgar Greek, because here they know neither Italian nor Greek, Latin, having almost completely lost the discipline of the Greek language. We recite it every feast at our church and our way [of catechism] seems so good to them, because they hardly ever understood the substance of our faith that they never heard. Both adults and children are coming, and even Greeks; the children and the teachers are copying the way [of catechism], in order to learn and teach it. The other Doctrines that have been printed these past years are of no use, because they do not understand them. I cannot express to Your Paternity the great good that will be made with thousands of these printed Doctrines. And therefore I send to Your Paternity the copy well translated and read, that in any case, for the love of God, have it printed with Greek and Latin characters; and send me two thousand, that is one thousand in Greek and one thousand in Latin, because it will open the eyes of so many Christian blind people, who never knew what the law of Christ is; and it is as necessary for the help of these souls and servants of God as a wooden plank for one who is drowning at sea.'

89 With regard to the use of term 'Greci' to identify the Orthodox denomination, cf. the respective discussion about the French term 'grec' in Papaïliaki, 'Des schismatiques et des orthodoxes', 304-6. 
Moreover, their translation was broadly copied for instruction purposes. Consequently, the catechism they had translated proved to be suitable for performing the multiple goals such a doctrinal textbook should achieve: it was a perfect pastoral manual for the Greek-speaking Catholic community of Chios; it could be used by teachers and pupils in the educational realm; lastly, through its accessible vernacular form, it could also be used to reach out to the Orthodox denomination, paving the way for its possible conversion. ${ }^{90}$

Compared to the Christian Doctrine by Castagnola, the older printed catechisms had come to nothing primarily because they were written in a language unintelligible to the Greek-speaking populations. ${ }^{91}$ On account of this, the Jesuit missionaries at Chios proposed to the Superior General of the Society of Jesus the publication of their translation. The suggestion of Castagnola was a double edition (one book in Greek font and the other in Latin font) of which two thousand copies, accordingly, would be sent as soon as possible to the Jesuit missionaries at Chios. The first mention of the proposal, along with a readable copy of the translation, had been made in the letter of 17 November $1592^{92}$ and Castagnola returned one month later. ${ }^{33}$ Some weeks thereafter, together with a letter dated 26 December 1592, he sent another copy of his translation, since he was in doubt about the fate of the first one. ${ }^{94}$ Eventually, it seems that both copies arrived in Rome in 1593, together with the corresponding letters. ${ }^{95}$

90 Proposing the printing of his Christian Doctrine, Castagnola concludes that his translation

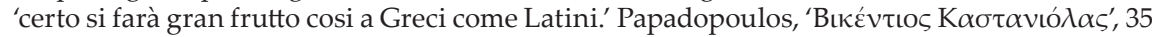
(letter of 26.12.1592). Notwithstanding Thomas Papadopoulos' assessment to the contrary (Pa-

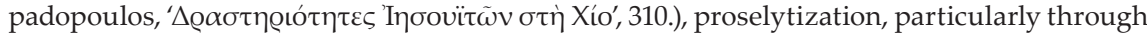
schooling, always remained in the scope of the Jesuit missionary. See, e.g., Castagnola's aspiration concerning the attendance of Orthodox, too, at a prospective Jesuit college and, later

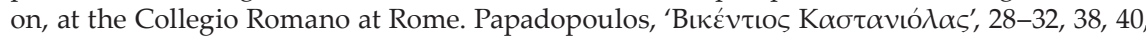
especially p. 29-30 (letter of 02.10.1592): 'Sarebbeno necessarii quà, per hora, dui padri, mastri boni, cosi in greco come sino al humanità et oltre, e dui fratelli coaiutori, che fossero specchi di virtù a tutta questa isola e più oltre, perchè verrebbeno da le altre isole a imparar; maxime li preti e li Greci ancora manderanno li suoi figli alle nostre scole; delli quali figli si potranno mandar al Seminario di costà li piu scielti e di bono ingegno.' In English translation: 'It would be necessary here to have, for now, two fathers, good teachers both in Greek and in the Humanities and beyond, and two assistant-brothers, who would be mirrors of virtue to all this island and beyond, because they would come from the other islands to learn; at the most, priests and even the Greeks will send their sons to our schools, of which sons we can send to the seminary from there the best qualified and of good intelligence.'

91 The identification of the doctrinal manuals he refers to is difficult. It is likely that they were in Latin or Italian.

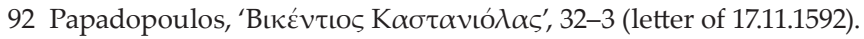

93 Ibid., 34-5 (letter of 13.12.1592).

94 Ibid., 35 (letter of 26.12.1592): 'Mando con questa una copia della Dottrina Christiana, traslata in greco vulgar e già credo l'altre gli siano capitate; ma per dubbio non siano pervenute, mando anco questa copia, acciò V. P. tà [Vostra Paternità], per l'amor de Dio, la faccia stampar presto e mandi un quantità, che certo si farà gran frutto cosi a Greci come Latini.'

95 These letters are now stored in the Archivium Societatis Jesu. Ibid., 18-21, 25, 31-33, 35-6. 
Although the time of the return of Castagnola to Rome cannot be estimated precisely, since his final report is undated,${ }^{96}$ he arrived in all probability between late $1593^{97}$ and early 1594 . Despite the fact that the final report on his first mission at Chios made no mention at all of his editorial proposal, the relevant imprimatur for the translation by the Society of Jesus is documented on 10 May 1594: 'reuista da tre Padri nostri che sono di natione Greca, e huomini sufficient, i quali dicono esser voltata fedelmente. In Roma 10. Maggio 1594. ${ }^{\prime 98}$ Arguably, in mid-1594, the translation of the Dottrina Christiana by Ledesma, rendered into vernacular Greek by Castagnola with the contribution of Bucceri during the first Jesuit mission at Chios, had been checked by a third Jesuit 'di natione Greca' at Rome and was approved to be sent for printing. When the translation was published in 1595 in Rome, however, only the name of Vincenzo Castagnola appeared on the title-page. ${ }^{99}$ Moreover, it was issued in a single edition printed in Greek and Francochiotic fonts per page, ${ }^{100}$ instead of two separate editions that Castagnola had suggested.

Clearly, a mission to foreign lands needed translations and the Jesuits were fully aware of this fact. ${ }^{101}$ In fact, the Christian Doctrine by Castagnola, representing the very first translation of a Catholic catechism into vernacular Greek, ${ }^{102}$ inaugurated the ambitious 'translational policy' of Rome-with the Jesuits as pioneers-towards the Greek-speaking populations of the Levant, Catholic or Orthodox. Nevertheless, in order for this policy to be successful, the translation would have to be both interlingual and intercultural, being the product of a negotiation between the missionary-translator and the cultural, devotional and religious coordinates of the mission's locus. ${ }^{103}$ In this sense, Castagnola (together with Bucceri) primarily took into account the culture and the religiosity of the Chiot Catholics, but also

96 Ibid., 36-40. Papadopoulos follows the old literature and assumes that the first mission of Castagnola at Chios lasted for one year, ending sometime after August of 1593. Ibid., 22.

97 Certainly after the 20 October 1593, when the last answer of Rome to a Castagnola's letter is documented. Ibid., 34.

98 The imprimatur was placed at the end of the edition. See Castagnola, Christian Doctrine (1595).

99 For the sake of brevity, I men tion only the name of Castagnola when referring to this translation, with the exception of a few instances.

100 See above, footnotes 35-37.

101 For the translation activity of the Jesuits in China, see R. Po-Chia Hsia, 'The Catholic mission and translations in China, 1583-1700', in P. Burke and R. Po-Chia Hsia (eds), Cultural Translation in Early Modern Europe (New York 2007) 39-51.

102 The earlier translated catechism by Émond Auger (Toulouse 1582), as well as the contemporary one by Peter Canisius (Ingolstadt 1595), were addressed to European students of Ancient Greek, since they were written in refined Attic Greek. See above, footnote 11. Cf. Sfoi-

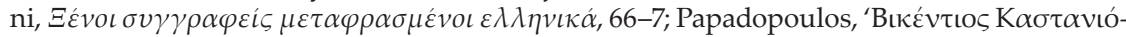
$\lambda \alpha \varsigma^{\prime}, 19 ;$ Papailiaki-Gamelon, 'Livres de catéchismes et pratiques scolaires', 138. Regarding the definition of that language form, see J. Bouchard, 'Refined Attic Greek: Hallmark of the Emerging Phanariot Nobility', in R. Vidu and A. Mindicanu (eds), Proceedings of the 40th Annual Congress of the American Romanian Academy of Arts and Sciences, July 28-31, Montreal, Canada (California 2016) 11-17.

103 P. Burke, 'Cultures of translation in early modern Europe', in P. Burke and R. Po-Chia Hsia 
the religious susceptibilities of the Orthodox denomination, attempting to adapt an Italian Jesuit catechism to the realities and the necessities of the multiconfessional society of an Aegean island like Chios. ${ }^{104}$ The outcome of this negotiation is a translation that avoids some sensitive topics in the debate between Western and Eastern Church (papal primacy, Filioque), obscures others (Communion, Purgatory) or adapts to the local devotional practices and cults (the Virgin Mary). Consequently, its dissimilarities from Ledesma's text, as well as Castagnola's selectivity, can be fully explained in terms of cultural translation and accommodation with the Greek-speaking recipients (readership or audience). ${ }^{105}$

Still, Castagnola's Christian Doctrine remains an unambiguously Catholic catechetical book. From the very first page, the instructions concerning the sign of the cross are distinctly Roman ${ }^{106}$ as is the description of Purgatory (though it is unnamed). ${ }^{107}$ Additionally, the Greek text maintains the financial obligation of the Catholic congregation as regards the episcopal or parish tithe ('decime'), ${ }^{108}$ though the latter had never been established in the Eastern Church. ${ }^{109}$ It also goes without saying that the concluding prayer and the hymns of praise to the Virgin Mary are Catholic; the former is an occasional post-Communion prayer and the Marian hymns are the 'Ave Maria' and 'Salve Regina'.110 Moreover, the whole structure of

(eds), Cultural Translation in Early Modern Europe (New York 2007) 7-38, especially p. 9-10, 15-17, 29. Cf. Worcester, 'Catechism', 146; Grendler, 'Jesuit Schools in Europe', 21.

104 The several variations of Ledesma's editions themselves actually helped Castagnola to adjust his text accordingly by selecting the appropriate excerpt among different versions of the original. It is, moreover, interesting that some limited form of accommodation is also observed in the reissues of Catagnola's translation. E.g. see Castagnola, Christian Doctrine (1595) 14; cf. Castagnola, Christian Doctrine (1609) $\zeta$ '.

105 Another interesting dimension of this negotiation, namely the simplification, has been noticed by Niki Papaïliaki on the occasion of composing a Capuchin catechism in vernacular Greek: 'En présence des futurs convertis, le missionnaire doit simplifier le plus possible son enseignement. À ce stade, la mission marque une rupture dans le dialogue théologique entre l'Occident et l'Orient. Les vérités dogmatiques occidentales sont diluées dans des formulations pédagogiques, et la diversité des méthodes mises en place pour l'instruction des fidèles est impressionnante. Derrière cette prétention à la simplification, peuvent se profiler d'autres méthodes d'évangélisation et de conversion.' Papaïliaki, 'Des schismatiques et des orthodoxes', 310-11.

106 Ledesma, Dottrina christiana (1593), 3: 'il segno della S[anta]. Croce, che si fa mettendo la

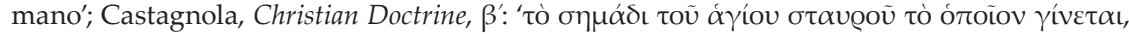

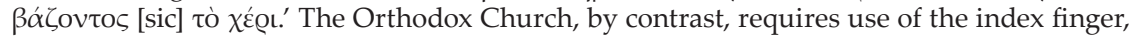
middle finger, and thumb, with this union of the three fingers-digits symbolizing the Trinity.

107 Castagnola, Christian Doctrine, ' '’- $-\eta^{\prime}$.

108 Ibid., ı $\eta$; cf. Ledesma, Dottrina christiana (1593), 16. Paradoxically, from the same section, 'Delli comandamenti della Chiesa', Castagnola has excised the related, devotional duty of the first offerings ('primitie'), which, by contrast, survives in the Orthodox worship.

109 General information about tithing in the Catholic and the Protestant Churches in Anonymous, 'Tithe', in Encyclopaedia Britannica, https://www.britannica.com/topic/tithe; Anonymous, 'tithes', in E. Livingstone (ed.), The Concise Oxford Dictionary of the Christian Church, https://www.oxfordreference.com/view/10.1093/acref/9780199659623.001.0001/acref9780199659623-e-5812.

110 Castagnola, Christian Doctrine, $\iota^{\prime}-1 \beta^{\prime}, \lambda^{\prime}$; cf. Ledesma, Dottrina christiana (1593), 10-11, 24. Be- 
sins and virtues that pervades most of the dialogue is based on the Moral Theology elaborated at the Council of Trent onwards, while the text entitled 'Confession'

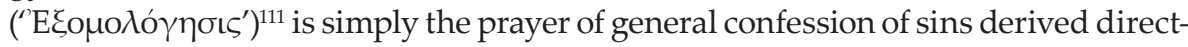
ly from the first part (i.e. for the catechumens) of the Tridentine Rite Mass. ${ }^{112}$ Even the Creed that the catechism contains, ${ }^{113}$ the so-called 'Apostle's Creed', ${ }^{114}$ is distinctively Western and had been explicitly rejected by the Orthodox in the Council of Ferrara-Florence (1438-1439). ${ }^{115}$ However, the point that leaves no doubt about the Catholic character of the book is its title-page. In all its editions the ministry of both the author and the translator is plainly stated, along with the Jesuit emblem in full sight (i.e. the initials of the Society of Jesus, 'IHS', with a cross over ' $\mathrm{H}^{\prime}$ ). ${ }^{116}$

sides, in the first edition this is perfectly clear, since the last two pages contain all these prayers and hymns in Latin. Castagnola, Christian Doctrine (1595) 78-9.

111 Castagnola, Christian Doctrine, $\kappa \gamma^{\prime}-\kappa \delta$. It is the translation of the text 'Confiteor' ('I confess') from Ledesma, Dottrina christiana (1593), 19-20. The Latin original is also issued at the end of the first edition, Castagnola, Christian Doctrine (1595) 79. Cf. Diego de Ledesma, Catecismo, y declaracion breve de la Dottrina Christiana, por preguntas, y respuestas entre Maestro, y Discipulo (Seville 1611) 119-130, especially p. 123.

112 The entry 'Tridentine Mass' in Wikipedia is particularly helpful and detailed: https://en. wikipedia.org/wiki/Tridentine_Mass. See also, J. W. O'Malley, Trent. What Happened at the Council (Cambridge MA-London 2013) 189-95.

113 Castagnola, Christian Doctrine, $\gamma^{\prime}-\delta^{\prime}$; Ledesma, Dottrina christiana (1593), 4-5. This creed is published in Latin, as well, at the end of the first edition. Castagnola, Christian Doctrine (1595) 78.

114 The consensus among scholars is that the 'Symbolum Apostolorum' was formed in France or Spain in the early eighth century. Because of its doctrinally neutral content, it has been widely used in catechisms and liturgical texts of both Catholic Church and many Protestant Churches. H. Bettenson and Ch. Maunder (eds), Documents of the Christian Church, 4th edn (Oxford-New York 2011) 25-6; J. N. D. Kelly, Early Christian Creeds, 3rd edn (London-New York 1972) 368ff. Cf. W. E. Phipps, The Apostles' Creed. The Ongoing Struggle of the Church to Define Its Basic Beliefs (Lewinston-Queenston-Lampeter 2010); Ph. Schaff, The Creeds of Christendom, with a History and Critical Notes, I. The History of Creeds (New York 1877) 14-23; Ph. Schaff, The Creeds of Christendom, with a History and Critical Notes, II. The Greek and Latin Creeds, with Translations (New York 1877) 45-55.

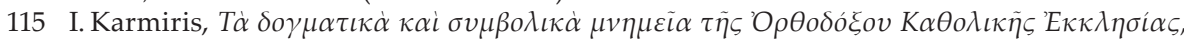
2nd edn, I (Athens 1960) 47-51.

116 See the title-pages of the first (Rome 1595) and the third edition (Venice 1609). Besides, the Jesuit emblem on the title-page is also testified in the record of the edition of 1604 and we can reasonably assume that it appeared in all the editions. Regarding the text of the title-pages see: Edition of Rome, 1595: Legrand, Bibliographie hellénique au XVe et XVI siècles,

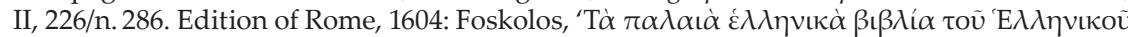

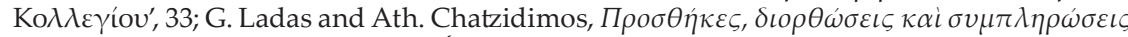

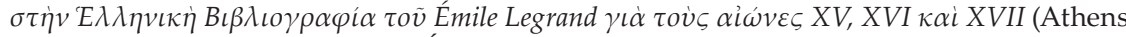
1976) 99. Edition of Venice, 1609: É. Legrand, Bibliographie hellénique ou description raisonnée des ouvrages publiés par des grecs au dix-septième siècle, I (Paris 1894) 62/n. 47. The later editions do not mention the name of the translator. Editions of Paris, 1657 and 1687: É. Legrand, Bibliographie hellénique ou description raisonnée des ouvrages publiés par des grecs au dix-septième siècle, II (Paris 1894) 99/n. 426 and p. 447/n. 615; É. Legrand, Bibliographie hellénique ou description raisonnée des ouvrages publiés par des grecs au dix-septième siècle, V (Paris 1903) 140/n. 211.

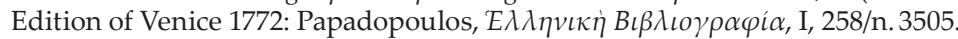




\section{The Christian Doctrine by Michail Mitros}

In stark contrast to the above, the publication at the end of Ioannis Makolas' Justin in $1686,{ }^{117}$ running to eighteen pages (p.365-382), is anonymous, despite the long length of its full title:

Here is also added the Christian Doctrine, in which the Teacher questions, and the Pupil answers. Being most indispensable for every Christian, and especially for the Pedagogues, who ought to teach and educate the children of the Christians what has been written in this, in order to become able from a very young age to enjoy its fruit and to know the orthodox Faith. Christian Doctrine, in which the Teacher questions, and the Pupil answers. ${ }^{118}$

The unique information regarding the possible identity of its author has been appended at the very end of the text: "These [excerpts] have been added to the Christian doctrine, By the Priest Michail Mitros from Ioannina, for the sake of somebody who asked for them. ${ }^{\prime 19}$ There is nothing else to demonstrate the origin or the date of the catechism, the identity of the author, let alone whether it is original or a translation.

Michail Mitros did not in fact simply revise the translation of Castagnola, making some changes and additions; ${ }^{120}$ or, at least, this is not the main issue. Although it is true that Mitros followed almost literally, for the most part, the text of Castagnola, a close reading reveals small but significant discrepancies. First of all, Mitros' version is the outcome of a thorough juxtaposition between an edition of the original Dottrina christiana by Ledesma ${ }^{121}$ and its translation by Castagnola. Specifically, in many cases Mitros improved the language of the text or made its wording clearer, based on the original, ${ }^{122}$ while there is one point where he apparently follows the first edition of Castagnola's translation. ${ }^{123}$ There are also a few differ-

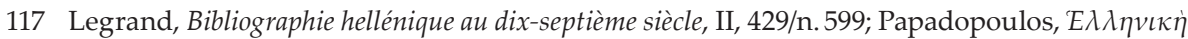

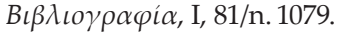

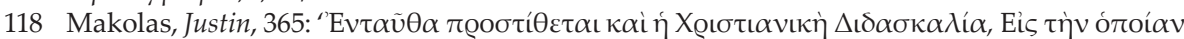

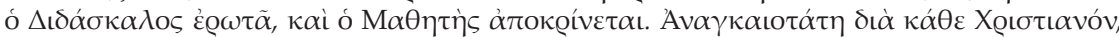

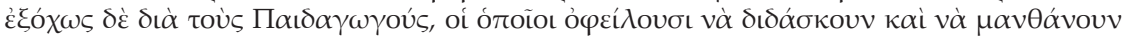

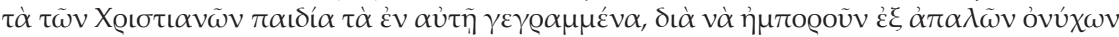

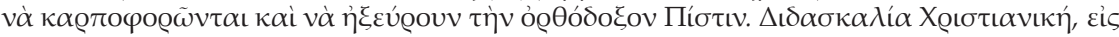

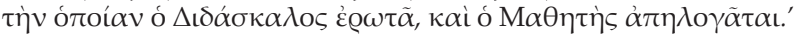

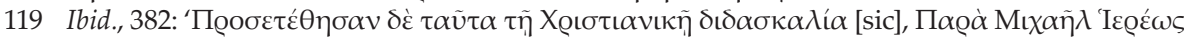

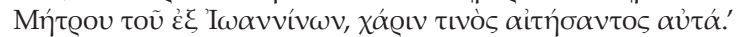

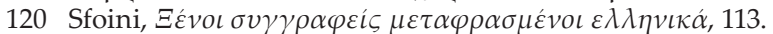

121 It is very difficult to identify the specific edition, as has been explained elsewhere.

122 Nevertheless, in some cases it is Castagnola's wording that looks more suitable than that of Mitros.

123 Ledesma, Dottrina christiana (1593), 6: 'nondimeno è un solo Dio.' Castagnola, Christian Doc-

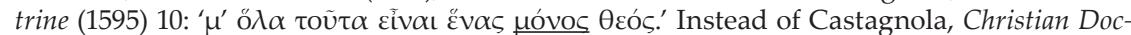

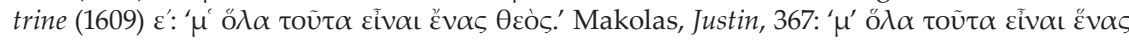
uóvoc $\theta \varepsilon$ có.' It should be noted that a reverse example also exists, but this seems to involve the elimination of a pleonasm. Ledesma, Dottrina christiana (1593), 7: 'E tutta la congregati- 
ences in small passages between Mitros' version and Castagnola's translation, ${ }^{124}$ which are likely due either to the use of a different edition of Ledesma or to a different translation choice.

Yet, apart from these translation discrepancies, two significant doctrinal differentiations can be found in Mitros' version. As mentioned above, in the section of Ledesma entitled 'Espositione d'alcuni articoli principali del Credo' Castagnola had consciously avoided translating the confessionally charged phrase on the Holy Spirit: 'il qual procede dal Padre, e dal Figliuolo.' ${ }^{125}$ But Mitro s was not content with that; he went one step further. Not only did he adapt the 'cultural translation' (or, rather, 'cultural silence') of Castagnola as regards the Filioque, ${ }^{126}$ but he also added the adversarial Orthodox doctrine (verbatim from the Nicene Creed) in the relevant point of the Apostles' Creed, a few pages before. ${ }^{127}$ Moreover, Mitros tried to hide the Western origin

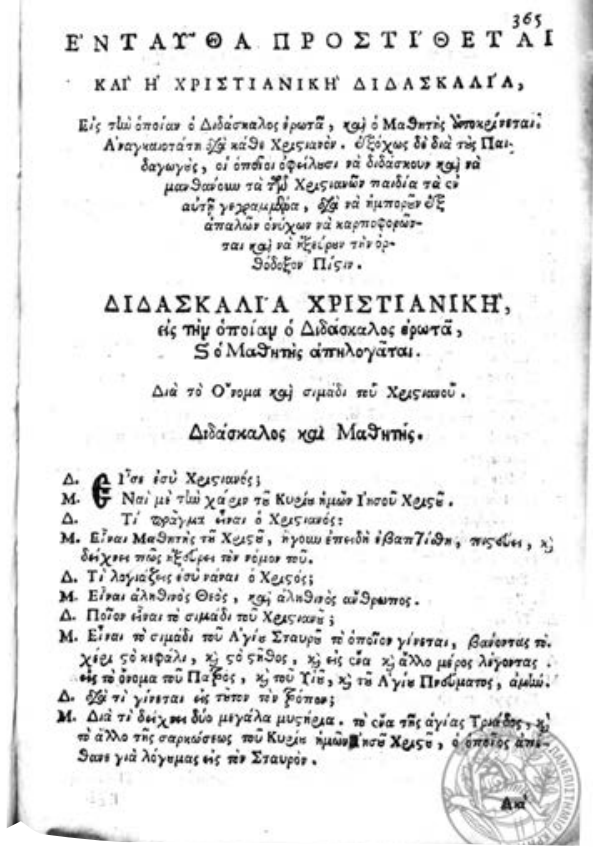

Fig. 6: The first page of Michail Mitros, Christian Doctrine (Venice 1686) (Anemi, Digital

Library of Modern Greek Studies) of this Apostles' Creed, since it had been rejected by the Orthodox. ${ }^{128}$ To do so, he adjusted some of its points to align with the Nicene Creed-the authoritative one for the Eastern Church. Specifically, he added both the adjective 'Apostolic' regarding the Church and the mention

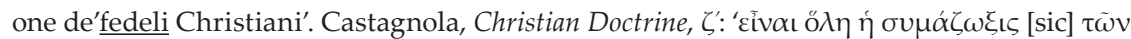

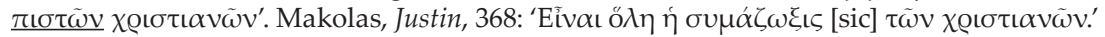

124 E.g. Ledesma, Dottrina christiana (1593), 4: 'e poi vederlo, e goderlo nell'altra.' Castagnola,

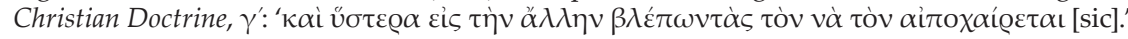

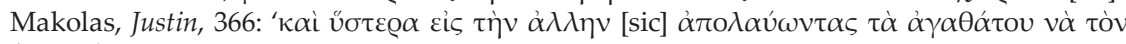

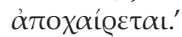

125 Ledesma, Dottrina christiana (1593) 7; cf. Castagnola, Christian Doctrine, $\sigma \tau^{\prime}$.

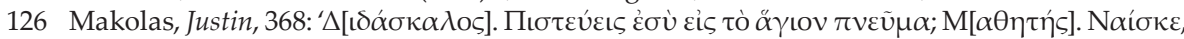

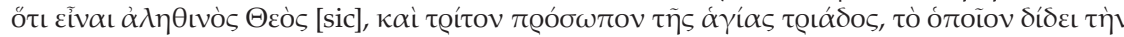

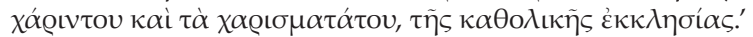

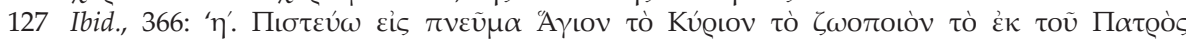

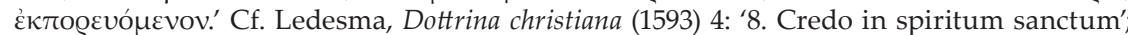

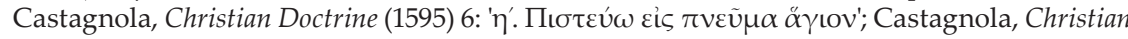

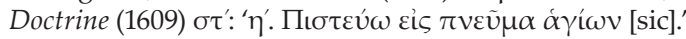

128 See above, page 151. 
of the Baptism concerning the Absolution. Moreover, he omitted the non-Nicene point on 'the communion of the saints.'.129

Similarly, Mitros attempted to further obscure the passage dealing with Purgatory, being aware that the translation by Castagnola, although it had removed the doctrinal term itself, ${ }^{130}$ had kept intact the description of that Catholic dogma. In particular, Castagnola had translated verbatim the relevant answer of the pupil from Ledesma's catechism:

T[eacher]. And because one part goes to heaven and one part to the boiling tar [of Hell], whom do we commemorate in this world?

P[upil]. Those who die in the grace of God, without having time to complete the penance for their sins, and after having paid for what they owed they go to Paradise. ${ }^{131}$

Notwithstanding the fact that Castagnola incorporated into the teacher's question the devotional practice of remembrance (which was approved by the corresponding Orthodox teaching), the content of the pupil's answer continued to reflect distinctively the Purgatory: 'and after having paid for what they owed they go to Paradise.' On account of this, Mitros decided to replace the aforementioned phrase modifying the meaning of the passage:

T[eacher]. And because one part goes to heaven and one part to tar, whom do we commemorate in this world?

P[upil]. Those who die in the grace of God, without having time to complete the penance for their sins, and we pray to Him to absolve them and to bring them to Paradise. ${ }^{132}$

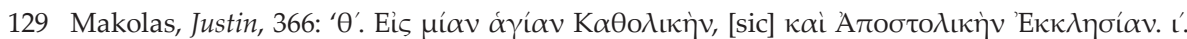

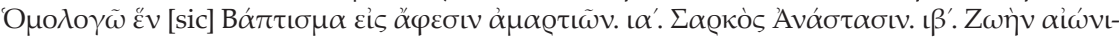

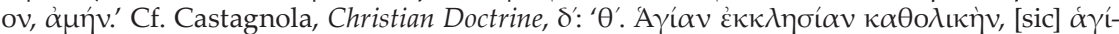

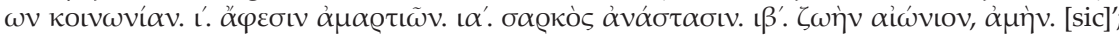
Ledesma, Dottrina christiana (1593), 4: '8. Credo in spiritum sanctum, Sanctam Ecclesiam Catholicam. 9. Sanctorum Communionem. 10. Remissionem peccatorum. 11. Carnis Resurrectionem. 12. Vitam aeternam. Amen Giesu.'

130 See above, page 142.

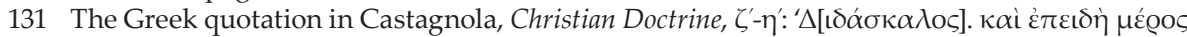

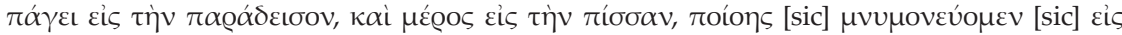

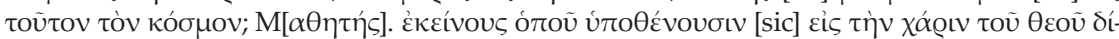

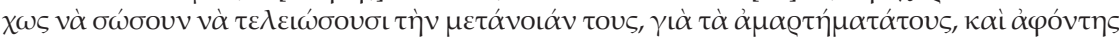

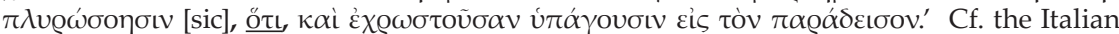
original in Ledesma, Dottrina christiana (1593) 8: 'M[aestro]. Chi và alle pene del Purgatorio? $\mathrm{D}$ [iscepolo]. L'anime di quelli che moiono in gratia di Dio, e non hanno fodisfatto del tutto per i lor peccati, e dopò d' hauer pagato le pene debite, andaranno in Paradiso, cosi sia.'

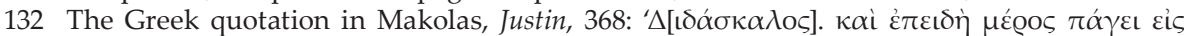

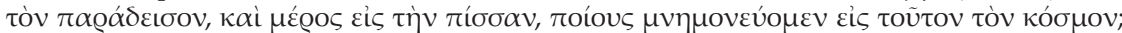

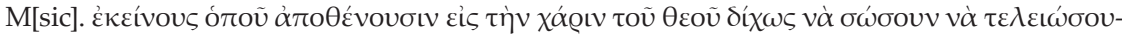

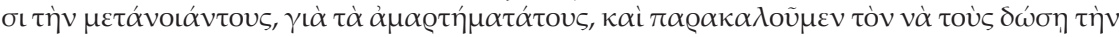

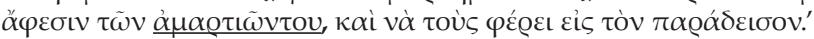


In this form, the passage seems to move closer to the respective Orthodox teaching and devotional practice, as regards the remembrance of the dead congregants and their absolution exclusively by divine grace. ${ }^{133}$

Michail Mitros' intervention at the end of the catechism is also significant. He chose not to publish the last antiphon, regarding the 'Ave Maria', as well as the occasional post-Communion prayer with which the Christian Doctrine by Castagnola ended. ${ }^{134}$ Instead, he replaced the latter with a very short Orthodox prayer ${ }^{135}$ and then appended an extensive passage running to almost three pages under the heading 'On the Holy Scripture', which concluded the catechism and the whole book. ${ }^{136}$ This is in fact the only text explicitly ascribed to 'the Priest Michail Mitros from Ioannina'. ${ }^{137}$

Yet, the authorial ascription is not the only particularity of this passage. Despite the fact that it has also the form of questions and answers, like the rest of Christian Doctrine, it could hardly be considered an elementary catechetical text as well. Its language is obviously more elegant and sophisticated compared to the vernacular Greek a few lines above, ${ }^{138}$ matching the advanced theological knowledge it contains. Indeed, this passage could be described as an introduction to Biblical Studies ${ }^{139}$ and, especially, to Hermeneutics. ${ }^{140}$ Although a small number of such mentions can also be found in Voulgaris' catechism issued in the same years in Venice, ${ }^{141}$ the two texts have no further similarities generally speaking. Furthermore, the topic of the Biblical Interpretation as such is absent from the remaining Catholic catechisms that had been published in Greek during the seventeenth and eighteenth centuries-even though they were extensive and detailed. Clearly, the passage 'On the Holy Scripture' that Michail Mitros added at the end of his version of Ledesma's catechism did not derive from a catechetical text.

Indeed, it comes from a polemical work entitled Manuale controversiarum huius temporis (Würzburg 1623) and was written by the Jesuit Martin Becanus (1563-

133 The contribution of Nikolaos Chrissidis in this volume deals with this topic in detail.

134 Castagnola, Christian Doctrine, $\lambda$ '.

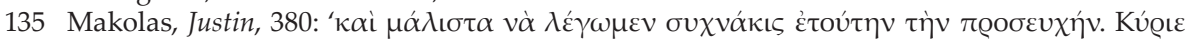

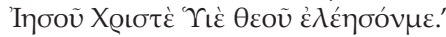

136 Ibid., 380-2.

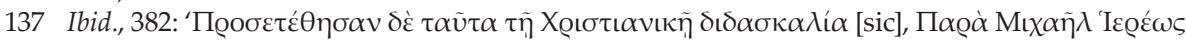

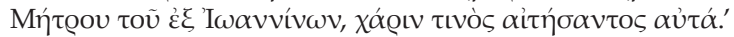

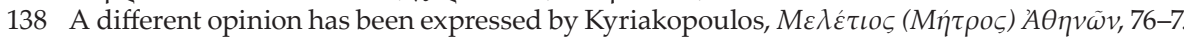

139 See J. W. Rogerson and Judith M. Lieu (eds), The Oxford Handbook of Biblical Studies (OxfordNew York 2006).

140 There is a multiplicity of equally valid terms describing the field of Hermeneutics: Biblical Interpretation, Biblical Criticism or Exegesis. From the vast relevant literature, see indicatively the overview of M. Reiser, 'The History of Catholic Exegesis, 1600-1800', in U. L. Lehner, R. A. Muller and A. G. Roeber (eds), The Oxford Handbook of Early Modern Theology, 16001800 (Oxford 2016) 75-88.

141 Nikolaos Voulgaris, Holy Catechesis. Namely Exegesis of the Divine and Holy Liturgy and Examination of the Ordained men (Venice 1681) 89-92. 
1624). ${ }^{142}$ Becanus, a Dutch Jesuit, taught Philosophy and Theology at the Universities of Würzburg, Mainz and Vienna and in his final years also became the confessor of the Habsburg Emperor Ferdinand II. He was a prolific writer who reflected the views of the Jesuit Cardinal Bellarmino, though he is better known as one of the central controversialists of the Society of Jesus in the German lands. ${ }^{143}$ His Manuale controversiarum huius temporis, with its Compendium Manualis controversiarum huius temporis de fide ac religione (Mainz 1623), were published more than fifty times until the late eighteenth century, producing many 'anti-Becanus respons-

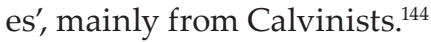

The relevant passage that concludes the version of the Christian Doctrine produced by Mitros is a selective translation of the first three 'Quaestiones' posed by Becanus in the 'Caput I. De Scriptura' of the 'Liber Primus. De controversiis communibus', in a total of five Books that constitute the Manuale controversiarum huius temporis. ${ }^{145}$ Michail Mitros rendered it into vernacular Greek following Becanus' questions with a further formatting of questions and answers, in order to adjust the foreign passage to the conversational form of his Christian Doctrine. In fact, Mitros provided a literal translation of only 'III. Quaestio. Quis sit sensus Scripturae literalis, \& quis mysticus?', ${ }^{146}$ whereas he made a very brief selection from the 'questions' concerning the canonical books and the authoritative translation of the Bible. ${ }^{147}$

As in his version of the Christian Doctrine, Michail Mitros also tries here to transfer Becanus' theological knowledge stripped of its explicit Catholic references. In particular, from the introduction of Becanus' chapter, Mitros refers simply to 'the translation [of the Holy Scripture]', in contrast to the detailed original: '2. Versio, seu translatio ex Hebraeo \& Graeco textu in latinum, Germanicum, Gallicum,

142 The full title is: R. P. Martini Becani Societatis Iesu theologi Manuale controversiarum huius temporis, in quinque Libros distributum ad Invictissimum et Sacratissimum Imperatorem Ferdinandum II. Austriacum, Catholicae fidei Defensorem. Herbipoli, Typis ac sumptib. Ioannis Volmari, $\mathcal{E}$ Michaelis Dalii. Anno M. DC. XXIII. Cum Gratia \& Privilegio Sacrae Caesareae Maiestatis.

143 For an interesting episode of the intricate relationship and cooperation of the Jesuit controversialist with the leadership of the Society and Bellarmino at Rome, see St. Tutino, Empire of Souls: Robert Bellarmine and the Christian Commonwealth (Oxford-New York 2010) 211-60.

144 For a comprehensive presentation of Becanus' life with a detailed record of his numerous books, see W. Raupp, 'Becanus (Bécan, Verbee[c]k, Van der Bee[c]k; Schellekens, Scell-), Martinus (Martin)', in St. Arend et al. (eds), Frühe Neuzeit in Deutschland 1620-1720. Literaturwissenschaftliches Verfasserlexikon, I (Berlin-Boston 2019) col. 481-502; cf. W. Raupp, 'Becan (Becanus), Martin', in W. Kühlmann (ed.), Killy Literaturlexikon. Autoren und Werke des deutschsprachigen Kulturraums, 2nd edn, I (Berlin-New York 2008) 382.

145 M. Becanus, Manuale controversiarum huius temporis (Würzburg 1623) 2-5. The same excerpt (paradoxically, more extensive in respect of the canon and the translations of Bible) is contained in M. Becanus, Compendium Manualis controversiarum huius temporis de fide ac religione (Mainz 1624) 14-25. In addition, an antecedent, partial version of the passage can be found in M. Becanus, Tituli Calvinistarum, collecti in ordinem redacti, et explicate (Mainz 1614) 18-66; cf. Becanus, Manuale controversiarum, 3.

146 Makolas, Justin, 380-2; cf. Becanus, Manuale controversiarum, 4-5.

147 'I. Quaestio. Qui libri scripturae sint Canonici?' and 'II. Quaestio. Quae [sic] sit legitima versio scripturae?'. Becanus, Manuale controversiarum, 2-4; cf. Makolas, Justin, 380. 
aut quemvis alium. ${ }^{\prime 148}$ On the other hand, when addressing the canon of the Bible, Mitros emphasizes that the 'orthodox [sic] Christians use it; ${ }^{\prime 149}$ a few lines later, however, with regard to the authoritative scriptural translation, he changes the attributive 'Nos Catholici' to 'we the orthodox [sic] Christians' and blurs the point by excising the mention of the Latin Vulgata. ${ }^{150}$ Moreover, Mitros' attempt to neutralize the passage coexists with the verbatim translation of the 'III. Quaestio', on the meanings of the Bible. Analyzing its double (literal and spiritual or mystical) sense, he avoids citing Thomas Aquinas, unlike Becanus who does so assiduously, ${ }^{151}$ and he changes the numbering in a citation to the Psalms, since there is a discrepancy between the Greek version of Septuagint and the Latin Vulgata, which Becanus has cited..$^{152}$ Mitros also abridges the concluding paragraph of the original, which associates each of the four meanings of the Holy Scripture (literal, allegorical, anagogical and moral) with its interpretation by four Latin Fathers of the Church (Jerome of Stridon, Ambrose of Milan, Augustine of Hippo and Pope Gregory I the Great, respectively), by noting vaguely that 'according to these four meanings of the Scripture, the holy Fathers interpret it: the one pursuant to one, and the other pursuant to another.'153 In fact, the passage 'On the Holy Scripture', seen independently of the rest of the text, would likely be described as a rather deliberate appropriation of the Catholic biblical knowledge into an Orthodox context. Its incorporation into the Christian Doctrine nevertheless entails a broader scope that challenges this certainty.

Unlike the case of Castagnola, where the motives and the translation process are clear, and the interpretation of his initiative as a cultural translation well-grounded, the version of the Christian Doctrine by Mitros raises many questions. Although it is a fact that his version is principally based on Castagnola's translation of the Dottrina christiana by Ledesma, it would be difficult to argue convincingly that Mitros simply resumes the cultural translation of the Jesuit catechism towards a further accommodation with the Greek-speaking or, more precisely, the Greek Orthodox audience. A few such pieces of evidence can, indeed, be identified; ${ }^{154}$ nevertheless, the Christian Doctrine by Michail Mitros has a fundamental difference from both the catechetical texts of Diego de Ledesma and Vincenzo Castagnola: its confessional identity has been drastically altered.

In fact, Mitros' Christian Doctrine could no longer be labelled as a Catholic catechism. The foremost alteration in this direction is without doubt the explicit addi-

148 Makolas, Justin, 380; cf. Becanus, Manuale controversiarum, 2.

149 Makolas, Justin, 380; cf. Becanus, Manuale controversiarum, 2.

150 Makolas, Justin, 380; cf. Becanus, Manuale controversiarum, 3.

151 Makolas, Justin, 380; cf. Becanus, Manuale controversiarum, 4.

152 Psalms 95.12, instead of 94.11. Makolas, Justin, 382; Becanus, Manuale controversiarum, 5.

153 Makolas, Justin, 382; cf. Becanus, Manuale controversiarum, 5.

154 Such as the original 'Rosario Della Madonna', rendered into the 'rodarion tis Panagias' by

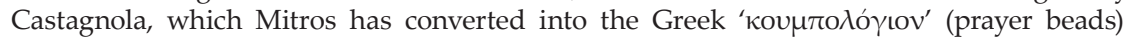
Ledesma, Dottrina Christiana (1593), 23; Castagnola, Christian Doctrine, кү'; Makolas, Justin, 379. 
tion of the Orthodox doctrine on the procession of the Holy Spirit only from the Father, in stark contrast to the Catholic Filioque. This major doctrinal change is followed by both the complete removal of any, even implicit, reference to the papal primacy ${ }^{155}$ and the radical rephrasing of the passage concerning the absolution of the dead congregants, with the intention of obscuring the Catholic teaching about the Purgatory and approaching the respective Orthodox belief of both the human commemoration and the exclusively divine absolution. Consequently, the attempt to 'Orthodoxize', so to speak, the Catholic catechetical text is evident.

Still, Mitros' version can also hardly be characterized as purely Orthodox. Aside from the confessionally charged points about the procession of the Holy Spirit and the Purgatory, some small interventions of Mitros are simply aimed at removing the distinct Catholic or, at least, non-Orthodox connotations from the Christian Doctrine, without affecting the very content of the text. Purgatory may be expurgated, but the numerous kinds of sins (deadly, venial etc.) have remained to remind the catechumens of it. ${ }^{156}$ The Western Apostles' Creed coexists with the Orthodox Nicene Creed, while the omission of a hymn to Mary at the end of the Christian Doctrine does not nullify the salient presence of the Catholic-derived worship of the Virgin Mary in the text. ${ }^{157}$ Moreover, the excerpt from Martin Becanus, on Biblical Interpretation, has been barely modified inasmuch as it does not state its Catholic derivation; the citation from Thomas Aquinas is still quoted, although he is not cited anymore.

Furthermore, the Christian Doctrine by Michail Mitros keeps intact passages of the original Dottrina christiana by Ledesma (following Castagnola's translation), which plainly reflect Roman religious and devotional practices. In particular, the instructions to the catechumens on how to cross themselves allude to the Catholic sign of the cross, ${ }^{158}$ while the Tridentine mass prayer of the general confession of sins is still there, ${ }^{159}$ together with the Western church tithes that should be paid by the congregants. ${ }^{160}$ Notably, the sign of the cross, as the principal external mark of both devotion and denominational inclusion, is a crucial confessional aspect that defines the aforementioned catechism from the very beginning. On the other hand, the mass prayer of the confession of sins may not have been easily recognized as belonging to the rite of Trent, if the audience of Mitros' version did not live in a Catholic city, like Venice.

155 Makolas, Justin, 368; cf. Castagnola, Christian Doctrine (1595) 14. Interestingly, however, the latter's third edition had also omitted the phrase in question. Castagnola, Christian Doctrine (1609) ' $\zeta$.

156 Makolas, Justin, 372 passim.

157 Ibid., 369-71, 379-80. An overview of the early modern Catholic Mariology and its close connection with Christology can be found in Tr. Pomplun, 'Baroque Catholic Theologies of Christ and Mary', in U. L. Lehner, R. A. Muller and A. G. Roeber (eds), The Oxford Handbook of Early Modern Theology, 1600-1800 (Oxford 2016) 104-18.

158 Makolas, Justin, 365; cf. above in this article, page 151.

159 Ibid., 376-7; cf. above, page 150.

160 Ibid., 374; cf. above, page 151. 
It is not clear why Mitros did not try to erase or replace these Catholic traces with Orthodox equivalents (which he could readily have found), if he really wanted to issue an Orthodox catechism. Instead, it seems plausible to assume that he consciously espoused and advocated some individual but substantial elements of the Catholic devotion and worship. Even if they were not strictly doctrinal issues, it cannot be overlooked that they were distinctively Roman Catholic. As a consequence, the confessional identity of Mitros' version of the Christian Doctrine remains ambiguous. In order to grasp the ambiguity, we need to contextualize this catechism by both positioning it into the historical context of the late-seventeenth-century Greek Orthodox community of Venice and focusing on its author, 'the Priest Michail Mitros from Ioannina'.

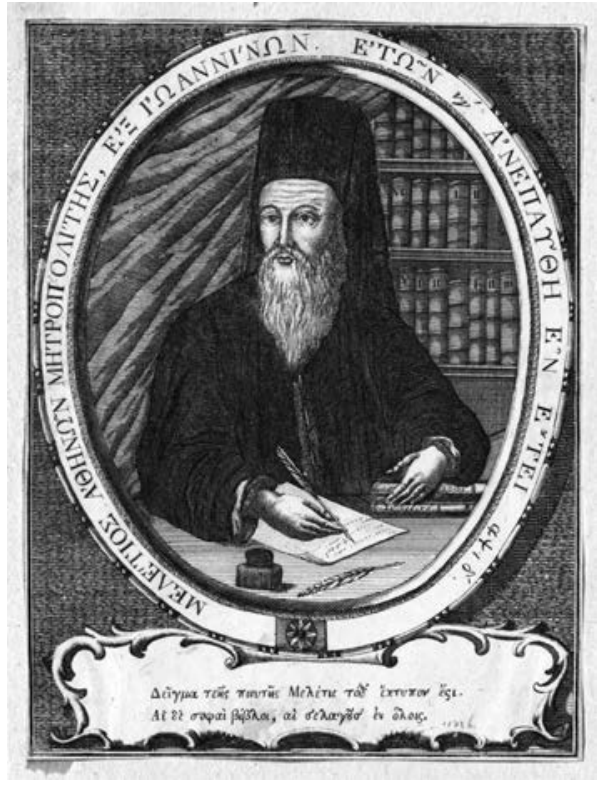

Fig. 7: Michail Mitros (later Metropolitan Meletios) (Österreichische Nationalbibliothek, Vienna)

Michail Mitros was born in 1661 at the Ottoman town of Ioannina, where he studied in the Nkiou(n)ma School, probably between 1677 and 1680. Mitros was then ordained a priest and in 1681 arrived in Venice. After the summer of 1687, he returned to Ioannina and was appointed as the teacher of the Epifanios School, where he worked until the summer of 1692. By the end of that year, he had been ordained Metropolitan of both Venetian Nafpaktos (Lepanto) and Ottoman Arta under the name Meletios. A few years later the Patriarchate of Constantinople deposed him, but he eventually managed to be elected Metropolitan of Athens in October 1703 and kept that see until his death, in December 1714. Indeed, Michail Mitros has been widely known in the literature under his church name 'Meletios Metropolitan of Athens', since his major works, the Geography Ancient and Modern and the Ecclesiastical History, were composed (or completed) when he was Metropolitan at Athens. ${ }^{161}$

161 There is an anonymous biography of Michail Mitros in his posthumous edition Meletios II, Metropolitan of Athens, Geography Ancient and Modern (Venice 1728) [7-8]. However, the figure of Michail Mitros/Metropolitan Meletios has not attracted appropriate attention from

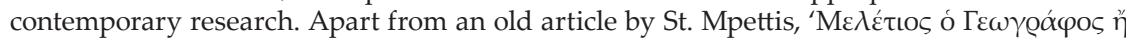

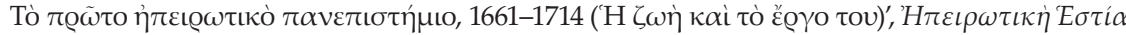
13 (1964) 522-44, 587-618 [republ. Athens-Ioannina 2007], there is only an extensive study by

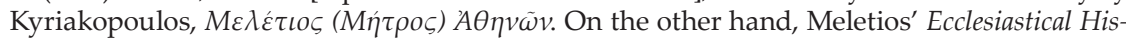


Mitros probably traveled to Venice sometime between 1680 and 1681, at the age of nineteen or twenty, and left the Serenissima after July of 1687, when he was twenty-six years old. Although it is quite probable that he continued his studies there, there is no specific information about that. Instead, we have evidence of his teaching activity in the school of Epifanios Igoumenos at Venice between March 1686 and July 1687. ${ }^{162}$ Moreover, 'the Priest Michail Mitros from Ioannina' appears as an editor and reviser of at least nine Greek books published by Venetian printing houses between 1685 and 1687. Specifically, he collaborated with the publisher Nikolaos Glykys on three editions ${ }^{163}$ and with Michelangelo Barboni on Makolas' Justin. The remaining books were issued under the mark of the second important Greek publisher of the late-seventeenth-century Venice, Nikolaos Saros. ${ }^{164}$ In sum, the editing production of Mitros was dense and quite balanced: five religious or liturgical books and four secular editions, allocated per four to the years 1686 and 1687, apart from the first one issued in 1685. Moreover, within the secular editions, besides the early modern Greek best-sellers with the numerous reprints throughout the sixteenth-eighteenth centuries (namely, the educational Grammar by Konstantinos Laskaris and the commercial Practical Arithmetic by Manouil Glyzounis), there are two books that had been issued for the first time: the grammatical handbook of Vissarion Makris, Technological Gleaning (Venice 1686), ${ }^{165}$ and the Historical Book called Justin by Ioannis Makolas (Venice 1686, single edition).

tory was the topic of my dissertation, and I am currently preparing a book on his intellectual

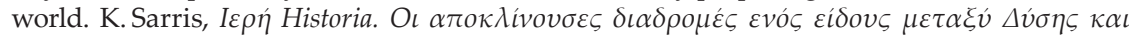

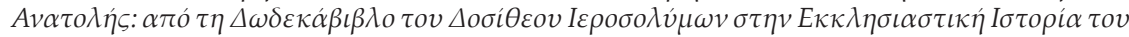

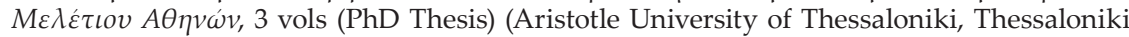

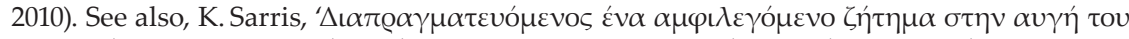

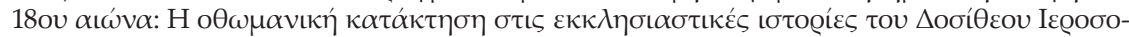

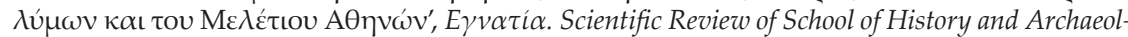
ogy, Faculty of Philosophy, Aristotle University of Thessaloniki 15 (2011) 117-25; K. Sarris, 'Meletios of Athens', in D. Thomas and J. Chesworth (eds), Christian-Muslim Relations. A Bibliographical History, XIV. Central and Eastern Europe (1700-1800) (Leiden-Boston 2020) 272-89; K. Sarris, 'Composing and publishing a non-confessional history in the age of Greek Orthodox confessions: The Ecclesiastical History by Meletios of Athens', in T. Anastassiadis, A. Girard, B. Heyberger and V. Kontouma (eds), Livres et confessions chrétiennes orientales. Histoire connectée entre Empire ottoman, monde slave et Occident (XVIe-XVIIIe siècles). Actes du colloque de Rome, 15-16 décembre 2016, publ. Bibliothèque de l'École des Hautes Études [in press].

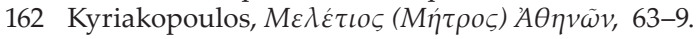

163 1) Minaion of December (Venice 1685); 2) Gospel (Venice 1686);3) Vissarion Makris, Technological Gleaning, In question and answer [form] concerning the Grammatical Art (Venice, 1686). On this printing house and the editions of Mitros there, see G. Veloudis, Tó $\varepsilon \lambda \lambda \eta v \iota k o$ $\tau v \pi o \gamma \rho \alpha-$

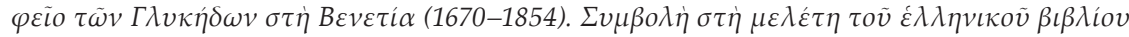

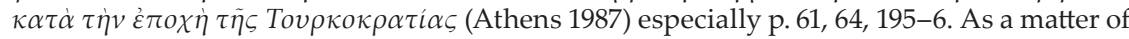
fact, the collaboration did not last beyond 1686; the Minaion's edition of 1689 was a republi-

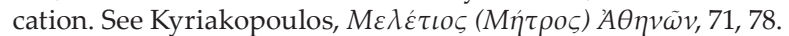

164 1) Konstantinos Laskaris, Grammar (Venice 1686); 2) Manouil Glyzounis, Book handy for everybody, containing the Practical Arithmetic or, better said, the Calculation (Venice 1687); 3) Ierodiakonikon (Venice 1687); 4) Triodion (Venice 1687); 5) Pentecostarion (Venice 1687).

165 It probably represents an initiative of Mitros himself, who had studied next to Makris at 
The title page of the latter advertises the presence of a catechetical manual in its contents:

Historical Book called Justin, Translated from the Latin language in the vulgar Greek by the Athenian, Ioannis Makolas; moreover some myths translated from the Latin language as well in the vulgar Greek by the same, printed at the expense and with the support of the most noble Mister Michail Peroulis from Athens; printed for the common benefit of the studious [readers], edited with the greatest care. In addition, at the end of this book there is also a Christian doctrine extremely necessary to everybody. Con licenza de superiori, e privilegio. Venice 1686, from Theogony, in the Month of February. By Michelangelo Barboni. ${ }^{166}$

This is in fact the version of Ledesma's Christian Doctrine that Michail Mitros

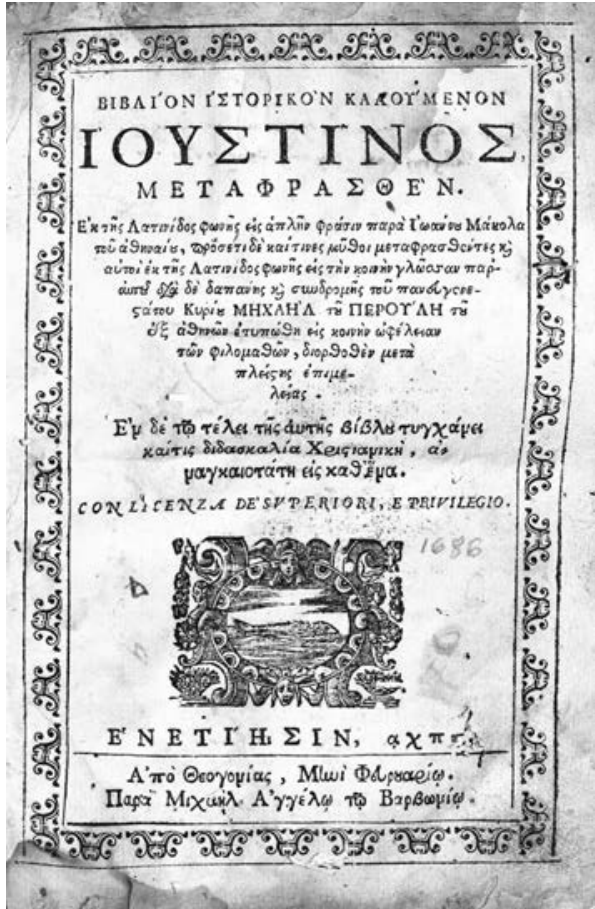

Fig. 8: Ioannis Makolas, Book called Justin, Venice 1686 (Onassis Library, Athens) had composed. The edition contains the Roman historical-ethical compilation entitled Epitoma (from the non-extant Historiae Philippicae by Gnaeus Pompeius Trogus) ${ }_{1}^{167}$ as well as a selection of twelve myths derived from Ovid's Meta-

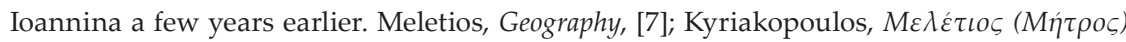

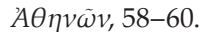

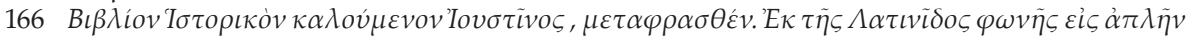

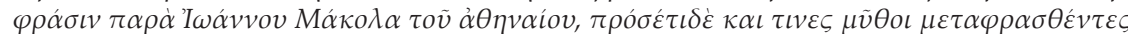

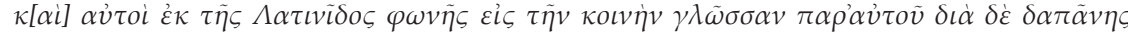

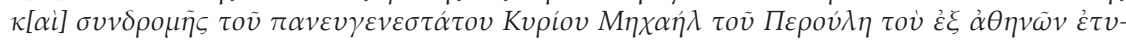

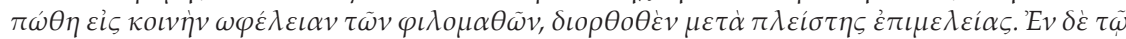

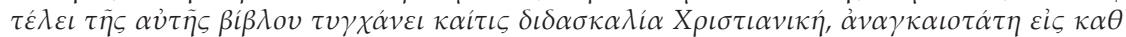

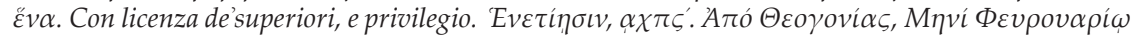

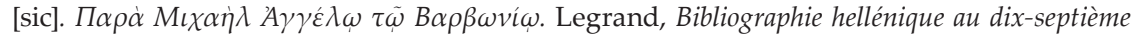

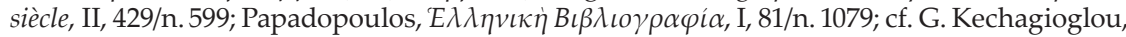

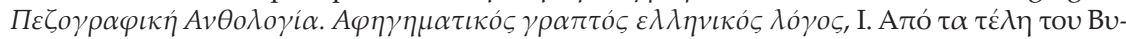

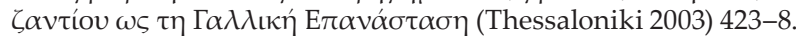

167 Regarding the Historiae Philippicae by Trogus and its epitome by Justin, see A. Borgna, Ripensare la storia universale. Giustino e l'Epitome delle Storie Filippiche di Pompeo Trogo [Spudasmata, 176] (Hildesheim-Zürich-New York 2018), which sums up the relevant literature. For a modern English translation of Justin's Epitome, see Marcus Iunianus Iustinus, Justin. Epitome 
morphoses, ${ }^{168}$ both rendered into the Greek vernacular by Ioannis Makolas. ${ }^{169}$ The voluminous book of almost four hundred pages printed in quarto is known as Justin, from the compiler of the Epitoma, Marcus Junianus Justinus. ${ }^{170}$

The edition of Justin incorporates the Christian Doctrine by Mitros as the third, final, and shortest text of the volume (p.365-382) - and the only one not written by Makolas. ${ }^{171}$ Furthermore, in contrast to the inconspicuous heading referring to Ovid's myths immediately after the end of the Epitoma by Justin-which is barely distinguishable from the main text- ${ }_{1}^{172}$ the final text is introduced by an emphatic title:

Here is added the Christian Doctrine as well, in which the Teacher questions, and the Pupil answers. Being most indispensable for every Christian, and especially for the Pedagogues, who ought to teach and educate the children of the Christians what has been written in this, in order to become able from a very young age to enjoy its fruit and to know the orthodox Faith. Christian Doctrine, in which the Teacher questions, and the Pupil answers. ${ }^{173}$

of the Philippic history of Pompeius Trogus, transl. J. C. Yardley [Classical resources series, 3] (Atlanta 1994). Cf. H. Beck, 'Pompeius Trogus', in R. S. Bagnall et al. (eds), The Encyclopedia of Ancient History (2012), doi:10.1002/9781444338386.wbeah08134; J. C. Yardley, Justin and Pompeius Trogus: A Study of the Language of Justin's Epitome of Trogus (Toronto-Buffalo-London 2003).

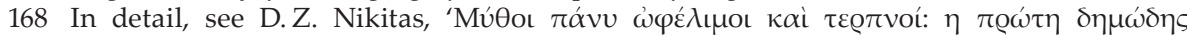

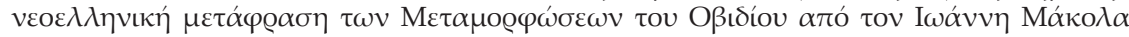

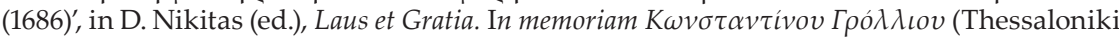
2012) 103-42. Cf. V. Pappas, 'Modern Greek Translations (1686-1818) of Latin Historical Works', Studia Philologica Valentina 17/14 (2015) 257-72, here p. 260.

169 Makolas' translation of Justin in vernacular Greek has been recently republished by K. Ga-

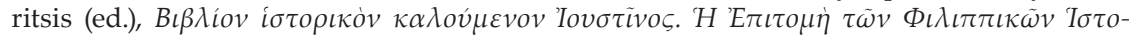

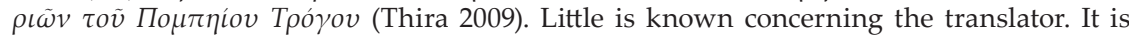
mentioned that Makolas was born at Athens in 1661 and was a member of a noble and prosperous family with strong ties to Venice. Interestingly, the aforementioned translations were his single scholarly work, executed in the intervals of his commercial activities. In fact, he was a prominent merchant in Venice, who was elected seven times 'guardiano' (trustee) and at least once president of the Greek Confraternity (1700-1701). Moreover, the Venetian Republic awarded him the title of count (1701) and, later on, recorded him in its libro d'oro

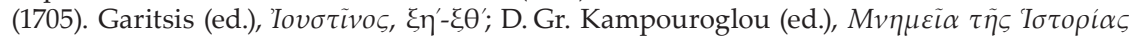

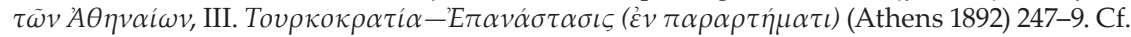
Pappas, 'Modern Greek Translations', 258.

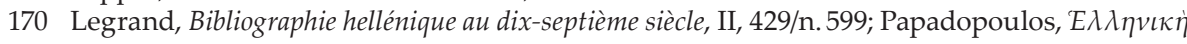

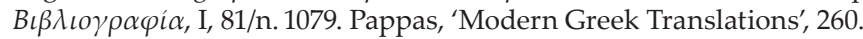

171 From the introductory texts by Makolas himself, as well as from the table of contents, it is obvious that he translated only the first two works. Makolas, Justin, [1-2], [8], [9-12].

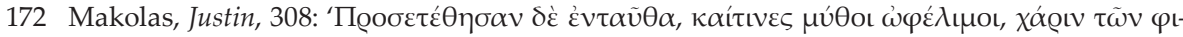
$\lambda \circ \mu \alpha \theta \tilde{\omega} \nu \alpha \dot{\alpha} v \theta \varrho \omega ́ \pi \omega v . '$

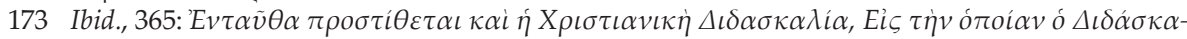

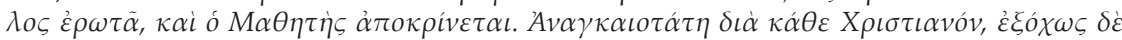

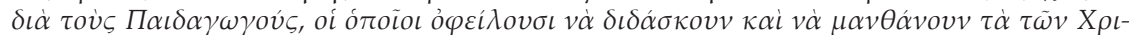

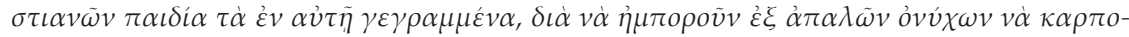


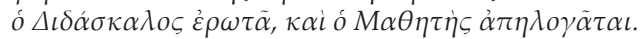


Despite its length, however, the title provides remarkably little information about the identity of the work. Only in his salutation to the sponsor of the volume, Michail Peroulis ${ }^{174}$, does Makolas indicate the use of an old edition, stating that: 'this Doctrine, being almost entirely destroyed because of time, I decided to revitalize and print it.' ${ }^{\prime 75}$ Of course, he refers to the Christian Doctrine by Castagnola, while the 'revitalization' of the text had been evidently assigned to 'the Priest Michail Mitros from Ioannina', who also adds the concluding excerpt 'On the Holy Scripture'. ${ }^{176}$

Moreover, Makolas tries to justify the peculiar combination of the texts, especially the inclusion of a catechism together with the translation of two Roman works derived from antiquity. First of all, he insists throughout the introductory texts that he wrote the book 'on account of the great benefit and delight of the many, and so that the people not be found in conditions of laziness and negligence. Because at this time the glorious and renowned genos of the Greeks, too, is severely lacking in such beneficial books. ${ }^{177}$ Further, he assures the reader that:

174 The biography of the supporter and patron of the edition, Michail Peroulis, corresponds to the general lines of the biography of the translator. A generation older than Makolas, Peroulis was a scion of another noble and wealthy Athenian family who emigrated to Venice before 1664, because of his trading activities. He became one of the richest members of the Greek Confraternity at Venice and four times its president (1683, 1694, 1697 and 1706). P. Mi-

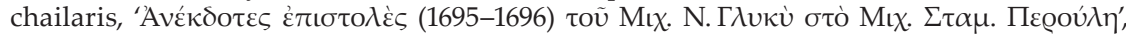
$\Theta \eta \sigma \alpha v \rho i \sigma \mu \alpha \tau \alpha 13$ (1976) 245-58, here p. 246-7, where the older relevant literature is cited.

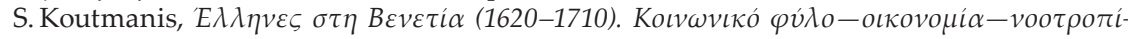
$\varepsilon \varsigma$ (PhD Thesis) (National and Kapodistrian University of Athens, Athens 2013) 199. Cf.

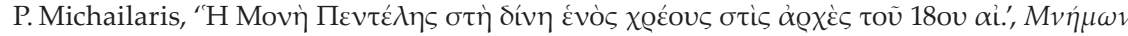

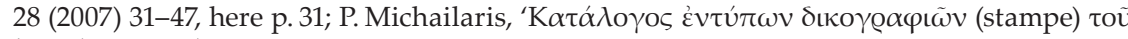

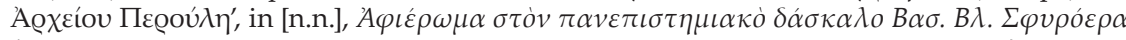

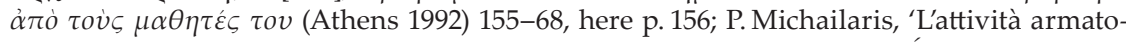
riale di Demetrio Peruli ed il suo intervento al traffic mediterraneo', in Économies méditerranéennes. Èquilibres et intercommunications, XIIe-XIXe siècles. Actes du IIe Colloque International d'Histoire (Athènes, 18-25 septembre 1983), I (Athens 1985) 175-86, here p. 176; P. Michailaris, 'Le avventure di una dote nello Stato venezian del Levante (XVIII sec.)', in Chr. Maltezou, A. Tzavara and D. Vlassi (eds), I Greci durante la venetocrazia: Uomini, spazio, idee (XIII-XVIII sec.). Atti del Convegno Internazionale di Studi (Venezia, 3-7 dicembre 2007) (Venice 2009) 131-40, here p. 133.

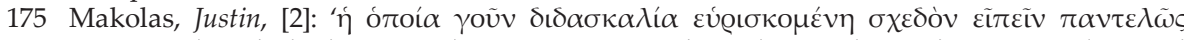

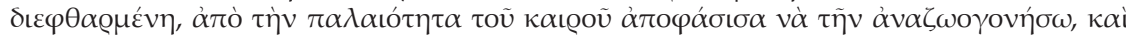

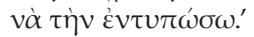

176 The role of Mitros in the edition of Makolas' Justin does not seem to be confined to its last text. Though he is not mentioned in the title-page, he composed the main epigrams in honor of both the author and his native town, Athens (ibid., [13]). Bearing in mind, additionally, the broader typographic activity of Mitros in the same period, it could be reasonably assumed that he edited the whole book.

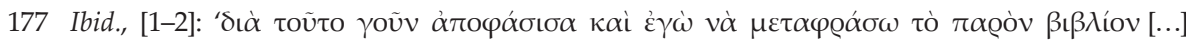

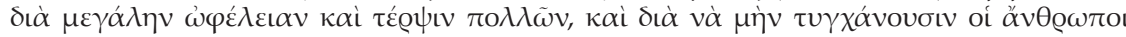

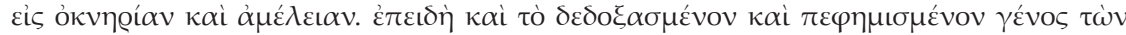

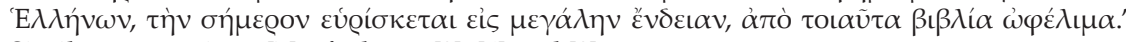
Similar excerpt in p. [7]; cf. also p. [2], [6] and [8]. 
by the Histories [of Justin] you will appear to be the most competent along with the most experienced in all the changes and the events of the old brave men and magnanimous kings. By the myths [of Ovid], on the other hand, you will be equipped to become the shrewdest and greatest contriver of various contrivances and meanings, and lastly, by the Christian doctrine you will undoubtedly be happy and blessed. ${ }^{178}$

Makolas describes the Christian Doctrine, in particular, as the 'last and the most necessary, [in order to] know correctly and comprehend perfectly the doctrines of our Christian and Orthodox faith [...] there is a beneficial Christian doctrine extremely necessary for everybody.' ${ }^{179}$ Although the author labels the whole book as a history, contrary to 'the other Historical books that gladden only bodily, [...] this one [gladdens] spiritually too. ${ }^{\prime 180}$ In fact, according to Makolas, this edition coheres through the recreational, didactic and spiritual objectives of the texts it contains. ${ }^{181}$

Makolas' rhetoric is not convincing, however. It can hardly vindicate the inclusion of the Christian Doctrine by Michail Mitros in the edition of Justin. Indeed, the motives for this addition could related to a third person, who is mentioned (but not named, however) in Mitros' text. Specifically, in the conclusion to the section 'On the Holy Scripture' it is stated that 'These [excerpts] have been added to the Christian doctrine, by the Priest Michail Mitros from Ioannina, for the sake of somebody who asked for them. ${ }^{\prime 182}$ The anonymous solicitant has been placed precisely in the last phrase, at the very end of the whole book, perhaps indicating his importance in

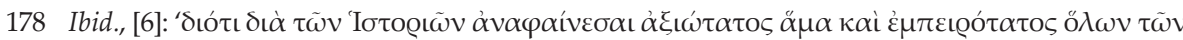

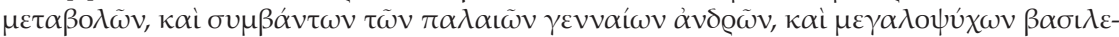

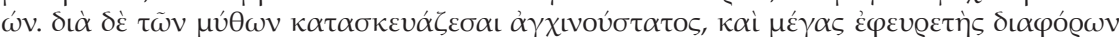

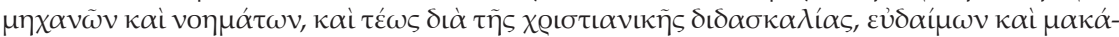

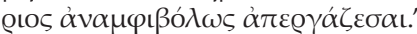

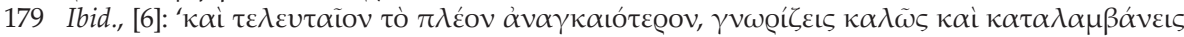

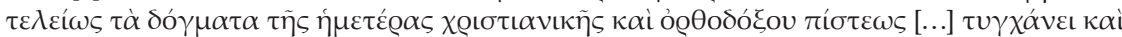

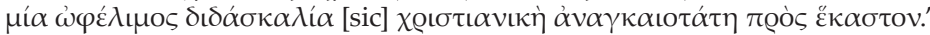

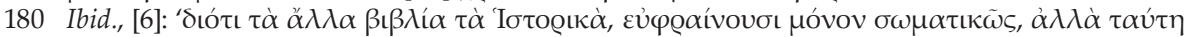
$\kappa \alpha \grave{i} \psi v \chi \iota \kappa \tilde{\omega} s . '$

181 Nevertheless, the use of Makolas' Justin as school textbook is doubtful, as its single edition

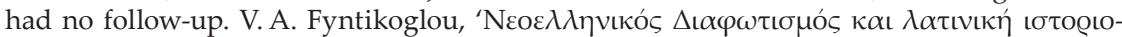

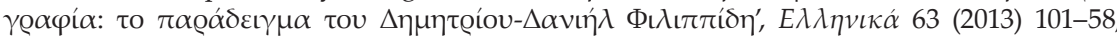
here p. 107. Cf. Pappas, 'Modern Greek Translations', 43. Besides, only one manuscript of the translation by Makolas - a copy of the edition, presumably - has been found so far, in Vienna, Österreichische Nationalbibliothek, Suppl. gr. 111 Han [Diktyon 71575]. A detailed study of this voluminous, modular book is pending, but it is beyond the scope of this article

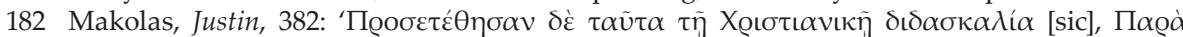

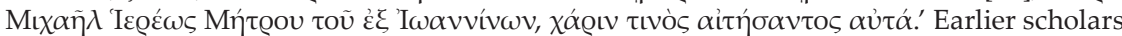
have assumed that it probably means Ioannis Makolas himself or Michail Peroulis.

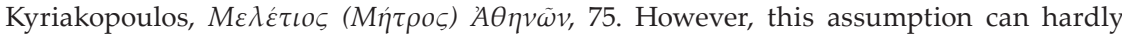
explain why an eponymous contributor of the first pages of the book becomes anonymous at the end. 
the whole publishing endeavor. Who could have asked Mitros to add the aforementioned section to the Christian Doctrine? More generally, who could have asked Mitros to compose and issue a confessionally ambiguous catechism in Venice in 1686?

With regard to the passage on scriptural Exegesis, the choice of the topic made by the unnamed person is not at all accidental. Indeed, scholarly and theological disputes about the interpretation of the Bible were dominant across the seventeenth-century confessionally divided Europe. ${ }^{183}$ The 1680 s in particular signaled an important turning point in these debates, following the publication in 1678 of the groundbreaking Histoire critique du Vieux Testament by the Oratorian French theologian, Richard Simon. ${ }^{184}$ Hence, the anonymous request that Mitros should supplement the Christian Doctrine with a passage relevant to Biblical Criticism reveals a person that was acquainted with the contemporary European discussion. Moreover, the unnamed scholar was in all likelihood also the one who had selected the specific passage-a passage connected with the Jesuit exegetical tradition which had been capitalized and surpassed by the Oratorian Simon. ${ }^{185}$

Even though the author of the passage 'On the Holy Scripture', Martin Becanus, was not among the famous Jesuit exegetes, ${ }^{186}$ he seems to have been well-known among the scholarly and church circles of the Greeks at Venice. Specifically, among the folios of the library catalogue of the prominent scholar and Metropolitan of Philadelphia (i.e. Venice) ${ }^{187}$ Gerasimos Vlachos (1679-1685) ${ }^{188}$ Becanus is

183 See the pioneering study of N. Hardy, Criticism and Confession: The Bible in the Seventeenth Century Republic of Letters [Oxford-Warburg Studies] (Oxford-New York 2017); cf. H. Nellen and P. Steenbakkers, 'Biblical Philology in the Long Seventeenth Century. New Orientations', in D. van Miert et al. (eds), Scriptural Authority and Biblical Criticism in the Dutch Golden Age: God's Word Questioned (Oxford-New York 2017) 16-58.

184 His Histoire critique du texte du Nouveau Testament was published in 1689, followed by three more works on the New Testament. On Simon's historical-critical method, see G. G. Stroumsa, 'Richard Simon: From Philology to Comparatism', Archiv für Religionsgeschichte 3 (2001) 89-107; Gr. McDonald, Biblical Criticism in Early Modern Europe. Erasmus, the Johannine Comma and Trinitarian Debate (Cambridge 2016) especially p. 144-56. Already in 1670, Baruch Spinoza had anonymously issued the Tractatus Theologico-Politicus, an iconoclastic interpretation of the Bible. For a prehistory of the Biblical Criticism in the Dutch Republic see D. van Miert, The Emancipation of Biblical Philology in the Dutch Republic, 1590-1670 (Oxford-New York 2018). For a concise introduction to Spinoza, see J. Israel, Radical Enlightenment. Philosophy and the Making of Modernity, 1650-1750 (Oxford-New York 2001) 159-74.

185 L. Murray, 'A History of Historiography on Jesuit Exegesis', in Jesuit Historiography Online, http://dx.doi.org/10.1163/2468-7723_jho_COM_193804.; cf. M. Fumaroli, 'The Fertility and the Shortcomings of Renaissance Rhetoric: The Jesuit Case', in J. W. O'Malley et al. (eds), The Jesuits. Cultures, Sciences and the Arts, 1540-1773, I (Toronto-Buffalo-London 2000) 90-106, here p. 97.

186 Despite the fact that he had also issued an exegetical work: Analogia Veteris et Novi Testamenti (Mainz 1620). Raupp, 'Becanus, Martinus', col. 490, 496.

187 An overview of the history of the Metropolitanate of Philadelphia in Venice presents E. Birtachas, 'Un "secondo" vescovo a Venezia: il metropolita di Filadelfia (secoli XVI-XVIII)', in M. Fr. Tiepolo (ed.), I greci a Venezia: atti del convegno internazionale di studio; Venezia, 5-7 novembre 1998 (Venice 2002) 103-22.

188 On Vlachos there is a recent lemma, with all the earlier literature, of W. von Scheliha and 
recorded twice: 'Martini Becani Tractatus de Sacramentis | Tractatus Tertius Pars Tertia' and 'Martini Becani Summae Theologiae scolasticae [sic] I Pars secunda'. ${ }^{189}$ Notwithstanding the fact that none of these books contains the Manuale controversiarum huius temporis, from which the aforementioned passage comes, this proves that the writings of the Jesuit Becanus did circulate within the Orthodox 'nazione greca' of the Serenissima, at the time when 'somebody' asked to add it in Mitros' version of the Christian Doctrine.

The owner of the library, Gerasimos Vlachos, may well have died in 1685, but his successor in the Orthodox metropolitan see, the controversial figure of Meletios Typaldos (1685-1713), soon proved to be well disposed to the Catholic Church. Matthaios Typaldos, to use his secular name, was born in Cephalonia in 1648 and studied in both the Flanginian School of Venice and the University of Padua (16651670). In 1671 he was elected teacher at the School of the Greek Confraternity. After a short period of teaching activity in Cephalonia (1673-1677) he returned to Venice as director of the Flanginian School. Parallel to the direction of the Flanginian School Typaldos taught again, from 1682 onwards, in the Fraternity's School until his solemn election as Metropolitan of Philadelphia, under the name Meletios, in 1685. ${ }^{190}$ Despite the almost unanimous support of the members of the Greek Confraternity of St Nicholas at the beginning, already from the early 1690s his tenure was marked by a severe and constant dispute over the confessional direction of the 'nazione greca' at Venice, the control over the Orthodox church of San Giorgio dei Greci and the undisguised pro-Catholic religious policy of Typaldos himself. The struggle between the majority of the Confraternity of Venice and the faction of the Metropolitan of Philadelphia, which went through various phases and ended only with Typaldos' death (May 1713) caused irreparable damage to the Orthodox community of Venice, which rapidly declined in the following few decades. ${ }^{191}$

O. Olar, 'Gerasimos Vlachos', in D. Thomas and J. Chesworth (eds), Christian-Muslim Relations. A Bibliographical History, X. Ottoman and Safavid Empires (1600-1700) (Leiden-Boston

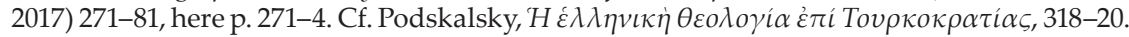

189 Archive of the Hellenic Institute in Venice, B. Church, 3. Metropolis of Philadelphia, Case 2b,

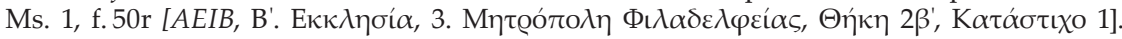

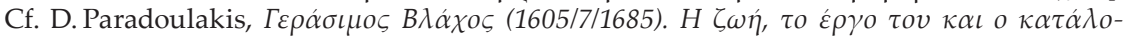

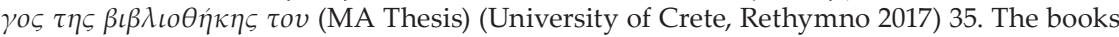
described in the catalogue entries are, apparently, two volumes of Martin Becanus' collected works entitled Summa theologiae scholasticae (first edition, Mainz 1612-1623): 1) Theologiae Scholasticae Pars Tertia. Tractatus Secundus De Sacramentis Ecclesiae (first edition, Mainz 1622) and 2) Summa Theologiae Scholasticae Pars Secunda in Duos Tomos Distincta. Tomus Prior (first edition, Mainz 1612) or [...] Tomi posterioris Tractatus primus de Fide, Spe, et Charitate (first edition, Mainz 1619) or [...] Tomi posterioris Tractatus secundus de Iustitia et Religione (first edition, Mainz 1620). Raupp, 'Becanus, Martinus', col. 493.

190 The ordination ceremony was held in March 1686, after the reception at Venice of the patriarchal letters of approval. For the teaching activities of Typaldos, see A. Karathanasis, $H$

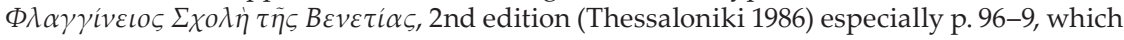
contains all of the older literature.

191 Individual aspects of the complicated affair concerning Meletios Typaldos have recently

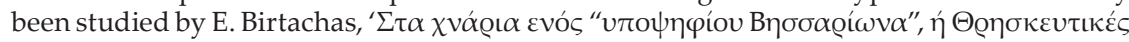


Although the overt pro-Catholic activity of Typaldos began around 1690 once he had restored close communication with Rome, his overtures to Catholicism can be dated from at least late 1685 or early 1686, when he allegedly requested, in vain, that the Vatican send Catholic bishops to Venice so as to ordain him as Metropolitan of Philadelphia. ${ }^{192}$ Nevertheless, the specific testimony is indirect, since it comes from a report composed by Roman prelates nearly five years later, in 1690. The Typaldos' affair involves secret reports, confidential documents, and personal correspondence with a plethora of indirect and dubious information, whereas the relevant explicit statements and public writings are few and mostly pseudonymous. Consequently, the version of the Christian Doctrine written by Michail Mitros in

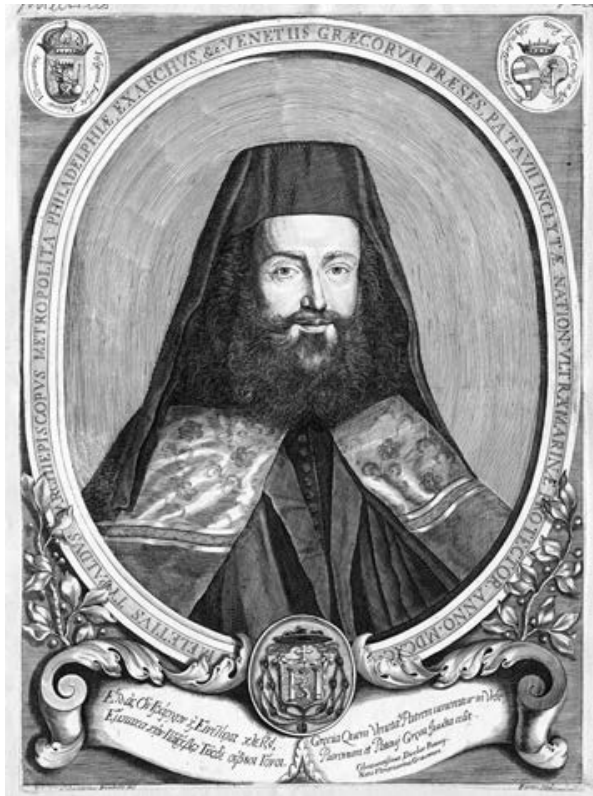

Fig. 9: Meletios Typaldos (Österreichische Nationalbibliothek, Vienna)

1686 could reasonably be interpreted to represent the first pro-Catholic manifestation of Meletios Typlados in pub-

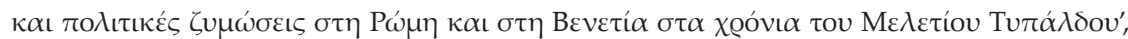

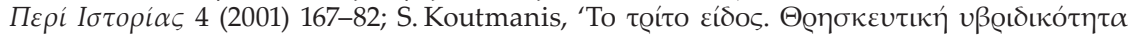

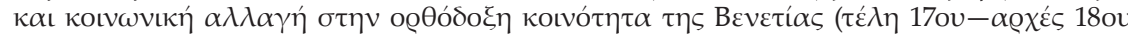
$\alpha \mathrm{t} \omega v \alpha)^{\prime}, \Theta \eta \sigma \alpha v \rho i \sigma \mu \alpha \tau \alpha 37$ (2007) 389-420; Th. Roussopoulos, Identity Disputes and Politics at the End of the 17th Century: The Archbishop Meletios Typaldos and his conflicting relations with the Greek Confraternity of Venice (PhD Dissertation) (University of Edinburgh, Edinburgh 2014);

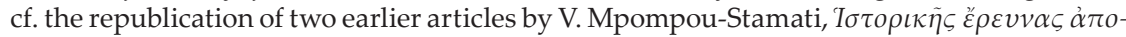

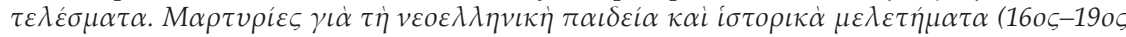
ai.) (Athens 2002) especially p. 133-236.

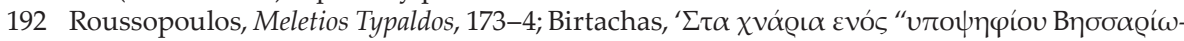
$v \alpha^{\prime \prime \prime}, 171-2$. In fact, considering ex post the teaching career of Typaldos, there is evidence that a special relation between him and the Venetian authorities existed almost a decade earlier. In 1677 the Riformatori dello studio di Padova (Reformers of the University of Padua) invited Typaldos to assume the direction of the Flanginian School in Venice and insisted on their decision, despite the objections of the dignitaries of Cephalonia. Moreover, the Riformatori approved three generous raises of Typaldos' annual income in the Flanginian School within just four years (1678-1681). Karathanasis, $\Phi \lambda \alpha \gamma \gamma$ iveı $\Sigma \varsigma \chi 0 \lambda \eta$, 97-8. Additionally, there are at least two certificates (January 1685 and December 1709) of Typaldos as 'pubblico revisore' of the Greek books issued at Venice-under the direction of the Riformatori dello

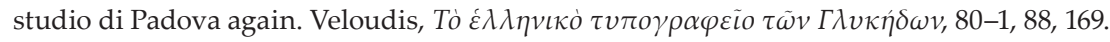


lic, although-or precisely because-it was published under the name of Mitros and after the unnamed request of 'somebody'.

In fact, the whole publishing initiative for Justin's volume came from the close circle of Typaldos associates. Specifically, some documents on the teaching activity of Michail Mitros at Venice and, later, at Ioannina ${ }^{193}$ prove that he had a close relationship with Meletios Typaldos, at least from 1686 onwards. Moreover, that year, Mitros was among the first to publicly praise Typaldos' election to the metropolitan see of Venice. ${ }^{194}$ Another who did so was Nikolaos-Nikodimos Vavatenis $(† 1730),{ }_{1}^{195}$ also a member of Typaldos' intellectual circle, and author of an epigram for Ioannis Makolas at the beginning of the edition of Justin. ${ }^{196}$ Among the creators of the epigrams dedicated to Makolas-alongside Mitros and Vavatenis-was Georgios Zandiris (1662 - ca 1729), ${ }_{1}^{197}$ one of the most influential and consistent promoters of Typaldos during the communal turmoil. ${ }^{198}$ Last but not least, Ioannis Makolas him-

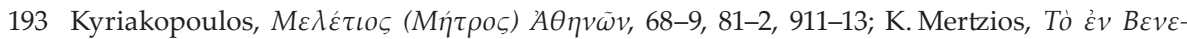

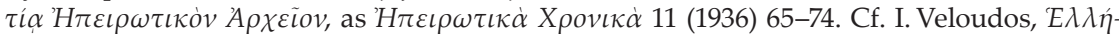

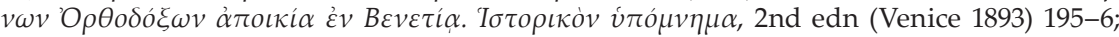

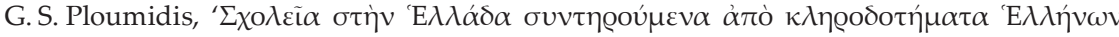

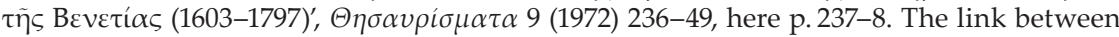
Michail Mitros and Meletios Typaldos has not been pointed out in the older literature. I am trying to outline it in the relevant chapter of my book on the former.

194 He appears as the editor of an exceptional Gospel in-folio published by the printing house of Nikolaos Glykys in honour of the recently ordinated Metropolitan of Philadelphia. É. Legrand, Bibliographie hellénique ou description raisonnée des ouvrages publiés par des grecs

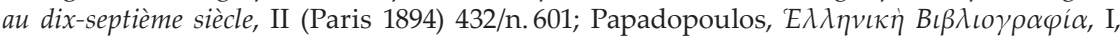

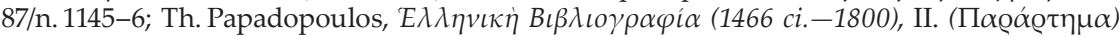

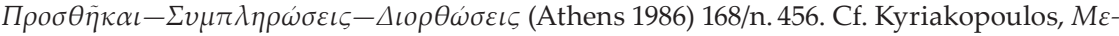
$\lambda \dot{\varepsilon} \tau \iota \circ \zeta(M \eta \dot{\tau} \rho \circ \varsigma)$ A $\theta \eta \dot{v} \tilde{\omega} v, 71$.

195 Editor of an almost identical Gospel by the printer Nikolaos Saros. Legrand, Bibliographie

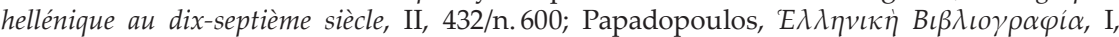
87/n. 1147. There are two recent studies regarding Nikolaos-Nikodimos Vavatenis, which

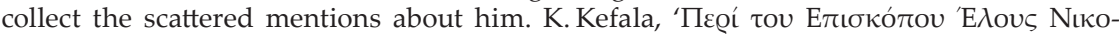

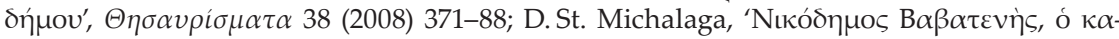

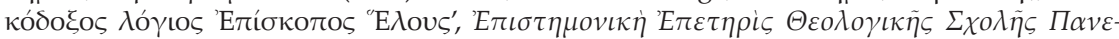

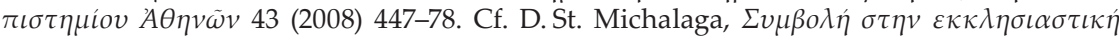

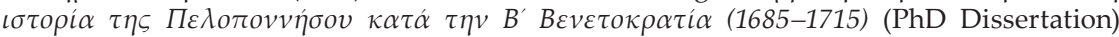
(National and Kapodistrian University of Athens, Athens 2006) 150-1, 160, 175, 323, 332;

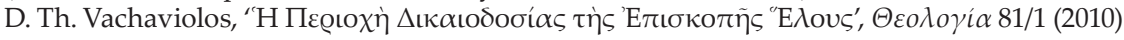

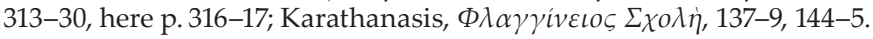

196 Makolas, Justin, [14].

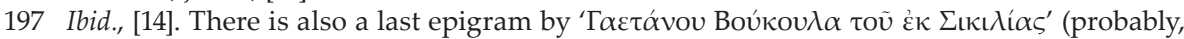
Gaetano Vuccula, in Italian), who has not been identified.

198 Zandiris practiced medicine as well as trade in Venice. He was a physician in the community-run Flanginian Hospital (1684-1713) and a notable member of both the Venetian state and the Greek Confraternity of St Nicholas, where he was elected twice as president (1705, 1713). He was also the principal founder of the Greek-Catholic Confraternity of St Spiridon in 1708. Details about Georgios Zandiris and the older literature concerning him in Ath.

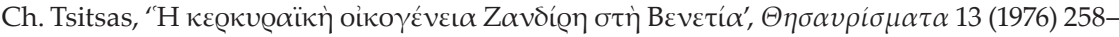

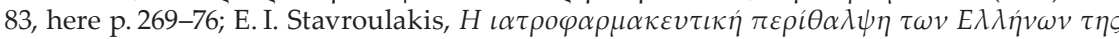

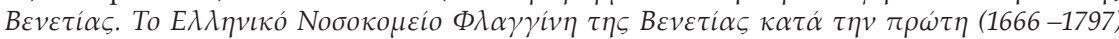


self was involved in the Typaldos' affair as well. Together with Georgios Zandiris and some other prominent and powerful Greeks, he was a member of the hard core of the pro-Catholic faction within the Greek Confraternity of Venice, which stood behind Meletios Typaldos and his plans from the beginning until his death. ${ }^{199}$

In summary, almost the whole group of the contributors to Justin derive from Typaldos' close circle: the translator, Ioannis Makolas, along with Georgios Zandiris were among his primary allies, while the editor, Michail Mitros, and Nikodimos Vavatenis seem to have been his protégés. ${ }^{200}$ By joining together the principal figures of Typaldos' faction, as well as some of his close followers, the publishing endeavor in fact proves to be more than a merely scholarly initiative to render into vernacular Greek and publish a historical-ethical work, some didactic myths and, in passing, a catechism. The edition of Justin in 1686, carried out by distinguished and leading members of the Greek Confraternity of Venice with great economic and social power, was certainly meant to have a great symbolic impact and significance for the 'nazione greca' of the Serenissima; and Meletios Typaldos was fully aware of this.

In this specific historical context, the issue of a confessionally ambiguous catechism, such as the version of the Christian Doctrine that Mitros composed, could on no account be incidental or supplemental. On the contrary, it assumes an autonomous dynamic driven by several elements. Firstly, the printing itself of the Christian Doctrine announces its independence within the volume: in contrast to both the complete lack of any general title at the beginning of the main text of Justin ${ }^{201}$ and the barely discernible heading of the Ovidean myths, ${ }^{202}$ there is a lengthy title-practically, a second title page-that leads into the catechetical text. ${ }^{203}$ The most significant element, however, is the conscious decision of the editor to add a paradoxical statement at the end of the catechism, because this statement both

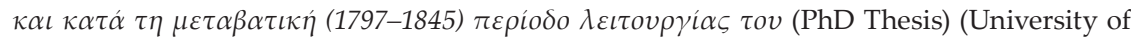

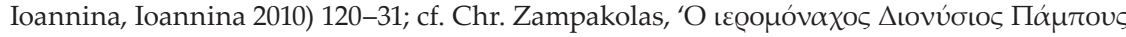

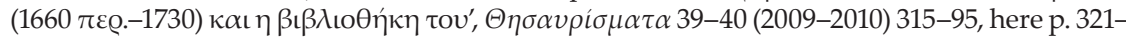
3; G. Ploumidis, 'La confraternita greco-cattolica di Santo Spiridione a Venezia (1708)', Bolletino della Badia Greca di Grotta Ferrata 27 (1972) 51-70, especially p. 58; K. D. Mertzios, 'Mıк@ò

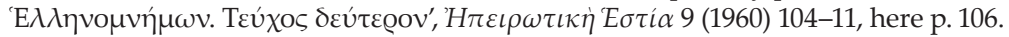

199 Indeed, at the height of the struggle, when the president of the Confraternity, Leonardos Kapetanakis, alongside Michail Peroulis resigned due to the overt interventions of the Venetian authorities (1710), the partisans of Typaldos took over the administrative board with Ioannis Chalikiopoulos as president and both Ioannis Makolas and Georgios Zandiris as

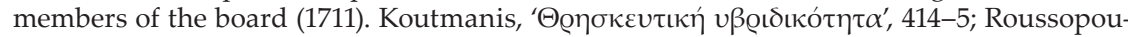

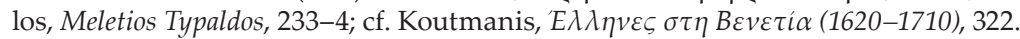

200 The same could be also argued about Michail Peroulis (though he confronted Typaldos later), accounting for the unanimous approval of the Greek elite at Venice that Typaldos received at the very beginning.

201 Makolas, Justin, 1.

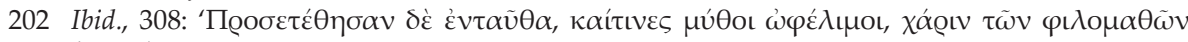

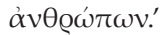

203 See above in the article, page 162. Makolas, Justin, 365. 
reveals and obscures: 'These [Becanus' excerpts] have been added to the Christian doctrine, by the Priest Michail Mitros from Ioannina, for the sake of somebody who asked for them.' ${ }^{204}$ The equivocation is striking. While the statement divulges the identity of the editor and author, Michail Mitros, at the same time it prevaricates on the solicitant's identity. Moreover, while it purports to be informative, it misleads. Yet the equivocation of the statement pertains rather to our own ignorance than to the contemporary readers of the book. They did know who the 'somebody' was. And it is precisely the awareness of this identity that generates the autonomous dynamic of the short Christian Doctrine within, as well as beyond, Makolas' Justin of 1686.

Indeed, this statement, seen in the context of the 'nazione greca' of the late-seventeenth-century Venice, effectively names the unnamed figure. In a book of Ioannis Makolas, issued in 1686, edited by Michail Mitros and with epigrams of Georgios Zandiris and Nikodimos Vavatenis, the 'somebody' could be none other than the central figure of their circle: the then famous-and soon thereafter notorious-Meletios Typaldos, the latest Metropolitan of Philadelphia at Venice. His involvement in the translation and the publication of a confessionally ambiguous text would not, of course, have been surprising. The Chistian Doctrine by Mitros in fact substantiates the assertion of the Roman sources about the direct contacts of Typaldos with Vatican since at least 1685-1686. Furthermore, it was not unusual that Typaldos guided and promoted through his circle the publication of pastoral textbooks in accordance with his objectives. A few years later, another one of his protégés, Methodios Anthrakitis, would issue the Christian Contemplations (Venice 1699), the Visit of a Confessor to a Patient (Venice 1707) and the Shepherd of Rational Sheeps (Venice 1708); all of them based-unsurprisingly-on Catholic templates. ${ }^{205}$

Typaldos' perspective sheds some light on an oddity already noticed in the content of the Christian Doctrine by Mitros concerning its confessional direction: the very ambiguity of this catechism lies in the observation that, although Mitros sedulously attempted to 'Orthodoxize' the doctrinal aspects of the Jesuit Dottrina christiana, he did not do the same with regard to the devotional aspects. Instead, he maintained in his text several distinctive elements of the Catholic worship. ${ }^{206}$ Interestingly, modern research has pointed out that this was also the case in the struggle between Meletios Typaldos and his adversaries within the Greek Confraternity of Venice; the main field of controversy-or, at least, the public one-was, precisely,

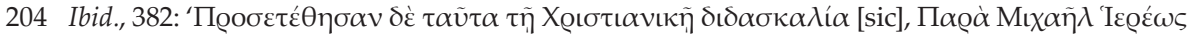

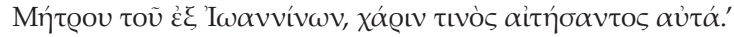

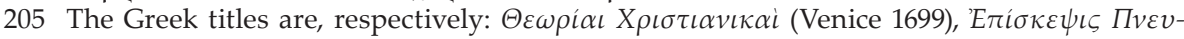

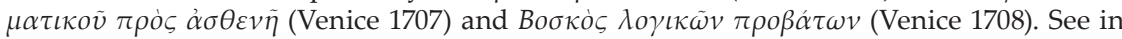
detail, V. Tsakiris, Die gedruckten griechischen Beichtbücher zur Zeit der Türkenherrschaft. Ihr kirchenpolitischer Entstehungszusammenhang und ihre Quellen (Berlin-New York 2009) especially

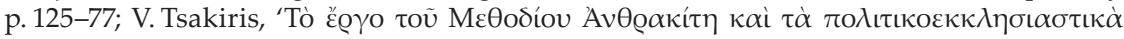

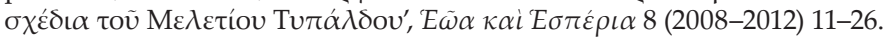

206 See above, page 158. 
the field of devotional matters. From the late 1690s his enemies frequently accused Typaldos constantly of challenging the Greek rite by undermining the purity of Orthodox worship. ${ }^{207}$ This significant coincidence may support the argument on the close link between Mitros' text and Typaldos' contrivance; it cannot, however, illuminate the very content of Mitros' confessional ambiguity.

On the other hand, the juxtaposition of the Christian Doctrine by Mitros with the discussion of 'religious hybridity' - as it has been labelled-among the Greeks in Venice at the same period ${ }^{208}$ leads to a similarly 'fertile' dead-end. This hybridity has been identified, in a narrow sense, with the Uniates ${ }^{209}$, but in the broadest sense it includes any form-and they are numerous, indeed-of unconscious or organic religious syncretism pertaining to the Orthodox community of Venice within a unique but inviolable limit: the Orthodox rite. ${ }^{210}$ Consequently, even though, at first glance, this all-pervading religious syncretism would match the peculiar blending of Orthodox and Catholic elements that coexist in Mitros' catechism, eventually it would be naïve to consider the latter as an anticipated product of such a fluid confessional condition. First of all, the Christian Doctrine by Michail Mitros transgresses precisely the acceptable boundaries of this religious hybridity, as it insults Orthodox devotional practices and worship. Nor does it cohere with a typical example of the religious porousness that marks the Orthodox community of Venice: the doctrinal topic of Purgatory. Starting from the first Orthodox Metropolitan of Philadelphia, Gavriil Seviros (late sixteenth century), and continuing until the famous preacher Ilias Miniatis (another sometime protégé of Typaldos ${ }^{211}$ ), the Catholic doctrine of the Purgatory had been implicitly adopted by the religious leaders of the Greek Confraternity at Venice. ${ }^{212}$ In the opposite direction, Mitros, re-translating the passage in question of the catechism, claims-in accordance with the Eastern Church-that only divine grace can absolve those condemned to hell, but not the prayers of the living faithful themselves. ${ }^{213}$

In seeking the confessional identity of the Christian Doctrine by Mitros, we should return to the central remark about its close relationship with Typaldos' plans and the question about the very content of these plans. Scholars studied

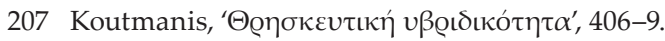

208 The term was introduced in the Greek case by the homonymous article of Sotiris Koutmanis. Ibid., 389-420.

209 Ibid., 390-1, 401-5.

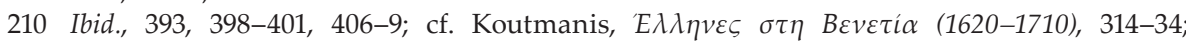

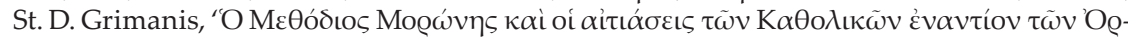

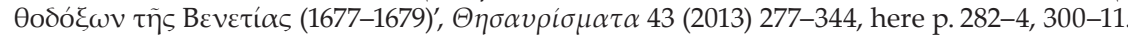
The sensitivity concerning the Greek rite is explainable, as the whole legal structure of the religious tolerance enjoyed by the Orthodox at Venice was based precisely upon in; the Venetian authorities purported that they were not 'schismatics' but only Uniates of Greek rite, while the Greek Confraternity tried to keep it intact as the best safeguard against the Roman insidiousness.

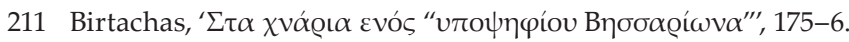

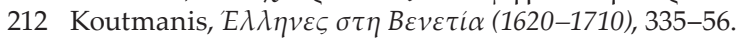

213 See above, pages 154-5. 
Typaldos' affair as early as the late nineteenth century ${ }^{214}$ and many scenarios have been proposed as to his aspirations: cardinal of the Roman Church, patriarch at Venice with jurisdiction across the Venetian territories of the Levant, or even patriarch at Constantinople. ${ }^{215}$ The common denominator of all these scenarios is the assumption of his Uniate religious identity. The figure of Typaldos continues to be puzzling to researchers, however. ${ }^{216}$ The affair surrounding him evolved gradually and in many phases, and was not necessarily based on a specific and single plan from the beginning. Moreover, the relevant sources, despite their abundance, are not helpful enough, as they come either from the Roman and Venetian allies of Typaldos or from his enemies-Orthodox, as well as Catholics; the evidence originating from Typaldos himself or his environment is limited and deliberately blurred. As such, the importance of Mitros' catechism is evident, because it is a theological handbook which could be probably considered the earliest documented manifestation of the confessional axis of Typaldos' venture.

Surprisingly, as far as the Christian Doctrine by Mitros is concerned, the confessional axis of Typaldos could not coincide (at least in 1686) with the Union of the Eastern Churches with Rome, as it had been elaborated from the Council of Ferrara-Florence (1438-1439) onwards. What is more, the Uniate profession of faith included the entire doctrinal set that Mitros had painstakingly censored (that is,

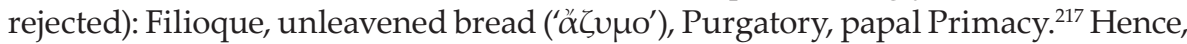
it would be impossible to argue that it constitutes an even disguised Uniate catechism-in the established sense of the term, of course. In fact, the confessional ambiguity of the Christian Doctrine by Mitros runs parallel to the essentially ambiguous religious venture of Typaldos.

What is beyond doubt, however, is that Mitros' catechism does adopt and propagate a kind of religious syncretism, but definitely the reverse of that hitherto typical among the Greek Orthodox inhabitants of Venice. It could be argued that it represents an unprecedented transconfessional endeavor, which aspires to capitalize on but also transcend the Uniate legacy by proposing a new receptivity and compromise beyond the doctrinal core of each confession. What the Christian Doctrine by Mitros implies is that the Greeks would adopt several Latin devotional practices and, therefore, communicate in sacraments with Catholics (a Uniate legacy), but without forsaking their Orthodox dogmas. Although the combination between 'essentials' and 'adiaphora' might look quite peculiar (if not mendacious)

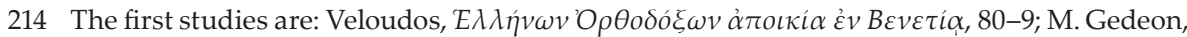
'Tuтád 289-92, 298-300, 305-8, 317-20.

215 For the relevant recent literature see above, footnotes 190-1.

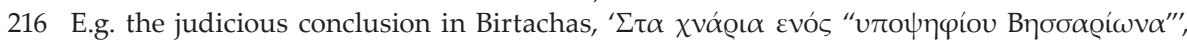
180-1. Moreover, the significant, almost total silence about Typaldos' affair across the otherwise meticulous handbook of Gerhard Podskalsky ( $\tau i \alpha \varsigma)$ is noteworthy.

217 Urban VIII, Pope of Rome, Professio orthodoxae fidei ab Orientalibus facienda (Rome 1671) 10-13.

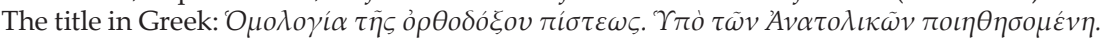


today, it was not so at that time. By the second half of seventeenth century the confessionally divided Europe experienced many irenic endeavors aiming to reach a compromise among the Christian denominations by setting aside their doctrinal differences. ${ }^{218}$ It is worth mentioning the corresponding irenic views of the Dutch Hugo Grotius, who 'emphasized the distinction between natural religion, consisting of a few rational tenets that could be derived from a priori and a posteriori reasoning, and many secondary, revealed articles of faith', namely some founding doctrines of the Christian religion (like the doctrine of the Trinity), which 'were open to discussion, because they were not self-evident or rationally demonstrable; they had to be derived from supernatural revelation.' ${ }^{219}$

Of course, the Venetian Republic was not the Dutch Republic: the religious realities in the two states differed greatly. Both were certainly multi-confessional states in nature, ${ }^{220}$ yet in contrast to the abundance of Reformed Churches that characterized the Dutch Republic, Venice was formally a Catholic state with a single established church: the Church of Rome. The deliberate religious toleration of the Serenissima depended on this religious consensus. ${ }^{221}$ The Orthodox populations of the Adriatic and the other Venetian possessions in the Levant (Ionian islands and the Peloponnese, in the late seventeenth century) settled on an evasive church condition, where their local Orthodox hierarchy had been somehow recog-

218 A detailed survey of Irenicism is given by H. Louthan, 'Irenicism and Ecumenism in the Early Modern World: A Reevaluation', Odrodzenie i Reformacja w Polsce 61 (2017) 5-30; E. Koch, 'Irenicism', in Gr. Dunphy and A. Gow (eds), Encyclopedia of Early Modern History Online, http://dx.doi.org/10.1163/2352-0272_emho_SIM_021518. Cf. J. E. Bradley, 'Toleration and movements of Christian reunion, 1660-1789', in St. J. Brown and T. Tackett (eds), The Cambridge History of Christianity, VII. Enlightenment, Reawakening and Revolution 1660-1815 (Cambridge-New York 2006) 348-70, especially p. 361-3. The interesting discussion in the Dutch Republic about the 'minimal religion' and a 'comprehensive church' has been studied by H. Nellen, 'Minimal Faith and Irenic Ideals in Seventeenth-Century Scholarly Circles. Hugo Grotius as a Guardian of Isaac Casaubon's Legacy', Church History and Religious Culture 94 (2014) 444-78.

219 Nellen, 'Minimal Faith and Irenic Ideals', 463, 468. Interestingly, the first elaborations of Grotius' Irenicism have been detected in a treatise of 1611 titled Meletius, sive de iis quae inter Christianos conveniunt epistola. It would be fascinating to think that the homonymy between this title and the ecclesiastical names of both Mitros and Typaldos (Meletios) suggests some specific intellectual entanglement. Nevertheless, Meletius was never published before its recent discovery. G. P. Meyjes (ed. and transl.), Hugo Grotius-Meletius, sive de iis quae inter Christianos conveniunt epistola (Leiden-New York-Copenhagen-Cologne 1988). It is worth mentioning, however, that, according to the editor, the name of Grotius' treatise comes from another Orthodox, Meletios Pigas, Patriarch of Alexandria (1590-1601) and proponent of the reconciliation among the Christian denominations. Ibid., 15-21.

220 As regards the Netherlands, see Part II under the homonymous heading in Th. M. Safley (ed.), A Companion to Multiconfessionalism in the Early Modern World (Leiden-Boston 2011). Albeit, surprisingly, this volume has not a single reference to the Venetian state.

221 For a recent overview see H. Saito, 'Religious policy in early modern Venice', in K. Fukasawa, B. J. Kaplan and P.-Y. Beaurepaire (eds), Religious Interactions in Europe and the Mediterranean World. Coexistence and Dialogue from the Twelfth to the Twentieth Centuries (London-New York 2017) 231-43. 
nized by Venice, even if it was officially characterized as 'schismatic' and, in some cases, fell ostensibly under the Latin bishop. ${ }^{222}$ The situation with the Orthodox in Venice itself was little different, because their community, the Scuola di San Nicolò dei Greci, was from the very beginning (1498) jus patronatum of the Venetian senate. As jus patronatum, the entire function of the Greek Confraternity, including the operation of its church, San Giorgio dei Greci, and the election of its hierarchy, as well as of the Metropolitan of Philadelpnia, was under the exclusive supervision of the civil Venetian provveditori di comun. The Catholic Patriarch of Venice had no jurisdiction over the (Orthodox) 'nazione greca' of the city who, officially, just followed the Greek rite. ${ }^{223}$

Even so, the Union of the Eastern Christians with the Western Church always remained the outright benchmark of any interconfessional dialogue or transconfessional venture across the Venetian territories. Besides, even the regular, completely formal and ostensible, official treatment of the Orthodox as 'schismatics' by the authorities designated the accession to Union as an essential prerequisite for the complete integration into Venetian society and state. Typaldos and his colleagues were fully aware of this reality, ${ }^{224}$ but the established Roman criteria for the Union (pursuant to the Florentine Decree) apparently did not satisfy them. Additionally, the distinct figure of the Uniate had been strongly criticized in the late-seventeenth-century Venice by both Orthodox and Catholic Greeks for being an oddity of double religious nature and, consequently, a 'neutral', a 'third [confessional] genre', if not a common and censurable opportunist. ${ }^{225}$

222 B. Arbel, 'Roman Catholics and Greek Orthodox in Venice's overseas colonies (mid-fifteenth to mid-seventeenth century)', in K. Fukasawa, B. J. Kaplan and P.-Y. Beaurepaire (eds), Religious Interactions in Europe and the Mediterranean World. Coexistence and Dialogue from the Twelfth to the Twentieth Centuries (London-New York 2017) 245-59; Sp. Karydis, ' $\mathrm{H}$

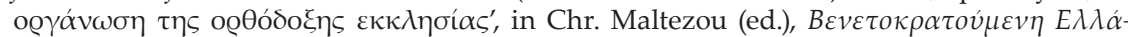

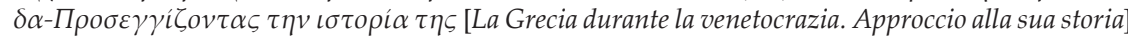

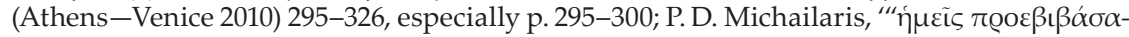

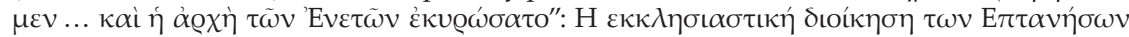

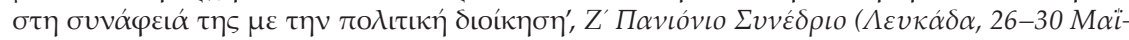

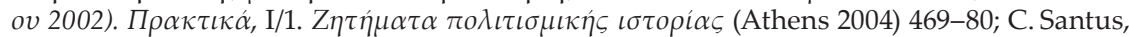
Trasgressioni necessarie: Communicatio in sacris, collaborazioni e conflitti tra le comunità cristiane orientali (Levante e Impero ottomano, XVII-XVIII secolo) (PhD Thesis) (Scuola Normale Superiore, Pisa-École Pratique des Hautes Études, Paris 2015) 229-88; D. Michalaga, $\Sigma v \mu \beta o \lambda \eta َ \sigma \tau \eta v$

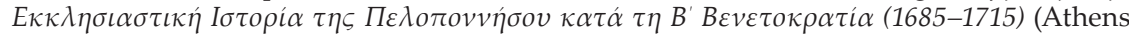
2008); M. Trogrlić, 'Religion und Konfessionen in Dalmatien im 17. und 18. Jahrhundert', in G. Ortalli and O. J. Schmitt (eds), Balcani occidentali, Adriatico e Venezia fra xiii e xviii secolo [Der westliche Balkan, der Adriaraum und Venedig (13.-18. Jahrhundert)] (Wien 2009) 327-50.

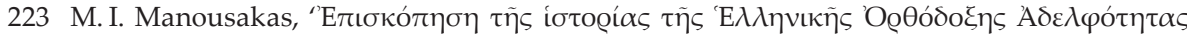

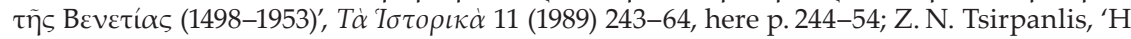

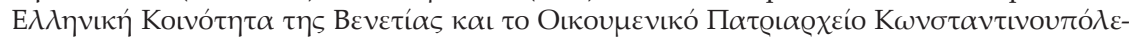

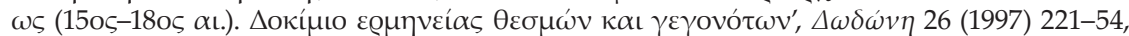

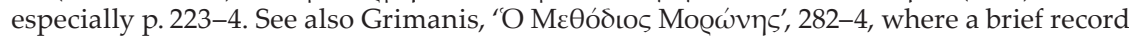
of the previous relevant literature can be found.

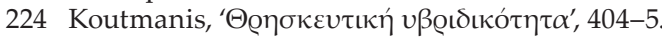

225 Ibid., 390-1, 398, 401-5. 
The Christian Doctrine by Mitros indicates, actually, that in 1686, at the beginning of Typaldos' affair, there was a circle of Greeks at Venice who strongly believed that a unity between the Orthodox and the Catholic Church would be desirable and possible, despite and beyond the narrow limitations of the Florentine Decree of Union of 1439 and its Tridentine modifications. ${ }^{226}$ That initiative, showing affinities with the contemporary European movement of Irenicism, would be characterized as some kind of an 'irenic Union'. ${ }^{227}$ In such an 'irenic Union', as inferred from Mitros' catechism, the Orthodox should keep their doctrinal particularities as 'essentials' (on Trinity, the Eucharist, the salvation of the souls and the ecclesiology), while deferring to some aspects of the Latin worship and devotion that were considered 'adiaphora' (the sign of the cross, the confession, the worship of Mary, the church tithes). Nevertheless, it was a unity of two distinct entities; the addition 'On the Holy Scripture' was quite clear, as to the 'heretical' Protestant translations of Bible, ${ }^{228}$ and it left no room for any accusations about Ecumenism.

In the mid-1680s, Typaldos and his supporters had many reasons to be optimistic about the outcome of their 'irenic' endeavor addressed to the Catholic Church. By 1682, a principal impediment to a compromise had been decisively undermined from within Catholicism; the 'Déclaration des Quatre articles' had rejected the Primacy of the Pope on behalf of the Gallican Church. ${ }^{229}$ What is more, across Catholic Europe the 1680s witnessed a remarkable revival of mystical spirituality expressed through the movement(s) of Quietism. As an alternative escape from the strict, post-Tridentine, Positive Theology, Quietism stressed the direct and unmediated contact of the faithful with God, setting aside the complicated doctrinal and ecclesiological issues. ${ }^{230}$ Its irenic deductions were apparent, since 'it was a

226 The text of that Profession of faith, certified by Pope Gregory XIII, in A. Possevino, Bibliotheca selecta de ratione studiorum. Ad Disciplinas et ad Salutem omnium gentium procurandam, I (Cologne 1607) 281-4.

227 I have coined this term in order to distinguish this Uniate endeavor from the Florentine Union, from which it differed significantly (see above in the article, page 172). This does not mean, however, that this endeavor could be included in Irenicism, or even Ecumenism, as explained below. It had simply been influenced to some extent by an 'irenic', and in a sense, European conjuncture-which is why I prefer to place quotation marks around 'irenic'.

228 It refers to the translations by Martin Luther, Johannes Oecolampadius and Sébastien

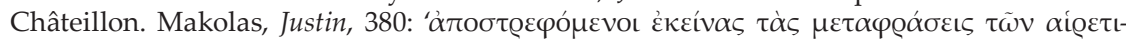

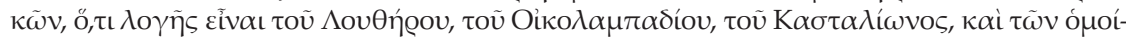
$\omega v$ tous.' Interestingly, Martin Becanus was also the author of a moderate-yet by no means irenic-treatise for 'an autonomous realm of contract law [valid even with heretics], unaffected by inter-confessional strife', under the title De fide haereticis servanda (1608). W. Decock, 'Trust Beyond Faith. Re-Thinking Contracts with Heretics and Excommunicates in Times of Religious War', Rivista Internazionale di Diritto Comune 27 (2016) 301-28, here p. 321.

229 For a comprehensive account of its religious and political context, as well as its aftermath, see J. Bergin, The Politics of Religion in Early Modern France (New Haven-London 2014) 206ff.

230 D. Deslandres, 'Quietism', in J. Dewald (ed.), Europe 1450 to 1789. Encyclopedia of the Early Modern World, V. Popular Culture to Switzerland (New York 2004) 124-5; U. L. Lehner and W. P. O'Brien, 'Mysticism and Reform in Catholic Theology between 1600 and 1800', in 
form of spirituality that easily crossed confessional boundaries.' ${ }^{231}$ In Italy, an important centre of Quietism had been developed in the Venetian Terraferma. The 'Quietisti' of Brescia had supporters in the local ruling class, while they maintained close contacts with members of the Roman curia and the theologian Miguel de Molinos (1628-1696), author of the famous quietist La guia espiritual (Rome 1675, Italian translation Rome 1681). ${ }^{232}$

The absolute emphasis of the 'Quietisti' of Venice on the Christian individual devotion rather than the Catholic doctrine and the potential irenic implications of those beliefs for the Catholic congregation had very likely fostered the confessional discussions within the Greek community of Venice and contributed to the elaboration of a notion of 'irenic Union', which Meletios Typaldos and his associates endorsed. Among them, Michail Mitros undertook, as early as 1686, to formulate and codify this notion in a catechetical text working simultaneously with both the Jesuit Dottrina christiana by Diego de Ledesma and its first Greek translation by Vincenzo Castagnola. Indeed, the outcome of that conjuncture-the Christian Doctrine in Mitros' version-was a transconfessional catechism that promoted an 'irenic Union' of Orthodox with Catholics on the initiative of the newly elected Greek Metropolitan of Venice, Meletios Typlados.

This undertaking could be hardly characterized merely as a cultural translation, or even appropriation, of Catholic catechetical knowledge into the Greek Orthodox community of the late-seventeenth-century Venice. It rather involves a peculiar transconfessional venture, which deploys a Jesuit catechism, modifying it drastically according to the Orthodox doctrines, so as to express an absolutely novel combination in the field of confessions. In this sense, the broader and dynamic notion of 'transfer' of theological knowledge is more appropriate, since it encompasses the adaptation, as well as the reconfiguration of knowledge in the new context. The unprecedented confessional formulation of an 'irenic Union' in fact resonates both the multiconfessional reality of the Venetian society and the coeval Quietistic trends within Catholicism. The objectives of this knowledge transfer and its transconfessional venture, undertaken by Meletios Typaldos' circle and articulated through the Christian Doctrine by Michail Mitros, were to claim under these new terms not only a different, 'irenic', Union of the Greek Orthodox with Catholic Church, but also the further integration of the 'nazione greca' into Venetian society.

U. L. Lehner, R. A. Muller and A. G. Roeber (eds), The Oxford Handbook of Early Modern Theology, 1600-1800 (Oxford 2016) 63-74, here p. 68-70. Regarding, in particular, the quietist affair and controversy in late-seventeenth-century France, see Bergin, The Politics of Religion, 277-85; Th. M. Lennon, Sacrifice and Self-interest in Seventeenth-Century France. Quietism, Jansenism, and Cartesianism (Leiden-Boston 2019).

231 Louthan, 'Irenicism', 11-12.

232 M. Sluhovsky, Believe Not Every Spirit: Possession, Mysticism, E Discernment in Early Modern Catholicism (Chicago-London 2007) 115-16. 


\section{Conclusion}

Being a Catholic catechism, the Dottrina Christiana by the Jesuit Diego de Ledesma incorporates-albeit in a simplified form-crucial dogmas and devotional practices derived from the core of Christian theology, some of which divided the Eastern and Western Churches for centuries. This is the basic premise from which Vincenzo Castagnola's and Michail Mitros's projects of transfer of theological knowledge begin. However, the outcome turns out to be extremely different, as both projects follow a procedure of decontextualization and recontextualization of Ledesma's catechism defined by modalities and historicity that are widely divergent.

On the one hand, the primary purpose of Castagnola, his colleagues and the leadership of the Society of Jesus was to render the Jesuit catechism by Ledesma both linguistically intelligible and culturally comprehensible to the Greek-speaking populations of the Aegean Islands and the Ottoman Empire. The negotiation was quite complicated, since the catechism, apart from being addressed to Greek-speaking Catholics, was also aimed at converting Greek Orthodox. Given that the scope was primarily pastoral and proselytizing and, secondarily, educational, the original material of the catechetical text by Ledesma had to be adapted accordingly. Yet, the adaptation should not affect the core of the Catholic doctrines. As a member of the Jesuit 'specialists in cultural translation', Castagnola and his colleagues considered the cultural and confessional particularities of the Greek-speaking regions but without transgressing their own confessional boundaries in their translation. Such was the process of accommodation that the confessional limits were clearly signaled even on the title-page: the ministry of both the author and the translator is noticeable, while the emblem of the Jesuits is there to remind everybody of the resolute aim of the Society of Jesus to propagate Catholicism across the globe, including the Greek world. Hence, the Christian Doctrine by Vincenzo Castagnola represents a clear and explicit example of cultural translation carried out by the Jesuits at the same time that Catholic Reformation was at its peak and a Greek Orthodox Age of Confessions was about to begin.

On the other hand, the transfer of Catholic theological knowledge in the version of Mitros is marked, at first glance, by a confessional ambiguity that disguises the transconfessional aspirations of the faction of Meletios Typaldos. It is not simply that the confessional boundaries between Catholicism and Orthodoxy were blurred, but that this blurring is unprecedented with regard to these interconfessional relations. ${ }^{233}$ The unprecedented nature of Mitros' confessional formulation can be primarily interpreted in the context of the Greek Orthodox Age of Confessions and in conjunction with the broadened concept of 'Confessionalization', perceived as a form of 'epistemic pressure' that raises and demands answers to unprecedented questions. ${ }^{234}$ Moreover, the uniqueness of the Christian Doctrine

233 Besides, everybody knew that the 'accommodatio'/'oikonomia' of the Union of Ferrara-Florence already represented a confessional ambiguity itself.

234 See above, pages $134-5$. 
that Mitros composes is situated exactly in the multiconfessional setting of the late-seventeenth-century Venice. In fact, the Council of Trent reintroduced with greater intensity the demand for the Union of the Eastern Church-which had faded for almost a century-by modifying the accommodating Florentine Decree to the confessionally strict, Tridentine Profession of faith for the Eastern Christians. ${ }^{235}$ In this new quest for Union, instead of answering with a yes or no, the circle of Meletios Typaldos attempted to give a new response. Living in the multiconfessional Venice and experiencing the connotations of this plurality, as well as the impact of Quietism in 1680s, they proposed through the Christian Doctrine by Michail Mitros-instead of a conversion-a transconfessional, so to speak 'irenic Union' with Rome. In such an 'irenic Union' the Catholic devotional practices would become 'adiaphora', while the doctrinal discrepancies would be considered 'essentials'.

The (cultural) translation produced by Castagnola and his colleagues proved to be successful enough. It was a brief, simple and comprehensible catechism in vernacular Greek, promoted by the active Society of Jesus in the Levant and reprinted many times. Following the general trend of the Catholic missions in the Greek-speaking lands, it principally contributed to the pastoral ministry of the missionaries among the Greek-speaking Catholics of the Aegean Islands and of other places in the Ottoman Empire where Jesuits had resided; its proselytizing function would be limited, however. All in all, the historicity of the Christian Doctrine by Vincenzo Castagnola intertwined with and depended on the historicity of the Catholic Reformation and, especially, the Jesuit missionary activity in the Levant. The dates and places of its (re)publications precisely capture this intertwining: the first two editions at an interval of ten years in the Roman center of the Society (Rome 1595 and 1604), a third one soon thereafter in Venice (1609), and, much later, two more editions from the influential Jesuit mission in France (Paris 1657 and 1687). It was issued again almost a century later, for the last time, in Venice in $1772{ }^{236}$ one year before the final suppression of the Society of Jesus across the world.

The success of Castagnola's initiative is also reflected in the choice of Michail Mitros and, thus, Meletios Typaldos to deploy this specific Catholic catechism as the canvas for illustrating their 'irenic Union'. Against all odds, the attitude of the Great Church at Constantinople towards Typaldos, Mitros and their transconfessional venture appeared to be at least forbearing, if not permissive. ${ }^{237} \mathrm{Al}-$ though the first serious allegations against the Metropolitan of Venice had already reached Constantinople in the early $1690 \mathrm{~s}^{238}$ and despite the fact that after 1700

235 See above, page 175.

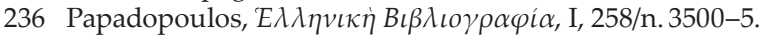

237 The wait-and-see position of the Greek Orthodox Church on Typaldos' affair has not been studied adequately, neither in its religious nor its political implications. For some aspects of the later suspicion about the Orthodoxy of Michail Mitros/Meletios of Athens, see Sarris, 'Composing and publishing a non-confessional history in the age of Greek Orthodox confessions'.

238 Roussopoulos, Meletios Typaldos, 27-8. 
the testimony of Ilias Miniatis and the correspondence between Nikolaos Komninos-Papadopoulos and Chrysanthos Notaras were very revealing, ${ }^{239}$ Typaldos was deposed only in June 1712-a year before his death. ${ }^{240}$ With regard to the wavering posture of the Patriarchate of Constantinople, a broader contextualization is needed, taking into consideration the contemporary heated confessional discussions in progress within the Greek Orthodox Church ${ }^{241}$ which were interwoven with the seismic political and military events in the aftermath of the Ottoman defeat in front of Vienna in 1683: the Great Turkish War of the Holy League (1683-1699), the Treaty of Karlowitz (1699) and, especially, the Venetian conquests in the southern Greek peninsula (1684-1688) with the establishment of the Realm of the Morea (1688). Both Typaldos with his associates and the church circles in Constantinople seemed to count on an enhanced role of Venice in the Levant; a possibility that might have made a discussion of a Union of some kind (even 'irenic') more appealing.

Ultimately, however, this transconfessional experiment did not work. The advantageous momentum turned out to be very short. Already the year before the issue of Mitros' Christian Doctrine, the Holy See had arrested Miguel de Molinos. In 1687 Quietism was condemned, while a wave of trials against 'heretics' swept Italy in the following years. ${ }^{242}$ Rome proved to be very reluctant to accept any compromise with Typaldos: in the summer of 1690, when contact between them was restored, Typaldos himself signed the revised Tridentine Profession of faith for the Eastern Christians. ${ }^{243}$ Though the Venetian state continued to support Typaldos' faction against its opponents in the Greek Confraternity, the aspiration of an 'irenic Union' may have gradually faded away, along with the grandiose plans of Serenissima concerning the future of the Realm of the Morea. At the end of the first decade of the eighteenth century, Venice's inability to play any important role in the Greek peninsula was evident to everybody, making any further inter- or trans-confessional discussion unprofitable for the Great Church at Constantinople. The course of the subsequent events is known. In 1712, Typaldos was deposed as an 'apostate', 'heterodox', 'impious', even 'atheist'. ${ }^{244}$ Eleven years later, in 1723, the works of his old protégé, Methodios Anthrakitis, were also condemned by

239 Obviously, it was not coincidental that the epistolary treatises sent by Komninos-Papadopoulos to Chrysanthos in the same period spoke about the 'misbelief of the Quietists in

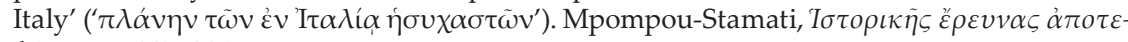
$\lambda \dot{\varepsilon} \sigma \mu \alpha \tau \alpha, 237-304$.

240 Roussopoulos, Meletios Typaldos, 28-9, 236.

241 See, in this volume, the article by Ionut Alexandru Tudorie.

242 Deslandres, 'Quietism', 124-5; de Boer, 'Borromeo, Penance, and Confessional Boundaries', 369-72; cf. Sluhovsky, Believe Not Every Spirit, 116-23. With regard to the persecution of the 'Quietisti' in Italy, see A. Malena, L'eresia dei perfetti. Inquisizione Romana ed esperienze mistiche nel Seicento italiano (Rome 2003).

243 That of Urban VIII, Pope of Rome, Professio orthodoxae fidei ab Orientalibus facienda (Rome 1671). Of course, the signing of the Uniate Profession of faith by Typaldos did not necessarily mean that he had consciously accepted the content of this Union. See Birtachas, ' $\Sigma \tau \alpha$

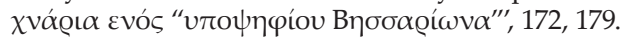

244 Gedeon, 'Tvтád 
the Synod of Constantinople, because they taught 'the atheist and most impious heresy of Molinos. ${ }^{245}$ Finally, in 1727, the Synod of Constantinople under Patriarch Ieremias III issued the Concise and principal exposition of the holy articles and doctrines of the Eastern Christian Church, which expounds 'the pure and healthy and perfect profession of the faith of the pious and orthodox Christians.' ${ }^{246}$ It goes without saying that the Christian Doctrine by Michail Mitros was never published again.

In summary, the transfer(s) of the Dottrina Christiana by Diego de Ledesma into the early modern Greek confessional landscape was marked by different modalities and historicity. Its cultural translation of Vincenzo Castagnola (1595), despite the accommodation method targeting multiconfessional Chios, did not transgress the Catholic confessional boundaries, since it always functioned as a main catechetical textbook in use by the Jesuit missions across the Greek-speaking populations of the Levant. Its use also determined its historicity: it was closely dependent on the reformative and missionary time of the Society of Jesus, until the final suppression of the latter. By contrast, the transfer carried out by Michail Mitros was more complicated and ambitious. Originating, in fact, from the circle around Meletios Typaldos, the Christian Doctrine that Mitros wrote and published at the end of Ioannis Makolas' Justin (1686) was intended to describe the basic tenets of a novel, transconfessional combination in the framework of multiconfessional Venice. Hence, Mitros employed both Ledesma's and Castagnola's catechisms as 'underlying' texts, in order to compose a confessionally new one. Though he fully respected their form and structure and he literally reproduced the majority of their content (even the wording of Castagnola), he made small but substantial changes, additions, removals, or restatements so that his work delineates in broad terms the coordinates of an 'irenic Union' of the Orthodox with Catholic Church. In this sense, the Christian Doctrine by Michail Mitros is the outcome of the peculiar convergence of a theological knowledge derived from both Orthodoxy and Catholicism, but under the special multiconfessional conditions evolved dialectically from the confessional-building throughout early modern Europe. This entanglement entailed multiple temporalities that could hardly blend together: post-Tridentine Uniate policy of Rome, the stillborn impetus of Catholic mysticism, the brief awakening of the Lion of Saint Mark, the balances within the 'nazione greca' of Venice, the still open-ended confessional formulation of the Greek Orthodox Church.

So many were drowning in the confessional seas, each reaching for the single plank that would be their salvation.

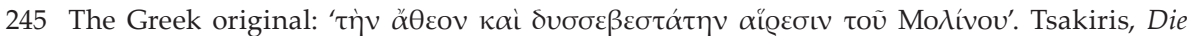
gedruckten griechischen Beichtbücher zur Zeit der Türkenherrschaft, 175-6.

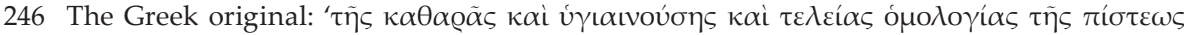

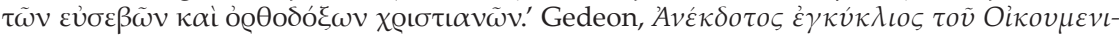

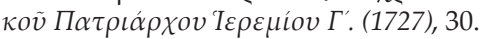




\section{Bibliography}

\section{Archives/Manuscripts}

Venice, Archive of the Hellenic Institute in Venice, B. Church, 3. Metropolis of Philadel-

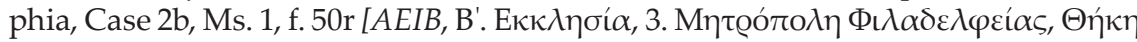

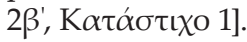

\section{Literature}

[Anonymous], 'tithes', in E. Livingstone (ed.), The Concise Oxford Dictionary of the Christian Church. https://www.oxfordreference.com/view/10.1093/acref/9780199659623. 001.0001/acref-9780199659623-e-5812.

[Anonymous], 'Tithe', in Encyclopaedia Britannica. https://www.britannica.com/topic/tithe.

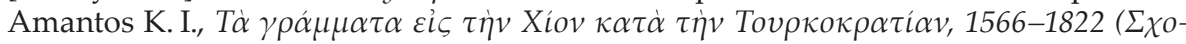

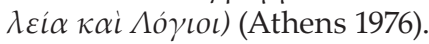

Arbel B., 'Roman Catholics and Greek Orthodox in Venice's overseas colonies (mid-fifteenth to mid-seventeenth century)', in K. Fukasawa, B. J. Kaplan and P.-Y. Beaurepaire (eds), Religious Interactions in Europe and the Mediterranean World. Coexistence and Dialogue from the Twelfth to the Twentieth Centuries (London-New York 2017) 245-59. Argenti Ph. P., The Religious Minorities of Chios: Jews and Roman Catholics (Cambridge 1970). Becanus M., Tituli Calvinistarum, collecti in ordinem redacti, et explicate (Mainz 1614).

- Manuale controversiarum huius temporis (Würzburg 1623).

- Compendium Manualis controversiarum huius temporis de fide ac religione (Mainz 1624).

Beck H., 'Pompeius Trogus', in R. S. Bagnall et al. (eds), The Encyclopedia of Ancient History (2012). doi: 10.1002/9781444338386.wbeah08134.

Belmonte J. M., To give Ornament, Splendor and Perfection: Diego de Ledesma and Sixteenth Century Jesuit Educational Administration (PhD Thesis) (Loyola University Chicago, Chicago IL 2006).

Bergin J., The Politics of Religion in Early Modern France (New Haven-London 2014).

Bettenson H. and Maunder Ch. (eds), Documents of the Christian Church, 4th edn (Oxford-New York 2011).

Bireley R., 'Redefining Catholicism: Trent and beyond', in R. P. Hsia (ed.), The Cambridge History of Christianity, VI. Reform and Expansion 1500-1660 (Cambridge 2007) 145-61.

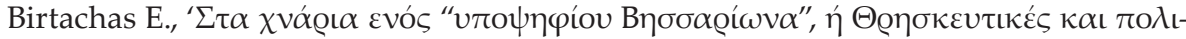

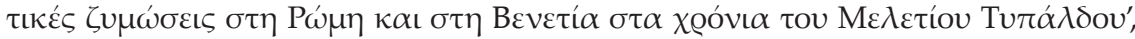

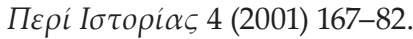

- 'Un "secondo" vescovo a Venezia: il metropolita di Filadelfia (secoli XVI-XVIII)', in M. Fr. Tiepolo (ed.), I greci a Venezia: atti del convegno internazionale di studio; Venezia, 5-7 novembre 1998 (Venice 2002) 103-22.

Boer W. de, The Conquest of the Soul. Confession, Discipline, and Public Order in CounterReformation Milan (Leiden-Boston-Köln 2001).

- 'At Heresy's Door: Borromeo, Penance, and Confessional Boundaries in Early Modern Europe', in A. Firey (ed.), A New History of Penance (Leiden-Boston 2008) 343-75.

Borgna A., Ripensare la storia universale. Giustino e l'Epitome delle Storie Filippiche di Pompeo Trogo [Spudasmata, 176] (Hildesheim-Zürich-New York 2018).

Bossy J., 'Moral Arithmetic: Seven Sins into Ten Commandments', in E. Leites (ed.), Conscience and Casuistry in Early Modern Europe (Cambridge 1988) 214-34. 
Bouchard J., 'Refined Attic Greek: Hallmark of the Emerging Phanariot Nobility', in R. Vidu and A. Mindicanu (eds), Proceedings of the 40th Annual Congress of the American Romanian Academy of Arts and Sciences, July 28-31, Montreal, Canada (California 2016) 11-17.

Bradley J. E., 'Toleration and movements of Christian reunion, 1660-1789', in St. J. Brown and T. Tackett (eds), The Cambridge History of Christianity, VII. Enlightenment, Reawakening and Revolution 1660-1815 (Cambridge-New York 2006) 348-70.

Burke P. and Hsia R. Po-Chia (eds), Cultural Translation in Early Modern Europe (New York 2007).

- 'Cultures of translation in early modern Europe', in P. Burke and R. Po-Chia Hsia (eds), Cultural Translation in Early Modern Europe (New York 2007) 7-38.

Campbell G., 'Catechisms', in The Oxford Dictionary of the Renaissance (Oxford 2003). https://www.oxfordreference.com/view/10.1093/acref/9780198601753.001.0001/acref9780198601753-e-754.

Capizzi C., 'Grecia', in Ch. E. O’Neill and J. M. Domínguez (eds), Diccionario Histórico de la Compañía de Jesús. Biográfico-Temático, II. Costa Rossetti-Industrias (Rome-Madrid 2001) 1809-11.

Carey P. W., Confession: Catholics, Repentance, and Forgiveness in America (Oxford-New York 2018).

Carter K. E., Creating Catholics: Catechism and Primary Education in Early Modern France (Notre Dame, IN 2011).

Casalini C., 'Rise, Character, and Development of Jesuit Education: Teaching the World', in I. G. Županov (ed.), The Oxford Handbook of the Jesuits (Oxford-New York 2019) 153-176.

Castagnola Vincenzo, Christian Doctrine (Rome 1595).

- Christian Doctrine (Venice 1609).

Clines R. J., 'The Society of Jesus and the Early Modern Christian Orient', in Jesuit Historiography Online (2016). http://dx.doi.org/10.1163/2468-7723_jho_COM_192582.

Comerford K.M., 'Clerical Education, Catechesis, and Catholic Confessionalism: Teaching Religion in the Sixteenth and Seventeenth Centuries', in K. M. Comerford and H. M. Pabel (eds), Early Modern Catholicism. Essays in Honour of John W. O'Malley, S.J. (Toronto-Buffalo-London 2001) 241-65.

Decock W., 'Trust Beyond Faith. Re-Thinking Contracts with Heretics and Excommunicates in Times of Religious War', Rivista Internazionale di Diritto Comune 27 (2016) $301-28$.

Deslandres D., 'Quietism', in J. Dewald (ed.), Europe 1450 to 1789. Encyclopedia of the Early Modern World, V. Popular Culture to Switzerland (New York 2004) 124-5.

Dmitriev M. V., 'Western Christianity and Eastern Orthodoxy', in R. P. Hsia (ed.), The Cambridge History of Christianity, vol. VI. Reform and Expansion 1500-1660 (Cambridge 2007) 321-42.

Donohue J., 'Middle East', in Th. Worcester et al. (eds), The Cambridge Encyclopedia of the Jesuits (New York 2017) 520-1.

Dursteler E., 'Education and Identity in Constantinople's Latin Rite community, c. 1600', Renaissance Studies 18/2 (2004) 287-303.

- Venetians in Constantinople. Nation, Identity, and Coexistence in the Early Modern Mediterranean (Baltimore 2006). 
Ermilov P., 'Towards a Classification of Sources in Byzantine Question-and-Answer Literature', in A. Rigo (ed.), Theologica Minora: The Minor Genres of Byzantine Theological Literature (Turnhout 2013) 110-25.

Fischer H., 'Konfessionalismus', in Theologische Realenzyklopädie, XIX. Kirchenrechtsquellen-Kreuz (Berlin-New York 1990) 426-31.

Flüchter A. and Wirbser R. (eds), Translating Catechisms, Translating Cultures. The Expansion of Catholicism in the Early Modern World (Leiden-Boston 2017).

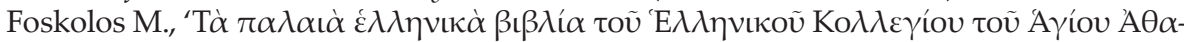

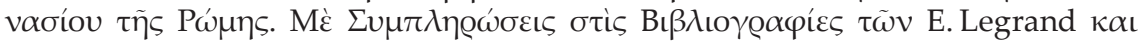

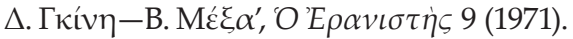

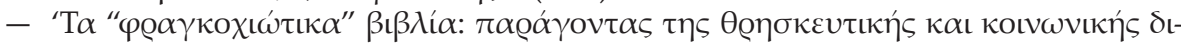

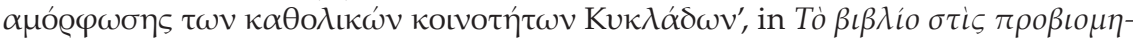

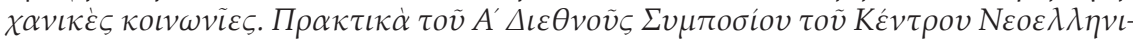
$\kappa \tilde{\omega} v ' E \rho \varepsilon v v \tilde{\omega} v$ (Athens 1982) 209-35.

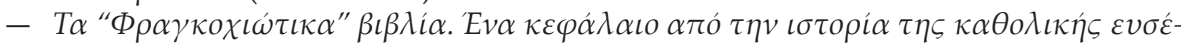

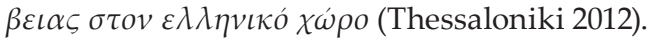

Fraas H.-J., Grünberg W., Bellinger G. J. and Hauptmann P., 'Katechismus', in Theologische Realenzyklopädie Online (Berlin-Boston 1988) 710-44. https://db.degruyter.com/ view/TRE/TRE.17_710_1D.

Frazee Ch. A., Catholics and Sultans. The church and the Ottoman Empire, 1453-1923 (New York 1983).

Fumaroli M., 'The Fertility and the Shortcomings of Renaissance Rhetoric: The Jesuit Case', in J. W. O'Malley et al. (eds), The Jesuits. Cultures, Sciences and the Arts, 1540 1773, I (Toronto-Buffalo-London 2000) 90-106.

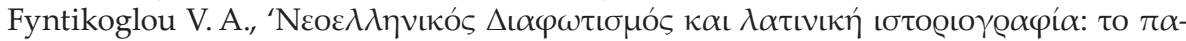

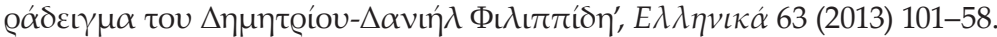

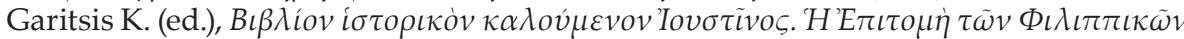

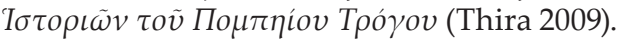

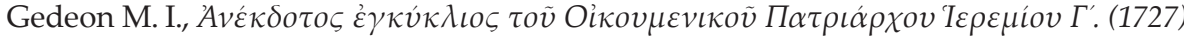

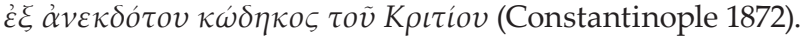

- 'Tuтád 276-80, 289-92, 298-300, 305-8, 317-20.

Golser K., 'Soziale Sünden, die zum Himmel schreien. Eine vergessene, aber anscheinend jetzt wieder aktuelle Kategorie', in A. Bondolfi and H. J. Münk (eds), Theologische Ethik heute. Antworten für eine humane Zukunft-Hans Halter zum 60. Geburtstag (Zürich 1999) 173-88.

Grendler P. F., 'Jesuit Schools in Europe. A Historiographical Essay', Journal of Jesuit Studies 1 (2014) 7-25.

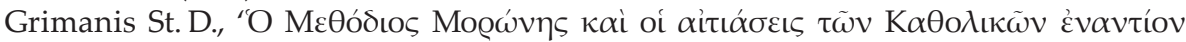

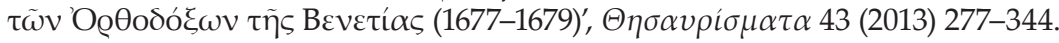

Hardy N., Criticism and Confession: The Bible in the Seventeenth Century Republic of Letters [Oxfrod-Warburg Studies] (Oxford-New York 2017).

Heiligenthal R. and Joest W., 'Gebot', in Theologische Realenzyklopädie, XII. Gabler-Gesellschaft/Gesellschaft und Christentum V (Berlin-New York 1984) 124-38.

Hellinga L., 'Catechism', in The Oxford Companion to the Book (Oxford 2010). https:// www.oxfordreference.com/view/10.1093/acref/9780198606536.001.0001/acref9780198606536-e-0930. 
Hsia R. Po-Chia, 'The Catholic mission and translations in China, 1583-1700', in P. Burke and R. Po-Chia Hsia (eds), Cultural Translation in Early Modern Europe (New York 2007) 39-51.

- 'Theological Developments in the Non-European World, 1500-1800', in U. L. Lehner, R. A. Muller and A. G. Roeber (eds), The Oxford Handbook of Early Modern Theology, 1600-1800 (Oxford 2016) 11-24.

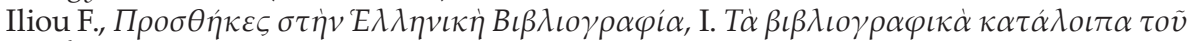

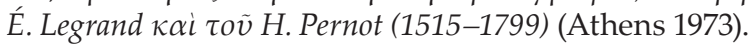

Israel J., Radical Enlightenment. Philosophy and the Making of Modernity, 1650-1750 (Oxford-New York 2001).

Iustinus M. I., Justin. Epitome of the Philippic history of Pompeius Trogus, transl. J. C. Yardley [Classical resources series, 3] (Atlanta 1994).

Janz R., 'Catechisms', in The Oxford Encyclopedia of the Reformation (Oxford 1996). https:// www.oxfordreference.com/view/10.1093/acref/9780195064933.001.0001/acref9780195064933-e-0247.

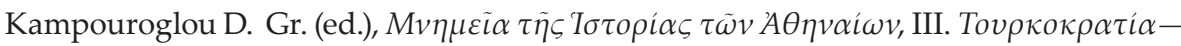

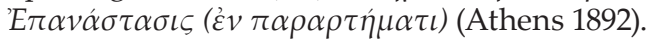

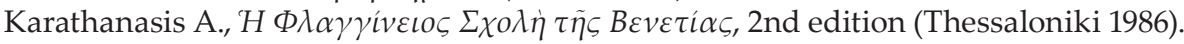

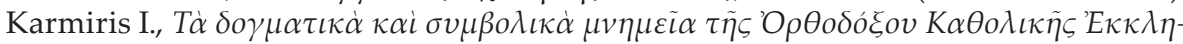
бi $\alpha \varsigma$, 2nd edn, I (Athens 1960).

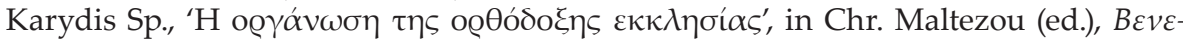

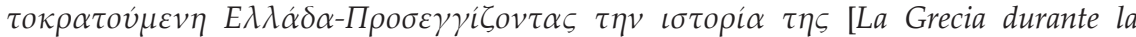
venetocrazia. Approccio alla sua storia] (Athens-Venice 2010) 295-326.

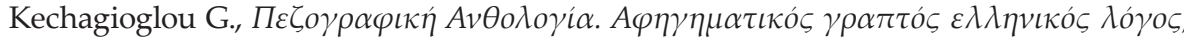

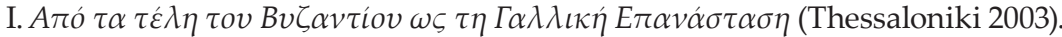

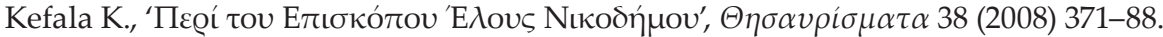

Kelly J. N. D., Early Christian Creeds, 3rd edn (London-New York 1972).

Klueting H., 'Confessionalization', in Religion Past and Present (2011). http://dx.doi.org/ 10.1163/1877-5888_rpp_COM_12055.

Koch E., 'Irenicism', in Gr. Dunphy and A. Gow (eds), Encyclopedia of Early Modern History Online. http://dx.doi.org/10.1163/2352-0272_emho_SIM_021518.

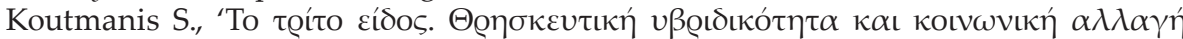

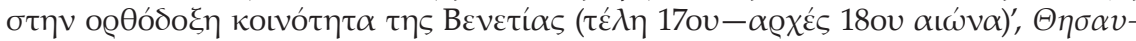
рí $\mu \alpha \tau \alpha 37$ (2007) 389-420.

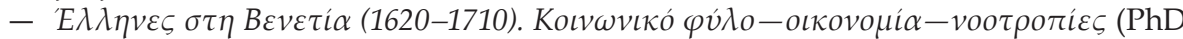
Thesis) (National and Kapodistrian University of Athens, Athens 2013).

Krajcar J., 'The Greek College under the Jesuits for the First Time (1591-1604)', Orientalia Christiana Periodica 31 (1965) 85-118.

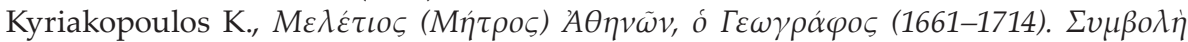

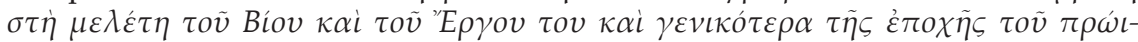
$\mu o v \Delta \iota \alpha \varphi \omega \tau \iota \sigma \mu o \tilde{v}, 2$ vols (PhD Thesis) (National and Kapodistrian University of Athens, Athens 1990).

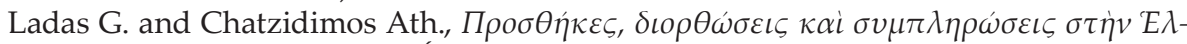

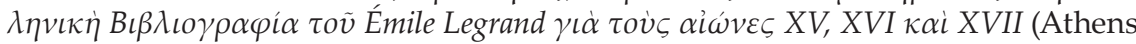
1976). 
Ledesma Diego de, Dottrina christiana breve, A modo di Dialogo, fra'l Maestro e'l Discepolo. Composta per il R. P. Iacomo Ledesma Dottor Theologo, della Compagnia di Giesu (Rome 1589).

- Dottrina christiana, Composta per il R. P. Giacomo Ledesma della Compagnia di Giesu. Di nuovo ristampata, \& diligentemente coretta (Rome 1593).

- Catecismo, y declaracion breve de la Dottrina Christiana, por preguntas, y respuestas entre Maestro, y Discipulo (Seville 1611).

Legrand É. (ed.), Relation de l'establissement des PP. de la Compagnie de Jésus en Levant (Paris 1869).

- Bibliographie hellénique ou description raisonnée des ouvrages publiés par des grecs au XVe et XVIe siècles, II (Paris 1885).

- Bibliographie hellénique ou description raisonnée des ouvrages publiés par des grecs au dix-septième siècle, I (Paris 1894).

- Bibliographie hellénique ou description raisonnée des ouvrages publiés par des grecs au dix-septième siècle, II (Paris 1894).

- Bibliographie hellénique ou description raisonnée des ouvrages publiés par des grecs au dix-septième siècle, V (Paris 1903).

Lehner U. L. and O'Brien W. P., 'Mysticism and Reform in Catholic Theology between 1600 and 1800', in U. L. Lehner, R. A. Muller and A. G. Roeber (eds), The Oxford Handbook of Early Modern Theology, 1600-1800 (Oxford 2016) 63-74.

Lennon Th. M., Sacrifice and Self-interest in Seventeenth-Century France. Quietism, Jansenism, and Cartesianism (Leiden-Boston 2019).

Louthan H., 'Irenicism and Ecumenism in the Early Modern World: A Reevaluation', Odrodzenie i Reformacja w Polsce 61 (2017) 5-30.

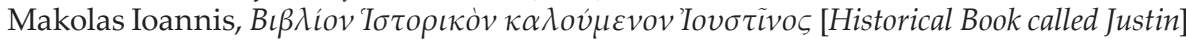
(Venice 1686).

Malena A., L'eresia dei perfetti. Inquisizione Romana ed esperienze mistiche nel Seicento italiano (Rome 2003).

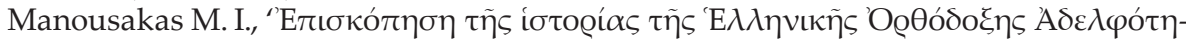

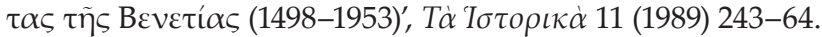

McDonald Gr., Biblical Criticism in Early Modern Europe. Erasmus, the Johannine Comma and Trinitarian Debate (Cambridge 2016).

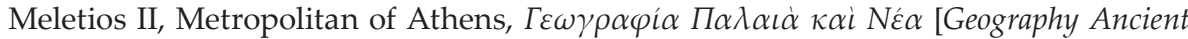
and Modern] (Venice 1728).

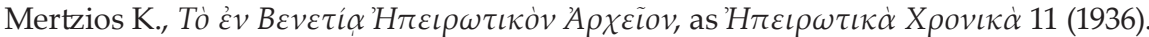

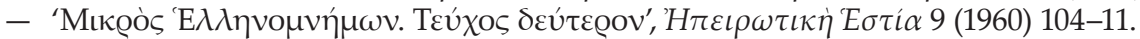

Meyjes G. P. (ed. and transl.), Hugo Grotius-Meletius, sive de iis quae inter Christianos conveniunt epistola (Leiden-New York-Copenhagen-Cologne 1988).

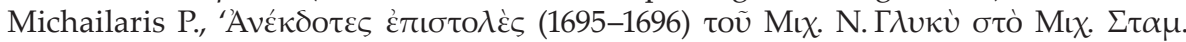

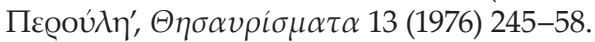

- 'Lattività armatoriale di Demetrio Peruli ed il suo intervento al traffic mediterraneo', in Économies méditerranéennes. Èquilibres et intercommunications, XIIe-XIXe siècles. Actes du IIe Colloque International d'Histoire (Athènes, 18-25 septembre 1983), I (Athens 1985) 175-86.

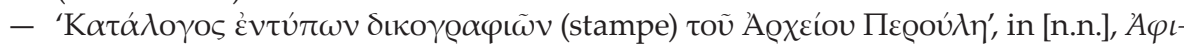

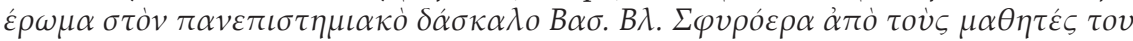
(Athens 1992) 155-68. 


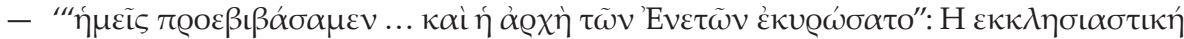

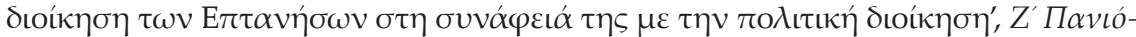

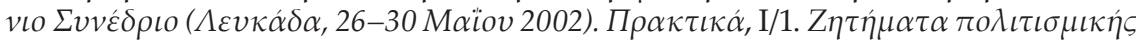

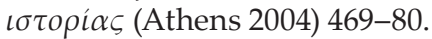

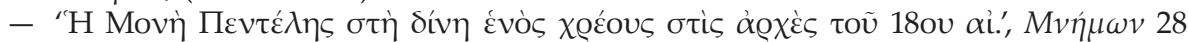
(2007) 31-47.

- 'Le avventure di una dote nello Stato venezian del Levante (XVIII sec.)', in Chr. Maltezou, A. Tzavara and D. Vlassi (eds), I Greci durante la venetocrazia: Uomini, spazio, idee (XIII-XVIII sec.). Atti del Convegno Internazionale di Studi (Venezia, 3-7 dicembre 2007) (Venice 2009) 131-40.

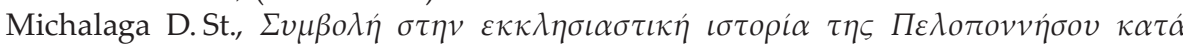

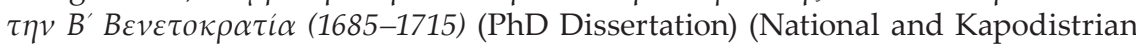
University of Athens, Athens 2006).

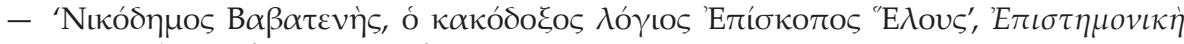

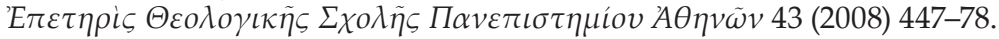

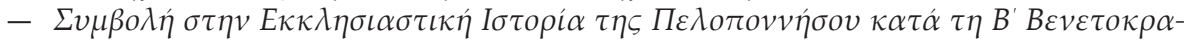

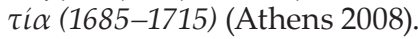

Miert D. van, The Emancipation of Biblical Philology in the Dutch Republic, 1590-1670 (Oxford-New York 2018).

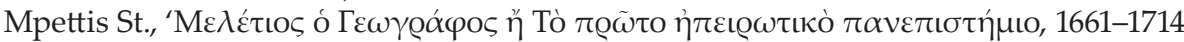

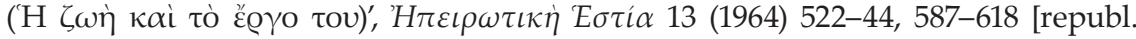
Athens-Ioannina 2007].

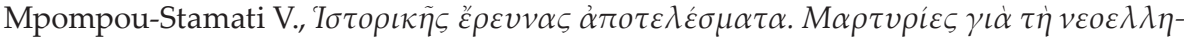

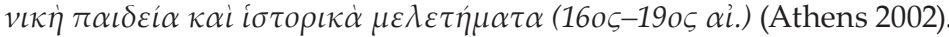

Murray L., 'A History of Historiography on Jesuit Exegesis', in Jesuit Historiography Online. http://dx.doi.org/10.1163/2468-7723_jho_COM_193804.

Myers W. D., "Poor, Sinning Folk". Confession and Conscience in Counter-Reformation Germany (Ithaca-London 1996).

- 'From Confession to Reconciliation and Back: Sacramental Penance', in R. F. Bulman and F. J. Parrella (eds), From Trent to Vatican II: Historical and Theological Investigations (Oxford-New York 2006) 241-66.

O'Malley J. W., Trent. What Happened at the Council (Cambridge MA-London 2013).

Nellen H., 'Minimal Faith and Irenic Ideals in Seventeenth-Century Scholarly Circles. Hugo Grotius as a Guardian of Isaac Casaubon's Legacy', Church History and Religious Culture 94 (2014) 444-78.

- and Steenbakkers P., 'Biblical Philology in the Long Seventeenth Century. New Orientations', in D. van Miert et al. (eds), Scriptural Authority and Biblical Criticism in the Dutch Golden Age: God's Word Questioned (Oxford-New York 2017) 16-58.

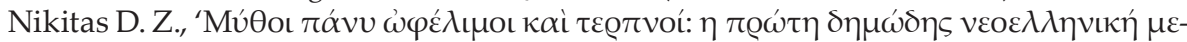

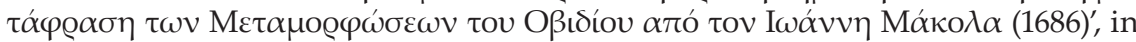

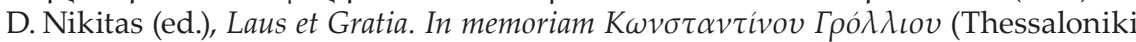
2012) 103-42.

Papadogiannakis Y., 'Erotapokriseis', in R. S. Bagnall e.a. (eds), The Encyclopedia of Ancient History, vol. V. Ec-Ge (Chichester 2013) 2491-3.

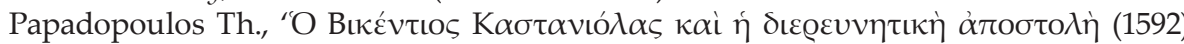

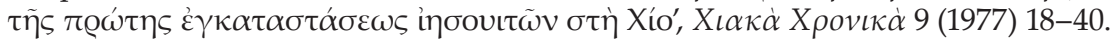




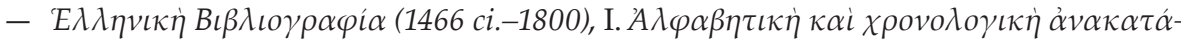
$\tau \alpha \xi \iota \varsigma$ (Athens 1984).

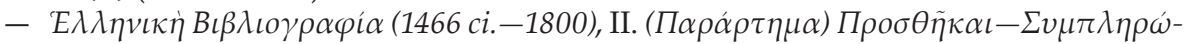
$\sigma \varepsilon \iota \varsigma-\Delta \iota \rho \rho \theta \omega \sigma \varepsilon \iota \varsigma$ (Athens 1986).

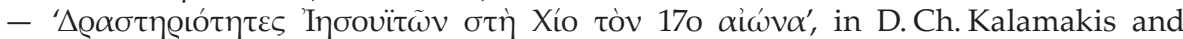

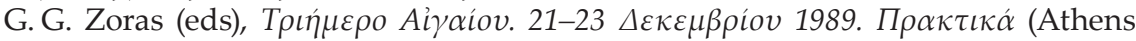
1990) 309-28.

Papaïliaki-Gamelon N., 'Livres de catéchismes et pratiques scolaires des missionnaires français en Grèce au XVIIe siècle', in H. Didier and M. Larcher (eds), Pédagogies missionnaires: traduire, transmettre, transculturer. 32e Colloque du CRÉDIC. Lisbonne 30 août-3 septembre 2011 (Paris 2012) 137-46.

Papaïliaki N., ‘Des schismatiques et des orthodoxes: action missionnaire française et unité de l'Église en Grèce aux XVIIe et XVIIIe siècles', in M.-H. Blanchet and Fr. Gabriel (eds), Réduire le Schisme? Ecclésiologies et Politiques de l'Union entre Orient et Occident (XIIIe-XVIIIe siècle) (Paris 2013) 303-12.

Pappas V., 'Modern Greek Translations (1686-1818) of Latin Historical Works', Studia Philologica Valentina 17/14 (2015) 257-72.

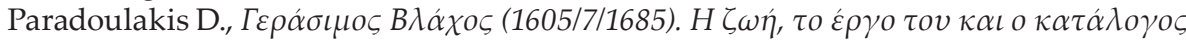
$\tau \eta \varsigma \beta \iota \beta \lambda \iota 0 \theta \eta \kappa \eta \varsigma \tau o v$ (MA Thesis) (University of Crete, Rethymno 2017).

Phipps W. E., The Apostles' Creed. The Ongoing Struggle of the Church to Define Its Basic Beliefs (Lewinston-Queenston-Lampeter 2010).

Platon, Metropolitan of Moscow, Orthodox Teaching, namely Synopsis of the Christian Theology, transl. Diamantis Korais (Athens 1836).

Ploumidis G., 'La confraternita greco-cattolica di Santo Spiridione a Venezia (1708)', Bolletino della Badia Greca di Grotta Ferrata 27 (1972) 51-70.

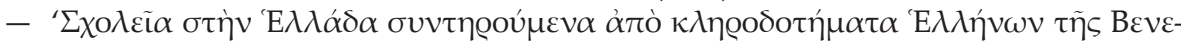

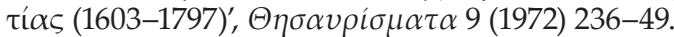

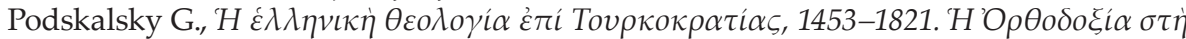

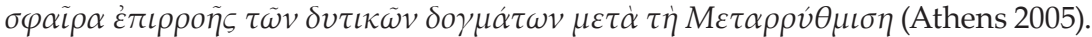

Pomplun Tr., 'Baroque Catholic Theologies of Christ and Mary', in U. L. Lehner, R. A. Muller and A. G. Roeber (eds), The Oxford Handbook of Early Modern Theology, 1600-1800 (Oxford 2016) 104-18.

Possevino A., Bibliotheca selecta de ratione studiorum. Ad Disciplinas et ad Salutem omnium gentium procurandam, I (Cologne 1607).

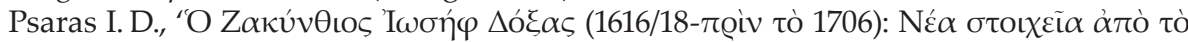

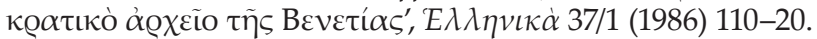

Ratschow C.H., 'Konfession/Konfessionalität', in Theologische Realenzyklopädie, XIX (Berlin-New York 1990) 419-26.

Raupp W., 'Becan (Becanus), Martin', in W. Kühlmann (ed.), Killy Literaturlexikon. Autoren und Werke des deutschsprachigen Kulturraums, 2nd edn, I (Berlin-New York 2008) 382.

- 'Becanus (Bécan, Verbee[c]k, Van der Bee[c]k; Schellekens, Scell-), Martinus (Martin)', in St. Arend et al. (eds), Frühe Neuzeit in Deutschland 1620-1720. Literaturwissenschaftliches Verfasserlexikon, I (Berlin-Boston 2019) col. 481-502.

Reiser M., 'The History of Catholic Exegesis, 1600-1800', in U. L. Lehner, R. A. Muller and A. G. Roeber (eds), The Oxford Handbook of Early Modern Theology, 1600-1800 (Oxford 2016) 75-88. 
Resines L., 'El catecismo de Diego de Ledesma', Archivum Historicum Societatis Iesu 66/132 (1997) 249-74.

Rodotà P. P., Dell'origine, progresso, e stato presente del Rito Greco in Italia, III. Degli Albanesi, Chiese greche moderne, e Collegio Greco in Roma coll'indice di tutta l'opera (Rome 1763).

Rogerson J. W. and Lieu J. M. (eds), The Oxford Handbook of Biblical Studies (OxfordNew York 2006).

Roussopoulos Th., Identity Disputes and Politics at the End of the 17th Century: The Archbishop Meletios Typaldos and his conflicting relations with the Greek Confraternity of Venice (PhD Dissertation) (University of Edinburgh, Edinburgh 2014).

Roussos-Milidonis M., I

Ruggieri V., 'Constantinopoli vista da P. Giulo Mancinelli S. J. (1583-1585)', Revue des études byzantines 60 (2002) 113-31.

Ruiu A., 'Conflicting Visions of the Jesuit Missions to the Ottoman Empire, 1609-1628', Journal of Jesuit Studies 1 (2014) 260-80.

Safley Th. M., 'Multiconfessionalism: A Brief Introduction', in Th. M. Safley (ed.), A Companion to Multiconfessionalism in the Early Modern World (Leiden-Boston 2011) 1-19.

Saito H., 'Religious policy in early modern Venice', in K. Fukasawa, B. J. Kaplan and P.-Y. Beaurepaire (eds), Religious Interactions in Europe and the Mediterranean World. Coexistence and Dialogue from the Twelfth to the Twentieth Centuries (London-New York 2017) 231-43.

Santus C., Trasgressioni necessarie: Communicatio in sacris, collaborazioni e conflitti tra le comunità cristiane orientali (Levante e Impero ottomano, XVII-XVIII secolo) (PhD Thesis) (Scuola Normale Superiore, Pisa-École Pratique des Hautes Études, Paris 2015).

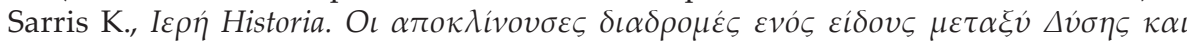

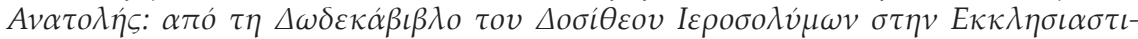
$\kappa \dot{~ I \sigma \tau o \rho i \alpha ~ \tau o v ~ M \varepsilon \lambda e ́ \tau ı o v ~ A \theta \eta v \omega ́ v, ~} 3$ vols (PhD Thesis) (Aristotle University of Thessaloniki, Thessaloniki 2010).

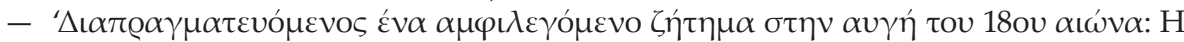

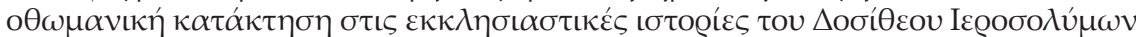

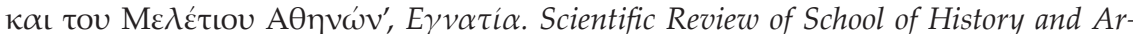
chaeology, Faculty of Philosophy, Aristotle University of Thessaloniki 15 (2011) 117-25.

- 'Meletios of Athens', in D. Thomas and J. Chesworth (eds), Christian-Muslim Relations. A Bibliographical History, XIV. Central and Eastern Europe (1700-1800) (LeidenBoston 2020) 272-89.

- 'Composing and publishing a non-confessional history in the age of Greek Orthodox confessions: The Ecclesiastical History by Meletios of Athens', in T. Anastassiadis, A. Girard, B. Heyberger and V. Kontouma (eds), Livres et confessions chrétiennes orientales. Histoire connectée entre Empire ottoman, monde slave et Occident (XVIe-XVIIIe siècles). Actes du colloque de Rome, 15-16 décembre 2016, publ. Bibliothèque de l'École des Hautes Études [in press].

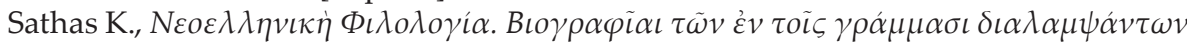

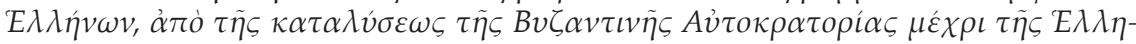

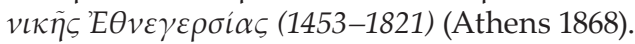

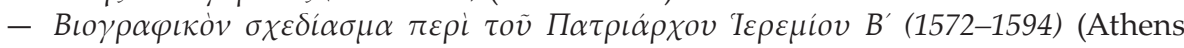
1870).

Schaff Ph., The Creeds of Christendom, with a History and Critical Notes, I. The History of Creeds (New York 1877). 
- The Creeds of Christendom, with a History and Critical Notes, II. The Greek and Latin Creeds, with Translations (New York 1877).

Scheliha W. von and Olar O., 'Gerasimos Vlachos', in D. Thomas and J. Chesworth (eds), Christian-Muslim Relations. A Bibliographical History, X. Ottoman and Safavid Empires (1600-1700) (Leiden-Boston 2017) 271-81.

Schilling H. and Tóth I. G. (eds), Cultural Exchange in Early Modern Europe, I. Religion and Cultural Exchange in Europe, 1400-1700 (Cambridge 2006).

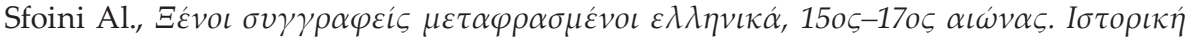

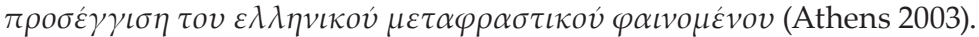

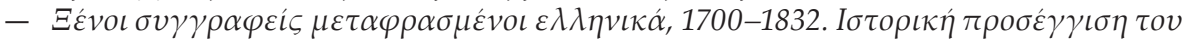

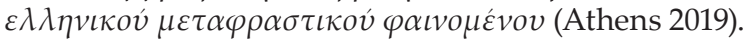

Shore P., 'Jesuits in the Orthodox World', in I. G. Županov (ed.), The Oxford Handbook of the Jesuits (Oxford-New York 2019) 318-48.

Sluhovsky M., Believe Not Every Spirit: Possession, Mysticism, E Discernment in Early Modern Catholicism (Chicago-London 2007).

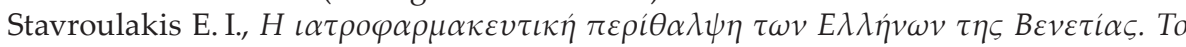

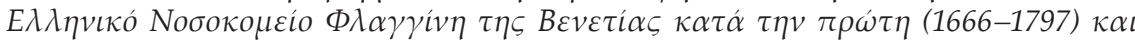

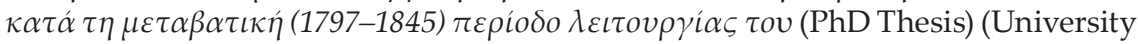
of Ioannina, Ioannina 2010).

Steckley J., 'Inventing new words. Father Jean de Brébeuf's Wendat Catechism of 1632', in A. Flüchter and R. Wirbser (eds), Translating Catechisms, Translating Cultures. The Expansion of Catholicism in the Early Modern World (Leiden-Boston 2017) 129-69.

Stroumsa G. G., 'Richard Simon: From Philology to Comparatism', Archiv für Religionsgeschichte 3 (2001) 89-107.

Tebartz-van Elst Fr.-P., Schulz E., Hauptmann P. and Fraas H.-J., 'Catechism', in Religion Past and Present (2011). http://dx.doi.org/10.1163/1877-5888_rpp_COM_11382.

Trogrlić M., 'Religion und Konfessionen in Dalmatien im 17. und 18. Jahrhundert', in G. Ortalli and O. J. Schmitt (eds), Balcani occidentali, Adriatico e Venezia fra xiii e xviii secolo [Der westliche Balkan, der Adriaraum und Venedig (13.-18. Jahrhundert)] (Wien 2009) 327-50.

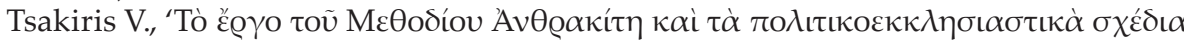

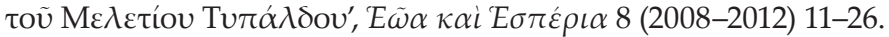

- Die gedruckten griechischen Beichtbücher zur Zeit der Türkenherrschaft. Ihr kirchenpolitischer Entstehungszusammenhang und ihre Quellen (Berlin-New York 2009).

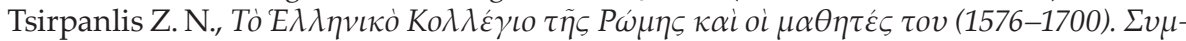

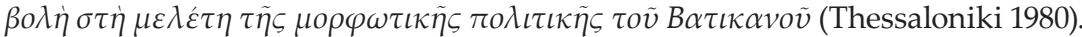

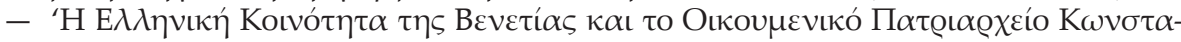

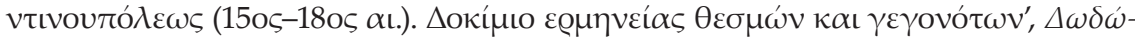
$v \eta 26$ (1997) 221-54.

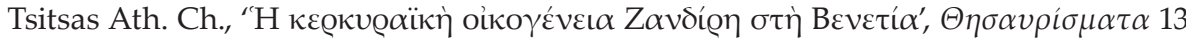
(1976) 258-83.

Tutino St., Empire of Souls: Robert Bellarmine and the Christian Commonwealth (OxfordNew York 2010).

Urban VIII, Pope of Rome, Professio orthodoxae fidei ab Orientalibus facienda (Rome 1671).

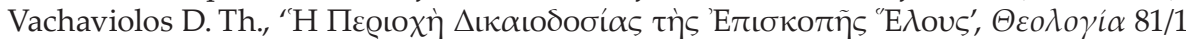
(2010) 313-30. 


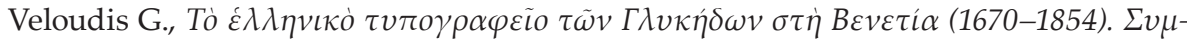

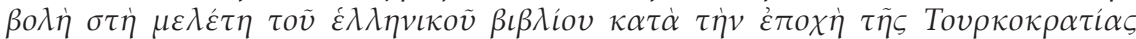
(Athens 1987).

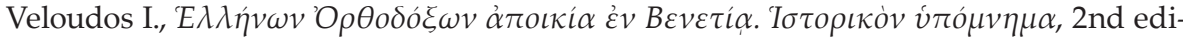
tion (Venice 1893).

Vitti M., 'Catechismi in "francochiotica" e il codique vaticano gréco', Orientalia Cristiana periodica 24 (1958) 257-75.

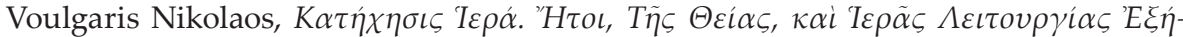

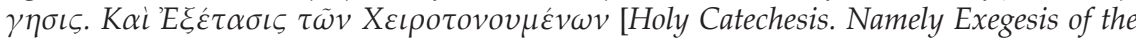
Divine and Holy Liturgy and Examination of the Ordained men] (Venice 1681).

Vovelle M., La Mort et l'Occident de 1300 à nos jours, 2nd edn (Paris 2000).

Wandel L. P., 'Confession', in Th. M. Safley (ed.), A Companion to Multiconfessionalism in the Early Modern World (Leiden-Boston 2011) 23-43.

- Reading Catechisms, Teaching Religion (Leiden-Boston 2016).

Worcester Th., 'Catechism', in Th. Worcester et al. (eds), The Cambridge Encyclopedia of the Jesuits (New York 2017) 145-6.

Yardley J. C., Justin and Pompeius Trogus: A Study of the Language of Justin's Epitome of Trogus (Toronto-Buffalo-London 2003).

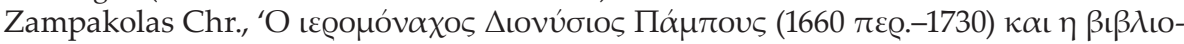

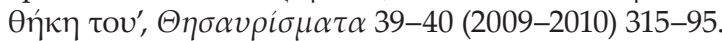

Županov I. G. and Fabre P. A., 'The Rites Controversies in the Early Modern World: An Introduction', in I. G. Županov and P. A. Fabre (eds), The Rites Controversies in the Early Modern World (Leiden-Boston 2018) 1- 26.

Zwierlein C. A., Imperial Unknowns. The French and British in the Mediterranean, 16501750 (Cambridge 2016).

- "Konfessionalisierung' europäisch, global als epistemischer Prozess. Zu den Folgen der Reformation und zur Methodendiskussion', in Chr. Strohm (ed.), Reformation und Recht. Ein Beitrag zur Kontroverse um die Kulturwirkungen der Reformation (Tübingen 2017) 1-51. 


\title{
'Slipping away from the claws of Roman Propaganda' or wishing to be 'at the service of the Apostolic Throne'?
}

\author{
The Ambiguous Relation between the Greek Rite and the Latin Rite \\ in the Life and Works of Antonios Katiforos*
}

Marco Cerasoli, Freie Universität Berlin

\section{Introduction}

In her biography of Katiforos (1685-1763) published in the monograph Antonio Catiforo e Giovanni Veludo interpreti di Fozio ${ }^{1}$ Margherita Losacco has convincingly shown the extent to which most of the nineteenth century literary sources provide us with incomplete or erroneous information on the figure of the Zakynthian 'protopapas' (' $\pi \varrho \omega \tau$ ¿ $\pi \alpha \pi \alpha \varsigma^{\prime}$, the local archpriest, i.e. the head of the Orthodox clergy on the island) and scholar. Relying on archival evidence brought to light by Karathanasis ${ }^{2}$, Fyrigos ${ }^{3}$ and Mpompou-Stamati ${ }^{4}$, Losacco was able to identify and correct various inaccuracies contained in the biographical tradition on Katiforos. With regard to biographical data for which no cross reference is offered by archives, we cannot help questioning the reliability of the portrait delivered by the literary sources. What should we think, for instance, of Katiforos' journey, made in an attempt to reach the Russian Tsar Peter the Great, or of his alleged relations with scholars and princes of his day? How can we reconstruct his cultural background, get a clearer picture of his philosophical interests and orientations, determine his contribution to the history of ideas in the Italian and Greek cultural areas?

* I wish to express my gratitude to Prof. Miltos Pechlivanos, Dr. Nikolas Pissis and Dr. Kostas Sarris for allowing me to publish this paper in the present volume. Their questions and comments on the drafts of my work were particularly helpful and inspiring.

1 M. Losacco, Antonio Catiforo e Giovanni Veludo interpreti di Fozio (Bari 2003) 39-107. This is the most complete and reliable biographical-bibliographical report on Katiforos available today, in which both literary sources and biographical evidence are analyzed. Much of the information presented here is based on this study.

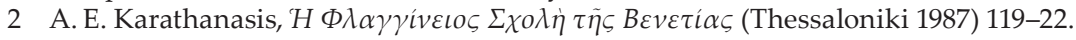

3 A. Fyrigos, 'Catalogo cronologico degli alunni e dei convittori del Pontificio Collegio Greco di Roma (1701-1803)', in A. Fyrigos (ed.), Il Collegio Greco di Roma. Ricerche sugli alunni, la direzione, l'attività (Rome 1983) 23-77, here p. 30.

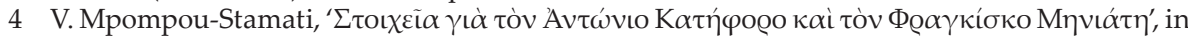

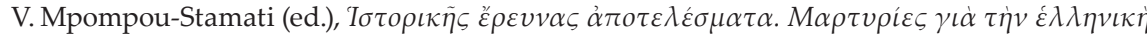

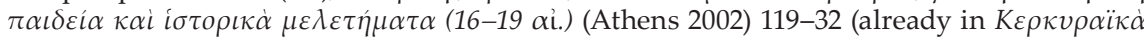

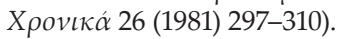


At the core of this contribution will be a further problematic aspect of Katiforos' biography and personality, namely the ambiguity of his confessional identity. Although the historiographical tradition presents him in many respects as a champion of the Greek Rite against the Roman one, significant connections between him and the Catholic world can be detected not only in his education, which took place for the most part at the Jesuit-managed Greek College of Saint Athanasius in Rome, but also in some of the networks to which he belonged, as well as in some of his works. In addition to this, the border between Orthodoxy and Catholicism was rather porous in the Ionian Islands and the city of Venice, the two geographical settings in which he lived.

In order to highlight Katiforos' confessional ambiguity I will analyze in the first place the reports by Panagiotis Chiotis ${ }^{5}$, Nikolaos Katramis ${ }^{6}$ and Konstantinos Sathas ${ }^{7}$ on the religious pressure which was allegedly put on the young Zakynthian student during his stay in Rome, and on his subsequent flight to Venice; my aim will be to show that these reports are misleading and to try to explain their origin. In the second place, I will review some major phases of Katiforos' life, bringing to the fore his links with the Catholic Church. For this purpose, I will rely on one source in particular: the Speech for the most venerable and most learned Antonios Katiforos written by Kontonis in $1757^{\circ}$. This Speech is the oldest biographical account of a certain length on Katiforos and presumably provides reliable information, since it was drawn up by a countryman and a pupil of him and it was not meant for publication, but was addressed privately to Evgenios Voulgaris, who was also acquainted with Katiforos. I will then examine some passages from Katiforos' Praefatio and explanatory notes to his Latin translation of Photius' Myriobiblos and from Vita di Pietro il Grande, the Italian biography of Peter the Great published in 1736; my point will be to show how close Katiforos was to the Catholic Church in his attempt to defend it, together with the Orthodox Church, against harsh criticism coming from some Protestant writers. In the end, I will give a short summary of a letter addressed by Katiforos in 1738 to Cardinal Angelo Maria Querini, Chief Librarian at the Vatican Library, in order to apply for a position of 'Graecus scriptor', a sub-librarian in charge of Greek manuscripts'. The letter to Querini provides

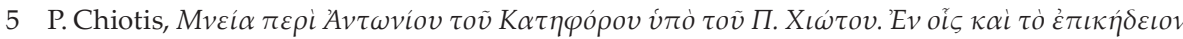

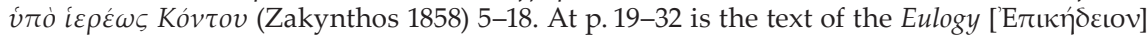
written for Katiforos by Antonios Kontos.

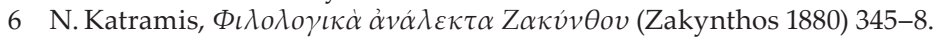

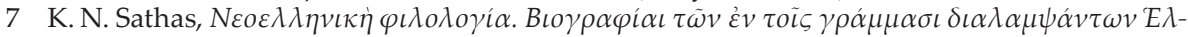

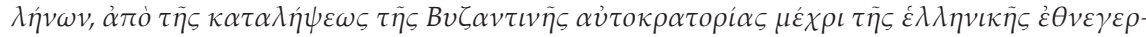
oía (1453-1821) (Athens 1868) 521-2.

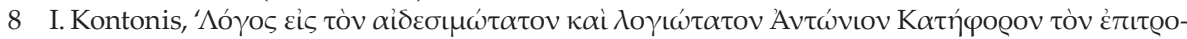

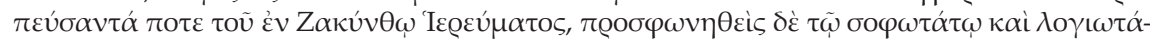

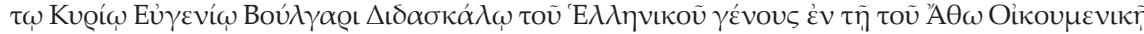

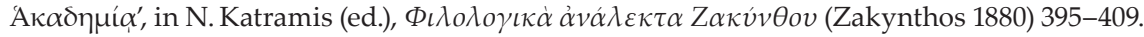

9 The Greek and Latin text of the letter was discovered by Margherita Losacco and published in Losacco, Antonio Catiforo, 221-3. 
indisputable evidence that the Orthodox archpriest from Zakynthos was eager to work for one of the major Catholic institutions of his day.

\section{Katiforos' flight from Rome: a case of confessional pressure?}

In the first paragraph of the biographical entry on Katiforos, Sathas mentions briefly his formative years in Rome (1702-1709): 'then he moved to Rome and attended the College of Saint Athanasius, but there, pestered and harassed because of his original religious beliefs, Katiforos fled secretly and slipped away from the claws of the Roman Propaganda, seeking refuge in Venice. ${ }^{10}$ A similar account can be read in Katiforos' short biographical sketch by Katramis: 'he studied in Rome at the College of Saint Athanasius, from which he secretly withdrew, so that his religious beliefs remained unshaken. ${ }^{11}$ During his stay in Rome, so can be inferred from both passages, Katiforos was put under pressure by Catholic institutions to shift from the Greek Orthodox Church to the Uniates, but he refused to give up his confessional identity and flew to Venice. He was even able to escape the control of the Congregation of Propaganda Fide, which was responsible among other things for the issue of the relations between Rome and the 'schismatics'.

Sathas draws his information, as he states in a footnote, from the A notice on Antonios Katiforos, written by Chiotis ${ }^{12}$ as an introduction to the text of the Eulogy given in 1763 at Katiforos' funeral service by the Zakynthian priest Antonios Kontos, one of Katiforos' pupils. Chiotis had found the manuscript of the 'laudatio funebris' in the family library of the Gouliarides in Zakynthos and published it in $1858 . .^{13}$ The purpose of his introduction was to extoll the merits of Katiforos and provide the reader with a chronological biographical framework, to help him understand the allusions contained in the Eulogy. In addition to the Catholic pressure, Chiotis mentions the role played by the Venetian ambassador in Rome as a decisive help for Katiforos, in his attempt to avoid punishment from Propaganda Fide: 'he would not have escaped persecution, had not the ambassador in Rome opened the wings of the lion of his State, which was quite powerful at that time, and saved him by unknown means after his flight to Venice. ${ }^{\prime 14}$

Where does Chiotis get the information about the confessional pressure put on Katiforos and about his dangerous flight to Venice? Not from the Eulogy by Kontos, who makes no mention of this; on the contrary, Kontos describes the stay of Katiforos in Rome as a period of intense learning and absolute dedication to study. ${ }^{15}$ Just a few lines before the quoted passage, Chiotis deprecates the attempts at the conversion to Catholicism that, according to Rodotà, were undertaken at the College of Saint Athanasius by teachers and assistants. It is unclear which

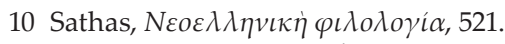

11 Katramis,

12 Chiotis, Mveí, $8-9$.

13 Ibid., 7.

14 Ibid., 9.

15 Ibid., 24. 
passage from Rodotà's treatise Chiotis has in mind, since he indicates no page in the footnote; his reference is probably to the section on the history of the Greek Pontifical College, where it is explained that the Greek students were requested to follow the Latin Rite inside the college and to accept some limitations after taking their degree from the institution. ${ }^{16}$ Describing the case of Katiforos Chiotis seems to emphasize arbitrarily the general situation illustrated by Rodotà.

The source of the news about Katiforos' flight to Venice with the help of the Venetian ambassador remains unknown. It could be assumed that Chiotis might have read it in the lost Zakynthian Chronicles by Dionysios Varvianis, who in his turn might have taken it from a corpus of anecdotes and memories transmitted orally in Zakynthos. Varvianis' Chronicles was consulted and frequently quoted by De Viazis in his article on Antonios Katiforos ${ }^{17}$ : there he makes no mention of the Venetian ambassador and indicates Chiotis and Katramis as the source of the news about the confessional pressure put on Katiforos, leading us into a vicious circle. It is unlikely that the news of the intervention of the Venetian ambassador, if related by Varvianis, would be omitted by De Viazis. Varvianis therefore cannot be the source of this information. How can we explain its presence in Chiotis? Does he follow a source which was unknown to all other biographers, without mentioning it? Does he implicitly venture a conjecture? No answer can be given with certainty to this question, but the intervention of the Venetian ambassador fits well within the framework of a biography which, as Losacco remarks ${ }^{18}$, tends to obliterate Katiforos' links with the Catholic world in order to outline a strongly Orthodox-coloured portrait of him. As for Katramis, the biographical sources on Katiforos explicitly quoted are Prokopiou ${ }^{19}$, Vendotis ${ }^{20}$, Zaveiras ${ }^{21}$-none of the

16 P. P. Rodotà, Dell'origine, progresso e stato presente del rito greco in Italia, III (Rome 1763) 156. On the profession of faith and the oath which were required of the Greek students, forcing them to accept the Tridentine doctrine of the Roman Catholic Church and to operate in favour of

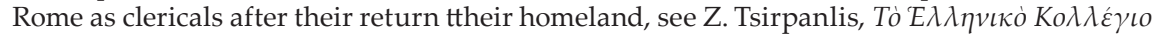

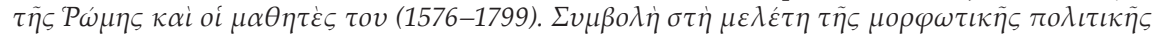

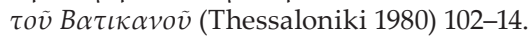

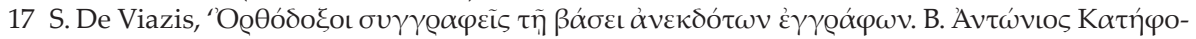

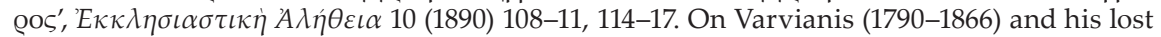

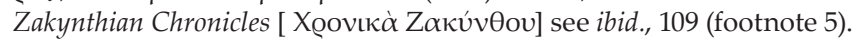

18 On Chiotis' attempt to give an Orthodox reconstruction of Katiforos' life, see Losacco, Antonio Catiforo, 53 and 56. On the involvement of the Venetian ambassador see ibid., 59, where Losacco points out that between September 1707 and September 1711 the diplomatic relations between the Holy See and the Republic of Venice were interrupted.

19 D. Prokopiou Pamperis, ‘Demetrii Procopii, Macedonis Moschopolitae, 'E $\pi \iota \varepsilon \tau \mu \eta \mu \varepsilon ́ \mu \eta \varepsilon ่ \pi \alpha-$

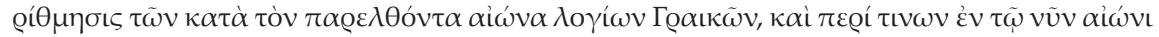

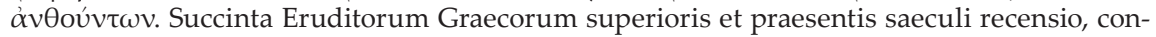
scripta mense Junio A.C. MDCCXX transmissaque Bucuresto, et nunc primum edita, cum Latina versione', in J. A. Fabricius (ed.), Bibliotheca Graeca, XI (Hamburg 1722) 769-808: 800-1.

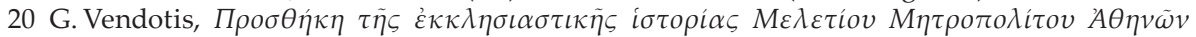
[Supplement to the Ecclesiastical History by Meletios, Metropolitan of Athens], IV (Vienna 1795) 140 and 223.

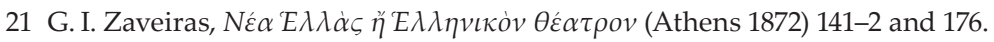


three mentions any confessional pressure-and Dionysios Varvianis: the same materials potentially available to Chiotis.

Thanks to the research of Mpompou-Stamati in the archive of Propaganda Fide, $^{22}$ we know that the news about Katiforos' alleged flight from Rome is false: he left the College of Saint Athanasius after submitting a regular request to depart for health reasons, as was the case for other students. The climatic conditions in Rome and frequent fasting proved hard to endure for many of them. ${ }^{23}$

On the other hand, although Kontos does not mention any confessional pressure on Katiforos, in the final paragraph of his speech he describes him as 'pride of the Eastern Church, glory of the Greeks, honour of Zakynthos'24. Just a few lines earlier he praises 'his zeal for our holy Orthodoxy', predicting that 'one day Greece, resurrected from the death of slavery' will be led by the books and the example of life left by Katiforos to 'respect for the Orthodox Church and its sacred clergy. ${ }^{25}$ For the Zakynthian audience attending the funeral service, Kontos portrays Katiforos as a model of Orthodox religious conscience, as well as of Greek national conscience. If the speech was really checked by Katiforos shortly before his death, as De Viazis reports ${ }^{26}$, the words of Kontos may be regarded as a kind of self-portrait, showing how Katiforos fashioned his image for his mainly Orthodox Zakynthian countrymen and how he wanted to be remembered by them.

It is not difficult to imagine that the echo of Kontos' Eulogy and the many anecdotes (real, plausible or imaginary, no one knows), told by those who had known Katiforos personally on the island, transmitted to the next generation and included into Varvianis' chronicle, constituted the basis of what one could call the Zakynthian biographical tradition about Katiforos. A local tradition that explains, at least to a certain extent, the myth of Katiforos attested by nineteenth-century sources: a glory for Zakynthos, a champion of Orthodoxy and a teacher of the Greek nation, an outstanding figure of European grandeur in the cultural landscape of his day, in contact with personalities like Menzikov and Frederick II, a corresponding member of European academies.

\section{Katiforos' first contacts with the Catholic world in Zakynthos}

In order to deconstruct the purely Orthodox portrait of Katiforos it is important to analyse the connections between him and the Catholic world emerging in some aspects of his life. He was born in 1685 in Zakynthos, which at that time was part of the 'Stato da Mar', under the control of the Republic of Venice since 1485. During the Venetian domination the Orthodox and the Catholic denominations were both present in Zakynthos, as in the rest of the Ionian Islands. The majority of the local population belonged to the Greek Rite, in the rural areas as well as in towns: the

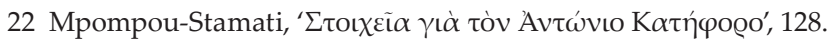

23 Losacco, Antonio Catiforo, 57-8.

24 Chiotis, Mveĩa, 31.

25 Ibid., 30-1.

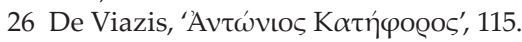


'villani' in the countryside, the vast majority of the 'popolani' and the 'cittadini' in town, as well as part of the 'nobiltà'. ${ }^{27}$ They had their spiritual leader in the 'protopapas', the archpriest of Zakynthos, elected by the community council and confirmed by the Venetian authorities; he was subject to the Orthodox Bishopric of Kefalonia and Zakynthos, which, after being in the jurisdiction of the Metropolitan Bishopric of Korinthos until 1628, was elevated in the same year to an Archbishopric by the Patriarch of Constantinople. ${ }^{28}$ To the Catholic Church on the other hand belonged the Venetians living on the island, with political, administrative, military or commercial responsibilities, and some local families, generally belonging to the upper layer of 'cittadini' or to the 'nobiltà'. The Latin Rite in Zakynthos was under the jurisdiction of the Catholic Bishopric of Kefalonia and Zakynthos. ${ }^{29}$ Despite the differences in doctrine, rituals and customs, the border separating the members of the two communities in everyday life, in Venice as well as in its dominions of the 'Stato da Mar', proved to be porous and easy to cross, at least in some cases. There were those who left one denomination in order to be received into the other and those who had connections with both confessions. The reasons can be traced back to various forms of welfare assistance granted by one of the two Churches, as was the case for the lower social classes; mixed marriages; the belonging to mixed social networks, as was frequently the case for members of the upper classes. ${ }^{30}$

Katiforos was born into a confessionally mixed family: his father, Dimitrios, was a Greek Orthodox Christian; his mother, Maria Michou was Catholic. Katiforos was baptized according to the Greek Rite. From the beginning he was very near to the demarcation line dividing the two denominations. Katiforos' father, a wealthy man belonging to the upper layer of 'cittadini', wished to be admitted into the island's

27 On the social structure on the Ionian Islands under the Venetian rule and its different ar-

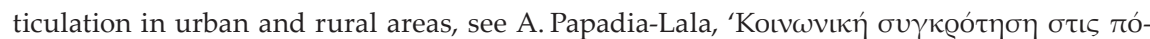

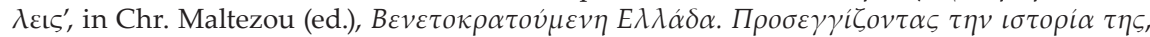

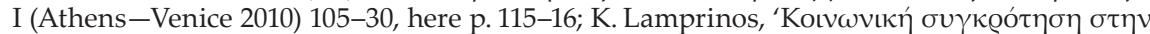

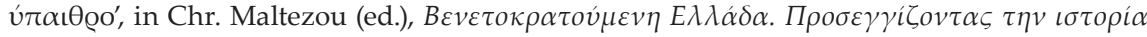

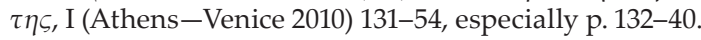

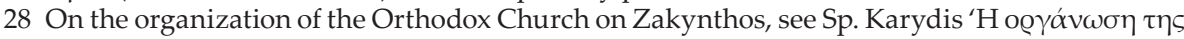

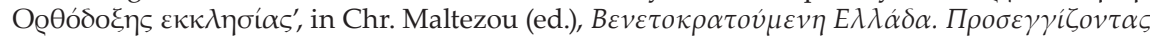

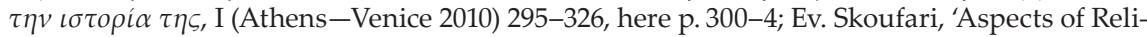
gious Coexistence: the Historiography of the Orthodox and Catholic Churches in the Ionian Islands during the Period of Venetian Domination', in A. Hirst and P. Sammon (eds), The Ionian Islands: Aspects of their History and Culture (Newcastle upon Tyne 2014) 264-75, here p. 270.

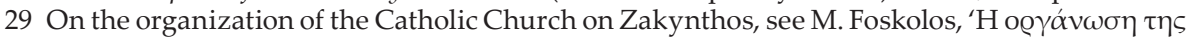

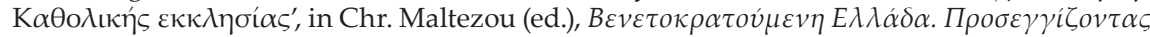
$\tau \eta v \iota \sigma \tau o \rho i \alpha ~ \tau \eta \varsigma$, I (Athens-Venice 2010) 337-56, especially p. 347-8.

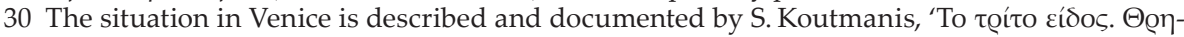

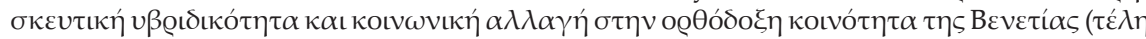

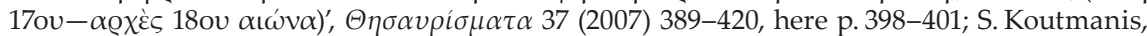

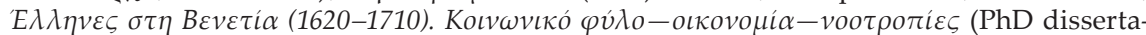
tion) (National and Kapodistrian University of Athens, Athens 2013) 314-23. The phenomena of conversions and religious hybridism on the Ionian Island must have had a lesser extent than in Venice because of the low number of Catholics living there. 
nobility. This wish he passed on to his sons, whose names would be entered the 'Libro d'Oro' of Zakynthos on 7 January 1717. Katiforos' family was going through a stage of social and political rise: the island's nobility performed a role of political intermediation between the Venetian establishment and the local population and took part, together with the 'cittadini', in the allocation of civil and religious offices in the local administration, either through a nomination from Venice or through a decision of the community council. ${ }^{31}$ The ties of this social group with the Catholic officials residing on the island or in the 'Dominante' were close.

The education ${ }^{32}$ that Katiforos received in Zakynthos was marked by the same confessional duplicity. In the beginning he attended the community school on the island; later he took private lessons in philosophy from Catholic priests, possibly the Conventual Franciscan Friars of the monastery dedicated to Saint Nikolas and the Prophet Elias. In the community school his teachers were Michail Rousmelis ${ }^{33}$ and Filippos Tsimplitis ${ }^{34}$. The former, who had graduated in philosophy from the University of Padua, served as parish priest at the Church of Saint Nikolas at the Dock (San Nicola al Molo), the parish church and later the burial place of Katiforos' parents, as well as the church which will be assigned to Katiforos himself some twenty years later. Rousmelis taught at the community school between 1693 and 1696, ${ }^{35}$ Katiforos must have taken his first steps in education under his guidance. Rousmelis may have been regarded by Katiforos at a later stage as a 'professional' model of teaching and preaching on the island. Filippos Tsimplitis had been a student at the Greek College in Rome, like his father and his grandfather before him. He taught in Zakynthos at the community school from 1696 to $1709^{36}$. He might have been Katiforos' mentor in learning the rudiments of classical languages, possibly also in view of his admission to the College of Saint Athanasius in Rome. The study of philosophy with Catholic priests-presumably some basic knowledge of logic-probably had the same goal.

The two aforementioned teachers symbolize two educational curricula as well as two confessional horizons which were open for a young Greek born to a wealthy family in the Ionian Islands, who was eager to pursue the ecclesiastical career. No intermediate or higher educational institution, let alone a theological faculty, was operating on the Ionian Islands at that time. One possible option was Rome, with the Greek College of Saint Athanasius, managed by the Jesuits. It issued what we

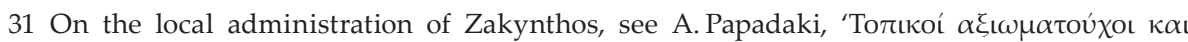

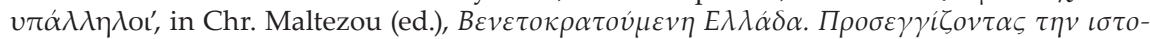
pí $\tau \eta \varsigma$, I (Athens-Venice 2010) 83-104, here p. 83-5.

32 On the education of the Orthodox clergy both on the Ionian Islands and elsewhere, see S. Karydis, 'Il clero ortodosso delle Isole Ionie sotto la dominazione veneziana', in Collegio Flangini 350

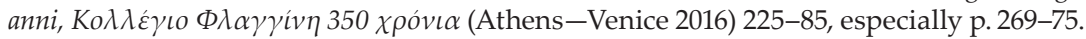

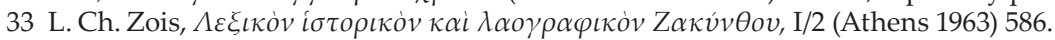

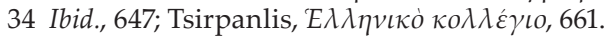

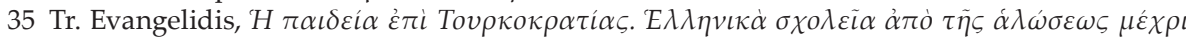

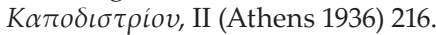

36 Ibid., 216. 
might call high school degrees in philosophy and theology, but imposed on its students an oath of loyalty to the Catholic Church: if they had completed their studies at the College, they had to be consecrated priests according to the Uniate rite or enter the Basilian monastic order or get back to their land of origin and proselytise in favour of the Catholics. ${ }^{37}$ On the other hand there were Venice, with the Flanginian College for intermediate education (classical languages and Italian, humanity, rhetoric and philosophy) ${ }^{38}$, and Padua, with its ancient university, where the Greeks had the opportunity to be accommodated at the colleges founded by Palaeokapas and Cottunius ${ }^{39}$.

The presence of Rousmelis among Katiforos' teachers may have suggested to Chiotis the idea that Katiforos began his studies in Padua at the Cottunian College and moved to Rome only later, ${ }^{40}$ enforcing in this way the Orthodox portrait of Katiforos. However, no archival document links the name of Katiforos to the two Paduan colleges. ${ }^{41}$ Kontonis makes no mention of Katiforos' stay in Padua; he informs us that the choice of Rome was made by the Catholic mother of Katiforos, now a widow. ${ }^{42}$ This circumstance implies a possible Catholic turn that might have taken place in the education of the young man since his father's death, due to the influence of his mother: first an Orthodox priest like Rousmelis, then a teacher close to Catholicism like Tsimplitis, then Catholic priests, finally the choice of Rome for Katiforos' studies.

\section{Rome, Venice and Zakynthos: education and career building along the border between Catholic and Orthodox world}

Katiforos arrived in Rome in July 1702 and left the college of Saint Athanasius in September 1709. It was during this period that, according to Chiotis, he was put under pressure by the Catholic Church. But contrary to this version, Katiforos appears to have been well integrated into the school community of Saint Athanasius: Kontonis informs us that he was charged with the tasks of teaching Greek grammar in the lower classes and supervising the school library. ${ }^{43} \mathrm{Had}$ Katiforos really suffered pressure or persecution on account of his confessional identity, the Orthodox Kontonis would not have kept it a secret in his Speech addressed to the equally Orthodox Voulgaris. The decision to interrupt his studies in Rome may

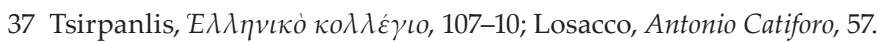

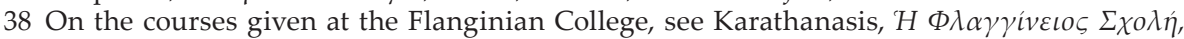
184-203.

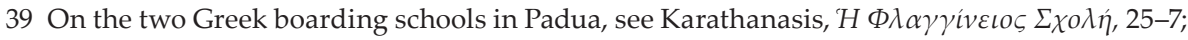

T. Bovo, Giovanni Cottunio e gli intellettuali greci a Padova nel XVII secolo: dalla matrice accademica alla prospettiva panellenica (PhD Thesis) (Università Ca'Foscari, Venice 2015) 75-130, http:// dspace.unive.it/handle/10579/5641.

40 Chiotis, Mveĩ $\alpha$, 7.

41 Losacco, Antonio Catiforo, 69 (footnote 97).

42 Kontonis, ' $\Lambda$ ó $\gamma o \varsigma^{\prime}, 398$.

43 Ibid., 399. 
well depend on the fact that Katiforos in this way avoided following the rule of the College and becoming a Uniate. ${ }^{44}$

Katiforos interrupted his studies in Rome while he was attending the course in theology, after completing his training in humanities (ancient literatures and poetics), rhetoric and philosophy. With a solid education and free from any obligation to the Roman Church, Katiforos was consecrated deacon in Venice in December 1710 by the Metropolitan Bishop of Philadelphia Meletios Typaldos. No source explains why Katiforos chose to be consecrated by the Catholic-oriented Typaldos and not by the local Orthodox Archbishop in Zakynthos or Kefalonia. We can speculate that he was already planning to build a career in Venice and was seeking connections, aiming at a position as a teacher at the Flanginian College or as parish priest at San Giorgio dei Greci ${ }^{45}$ and knowing how influential the support of the Metropolitan Bishop of Philadephia had been up to that point in the Greek Confraternity. Another hypothesis is that the pro-Catholic policy pursued by Typaldos in those years ${ }^{46}$ could give Katiforos the opportunity to enter the hierarchy of the Orthodox Church while remaining close to Rome at the same time.

Katiforos settled down in Venice in 1716, as teacher and rector of the Flanginian College. Meletios Typaldos had died three years earlier and the Greek Confraternity seemed to be eager not to confirm in his teaching position a man who had enjoyed the support of the late Archbishop: Ioannis Chalkias ${ }^{47}$. It is only a matter of speculation that Katiforos' consecration as a priest in Zakynthos by the local Orthodox Archbishop and a period of about four years (1711-1715) spent teaching and preaching on the island may have contributed towards making him less suspicious of Catholic sympathies in the eyes of the Confraternity members.

What may have contributed to his election as teacher and rector of the Flanginian College are his cultural background, the experience and knowledge gained while travelling through Europe (probably between 1715-1716), as well as his mild and conciliatory temperament. This last quality must have proved useful for the Greek community, in a moment when it was bitterly divided because of the consequences of Typaldos' policy and confronted with the influx of refugees from the

44 Losacco, Antonio Catiforo, 56-8.

45 Ioannis Chalkias, Ioannis Patoussas and Apostolos Michos had studied at the Greek College in Rome just a few years before Katiforos, were close to Meletios Typaldos and had succeded in getting positions either at the Flanginian College or at San Giorgio dei Greci; see Karatha-

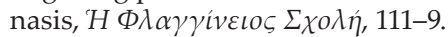

46 On Meletios Typaldos and his religious policy see: I. Veloudos, $H^{\top} E \lambda \lambda \eta \dot{v} \omega \nu{ }^{\prime} O \rho \theta o \delta o ́ \xi \omega \nu \dot{\alpha} \pi \circ \iota^{-}$

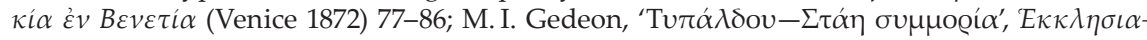

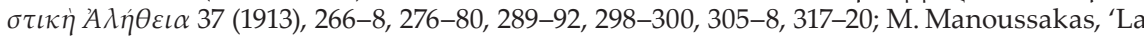
comunità greca di Venezia e gli arcivescovi di Filadelfia', in La chiesa greca in Italia dall'VIII al XVI secolo. Atti del convegno storico interecclesiale (Bari 30 Aprile-4 Maggio 1969), I (Padova 1973) 45-87: 66-7.

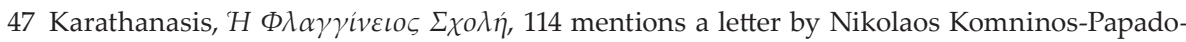
poulos to Chrysanthos Notaras where Chalkias is described as scandalmonger and trans-

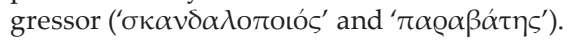


Peloponnese and some of the 'Levante' islands during the last Venetian-Turkish war of $1714-1718 .{ }^{48}$

In 1720 Katiforos resigned from his position as rector and teacher at the Flanginian College, in order to run in the election for 'protopapas' of Zakynthos. He must have been confident of his chances of success: his recently acquired nobility, the connections in Venice, a prestigious educational and professional curriculum, which would soon be crowned with his inclusion in the Recensio of Prokopiou. The Recensio was being prepared in those very months and would grant Katiforos a sort of official recognition before the Republic of Letters. Kontonis informs us that despite the support of many on the island, Katiforos failed to be elected. ${ }^{49} \mathrm{He}$ may have been a member of the island nobility for too short a time; he had been far from Zakynthos in the previous four years, having had fled from the island at the very time the Ottoman fleet was threatening it..$^{50}$

Katiforos succeeded in being elected 'protopapas' in 1725. The next year he was appointed substitute Archbishop of Kefalonia and Zakynthos, following the death of the serving prelate, Agapios Loverdos. The election of Katiforos this time must have been made easier by his presence on the island since 1720. A further element which could have had a positive influence on his election is his participation in the 1724 theological debate in Zakynthos between the Franciscan Friar Pozzo di Borgo, vicar of the Catholic Bishop in Zakynthos, and the Orthodox Antonios Komoutos on the issue of the celebration of the Eucharist. Katiforos is reported to have composed two epistolary treatises addressed to Pozzo di Borgo on the Eucharist and on the temporal power of the Pope. ${ }^{51}$ The years 1725-1730 mark the peak of Katiforos' ecclesiastical career and can be regarded as the period of his most intense commitment to the cause of Orthodoxy. In the following decade events would take a different turn.

\section{Katiforos' second stay in Venice and his translation of Photius' Myriobiblos}

In 1732 Katiforos settled down in Venice for the second time. There he taught Greek at the Confraternity's school and occasionally preached at San Giorgio dei Greci. But interesting and stimulating job opportunities were also offered to him outside the Greek-Orthodox community: the cooperation with some Venetian publishing houses and the possibility of establishing links with members of one of the most important cultural circles of the city, gathered around the prestigious Apostolo $Z_{\text {eno }}{ }^{52}$. In these contexts, the ties between Katiforos and the Catholic world got even closer than before.

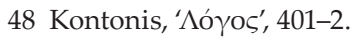

49 Ibid. 403.

50 Ibid. 405.

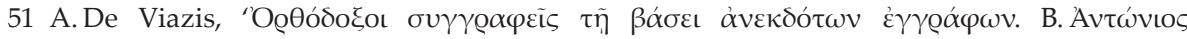

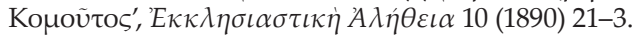

52 On Apostolo Zeno and the most important intellectuals gathered around the Giornale de'let- 
Katiforos' first task was the preparation of a textbook for the Greek publisher Dimitrios Theodosiou: a grammar of ancient Greek, which in barely four hundred pages offers a clear and essential outline of phonetics, morphology, syntax, old Greek dialects, metrics and poetics: a useful and practical didactic tool for students and teachers. ${ }^{53}$

In 1735 Katiforos started to work for one of the most prestigious printers in Venice, Francesco Pitteri ${ }^{54}$ : the Zakynthian scholar had been charged to revise the Greek text and prepare a Latin translation of Photius' works, accompanied by a commentary. ${ }^{55}$ For the same printing house Katiforos would publish (anonymously in 1736, with his name on the frontispiece in the second edition in 1739) a biography of the Russian Tsar Peter the Great; ${ }^{56}$ between 1737 and 1743 he would edit the yearbook of political information Storia dell'anno. ${ }^{57}$

At that time Pitteri was one of the most successful Venetian printing houses; among the investors who supported it were even members of the families Ruzzini and Loredan, belonging to the political elite. The catalogue of the printing house shows four main thematic areas: religion, with works of both popular devotion and historical and theological erudition; political information and contemporary history; textbooks on medicine, law, philosophy, theology; great works of reference. Many of the authors were Catholic clerics.

The sponsor of the Universorum Photii operum editio, Filippo Beroardi, had previously financed the expensive edition of Le Nain de Tillemont, Mémoires pour sérvir à l'histoire ecclésiastique, and the theological treatise Adversus haereses by Saint Irenaeus. ${ }^{58}$ Beroardi's interest seemed to be oriented towards the history of the church, in particular towards the history of dogma and heresy. The coordination of the project and the task of drafting a general introduction was entrusted to the Benedictine monk Francesco Rota, professor of philosophy and theology at the Monastery of San Giorgio Maggiore in Venice. Even Apostolo Zeno took part in

terati d'Italia, see B. Dooley, Science, Politics and Society in Eighteenth-Century Italy. The Giornale de'letterati d'Italia and its World (New York-London 1991) 10-36.

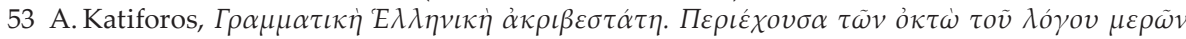

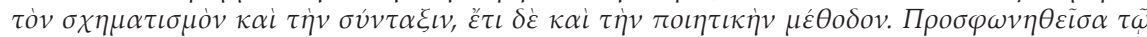

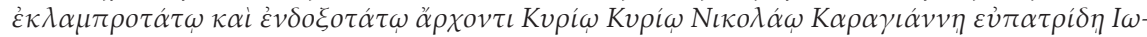

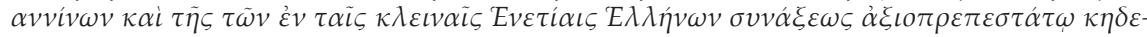
$\mu o ́ v \iota$ [A most accurate grammar of Ancient Greek. Containing the morfology and syntax of the eight parts of speech as well as an introduction to poetry. Dedicated to the most illustrious and famous Lord Nikolaos Karagiannis, a nobleman from Giannina and most respectable guardian of the Greek Confraternity in the glorious city of Venice] (Venice 1734).

54 M. Infelise, L'editoria veneziana nel '700 (Milano 1991) 148-56.

55 The reconstruction of Katiforos' edition of Photius and the analysis of some of the extant manuscripts are extensively dealt with in 'Losacco, Antonio Catiforo, 109-70.

56 Anonymous [A. Katiforos], Vita di Pietro il Grande Imperador della Russia; estratta da varie memorie, pubblicate in Francia e in Olanda (Venice 1736).

57 Storia dell'anno 1730-1742 (Amsterdam [actual place of publication Venice] 1737-1743).

58 Losacco, Antonio Catiforo, 111; the information is provided by Apostolo Zeno in a letter written on 21 December 1735, quoted by Losacco, in which Katiforos is mentioned as a translator of Photius. 
the enterprise 'incognito': he opened his rich library to Katiforos and helped him to find good manuscripts for the revision of the Greek text. The introduction to the Myriobiblos ${ }^{59}$ and the commentaries to this work shed some light on the confessional attitude of the Zakynthian priest, as Losacco has highlighted in her study.

The aim of the edition, as Katiforos writes in the 'Preface', was to provide a more adequate and correct Latin translation than the one published by the Jesuit André Schott over a century earlier. ${ }^{60}$ Despite the dissatisfaction of the Republic of Letters with its many inadequacies, Schott's version had remained the only one available in print. ${ }^{61}$ Katiforos underlines the presence in it of countless mistakes ${ }^{62}$ and points out that the Jesuit scholar 'moves away from the original Greek text; it is unclear whether he does so consciously and intentionally or unwillingly and without being aware of it. ${ }^{163}$ In another passage Katiforos is even more explicit: 'What should I say about the fact that frequently Schott, intentionally and in full awareness, out of a deliberate intention translates some passages differently from how they are formulated in the Greek text, whenever he thinks that the original text is contrary to common opinion or to Catholic dogma? ${ }^{\prime 64}$ Schott's translation is incorrect, in Katiforos' words, not only because of erroneous grammatical interpretations and poor renditions of the Greek original, but also because of deliberate distortions, behind which theological reasons can easily be surmised..$^{65}$ Katiforos, however, does not want to be involved in theological controversies: he confines himself to the statement that he will correct, where necessary, the Jesuit's translation and will give an account of his interventions in the notes 'ad locos'. Then, in the final paragraph of the introduction, he warns his readers: 'I expect from the fairness of my readers that they bear in mind that this work is not something new written by me with hostile intentions, but a mere translation of a work written by someone else. ${ }^{\prime 6}$ Soon after that he concludes: if something, in the sense or in the form of the text, should displease the readers, they should compare it with the original Greek and verify that he has acted in his capacity of translator.

59 The 'Preface' ['Praefatio'] by Katiforos to the Myriobiblos was published in Losacco, Antonio Catiforo, 225-30.

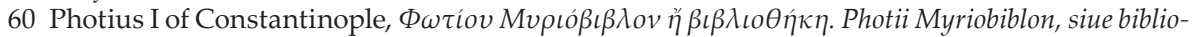
theca librorum quos legit et censuit Photius patriarcha Constantinopolitanus, Graece edidit Dauid Hoeschelius Augustanus, \& notis illustrauit. Latine vero reddidit \& scholiis auxit Andreas Schottus, ed. D. Hoeschel, transl. A. Schott (Geneva 1612).

61 Losacco, Antonio Catiforo, 10.

62 Ibid., 226, 1. 28-9: 'cum tamen interpretationem illam [...] innumeris scatere erratis adfirmarent omnes.'

63 Ibid., 229, 1. 147-9: 'sive prudens ac consultus, sive imprudens et invitus a Graeca aberrat veritate.'

64 Ibid., 227, 1. 77-9: 'Quid, quod haud raro Schottus, sciens prudensque, deliberato animo res aliquas aliter convertit ac eas exhibet Graecus textus, quando hic nimirum visus est ipsi vel communi opinioni vel catholico dogmati adversari.'

65 Ibid., 163-8.

66 Ibid., 230, 1. 167-9: 'Id unum interim ab aequitate legentium postulantes, ut meminerint meum hunc laborem non esse novum aliquod mei Martis opus, sed operis ab alio conscripti interpretationem.' 
On the base of these statements the readers may expect to read a Latin translation which is free from dogmatic (Catholic-oriented) distortions. But this does not seem to be the case with Katiforos' rendition. Nothing in the notes-which are almost entirely linguistic or historical-linguistic in character-suggest an anti-Catholic, or Orthodox-oriented, attitude in the way of dealing with the mistakes made by Schott. A further element indicating Katiforos' cautious attitude is Kontonis' testimony. He praises enthusiastically the good quality of Katiforos' translation and underlines the fact that he has accomplished a difficult linguistic enterprise; no mention is made of the translator's correcting the dogmatic distortions introduced by Schott. ${ }^{67}$ On the contrary, Katiforos is even ready to defend some of Schott's 'errores at allucinata', if they arise from the intention of defending 'Catholic dogma' against heretical propositions or Protestant doctrines.

In her analysis, Losacco stresses the fact that it is only in two of the more than three hundred notes to the Myriobiblos that Katiforos provides examples and explanations for the accusation, formulated in the 'Preface', of a conscious manipulation of Photius' text by Schott: these are the notes to chapters 6 and 229. ${ }^{68}$ Losacco points out that in both cases Katiforos, while acknowledging the linguistic inaccuracy and the attempted manipulation by Schott, actually agrees with the Jesuit's interventions against Photius. In the first case, Photius had given his preference to the anti-Eunomian writings by the heretic Theodore of Mopsuestia than to the anti-Eunomian treatise by Gregory of Nyssa. Katiforos praises Schott for having manipulated the translation in such a way as to hide this preference. ${ }^{69}$ In chapter 229 of the Myriobiblos, four treatises by Ephraim of Antioch were excerpted by Photius; Schott's manipulation in this case would aim, according to Katiforos' interpretation, to eliminate a possible patristic witness in support of the Protestant Eucharistic doctrine of the Consubstantiation against the Catholic and Orthodox doctrine of the Transubstantiation. Katiforos defends the alteration introduced by Schott and quotes Bellarmino and Meletios Syrigos, a Catholic and an Orthodox theologian. ${ }^{70}$ This seems to suggest: 1 . that Katiforos chose to stress what unites the two confessions, the Roman Catholic and the Orthodox one, against Protestantism and heresy; 2 . that he uses the adjective Catholic to refer to the doctrines which are shared both by the Roman Catholic and the orthodox Church. This orientation is present also in the biography of Peter the Great.

\section{The biography of Peter the Great: Katiforos' defence of the Catholic and Orthodox Churches}

The decision by Pitteri to publish a biography of Peter the Great in 1736 can be easily linked to the outbreak of the Russian-Turkish war of 1736-1739; to the natural curiosity of the readership for Russia, a military power that was challenging the

67 Kontonis, '^ó $\gamma o \varsigma^{\prime}, 405$.

68 Losacco, Antonio Catiforo, 153 and 396.

69 Ibid., 425-7.

70 Ibid., 428-39. 
Ottoman empire; perhaps also to the desire of Venice to support Russia among the public opinion, despite its neutrality in the conflict. ${ }^{71}$ That readers were deeply interested in this topic can be inferred from the fact that Pitteri was not the only printing house to issue a biography of Peter the Great in this period: a four-volume biography of the Tsar was published in the same year by the publisher Giammaria Lazzaroni; ${ }^{72}$ two biographies of Peter in vernacular Greek, thus intended to reach a Greek-speaking readership in the Venetian dominions and in South-East Europe, were published in 1737 by Antonio Bortoli and Santo Pecora. ${ }^{73}$ In the same year, Antonio Bortoli was granted permission and the privilege from the 'Riformatori dello Studio di Padova' to publish a periodical with the translations of the Amsterdam gazettes into Modern Greek. ${ }^{74}$

As can be inferred both from the title page of the 1736 edition and from its introduction, ${ }^{75}$ Katiforos presents himself not as the author of the biography, but only as the compiler of three books on Peter written by John Perry, ${ }^{76}$ Friedrich Christian Weber, ${ }^{77}$ Ivan Nestesuranoi ${ }^{78}$ (pseudonym used by Jean Rousset de Mis-

71 A confirmation can be found in a passage which Katiforos did not read in his sources. On Empress Anna, Katiforos states that she 'tries in any possible way with her powerful armies to overthrow the pride of the enemies of the Christian name', a clear allusion to the war between Russia and the Ottoman empire. Cf. Katiforos, Vita di Pietro, 202; this one, as well as all the quotations from Katiforos' Vita di Pietro, are taken from the 1748 reprint of the 1739 enlarged and definitive edition.

72 I. Nestesuranoi [J. Rousset de Missy], Memorie del Regno di Pietro il Grande Imperadore di Russia, Padre della patria ec. ec. ec. del B. Iwan Nestesuranoi, divise in quattro tomi, nuovamente tradotte dal francese nel volgare italiano (Venice 1736).

73 Of the two Greek biographies of Peter the Great, the first is a translation by Alexandros Kan-

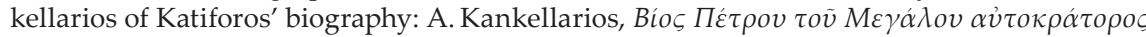

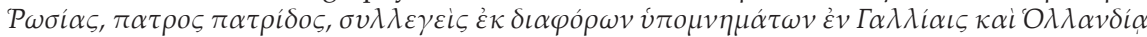

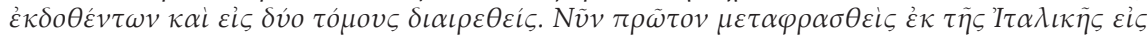

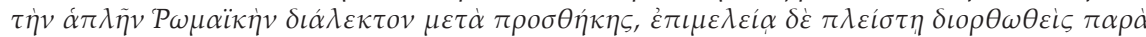
$\kappa v \rho i ́ v$ A $A \varepsilon \xi \dot{\alpha} v \delta \rho \circ \mathrm{K} \alpha \gamma \kappa \varepsilon \lambda \lambda \alpha \rho i$ ov [Life of Peter the Great, Emperor of Russia, father of the nation, collected from various accounts published in French and Holland and divided in two volumes. Now for the first time translated from Italian into the simple Romaic language with an addition, edited with the greatest care by Alexandros Kankellarios], 2 vols (Venice 1737). The other biography of Peter the

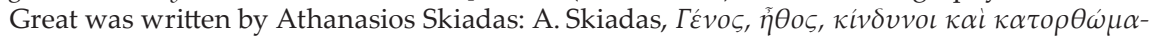

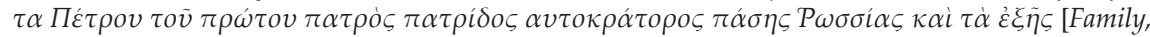
character, dangers and undertakings of Peter the first, father of the nation, emperor of all Russia etc.]

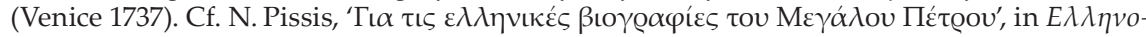

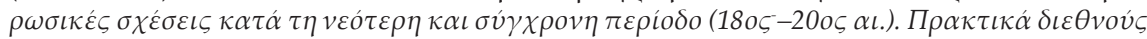

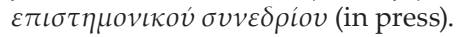

74 M. Infelise, 'Sulle prime gazzette a stampa veneziane', in L. Antonelli, C. Scarpa and M. Infelise (eds), Per Marino Berengo. Studi degli allievi (Milan 2000) 469-79: 474-5.

75 Katiforos, Vita di Pietro, 9-11.

76 J. Perry, The State of Russia under the present Zar (London 1716); Katiforos quoted from the French translation published in Paris in 1717: J. Perry, État présent de la Grande Russie ou Moscovie (Paris 1717).

77 F. Ch. Weber, Das Veränderte Russland (Frankfurt a.M. 1721). Katiforos quotes the French translation in the introduction: F. Ch. Weber, Nouveaux Mémoires sur l'état présent de la Grande Russie ou Moscovie, 2 vols (Paris 1725). 
sy). An accurate comparison between the Italian text published by Pitteri and the three sources shows that Katiforos translated, with some cuts and reshaping, the French biography issued by Rousset de Missy, which in turn relied on the works of Perry and Weber. Nonetheless it is possible to identify some original contributions by Katiforos in some sections of the introduction, as well as in various additions, omissions, manipulations of his main source. A number of these contributions prove to be helpful in order to shed light on Katiforos' confessional positioning.

In the first pages of the book Katiforos declares his intention to eliminate everything from the works consulted that could be morally harmful for the Catholic reader: 'Therefore, since the aforementioned books were full of such reckless and scandalous propositions, it is neither fair nor expedient to simply translate them for the Catholic Reader, as it has been done so far with so many very useful writings. ${ }^{79}$ What are the morally harmful aspects and what is the exact meaning of the adjective 'Catholic'? An answer can be found in the introduction and in some passages of the text.

The most harmful element is the hostility towards the Russian Orthodox Church, but also towards the Roman Church, that Perry and Weber-both Protestants-showed, according to Katiforos, in some remarks contained in their works. 'Since they are both Protestant Writers, they attack continually and irreverently the Religion of the Muscovites, particularly in those aspects in which the Ruthenian Church agrees with the Roman one. ${ }^{80}$ Katiforos gives immediately an example of what he means, namely Perry's persuasion that

the only obstacle which prevents the Tartars, subjects of Russia, from embracing the Christian Faith is the perfidy and ignorance of the Muscovites in worshipping the Images [...] the Tartars being terrified at the idea of embracing such a Religion; since God cannot be painted or represented in any other way by men. ${ }^{81}$

A little further in the text the following sentence by Perry is quoted: 'If faith was preached among Tartars in a way as pure as it is preached in England, and by Ministers who lead such an honourable life as the Anglicans, they would have

78 I. Nestesuranoi [Jean Rousset de Missy], Mémoires du regne de Pierre le Grand, Empéreur de Russie, père de la Patrie ecc. ecc. par le B. Iwan Nestesuranoi, 4 vols (Amsterdam 1725).

79 Katiforos, Vita di Pietro, 13: 'Essendo dunque i surriferiti libri aspersi di simili temerarie e scandalose proposizioni, non era lecito né espediente presentarli al Lettore Cattolico semplicemente tradotti, come si è fatto sinora di tanti utilissimi scritti.'

80 Ibid., 9: 'Essendo amendue questi Scrittori Protestanti, non lasciano di lacerare con insolenza la religione de'Moscoviti, principalmente in que'punti, nei quali la Chiesa Rutena conviene con la Romana.'

81 Ibid., 9-10: 'l'unico ostacolo, che impedisce i Tartari sudditi della Russia dall' abbracciare la Cristiana Fede essere la perfidia e ignoranza dei Moscoviti nell'adorar le Immagini [...] avendo essi Tartari il terrore di abbracciare una tale Religione; non potendo Dio in veruna forma essere dipinto o rappresentato dagli uomini.' 
already converted. ${ }^{\prime 82}$ Katiforos refutes it by saying: 'As though it was not known to everyone that the Anglican clergy has the same vices in their life and their way of preaching that they want to blame on the Catholic Clergy of the Roman and of the Greek Churches. ${ }^{\prime 83}$ A further defence of the 'Catholic Church' is made against criticism put forward by Rousset de Missy. According to Katiforos, this writer 'appears to be more inclined to the doctrines of the Protestants than to the ones of the Catholics, and often shows hesitation and disbelief as far as the very foundations of simple Christianity are concerned. ${ }^{84}$ In another passage, Rousset de Missy is accused of desecrating 'everything that is hold sacred in the Church, mocking Sacraments and Rituals, Priests and Monks, Bishops and Patriarchs, Cardinals and Popes. ${ }^{\prime 85}$

It is apparent from these examples that Katiforos defends both the Roman Catholic and the Greek and Russian Orthodox Church against what he regards as accusations coming from Protestant authors. By using the adjective 'Catholic', Katiforos refers in the first place to the Roman Church, as opposed to the Greek Church ('Chiesa Greca', 'Rito Greco', 'Chiesa Orientale') and the Ruthenian Church ('Chiesa Rutena', expression by which Katiforos means the Russian Orthodox Church, not the Uniate Ruthenian Church), as is shown by the linguistic usage in the biography. The semantic opposition between the terms 'Cattolico' and 'Greco' is confirmed by Koutmanis' analysis on a corpus of eighteenth-century documents produced in Venice by Catholic and Orthodox (with the triple opposition 'Cattolico'-'Ortodosso' - 'Greco Cattolico', the last one referring to the Uniates) ${ }^{86}$. At the same time, however, in connection with Protestant accusations, Katiforos emphasizes the theological and dogmatic doctrines shared by the two confessions (the Roman Catholic and the Orthodox one) rather than what is peculiar to each of them; these shared doctrines are referred to as Catholic. That the adjective 'Cattolico' could be also claimed by Greek Orthodox Christians wanting to underline the authenticity of tradition and correctness of their doctrine is equally shown by Koutmanis. ${ }^{87}$

A confirmation of this can be found in two more passages from the Vita di Pietro il Grande. In the first one we can notice a juxtaposition between 'the weapons of the foreigners, a Lutheran people of heretics' (with reference to General Gordon and the military body of veterans coping with an insurrection in Moscow; many of the

82 Ibid., 10-11: 'Se a Tartari si predicasse la Fede così pura come si predica in Inghilterra, e da Ministri di vita così onesta come sono gli Anglicani, l'avrebbero finora ricevuta.'

83 Ibid., 10-11: 'Quasi non fosse notissimo che il Clero Anglicano, nel suo vivere e nel suo predicare $[. .$.$] non va esente da quei difetti che voglionsi addossare al Clero Cattolico della Chiesa$ Romana e della Greca.'

84 Ibid.,11: 'mostrasi più propenso alle dottrine de'Protestanti, che alle Cattoliche, e sovente si fa vedere titubante e miscredente ne'fondamenti medesimi del semplice Cristianesimo.'

85 Ibid., 12: 'quanto v'ha di sacro nella Chiesa, dileggiando e motteggiando Sagramenti e Rituali, Sacerdoti e Religiosi, Vescovi e Patriarchi, Cardinali e Pontefici.'

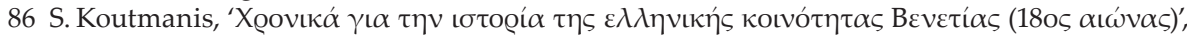

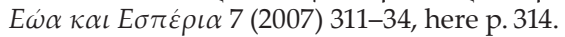

87 Ibid., 314. 
soldiers were foreigners and Protestants as well) and the 'Muscovites, a Catholic and Orthodox people. ${ }^{\prime 88}$ In the second passage, while talking about the worship of the icons and of the saints, Katiforos remarks that 'the whole Ruthenian nation, despite the contacts with the Protestants, remained faithful to the old tradition of the Catholic church about the worship of the images and the invocation of the saints. ${ }^{89}$

The most interesting sign of a conciliatory attitude on the part of the Orthodox Katiforos towards Catholicism is found in the second edition of the biography (1739), in another section which must be counted among Katiforos' own contributions. It is the full translation into Italian of the long document prepared by the Sorbonne theologians ${ }^{90}$ and presented to Peter during his visit in Paris in 1717, advocating a reunification between the Russian Church and Rome. Katiforos introduces the document with the following words: 'I believe that I will do something agreeable for my Readers if I give a full and faithful translation of the following document into Italian, since it deserves their attention; this does not mean that we approve of all that is contained in it. ${ }^{\prime 91}$ A short summary of the document could run as follows. After emphasizing the theological heritage shared by the two Churches, the document examines some of the most controversial matters between the two denominations, namely the way the Eucharist was celebrated, the primacy of the Pope, the procession of the Holy Spirit; then solutions are proposed for a reunification to be made possible. Ritual matters like the celebration of the Eucharist, according to the doctors of the Sorbonne, cannot be considered a real obstacle on the way towards reunification: they point out that 'discipline' may be different in various parts of the Church, as had been the case until the Great Schism; there are also Greeks living in communion with Rome while preserving their rituals. The doctors of Sorbonne are convinced that the pope does not want to abolish the rituals of the Orthodox Church, just as he does not want to abrogate the customs of the Gallican clergy, so much so that the pope would not even have the authority to do so. The different way in which the Eucharist is celebrated is not a problem, since the doctrine of the Transubstantiation of bread and wine is also accepted by the Orthodox Church. As for the Pope, he should be granted primacy among the bishops, in his capacity as the successor of the apostle Peter; he should be recognized as a symbol of the unity of the Church, but the authority of the Pope, according to the doctors, must be limited by the sacred canons and

88 Katiforos, Vita di Pietro, 98.

89 Ibid., 248.

90 Katiforos doesn't mention the source of the document. G. Podskalksy, $H$ $\varepsilon \lambda \lambda \eta v \iota \kappa \eta \theta \varepsilon o \lambda o \gamma i \alpha$

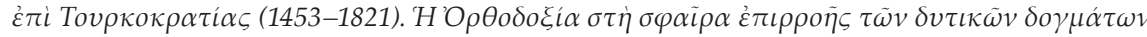
$\mu \varepsilon \tau \dot{\alpha} \tau \eta \mu \varepsilon \tau \alpha \rho \rho v \theta \mu \iota \sigma \eta$ (Athens 2008) 66, footnote 66, indicates that a publication of the document is in 'Narratio de Sorbonnae conatu conciliandi Ecclesiam magnae Russiae cum Ecclesia Latina', in V. E. Löscher (ed.), Unschuldige Nachrichten von alten und neuen theologischen Sachen 18 (Leipzig 1718) 331-48.

91 Katiforos, Vita di Pietro, 259: 'la seguente Scrittura, che per essere degna della pubblica curiosità, stimo far cosa gradevole ai Lettori col tradurla fedelmente in Italiano, e registrarla in questo luogo tutta intera, senza che per noi tutto quello si approvi che in essa contiensi.' 
the authority of the councils. He is not to be credited with infallibility, since he needs to be supported by the councils in matters of faith; he has no right to impose ecclesiastical authority on kings in temporal matters, nor can he free subjects from the oath of loyalty and obedience to their sovereigns. The relationship between the Gallican clergy and the papacy is presented as a model: the papacy does not interfere in the administration of the French Church and the French bishops do not break unity with Rome. The doctors are confident that a satisfactory theological solution can be found even in the question of the procession of the Holy Spirit, which they tend to interpret as a misunderstanding of some patristic passages. ${ }^{92}$

The rejection of the proposal coming from the Sorbonne theologians was discussed at length in Russia, accurately prepared and sent a year later by a committee of Russian bishops and clerics. ${ }^{93}$ Katiforos seems to be much worse informed on it than he is on the proposal. According to him Peter presented the document to the Russian bishops only two years later and they, for their part, decided to send no answer to the Sorbonne. ${ }^{94}$ He briefly reports the reactions of the committee: it was not the Greek Church which separated from the Catholic Church, but the Latins; the dogma of the procession of the Holy Spirit was formulated in an insidious way; some patristic passages were misquoted; Russian bishops could by no means accept the Primacy of the Pope; if some Greek had spoken in favour of the Pope, they were corrupt men and flatterers of the Roman Court. At the end of Katiforos' report the committee suggested to Peter that

it could be dangerous to introduce innovations into the religion of the Russians, converted to the Christian faith by Greek prelates and missionaries, and familiar with the rites and dogmas of the Eastern Church. This was enough for the Tsar to abandon any project and to decide that the topic should be no longer discussed..$^{95}$

The Italian-speaking Catholic readers were given the chance to read the text of a detailed proposal of union, followed by a reply which was too short, not theologically argued, and full of resentment against the Primacy of the Pope. The arguments in favour of this union are better developed and more accurately formulated than those against it. In order to explain this circumstance, it can be assumed that Katiforos did not know the text of the reply sent by the Russian prelates. Another explanation might be that an in-depth theological discussion would be out of place in a short book, as Katiforos himself seems to suggest. ${ }^{96}$ A third possibility might be that he was acting according to the Catholic orientation of the publishing house and of his readers. But if we assume that he was writing freely, expressing his own ideas, he may have wanted to draw the attention of his readers

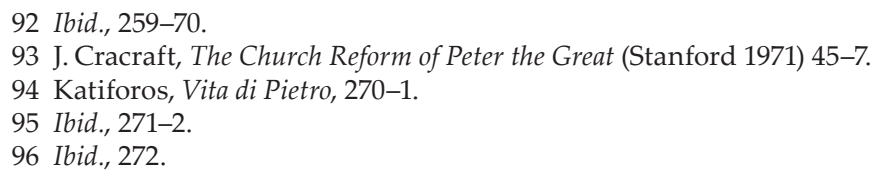


to a possible model of union between Orthodoxy and Catholicism which was an alternative to the traditional Uniate approach-new model that had the advantage of preserving not only the identity of the Greek rite, but of giving Orthodox bishops more freedom from the authority of the Pope. The document of the doctors of the Sorbonne had already drawn the attention of the Orthodox hierarchy too: Chrysanthos Notaras had translated the proposal into Greek. ${ }^{97}$

It is worth noting that in the Greek translation of the biography by Kankellarios (dated to 1737) the episode is related very shortly, with no account whatsoever of the theological pro-union arguments of the proposal; the refusal is attributed to Peter himself and is pronounced by him at the very moment of receiving the proposal in France. ${ }^{98}$ On the other hand, the biography written by Skiadas only alludes to the episode, dedicating no more than five lines to it. ${ }^{99}$ Is this a consequence of a different confessional position of the two authors, less open to Catholicism, or of the different public (a Greek speaking and Orthodox one) to which their books were destined?

That Katiforos was very conciliatory towards the Catholic Church is shown also by another element in the biography of Peter, namely Katiforos' positive attitude towards the Society of Jesus. In the introduction Katiforos vehemently attacks Rousset de Missy for his accusations against the Jesuits, which are listed among the signs of disrespect toward religion:

He directs his poisonous tongue mainly against the Venerable Society of Jesus, maintaining that the Jesuit fathers do not wish to be called Monks, because they do not possess their virtues, even though they have all their vices; that they creep into every place where they hope to gain something; that they can cause great bewilderment in every State and that they must be abhorred by every pious and wise man..$^{100}$

\section{Katiforos' letter to cardinal Querini: seeking a job in the heart of the Catholic world}

The document that more than any other proves to be useful in order to demonstrate Katiforos' opening to the Catholic Church dates back to the same years. It is a letter addressed by him to Cardinal Angelo Maria Querini in 1738, an application for the vacant position of 'scriptor Graecus' at the Vatican Library. ${ }^{101}$ In the

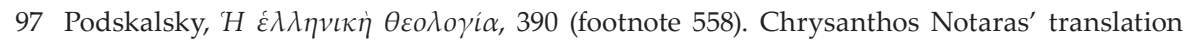
dates back to 1720 and remains in manuscript.

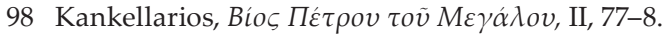

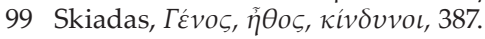

100 Katiforos, Vita di Pietro, 12: "Aguzza principalmente la velenosa lingua contro la Venerabile Compagnia di Gesù, ora asserendo che $i$ Padri Gesuiti non vogliono essere chiamati Monaci, non avendone le virtù, quantunque ne abbiano tutti $i$ vizi; ora che i medesimi si insinuano mirabilmente per tutto, ove sperano di trovar qualche lucro; ora che essi sono capaci di cagionar grandi sconcerti in ogni Stato e però devono essere da ogni nomo pio e prudente aborriti."

101 Losacco, Antonio Catiforo, 221-3. 
second half of the letter Katiforos provides a short 'curriculum vitae', interesting for what is included, for what is omitted, but above all for its conclusion. Katiforos informs Querini that he had studied philosophy and theology for seven years 'utraque lingua' at the Greek College of Saint Athanasius, but no mention is made of the interruption of his studies. He recounts his own teaching and pastoral activity carried out in Zakynthos, but nothing is said about his offices as Archpriest and as substitute for an Orthodox Bishop. No mention either is to be found in this letter of his tasks as a teacher and director of the Flanginian College in Venice and as preacher at San Giorgio dei Greci.

Did Katiforos want to let Querini believe that he proselytized in favour of Rome, as one might expect from a former student of Saint Athanasius? He mentions no word of the journey undertaken to reach the court of Peter the Great. Among his works only the Greek grammar is mentioned; there is no hint of the life of Peter the Great and of his role as editor of the Storia dell'anno. Katiforos recalls the translation into Latin of Photius' Myriobiblos and other works of the same author, but hastens to add, so as to avoid any suspicion of heresy, that he was persuaded to accept and perform this job by a publisher. In the end Katiforos assures cardinal Querini that he is eager to return to Rome: 'in order to serve the Apostolic Throne with my modest abilities and to spend the rest of my life, which is already approaching old age, under the powerful protection of Your extraordinary Holiness. ${ }^{\prime 102}$ The letter to Querini did not produce the expected result, so Katiforos did not spend the rest of his life at the service of the Apostolic Throne, but stayed in Venice until 1743, before getting back to Zakynthos, where he came to be regarded by his compatriots, as it has been said at the beginning of this contribution, as a 'pride of the Orthodox Church'.

\section{Conclusion}

The data presented and analysed so far have shown how difficult it is to define Katiforos' confessional identity in a clear way. Officially he belongs to the Orthodox Church: this is shown by the baptism received according to the Orthodox rite; by his serving as an Orthodox priest and archpriest in Zakynthos; by his funeral and burial in an Orthodox parish church on his native island. The biographical sources, particularly those connected with Zakynthos, praise him as a champion of Orthodoxy.

Yet, if Katiforos' Orthodox portrait delivered by his biographers is not taken at face value, some contradictions and exaggerations emerge. His contacts with $\mathrm{Me}-$ letios Typaldos; his defensive attitude of both Orthodoxy and Catholicism against the Protestant writers in the biography of Peter the Great and, in a more discrete way, in the commentary on Photius' Myriobiblos; his interest in the proposal of

102 Ibid., 223: 'meas qualescumque facultates Apostolici Throni servitio aliquando dicarem reliquosque aetatis iam ad senectutem flectentis dies sub potenti transigam protectione tuae eximiae sanctitatis.' 
union between the Russian Orthodox and the Catholic Churches presented by the Sorbonne theologians to Peter the Great; his wish to work in the Vatican Library in Rome, at the heart of Catholicism; all these elements seem to point at an ambiguous confessional position, on the edge between the Catholic and Orthodox worlds.

Katiforos, who lived and operated in a social and cultural context marked by the double presence of the Catholic and the Orthodox churches, seems to be moving within the grey zone which stretches along this confessional border. No archival evidence has emerged so far that will enable us to decide whether this has to be considered as a well calculated strategy on the part of Katiforos, aimed at getting personal advantages in terms of social and economic promotion, or as the result of his wish to be a linking, rather than a divisive, element between the two sides of the confessional border.

\section{Bibliography}

Anonymous [Antonios Katiforos], Vita di Pietro il Grande Imperador della Russia; estratta da varie memorie, pubblicate in Francia e in Olanda, 1st edn (Venice 1736).

Bovo T., Giovanni Cottunio e gli intellettuali greci a Padova nel XVII secolo: dalla matrice accademica alla prospettiva panellenica (PhD Thesis) (Università Ca'Foscari, Venice 2015). http://dspace.unive.it/handle/10579/5641.

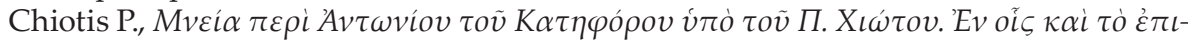

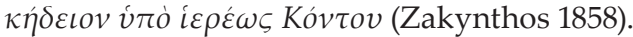

Cracraft J., The Church Reform of Peter the Great (Stanford 1971).

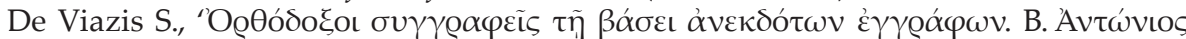

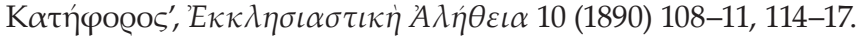

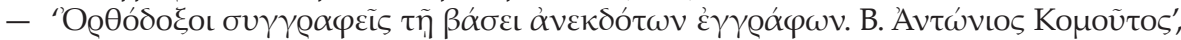

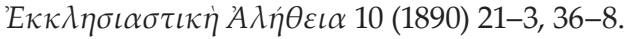

Dooley B., Science, Politics and Society in Eighteenth-Century Italy. The Giornale de'letterati d'Italia and its World (New York-London 1991).

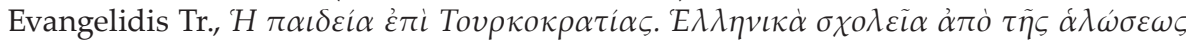

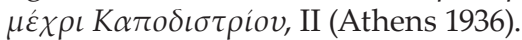

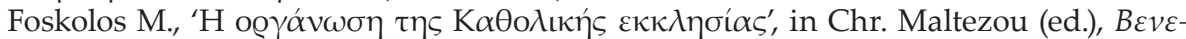

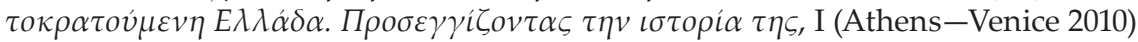
337-56.

Fyrigos A., 'Catalogo cronologico degli alunni e dei convittori del Pontificio Collegio Greco di Roma (1701-1803)', in A. Fyrigos (ed.), Il Collegio Greco di Roma. Ricerche sugli alunni, la direzione, l'attività (Rome 1983) 23-77.

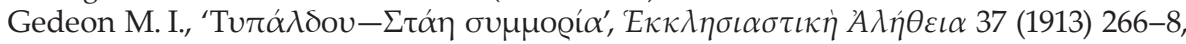
276-80, 289-92, 298-300, 305-8, 317-20.

Infelise M., L'editoria veneziana nel '700 (Milano 1991).

- 'Sulle prime gazzette a stampa veneziane', in L. Antonelli, C. Scarpa and M. Infelise (eds), Per Marino Berengo. Studi degli allievi (Milan 2000) 469-79.

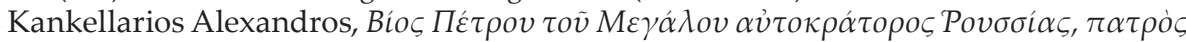

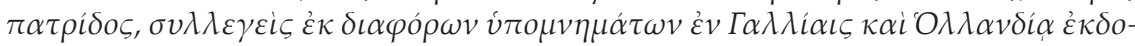

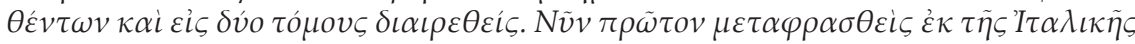




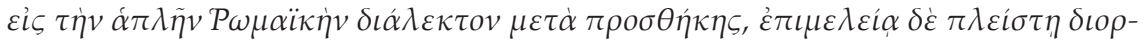

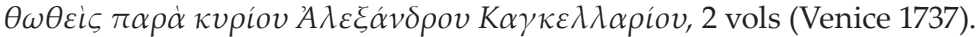

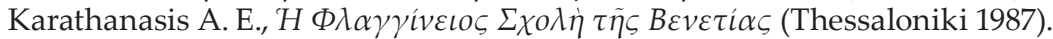

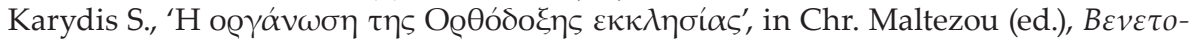

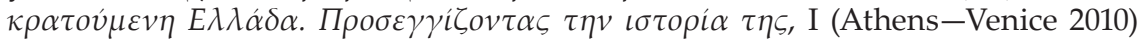
295-326.

- 'Il clero ortodosso delle Isole Ionie sotto la dominazione veneziana', in Collegio

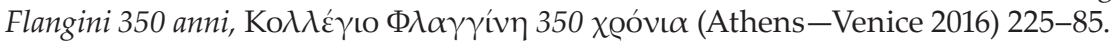

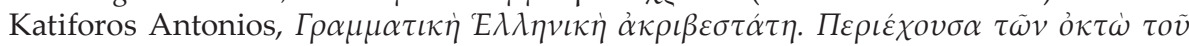

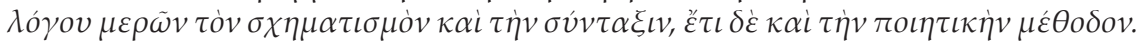

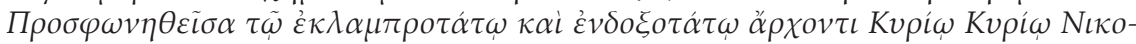

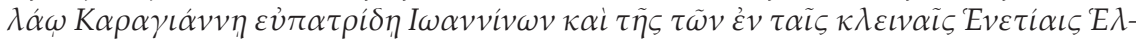

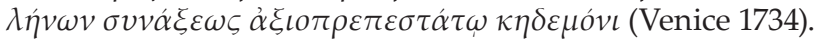

- Vita di Pietro il Grande Imperador della Russia, scritta dall'abate Antonio Catiforo. Edizione seconda, riveduta ed accresciuta dall'Autore, 2nd edn (Venice 1739).

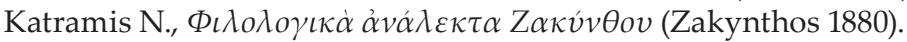

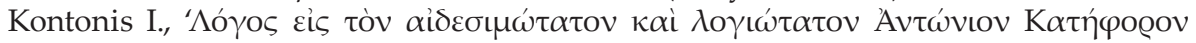

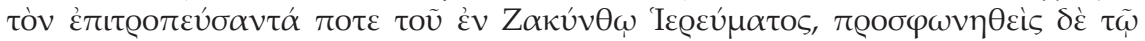

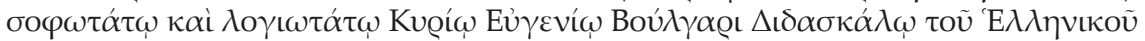

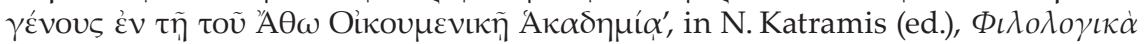
$\dot{\alpha} v \alpha \dot{\lambda} \varepsilon \kappa \tau \alpha$ Z $\alpha \kappa v ́ v \theta o v$ (Zakynthos 1880) 395-409.

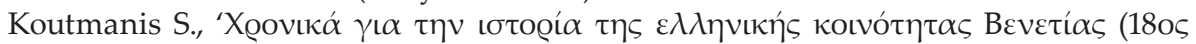

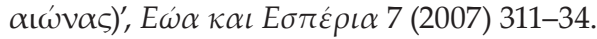

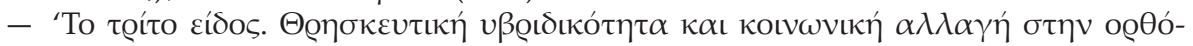

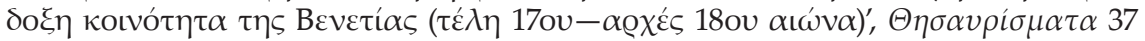
(2007) 389-420.

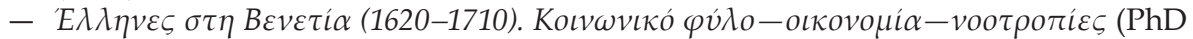
Thesis) (National and Kapodistrian University of Athens, Athens 2013).

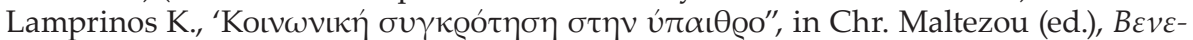

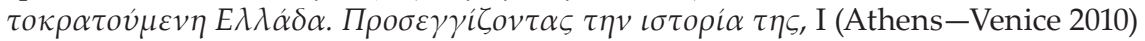
131-54.

Losacco M., Antonio Catiforo e Giovanni Veludo interpreti di Fozio (Bari 2003).

Löscher V. E. (ed.), 'Narratio de Sorbonnae conatu conciliandi Ecclesiam magnae Russiae cum Ecclesia Latina', in Unschuldige Nachrichten von alten und neuen theologischen Sachen 18 (Leipzig 1718) 331-48.

Manoussakas M., 'La comunità greca di Venezia e gli arcivescovi di Filadelfia', in La chiesa greca in Italia dall'VIII al XVI secolo. Atti del convegno storico interecclesiale (Bari 30 Aprile - 4 Maggio 1969), I (Padova 1973) 45-87.

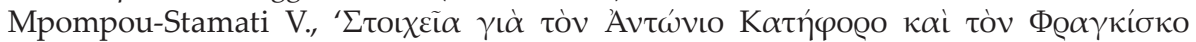

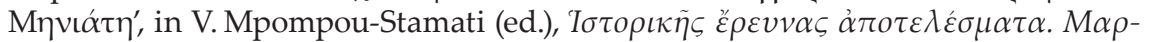

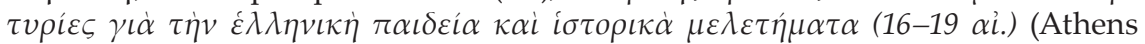
2002) 119-32.

Nestesuranoi I. [J. Rousset de Missy], Mémoires du regne de Pierre le Grand, Empéreur de Russie, père de la Patrie ecc. ecc. ecc. par le B. Iwan Nestesuranoi, 4 vols (Amsterdam 1725).

- Memorie del Regno di Pietro il Grande Imperadore di Russia, Padre della patria ec. ec. ec. del B. Iwan Nestesurianoi, divise in quattro tomi, nuovamente tradotte dal francese nel volgare italiano (Venice 1736). 


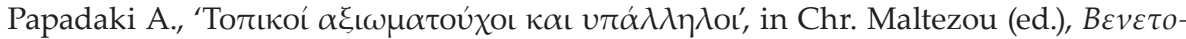

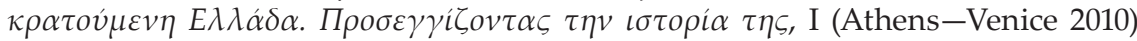
83-104.

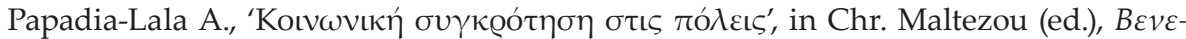

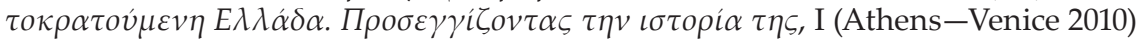
105-30.

Perry J., The State of Russia under the present Zar (London 1716).

- Etat présent de la Grande Russie ou Moscovie (Paris 1717).

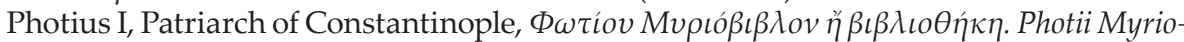
biblon, siue bibliotheca librorum quos legit et censuit Photius patriarcha Constantinopolitanus, Graece edidit Dauid Hoeschelius Augustanus, \& notis illustrauit. Latine vero reddidit $\mathcal{E}$ scholiis auxit Andreas Schottus, ed. D. Hoeschel, transl. A. Schott (Geneva 1612).

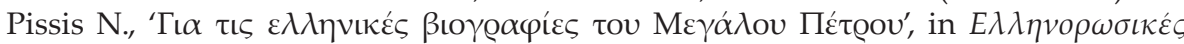

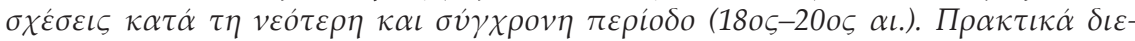

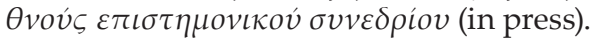

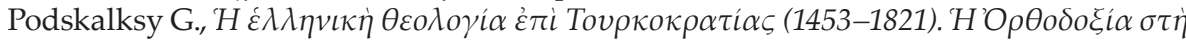

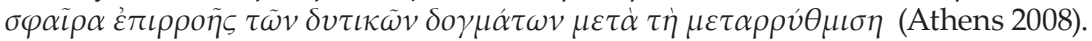

Prokopiou Pamperis Dimitrios, ‘Demetrii Procopii, Macedonis Moschopolitae, 'E $\pi$ -

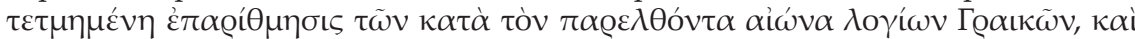

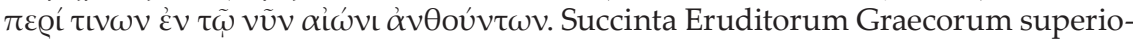
ris et praesentis saeculi recensio, conscripta mense Junio A.C. MDCCXX transmissaque Bucuresto, et nunc primum edita, cum Latina versione', in J. A. Fabricius (ed.), Bibliotheca Graeca, XI (Hamburg 1722) 769-808.

Rodotà P. P., Dell'origine, progresso e stato presente del rito greco in Italia, 3 vols (Rome 1758-1763).

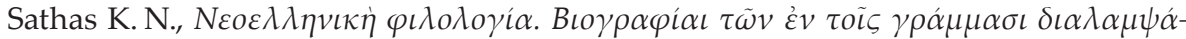

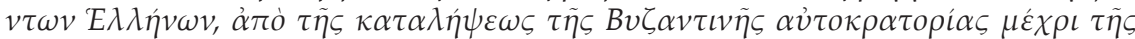
$\varepsilon \lambda \lambda \eta v \iota \kappa \tilde{\eta} \varsigma \dot{\varepsilon} \theta v \varepsilon \gamma \varepsilon \rho \sigma i \alpha \varsigma$ (1453-1821) (Athens 1868).

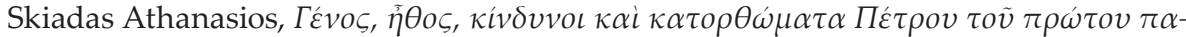
$\tau \rho \dot{\varsigma} \varsigma \pi \alpha \tau \rho i \delta o \varsigma \alpha \dot{v} \tau о \kappa \rho \alpha ́ \tau о \rho о \varsigma ~ \pi \alpha ́ \alpha \eta \varsigma ~ P \omega \sigma \sigma i \alpha \varsigma, ~ \kappa \alpha i ~ \tau \dot{\alpha} \dot{\varepsilon} \xi \tilde{\eta} \varsigma$ (Venice 1737).

Skoufari Ev., 'Aspects of Religious Coexistence: the Historiography of the Orthodox and Catholic Churches in the Ionian Islands during the Period of Venetian Domination', in A. Hirst and P. Sammon (eds), The Ionian Islands: Aspects of their History and Culture (Newcastle upon Tyne 2014) 264-75.

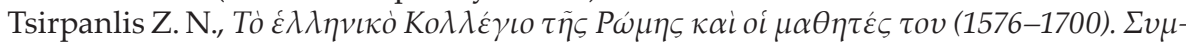

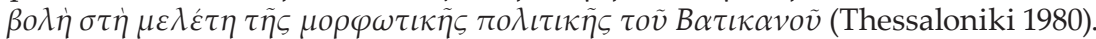

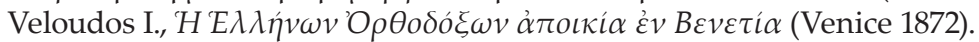

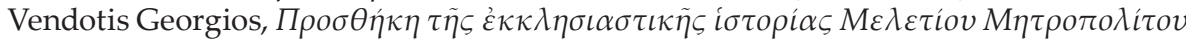

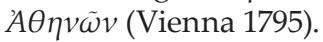

Weber F. Ch., Das Veränderte Russland (Frankfurt a.M. 1721).

- Nouveaux Mémoires sur l'état présent de la Grande Russie ou Moscovie, 2 vols (Paris 1725).

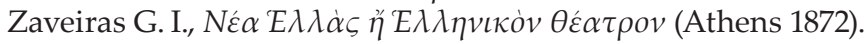

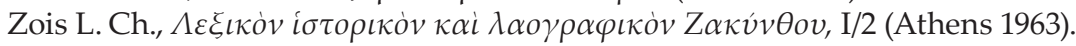





\title{
Institution-building Processes in Eastern Christianity: Pantelis Sevastopoulos and the Foundation of the Evangelical School of Smyrna
}

\author{
Niki Papaïliaki, Paris
}

Despite the progress in the research concerning the history of Smyrna in the Ottoman era, we still have very few testimonies providing information on the foundation of the Evangelical School. ${ }^{1}$ For most such testimonies, the creation of the School (1733/1743) corresponds to the activity of a committee of eminent Greeks from Smyrna, headed by Pantelis Sevastopoulos and motivated by the urgency to address the lack of a Greek educational institution in the city and to counterbalance the Jesuits' proselytism towards Orthodox children. Moreover, as argued by the School archival documents, ${ }^{2}$ Sevastopoulos, in order to guarantee the security of the institution, would have placed it under the protection of the English Consul, representative of the Levant Company at Smyrna. All of these testimonies, as well as the edition of the documents from the archive of the School, date from the nineteenth century.

If we want to reexamine the conditions of the foundation of Evangelical School, we will have to proceed in the domain of knowledge transfer and the creation of educational institutions in the context of the confessionalization paradigm. In this context, the educational process-aggressive propaganda, proselytism, or defensive strategy-becomes an important component of the confessional conflicts of divided Christianity into which influential members of civil society were drawn.

In the absence of new testimonies, we shall present here the narrative developed in the nineteenth century and try to sketch the profile of the School's donor with the aid of information from the French archives.

\section{Adamantios Korais on Sevastopoulos' school}

Adamantios Korais is our most important witness on the school, which he attended in his early childhood. Many years later, in his autobiography, he still remembered the poverty of knowledge and the abundance of blows he had suffered there:

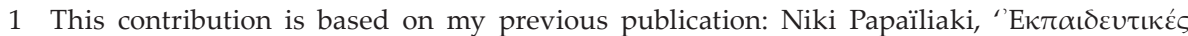

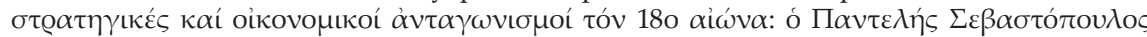

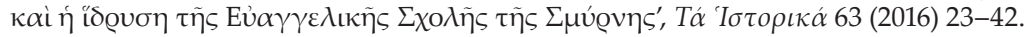

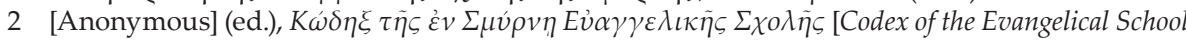
in Smyrna] (Smyrna 1876). 
As my father burned with a great love of education, it followed that he should take care of the education of his children. If my grandfather [Diamantis Rysios] had been still alive then, he would have unhesitatingly entrusted him with this care, but his death had forced my father to hand us over to a Greek school, recently established then by a man from Chios, Pantoleon Sevastopoulos and directed by a monk from Ithaca. The teacher and the School resembled all the other teachers and schools of Greece at that time, which means that they were providing very poor teaching followed by abundance of blows. We were beaten so hard there that my brother, as he couldn't bear it any longer, he gave up Greek education despite our parents' opinion. ${ }^{3}$

Nor had Korais forgotten the teaching of logic he had received in the Evangelical School-which was probably based on a book by Theofilos Korydallefs ${ }^{4}$, and which was completely different from the logic he would study some years later in Amsterdam. ${ }^{5}$

After the destruction of its building in 1778 by fire, the School, administrated by a new committee, ${ }^{6}$ was transferred to a new edifice financed by Ioannis Kanas. This second donor of the institution had also financed the Metropolitan Platon's Orthodox Confession, which was translated into Greek by Adamantios Korais ${ }^{7}$ after

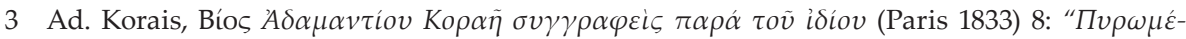

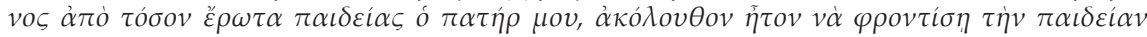

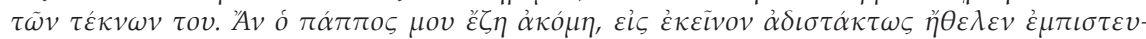

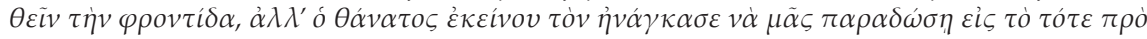

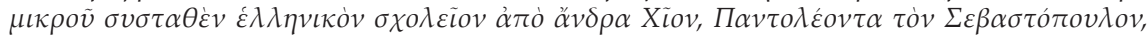

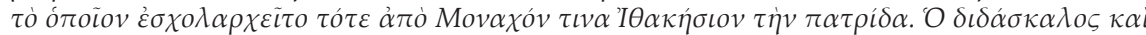

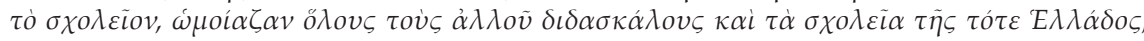

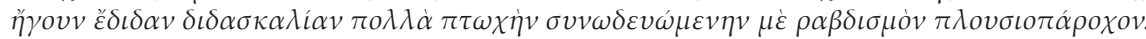

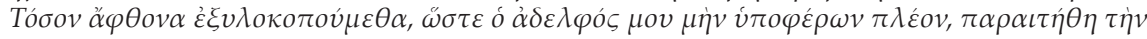

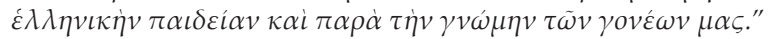

4 Among the few books found by Paranikas in the school library, he mentions Theofilos Koryd-

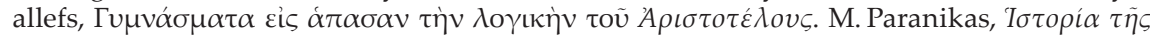

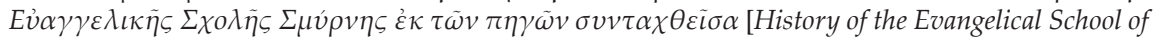
Smyrna deriving from the sources] (Athens 1885) 21, note 2.

5 In Amsterdam, Adrian Vyrton taught Korais from a book of logic written by his wife (Josina Carolina van Lynden). Korais, Bíos, 17.

6 On this committee, which was made up by Ioannis Mavrogordatos, Ioannis Kanas, Ioannis Omiros, Michail Chourmouzis and Dimitrios Mpachatoris, see Paranikas, 'Iotogí $\alpha, 16-19$. Ioannis Mavrogordatos, a pious man who was constantly at prayer-as Koumas informs Korais

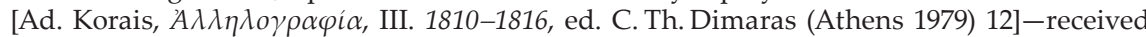
Makarios of Corinth in Smyrna, in 1777 and also financed the edition of Filokalia [Фı

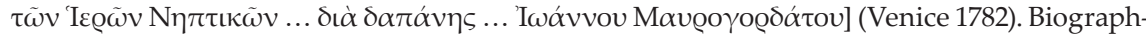

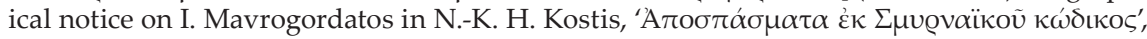

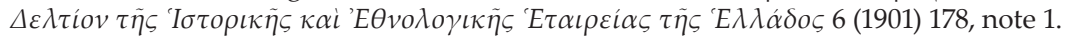

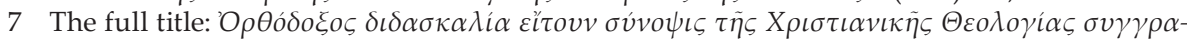

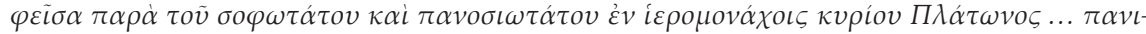

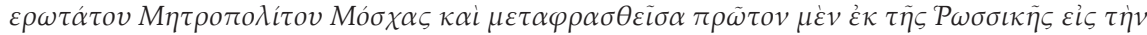

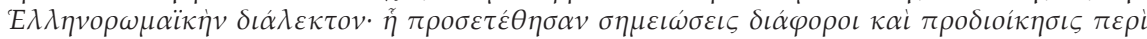

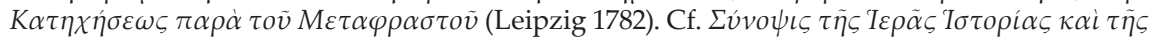


his return from Amsterdam, during the period of his inactivity in Smyrna. In 1810, when Koumas, the director of the new Philological Gymnasium, ${ }^{8}$ accused the Evangelical School of having become a 'community of ascetics' ('kotvóßıov $\left.\dot{\alpha} \sigma \kappa \eta \tau \tilde{\omega} v^{\prime}\right),{ }^{9}$ the School was managed by Gavriil of Vryoula, who was known for his neo-Hesychastic writings. ${ }^{10}$ At that moment, Korais intervened in the conflict, claiming that if Sevastopoulos had been still alive then he would have financed the Gymnasium as much as the Evangelical School. ${ }^{11}$

Testimonies on Pantelis Sevastopoulos, whom Konstantinos Oikonomos and Andreas Mamoukas also referred to as Sari Pantelis, ${ }^{12}$ are few and far between. And while the legend that persisted in Smyrna in the nineteenth century presents him as 'someone totally lacking in education', 13 the historian Konstantinos Amantos considers him a protector of letters, a philanthropist, and an experienced and intelligent politician. ${ }^{14}$ According to Philip P. Argentis, he was born in Chios in 1682 and he was the son of Emmanouil Sevastopoulos and Loxandra Avgerinou. ${ }^{15}$ After 1718, having established himself in Smyrna, he worked as a financier, granting loans to merchants and investing in trading companies. ${ }^{16}$ There he also participated in the elections of the Greek Community of the city and contributed to the construction of its hospital. ${ }^{17}$ From 1733 to 1747 he was closely involved in the creation of the Evangelical School. The date of his death is uncertain. According to a document from the Codex of Smyrna, Sevastopoulos passed away after 26 July 1756 and before 12 February 1759.18

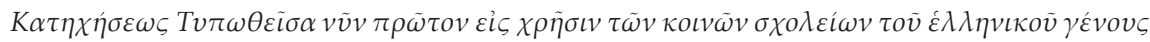
(Venice 1783).

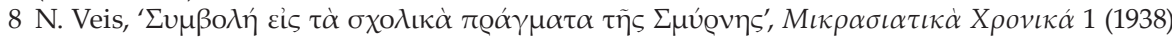

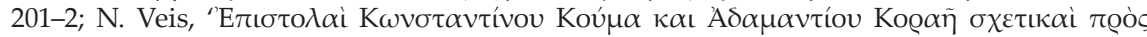

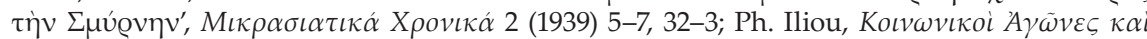

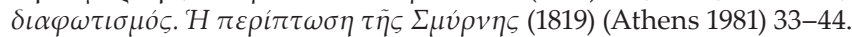

9 Paranikas, Iotooía, 37.

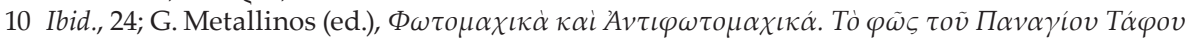

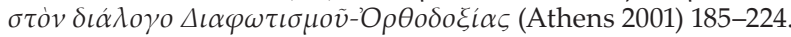

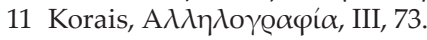

12 From the turkish sart=yellow, pale, blond.

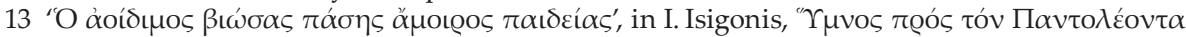

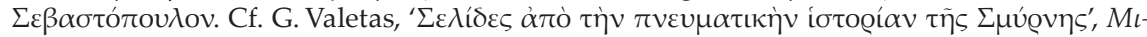

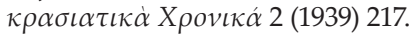

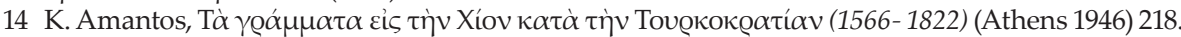

15 Ph. P. Argenti, Le libro d'oro de la noblesse de Chio, I. Notices historiques (London 1955) 125-126

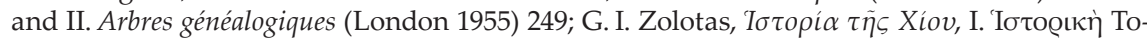

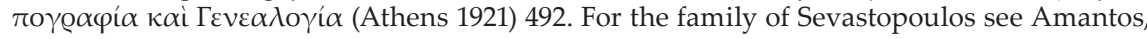

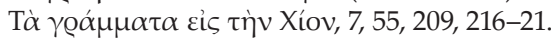

16 For the loan of eighty reals he grants to the merchant Michalis Melos in 1718, see Archive of the Hellenic Institute in Venice, Smyrna, $\mathrm{n}^{\circ} 118 \mathrm{a}$, document 79 . In 1756 he financed a new trading

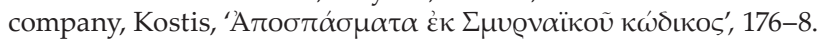

17 In 1725, he was elected elder ( $\delta \eta \mu \gamma \gamma \varepsilon \rho \omega v)$ of the Greek Community of Smyrna with Diaman-

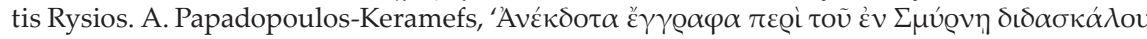

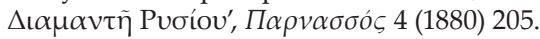

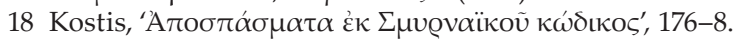




\section{The Greek historiography of the nineteenth century on the foundation of the Evangelical School}

In his 1831 work Rough Treatise about Smyrna ${ }^{19}$, Konstantinos Oikonomos attributed the foundation of the 'old School' to Sevastopoulos and a committee of Greeks of Smyrna who were motivated by love of education (' $\left.\varphi \iota \lambda о \mu \alpha \dot{\alpha} \theta \varepsilon \alpha^{\prime}\right)$, philanthropy and a desire to emulate their glorious ancestors:

The people of Smyrna do not seem to have forgotten their old ancestors in charity and love of education. In the agitation of their misfortunes, they took care in the beginning of the last century to establish their famous hospital and the so-called Old School. [Note:] (a) In the construction of both of these common charities, the late Sari Pantelis surpassed the others in zeal. The names of those esthetes and philanthropists are commemorated and will be commemorated forever, as benefactors of their homeland. ${ }^{20}$

Yet in a series of publications in subsequent decades, the foundation of the School became associated with Sevastopoulos' intention to prevent the appropriation of the Greek educational domain by the Jesuits. In 1848 a chronicle of Sevastopoulos' adventures that arose from his educational activity was anonymously published in Iakovos Pitzipios' magazine Repository of Pleasant and Useful Knowledge [AroOń-

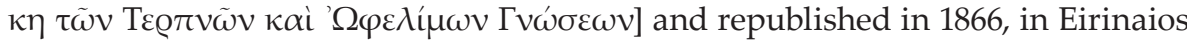

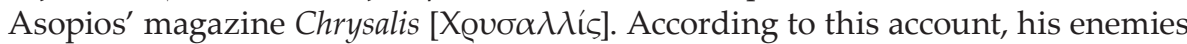
(the Jesuits), jealous of his success, would have intervened to have him captured and transferred to France:

At the beginning of the eighteenth century there was no noteworthy Greek school in Smyrna, until 1730 when the Jesuits established there a public one under the protection of France. In this school they taught the Greek language, and many of the Greek inhabitants of Smyrna sent their children there. For this reason, Sari Pantelis, one of the Chian merchants established in Smyrna, suspecting that the Jesuit school aimed at proselytizing, founded the so-called Evangelical School and in order to protect it from the Jesuits' intrigues, placed it under the protection of the English Consulate. As they could not affect it, the enemies of the School decided to harm its founder; a French merchant ship seized him by fraud and brought him to

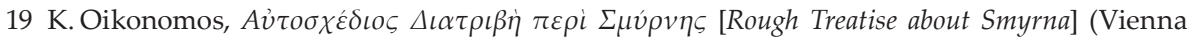
1818 and 2nd edn Malta 1831).

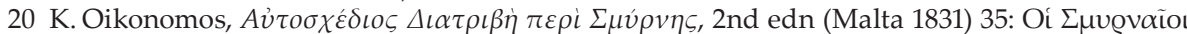

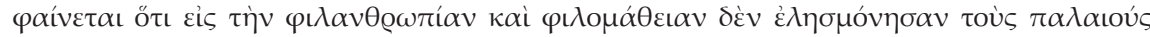

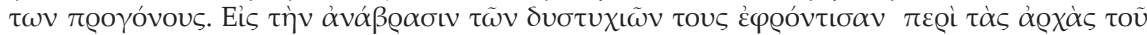

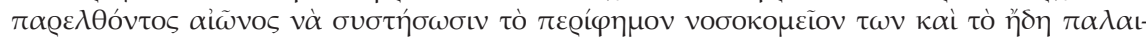

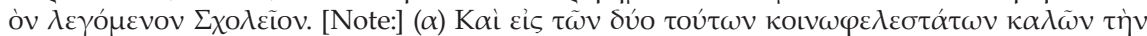

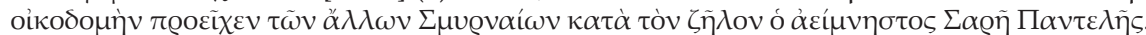

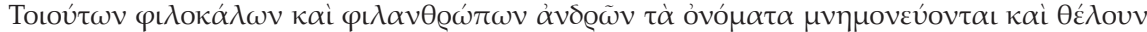

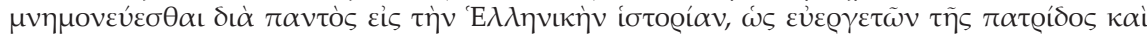
$\tau \tilde{\omega} \nu$ ó $\mu о \gamma \varepsilon v \tilde{\omega} \nu \tau \omega \nu$. 
France, where he was detained in a secret prison for several years until his relatives, when they discovered he was in France, acted with the help of the Ottoman government to secure his liberation. The Evangelical School has been preserved until today in Smyrna. ${ }^{21}$

In his small study on the Evangelical school published in 1881, Andreas Mamoukas follows the anonymous text faithfully, but omits the narration of Sevastopoulos' adventures in France. In Mamoukas' account, Sevastopoulos, alerted by the danger of Jesuits proselytism and motivated-as well as those who had assisted him-by piety and love of his homeland, founds a public school in Smyrna:

Around 1730, the Jesuits founded a public school [in Smyrna] under the protection of France; in this school they also taught the Greek language. Many of the inhabitants of Smyrna sent their children there to receive education. At that time, Pantoleon Sevastopoulos from Chios, one of the established great merchants (also known as Sari Pantelis, according to the custom of the Chians, who give to each family, next to its genealogical name, a special nickname or sobriquet), suspecting that the school founded by the Jesuits aimed proselytism, assisted by some of his compatriots, merchants from Chios and other citizens of Smyrna who were possessed by the same piety and love for their homeland, founded a public school. ${ }^{22}$

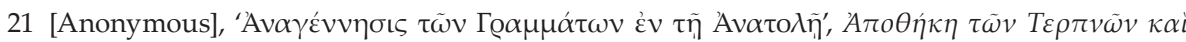

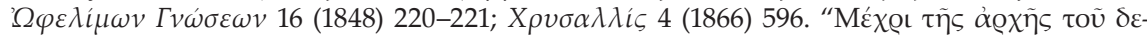

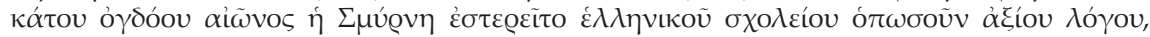

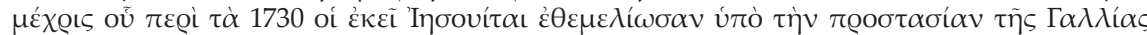

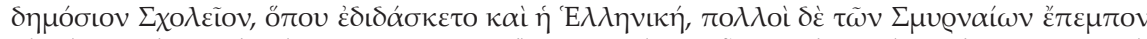

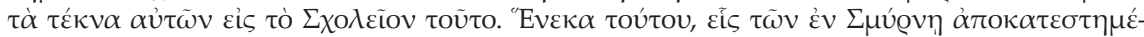

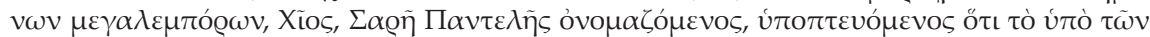

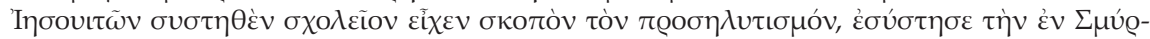

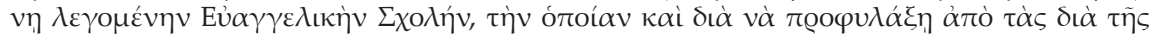

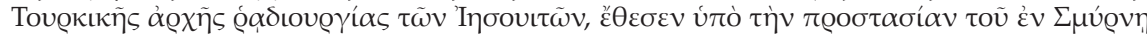

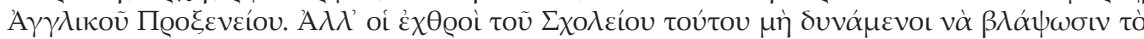

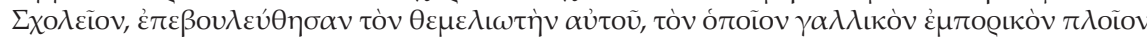

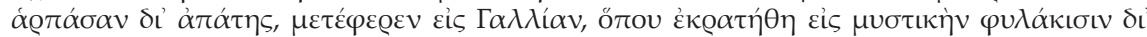

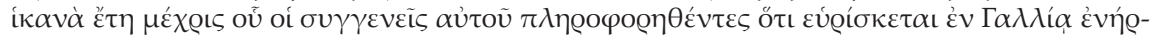

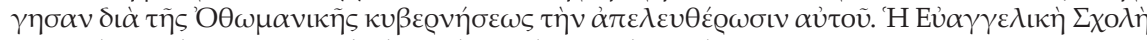

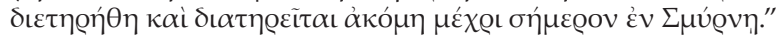

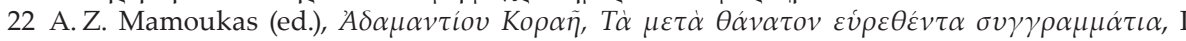

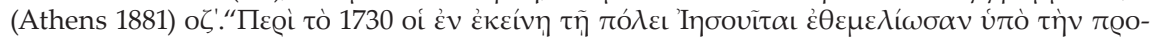

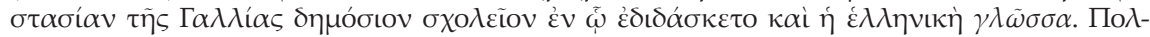

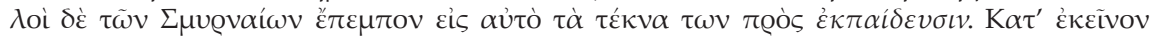

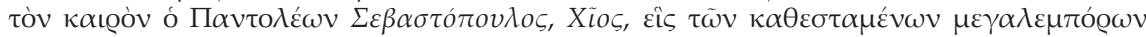

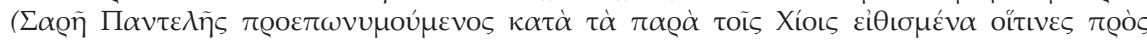

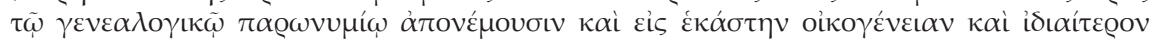

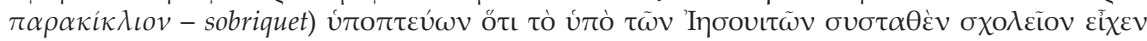

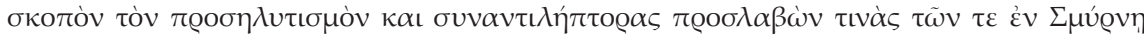

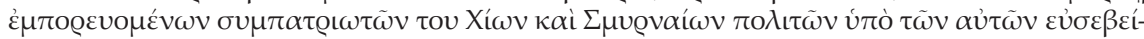

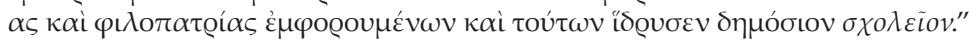


In 1871, Konstantinos Oikonomos' Rough Treatise ${ }^{23}$ was re-edited by Sofoklis Oikonomos. In his commentary on the passage in which Konstantinos Oikonomos refers to the churches of Smyrna, the editor exposes the conflicts between Orthodox and Catholics, ${ }^{24}$ denounces the French missionaries' strategies of seducing Greeks and recalls their attempts to interfere with Greek education in Smyrna: 'The Jesuits who settled in Smyrna in 1624 with the complicity of the French consul Samson Napollon ${ }^{25}$ did not deprive themselves of any audacity; and what did they not invent in their efforts to seduce, through schools, the Orthodox children?'26

Sofoklis Oikonomos was responding here to the comments of B. F. Saarlsthe translator of the Rough Treatise into French ${ }^{27}$-regarding the Orthodox attempts to appropriate the Catholic churches of Smyrna, and refers to the Chronicle of the French Jesuits' establishment in the East published by Émile Legrand in $1869 .{ }^{28}$ This chronicle is representative of a great number of narratives ('récits de mission') produced by the French Catholic mission. In these narratives, the statistics concerning the student population of the small catechetical units established by the missionaries everywhere are oriented towards the promotion of their missionary activity. Especially in the late nineteenth century, when France used the missions-as an integral component of its foreign policy-to spread its school network throughout the East, these narratives legitimized the missionaries' multi-secular presence in the region.

In 1876, the Codex of the Evangelical School was published in Smyrna. According to Paranikas, its editor was Aristotelis Fontrier. ${ }^{29}$ A descendant of a French Protes-

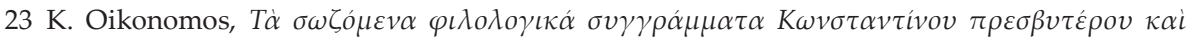
Oikovó

24 Ibid., 340, 411-412.

25 'Les pères Jésuites purent s'établir à Smyrne grâce à la demande expresse que fit Samson Napollon, consul de 1623-1624, à son ambassadeur à Constantinople, d'obtenir la permission de s'attacher deux pères jésuites.' Fr. Bauden (ed.), Le voyage à Smyrne. Un manuscrit d'Antoine Galland (1678) (Paris 2000) 265. For Samson Napollon, 'a corsican-born merchant, naturalized citizen of Marseille [...] heavily involved in the merchant consulships in the Ottoman Levant', see P. N. Miller, 'Peiresc and the Study of Islamic Coins in the Early Seventeenth Century', in A. M. Stahl (ed.), The Rebirth of Antiquity: Numismatics, Archaeology and Classical Studies in the Culture of the Renaissance (Princeton NJ 2009) 137. Reprinted in P. N. Miller, Peiresc's Orient, Antiquarism as cultural history in the Seventeenth century (variorum) (London-New York 2012) III.

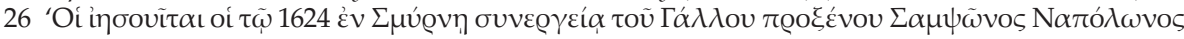

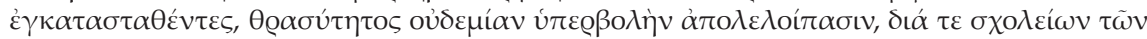

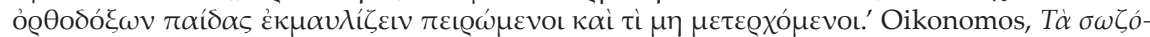

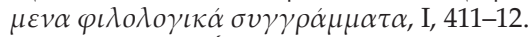

27 K. Oikonomos, Étude sur Smyrne par Constantin Ikonomos, traduite du grec par Bonaventure F. Slaars et enrichie par le traducteur d'un appendice et de notes nombreuses, étendues et variées qui la complètent, transl. B. F. Saarls (Smyrna 1868) 148-50.

28 É. Legrand (ed.), Relation de l'établissement des R. R. Pères de la compagnie de Jésus au Levant, édition conforme au manuscrit de la Bibliothèque nationale (Paris 1869) 13-17.

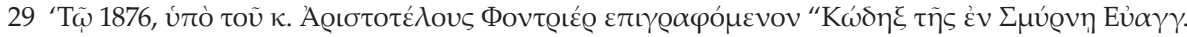

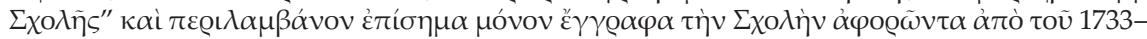

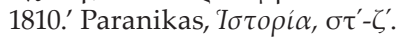


tant family that had settled in Naxos in the seventeenth century and converted to Orthodoxy, Aristotelis Fontrier (1835-1907) was a well-known merchant, but also a talented scholar, amateur archeologist and an 'aristocrat des archives'. Elected Dimogeron (elder) of the Greek community in 1890, he was at the same time one of the notables of the French colony of Smyrna. ${ }^{30}$

The editor dedicates the Codex to the eternal memory of Pantoleon Sevastopoulos, the founder of the School, to those who had assisted him, Ierotheos Dendrinos, Georgios Omiros and Zorzis Vitalis, and to the memory of the first commissioners. ${ }^{31}$ Five of the documents edited here refer to the successive steps of the School's foundation from 1733 to 1747. In the first document of 1733, Sevastopoulos, Omiros and Vitalis take over the school management ${ }^{32}$ personally and Ierotheos Dendrinos is appointed as teacher for life. In the second document of 1743, Sevastopoulos and Omiros delegate the investment of the capital set up by donations (most notably by Sevastopoulos) to a four-member committee. The profits generated by the interests have to be used to remunerate Dendrinos and cover the School's expenses. ${ }^{33}$ The document of 1743 explicitly states that the appointment of a steering committee was intended to secure the newly established School from any intervention: 'that no one, neither ecclesiastic nor layman, neither Greek nor foreigner, has the power to threaten, confuse and disturb this established school dedicated to the Son of God, neither any relative, nor any heir.' ${ }^{34}$ However, in his 1747 will, Sevastopoulos placed the School under British protection. Specifically, he appoints the English consul as commissioner of commissioners and supervisor of the School:

I, the founder, noting the vulnerability of the nation and the fragility of the enterprise, I place the above mentioned school under the protection of his Excellence my Lord the Consul of the English and under the defense of the brave Anglican Company, so that they continue to safeguard the above mentioned school as the defenders of the weak and as the servants of the Christ; having accepted all this, I hope that they become protectors and defenders of this evangelical work, by avoiding any family, political or ecclesiastical aggression and that each Consul will be the commissioner of commissioners and the supervisor. ${ }^{35}$

30 G. Radet, 'Aristote Frontier', Revue des études anciennes 9/4 (1907) 376-80; M.-C. Smyrnelis, Une société hors de soi, identités et relations sociales à Smyrne aux XVIIIe et XIX siècles (Paris 2005) 185.

$31 K \omega \dot{\delta} \eta \xi \tau \tilde{\eta} \varsigma \dot{\varepsilon} v \Sigma \mu \hat{v} \rho v \eta E \hat{v} \alpha \gamma \gamma \varepsilon \lambda \iota \kappa \tilde{\eta} \varsigma \Sigma \chi 0 \lambda \tilde{\eta} \varsigma, 3$.

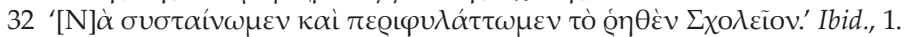

33 Ibid., 2-3. For Sevastopoulos' donation of an inn in Smyrna and of a house in Narlikioi near Bournova, see ibid., 5-7. The annual income of the inn (300 grosia) covers, besides the expenses of the school, a scholarship for four indigent students, as well as the salary of a new teacher, called here pedagogue or teacher of common letters.

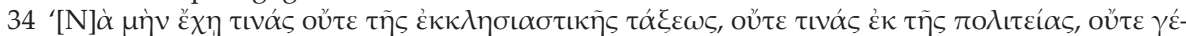

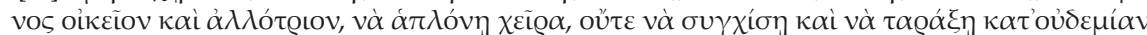

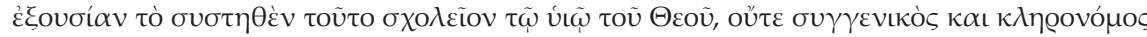
тเvós.' Ibid., 2-3.

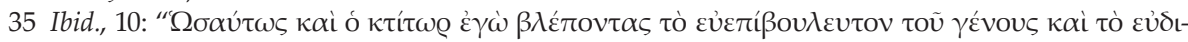


In addition, both in the document of 1743 as well as in the 1747 will, Sevastopoulos insists on the identity and orientation of the educational project. He dedicates the School to Jesus Christ and declares it 'as a school of His Evangelical commands and tutor school of all Greek lessons. ${ }^{36}$

In 1885 the School's director, Matthaios Paranikas (1878-1885), published in Athens the History of the Evangelical School of Smyrna deriving from the sources. Paranikas adds to the list of documents edited in the Codex of the Evangelical School one taken from the Codex of the Metropolis of Smyrna. According to this, as early as 1732, Sevastopoulos had already taken part in a committee that assumed part of the expenses of a school, the rest being provided by the parish of Agia Foteini. ${ }^{37}$

For Paranikas, the committee that intervened in 1733 did not create a new school but rather 'reformed' the preexisting school of Ierotheos Dendrinos, which was established in 1717 on the Metropolitan Ananias' initiative. ${ }^{38}$ The latter replaced Diamantis Rysios' school, which established in 1707 on the initiative of Patriarch Gavriil III. ${ }^{39}$ Based on the above-mentioned commentary by Sofoklis Oikonomos, Paranikas supports the view that in 1707 Gavriil III was motivated by the urgency to fill the educational gap in Smyrna because:

Taking advantage of this misery of the Greeks, the Jesuits who had settled in the city since 1624, were trying with all their might to attract Orthodox children to their school. From the tradition we know that they had even suggested to our people that a special school be established for the Greeks' children. ${ }^{40}$

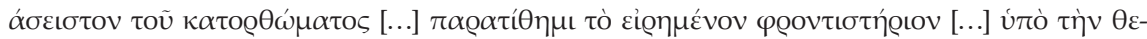

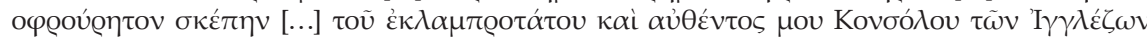

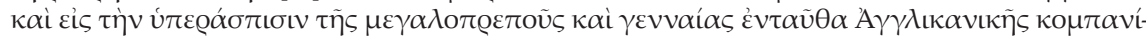

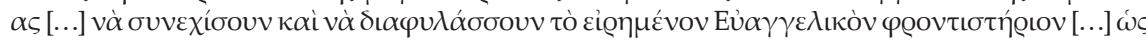

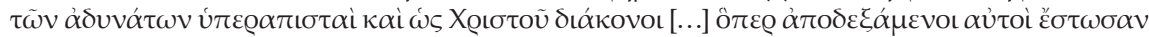

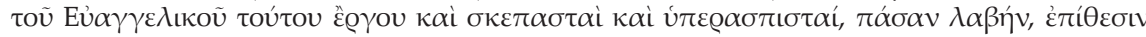

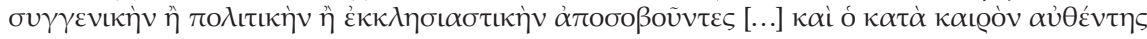

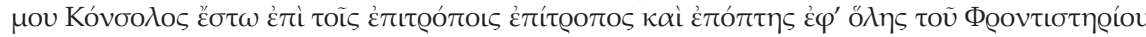

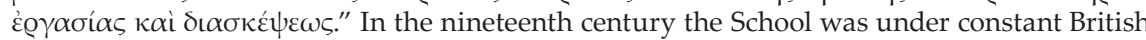
protection: 'The Evangelical School according to the founder's will is entirely independent of the authorities of the Orthodox Community of Smyrna and is under the direct protection of

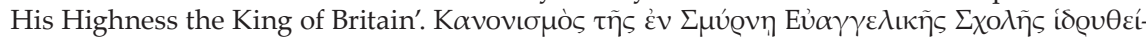

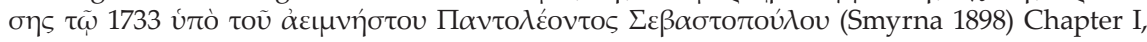
Article 3; 'The supreme authority of the Evangelical School is a twelve-member commission consisting of Orthodox citizens, inhabitants of Smyrna, irrespective of social status, known in good conduct, having completed their thirtieth year of age and according to the will of the founder, under the supervision of the Smyrna English Consul.' Ibid., Chapter III, Article 6.

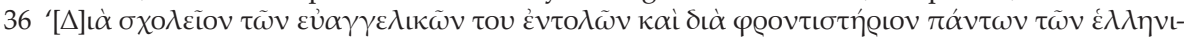

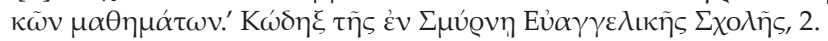

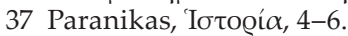

38 Ibid., 4.

39 Ibid., 3.

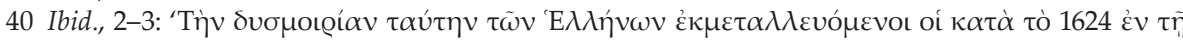

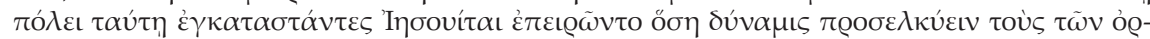


Thus, Paranikas places Sevastopoulos' action and the existence of the Evangelical School within the continuity of orthodox educational strategy as prompted by the fear of seeing the Greek educational domain being overwhelmed by French Jesuit pedagogy.

It is obvious that if we were to obtain more information about the Evangelical School's main donor, we would have to examine the archive of the School, which has regrettably been lost. However, proceeding from the indication of Sevastopoulos' presence in France, we can consult the French consular archives, which are particularly rich concerning Chios in the eighteenth century.

\section{From Smyrna to Marseilles: the French archival testimony}

The correspondence of the French Consul at Chios, Jean-François Bonnal, ${ }^{41}$ with the French Minister of the Navy, Jérôme Phélypeaux de Pontchartrain, and the French Ambassador at Constantinople, Charles de Ferriol, ${ }^{42}$ from 1705 till 1708, preserves traces of the adventures of 'Pandeli Stratidiko Sebastopoulo' ${ }^{43}$ in France. According to this archival testimony, Sevastopoulos embarked from Smyrna to Marseilles in the autumn of 1705, tracking two French merchants who had fled to France after having left him large debts. ${ }^{44}$ No sooner had he arrived in Marseilles than he was arrested and imprisoned.

As soon as this news arrived in Chios, the Greek authorities of the island protested to the Consul and pointed out that Sevastopoulos was a dragoman of hon-

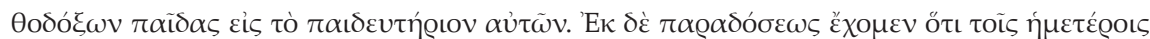

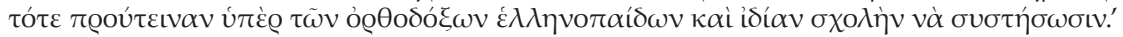

41 Archives Nationales Françaises [= AnF], Affaires étrangères [= AE], Correspondance Consulaire B/I/1009, Chios (1696-1722): I. Letters of the Consul of Chios Jean-François Bonnal to the Minister of the Marine: 08/01/1705, f. 27; 02/11/1705, f. 36v-37r; 29/11/1705, f. 38v-40v; 13/04/1706, f. 43v-45r; $27 / 08 / 1706$, f. $48 v-50 v ; 31 / 10 / 1706$, f. $95 v-97 v ; 27 / 12 / 1706$, f. $98 v-100 v ; 13 / 04 / 1707$, f. 46v-47v; 27/10/1707, f. 116v-121r; 04/02/1708, f. 124v-125r. (Bonnal's letter of 31/10/1706 is edited in Ph. P. Argenti, Diplomatic Archive of Chios 1577-1841, II (Cambridge 1954) 892-3). II. Letter of J. Daniel to the Consul and to the authorities of the French nation in Smyrna: 23/09/1705, f. 53v-54v. Letters of J. Daniel to the Minister of the Marine: 10/10/1705, f. 30v-35v; 24/08/1706, f. $82 \mathrm{v}-87 \mathrm{v} ; 25 / 09 / 1706$, f. $75 \mathrm{v}-81 \mathrm{v}$. III. Letters of Stellio Rafaeli to the Minister of the Marine: 01/03/1708, f. 126v-128r; 05/05/1708, f. 129v-131v; 10/07/1708, f. 139v-140v. AnF, AE, Correspondance Consulaire, B/I/385, Constantinople (1706-1708): Correspondence of the French Ambassador at Constantinople Charles de Ferriol with the Minister of the Marine: 06/05/1706, f. 37; 01/11/1706, f. 99; 19/02/1707, f. 119; 15/05/1707, f. 174.

42 Concerning Jean-François Bonnal, Consulary Agent in Chios, see A. Mézin, Les consuls de France au siècle des Lumières (1715-1792) (Paris 1998) 150-1. For Charles de Ferriol, Baron d'Argental, Ambassador of France at Constantinople (1699-1711), see J.-L. Baqué-Grammont, S. Kuneralp and F. Hitzel, Représentants permanents de la France en Turquie (1536-1991) et de la Turquie en France (1797-1991) [Varia Turcica, 22] (Istanbul 1991) 26-7.

$43 \mathrm{AnF}, \mathrm{AE}$, Correspondance Consulaire B/I/1009, Bonnal to the Minister of the Marine, 02/11/1705, f. 36v: 'Le grec s'appelle Pandelli Stratidico Sevastopoulo'; f. 116v: 'le grec Pandeli Stratidico'; AnF, AE, Correspondance Consulaire B/I/385, f. 99: 'le sieur Stratidico Sevastopulo [...] la famille Stratidico Sevastopulo.'

$44 \mathrm{AnF}, \mathrm{AE}$, Correspondance Consulaire B/I/1009, Bonnal to the Minister of the Marine, 02/11/1705, f. 36r. 
or and servant of the Dutch nation of Smyrna, a Dutch protégé and not a native Dutchman. ${ }^{45}$ The Greeks of Chios were conscious that, as Sevastopoulos had been in France during the War of Spanish succession, his status as a Dutch protégé would have rendered him suspect to the French authorities, who would not delay in requesting information about him from the Consul at Chios.

Jean-François Bonnal, in his correspondence with the Minister of the Marine, portrays Sevastopoulos as a dangerous enemy of the French religion and the French nation and denounces him as one of the main persecutors of the Catholic missionaries. ${ }^{46}$ One year later, in November 1706, the French ambassador at Constantinople applied to the Minister of the Navy for the release of the prisoner. In his letter, Ferriol argued that Alexandros Mavrokordatos had promised to intervene in the confessional conflicts in Chios, ${ }^{47}$ reintegrate Catholics into the island's Community authority and force the Greeks to pay for the restoration of missionaries' churches. ${ }^{48}$ However, the Consul Bonnal continued to insist on the prisoner's dangerousness, including with his letter to the Minister the ones that Sevastopoulos had addressed to the Dimogerontes (elders) of Chios. In these intercepted letters, Sevastopoulos invites the Greek authorities of Chios to simulate friendship with the Catholics and convince Mavrokordatos to intercede with the Ottomans on his behalf. ${ }^{49}$ Thus, the Chian trader continued to be detained in Marseilles for another whole year, until Bonnal informed the Minister in October 1707 that Sevastopoulos had surrendered and asked the community leaders of Chios to comply with French requirements. ${ }^{50}$ By February 4, 1708, Sevastopoulos has already arrived in Smyrna on a Dutch ship. ${ }^{51}$

45 Ibid., Bonnal to the Minister of the Marine, 03/04/1706, f. 44r.

46 Ibid., Bonnal to the Minister of the Marine, 02/11/ 1705, f. 36r: 'ce malheureux Pandelli et son frère George qui sont les premiers grecs de ce pays-ci viennent de faire emprisonner huit de nos principaux latins moyennant cinquante bourses qu'eux et les autres grecs ont compté aux turcs et cela sans autre raison que parce que ils sont catholiques.'

47 For the confessional conflicts in Chios see Ph. P. Argenti, The Religious Minorities of Chios. Jews and Roman Catholics (Cambridge 1970) 295-307.

48 Argenti, Diplomatic Archive of Chios, II, 893.

49 Bonnal summarizes the content of Sevastopoulos' letters to the Greeks of Chios. AnF, AE, Correspondance Consulaire B/I/1009, Bonnal to the Minister of the Marine, 27/12/1706, f. 98r-v: " $1^{\circ}$. Les Français sont les démons de l'enfer et la France le plus maudit pays. $2^{\circ}$. Il faut que les Grecs se plaignent au Grand Vizir parce qu'un sujet du Grand Seigneur est au cachot français. $3^{\circ}$. Il faut simuler l'amitié avec les Latins jusqu'à son retour. $4^{\circ}$. Qu'on se mette Maurocordato à la tête de tout cela, comme celui qui a une plus ancienne expérience dans les affaires et qui sait les conduire avec plus d'adresse contre l'ambassadeur." Cf. ibid., Bonnal to the Minister of the Marine, 13/04/1707, f. 46v-47r: "Maurocordato et le Patriarche sont tous de concert pour tirer Sevastopoulo de prison après quoi peu leur importera d'avoir donné des paroles, et ils n'en tiendront que ce qu'ils voudront. C'est ainsi que Sevastopoulo lui-même a la hardiesse de leur écrire du fonds de sa prison, que ne dirait-il pas s'il avait sa liberté et qu'il put parler de vive voix."

50 Ibid., Bonnal to the Minister 27/10/1707, f. 116r: "[L]e grec Pandeli Stratidico a fort changé de style dans ses dernières lettres, il mande à ses Grecs que le Roi est par tout redoutable à ses ennemis, que la paix n'est pas éloignée et que c'est à eux désormais à se comporter à l'égard des Français et des catholiques de manière que sa majesté n'ait plus à se plaindre d'eux. En effet lesdits Grecs depuis quelque temps sont devenus fort paisibles."

51 Ibid., Bonnal to the Minister of the Marine, 04/02/1708, f. 124v: 'Sevastopoulo est arrivé à 


\section{The transfer of confessional and financial conflicts in the domain of education}

As can be deduced from the French consular archives, Sevastopoulos was imprisoned in France in the years 1705-1708, during the war of Spanish succession-almost thirty years before the foundation of the Evangelical School. It is obvious that a part of Greek historiography shifts his adventures of 1705-1708 into the years that followed School's foundation and presents them as an abduction due to French Jesuit intrigues.

The French Consular sources highlight the Greek orthodox trader's position in the context of confessional conflicts, as well as in the context of the antagonism between French and Dutch in the international trade of the Levant, in the beginning of the eighteenth century.

During that period, which follows the revocation of the Edict of Nantes, French financial policy in the East coalesced with the efforts of the French Ambassador at Constantinople to monopolize the protection of Christians in the Ottoman Empire. ${ }^{52}$ This situation was exacerbated by the presence of French missionaries sent to the Ottoman Empire in order to supervise the Christian flock and ensure they conform to the principles of the Counter-Reformation. The elimination of those considered dangerous for Catholicism was not a rare phenomenon.

At the beginning of 1705, a few months before Sevastopoulos' arrest in Marseilles, the French Consul in Chios, on his Ambassador's order, had the Armenian Patriarch Avetik arrested and secretly sent to France..$^{53}$ Shortly thereafter, the Ottomans, investigating this disappearance of an Ottoman subject-and more importantly, of a religious leader-began to suspect French representatives at Constantinople and Chios of involvement in the incident. The study of the consular archives allows us to presume a correlation between the Armenian Patriarch's abduction and Sevastopoulos' imprisonment in Marseilles. The Chian trader's captivity was a major card in the hands of the French Ambassador to help ensure Mavrokordatos' neutrality. By negotiating for Sevastopoulos' release, Charles de Ferriol could dampen any suspicion of French involvement in Avetik's disappearance. ${ }^{54}$

Smyrne il y a 15 jours sur un vaisseau hollandais parti de Livourne, nos grecs sont toujours tranquilles, non tant à cause de son retour qu'à cause de notre Pacha qui n'est pas homme à leur laisser prendre le pied que leur donnait son prédécesseur.'

52 J. P. Farganel, 'Les échelles du Levant dans la tourmente des conflits méditerranéens au XVIIIe siècle : la défense des intérêts français au fil du temps', Cahiers de la Méditerranée 70 (2005) 1-17.

$53 \mathrm{AnF}, \mathrm{AE}$, Correspondance Consulaire B/I/1009, Bonnal to the Minister of the Marine, 27/10/1707, f. 116v-121r, here f. 118v-119v. For Avetik, see M. Brosset, Le prétendu masque de fer arménien ou Autobiographie du Vartabied Avétik de Tokhath, déposédu patriarcat de Constantinople et de l'emploi de Supérieur de Jérusalem, traduite de l'arménien (St Petersburg 1874); R. H. Kévorkian, 'Le Patriarcat Arménien de Constantinople et l'Occident catholique au XVIIe siècle', Revue du Monde Arménien Moderne et Contemporain 1 (1994) 19-29.

$54 \mathrm{AnF}, \mathrm{AE}$, Correspondance Consulaire B/I/385, Charles de Ferriol to the Minister of the Marine, 01/11/1706, f. 99: "Ainsi je vous supplie très humblement Monsieur, d'ordonner que le sieur Stratidico Sevastopulo soit mis en liberté. Je me servirai de cette grâce pour ce qui regarde Avedic que le Grand Seigneur et le Vizir ne manqueront pas de me demander dans quelque-temps et je ferai voir par-là que je m'emploie volontiers pour faire plaisir à la Porte, 
The archival testimonies on Sevastopoulos' adventures in 1705-1708 also bring us back to the confessional conflicts in Chios, conflicts that were inextricably linked to economic competition between European merchants and local traders. ${ }^{55}$

According to Bonnal, Greek traders were monopolizing the currency exchanges on the island of Chios and making excessive and unfair profits to the detriment of French merchants. ${ }^{56}$ Moreover, they were using the wealth they had amassed from dealing with French merchants to slander the Catholics before the Ottoman authorities. ${ }^{57}$

Bonnal's obsession with the Greeks' treacheries and the use of dishonest profits to bribe the Ottomans and persecute the Catholics of the island was dictated by his personal concerns for his own commercial activity. However, the main point of interest of his testimony is that he assimilates competitors with French trade to the enemies of the Catholic religion and of the French nation. ${ }^{58}$

mais que je ne peux pas m'enquérir pour les choses qui ne sont pas à ma disposition. La famille Stratidico Sevastopulo voulait se présenter devant sa hautesse pour demander leur parent arrêté en France ; je n'aurais pas manqué des raisons pour justifier qu'il y était justement retenu, mais cela aurait pu donner quelque dégout à la Porte et à la conjoncture présente, il est à propos d'éviter toute sorte de mécontentement. Je ferai entendre à Maurocordato qu'il a bonne part à la délivrance de Stratidico Sevastopulo."

55 D. Panzac, 'L' Escale de Chios un observatoire privilégié de l'activité maritime en mer Égée

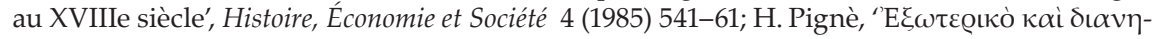

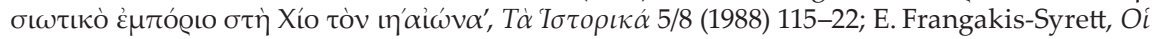

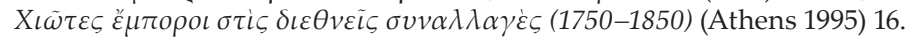

$56 \mathrm{AnF}$, AE, Correspondance Consulaire B/I/1009, Bonnal to the Minister of the Marine, 27/12/1706, f. 99r-100r: "Comme ils sont les seuls qui aient ici les fonds convenables, il faut qu'on en passe bon gré mal gré par le prix qu'ils mettent aux piastres, s'entendant tous, les uns les autres, pour ne donner rien de plus, pendant qu'ailleurs elles valent le quatre et cinq pour cent par-dessus. Je ne parle pas des poids altérés sur lesquels je les ai souvent surpris en faute et que je ne puis me vanter d'avoir fait remettre dans la justesse,-quelque précaution que je puisse prendre, je ne voudrais pas répondre que de temps en temps ils me jouassent en cela quelque tour de leur métier-, mais, Monseigneur, ce qui fait le plus de mal c'est de voir les gains énormes qu'ils font avec notre argent aux passages de bateaux, caïques, londres et autres bâtiments, qui de tous les quartiers de l'Empire turc font trois fois l'an le voyage d'Égypte. Comme ce sont les piastres sévillanes et non les monnaies courantes de l'Empire qui ont cours dans ce pays-là, les marchands prennent des Grecs de Chio lesdits piastres à huit et dix pour cent de bénéfice, ce qui chaque année les met en état de nous faire la guerre avec nos propres armes."

57 Ibid., Bonnal to the Minister of the Marine, 27/12/1706, f. 100r.: "Il est constant que tout ce que les Grecs font ici contre la religion, ils ne le font qu'à force de l'argent et il est encore plus constant que l'argent le plus clair et le plus liquide qu'ils aient ici leur vint des piastres espagnoles que nos négociants français échangent tous les jours par milliers dans leurs comptoirs."

58 Ibid., Bonnal to the Minister of the Marine, 02/11/1705, f. 36r: 'contre les Français et quelque fois même contre la sacrée personne du Roy, qu'ils regardent comme l'unique soutien de la catholicité.' Ibid., Bonnal to the Minister of the Marine, 27/12/1706, f. 98v: 'j'ai bien de la passion d'y voir de mon temps [les affaires] de la Religion, de la Nation et du Commerce sur le pied le plus avantageux possible.' 
Although in 1818 Konstantinos Oikonomos attributed the creation of the School to the studiousness of the Smyrnans, from 1848 to 1885, Greek historiography converged on the opinion that its foundation was aimed at preventing Catholic proselytism in the domain of education. By 1881, Andreas Mamoukas had already

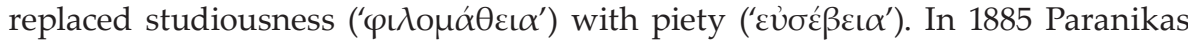
argued that the creation of the School was continuous with Diamantis Rysios' educational activity, which was also dictated by the necessity to provide Orthodox children with a Greek education that would turn them away from the Jesuit schools. In fact, Paranikas believed that Sevastopoulos acted in conformity with Greek ecclesiastical authorities, whereas the first five documents of the Codex of the Evangelical School edited in 1876, reveal a founding program gradually distancing itself from the ecclesiastical and community authorities of Smyrna.

By the end of the nineteenth century, the history of the School was written, and its creation-in accordance with the patriarchal educational policy-explained in the context of the religious conflicts between Orthodox and Catholics. This opinion led to the relativization of Sevastopoulos' role and eliminated any eventual divergence from the ecclesiastical educational strategy. The contradictions arising from the Codex' documents are veiled.

The Greek historiographic narrative reflects Greek educational activity of the second half of the nineteenth century and the anxiety caused by the extension of Catholic missionaries' educational network in the East. Sevastopoulos is uniformly characterized as a predecessor driven by a deep desire to create already in the early eighteenth century a pioneering school to oppose Catholic proselytism. Moreover, Greek historiography eliminates any reference to the confessional conflicts between Catholics and Protestants, as well as to the Western antagonism regarding the international trade of the Ottoman Empire. Thus, the confessional and economical conflicts of the eighteenth century, to which Greek Orthodox traders such as Sevastopoulos were exposed, were reduced to a confessional conflict between Orthodox and Catholics.

It is certain that Sevastopoulos lived in a world where economic antagonisms and international political relations became intermingled with confessional competition of Catholics and Protestants in the Ottoman Empire. However, as we infer from a close analysis of French consular archives, economic antagonisms far outweighed confessional affiliation. The strict religious and economic control imposed by the French on their merchants dealing with local traders was aimed at eliminating not only the Orthodox but also those Catholics who did not subscribe to this monopolistic policy. ${ }^{59}$ Complaints and disputes, as they are expressed in the consular sources, have to be ascribed to the competition between Western merchants and local traders. ${ }^{60}$

59 Ibid., Daniel to the French Consul of Smyrna, 23/09/1705, f. 54v; Daniel to the Minister of the Marine, 10/10/1705, f. 30r-31v, 33r; Stellio Rafaeli to the Minister of the Marine, 01/03/1708, f. 126r; Daniel to the Minister, 25/09/1706, f. 78; Stellio Rafaeli to the Minister, 01/03/1708, f. 127r. 60 E. Eldem, French Trade in Istanbul in the Eighteenth Century (Leiden 1999) 226: "Hidden behind 
As a local trader, and in order to cope with this Western policy in the Levant, Sevastopoulos activated all those networks that would enhance his position in international trade. According to our sources, the Greek trader seemed able, in 1705-1708, to maintain good relationships with the communal authorities of Chios, Alexandros Mavrokordatos, and the Patriarch, while also being able to secure Dutch protection.

In 1743/1747, however, according to the School's founding documents, these affinities seemed to fade away; Sevastopoulos placed the School under English protection, and the founding project, which dedicated the School to Christ and focused the curriculum on the teaching of the New Testament, departed from the educational program of the Ecumenical Patriarchate. Alongside this, the appointment of a committee that would lead the School testifies to a certain divergence from the Greek community authorities of Smyrna. However, we have not yet discovered any contemporary testimony on an eventual change in Sevastopoulos' status as a protégé. ${ }^{61}$ In addition, we know that it was only in 1810 that the Ottoman authorities officially recognized English protection of the Evangelical School. ${ }^{62}$

Our research has not yet elucidated what happened in the thirty years to transform the young trader imprisoned in Marseilles in 1705 into the mature financier in Smyrna after 1733. In this time, due to his position as an influent intermediary in the international trade in the Levant, he must have mobilized his commercial networks to inaugurate new processes of knowledge transfer and would have used some of the capital he had accumulated to establish charities and the Evangelical School, which departed significantly from traditional Orthodox or Catholic norms and were more oriented towards the model of the Reformation. Further research on his relations with British and Dutch in Smyrna will throw some light in the formulation of the educational program of the School. We will then be able to conclude whether his involvement in the knowledge transfer testifies to a religious link with Reformation, or reveals his desire to establish a Greek school liberated from traditional religious standards.

a patronizing and self-righteous façade, this attitude masked a much more profound malaise, linked to a very practical problem of control over the market. In many cases, what the French perceived-or rather described-as malicious attacks by local traders and other actors were, in fact, defensive moves for containing and minimizing foreign penetration in the ottoman market structures."

61 In 1733, the English consular mission of Smyrna consisted of the Consul Samuel Crawley, the Pastor Charles Burdett, and the Secretary Georges Boddington. They represented the Levant Company in Smyrna and maintained close social relations with the Dutch consular mission. Ch. Laidlaw, The British in the Levant: Trade and Perceptions of the Ottoman Empire in the Eighteenth Century (London-New York 2010) 185.

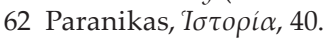




\section{Bibliography}

\section{Archives/Manuscripts}

Paris, Archives nationales Françaises [ $=$ AnF], Affaires étrangères [ $[=\mathrm{AE}]$, Correspondance Consulaire, B/I/385, Constantinople (1706-1708).

Paris, Archives Nationales Françaises [= AnF], Affaires étrangères [= AE], Correspondance Consulaire B/I/1009, Chios (1696-1722).

Venice, Archive of the Hellenic Institute in Venice, Smyrna, n 118a, document 79 [AEIB, $\Sigma \mu u ́ \varrho v \eta, \alpha \varrho .118 \alpha, \dot{\varepsilon} \gamma \gamma \varrho \alpha \varphi$ \% 79].

\section{Literature}

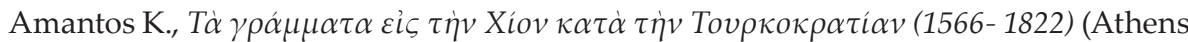
1946).

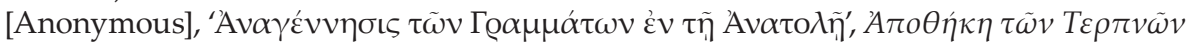

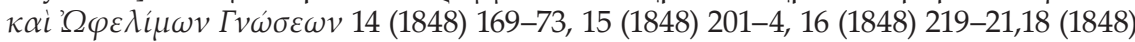
265-8, 1 (1849) 17-20.

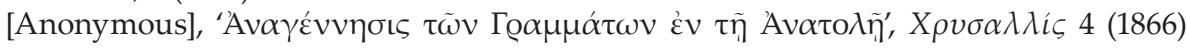
$592-6$.

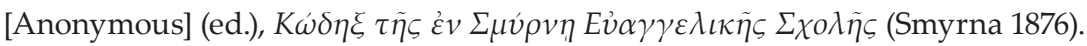

Argenti Ph. P., Diplomatic Archive of Chios 1577-1841, II (Cambridge 1954).

- Le libro d'oro de la noblesse de Chio, 2 vols (London 1955).

- The Religious Minorities of Chios. Jews and Roman Catholics (Cambridge 1970).

Baqué-Grammont J.-L., Kuneralp S. and Hitzel F., Représentants permanents de la France en Turquie (1536-1991) et de la Turquie en France (1797-1991) [Varia Turcica, 22] (Istanbul 1991).

Bauden Fr. (ed.), Le voyage à Smyrne. Un manuscrit d'Antoine Galland (1678) (Paris 2000).

Brosset M., Le prétendu masque de fer arménien ou Autobiographie du Vartabied Avétik de Tokhath, déposé du patriarcat de Constantinople et de l'emploi de Supérieur de Jérusalem, traduite de l'arménien (St Petersburg 1874).

Eldem E., French Trade in Istanbul in the Eighteenth Century (Leiden 1999).

Farganel J. P., 'Les échelles du Levant dans la tourmente des conflits méditerranéens au XVIIIe siècle : la défense des intérêts français au fil du temps', Cahiers de la Méditerranée 70 (2005) 1-17.

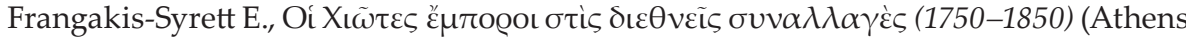
1995).

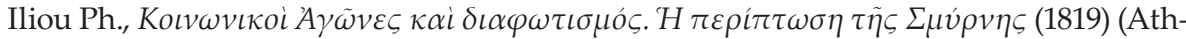
ens 1981).

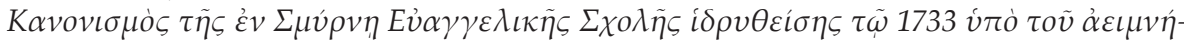

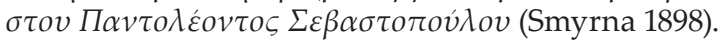

Kévorkian R. H., 'Le Patriarcat Arménien de Constantinople et l'Occident catholique au XVIIe siècle', Revue du Monde Arménien Moderne et Contemporain 1 (1994) 19-29.

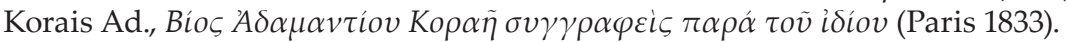

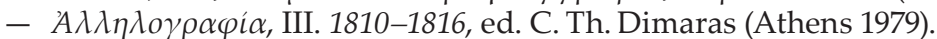

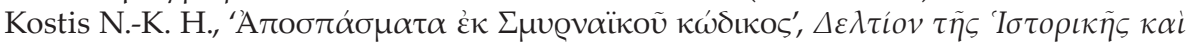

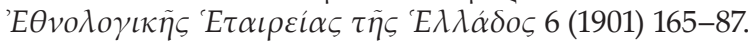

Laidlaw Ch., The British in the Levant: Trade and Perceptions of the Ottoman Empire in the Eighteenth Century (London-New York 2010). 
Legrand É. (ed.), Relation de l'établissement des R. R. Pères de la compagnie de Jésus au Levant, édition conforme au manuscrit de la Bibliothèque nationale (Paris 1869).

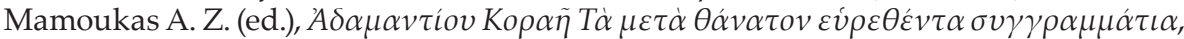
I (Athens 1881).

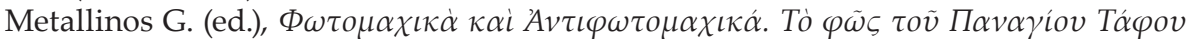

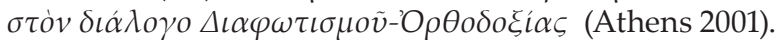

Mézin A., Les consuls de France au siècle des Lumières (1715-1792) (Paris 1998).

Miller P. N., 'Peiresc and the Study of Islamic Coins in the Early Seventeenth Century', in A. M. Stahl (ed.), The Rebirth of Antiquity: Numismatics, Archaeology and Classical Studies in the Culture of the Renaissance (Princeton NJ 2009) 101-55. Reprinted in P. N. Miller, Peiresc's Orient, Antiquarism as cultural history in the Seventeenth century (variorum) (London-New York 2012) III.

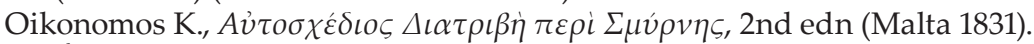

- Étude sur Smyrne par Constantin Ikonomos, traduite du grec par Bonaventure F. Slaars et enrichie par le traducteur d'un appendice et de notes nombreuses, étendues et variées qui la complètent, transl. B. F. Saarls (Smyrna 1868).

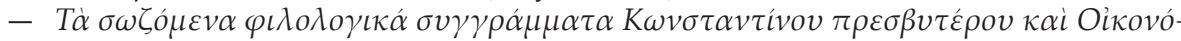

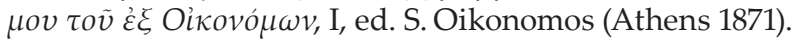

Panzac D., 'L'Escale de Chios un observatoire privilégié de l'activité maritime en mer Égée au XVIIIe siècle', Histoire, Économie et Société 4 (1985) 541-61.

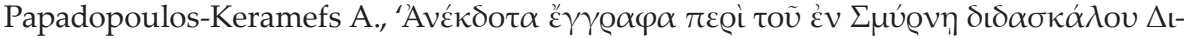

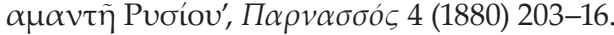

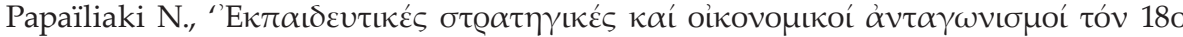

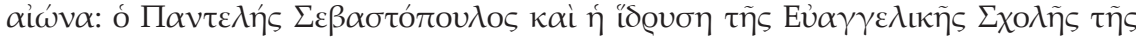

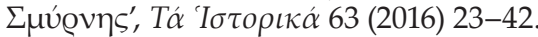

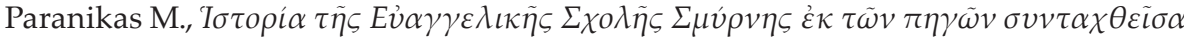
(Athens 1885).

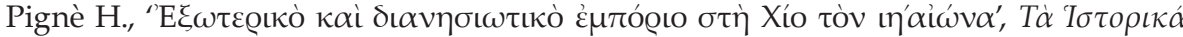
5/8 (1988) 115-22.

Radet G., 'Aristote Frontier', Revue des études anciennes 9/4 (1907) 376-80.

Smyrnelis M.-C., Une société hors de soi, identités et relations sociales à Smyrne aux XVIIIe et XIX siècles (Paris 2005).

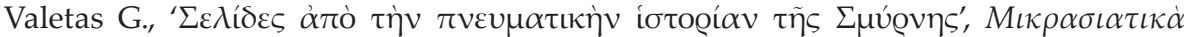
Хроvıка́ 2 (1939) 199-262.

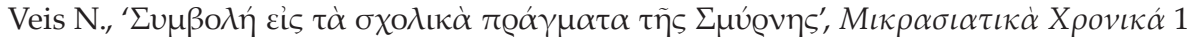
(1938) 193-237.

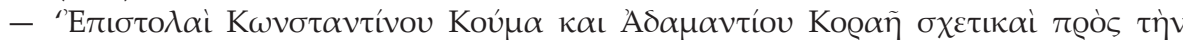

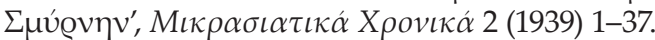

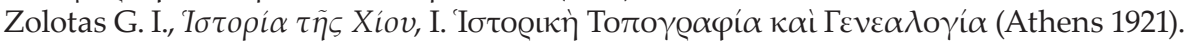


III

Between Akribeia and Oikonomia 



\section{The Archimandrite and the Astronomer \\ The Visit of Chrysanthos Notaras to Giovanni Domenico Cassini: a new Approach* \\ Vassa Kontouma, EPHE, PSL-Paris}

On 21 June 1667-the day of the summer solstice-the mathematicians of the French Royal Academy of Sciences drew the prime meridian of the world on the ground of a Paris suburb. Designed as a citadel of science under the supervision of the architect Claude Perrault, the Observatory was quickly built on the same path. In 1669, Louis XIV's minister Jean-Baptiste Colbert invited the Italian astronomer Giovanni Domenico Cassini to lead the institution, where he settled, installing a dynasty of scientists and promoting French science as the most innovative of its time. ${ }^{1}$

Thirty years later, at the summit of his reputation, Cassini generously welcomed to the Observatory an unusual visitor: Chrysanthos Notaras, a literate archimandrite, but also the nephew of the Patriarch Dositheos II of Jerusalem. What was the real purpose of this encounter, and why did it take place in April 1700? In the following contribution, I will try to provide some answers to these questions, by reconsidering and completing the available evidence.

\section{Chrysanthos' visit to Paris and his subsequent reputation in the East}

The testimonies

The archimandrite's visit to Paris is precisely documented by a series of wellknown sources. The first information about it dates from the very moment of his departure from Padova, where he followed the classes of the Greek Catholic professor Nikolaos Komninos-Papadopoulos, studying theology and canon law at the latter's scuola privata. ${ }^{2}$ In a letter dated 8 April 1700, and addressed to Patriarch Dositheos, Komninos-Papadopoulos gives following information:

* This paper is the product of a research carried out in several stages during the years 20172019, in the framework of the workshop 'Confessionalization and/as knowledge transfer in Eastern Christianity' (Berlin, December 2017), of my seminar at the École pratique des hautes études (Paris), and of a visit at Balliol College (Oxford, May 2018) at the invitation of J.-P. Ghobrial, who suggested me its definitive title. My thanks to all colleagues involved in these exchanges.

1 The Paris Observatory keeps a rich collection of manuscripts and archives. See N. Daliès, 'Les archives à la Bibliothèque de l'Observatoire de Paris', Gazette des archives 179 (1997) 321-31. Some of the documents I will refer to below are now online: https://bibnum.obspm.fr.

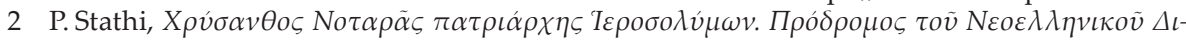
$\alpha \varphi \omega \tau \iota \sigma \mu o \tilde{v}$ (Athens 1999) 82-8. Chrysanthos stayed in Padova in the period 1697-1700. 
[My very dear Chrysanthos] set off with the very noble Sir Răducan ${ }^{3}$ on Great Monday, the 5th April, according to the Italian calendar. Having begun his trip to the Celts, ${ }^{4}$ he tore out of me, not only my heart, but also the pleasure and the glory of my teaching. ${ }^{5}$

The mention of the visit comes from Chrysanthos himself. It appears in one of the archimandrite's most famous works, published in Paris sixteen years later, his Introduction to Geographics and Sphaerics, ${ }^{6}$ as a long parenthesis included in a paragraph dealing with the measurement of the circumference of the Earth:

In the year of Christ 1669 and 1670, Picard, official mathematician of the Royal Academy of the king of France Louis the fourteenth [...] discovered that a celestial degree of the great Circle traces on earth fifty-seven thousand and sixty Parisian toises [...]. However, at the time when this operation [of measurement] was conducted in the Province Vastinensis ${ }^{7}, \mathrm{Mr}$ Giovanni Domenico Cassini was also present, an excellent mathematician and first astronomer of the Royal Academy, freshly arrived from Italy at the invitation of the King-whom I met in Paris in the year of Christ 1700. Now we enjoyed on his part genuine philanthropy: he welcomed us as a friend and lodged us for a whole week in his home (in the Royal Observatory). With him, we observed with the largest telescopes the Moon, Jupiter and the satellite stars which encircle it, the Galaxy and other things. Thus he informed us that he had discovered, through numerous methods and observations, that one minute of the circumference of the Earth, i.e. an average Italic mile, is 5706 feet from Paris [...]. He also instructed us concerning various mathematical measures [...]. We have introduced this account of the measurement of the circumference of the earth in the middle [of our speech], so that

3 On Rădu Cantacuzino, see V. Vasiliu, 'Costantino Brâncoveanu e il Cattolicismo. Alcune notizie nuove intorno alla sua politica religiosa', Ephemerides Dacoromana. Annuario della Scuola romena di Roma 3 (1925) 110-28; P. Cernovodeanu and N. Vătămanu, 'Trois lettres inédites de Jean Comnène', Revue d'Histoire roumaine 11 (1972) 137-45.

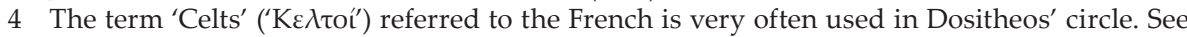

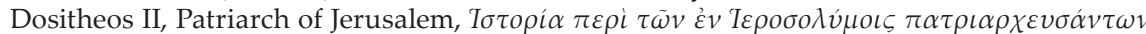
[History concerning the Patriarchs in Jerusalem] (Bucharest 1715 [ca 1722]) 1217 (Book XII, ch. 6,

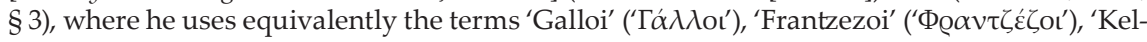

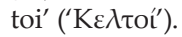

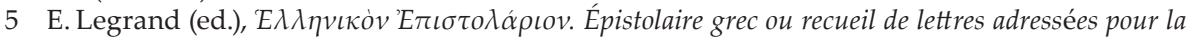
plupart à Chrysanthe Notaras patriarche de Jérusalem par les princes de Valachie et de Moldavie (Paris

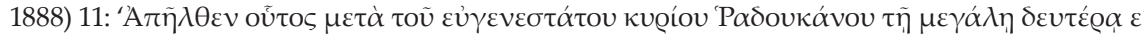

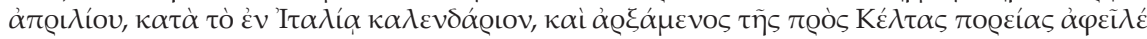

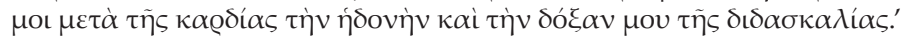

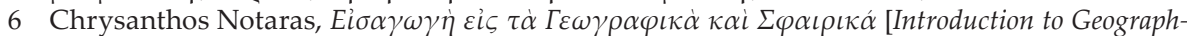

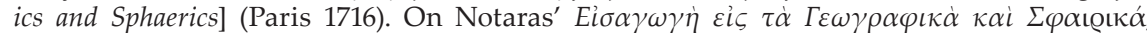
see among others G. Aujac, 'Deux manuels grecs de Géographie à l'aube du XVIII' siècle',

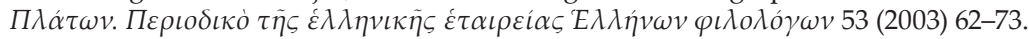

7 The Latin denomination of the region of Gâtinais, in the South of Paris. 
everyone might understand firstly that it has been the subject of careful research $[\ldots]$, and secondly the inherent difficulty thereof $[\ldots]{ }^{8}$

This detailed account is furthermore corroborated by a third mention evoking Chrysanthos' exchanges with 'the wise men of the Western Church', and particularly with some French theologians of his time. Given in the preface to the History concerning the Patriarchs in Jerusalem - the posthumous work of Dositheos published by his nephew in 1715 [ $=$ ca $\left.1722^{\circ}\right]$-this account generally condemns the methods of the Jesuits, 'these very wise men, about whom the tears come to me, because they get lost in vain doctrines', but also praises 'almost the entire Gallican Church', which does not share the Jesuit doctrines about papal monarchy and infallibility, and particularly the Church historian Louis Ellies Dupin, whom Chrysanthos met in person in Paris:

For not all Western sages, nor nearly the entirety of the Gallican Church advocate this vain doctrine and error relative to their bishop of Rome, as I have learned myself and attest as true, in full awareness, through the conversation I had with several men in Italy, France, Germany, Poland, and especially in Paris, [...] notably with Louis Ellies Dupin, theologian of the Sorbonne, an admirable and learned man, an erudite and an experienced and trustworthy expert on the Church councils, Holy Fathers and ecclesiastical historians. ${ }^{10}$

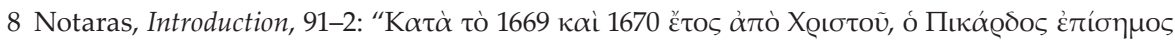

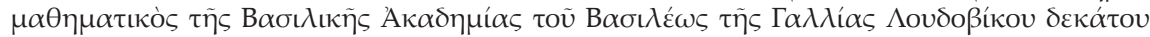

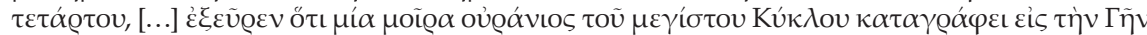

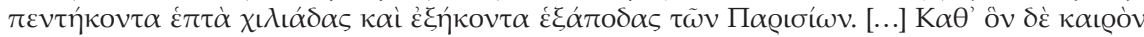

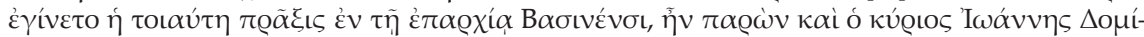

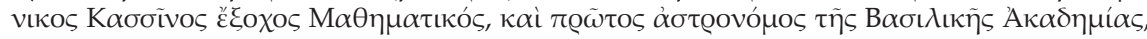

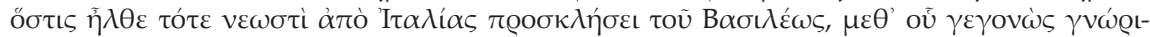

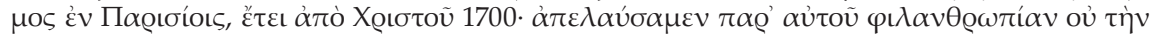

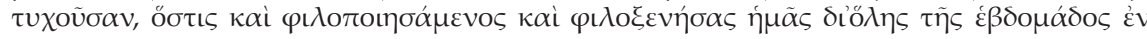

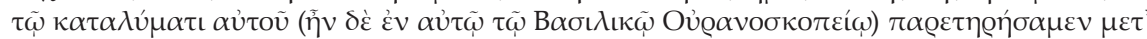

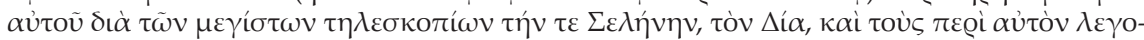

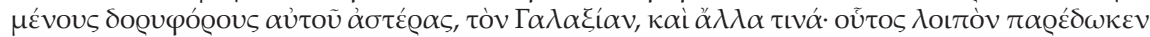

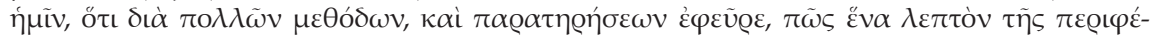

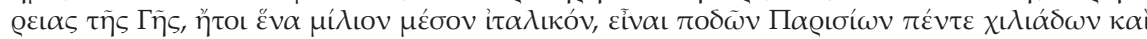

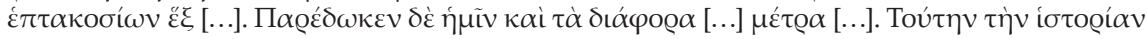

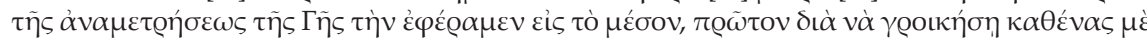

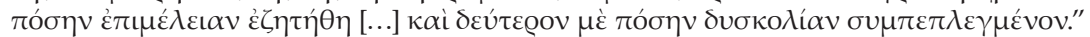

91715 is the publication year indicated on the first edition of the book. It seems however to

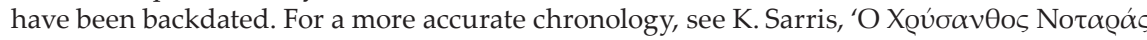

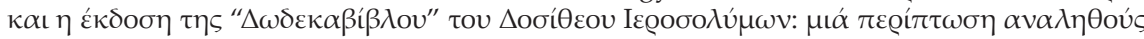

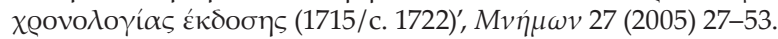

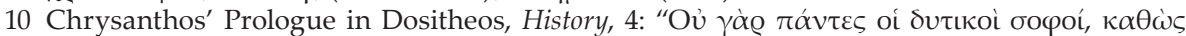

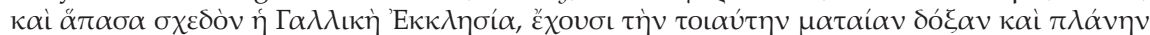

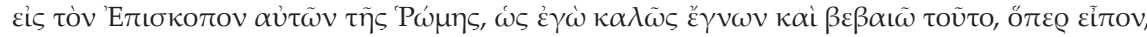

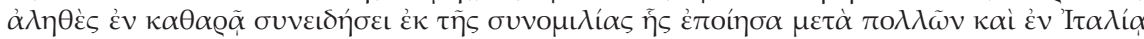

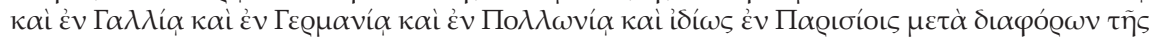


This is also confirmed much later by an indirect testimony of the Dominican Michel Lequien (1661-1733), reported in 1740 by the editor of his Oriens christianus:

Many people saw this man [= Chrysanthos] in Paris when he was younger, [and found that he was] a most learned and very accomplished man, that he had a sweet disposition and was most acceptable to all [...]. 'I declare that I am indebted to him for several reasons': these are the words of Father Lequien, the author of the present work. ${ }^{11}$

Last but not least, an anonymous epigram to the glory of the archimandrite, published ad limina of his Introduction to Geographics and Sphaerics, praises in the following terms his Parisian visit, during which he would appear to have been considered-according to a statement attributed to Cassini-as 'Euclid redivivus':

You visited the cities of so many men, and you came to know their spirit, Excellent man, you who give birth to all forms of wisdom!

The cities of the Argeans, Thracians, Dacians, Batavians, Italians

And Antenorids [= Venetians] are witnesses to it.

And Paris even more, the city with the great name, testifies to it.

Cassini, this man with elevated spirit, admired you there,

He admired your knowledge given by God and your language,

And thought he was talking to another Euclid. ${ }^{12}$

It is interesting to see that all these flattering reports were taken for granted and even elaborated by Konstantinos Nikolopoulos [or Nicolopoulo] in Michaud's Bio-

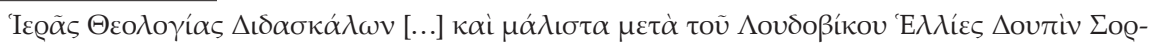

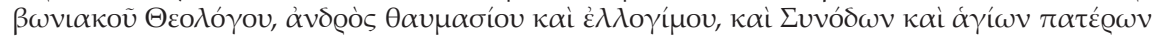

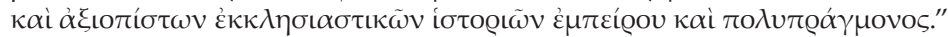

11 M. Lequien, Oriens christianus in quatuor patriarcatus digestus, III (Paris 1740, posthumous edition) 525-6: 'Hunc in minoribus agentem Lutetiae Parisiorum multi viderunt, virum apprimè doctum \& humanissimum, suavissimaque indole omnibus acceptissimum [...]. Ei autem multiplici nomine obnoxium me profiteor, verba sunt P. le Quien auctoris hujus operis'. An original letter from Lequien to Chrysanthos, dated 5 October 1720, is also preserved in the Bibliothèque nationale de France [= BnF], Paris, Suppl. gr. 1093 [Diktyon (Réseau numérique pour les manuscrits grecs) 53757], f. 66r-v.

12 Notaras, Introduction, f. $4 \mathrm{r}$ (latin translation of the epigram on f. $4 \mathrm{v}$ ): " $\Omega$ тó $\sigma \sigma \omega v \dot{\alpha} v \delta \varrho \tilde{\omega} v$

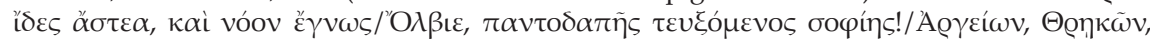

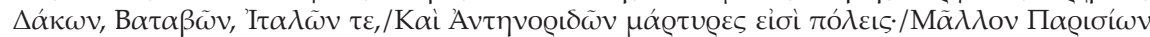

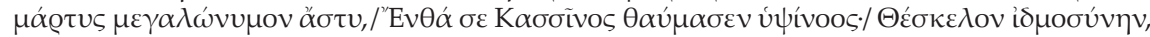

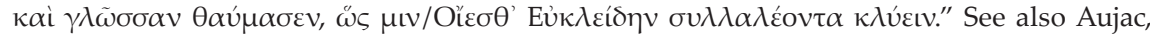
'Deux manuels', 72. It should be noted that Chrysanthos himself wrote a commentary on Euclid while in Padua, between April and November 1698. It is kept in the autograph, $\mathrm{Na}$ tional Library of Greece [= NLG], fonds of Metochion Panagiou Tafou [Metochion of the Holy

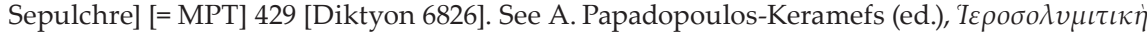

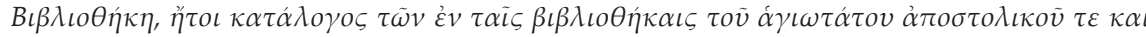

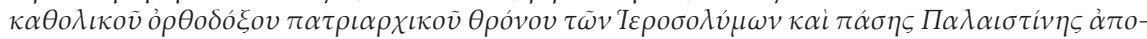

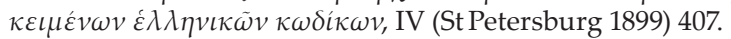


graphie universelle. Relying on them, but also on a brief and general allusion by Dimitrios Prokopiou ${ }^{13}$, he described Chrysanthos' trip as follows:

He travelled in almost all learned Europe to increase his knowledge. He spent a rather long time in Paris, where he perfected himself in the study of astronomy, ardently following the lessons of the celebrated Cassini, who regarded him as one of his best pupils, and had a special esteem for him. Chrysanthos attracted the friendship of almost all the men of the capital who were the most distinguished in the sciences. He was intimately bound up with Father Lequien, to whom he provided abundant materials for the composition of his Oriens christianus. ${ }^{14}$

Unfortunately, Nicolopoulo's elaborations gave rise to the widely held opinion that the archimandrite went on to study with Cassini, followed his path, and disseminated later the new science in the East. ${ }^{15}$ However, as suggested by Pinelopi Stathi, ${ }^{16}$ this interpretation must be relativised: Chrysanthos did not study in Paris. On the one hand, he himself talks of a single week spent at the Observatory, giving the impression of having been received as a distinguished guest, rather than a student-an interpretation enhanced by the tone of the epigram; and on the other hand, after 20 July 1700, Cassini was no longer in the capital: he had left on his grand 'Voyage de la Méridienne' which was to continue until December of the same year. ${ }^{17}$

Moreover, it is difficult to imagine that Chrysanthos stayed on in Paris at the very moment when the issue of the Holy Places was fiercely disputed in Constantinople under the impulse of Patriarch Dositheos, as part of the Russian-Ottoman peace treaty of July 1700. As an immediate consequence of this affair, Chrysanthos' ${ }^{\prime}$ presence is attested in Constantinople, ${ }^{18}$ and then in Walachia in the autumn of $1700 .{ }^{19}$ As early as 5 January 1701 he arrives in Russia, where he acts as envoy

13 D. Prokopiou Pamperis, ‘Demetrii Procopii, Macedonis Moschopolitae, 'E $\pi \tau \varepsilon \tau \mu \eta \mu \varepsilon ́ v \eta ~ \varepsilon ̇ \pi \alpha-$

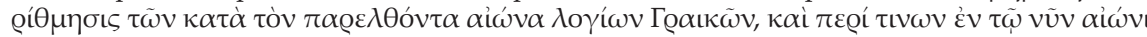
$\dot{\alpha} v \theta$ oúv $\tau \omega v$. Succinta Eruditorum Graecorum superioris et praesentis saeculi recensio, conscripta mense Junio A.C. MDCCXX transmissaque Bucuresto, et nunc primum edita, cum Latina versione', in J. A. Fabricius (ed.), Bibliotheca Graeca, XI (Hamburg 1722) 792-3: Chrysan-

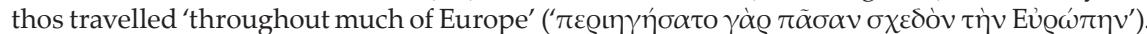

14 [Constantin-Agathophron Nicolopoulo], 'Notaras (Chrysanthe)', in L.-G. Michaud (ed.), Biographie universelle, ancienne et moderne ... , XXXI (Paris 1822) 404-5 (my translation).

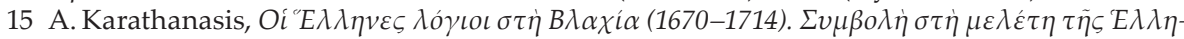

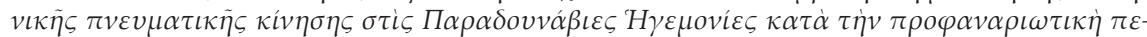

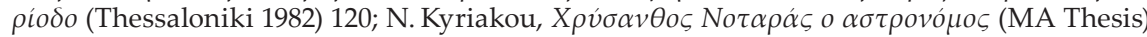

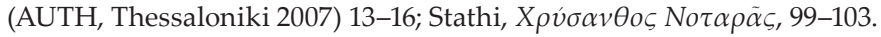

16 Ibid., 89.

17 The diary of this trip written by Jacques Cassini has been preserved: Bibliothèque de l'Observatoire de Paris [= BOP], D2/39, https://bibnum.obspm.fr/ark:/11287/mTWrq. See also L. Gallois, 'L'Académie des Sciences et les origines de la carte de Cassini', Annales de Géographie 99 (1909) 193-204; 100 (1909) 297-8 [Gallois gives the date of 20 August, which seems erroneous].

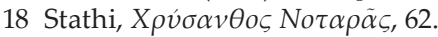

19 Vasiliu, 'Costantino Brâncoveanu', 116. 
of his uncle, bearing letters to the Tsar in favour of the patriarchate of Jerusalem. ${ }^{20}$ On 18 March 1701 he is still in Moscow. ${ }^{21}$ And finally, on 6 April 1702, he is back in Jerusalem, where he is ordained metropolitan of Cesarea in the church of the Anastasis. It appears therefore that his stay in Paris lasted no more than two or three months.

\section{The glorious return}

If the Paris trip can hardly be considered as part of a study tour, nevertheless Chrysanthos' visit to the Observatory impressed his contemporaries more than all his other activities in the West. In fact, after his return, the archimandrite was considered a great connoisseur and purveyor of astronomical instruments and geographical tools in the erudite circles of the Ottoman Empire. He himself mentions a 'precisely divided, one-foot long quadrant' purchased by him in Paris and which permitted him to revise the measurement of degrees of longitude and latitude in his 'own convent in Constantinople', i.e. the Metochion of the Holy Sepulchre. ${ }^{22}$ In the secondary literature there is also the mention of an astrolabe. According to a late account, the archimandrite had constructed it in Paris and had brought it back to the East. Found in 1892 in Jerusalem but later destroyed, this astrolabe bore the following inscription: 'This instrument was built by the monk Chrysanthos under the direction of Cassini for the brothers of Jerusalem, so that they might worship the Lord through His works.. ${ }^{23}$ It probably belonged to a whole batch of tools reported in the inventory of the school of the monastery of the Holy Cross around 1895:

At that time it was not only a large number of useless books that were thrown into the monastery's ovens, but also various geographical spheres, which had been consecrated [to the patriarchal institution] by Chrysanthos Notaras, Patriarch of Jerusalem, as well as large geographical maps repre-

20 The date appears in a Russian archival document: Russian State Archive of Early Acts $(=R G A$ $D A), 52-1,1701$, no. 2, 105ff. See I. I. Bantyš-Kamenskij, Reestry grečeskim delam Moskovskogo Arkhiva Kollegii inostrannykh del. Rossijskij Gosudarstvennyj arkhiv drevnikh aktov. Fond 52. Opis' 1, B.L. Fonkič (ed.) [Rossia i Khristianskij Vostok. Biblioteka, 2] (Moscow 2001) 226. See also M. M. Bernacki, 'Dosifej II Notara, Patriarkh Ierusalimskij', in Pravoslavnaia Enciklopediia, vol. XVI (Moscow 2007) 71-7, here p. 74.

21 Vasiliu, 'Costantino Brâncoveanu', 114; N. Nilles, Symbolae ad illustrandam historiam ecclesiae orientalis in Terris coronae S. Stephani, I (Eniponte [= Innsbruck] 1885) 101-3, here p. 102.

22 This information appears in the following statement of longitude and latitude recorded by

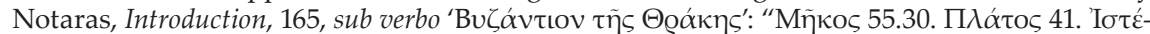

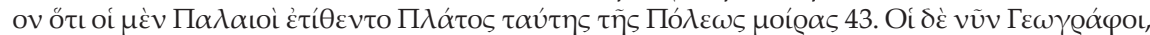

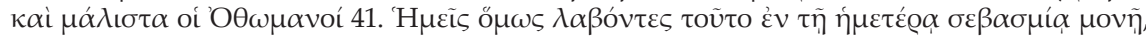

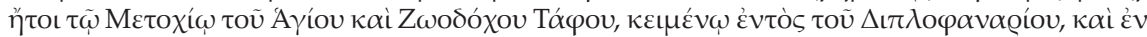

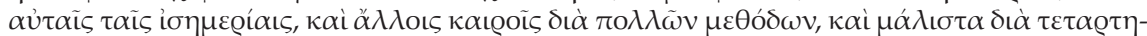

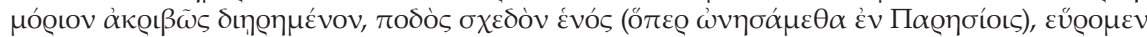

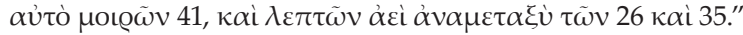

23 See Stathi, $X \rho \dot{v} \sigma \alpha v \theta o \varsigma$ No $\alpha \rho \tilde{\alpha} \varsigma, 90-1$, who quotes G. L. Arvanitakis, 'Notes astronomiques', Le Messager d'Athènes, n. 5217 (February 1939). 
senting each people of the countries of Europe, Asia, Africa, America and Polynesia, painted with bright and indelible colours, which had become useless because of the mould, and so have been thrown into the fire. As for the astronomical and mathematical instruments used by the late Chrysanthos, Patriarch of Jerusalem, all of them were destroyed because of the rust. Only one or two of them are [still] kept in the library of the Theological School, in memory of the late Chrysanthos, the excellent mathematician of that time. [In note:] It must be remarked that in the library of the Metochion of the Holy Sepulchre in Constantinople are also preserved in a box a considerable number of astronomical instruments, which were used by the late Chrysanthos. But these too are rusty. ${ }^{24}$

Hence, it appears that Chrysanthos had progressively constituted, in Jerusalem as well as in Constantinople, an important collection of scientific instruments which corresponded to his specific interest in mathematics, astronomy and geography. Until it was completely destroyed this collection impressed posterity and perpetuated his name as that of an immensely skilled and enlightened man. Thus, he was solicited on all sides. A correspondent from Chios asked him for instructions when he intended to build an astrolabe. ${ }^{25}$ On 26 February 1713, the Prince of Moldavia, Nikolaos Mavrokordatos, wrote to him: 'We received also the telescope and we thank Your Beatitude for it.' ${ }^{26}$ On 11 November 1716, Chrysanthos was the posthumous dedicatee of a manuscript of Meletios Mitros' Geography Old and New. ${ }^{27}$ The Ottoman scholar Esad Efendi, who had ties of trust and friendship with Chry-

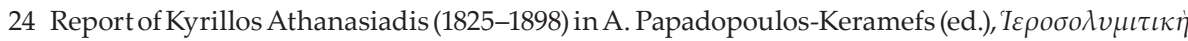

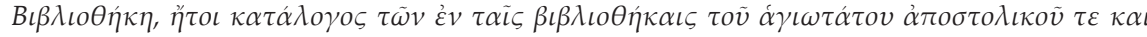

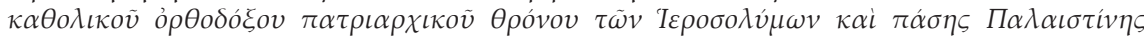

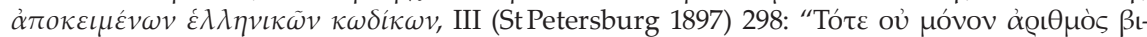

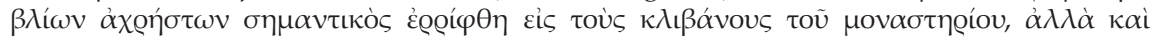

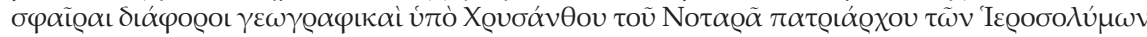

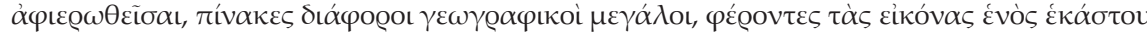

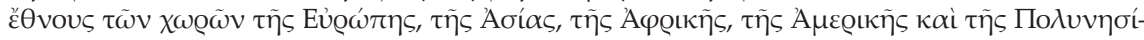

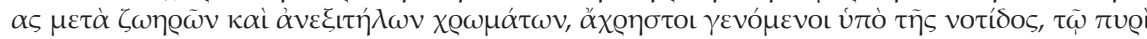

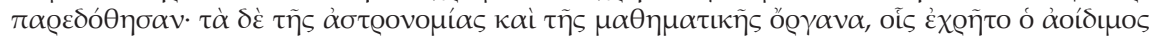

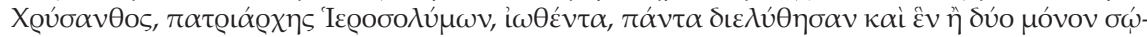

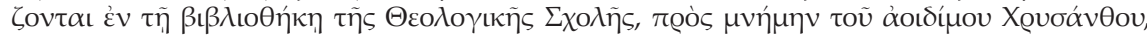

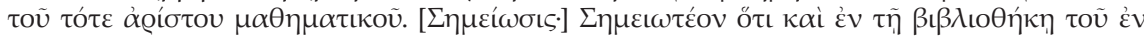

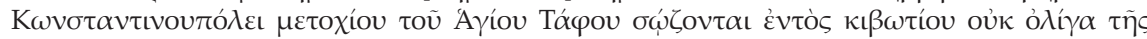

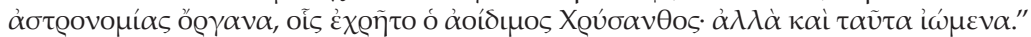

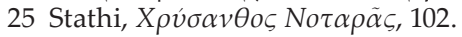

26 E. Hurmuzaki (ed.), Documente privitoare la istoria Românilor, XIV/I. 1320-1716: Documente Gre-

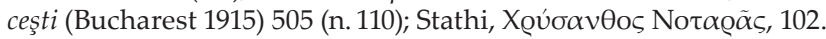

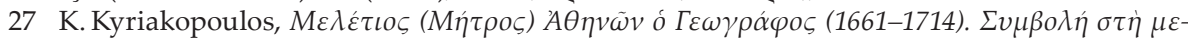

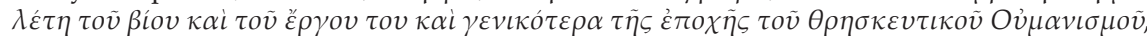
2 vols (PhD Thesis) (National and Kapodistrian University of Athens, Athens 1990) 186-98. Already started in 1707, Meletios' publication project was not completed during his lifetime, and the book came out only in 1728, in Venice. Aside from the NLG, MPT 241 [Diktyon 6638], which contained the Geography Old and New, Chrysanthos had also in his library a copy of the 
santhos, and also his master Ali Efendi, the Porte's astrologer ('münecimbaşi'), corresponded with him on various astronomical subjects. ${ }^{28}$

Moreover, the archimandrite's best-known portrait shows him with his left hand on a globe and the right holding a compass-in a similar way to that in which Cassini and other Western scientists and explorers were depicted at the time. ${ }^{29}$ This engraving appeared on the frontispiece of the Introduction to Geographics and Sphaerics, when Chrysanthos was already patriarch of Jerusalem. And although this portrait was obviously drawn many years before its publication, when he was still travelling in the West, ${ }^{30}$ the fact remains that the image it presentedthe young Chrysanthos as an astronomer and a geographer ${ }^{31}$-was still important enough to illustrate the patriarch's book.

Finally, let us add this crucial information: on his return, Chrysanthos was not only regarded as an excellent scientist, but also as a man faithful to the Orthodox tradition. This is clearly shown in a particularly interesting letter sent to him by Alexandros Mavrokordatos in the year 1702 or later:

Of your peregrinations in Europe and in the countries and cities which are there I admire nothing more than your return, for your progress and your achievements have not altered or falsified your manners or your convictions. Those who choose to leave and to travel have much to gain from knowing the cities and minds of the multitude [...]. But I have often becried and mourned those who [...] defiled their thoughts with degenerate doctrines [...]. Even if they were not shipwrecked during their journey, they have not been less affected by this terrible sinking of their manners and their souls on dry land. As for you, very learned man, thanks to God in His excellence, you have preserved [your soul] [...] and you have returned from this trip by having obtained great benefits [...]. As a bee who loves

Astronomical Book, written in 1700, by the same Meletios, namely the NLG, MPT 420 [Diktyon

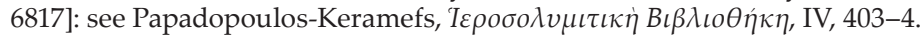

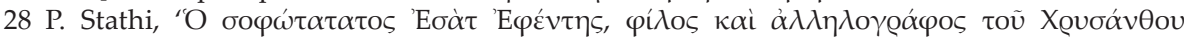

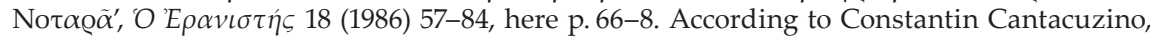
Ali Efendi 'lost the rules of astrology by seeing the confusion of the movement of the stars'

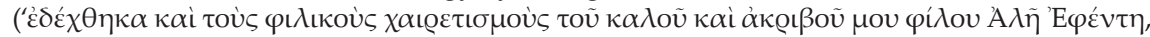

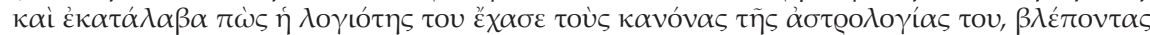

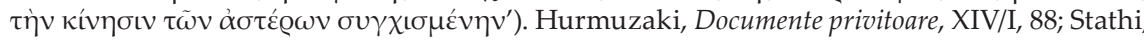

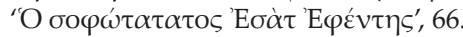

29 See for instance the engraving of Louis Cossin, Portrait de J. D. Cassini, en buste, de 3/4 dirigé à gauche (Paris 1712), https://catalogue.bnf.fr/ark:/12148/cb41506294n. Since 1578, Ptolemy was also represented with a compass and two globes. J.-M. Besse, 'Le regard du cosmographe', in C. Hofmann and Fr. Nawrocki (eds), Le monde en sphères (Paris 2019) 118-23, here p. 122.

30 The engraving bears an epigram with the initials 'N. B.' corresponding to Nikolaos Vouvou-

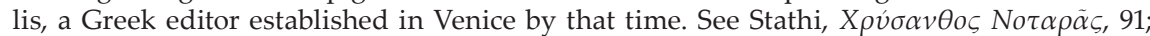

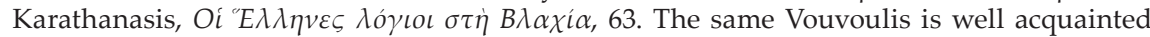
with Komninos-Papadopoulos. Vasiliu, 'Costantino Brâncoveanu', 114-5.

31 On the front page of Chrysanthos' Introduction, there is an engraving with two globes representing Astronomy and Geography. 
the effort, you have drawn pure honey from the science of those very bitter flowers. $^{32}$

\section{Chrysanthos before visiting Paris: a distinguished scientist fostered by Protestant and Catholic networks}

Chrysanthos' scientific interests in the years 1680-1693

Even if Chrysanthos did not study in Paris and if, moreover, he resisted the siren calls of the West, does this mean that his visit to the Observatory was the result of simple curiosity, or that it was merely a fashionable attraction offered to the nephew of a powerful hierarch from the Christian East? ${ }^{33}$ In my opinion, this is not the case. On the contrary, I believe-and this is what I wish to explore in this paperthat in 1700 the man of whom François Sevin later said that 'the Greeks regard him as the most learned figure of his century ${ }^{\prime 34}$, already possessed solid knowledge in the field of modern science, and particularly in astronomy and geography, two closely related disciplines.

We do not know the date of Chrysanthos' birth, nor that of his arrival at Constantinople. However, it can be assumed that in 1680, when he adorned the man-

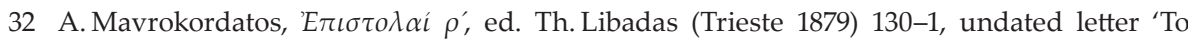

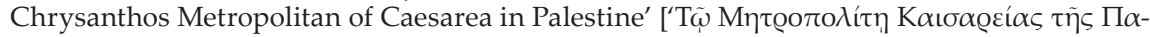

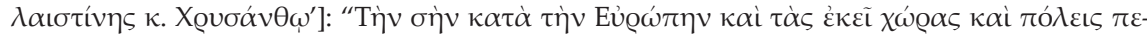

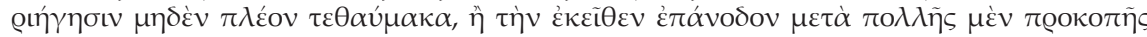

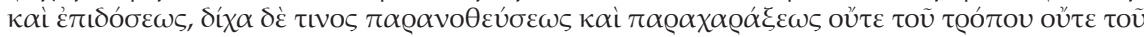

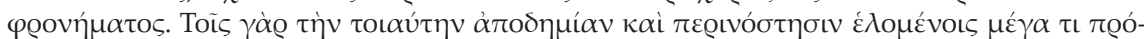

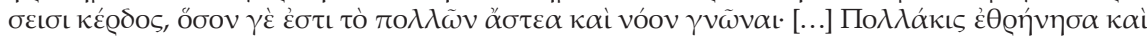

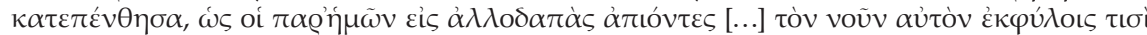

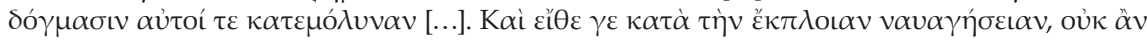

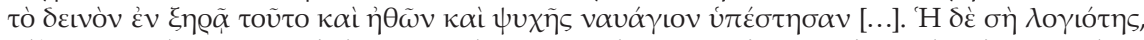

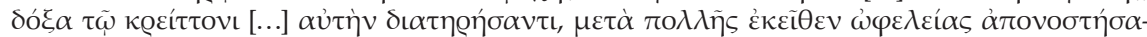

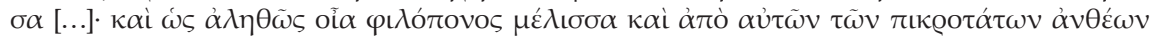

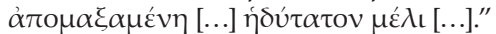

33 In the 17th century, the Observatory with its 'machines' was a place that the Court attended as an attraction, and where many personalities and their families were welcomed. These social activities, known as 'passion des astres', are well documented by Cassini, who himself acted as a courtier. See, for instance G. Picolet, 'Une visite du jeune Saint-Simon à l'Observatoire de Paris', Cahiers Saint-Simon 26 (1988) 59-68. Cassini's taste for the Court, and the doubtful scientific choices that sometimes resulted from it, were heavily criticized in the nineteenth century for 'having stopped the progress of science'. See R. Radau, 'L'Observatoire de Paris depuis sa fondation', Revue des Deux Mondes [2nd Period] 73 (1868) 740-68, who considers the French observatory as 'un édifice de parade' (ibid., 744).

34 Letter of François Sevin to Maurepas (Constantinople, 16 April 1729) in H. Omont (ed.), Missions archéologiques françaises en Orient aux XVII et XVIII siècles, I (Paris 1902) 469: "Le Patriarche me donna parole positive, non seulement de me montrer sa bibliothèque, lorsque sa santé seroit rétablie, mais encore de maider de tout son crédit. Il en a beaucoup en ce pays cy, les Grecs le regardent comme le plus sçavant personnage de son siècle; ils ont tort, et je puis vous assurer que jamais connoissances ne furent plus superficielles; c'est un petit homme plein de feu et très simple, quant à l'extérieur, mais qui, sous ses dehors de simplicité, cache bien de l'esprit et du manège. [...] Deux métropolites vinrent avant-hier m'apporter de sa part un traité de géographie qu'il a publié autrefois." 
uscript MPT 261 [Diktyon 6658] with a possessor's note, he was more than twenty years old ${ }^{35}$ and had studied rhetoric. A year later, in 1681, his teacher at the Patriarchal Academy was Sevastos Kyminitis from Trebizond; Kyminitis taught him Aristotelian philosophy, and especially the Topics. This teaching drew on the commentaries of the radical Neo-Aristotelian Theofilos Korydallefs, a disciple of Cesare Cremonini in Padua and a defender of both geocentrism and the total emancipation of philosophy vis-à-vis scholasticism. Indeed, among the manuscripts owned by Chrysanthos at the time was also the manuscript MPT121 [Diktyon

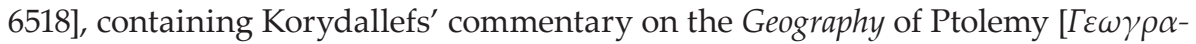
$\varphi \iota \kappa \dot{v} \varphi \dot{\eta} \gamma \eta \sigma \iota \varsigma]$.

However, the scientific curiosity of the young Chrysanthos goes beyond the framework of Neo-Aristotelianism. Encouraged by his masters in Constantinople or by his own reading of manuscripts, he undertook to broaden his astronomical knowledge by exploring the Arab and Byzantine traditions which themselves had relied since the thirteenth century on Persian astronomy from the Maragha School. ${ }^{36}$ Thus, in the same manuscript, MPT 121 [Diktyon 6518], Chrysanthos copied Isaac Argyros' Treatise on the Astrolabe and, in MPT 198 [Diktyon 6595], the Greek translation of an astronomical book by Abu Ma'shar. Finally, in the early 1680s, he began writing an Explanation and description of the quarter of the sphere, called rup-dagire in Arabic, a text preserved in the manuscript MPT 200 [Diktyon 6597] and which attracted great attention. ${ }^{37}$ But of course, all these astronomical and geographical concepts were not disrupted by modern science, even if Galileo was teaching in Padua when Korydallefs was studying there. ${ }^{38}$

According to recent research, Chrysanthos' traditional beliefs in the field of Astronomy were dispelled during his trip to Moscow in 1692, after the reading of a Compendium historicum de Astronomia apud Sinas addressed to Alexis I Mikhailovich (1645-1676) by the Jesuit astronomer and missionary Ferdinand Verbiest. In

35 According to the Holy Canons, since he was an archdeacon by that time, he should have been more than twenty-five years old. One can ask, however, if the canonical order was strictly followed.

36 See G. Saliba, 'The role of Maragha in the development of Islamic Astronomy: a scientific revolution before the Renaissance', Revue de synthèse 4/3-4 (1987) 361-73; G. Saliba, 'Revisiting the astronomical contacts between the World of Islam and Renaissance Europe: the Byzantine connection', in P. Magdalino and M. Mavroudi (eds), The Occult Sciences in Byzantium (Geneva 2006) 361-74; E. Nicolaidis, Science and Eastern Orthodoxy. From the Greek Fathers to the Age of Globalization, transl. Susan Emanuel (Baltimore MD 2011) 106-18.

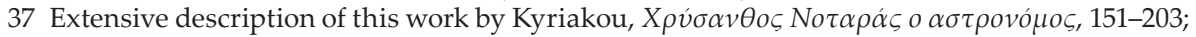

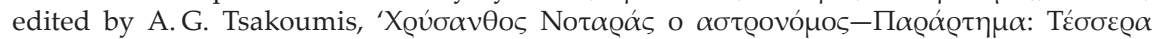

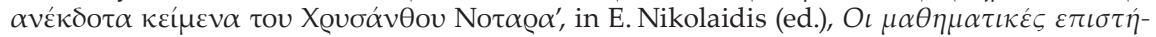

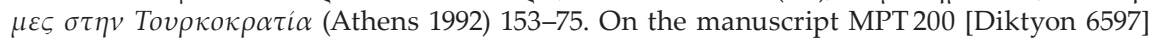

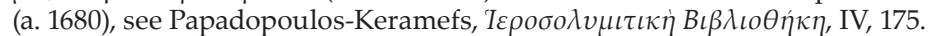

$38 \mathrm{Cl}$. Tsourkas, Les débuts de l'enseignement philosophique dans les Balkans. La vie et l'œuvre de Théophile Corydalée (1570-1646) (Thessaloniki 1967) 35-44, reports that Korydallefs was proclaimed doctor of the University of Padua in 1613 and supposes that he began his studies there in 1607. Galileo taught in the same University from 1592 to 1610. 
1677-1678, this text had been brought from China by Nicolas Spathar Milescu, a Greek born in Moldavia and appointed to the service of the Tsar. ${ }^{39}$

When he arrived in Beijing in 1676 for a round of negotiations between the two empires, Spathar Milescu was received by Verbiest who held the position of head of the Mathematical Board and director of the Observatory. Appointed to this prestigious position as a result of a long and violent controversy which opposed him to Chinese astronomers, the Jesuit had managed to impose his scientific theories, which were completely new in the Far East. In particular, he had convinced the young Emperor K'ang-hsi (1661-1722) of the accuracy of his observations on the calendar. His methods, and also the new instruments he installed at the Beijing Observatory, in the end won the approval of all the court astronomers. ${ }^{40}$ In welcoming Milescu, and acting himself as a mediator between the Tsar's ambassador and the Chinese Emperor, Verbiest willingly preserved the interests of the Jesuits; but he also took advantage of his position and tried to suggest to the Tsar a reform of the Julian calendar. He therefore composed for him the small Compendium, which he completed with engravings representing the new instruments of the Observatory of Beijing. However, when Spathar came back to Moscow, Alexis I was already dead, and it is not known if the document was ever handed over to his successor. Its pro-Jesuit content and proposal of reform had certainly upset the ambassador, and he may have withheld the treatise.

In 1689, the Patriarch Dositheos-whose anti-Latinism is well known-contacted Spathar. ${ }^{41}$ He questioned him extensively about China, and finally sent his nephew to him. In Moscow, Chrysanthos had close contact with Milescu, who allowed him to copy Verbiest's manuscript, and gave him also an account of his own trip. ${ }^{42}$ In 1693, when he returned to Constantinople, Chrysanthos brought these documents with him. According to Euthymios Nikolaïdis, the archimandrite's discovery of 'Jesuit science ${ }^{\prime 33}$ through this amazing detour inspired him to undertake studies at Padua in his mature years:

39 Ferdinand Verbiest, Magno Principi Tsari et Magno Duci Alexio Michaelovicz, Compendium historicum de Astronomia apud Sinas restituta ..., anno Christi MDCLXXVI. To date, only one copy of this treatise is known, the manuscript MPT 423 [Diktyon 6820] brought by Chrysanthos from

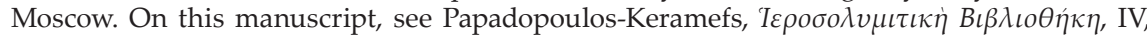
405, reconsidered by E. Nikolaidis, 'Verbiest, Spathar and Chrysanthos. The spread of Verbiest's science to Eastern Europe', in W. F. Vande Walle and N. Golvers (eds), The History of the Relations between the Low Countries and China in the Qing Era (1644-1911) (Leuven 2003) 37-57, here p. 51. Also N. Golvers and E. Nicolaidis, Ferdinand Verbiest and Jesuit science in 17th century China: an annotated edition and translation of the Constantinople manuscript (1676) (Athens-Leuven 2009).

40 On this affair, see Pingyi Chu, 'Scientific dispute in the Imperial Court: the 1664 calendar case', Chinese Science 14 (1997) 7-34.

41 Letter of Dositheos to Milescu, in E. Legrand (ed.), Bibliothèque grecque vulgaire, III (Paris 1881) xxxv.

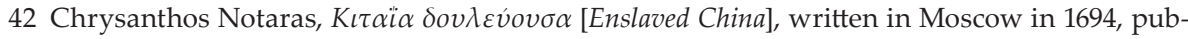

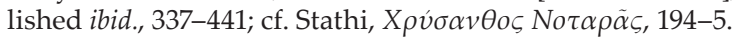

43 On this qualification, see below. 
The copy made for Chrysanthos introduced him to a new world. The presentation of Verbiest's science provided by this text was extremely important for Chrysanthos' scientific future. This was an encounter with 'another' science, and it provided Chrysanthos with a strong motivation to study the 'new knowledge'. Immediately after his sojourn in Moscow, in 1697, he travelled to Italy [...]. Here, he found books and teaching more up-to-date than those provided by Verbiest's manuscripts. With respect to astronomy, three years later, in 1700, he visited the most modern and scientifically important institution of that time, the Observatory of Paris [...]. The spread of the new astronomy to Eastern Europe and the Ottoman Empire begins after that date, and Chrysanthos' encounter with Verbiest's astronomy was the first important contact between Greek scholars and the new European science, which, in this case, came from China through Russia. ${ }^{44}$

Even if Chrysanthos' fascination with the instruments of the Beijing Observatory as described and illustrated by Verbiest was genuine, new evidence allows us to relativize this narrative and to affirm that the archimandrite already had a certain knowledge of modern science before 1692. But in this case, he gained access to it not through Catholic networks, but through Protestant-and especially Anglican-channels.

\section{An extraordinary order}

According to the correspondence between Dositheos and John Covel, chaplain to the Levant Company in Constantinople in the years 1670 to 1676, and Master of Cambridge in the long period of 1688-1722, a very impressive order related to Chrysanthos' scientific interests was made in November 1689 and supplemented in January 1690. It is clearly attested by a letter preserved in the manuscript of the British Library, Harley 6943 (1672-1711) [Diktyon 39727], f. 89r-v, and included in a larger folder (f. $89 \mathrm{r}-92 \mathrm{v}$ ), to which a specific study should be undertaken. This exchange, which is to be found in the Appendix, occurs between a certain number of actors as follows:

On 9 October 1684, ${ }^{45}$ while Europe was torn apart and communication between the Ottoman Empire and Western countries became extremely difficult, Thomas Coke ${ }^{46}$ secretary of the Levant Company for several decades and chancellor of the British Residency in Constantinople, wrote a letter to John Covel informing him of an exchange he had had with the patriarch Dositheos. In fact, the three men knew one another, and had perhaps met while Covel was still in the East. ${ }^{47}$ In his letter,

44 Nikolaidis, 'Verbiest, Spathar and Chrysanthos', 57.

45 Appendix, I.

46 On him, see J.-P. Ghobrial, The Whispers of Cities. Information Flows in Istanbul, London, and Paris in the Age of William Trumbull (Oxford 2013) especially p. 137-42.

47 Covel and Dositheos had met in Adrianople, in 1675. See V. Kontouma, 'Christianisme orthodoxe. Recherches sur Dosithée II de Jérusalem (1669-1707)', Annuaire de l'École pratique des 
Coke gives the following information: around March 1684, Ioannakis Porfyritis ${ }^{48}$ had contacted him and had given him a book from Dositheos. Intended for Covel, the book was immediately sent to England, but Coke had received no reply. So, another book was to be sent. Given by Dositheos himself, it was a work of Nektarios of Jerusalem dealing with the Pope's primacy. ${ }^{49}$ The dispatch was made through Mr. Barclay, an employee of the Resident.

Five years later, on 2 November 1689,50 Covel had still not responded, but Coke wrote to him again, encouraged by Mr. Gerard, an otherwise unknown person who gave him news of the Master's promotion, probably to Vice Chancellor of Cambridge. In fact, Coke had had another encounter with Dositheos. The latter gave him two books for Covel: 'Nektarios', which had been sent earlier but was supposed to have been lost, and 'Symeon' printed in 1683 in Iași. ${ }^{51}$ This time, however, Dositheos did not simply send presents. He also wanted to place a very precise order, transmitted by Coke.

This order, which is extraordinary in respect of its size and the value of the items requested, is divided into two lots. First, there is a series of books published in the West, including 'all the Byzantine Historians' of La Byzantine du Louvre, a luxury collection patronized by Louis XIV..$^{52}$ Other titles are detailed in an autograph list written by Dositheos ${ }^{53}$ and attached to Coke's letter. The patriarch stress-

hautes études 124 (2015-2016) 207-18, here p. 216-17. It is likely that Coke was part of the same British delegation to Adrianople in which most of the Residency seems to have participated in 1675.

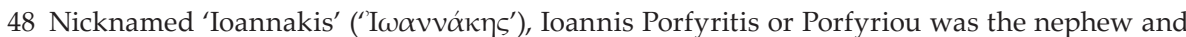
the assistant of the Grand Dragoman Panagiotis Nikousios (d. 1673). He himself became a dragoman in the service of Austria, then of the Porte. He belonged to the circle of close collaborators of Patriarch Dositheos. For more on Porfyritis, see B. Sfyroeras, Oi $\Delta \rho \alpha \gamma o v \mu \alpha \dot{v o l}$

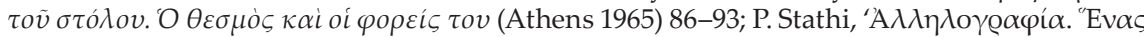

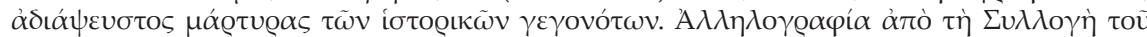

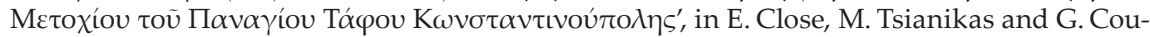
valis (eds), Greek Research in Australia: Proceedings of the Sixth Biennial International Conference of Greek Studies, Flinders University June 2005 (Adelaide 2007) 389-400, here p. 394-5.

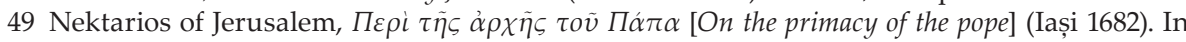
fact, this is the first work out of the presses of the Patriarch. See E. Legrand (ed.), Bibliographie hellénique ou description raisonnée des ouvrages publiés par des Grecs au dix-septième siècle, II (Paris 1894) 568; K.-P. Todt, 'Dositheos II. von Jerusalem', in C. G. Conticello and V. Conticello (eds), La théologie byzantine et sa tradition, II (XIII -XIX s.) (Turnhout 2002) 659-720, here p. 670; F. Gabriel, 'Tradition orientale et Vera Ecclesia : une critique hiérosolymitaine de la primauté pontificale. Nektarios, de Jassy à Londres (v. 1671-1702)', in M.-H. Blanchet and F. Gabriel (eds), Réduire le Schisme ? Ecclésiologies et politiques de l'union entre Orient et Occident (XIII siècle) (Paris 2013) 197-236.

50 Appendix, II.

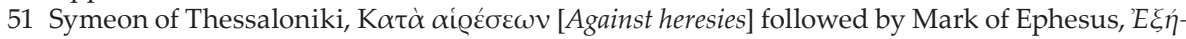

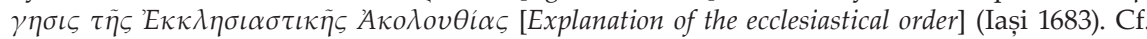
Legrand (ed.), Bibliographie hellénique, II, 578; Todt, 'Dositheos II. von Jerusalem', 670-1.

52 See N. Petit, 'La Byzantine du Louvre', in M.-F. Auzépy and J.-P. Grélois (eds), Byzance retrouvée. Érudits et voyageurs français (XVI $-X V I I I^{e}$ siècles). Catalogue de l'exposition. Chapelle de la Sorbonne, Paris, 13 août-2 septembre 2001 (Paris 2001) 70-80 and 81-4.

53 Appendix, IV. 
es that the works must be in Greek or in a bilingual Greek-Latin version. Books in Latin alone do not suit him, as he does not read this language. Second, Coke's letter refers to a series of maps and geographic and astronomical instruments, as well as a series of Commentaries on Aristotle. This batch is not mentioned in the autograph list. ${ }^{54}$ It seems to correspond to an oral request made by the Patriarch and his relatives-Coke once says 'they' instead of 'he'-and, in this case, Latin is not a problem. We can also add that the content of the order is not related to Dositheos' interests, but rather to the concerns of his nephew Chrysanthos, already a connoisseur of Arab-Byzantine astronomy by that time. The exact content of the second lot is detailed in Coke's letter:

He desires also a paire of Globes of about 14 inches diameter, and a paire of small globes about the bignesse of one's fist for to carry easily in a journey, and 4 Maps of the foure parts of the world, but these all in Latin, and not in English. They desire the Globes may have two Poles, and the brasse circle to remove from one to the other. He desires also, all the Greeke Comentators on Aristotles Metaphysics, as Alexander, Themistius, Ammonius, and The bookes must bee carefully packt up, that they bee not damaged, and especially the Globes, that they bee not broken. ${ }^{55}$

Coke also states that the order will be paid through Thomas Palmer, merchant of the Levant Company. He does not say, however, whether the Company advances the money, or whether it fully bears the costs, as a tribute to the patriarch.

The exchange continues on 14 January $1690,{ }^{56}$ as Coke, fearing that his letter has again gone missing, sends a duplicate of it. He also adds to the order the Geographical Dictionary of Filippo Ferrari, ${ }^{57}$ presumably requested by Chrysanthos in the meantime. Finally, in March 1690, ${ }^{58}$ Thomas Palmer contacts Covel from London for payment of the purchases, announcing that the parcels will leave England within a period of twelve months.

It seems that the order was sent within this deadline, and that it arrived safely. Indeed, Covel notes on the back of Palmer's letter: 'He will pay me for the patriarch's books, ${ }^{59}$ a sign that he was preparing to insure the purchases. Moreover, many of the books ordered by the Patriarch appear in the first inventory of the Metochion library. ${ }^{60}$ But why did the Master of Cambridge agree to attend to such

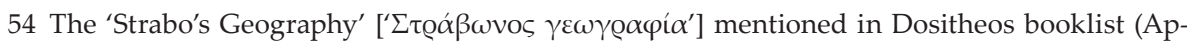
pendix, IV) is intended for himself, and not for Chrysanthos. Indeed, Strabo is quoted in Dositheos' History.

55 Appendix, II, first part.

56 Appendix, II, second part.

57 Philippus Ferrarius, Lexicon Geographicum, ed. William Dillingham (London 1657); 2nd ed. Michel Antoine Baudrand (Paris 1670).

58 Appendix, III.

59 Appendix, III.

60 This research is currently in progress. On the inventory of manuscripts and printed books of the Metochion Library (NLG, MPT 93 [Diktyon 6490]), which was compiled at the death of 
a large and cumbersome order? Obviously, this is related to the very special relationship he had with Dositheos. Since they had met at Adrianople in 1675, the two men had been in frequent correspondence. Dositheos gave the Englishman some manuscripts, and Covel had begun to translate into Latin the treatise On the Primacy of the Pope by Nektarios, a translation which he dedicated to the patriarch in $1685,{ }^{61}$ calling for empathy 'between the Eastern Church and the British Church', ${ }^{62}$ and hoping that the Orthodox would endorse the Anglican point of view. As for Dositheos, he was concerned with the publication and distribution of some fiercely anti-Catholic books, a project for which he expected the support of Protestant networks, if not outright funding by the Levant Company.

Because of the difficulties of navigation, ${ }^{63}$ it appears that the long-awaited order did not arrive in Constantinople until the summer of 1692. In 1689, Dositheos had probably thought that it would be a good gift for his nephew, who was about to be ordained. But Chrysanthos received it three years later, and it is unclear whether he could really make use of it, since he was preparing to leave for Russia. However, in 1689 Chrysanthos knew exactly what he wanted. Among other things, he knew the size and characteristics of the globes: by this time, he had already seen and used such objects. This need not surprise us. In 1688, he had travelled to Berlin and Poland, where he had certainly had his first contacts with the new science. Even in Constantinople, and when travelling by sea to Jerusalem or the Black Sea, he must have seen on ships of the Levant Companies the terrestrial and celestial globes commonly used for navigation. ${ }^{64}$ Last but not least, the archimandrite frequented the Wallachian court of Constantin Brâncoveanu, where the interest in astronomy and geography seems to have been as great as his own. ${ }^{65}$

\section{Astronomy and cartography at the Wallachian court}

Since Ptolemy, a number of distinct sciences-mathematics, astronomy and geography-converged to form the single discipline of cosmography. The Christians had included this in theology, perceiving the universe as created. In rediscovering Ptolemy in the fifteenth century, and by laying the foundations of the scientific

Chrysanthos in 1731, see A. Lampadaridi, 'La bibliothèque du Métochion du Saint-Sépulcre à Constantinople à travers ses inventaires anciens', in A. Binggeli, M. Cassin, M. Detoraki and A. Lampadaridi (eds), Bibliothèques grecques dans l'Empire ottoman (Leuven 2020) 291-310.

61 V. Kontouma, 'Christianisme orthodoxe. Recherches sur Dosithée II de Jérusalem (suite)', Annuaire de l'École pratique des hautes études 125 (2016-2017) 251-5, here p. 253.

62 V. Kontouma, 'Recherches sur Dosithée II de Jérusalem', 217-8 (text from the manuscript Brit-

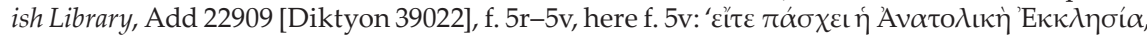

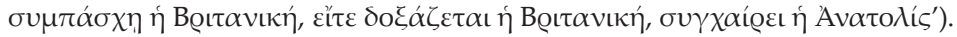

63 On the difficulties faced by British ships in this period, see E. D. Tappe, 'Documents concerning Rumania in the Paget papers', The Slavonic and East European Review 33/80 (December 1954) 201-11.

64 P. Van der Krogt, 'L'usage des globes dans la société européenne aux XVI ${ }^{\mathrm{e}}-\mathrm{XVII}{ }^{\mathrm{e}}$ siècles', in C. Hofmann and Fr. Nawrocki (eds), Le monde en sphères (Paris 2019) 144-50.

65 Chrysanthos was active in this circle for long periods $(1684 ; 1687,1688 ; 1689 / 90 ; 1693-1696$; 1702-1707; 1707/1708; 1713-1715 and 1727/1728). See Stathi, X 
revolution, the West did not depart from this world-view. ${ }^{66}$ On the contrary, progress in mathematics led to progress in astronomy, the latter brought about a new approach to geography, and this in turn opened new possibilities for navigation. ${ }^{67}$ Conversely, explorations facilitated not only progress in geography, but also in astronomy. Cassini clearly explains this in his essay De l'origine et du progrès de l'astronomie et de son usage dans la géographie et dans la navigation, published in 1693:

The main purpose that the Academy has set for itself in astronomical observations has always been to apply them to the advancement of Geography and Navigation. And for this purpose, nothing was more useful than to determine what part of the circumference of the earth corresponds precisely to a celestial degree. [...] After having determined the magnitude of a degree of the circumference of the Earth, several voyages were made to establish the degrees of longitude, comparing the observations which one would make in very distant places with those made simultaneously at the Observatory. ${ }^{68}[\ldots]$ The king, having been informed of the utility drawn from the observation of the eclipses of the moons of Jupiter to establish the degrees of longitude, ordered that this method should be applied to new maps of France. Immediately the Academy sent men to make many observations of these eclipses on all the coasts of the realm, and by comparison of these observations with those made simultaneously in Paris, it was found that the modern geographers who had wanted to correct Ptolemy had drawn too far westward the Western shores of the realm [...]. Based on these clarifications we have drawn up a map of the whole known earth on the floor of a tower of the Observatory, in which we have diverged from some more modern maps by $20^{\circ}$ in longitude of the Eastern lands. And the observations of the eclipses which were made in the East Indies and in Paris confirmed this difference, something which was difficult to do without the help of celestial observations. ${ }^{69}$

66 Besse, 'Le regard du cosmographe', 118-23.

67 The measurement of meridians, on which scientists such as Picard and Cassini conducted ground-breaking research, combined astronomical observations and complex calculations. Thanks to a better calculation of degrees of longitude, this also led to the refinement of geography and, thereby, to the production of maps of unprecedented precision and accuracy. See Gallois, 'La carte de Cassini', issue 100, 297-8.

68 Jean-Dominique Cassini, 'De l'origine et du progrès de l'astronomie et de son usage dans la géographie et dans la navigation', in Recueil d'observations faites en plusieurs voyages par ordre de Sa Majesté pour perfectionner l'Astronomie et la Géographie, avec divers Traités astronomiques, par Messieurs de l'Académie Royale des Sciences (Paris 1693) 1-43, here p. 39-40 (my translation).

69 Ibid., 42 (my translation). 
In some cases, scientists sought to adhere to divine laws, something that explains the enthusiasm for Tycho Brahe's cosmological theories. ${ }^{70}$ The Jesuit astronomer Giovanni Battista Riccioli took up Brahe's theories and revised them to preserve the principle of the stillness of the earth, considered to be in accordance with Scripture. ${ }^{71}$ By resorting to the traditional distinction between astronomical hypotheses and physical reality, he allowed the hypothetical use of heliocentrism, thus relativized. Admitted by the Catholic Church, such theories legitimized the practical applications of the new astronomy. As illustrated by the case of Verbiest, this formal geocentrism gave rise to the development of a 'Jesuit science' in which astronomical observation, cartography and missionary activity were associated and supported by the 'transcontinental network of the Society of Jesus'. ${ }^{72}$

In the Orthodox East, a centre of power concerned itself with these developments: at the Wallachian court of Constantin Brâncoveanu intellectuals were interested in cosmological studies. Here, the figure of Stolnic Constantin Cantacuzino-the uncle of Brâncoveanu and the father of Rădu Cantacuzino-played a decisive role. He himself had been trained at the university of Padua in the years 1667-1669, and had maintained links of friendship there, especially with Nikolaos Komninos-Papadopoulos. In Wallachia, at Mărgineni, he had brought together a library of exceptional quality where one could find cosmological treatises. ${ }^{73}$ In 1696 he received an astronomical telescope from the British Resident at Constantinople, William Paget. ${ }^{74}$ Finally, he was the dedicatee of a curious Prognostikon related to the solar eclipse of 23/13 September $1699 .{ }^{75}$ Having grown up in the family environment of the Stolnic, Constantin Brâncoveanu shared his interests. He built himself a prestigious library in Hurezi and maintained friendship and correspondence with great personalities of the West, including Cardinal Giovanni Francesco Albani, who became Pope in November 1700 under the name of Clement XI. ${ }^{76}$

70 See M. P. Donato, 'Scienza e Teologia nelle Congregazioni Romane. La questione atomista, 1626-1727', in A. Romano (ed.), Rome et la science moderne. Entre Renaissance et Lumières (Rome 2008) 595-634, here p. 595.

71 F. Beretta, 'L'héliocentrisme à Rome à la fin du XVII siècle : une affaire d'étrangers ? Aspects structurels d'un espace intellectuel', in A. Romano (ed.), Rome et la science moderne. Entre Renaissance et Lumières (Rome 2008) 531-54, here p. 547, note 80; M.-P. Lerner, 'L'entrée de Tycho Brahe chez les jésuites ou le chant du cygne de Clavius', in L. Giard (ed.), Les Jésuites à la Renaissance. Système éducatif et production du savoir (Paris 1995) 145-85.

72 A. Romano, 'L'horizon romain de la science moderne. Des sentiers à ouvrir', in A. Romano (ed.), Rome et la science moderne. Entre Renaissance et Lumières (Rome 2008) 637-59, here p. 651, note 32 (in this paper, Romano opposes Jesuit theories to those of the Dominicans, who still relied on Scholastic Aristotelianism).

73 C. Dima-Drăgan, Biblioteca unui umanist român Constantin Cantacuzino Stolnicul (Bucharest 1967) 68-70; C. Dima-Drăgan and M. Carataşu, ‘Un manuscrit inédit du Docteur Jean Comnène', Revue d'études sud-est européennes 11 (1971) 107-20, here p. 112-13, note 5.

74 Tappe, 'Documents concerning Rumania in the Paget papers', 202; Dima-Drăgan and M. Carataşu, 'Un manuscrit inédit du Docteur Jean Comnène', 113.

75 Ibid., passim.

76 Vasiliu, 'Costantino Brâncoveanu', 110-3. 
It was on the decision of Stolnic Cantacuzino and Prince Brânconveanu that Chrysanthos and Rădu were sent to Padua, where their activities included the printing of maps sponsored by the Wallachian Court. The most important of these is an original map of Wallachia, the first of its kind. This map resulted from a revision of degrees of longitude and latitude, and provides an abundance of information of geophysical, archaeological, political and economic character. Preserved in a single copy in the British Museum, the map has been the subject of several studies. A beautiful object, it bears a dedication to the Prince Brâncoveanu and is decorated with his arms and portrait. ${ }^{77}$ The second map is the first 'mappa mundi' in Greek. It also bears the portrait of the Prince of Wallachia and the arms of the principality. Evangelos Livieratos and his team have shown that it is related to Dutch cartography-at that time in its golden age-especially because it indicates the routes followed by the Dutch United East India Company (Vereenigde Oostindische Compagnie) in all oceans, a feature which is to be found on an anonymous map (Amsterdam or Paris ca 1670) - and also on Guillaume Delisle's world map printed in 1700 in Paris, something which is puzzling. ${ }^{78}$ Finally, there is a small 'mappa mundi' included in the Introduction to Geographics and Sphaerics of 1716, which is explicitly dated to 1700, however. It is based on a Dutch map of Jan Luyts (Utrecht 1692), also published with a geographical work of the latter. ${ }^{79}$

Significantly, Chrysanthos and Rădu printed these three maps at the press of the 'Seminario vescovile' of Padua. This was an exception for Orthodox publishing activities, which usually used private printers in Venice in order to circumvent Roman censorship. But this was not the intention in this case. Created in 1684 by Cardinal Gregorio Barbarigo ${ }^{80}$ on the model of the Propaganda fide, the seminary's press was richly endowed and followed a clearly confessional purpose: to publish texts in rare languages for the conversion of infidels and Eastern schismatics. ${ }^{81}$ In this sense, the choice of this printing house is extraordinary. It is to be explained

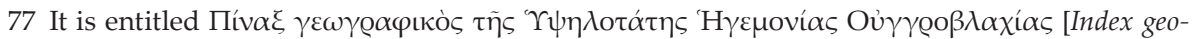
graphicus of the Very-High Principality of Hungary-Wallachia] (Padua 1700). See I. Bianu and D. Simonescu (ed.), Bibliografia Românească veche 1508-1830, IV (Bucharest 1944) 27-8; G. Tolias, 'Maps printed in Greek During the Age of Enlightenment, 1665-1820', e-Perimetron 5/1 (2010) 1-48, here p. 19.

78 E. Livieratos, Chr. Boutoura, M. Pazarli, N. Ploutoglou and A. Tsorlini, 'The very first printed map in Greek, a derived map from Dutch cartography: Chrysanthos Notaras' world map (1700) vs Jan Luyts' world map (1692)', e-Perimetron 6/3 (2011) 200-18.

79 Ibid., passim. It has to be noted that Chrysanthos and Luyts had common beliefs in scientific areas, which they clearly expressed in their geographies: both followed the Ptolemaic astronomical system, and defended geocentrism, despite their firm knowledge of the modern heliocentric theories.

80 It should be noted that Barbarigo professed heliocentrism in secret: see Beretta, 'L'héliocentrisme à Rome', 548.

81 On this printing press, see G. Bellini, Storia della Tipografia del Seminario di Padova (1684-1938) (Padua 1938); M. Callegari, 'Strategie du produzione libraria a Padova nel Settecento', in G. Petrella (ed.), Navigare nei mari dell'umano sapere. Bibliotheche e circolazione libraria nel Trentino e nell'Italia del XVIII secolo. Atti del convegno di studio (Rovereto, 25-27 ottobre 2007) (Trent 2008) 33-43. 
by the close relationship that our Orthodox team had with Komninos-Papadopoulos, and by the excellent relations between Brâncoveanu and Cardinal Albanirelations which are certainly due to some political calculation. Indeed, as stated by Albani, 'being an absolute and schismatic prince', Brâncoveanu needed to be convinced 'not by force, but only by good manners and an ingenious policy.' ${ }^{82}$ It is thus significant to read in a letter addressed by Chrysanthos to Komninos-Papadopoulos in 1702, that 'for four years', i.e. since 1698, he had tried 'to introduce to these good Lords some favorable opinion of the Latins' ${ }^{83}$

As I hope I have shown through this series of episodes, Chrysanthos was far from being a neophyte when he arrived in Paris in April 1700. Quite the opposite. Although he had not received any comprehensive training in the new sciences, he was experienced in astronomical questioning and practiced cartography according to the methods of his time. In addition, he had strong networks behind him, including a Catholic network open to the new science, and an Anglican network ready to supply instruments through the Levant Company. Through his reading of Verbiest, his conversations with Milescu and the many exchanges that Dositheos and Constantine Cantacuzino had had with Protestants, he knew the current scientific-religious issues, the orientations of 'Jesuit science' and the renewed debates on the astronomical validity of calendars, both Julian or Gregorian.

\section{The exceptional year 1700 and Cassini's scientific-religious project}

\section{Cassini, a committed Catholic}

In the framework described above, Giovanni Domenico Cassini's own religious commitment is well-known, though all too often this has been overshadowed by the attention paid to his first-rate discoveries, notably on the rings of Saturn and its satellites. ${ }^{84}$ A student of the Jesuits and a disciple of Riccioli in Bologna, the eminent astronomer remained in contact with several missionaries who often shared with him their geographical and astronomical observations abroad. ${ }^{85}$ Faithful of

82 Vasiliu, 'Costantino Brâncoveanu', 118: 'essendo Principe Assoluto e scismatico, nulla si potrebbe rimediar con cattivo, ma solamente con le buone maniere, e con ingegnosa Politica.'

83 Ibid., 115, 118: 'quanto in quattro anni s'è fatto per introdur in quei SS-ri qualche buon concetto de' Latini.' As illustrated by Vasiliu (ibid., 114, note 2), Komninos-Papadopoulos firmly believed that Chrysanthos had embraced in secret the Catholic faith ('ben affetto alla fede cattolica, di cui nascostamente professa I dogma'). Since double-speak is largely used in these exchanges, it is difficult to say if Chrysanthos was sincerely convinced by his master while in Padua, or if he pretended so to maintain good relations with him.

84 As briefly mentioned above (footnote 33), Cassini enjoyed court life. To understand the singularity of this exceptional Italian scientist, let us recall here that he was trained by the Jesuits of Genoa, appointed professor of astronomy at the University of Bologna when he was twenty-five years old, and called to France by Colbert in 1669 after the publication of his Ephemerides Bononienses Mediceorum siderum (Bologna 1668).

85 See for instance a report with observations from Smyrna, Thessaloniki, the Aegean Islands and Crete, sent by Louis Feuillée, a friar of the Order of Minimi and a scientist: 'Extrait des observations astronomiques que le R. P. Feüillée Minime a faites au Levant pendant les années 1700 et 1701', Histoire de l'Académie royale des Sciences, a. 1702 (Paris 1743) 7-15. On this 
the Catholic Church, he never openly defended heliocentrism. Officially, he appeared as a defender of the cosmology of Ptolemy, ${ }^{86}$ confining himself to the practical applications of the new science. For that reason, it has been said of him that 'he passed quietly from one system to another without displaying his opinions. ${ }^{187}$

An autobiographical note copied by his son Jacques begins with an episode of his childhood where he appears to have been fascinated by St Francis Xavier, the so-called apostle of the Indies: 'Having heard in the church of St Ambrose a panegyric of St Francis Xavier, he immediately translated its most beautiful parts into Latin verses and presented them to his regent. And the latter made him Prince of Poets of his class. ${ }^{\prime 88}$ It was also under such inspiration that he concluded his essay De l'origine et du progrès de l'astronomie:

To what we have said about the utility of Astronomy we can add the advantages that we have gained and that we receive from it every day for the propagation of the Faith. Thanks to the acknowledgment and the protection of this science, those who have devoted themselves to the preaching of the Gospel to unbelievers penetrate into the most remote countries and live not only securely, but also completely free to preach the Faith, enjoying the admiration of the people, gaining access to the privacy of great men, and even winning the favor of the sovereigns. This science opened to missionaries the vast empire of China, whose entrance was closed to all foreigners by the laws of the country and reasons of state..$^{89}$ It has helped to gain permission to build churches and to practice publicly the true religion. This is why the king [Louis XIV] wanted the missionaries who went to preach the Gospel to China, to the kingdom of Siam, and to the other East Indian states, to be instructed in the ways in which the Academy [of Sciences] makes astronomical observations, and to receive its broad instructions of what they should do and what they should note during their journey.

The observations which these missionaries have already made in accordance with the Academy and which they have sent to it, being compared with those which have been made at this same time at the Observatory, have already proved enlightening. We cannot doubt that the [observations] which we shall continue to make in these faraway lands, will contribute much to the progress of Astronomy. If the people who practice this science

subject, M. Cams, 'Les missions jésuites en Extrême-Orient et les échanges de connaissances cartographiques (XVII ${ }^{\mathrm{e}}-\mathrm{XVIII}{ }^{\mathrm{e}}$ siècles)', in C. Hofmann and Fr. Nawrocki (eds), Le monde en sphères (Paris 2019) 160-5.

86 Cassini's efforts to 'save' Ptolemy appear in an unpublished work, Ptolemaica methodus apogaeorum excentricitatum et anomaliarum ad geometricam normam emendata et promota, followed by Correctiuncula theoriae Ptolemaicae et aliorum omnes concilians. It is preserved in the manuscript Bibliothèque de l'Observatoire de Paris [= BOP], B4/2 (7), https://bibnum.obspm.fr.

87 See A. Danjon, 'Jean-Dominique Cassini et les débuts de l'Astrophysique', L'Astronomie 77 (1963) 4-16, here p. 12: 'il passa discrètement d'un système à l'autre sans afficher ses opinions.'

88 'Note sur J. D. Cassini écrite de la main de Jacques Cassini son fils', BOP, B4/3 (3), f. 33r.

89 Allusion to Verbiest's achievements in China (see above, footnotes 39-40). 
in foreign countries carry on a correspondence with the Academy and convey their observations in the same way that [the Academy] shares these same with them, there is reason to hope that in a short time not only Astronomy, but also Geography and the art of Navigation will be brought to the highest perfection. ${ }^{90}$

While in Italy, Cassini had benefited from the benevolence of Pope Alexander VII, to whom he had presented an engraved map of the universe in 1659: Systema revolutionum superiorum planetarum circa terram ab anno 1659 ad sequentes per tricenos dies. ${ }^{91}$ Using his geographical skills, Clement IX, the successor of Alexander VII, charged him with the task of setting the borders of the Papal States and Tuscany. ${ }^{92}$ Finally, when Cassini had already been settled in France for a long time, Clement XI appointed him as consultant to an ephemeral Congregation of the Calendar, which was formed within the Congregation of Rites. Presided over by Cardinal Enrico Noris, ${ }^{93}$ it also included the astronomer Francesco Bianchini, Cassini's long-time correspondent, ${ }^{94}$ as well as Giacomo Filippo Maraldi, his nephew and close associate. Very little is known about this commitment to the question of the Calendar. However, it is recorded in a report of the Academy of Sciences dated 1701:

The question of the Calendar [...] was treated in Rome in a Congregation established by the Pope [...]. It was to investigate whether there was any reform to be made in the Gregorian calendar, in order to remove any reason for the Protestant states not to accept it. Cardinal Noris received an order from the Pope that the Congregation should correspond with Cassini on this subject, and letters were written to him several times, by M. Bianchini, secretary, and by M. Maraldi, who had gone to Rome after Bianchini finished his work on the meridian-with which M. Cassini had given him much help-having received the honor of being appointed by the pope to participate in the Congregation of the Calendar. The opinion of M. Cassini was that nothing was lacking in the Gregorian calendar, no reform to be made, as long as the intention of Pope Gregory XIII was followed exactly, and there was no deviation from it in any way. ${ }^{95}$

90 Cassini, 'De l'origine et du progrès de l'astronomie', 42-3 (my translation).

91 J. D. Cassini, Mémoires pour servir à l'histoire des sciences et à celle de l'Observatoire royal de Paris, suivis de la vie de J.-D. Cassini écrite par lui-même (Paris 1810) 326-7.

92 Ibid., 329.

93 Ten years earlier, Enrico Noris had published his Dissertationes duae. I. De Paschali Latinorum cyclo annorum LXXXIV. II. De cyclo Paschali ravennate annorum XCV (Florence 1691).

94 Beretta, 'L'héliocentrisme à Rome', 537-41. Three letters of Bianchini to Cassini have been preserved: BOP , B 4/9 (54bis), 29 June 1699; B 4/9 (55), 25 April 1702; B 4/9 (56), 7 April 1705.

95 [Anonymous], 'Sur le calendrier', Histoire de l'Académie royale des Sciences, a. 1701 (Paris 1704) 107 (my translation). 
Many writings such as unpublished observations and published reports ${ }^{96}$ revealed the views of the astronomer in this matter. Among other things, Cassini was interested in the adjustments of the epact and the reintroduction of the Golden Number, the establishment of updated astronomical tables and the identification of the so-called Paschal Moons. Discussions on this subject continued until 1704, when Cassini presented to the Academy of Sciences some Réflexions sur des Mémoires touchant la correction grégorienne communiquées par M. Bianchini $i^{97}$. I shall not dwell on this little-explored question, which deserves extensive research. Here, however, are some chronological milestones which I was able to identify in the extensive documentation left by Cassini and his collaborators:

- 1680-1683. Two reports titled Sur les périodes lunisolaires ou sur le règlement des temps, ${ }^{98}$ and 'Diverses additions et corrections au calendrier'.$^{99}$

- 1690, 22 August. Incognito visit of king James II of England to the Observatory. Among the many exchanges that took place during this visit, this one is of interest for the calendar question:

His Majesty has shown two silver plaques shaped as a medal, one of which was used to find for every day the corresponding day of the week, during several centuries, the one according to the Julian calendar, the other according to the Gregorian calendar. But [H. M.] said that the latter was erroneous, and could only serve until the end of the present century, because it had not been taken into account that it was necessary to remove the year 1700 . This gave an opportunity to Mr Cassini to speak of an exact and perpetual Table he had made for the Gregorian calendar. ${ }^{100}$

96 See, for instance, the following archive documents of the Bibliothèque de l'Observatoire de Paris: 'Canonum Calendarii Gregoriani supplementum', B 4/1 (13); 'De usu tabularum', B 4/1 (23); 'Quelle est la lune qu'on doit appeler la lune de mars', B 4/1 (51); 'Ensemble de textes latins relatifs aux calendriers grégoriens et juliens', B 4/1 (52)-(53); 'Quelle est la lune de mars', B 4/1 (68); 'Sur cette question. Quelle doit être la lune de mars', B 4/1 (78); 'Sur le calendrier' (1701-1703), B 4/3 (68); 'Continuation du calendrier', B 4/3 (69); 'Réflexions sur l'ancien canon pascal de Saint Hippolyte', B 4/3 (77); 'Sur la proposition d'accorder les calendriers', B 4/3 (79); 'De la justesse admirable de la correction grégorienne des cycles lunaires', B 4/3 (80); 'De la règle des temps', B 4/4 (3). Often anonymous, these documents are related to Cassini and his collaborators. Several have been included in reports of the Académie royale des Sciences under the name of J. D. Cassini or under his authority: 'Sur le calendrier', Histoire de l'Académie Royale des Sciences, a. 1700 (Paris 1741) 127; 'Sur le calendrier', ibid., a. 1701 (Paris 1704) 107-10; 'De la correction grégorienne des mois lunaires ecclésiastiques', ibid., a. 1701 (Paris 1719) 367-84; 'Sur le calendrier', ibid., a. 1703 (Paris 1720) 91.

97 [Anonymous], 'Réflexions sur des Mémoires touchant la correction grégorienne communiquées par M. Bianchini à M. Cassini', Histoire de l'Académie royale des Sciences, a. 1704 (Paris 1704) 142-5.

98 [Anonymous], 'Sur les périodes lunisolaires ou sur le règlement des temps', in Histoire de l'Académie royale des Sciences, I. 1666-1686 (Paris 1733) 314-7.

99 See [Anonymous], 'Diverses Observations Astronomiques', in Histoire de l'Académie royale des Sciences, I. 1666-1686 (Paris 1733) 383.

100 [Anonymous], 'Astronomie', in Histoire de l'Académie royale des Sciences, II. 1686-1699 (Paris 1733) 94-104, here p. 103 (my translation). 
- 1697. Together with Bernard de Fontenelle, ${ }^{101}$ considerations on the Paschal Canon of Saint Hippolytus of Rome and refutation of the proposals of the Protestant scientist Erhard Weigel on the universal calendar:

Mr Erhard Wegelius, professor of Mathematics at Jena, asked for the judgment of the Academy on a means he proposed for adjusting the calendar of all Christian peoples; Mr Cassini was charged to examine this; the Author desired that in each kingdom a Company should be established which would pay particular attention to the correction of the calendar, [...] but only on the basis of astronomical observations, as was done in the first five centuries of the Church. M. Cassini replied that with regard to the Companies for the correction of the Calendar, it was up to those who followed the Julian calendar to provide for this, since those who followed the Gregorian found [this calendar] perfectly in agreement with Heaven, and had no new measures to take in this respect; that the Gregorian calendar did not exclude astronomical observations, and that it was adjusted to the entire extension of the solar year. ${ }^{102}$

- 1700. Observations on the Lunar eclipse of 5 March 1700 (Paschal Moon):

As on the Gregorian Calendar there are always three century years in a row out of four which are not century leap-years, although by nature they should be so and the year 1700 was one of them, M. Cassini, who had found an easier rule than that of this Calendar to determine the epacts of those years, wished to see if the epact which had provided him with the rule coincided with the day of the eclipse which had just been observed. According to this epact, the full moon fell exactly on 5 March. ${ }^{103}$

- 1701. Memorandum on changes that occurred in Europe following the adjustment of the calendars. ${ }^{104}$

101 [B. Le Bouyer de Fontenelle], 'Sur l'Ancien Canon pascal de StHippolyte', Histoire de l'Académie royale des Sciences, II. 1686-1699 (Paris 1733) 300-17; the same year, [B. Le Bouyer de Fontenelle], 'Sur les deux éclipses de cette année, et principalement sur celle de Lune, employée à l'examen du calendrier', Histoire de l'Académie royale des Sciences, II. 1686-1699 (Paris 1733) 322-31.

102 [Anonymous], 'Sur le calendrier et sur la différence entre les cycles lunaires et solaires', Histoire de l'Académie royale des Sciences, II. 1686-1699 (Paris 1733) 318-22, here p. 318 (my translation). On Weigel's theories on the calendar, see E. Koller, Strittige Zeiten. Kalenderreformen im Alten Reich, 1582-1700 (Berlin-Boston 2014) 338-99; J. Hamel, 'Erhard Weigel und die Kalenderreform des Jahres 1700', in R. E. Schielicke, Kl.-D. Herbst and St. Kratochwil (eds), Erhard Weigel-1625 bis 1999. Barocker Erzvater der deutschen Frühaufklärung (Frankfurt a.M. 1999) 135-56.

103 [Anonymous], 'Sur l'éclipse de Lune du 5. Mars', Histoire de l'Académie Royale des Sciences, a. 1700 (Paris 1719) 109-11, here p. 110-11 (my translation).

104 [Anonymous], 'Sur le calendrier', Histoire de l'Académie Royale des Sciences, a. 1701 (Paris 1719) $127-9$. 
A European affair: the curious year 1700

As I pointed out at the beginning of this paper, Chrysanthos left Padua for Paris 'on Great Monday, the 5th of April [1700], according to the Italian calendar', and it seems to me that this date was not incidental. At this time, a month had passed since the eclipse of the Paschal Moon observed by Cassini, and thirty-two days since a notable event in European history: the removal of the leap-day in February in Catholic countries which had already adopted the Gregorian reform, and the adjustment of eleven days for several Protestant countries which still kept the Julian calendar. ${ }^{105}$ In France, Belgium and most Catholic countries, the suppression of 29 February was no big problem. There was fear, however, of a non-coincidence between the real full moon and the Paschal Moon-a fictitious representation of the eclipse of the full moon which occurs after the vernal equinox and which is used to determine the date of Easter. For this would have made it necessary to correct the computation of Pope Gregory XIII. The difficulty was all the greater because this computation was based on the geocentric hypothesis which the astronomers of the Observatory had tacitly dismissed. In the Protestant regions of Germany, the Netherlands, Denmark, and Sweden, the question was even more delicate. The aim was to reform the Julian computation, the errors of which had become too obvious, without proving the correctness of the Catholic astronomical Tables. On 28/18 February 1700, Europe held its breath; and on 5 March, the time arrived to verify if the Paschal Moon was also a full moon 'according to the astronomical truth'.

In the event, Cassini did not see much that night, because 'the sky was covered in Paris. ${ }^{\prime 106}$ However, in a report kept at the Observatory, he noted:

On the occasion of this eclipse, which occurred in the first century year without a leap-day in the form of the Gregorian calendar, I examined my method of finding the days of the new and full moons in perpetuity by my great period of 11600 Gregorian years which begins the common year of JC. [...] The epacts that are found by this very simple rule agree with all century years which are calculated in the Table [of the moveable feasts of the Gregorian computation], although they sometimes exceed by one day that of common century years, as it happens this present year, and the following century year, namely 1800 . But the restoration of these epacts to century leap-years in the period of 11600 years, confirms the accuracy of the Gregorian periods and make them consistent with the astronomical periods. ${ }^{107}$

105 See Koller, Strittige Zeiten, $409 \mathrm{ff}$.

106 'Éclipse de lune du 5 mars [1700]', BOP, B 4/3 (25), 183r (my translation): 'Le ciel étoit couvert à Paris le matin du 5 mars de cette année 1700 à l'heure où nous devions voir le commencement de l'éclipse.'

107 Ibid., 183r-v (my translation): "À l'occasion de cette éclipse arrivée la première année centième non bissextile dans la forme du calendrier grégorien, j'ay examiné ma méthode de trouver les jours des nouvelles et pleines lunes à perpétuité par ma grande période de 11600 années grégoriennes qui commence l'année vulgaire de JC. [...] Les épactes qui se trouvent 
The adjustment advocated by Cassini to make the real full moon coincide with the fictitious Paschal Moon, had thus made it possible to save the Gregorian computation and his geocentric hypothesis at little cost. It had also shown that the Observatory, founded by the Most Christian King Louis XIV, was not only at the forefront of science, but acted as a universal authority helping to resolve ecclesiastical questions which had long divided Europe-in the same way that Alexandrian science had sustained the decisions of the Council of Nicaea in 325. This idea is clearly expressed in the Memorandum of 1701, which summarizes the exchanges between the Academy of Sciences and the German philosopher and scientist Gottfried Wilhelm Leibniz: ${ }^{108}$

A movement which took place this year in Germany, and which had some connection with the Academy of Sciences, has made clear how important Astronomy is on certain occasions for ecclesiastical and political affairs. The reform of the Gregorian calendar, although necessary and well concerted, was not accepted by the Protestants because it came from Rome. [...] In making this astronomical calculation Mr Leibniz was instructed to consult the Academy. He did so in a letter sent from Hannover and dated 8 February 1700. After exposing the fact [...], he added that 'as once the Church had appealed to the mathematicians of Alexandria in order to execute the canons of the great Council of Nicaea, and to be informed of the true time of Easter, it was convenient on the present occasion to follow the advice of excellent astronomers'; and that 'since the king, by a magnificent foundation, of which there were no other examples in Christendom, had just established forever the Academy of Sciences, it was a relief which his Majesty gave to the Church in these matters, and of which it was necessary to take benefit. ${ }^{\prime 109}$

In this case, Rome was behind. The Congregation of Rites dithered: in 1701, it had not yet decided anything, and it was also at that moment that the Calendar Congregation was created, of which I have spoken earlier. By contrast, Gallican France had clearly and immediately imposed its own perspective:

In Rome ways were sought for a complete conciliation on the Calendar, and the Congregation of Rites was working on it. The King ordered that the Academy should remain far from what was being done in Rome; but if it

par cette règle si simple s'accordent à toutes celles des centièmes bissextiles qui sont calculées dans la dite Table, bien qu'elles excèdent quelquefois d'un jour celle des centièmes communes, comme il arrive cette même année, et la suivante centième 1800. Mais le rétablissement de ces épactes aux centièmes bissextiles dans la période de 11600, confirme la justesse des périodes grégoriennes qui les rétablissent conformes aux astronomiques."

108 For Leibniz's positions on the calendar question, see G. W. Leibniz, Sämtliche Schriften und Briefe. Dritte Reihe: Mathematischer, naturwissenschaftlicher und technischer Briefwechsel, VIII (Berlin-Boston 2015) xxvii-xxxiii. It must be specified that Leibniz had had exchanges with Cardinal Noris since 1689. See, ibid., xxx.

109 [Anonymous], 'Sur le calendrier', Histoire de l'Académie Royale des Sciences, a. 1701 (Paris 1719) $127-9$. 
could satisfy what was requested [from Rome], he left it free. [...] The king had written to the prince of Monaco, then his ambassador in Rome, to tell him what had happened in France regarding the calendar, and the prince of Monaco had replied to the count of Pontchartrain in a letter of 3 August 1700 that he had spoken of this affair with cardinal Spada, who had greatly praised the king's attention to the court of Rome, and had told him that the Congregation of Rites would not take any decision without consulting the Academy of Sciences, which is much more enlightened on these subjects than anyone in Italy. ${ }^{110}$

Such was the political and religious context in which the nephew of the patriarch Dositheos and the son of Stolnic Constantin Cantacuzino left Padua for Paris and the Observatory. In my opinion, it would be particularly naive to consider that this journey, on which Chrysanthos met not only Cassini, but also Gallican theologians, was a simple study trip. The whole of Europe was talking about the reform of the calendar. If the Observatory-the new Alexandria, according to Leibnizwelcomed with honors an archimandrite keen on science, accustomed to dialogue with the Catholics and who enjoyed the full confidence of Christian elites of the Greek East, it is certain that the calendar question was also on the agenda: astronomy and religious affairs still remained intimately connected.

\section{Chrysanthos invited to the Observatory: new considerations}

We do not have explicit sources to affirm that Chrysanthos' visit to Paris was related to the calendar reform. However, what has been stated above constitutes strong circumstantial evidence, which is further reinforced by the curious visit of Rădu Cantacuzino to Cardinal Albani-a visit which took place shortly before the Paris trip. ${ }^{111}$ Indeed, the future Clement XI was involved in the calendar debate; he was very close to the astronomer Francesco Bianchini, who at the end of 1700 became Papal Chamberlain ('cameriere d'onore'). The present state of research does not allow us to say much more about this visit for the moment; but it should be noted that in a letter of appreciation and congratulation sent the next year to Clement XI, Brâncovean signals his attachment to the new Pope with a quite rare expression for an Orthodox: 'summum Romanum adoro et veneror Pontificem.' The Pope's answer is also explicit: the lamb must hasten to join his pastor for the unity of the flock and for his own salvation. ${ }^{112}$

In fact, since the sixteenth century, the Gregorian reform had exacerbated the schism. Solicited by Gregory XIII and initially willing to discuss this subject, Ieremias II of Constantinople had soon adopted a hostile attitude to the calendar

\footnotetext{
110 Ibid., 129.

111 Vasiliu, 'Costantino Brâncoveanu', 112-3. Rădu's visit to Albani occurred in the beginning of 1700 .

112 Ibid.: 'si pastoris, quem gerimus, vocem oves salutaria pascua ultro accurrentes agnoscant et ad dominicum gregem in eisdem unitate iugitur permansurae festinent.'
} 
reform, fearing a changeover to Rome in the Romanian Principalities and the Ukraine. ${ }^{113}$ From then on, the Orthodox Church repeatedly expressed its strong attachment to the doctrine of the Council of Nicaea. In the seventeenth century, Dositheos himself had briefly but explicitly condemned the Gregorian reform in a chapter of his History concerning the Patriarchs in Jerusalem. ${ }^{114}$ Furthermore, in an unpublished part of the same work conserved in the manuscript MPT 242 [Diktyon 6639], the Patriarch developed his point of view on the question, strongly rejecting the authority of astronomy over Tradition:

It was not sufficient for the Pope of Rome to assert [...] nonexistent stories, but now he poses astronomy in principle of the Holy Passover, [astronomy] which all the Holy Scripture and all Holy Fathers reject and expel from the Holy Church as vain and false. But if the Greeks themselves insulted it [...], should not the Christians consider it detestable, and the teacher of pagan and impious doctrines? Now, concerning the feast of the Holy Passover, we are talking about years, equinoxes, full moons, but we do not take astronomers as principles. ${ }^{115}$

Educated by his uncle on ecclesiastical matters, Chrysanthos could neither ignore nor openly oppose this latter's positions. Because of his more affable personality and his keen interest in astronomy, he could, however, give hope to some Catholics, including his teacher Nikolaos Komninos-Papadopoulos, that he would adopt a more moderate point of view. Through Cassini, all these people hoped to make him accept, at least, the 'astronomical truth', which had already received the support of Leibniz and German Protestants. As to the position of the Wallachian court, it seemed more flexible, as appears from the correspondence of Brâncoveanu I have just quoted. Finally, the French context in which the discussion was to be held had two advantages over Rome: more neutral because of Gallicanism, France was also politically more acceptable to the Ottoman power. Thus, we can assume that Catholic scholars had put all their hopes in this visit. A switch of the Orthodox to the Gregorian computation, or at least to the 'astronomical truth', would not

113 See Chr. Hannick and K.-P. Todt, 'Jérémie II Tranos', in C. G. Conticello and V. Conticello (eds), La théologie byzantine et sa tradition, II. XIII $-X I X^{e}$ s. (Turnhout 2002) 551-615, here p. 563-6; V. Tzoga, 'Sigillion inédit du patriarche de Constantinople Jérémie II et d'Alexandrie Sylvestre sur la réforme du calendrier', Byzantinische Zeitschrift 107 (2014) 221-52.

114 Dositheos, History, 1169 (Book XI, ch. 8), 1192 (Book XII, ch. 2, § 2).

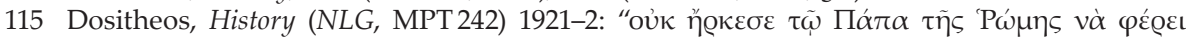

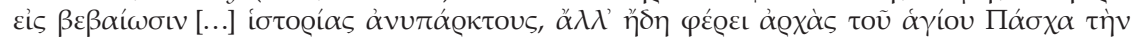

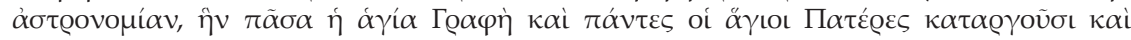

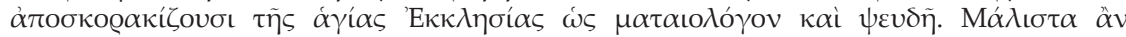

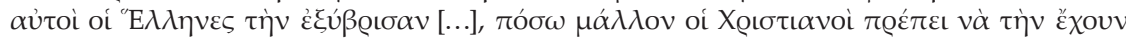

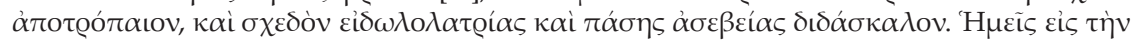

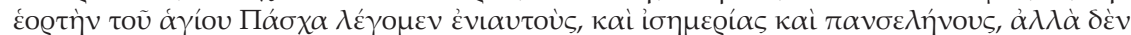

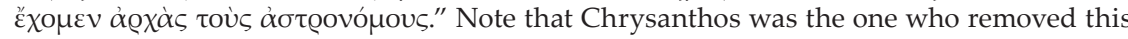
passage from the posthumous edition of the History. I am grateful to Kostas Sarris for having indicated me this unpublished passage. 
only have been a step towards union; it would also have given the endorsement of the hierarchies of Nicaea and Alexandria-historically important for the determination of the date of Easter-and reconciled the principles of ancient with the discoveries of modern astronomy.

Cassini himself could not neglect this aspect, as he drew much of his information from missionaries and explorers. To have on the spot, in the East, in Constantinople, Nicaea or Jerusalem, a collaborator experienced in the new science, able to make accurate astronomical observations and to transmit his data to the Observatory, would have been an asset for him personally. Chrysanthos was a good candidate. Although he was busy preparing his 'Voyage de la Méridienne', Cassini took the time to explain to the archimandrite the equivalence of the measurements and to show him how to use the new instruments. He also guided him in the construction of instruments, and perhaps provided him with several of them. In short, one may assume that he prepared him and equipped him, hoping that he could be one of his informers in the East.

Did he also try to convince him of the relevance of Gregorian computation, or at least of the necessity of referring to the new Tables of the Observatory? As already stated above, this hypothesis seems highly probable in the context of the spring of 1700. Chrysanthos was of a scientific mind. During his week at the Observatory, while scanning the movements of the Moon and planets through the large telescopes, he was perhaps seduced by the 'astronomical truth'. However, he remained absolutely faithful to the orientations given by his uncle Dositheos, and did not reveal anything. The richly illustrated publication of his Introduction to Geographics and Sphaerics was the only fruit-delicious to him-of his stay in Paris. And two years later, when he became metropolitan of Caesarea in Palestine, and thereby the appointed successor to the patriarch of Jerusalem, Mavrokordatos congratulated him on his choice. As the Great Interpreter of the Porte had understood, 'nothing was more admirable than his return.'116

\section{Conclusions}

From a very early stage, the visit of Chrysanthos Notaras to Paris, and his scientific meeting with Giovanni Domenico Cassini, was considered as the tipping point in which the new science, and thus modernity, entered Eastern Christianity. The archimandrite has for this reason been depicted as a forerunner of the 'Modern Greek Enlightenment'.117

However, this visit is problematic. While it undoubtedly took place, there are still many grey areas, and the legend built around Chrysanthos has further obscured them. In 1700, when he arrived in Paris, the archimandrite was about forty years old. He was not a neophyte in the scientific field: he knew well the cosmol-

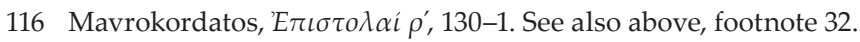

117 Stathi's monography is even titled (in translation): Chrysanthos Notaras ... Forerunner of the Modern Greek Enlightenment (see above, footnote 2). 
ogy of Ptolemy, he had studied books of Arab-Byzantine astronomy, he had mastered the use of the astrolabe. If we go a little further in the analysis of sources, we also see that his many visits to the Wallachian court, between 1684 and 1696, had put him in contact with new science; that his trip to Moscow in 1692 gave him access to the Compendium of Ferdinand Verbiest; finally, that a purchase order placed in England by his uncle Dositheos in 1689 contains several geographical tools of which he seems to be not only the recipient, but also the sponsor.

This order is interesting in many respects. It shows among other things the exchanges that Dositheos' network had with important agents of the Levant Company, and the desire of some Anglicans, like John Covel, to make the patriarchate of Jerusalem adhere to their own religious choices. But the Protestants were not the only ones to materially support the action of Dositheos from the point of view of proselytism. The Catholics-who had briefly approached the Patriarch in the 1670s-had a similar attitude towards the Wallachian court and thereby towards Chrysanthos. Thus, the 'Seminario vescovile' of Padua welcomed in its printing works a cartographic operation sponsored by Brâcoveanu and Stolnic Cantacuzino and implemented by our archimandrite and Rădu Cantacuzino. In the same period, the latter was received in Rome by Cardinal Giovanni Francesco Albani, a powerful Church dignitary interested in the new science, who was to become Pope a few months later. Moreover, the two men spent three years with Nikolaos Komninos-Papadopoulos, a Catholic Greek well integrated in Roman ecclesiastical circles.

Considering Chrysanthos' host in Paris, namely Cassini, another complicating factor must be added to this evidence: the proximity of the famous astronomer to this same Catholic background-a proximity which is often overlooked. Raised at the Jesuit school, the scientist had been the disciple of Giovanni Battista Riccioli, and had maintained constant links with the missions; he had been the advisor of two Popes; one of his scientific correspondents was Francesco Bianchini, the right-hand man of cardinal Albani; his nephew Giacomo Filippo Maraldi, who participated in the 'Voyage de la Méridienne', became a member of the Calendar Congregation in 1701; finally, he himself was consulted over a long period, from 1680 to 1701, about possible corrections to the Gregorian calendar.

In fact, the year 1700 was about to introduce a shift in this calendar and thus render obsolete the decisions of the Pope Gregory XIII who had instituted it in 1582. King James II of England had ironically reminded Cassini of this problem when he visited the Observatory in 1690. Having never officially supported heliocentrism, the astronomer had all the confidence of Catholic circles, especially on this issue. He had therefore been called to the rescue, and had responded to this mission with the utmost dedication. Thanks to his calculations, but also to his authoritative announcements, the Gregorian calendar was saved. Better, many Protestant countries-although not England-agreed to conform to the 'astronomical truth' which was also his.

For the unification of Christendom under one calendar-a necessarily Roman calendar-it was important to convince the Orthodox, who were strongly attached 
to the Julian calendar and had remained hostile to any such reform since the sixteenth century. Ferdinand Verbiest, a Jesuit missionary who had achieved the feat of introducing the Gregorian calendar in China, had made an attempt to persuade the Tsar Alexis I, but this had failed completely. Brâncoveanu's desire to print the first modern map of Wallachia, and the study trip of Chrysanthos and Rădu to Padua, appeared as an opportunity to be seized. In any case, in 1700, when the question of the accuracy of the Gregorian calendar was in full swing in Europe, the two men were invited to Paris and welcomed at the Observatory. My position is that the primary purpose of this invitation was to conduct discussions on the calendar, or at least convince the archimandrite of the 'astronomical truth' of Cassini's calculations.

In the present state of research, we do not know if Chrysanthos was tempted during the week spent with his host, or if the discussion broke off immediately. If we consider what he says about it in 1716, the memory he kept of Cassini remained diffuse: in spite of the accent which was put on the event later, Chrysanthos alluded to his stay at the Observatory only in passing, in the form of an interpolation, as if it had been a mere parenthesis in his life. Of his travels in Europe, and especially in Paris, he spoke clearly in his Prologue to the History concerning the Patriarchs in Jerusalem. But here too, we find only sustained praise of Gallican France, and not a word about Cassini, who himself was obviously not a Gallican. Did the close relationship of the astronomer to 'Jesuit science' end up hurting the feelings of the archimandrite? In the same Prologue, Chrysanthos' judgment is explicit: Jesuits are 'these very wise men, at the thought of whom tears come to me, because they get lost in vain doctrines, [...] thus leading [...] the simplest among Eastern and Western Christians to behave towards each other as enemies. ${ }^{\prime 18}$ Should it not be regarded as the sign of a great personal disappointment?

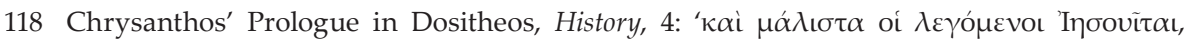

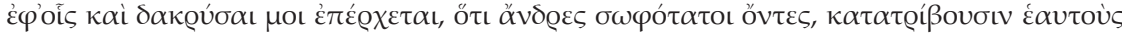

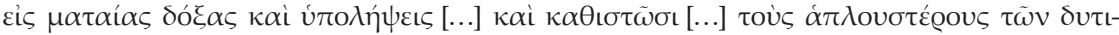

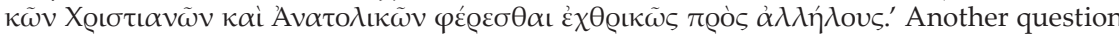
remains: who in Paris, published Chrysanthos' book in 1716? Cassini had died in 1712. 


\section{Appendix}

Dositheos' order in John Covel's correspondence:

Ms. British Library, Harley 6943 (1672-1711), f. 88r-92v

\section{Thomas Coke to John Covel}

f. $88 \mathrm{r}$

Pera October the $9^{\text {th }} 1684$ I

Reverend Sirl

Last March by Mr Baxter a Gentleman of my Lord I sent youl a booke, and papers what it was I know not given me by Ginacchi forl which I hope long are this you have received. Here enclosed I have forwarded to you an other letter of Gionacchi ${ }^{119}$, and a Booke of Nectarius| late Patriarch of Jerusalem against the Supremacy of the Pope, printed at Yasl in Moldavia by the present Patriarch ${ }^{120}$. I have recomended it to the \{c\}are of Mr Barclay a Servant of my Lord's going for England to leave itl at the seaven Stars in Paul's Church yard. The French Ambassador isl \{g\}onne to Adrianople to audience, my Lord was also called to audience butl sicknesse excused him from the journey, tho I doubt whether at the Courtl stay at Adrianople next sumer wee may not ${ }^{121}$ forced to goe. All things arel kept so secret by the Turkes at Court, that wee can heare no newes froml Hungary or Poland, being absolutly ignorant whether Buda be takenl and what State it's in. The Visir ${ }^{122}$ is politicly sick, under color of an ulcerl which he hath in his leg not appearing publicly but very rarely, and that but shortl in dispatch at Divan. The Gran Signore ${ }^{123}$ goes as usually a hunting. Greatl \{p\}reparations are made for next, as is every third man in the Empire, I but tho they may have an numerous army, yet they will be raw, and unexpert $\mid$ men, and should the Army be beaten it would give a great shake to theirl Empire. If the peace be well settled in Christendome but for a few yeares| \{and\} the confederates ${ }^{124}$ continue united the Turk must make either make al \{v\}ery advantagous $<$ war> peace, or hazard all by persisting in warre. Mr Mauricel \{G\}reene dyed August the 16 at Adrianople of a feavor, and Signore Antonio ${ }^{125}$ is nowl here very sick, it hash been very sickly time there. Sir I must beg your pardonl for my abrupt writting. There being a Ship just now on departure, and one \{that departed two days past which hath not permitted leasure to

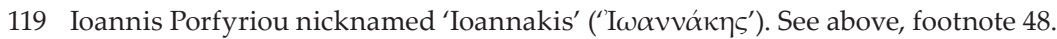

120 Nektarios, On the Primacy of the Pope. See above, footnote 49.

121 Read: not [be]

122 Bayburtlu Kara Ibrahim Pasha, Grand Vizier from 25 December 1683 to 18 November 1685.

123 Mehmed IV, nicknamed 'Avc1' ('the Hunter'), because of his passion for hunting. He reigned from 2 January 1642 to 6 January 1693.

124 The Holy League of 1684.

125 Probably Antonio Perone or Perrone, second interpreter of the British Resident in the time of John Finch, namely from 1674-1681. 
writte tol \{man\}y of my fremds, besides my wife is newly deliverd of a boy that forl $\{\mathrm{I}\}\{\mathrm{h}\}$ ave now three Sonne, these accidents hinder enlarging so withl \{a\}ll respect and affection I remainel

Your reall fremd and humble Servantl

Thomas Cokel

f. $88 \mathrm{v}$

〈Th. Coke. Oct. 9.I 1684 ${ }^{126}$ /For the Reverend Dr John Covill।

To be left at Mr Cooke's a Wollenl draper's at the Seaven Starres inl St Paul's Church Yard with a Greeke bookel a small foliol

Londonl

\section{Thomas Coke to John Covel}

f. 89r To Dr John Covill. Constantinople November the $2^{\mathrm{d}} 1689$.

\section{Copie.l}

Sir I beg your pardon for so long a silence, but I had no newes I concerning you, how, or where to write you till Mr Gerard in/formed me of the favour he seeked from you, and your kind remembranlce of me. I do heastily congratulate your good fortune, and hopel to heare of the augmentation of it. I was latly with the Patriarchl of Jerusalem who sends you the enclos'd letter, and I have froml him two bookes (I suppose) Nectarius against the Popes Supremacy, ${ }^{127}$ and I Simeon Metropolite of Thessalonica of the Articles and Rites of thel Greeke Church. ${ }^{128}$ I formerly sent you myselfe these two but knowl not whether they arriv[e]d you, with the first occasion I shall forwardl these to you.

The Patriarch hath desir'd me to procure himl some Greeke bookes of which you have herewith a List, he would have them in Greeke alone, what can be had so, else in Greeke, or Latin, and among| them all the Byzantine Historians, I know not how many volumes theyl are I think 22. I would not give you this trouble, but yet I know you can't want fremds that at your place can easily procure them, or atl London, and for the Expence Mr Thomas Palmer will furnish youl the mony. He desires also a paire of Globes of about 14 inches I diameter, and a paire of small globes about the bignesse of one's fistl for to carry easily in a journey, and 4 Maps of the foure parts of thel world, but these all in Latin, and not in English. They desire thel Globes may have two Poles, and the brasse circle to remove from one to the other. He desires also, all the Greeke Comentators| on Aristotles Metaphysics,

126 Handwritten note by John Covel.

127 Nektarios, On the Primacy of the Pope. See above, footnote 49.

128 Symeon, Against Heresies. See above, footnote 51. 
as Alexander, Themistius, Ammonius, and Thel bookes must bee carefully packt up, that they bee not damaged, and I especially the Globes, that they bee not broken. I beleive the Byzantinel Historians are 24 vol[umes] ${ }^{129}$ and of great price, but what ever the expence is $\mid \mathrm{Mr}$ Palmer will pay it. I desire the price of every booke distinctl as of the other things for my better making up of my account with thel Patriarch.

January the $14^{\text {th }} 1689 / 90$

Reverend Sir the foregoing I sent by way of Venice, but in these dangerous $^{130} \mid$ for feare of an unlucky accident I send you its duplicate. There has ${ }^{131}$ | no opportunity yet presented to forward you the two bookes above mentiond nor will bee till the Convoy comes of which wee are here inl ignorance when it may bee. I am glad to heare of the Kind receptionl you had from his Majestie, and wish you prosperous effects from it.I What newer occurres here I send you in an annext paper, we have no newes of Mr Gerard being departed England. I am your most reall fremd and Server.I Thomas Coke.I $\left\langle\right.$ Pray send the best Geographical Dictionary I think Ferarius ${ }^{132}$ is so esteemed.

f. $89 \mathrm{v}$

〈T. Coke a Copy. nov. 2.1689| and new letter Jan. 14. 1689/90I〉

For Dr John Covelll

$\left\langle\right.$ Nov. $2^{\mathrm{d}}$. 1689. Copyl〉

\section{Thomas Palmer to John Covel}

f. $90 \mathrm{r}$

London March 7th 1689/90

Reverend Sir

I have reed yours of first instant| giving Me to Understand that Mr Thomas Coke of Constantinople hadl Intreated you to buy him severale Bookes for the Patriarchl of Jerusalem, and farther acquainting that I will furnish you with I what Mony they shall amount to, such I Promise to Complyl \& pay Unto you when ever Comanding to me. You will havel a long time to provide them not apprehending any Convoy ${ }^{133} \mid$ will goe hence for Constantinople in 12 Months. when Ever any goes ${ }^{134}$ will not faile to give you timely

129 In 1689, thirty-three volumes were already published in this collection, and not twenty-two or twenty-four, as Coke writes in this letter (volume XXIV was edited already in 1660). See above, footnote 52 .

130 Read: dangerous [times]

131 Read: has [been]

132 Filippo Ferrari, Lexicon Geographicum (London 1657; Paris 1670). See above, footnote 57.

133 Read: Convoy [that].

134 Read: goes [I]. 
Notice, in the Interim | you may be providing, have this day advised $\mathrm{Mr}$ Coke of it, Soel with due respects ${ }^{135}$ Crave leave \& remain

Sir your affectionate humble Servant|

Thomas Palmer

f. $91 \mathrm{v}$

To the Reverend Doctor John Covell

At Christ Collegel

Cambridgel

〈T. palmer. March. 7. 89/90.।

He will pay mel

For the Patriarchs books. $\left.\left.\right|^{136}\right\rangle$

\section{Dositheos' booklist}

\section{f. $92 \mathrm{r}$}

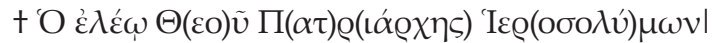

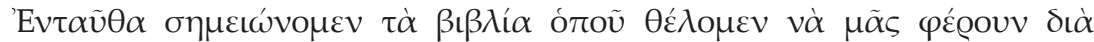

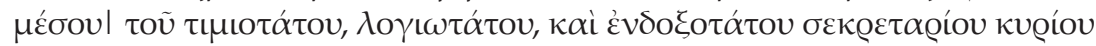

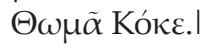

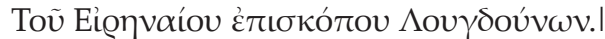

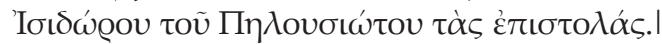

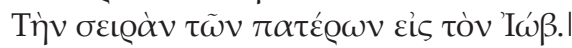

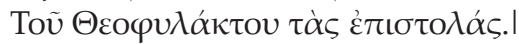

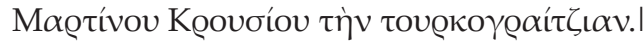

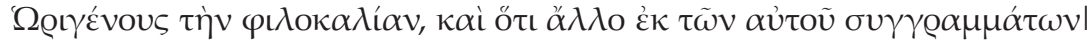

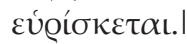

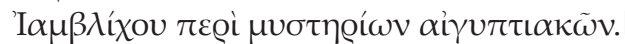

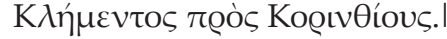

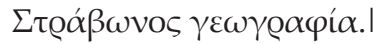

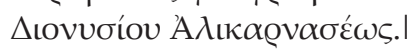

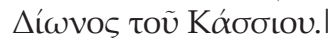

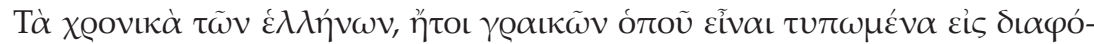
อous тótous.I

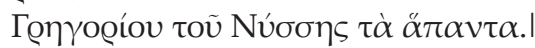

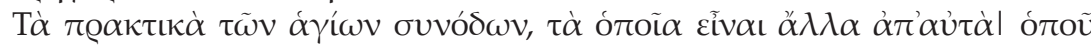

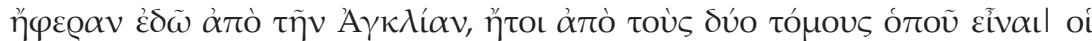

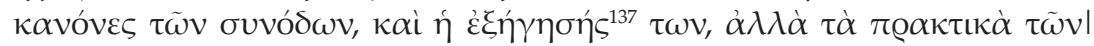

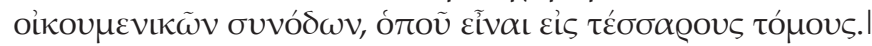

135 Read: respect [I].

136 Handwritten note by John Covel.

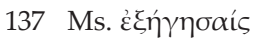




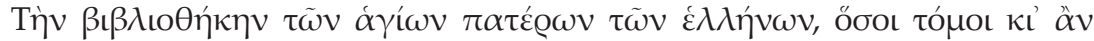
EĨvou.l

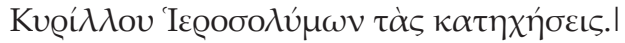

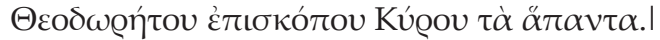

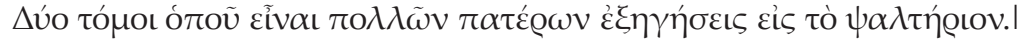

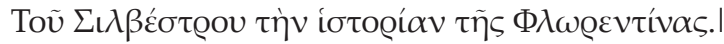

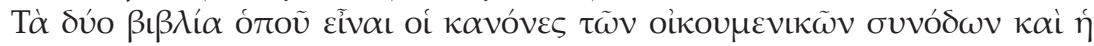

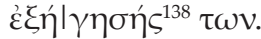

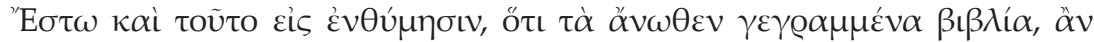

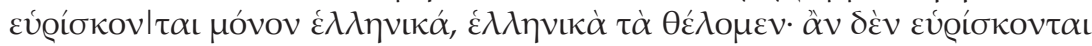

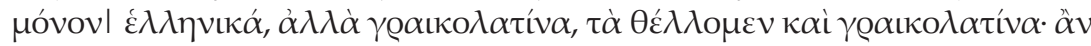

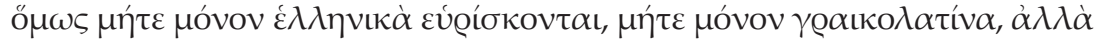

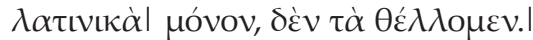

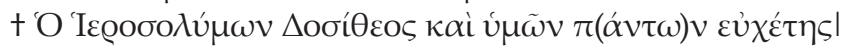

f. $92 \mathrm{v}$

〈List of Bookes to be bought|

B. $\rangle$

\section{Bibliography}

Archives/Manuscripts

Athens, National Library of Greece [= NLG], fonds of Metochion Panagiou Tafou [Metochion of the Holy Sepulchre] [= MPT 242 [Diktyon 6639 (Réseau numérique pour les manuscrits grecs)]. ${ }^{139}$

MPT 93 [Diktyon 6490], MPT 121 [Diktyon 6518], MPT 198 [Diktyon 6595], MPT 200 [Diktyon 6597], MPT 241 [Diktyon 6638], MPT 242 [Diktyon 6639], MPT 261 [Diktyon 6658], MPT 420 [Diktyon 6817], MPT 423 [Diktyon 6820], MPT 429 [Diktyon 6826]

London, British Library, Add 22909 [Diktyon 39022].

London, British Library, Harley 6943 (1672-1711) [Diktyon 39727].

Moscow, Russian State Archive of Early Acts (= RGADA), 52-1, 1701, no. 2.

Paris, Bibliothèque nationale de France [= BnF], Paris, Suppl. gr. 1093 53757].

Paris, Bibliothèque de l'Observatoire de Paris [= BOP (https://bibnum.obspm.fr)], B4/1-4.

Paris, Bibliothèque de l'Observatoire de Paris [= BOP], B 4/9.

Paris, Bibliothèque de l'Observatoire de Paris [= BOP], D2/39.

Paris, Bibliothèque de l'Observatoire de Paris [= BOP], BOP, B4/2 (7).

Paris, Bibliothèque de l'Observatoire de Paris [= BOP], BOP, B4/3 (3); (25).

Paris, Bibliothèque de l'Observatoire de Paris [= BOP], BOP, B 4/9 (54bis); (55); (56).

Paris, Bibliothèque de l'Observatoire de Paris [= BOP], BOP, D2/39.

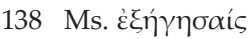

139 See the relevant database Pinakes: Textes et manuscrits grecs, https://pinakes.irht.cnrs.fr. 
[Anonymous], 'Sur le calendrier', Histoire de l'Académie royale des Sciences, a. 1701 (Paris 1704) 107-10.

[Anonymous], ‘Réflexions sur des Mémoires touchant la correction grégorienne communiquées par M. Bianchini à M. Cassini', Histoire de l'Académie royale des Sciences, a. 1704 (Paris 1704) 142-5.

[Anonymous], 'Sur l'éclipse de Lune du 5 Mars', Histoire de l'Académie Royale des Sciences, a. 1700 (Paris 1719) 109-11.

[Anonymous], 'Sur le calendrier', Histoire de l'Académie Royale des Sciences, a. 1701 (Paris 1719) 127-9.

[Anonymous], 'Sur les périodes lunisolaires ou sur le règlement des temps', in Histoire de l'Académie royale des Sciences, I. 1666-1686 (Paris 1733) 314-7.

[Anonymous], 'Diverses Observations Astronomiques', in Histoire de l'Académie royale des Sciences, I. 1666-1686 (Paris 1733) 381-3.

[Anonymous], 'Astronomie', in Histoire de l'Académie royale des Sciences, II. 1686-1699 (Paris 1733) 94-104.

[Anonymous], 'Sur le calendrier et sur la différence entre les cycles lunaires et solaires', Histoire de l'Académie royale des Sciences, II. 1686-1699 (Paris 1733) 318-22.

\section{Literature}

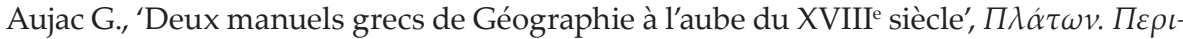

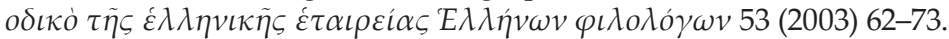

Bantyš-Kamenskij I. I., Reestry grečeskim delam Moskovskogo Arkhiva Kollegii inostrannykh del. Rossijskij Gosudarstvennyj arkhiv drevnikh aktov. Fond 52. Opis' 1, B.L. Fonkič (ed.) [Rossia i Khristianskij Vostok. Biblioteka, 2] (Moscow 2001).

Bellini G., Storia della Tipografia del Seminario di Padova (1684-1938) (Padua 1938).

Beretta F., 'L'héliocentrisme à Rome à la fin du XVII e siècle: une affaire d'étrangers? Aspects structurels d'un espace intellectuel', in A. Romano (ed.), Rome et la science moderne. Entre Renaissance et Lumières (Rome 2008) 531-54.

Bernacki M. M., 'Dosifej II Notara, Patriarkh Ierusalimskij', in Pravoslavnaia Enciklopediia, vol. XVI (Moscow 2007) 71-7.

Besse J.-M., 'Le regard du cosmographe', in C. Hofmann and Fr. Nawrocki (eds), Le monde en sphères (Paris 2019) 118-23.

Bianu I. and Simonescu D. (ed.), Bibliografia Românească veche 1508-1830, IV (Bucharest 1944).

Callegari M., 'Strategie du produzione libraria a Padova nel Settecento', in G. Petrella (ed.), Navigare nei mari dell'umano sapere. Bibliotheche e circolazione libraria nel Trentino e nell'Italia del XVIII secolo. Atti del convegno di studio (Rovereto, 25-27 ottobre 2007) (Trent 2008) 33-43.

Cams M., 'Les missions jésuites en Extrême-Orient et les échanges de connaissances

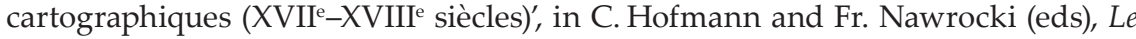
monde en sphères (Paris 2019) 160-5.

Cassini J.-D., 'De l'origine et du progrès de l'astronomie et de son usage dans la géographie et dans la navigation', in Recueil d'observations faites en plusieurs voyages par ordre de Sa Majesté pour perfectionner l'Astronomie et la Géographie, avec divers Traités astronomiques, par Messieurs de l'Académie Royale des Sciences (Paris 1693) 1-43.

Cassini J.-D., Mémoires pour servir à l'histoire des sciences et à celle de l'Observatoire royal de Paris, suivis de la vie de J.-D. Cassini écrite par lui-même (Paris 1810). 
Cernovodeanu P. and Vătămanu N., 'Trois lettres inédites de Jean Comnène', Revue d'Histoire roumaine 11 (1972) 137-45.

Chu P., 'Scientific dispute in the Imperial Court: the 1664 calendar case', Chinese Science 14 (1997) 7-34.

Daliès N., 'Les archives à la Bibliothèque de l'Observatoire de Paris', Gazette des archives 179 (1997) 321-31.

Danjon A., 'Jean-Dominique Cassini et les débuts de l'Astrophysique', L'Astronomie 77 (1963) 4-16.

Dima-Drăgan C., Biblioteca unui umanist român Constantin Cantacuzino Stolnicul (Bucharest 1967).

- and Carataşu M., 'Un manuscrit inédit du Docteur Jean Comnène', Revue d'études sud-est européennes 11 (1971) 107-20.

Donato M. P., 'Scienza e Teologia nelle Congregazioni Romane. La questione atomista, 1626-1727', in A. Romano (ed.), Rome et la science moderne. Entre Renaissance et Lumières (Rome 2008).

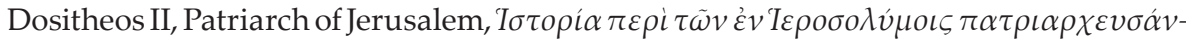
$\tau \omega v$ [History concerning the Patriarchs in Jerusalem] (Bucharest 1715 [ca 1722]).

Feuillée Louis, 'Extrait des observations astronomiques que le R. P. Feüillée Minime a faites au Levant pendant les années 1700 et 1701', Histoire de l'Académie royale des Sciences, a. 1702 (Paris 1743) 7-15.

Gabriel F., 'Tradition orientale et Vera Ecclesia : une critique hiérosolymitaine de la primauté pontificale. Nektarios, de Jassy à Londres (v. 1671-1702)', in M.-H. Blanchet and F. Gabriel (eds), Réduire le Schisme ? Ecclésiologies et politiques de l'union entre Orient et Occident (XIII - XVIII ${ }^{e}$ siècle) (Paris 2013) 197-236.

Gallois L., 'L'Académie des Sciences et les origines de la carte de Cassini', Annales de Géographie 99 (1909) 193-204; 100 (1909) 289-310.

Ghobrial J.-P., The Whispers of Cities. Information Flows in Istanbul, London, and Paris in the Age of William Trumbull (Oxford 2013).

Golvers N. and Nicolaidis E., Ferdinand Verbiest and Jesuit science in 17th century China: an annotated edition and translation of the Constantinople manuscript (1676) (AthensLeuven 2009).

Hamel J., 'Erhard Weigel und die Kalenderreform des Jahres 1700', in R. E. Schielicke, Kl.-D. Herbst and St. Kratochwil (eds), Erhard Weigel-1625 bis 1999. Barocker Erzvater der deutschen Frühaufklärung (Frankfurt a.M. 1999) 135-56.

Hannick Chr. and Todt K-P., 'Jérémie II Tranos', in C. G. Conticello and V. Conticello (eds), La théologie byzantine et sa tradition, II. XIII $-X I X^{\mathrm{e}}$ s. (Turnhout 2002) 551-615.

Hurmuzaki E. (ed.), Documente privitoare la istoria Românilor, XIV/I. 1320-1716: Documente Greceşti (Bucharest 1915).

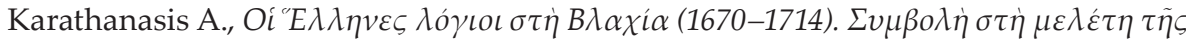

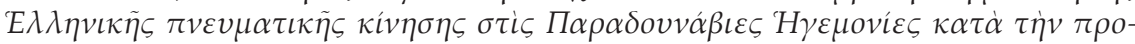

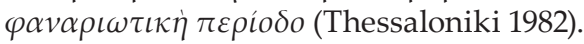

Koller E., Strittige Zeiten. Kalenderreformen im Alten Reich, 1582-1700 (Berlin-Boston 2014).

Kontouma V., 'Christianisme orthodoxe. Recherches sur Dosithée II de Jérusalem (1669-1707)', Annuaire de l'École pratique des hautes études 124 (2015-2016) 207-18.

- 'Christianisme orthodoxe. Recherches sur Dosithée II de Jérusalem (suite)', Annuaire de l'École pratique des hautes études 125 (2016-2017) 251-5. 


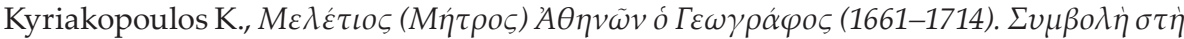

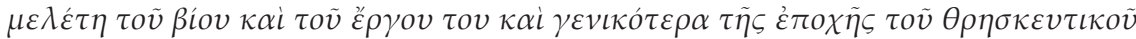

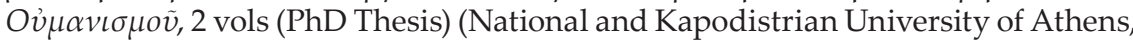
Athens 1990).

Lampadaridi A., 'La bibliothèque du Métochion du Saint-Sépulcre à Constantinople à travers ses inventaires anciens', in A. Binggeli, M. Cassin, M. Detoraki and A. Lampadaridi (eds), Bibliothèques grecques dans l'Empire ottoman (Leuven 2020) 291-310.

[Le Bouyer de Fontenelle B.], 'Sur l'Ancien Canon pascal de St Hippolyte', Histoire de l'Académie royale des Sciences, II. 1686-1699 (Paris 1733) 300-17.

- 'Sur les deux éclipses de cette année, et principalement sur celle de Lune, employée à l'examen du calendrier', Histoire de l'Académie royale des Sciences, II. 1686-1699 (Paris 1733) 322-31.

Legrand E. (ed.), Bibliothèque grecque vulgaire, III (Paris 1881).

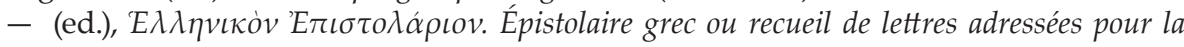
plupart à Chrysanthe Notaras patriarche de Jérusalem par les princes de Valachie et de Moldavie (Paris 1888).

- (ed.), Bibliographie hellénique ou description raisonnée des ouvrages publiés par des Grecs au dix-septième siècle, II (Paris 1894).

Leibniz G. W., Sämtliche Schriften und Briefe. Dritte Reihe: Mathematischer, naturwissenschaftlicher und technischer Briefwechsel, VIII (Berlin-Boston 2015).

Lequien M., Oriens christianus in quatuor patriarcatus digestus, III (Paris 1740).

Lerner M.-P., 'L'entrée de Tycho Brahe chez les jésuites ou le chant du cygne de Clavius', in L. Giard (ed.), Les Jésuites à la Renaissance. Système éducatif et production du savoir (Paris 1995) 145-85.

Livieratos E., Boutoura Chr., Pazarli M., Ploutoglou N. and Tsorlini A., 'The very first printed map in Greek, a derived map from Dutch cartography: Chrysanthos Notaras' world map (1700) vs Jan Luyts' world map (1692)', e-Perimetron 6/3 (2011) 200-18.

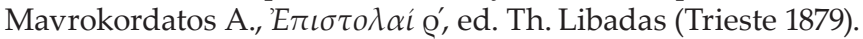

Nicolaidis E., Science and Eastern Orthodoxy. From the Greek Fathers to the Age of Globalization, transl. Susan Emanuel (Baltimore MD 2011).

- 'Verbiest, Spathar and Chrysanthos. The spread of Verbiest's science to Eastern Europe', in W. F. Vande Walle and N. Golvers (eds), The History of the Relations Between the Low Countries and China in the Qing Era (1644-1911) (Leuven 2003) 37- 57.

[Nicolopoulo C.-A.], 'Notaras (Chrysanthe)', in L.-G. Michaud (ed.), Biographie universelle, ancienne et moderne ..., XXXI (Paris 1822) 404-5.

Nilles N., Symbolae ad illustrandam historiam ecclesiae orientalis in Terris coronae S. Stepha$n i$, I (Eniponte [= Innsbruck] 1885).

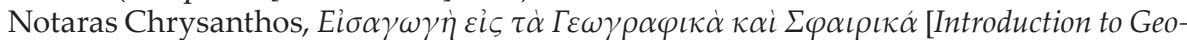
graphics and Sphaerics] (Paris 1716).

Omont H. (ed.), Missions archéologiques françaises en Orient aux XVII et XVIII siècles, I (Paris 1902).

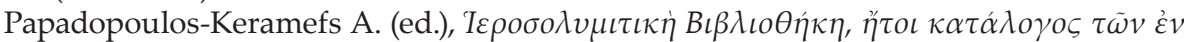

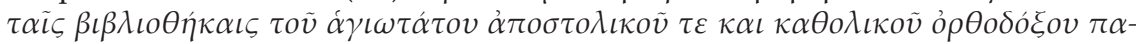

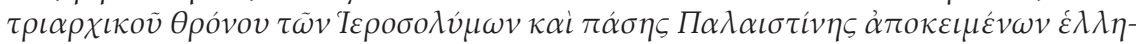
$v \iota \kappa \tilde{\omega} v \kappa \omega \delta i \kappa \omega v$, III (St Petersburg 1897).

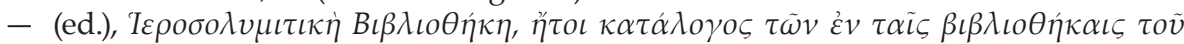

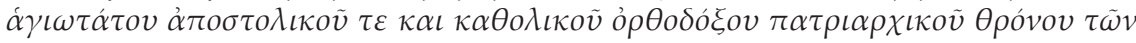




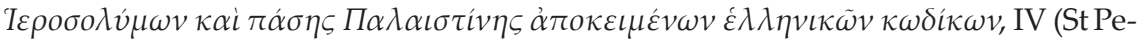
tersburg 1899).

Petit N., 'La Byzantine du Louvre', in M.-F. Auzépy and J.-P. Grélois (eds), Byzance retrouvée. Érudits et voyageurs français (XVI $-X V I I I^{e}$ siècles). Catalogue de l'exposition. Chapelle de la Sorbonne, Paris, 13 août-2 septembre 2001 (Paris 2001) 70-84.

Picolet G., 'Une visite du jeune Saint-Simon à l'Observatoire de Paris', Cahiers Saint-Simon 26 (1988) 59-68.

Prokopiou Pamperis Dimitrios, ‘Demetrii Procopii, Macedonis Moschopolitae, 'E $\pi$ -

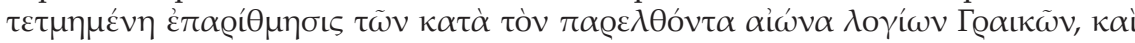

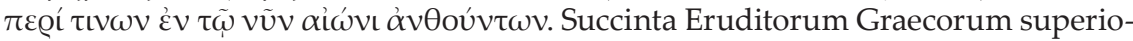
ris et praesentis saeculi recensio, conscripta mense Junio A.C. MDCCXX transmissaque Bucuresto, et nunc primum edita, cum Latina versione', in J. A. Fabricius (ed.), Bibliotheca Graeca, XI (Hamburg 1722) 769-808.

Radau R., 'L'Observatoire de Paris depuis sa fondation', Revue des Deux Mondes [2nd Period] 73 (1868) 740-68.

Romano A., 'L'horizon romain de la science moderne. Des sentiers à ouvrir', in A. Romano (ed.), Rome et la science moderne. Entre Renaissance et Lumières (Rome 2008) 637-59.

Saliba G., 'The role of Maragha in the development of Islamic Astronomy: a scientific revolution before the Renaissance', Revue de synthèse 4/3-4 (1987) 361-73.

- 'Revisiting the astronomical contacts between the World of Islam and Renaissance Europe: the Byzantine connection', in P. Magdalino and M. Mavroudi (eds), The Occult Sciences in Byzantium (Geneva 2006) 361-74.

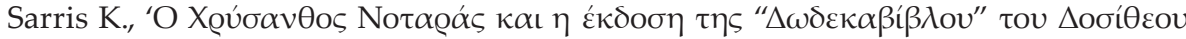

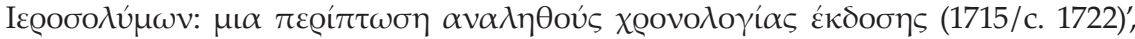

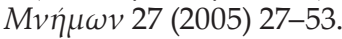

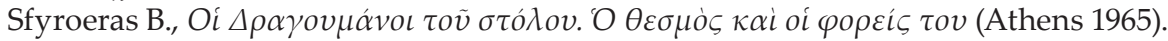

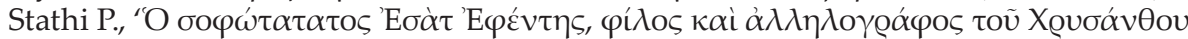

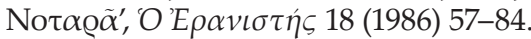

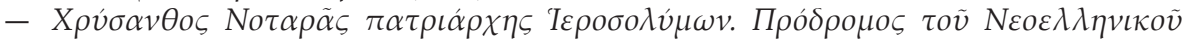
$\Delta \iota \alpha \varphi \omega \tau \iota \sigma \mu o \tilde{v}$ (Athens 1999).

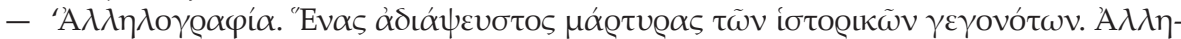

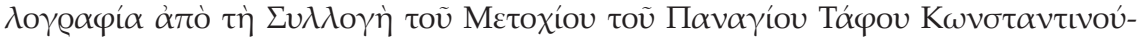
$\pi \mathrm{o} \lambda \eta s^{\prime}$, in E. Close, M. Tsianikas and G. Couvalis (eds), Greek Research in Australia: Proceedings of the Sixth Biennial International Conference of Greek Studies, Flinders University, June 2005 (Adelaide 2007) 389-400.

Tappe E. D., 'Documents concerning Rumania in the Paget papers', The Slavonic and East European Review 33/80 (December 1954) 201-11.

Todt K.-P., 'Dositheos II. von Jerusalem', in C. G. Conticello and V. Conticello (eds), La théologie byzantine et sa tradition, II. (XIII -XIX ${ }^{e}$ s.) (Turnhout 2002) 659-720.

Tolias G., 'Maps printed in Greek during the Age of Enlightenment, 1665-1820', e-Perimetron $5 / 1(2010) 1-48$.

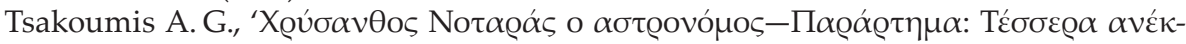

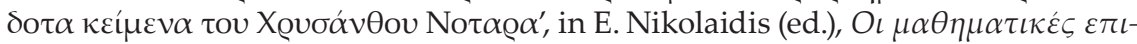

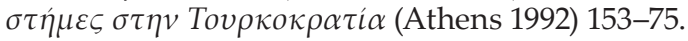

Tsourkas Cl., Les débuts de l'enseignement philosophique dans les Balkans. La vie et l'œuvre de Théophile Corydalée (1570-1646) (Thessaloniki 1967). 
Tzoga V., 'Sigillion inédit du patriarche de Constantinople Jérémie II et d'Alexandre Sylvestre sur la réforme du calendrier', Byzantinische Zeitschrift 107 (2014) 221-52.

Van der Krogt P., 'L'usage des globes dans la société européenne aux XVI $-X V I I^{\mathrm{e}}$ siècles', in C. Hofmann and Fr. Nawrocki (eds), Le monde en sphères (Paris 2019) 144-50.

Vasiliu V., 'Costantino Brâncoveanu e il Cattolicismo. Alcune notizie nuove intorno alla sua politica religiosa', Ephemerides Dacoromana. Annuario della Scuola romena di Roma 3 (1925) 110-28. 


\title{
The Eucharistic Controversy between the 'Orthodox' Dositheos II of Jerusalem and the 'Calvinist' Ioannis Karyofyllis (1689-1697)*
}

\author{
Ionuț-Alexandru Tudorie, St Vladimir's Orthodox Theological Seminary (Yonkers NY)
}

You are introducing novelties, you reopen issues settled many years ago, wishing to do useless work, writing confessions and expositions of faith, as if the Eastern Church had become needy and helpless in your days. You have abandoned the terms which the Holy Doctors used for a dim understanding concerning the Sacrament of the Holy Communion, from which the religion was established up to the present day, you teach transubstantiation and are asking questions about how it happens and how it is made. Disregarding whatever the holy theologians have said about not inquiring into the hidden mysteries, you are inquiring and writing about these. Perhaps you are not reading, as indeed you have not read the words of the Holy [Ioannis] Damaskinos in his chapter about this Sacrament 'but if you inquire into what way it happens, it is enough for you to hear that it happens through the Holy Spirit' and we know nothing more. However, now you are stirring up and innovating, because you have decided to learn how it happens, and you accept all the gossip of the Westerners on this supernatural mystery, together with the odd expression 'transubstantiation'

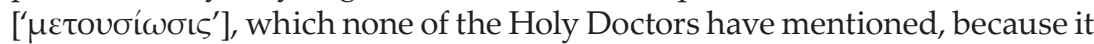
is inappropriate for expressing the transformation of this Holy Sacrament. ${ }^{1}$

* This research project has received funding from the European Research Council (ERC) under the European Union's Horizon 2020 Research and Innovation Programme (ERC CoG 2014, grant agreement no. 648498).

For most of the cases (except Karyofyllis), despite the lengthiness of some footnotes, the selected bibliographical entries for further readings related to cited Byzantine or Greek authors are complementary to those already included in the Modern Greek updated version of Gerhard

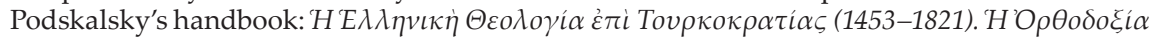

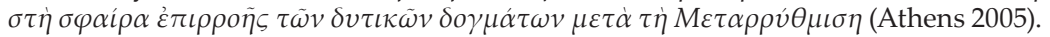

1 Excerpt from a letter of Ioannis Karyofyllis to Chrysanthos Notaras (15 October 1690),

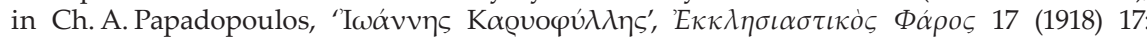

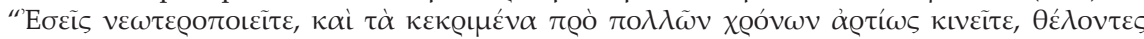

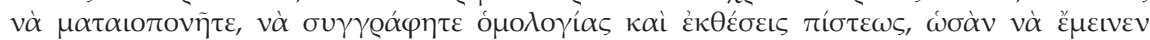

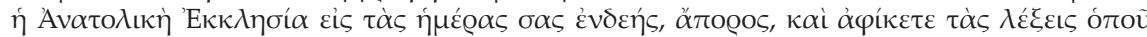

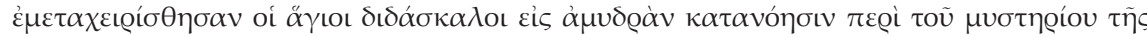

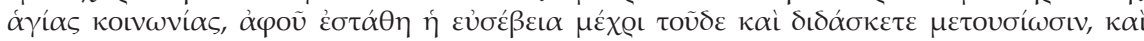

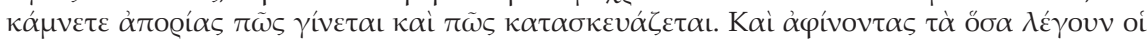


This long quotation from a letter of Ioannis Karyofyllis, the Great Logothete of the Great Church, addressed to hieromonk Chrysanthos Notaras, dealt with two important issues for Eastern Christianity. The first of these was the discourse against

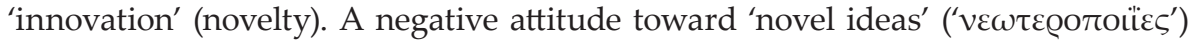
is to be found already in Byzantine society: they 'did not appreciate innovation and claimed to have stuck to tradition. Imitation and repetition of the standard authorities-i.e. Church Fathers, in the quoted paragraph-was praiseworthy Reforms were usually couched in terms of the restoration of the past rather than of innovation,' but this 'does not mean that Byzantine culture totally lacked originality.'2 Much more than in any other case, when it comes to religious dogma, an

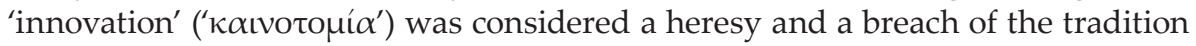
(' $\pi \alpha \varrho \alpha ́ \delta o \sigma \iota \varsigma$ '). After the fall of Constantinople (1453) and especially after the Reformation in Western Europe, despite the exposure of Eastern Christianity to several 'novelties', this conservative stance-as expressed here by Karyofyllis-was perceived as a means to secure the 'orthodoxy' of the faith. On the other hand, it is important to mention that a similar discourse against what was considered to be 'bad innovation' ('bid'a') also existed among the Ottoman Muslims in the sixteenth and seventeenth centuries, having its strongest adherents especially in the followers of Kadizade Mehmed Efendi (1582-1635). ${ }^{3}$

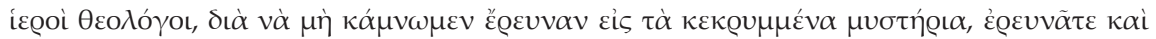

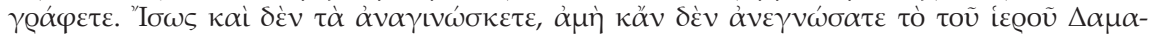

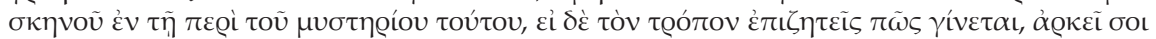

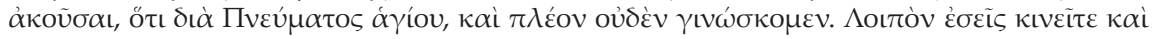

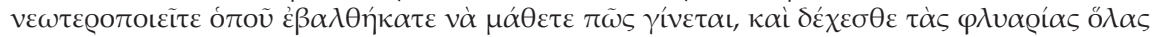

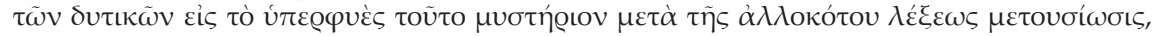

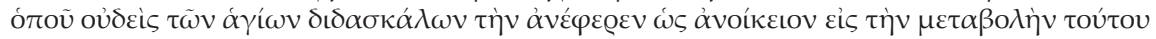

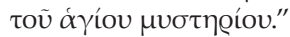

2 A. K[azhdan] and A. C[utler], 'Innovation', in A. P. Kazhdan (ed.), The Oxford Dictionary of Byzantium, II (New York-Oxford 1991) 997-8. For a few recent articles on innovation in the Byzantine period, see A. P. Kazhdan, 'Innovation in Byzantium', in A. R. Littlewood (ed.), Originality in Byzantine Literature, Art and Music. A Collection of Essays (Oxford 1995) 1-14; A. Spanos, 'To Every Innovation, Anathema (?). Some Preliminary Thoughts on the Study of Byzantine Innovation', in H. Knudsen et al. (eds), Mysterion, strategike og kainotomia. Et festskrift til ære for Jonny Holbek (Oslo 2010) 51-9; A. Spanos, 'Was Innovation Unwanted in Byzantium?', in I. Nilsson and P. Stephenson (eds), Wanted: Byzantium. The Desire for a Lost Empire (Uppsala 2014) 43-56.

3 See the chapter on 'innovation' included in The Balance of Truth, completed in November 1656 by Kātib Çelebi (Mustafā ibn 'Abd Allāh/Hajji Kalfa). Kātib Chelebi, The Balance of Truth, transl. G. L. Lewis (London 1957) 89-91 (here p. 89): “By 'innovation' ('bid'a') is meant any new development in matters sacred or mundane, appearing during or after the second age; that is, anything which did not exist in the time of the Prophet (on him be the peace and the blessing of God) and his noble Companions (God be pleased with them), and of which there is no trace in any of the three categories of Sunna and concerning which there is no tradition. Such things are of two kinds. The first is called 'good innovation': that which was not known in the time of the Prophet but which the leaders of the Faith have subsequently allowed as filling a need. Examples are the building of minarets and the manufacture of books. The second is 'bad innovation': for example, in matters of faith, the beliefs of misguided schismatics who differ from the followers of the Sunna, and, in matters of practice, the forms of worship invented by the common people on no authority but their own." For the innovation controversy 
The second issue addressed by Karyofyllis in his letter was the Orthodox position regarding the real presence of Christ in the Eucharist, which was related to the Western Eucharistic controversy. This controversy, which errupted in 1626 when the French pastor Edmé Aubertin (1595-1652) published his Conformité de la créance de l'Église et de S. Augustin sur le sacrement de l'Eucharistie, opposée à la réfutation des cardinaux Du Perron, Bellarmin et autres, continued between the Jansenists and Protestants throughout the seventeenth century, but the high clergymen of Eastern Christianity were also drawn into it by the missionaries who systematically asked them to express their position on the subject of the Eucharist. ${ }^{4}$ Therefore, after the Byzantine-Latin disputes over the 'unleavened bread' (eleventh century) ${ }^{5}$ and the

in Medieval Islam (fourteenth century) and Kadıadeli's offensive in the seventeenth century against 'bad innovation', see Muhammad Umar Memon (ed.-transl.), Ibn Taimìya's Struggle against Popular Religion. With an Annotated Translation of his Kitāb iqtidā' aș-șirāt al-mustaqìm mukhālafat așhāb al-jaḥim (The Hague-Paris 1976) 23-87; M. C. Zilfi, 'The Kadızadelis: Discordant Revivalism in Seventeenth-Century Istanbul', Journal of Near Eastern Studies 45 (1986) 251-69; M. Sariyannis, 'The Kadizadeli Movement as a Social and Political Phenomenon: the Rise of a Mercantile Ethic', in A. Anastasopoulos (ed.), Political Initiatives 'From the Bottom Up' in the Ottoman Empire: Halcyon Days in Crete VII. A Symposium Held in Rethymno, 9-11 January 2009 (Rethymno 2012) 263-89. A very recent and interesting comparative analysis on this discourse against any form of religious innovation among the Muslim and Greek Orthodox Ottoman subjects was published in: E. Kermeli, 'Kyrillos Loukaris' Legacy: Reformation as a Catalyst in the 17th Century Ottoman Society', The Muslim World 107 (2017) 740-8.

4 For an excellent article on the Eastern Christians participation in this Western controversy, see F. Gabriel, 'Les témoins orientaux d'une querelle latine : Orthodoxie et professions de foi dans La Perpétuité de la foi', in M.-H. Blanchet and F. Gabriel (eds), L'Union à l'épreuve du formulaire : professions de foi entre Églises d'Orient et d'Occident (XIIIe-XVIIIe siècle) (Leuven-ParisBristol CT 2016) 373-89. For more details on this theological quarrel, see R. Snoeks, L'argument de tradition dans la controverse eucharistique entre catholiques et réformés français au XVIIe siècle (Louvain-Gembloux 1951); P.-F. Burger, 'Pierre Nicole, la Perpétuité et l'abbé Eusèbe Renaudot', Chroniques de Port-Royale 45 (1996) [Pierre Nicole (1625-1695)] 135-53; J.-L. Quantin, 'De la Contre-Réforme comme monopole: les anti-jansénistes et la Perpétuité de la foi' and H. Bost, 'Jean Claude controversiste: Charenton contre Port-Royale?', Chroniques de Port-Royale 47 (1998) [Port-Royale et les Protestants] 115-48 and 149-77, respectively; J.-L. Quantin, Le catholicisme classique et les Pères de l'Église. Un retour aux sources (1669-1713) (Paris 1999) 321-56; M. Adam, L'Eucharistie chez les penseurs français du dix-septième siècle (Hildesheim-Zürich-New York 2000) 117-56; D. A. Michelson, La Perpétuité de la foi: The Appeal to Eastern Christianity of Jean Claude's Eucharistic Polemics Viewed in its French Reformation and Counter Reformation Contexts (MA Thesis) (Trinity Evangelical Divinity School, Deerfield IL 2001); J. D. Woodbridge, 'La grande chasse aux manuscrits, la controverse eucharistique et Richard Simon', in O. Elyada and J. Le Brun (eds), Conflits politiques, controverses religieuses: Essais d'histoire européenne aux 16e-18e siècles (Paris 2002) 143-75; A. Hamilton, 'From East to West: Jansenists, Orientalists, and the Eucharistic Controversy', in W. Otten, A. J. Vanderjagt and H. De Vries (eds), How the West Was Won: Essays on Literary Imagination, the Canon, and the Christian Middle Ages for Burcht Pranger (Leiden-Boston 2010) 83-100; O. Olar, 'Un temps pour parler. Dosithée de Jérusalem et le Synode de Jassy (1642)', Analele Putnei 10 (2014) 225-36; V. Kontouma and S. Garnier, '1672: Concilium Hierosolymitanum', in A. Melloni (ed.), Conciliorum Oecumenicorum Generaliumque Decreta, IV/1 (Turnhout 2016) 268-70.

5 For the context of the Great Schism and the unleavened bread controversy, see C. Will (ed.), Acta et scripta quae de controversiis Ecclesiae Graecae et Latinae saeculo undecimo composita extant (Leipzig-Marburg 1861); L. Bréhier, Le schisme oriental du XIe siècle (Paris 1899); A. Michel, 
'moment of the consecration of the Eucharist' (fifteenth century), ${ }^{6}$ at the end of the seventeenth century Greek-speaking Eastern Orthodoxy was shaken by another Eucharistic controversy: in order to better express one of the hidden mysteries of

Humbert und Kerullarios. Quellen und Studien zum Schisma des XI. Jahrhunderts, 2 vols (Paderborn 1924-1930); M. Jugie, Le schisme byzantin. Aperçu historique et doctrinal (Paris 1941) 187-246; A. Michel, 'Schisma und Kaiserhof im Jahre 1054: Michael Psellos', in 1054-1954. L'Église et les Églises: neuf siècles de douloureuse séparation entre l'Orient et l'Occident. Études et travaux sur l'Unité chrétienne offerts à Dom Lambert Beauduin, I ([Chevetogne] 1954) 351-440; J. H. Erickson, 'Leavened and Unleavened: Some Theological Implications of the Schism of 1054', St Vladimir's Theological Quarterly 14 (1970) 155-76; M. H. Smith III, And Taking Bread ... Cerularius and the Azyme Controversy of 1054 (Paris 1978); P. Gemeinhardt, Die Filioque-Kontroverse zwischen Ost- und Westkirche im Frühmittelalter (Berlin-New York 2002) 322-98; T. M. Kolbaba, 'The Legacy of Humbert and Cerularius: the Tradition of the Schism of 1054 in the Byzantine Texts and Manuscripts of the Twelfth and Thirteenth Centuries', in Ch. Dendrinos et al. (eds), Porphyrogenita. Essays on the History and Literature of Byzantium and the Latin East in Honour of Julian Chrysostomides (Aldershot-Burlington VT 2003) 47-61; I. I. Ică Jr., '950 de ani de la Marea Schismă. Interpretări și documente (I-II)', Revista Teologică 14/86 (2004) 8-41, 79-113; T. Kolbaba, 'On the Closing of the Churches and the Rebaptism of Latins: Greek Perfidy or Latin Slander?', Byzantine and Modern Greek Studies 29 (2005) 39-51; J. R. Ryder, 'Changing Perspectives on 1054' and T. Kolbaba, '1054 Revisited: Response to Ryder', Byzantine and Modern Greek Studies 35 (2011) 20-37 and 38-44, respectively; V. Grolimund, 'Die Entwicklung der Theologie der Eucharistie in Byzanz von 1054-1453', in I. Perczel, R. Forrai and G. Geréby (eds), The Eucharist in Theology and Philosophy: Issues of Doctrinal History in East and West from the Patristic Age to the Reformation (Leuven 2005) 160-4; Ch. Gastgeber, 'The So-Called Schism of 1054 and Its Impact on Byzantine Society', in B. Crostini and G. Peers (eds), A Book of Psalms from Eleventh-Century Byzantium: The Complex of Texts and Images in Vat. Gr. 752 (Vatican 2016) 193-225.

6 For more details on this theological disagreement briefly discussed in June 1439 in Florence, see E. Mapelli, La questione dell'epiclesi al Concilio di Firenze (Venegono Inferiore 1940); E. Boularand, 'L'Epiclèse au Concile de Florence', Bulletin de Littérature Ecclésiastique 60 (1959) 241-73; J.-L. van Dieten, 'Die Erklärung Bessarions zur Forma Eucharistiae. Kritische Fragen zu einem Protokoll', Annuarium Historiae Conciliorum 16 (1984) 369-84; W. Brandmüller, 'Die theologischen Themen des Konzils von Ferrara-Florenz', in A. Ziegenaus (ed.), Sendung und Dienst im bischöflichen Amt. Festschrift der Katholisch-Theologischen Fakultät der Universität Augsburg für Bischof Josef Stimpfle zum 75. Geburstag (St Ottilien 1991) 166-8; Grolimund, 'Eucharistie in Byzanz', 182-5; Ch. Kappes, The Epiclesis Debate at the Council of Florence (Notre Dame 2019). It is interesting to note here that Metropolitan Petro Mohyla of Kiev (1633-1646), in his Orthodoxa Confessio Fidei Catholicae et Apostolicae Ecclesiae Orientalis (Kiev, 1638-1640), Brief Summary of the Teaching in Articles as Taught by the Eastern Church (known as Small Catechism, the original in Polish; Kiev, 1645), and Trebnik (Kiev, 1646), under the influence of Latin theology as expressed in Summa doctrinae christianae (Vienna, 1555) by Petrus Canisius, included the Latin answer to this issue, namely that the consecration of the Eucharist take place when the officiant declaims the words of Christ ( $M t$ 26: 26-28: 'Take, eat; this is My Body [...] Drink of it, all of you, for this is My Blood of the Covenant') and not at the sotto voce special prayer of the

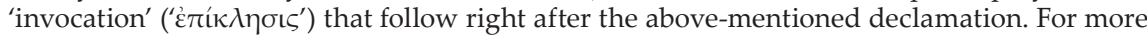
information on Latin influence on Mohyla's Orthodoxa Confessio Fidei, see E. de Hurmuzaki (ed.), Documente privitóre la Istoria Românilor, IV/1. (1600-1649) (Bucharest 1882) 668; M. Viller, 'Notes et mélanges: Une infiltration latine dans la théologie orientale. La Confession orthodoxe attribuée à Pierre Moghila et le Catéchisme de Canisius', Recherches de Science Religieuse 3 (1912) 159-68; A. Malvy and M. Viller, La Confession orthodoxe de Pierre Moghila, Métropolite de Kiev (1633-1646) approuvée par les Patriarches grecs du XVII siècle [Orientalia Christiana 10 (1927), n. 39] (Rome-Paris 1927) XCI-CVI, CXIV-CXXIX, 60-3; M. Jugie, 'La Confession orthodoxe de Pierre Moghila: à propos d'une publication récente', Échos d'Orient 28 (1929) 417-8; N. I. Popo- 
Orthodox Christianity, namely the real presence of Christ in the Holy Communion 'that happens through the Holy Spirit', some Byzantine theologians resorted to a

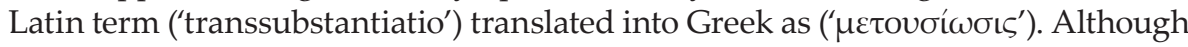

viciu, Epicleza euharistică (Sibiu 1933) 263-8; T. Ionesco, La vie et l'œuvre de Pierre Movila, Métropolite de Kiev (Paris 1944) 185-236; O. Bârlea, De Confessione Orthodoxa Petri Mohilae (Frankfurt

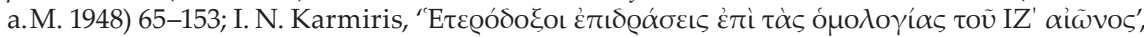

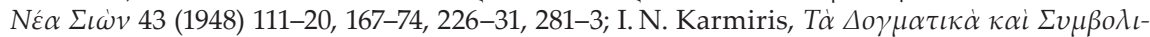

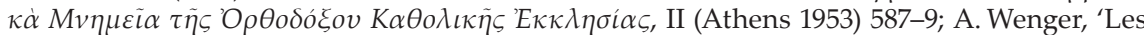
influences du rituel de Paul V sur le Trebnik de Pierre Moghila', in Mélanges en l'honneur de Monseigneur Michel Andrieu (Strasbourg 1956) 486-9; R. Gundlach, 'Kirche und Sakrament in der Confessio Orthodoxa des Petrus Mogilas', Kirche im Osten 4 (1961) 31-3; A. Zhukovs'kij, Petro Mogila i pitannja ednosti Cerkov (Paris 1969) 169-84; R. P. Popivchak, Peter Mohila, Metropolitan of Kiev (1633-1647). Translation and Evaluation of His Orthodox Confession of Faith (1640) (PhD Thesis) (Catholic University of America, Washington DC 1975) 262-96; G. Florovsky, Ways of Russian Theology, I [The Collected Works of Georges Florovsky 5] (Belmont MA 1979) 74-8; P. Hauptmann, 'Petrus Mogilas (1596-1646)', in H. Fries and G. Kretschmar, Klassiker der Theologie, I (München 1981) 387-9; P. Meyendorff, ‘The Liturgical Reforms of Peter Moghila: A New Look', St Vladimir's Theological Quarterly 29 (1985) 101-14; G. Podskalsky, Griechische Theologie in der Zeit der Türkenherrschaft (1453-1821). Die Orthodoxie im Spannungsfeld der nachreformatorischen Konfessionen des Westens (München 1988) 233-6 [Greek version: 301-5]; R. Žužek, 'L'escatologia di Pietro Moghila', Orientalia Christiana Periodica 54 (1988) 353-80; F. J. Thomson, 'Peter Mogila's Ecclesiastical Reforms and the Ukrainian Contribution to Russian Culture. A Critique of Georges Florovsky's Theory of The Pseudomorphosis of Orthodoxy', Slavica Gandensia 20 (1993) 93-100; S. Janeras, 'L'Esperit Sant en la Confessio Orthodoxa de Pere Moguila', in J. Busquets and M. Martinell (eds), Fe i teologia en la història. Estudis en honor del Prof. Dr.

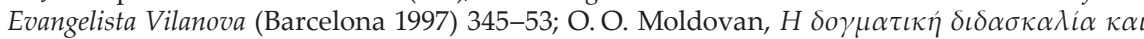

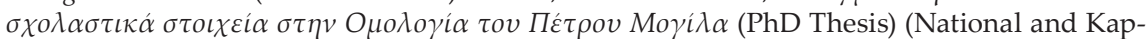
odistrian University of Athens, Athens 2012) 129-243; M. G. Bartolini, 'Visible Rituals: Theology and Church Authority in the Iconography of the Seven Sacraments in Peter Mohyla's Trebnik (1646)', The Slavonic and East European Review 98 (2020) 60-105. This issue was still under debate in Russia at the end of seventeenth century and Patriarch Joachim (1674-1690) convened a local Synod in Moscow in 1690 to condemn the 'latinized' theologians for their deceitful teaching that the consecration of the Eucharist take place at the moment when Jesus' words are recited by the minister. For more details on this episode, see I. Shliapkin, 'K istorii polemiki mezhdu moskovskimi i malorusskimi uchenymi v konce XVII veka', Zhurnal Ministerstva Narodnago Prosveshhenija 241 (1885) 210-52; G. Mirkovich, O vremeni presushhestvlenija Sv. Darov: Spor, byvshij v Moskve vo vtoroj polovine XVII-go veka (Opyt istoricheskago izsledovanija) (Vilnius 1886); Th. Spáčil, Doctrina Theologiae Orientis separati de SS. Eucharistia, II [Orientalia Christiana 14 (1929), n. 50] (Rome 1929) 25-7; Popoviciu, Epicleza euharistică, 7-8; S. Salaville, 'Épiclèse eucharistique', in A. Vacant, E. Mangenot and É. Amann (eds), Dictionnaire de Théologie Catholique contenant l'exposé des doctrines de la Théologie Catholique, leurs preuves et leur histoire, V/I (Paris 1939) 262-3; Podskalsky, Griechische Theologie, 278-9, 395 [Greek version: 353-4, 491]; O. B. Strakhov, The Byzantine Culture in Muscovite Rus': The Case of Evfimii Chudovskii (1620-1705) (Köln-Weimar-Vienna 1998) 37-42; W. von Scheliha, Russland und die orthodoxe Universalkirche in der Patriarchatsperiode (1589-1721) (Wiesbaden 2004) 441-63; T. V. Panich, Kniga "Shhit very" v istoriko-literaturnom kontekste konca XVII veka (Novosibirsk 2004); M. M. Bernatskij, 'Osvjashhenie pominal'nyh chastic v kontekste spora o vremeni presushhestvlenija Svjatyh Darov, sostojavshegosja v poslednej chetverti XVII v. v Moskve: Glava o pominal'nyh chasticah v «Shhite very» i «Ostene» (publikacija po rukopisjam GIM. Sin. 346, 452, 546)', Vestnik PSTGU (Serija I: Bogoslovie. Filosofija) 16 (2006) 129-44; M. M. Bernatskij, 'Spory o vremeni prelozhenija Darov i dr. voprosy bogoslovsko-liturgicheskogo haraktera v rossijskom bogoslovii XVII v.', in Pravoslavnaja Enciklopedija, XVII (Moscow 2008) 649-50. 
both Churches, Roman-Catholic and Orthodox, assert the real presence of Christ in the Eucharist in contrast to the tenet of a symbolic-spiritual presence in the Protestant doctrine, a difference still exists between the two: against Ratramnus of Corbie (ninth century) and Berengarius of Tours (c. 999-1088), who denied the identity of the Eucharist with the physical Body of Christ-bread and wine being only efficient 'signs' of Christ's spiritual-heavenly body-the 'doctor Ecclesiae' Thomas Aquinas, employing the Aristotelian philosophical system and the distinction between substance and accident ('hylomorphism'), explained that what appear to be bread and wine ('accidents') are actually the Body and Blood of Christ ('substance'); the substance has changed without the accidents changing. Later on, in October 1551, during the Council of Trent (1545-1563) the transubstantiation theory was articulated in a concise form and accepted by the Roman-Catholic Church. To the objection that this term is a novelty and was not used in the Scriptures, it was replied

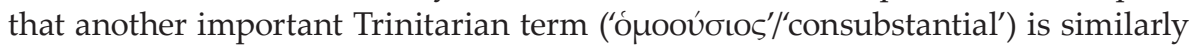
not to be found in the Scriptures, but was used by the Holy Fathers at the First Ecumenical Council in Nicea (325) in order to clearly explain the relationship between God the Father and the Son. ${ }^{7}$

As mentioned, this quotation is from a missive of Ioannis Karyofyllis (c. 1610-

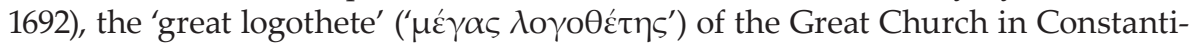

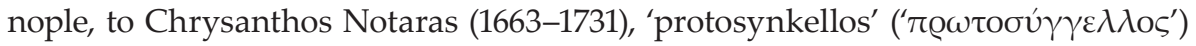
and hieromonk, nephew of the Patriarch of Jerusalem, Dositheos II (1641-1707). The precise date when it was dispatched was October 15, 1690, before the local Synod convened in Constantinople at the end of the first week of Great Lent in 1691, which questioned Ioannis Karyofyllis regarding his opinion on the real presence of Christ in the Eucharist.

This article aims to elucidate the context that made it possible for two prominent figures of Eastern Christianity, one a patriarch and the other a famous professor and high official of the Ecumenical Patriarchate, to open a new battlefield on theological issues at the end of the seventeenth century, after the huge scandal involving Kyrillos Loukaris (1570-1638) and the ensuing proliferation of different 'Orthodox' confessions of faith. The second research question pertains to the confessional attributes usually attached to Ioannis Karyofyllis and Dositheos II of Jerusalem: were they really 'Calvinist' and 'Orthodox', respectively, in their opinions on the real presence of Christ in the Eucharist?

7 For two excellent syntheses on this topic, see E. Yarnold, 'Transsubstantiation', in I. Perczel, R. Forrai and G. Gerebý (eds), The Eucharist in Theology and Philosophy: Issues of Doctrinal History in East and West from the Patristic Age to the Reformation (Leuven 2005) 382-7; D. Grumett, Material Eucharist (New York 2016) 144-190. See also Ch. Kappes and W. Albrecht, The Secret History of Transubstantiation: Pulling Back the Veil on the Eucharist (Eagle Pass TX 2021) 180-254. For detailed analyses of Thomas Aquinas and the Tridentine statement on the praesentia corporalis of Christ in the Eucharist, see R. Hütter, Aquinas on Transubstantiation: The Real Presence of Christ in the Eucharist (Washington 2019); J. Wohlmuth, Realpräsenz und Transsubstantiation im Konzil von Trient: eine historisch-kritische Analyse der Canones 1-4 der Sessio XIII, I-II (BernFrankfurt a.M. 1975). 


\section{Two friends and one theological issue}

Ioannis Karyofyllis ${ }^{8}$ was born at the beginning of the seventeenth century (ca 1610) in Karyes in Thrace, ${ }^{9}$ near Constantinople. His name, Karyofyllis, is obvi-

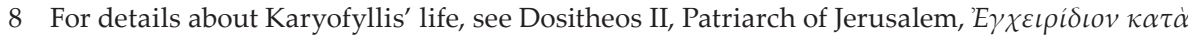

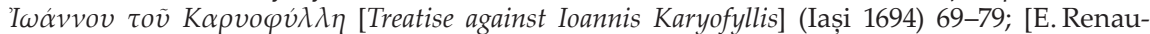
dot], La perpétuité de la foy de l'Église catholique touchant l'eucharistie, IV (Paris 1711) 384-401; [E. Renaudot], La perpétuité de la foy de l'Église catholique sur les sacrements, et sur tous les autres points de religion $\mathcal{E}$ de discipline, que les premiers Réformateurs ont pris pour prétexte de leur schisme; prouvée par le consentement des Églises orientales, V (Paris 1713) 41-8; A. Papadopou-

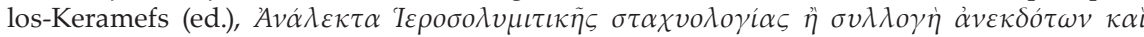

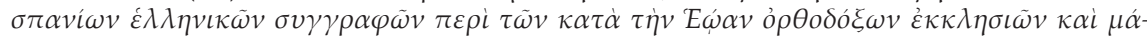

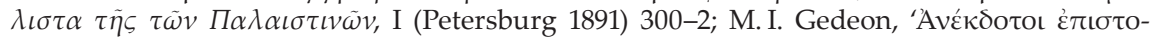

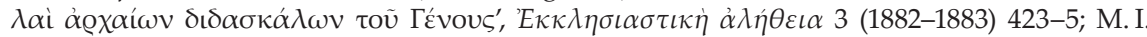

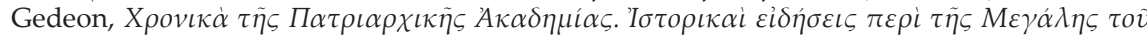

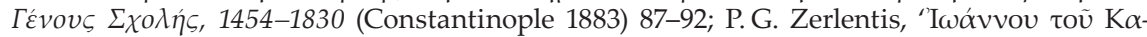

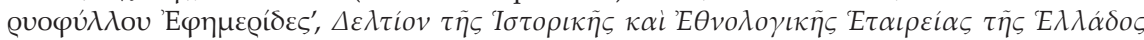

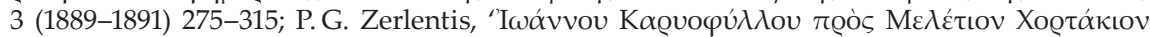

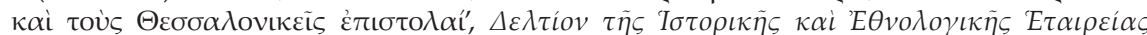

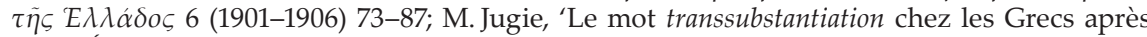

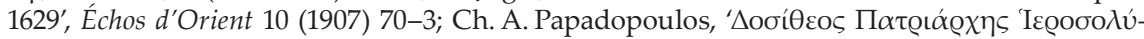

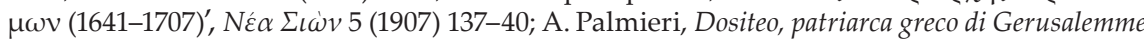
(1641-1707): Contributo alla storia della teologia greco-ortodossa nel secolo XVII (Firenze 1909) 33-7;

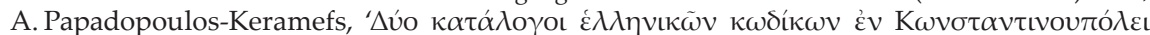

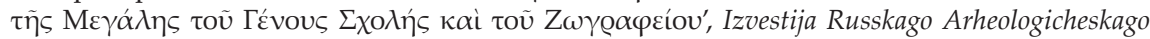
Instituta v Konstantinopole 14 (1909) 101-53; N. Iorga, 'Quelques données nouvelles au sujet des relations entre les Principautés Roumaines et l'Église Constantinopolitaine dans la seconde moitié du XVIIe siècle', Bulletin de la Section Historique [Académie Roumaine] 3 (1915) 143-53;

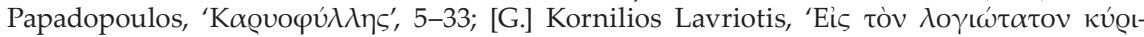

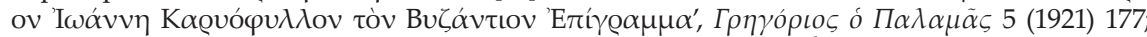
A. Palmieri, 'Caryophylles Jean', in A. Vacant, E. Mangenot and É. Amann (eds), Dictionnaire de Théologie Catholique contenant l'exposé des doctrines de la Théologie Catholique, leurs preuves

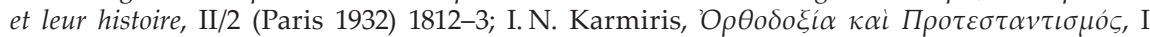
(Athens 1937) 257-9; D. Russo, 'Ioan Cariofil și operele lui', in D. Russo, Studii istorice greco-române. Opere postume, I (Bucharest 1939) 181-91; N. Chițescu, 'O dispută dogmatică din veacul al XVII-lea la care au luat parte Dositei al Ierusalimului, Constantin Brâncoveanu și

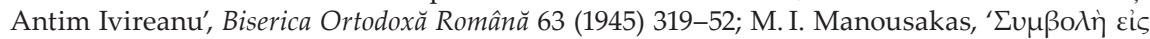

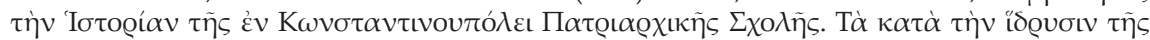

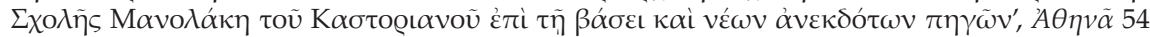
(1950) 25-7; M. Jugie, 'Caryophyllès ou Karyophyllès (Jean)', in G. Jacquemet (ed.), Catholicisme. Hier-Aujourd'hui-Demain, II (Paris [1954]) 609-10; Karmiris, Mv $\mu$ عĩa, 773-83; P. Ș. Năsturel, 'Contribuții la viața lui Ioan Cariofil în legătură cu Biserica Romînească', Mitropolia Olte-

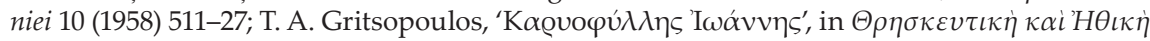

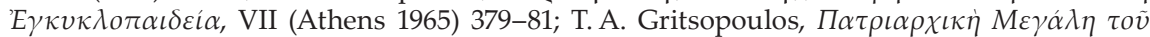

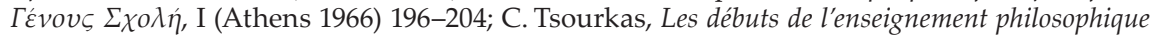
et de la libre pensée dans les Balkans: la vie et l'oeuvre de Théophile Corydalée (1570-1646), 2nd edn (Thessaloniki 1967) 375-7, 385; N. M. Vaporis, 'A Study of the Ziskind MS No. 22 of the Yale University Library: Some Aspects of the History of the Ecumenical Patriarchate of Constantinople in the Seventeenth and Eighteenth Centuries', The Greek Orthodox Theological Review [Supplement] 12 (1967) 1-40; 13 (1968) 41-84; 14 (1969) 85-124; C. Tsourkas, Germanos Locros, archevêque de Nysse et son temps (1645-1700). Contribution à l'histoire culturelle des Balkans au XVIIe

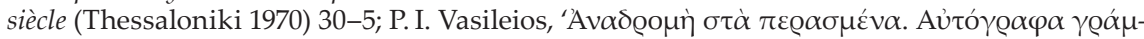

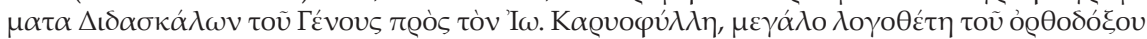


ously related to his birthplace. Occasionally he was also referred to as 'Ioannis Vyzantios,', ${ }^{10}$ suggesting that he was born near the former Byzantine capital city

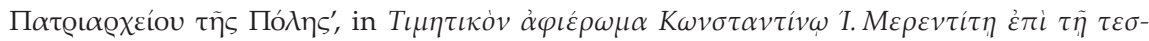
$\sigma \alpha \rho \alpha \kappa o v \tau \alpha \varepsilon \tau \eta \rho i \delta \iota \tau \tilde{\eta} \varsigma \dot{\varepsilon} \kappa \tau \alpha \iota \delta \varepsilon v \tau \iota \kappa \tilde{\eta} \varsigma \alpha \hat{v} \tau o \tilde{v} \delta \rho \alpha ́ \sigma \varepsilon \omega \varsigma$ (Athens 1972) 27-39; N. M. Vaporis, 'Codex $\left(\Gamma^{\prime}\right)$ Gamma of the Ecumenical Patriarchate of Constantinople', The Greek Orthodox Theological Review [Supplement] 18 (1973) 19-31; P. Cernovodeanu and M. Caratașu, 'Lettres du prince de Valachie Constantin Brancovan aux savants grecs Jean et Ralakis Caryophyllis', Revue des Études Sud-Est Européennes 14 (1976) 143-64; G. A. Maloney, A History of Orthodox

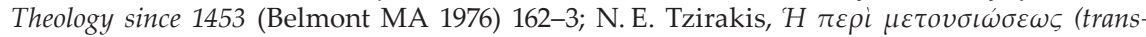

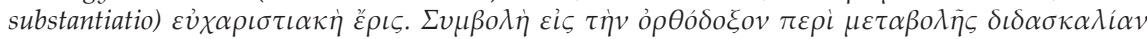
$\tau o \tilde{v} I Z$ ' $\dot{i} \tilde{\omega} v o \varsigma$ (PhD Thesis) (National and Kapodistrian University of Athens, Athens 1977)

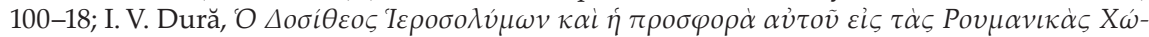
$\rho \alpha \varsigma \kappa \alpha i \tau \dot{\eta} v ' E \kappa \kappa \lambda \eta \sigma i \alpha v \alpha \hat{v} \tau \tilde{\omega} v$ (PhD Thesis) (National and Kapodistrian University of Ath-

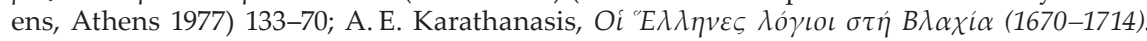

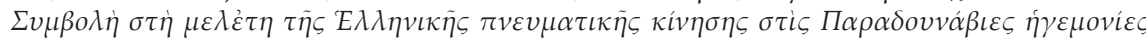

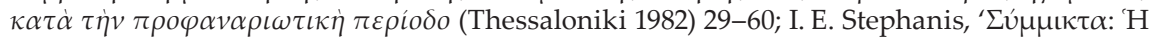

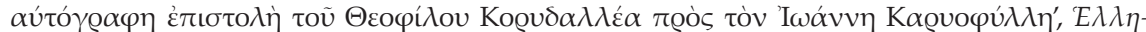

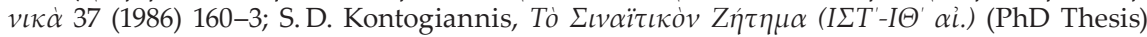
(National and Kapodistrian University of Athens, Athens 1987) 90-107; D. Manu, 'Importanța Sinoadelor Răsăritene din secolul al XVII-lea pentru unitatea Ortodoxiei' (teză de doctorat-partea a II-a), Ortodoxia 39 (1987) 67-71, 79-82; Podskalsky, Griechische Theologie, 236-42 [Greek version: 305-11]; A. Elian, 'Cultura teologică în epoca brâncovenească', Biserica Ortodoxă Română 106 (1988) 109-12; D. Hadzimanou, La vie et l'œuvre d'Eugène Yannoulis d'après sa correspondance (1638-1682) (PhD Thesis) (Université de Paris-Sorbonne IV, Paris 1991) 75-6, 188-9; G. Hering, 'Karyophylles, Johannes', in F. W. Bautz and T. Bautz, (eds), Biographisch-Bibliographisches Kirchenlexikon, III (Herzberg 1992) 1194-6; B. L. Fonkich, 'Avtografy Ioanna Kariofillisa', in B. L. Fonkich, Grecheskie rukopisi evropejskih sobranij. Paleograficheskie i kodikologicheskie issledovanija 1988-1998 gg. (Moscow 1999) 132-6; B. L. Fonkich, 'Diplomatika i paleografija',

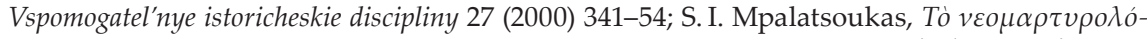

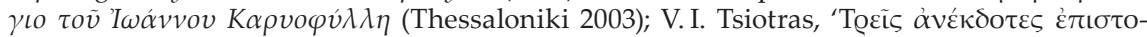

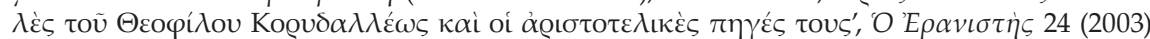
11-27; B. L. Fonkich, 'Ioann Kariofillis i ego rol' v istorii russko-grecheskih svjazej v XVII v.', in Rossiia i Khristianskii Vostok 2-3 (2004) 392-5; M. M. Bernatskij, 'Konstantinopol'skij Sobor 1691 g. i ego recepcija v Russkoj Pravoslavnoj Cerkvi (k voprosu o kanonicheskom statuse termina «presushhestvlenie»)', Bogoslovskie Trudy 41 (2007) 133-45; M. M. Bernatskij, 'Dogmaticheskoe uchenie o Evharistija v opredelenijah Pomestnyh Soborov XVII v.', in Pravoslav-

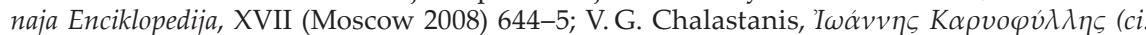

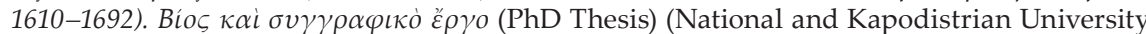

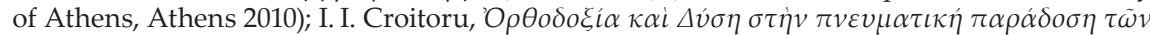

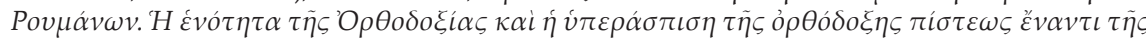
$\pi \rho о \tau \varepsilon \sigma \tau \alpha \nu \tau \iota \kappa \tilde{\eta} \varsigma \pi \rho о \tau \alpha \gamma \alpha \dot{v} \delta \alpha \varsigma \kappa \alpha \tau \dot{\alpha} \tau \dot{o} v$ IZ $\alpha \dot{\imath} \omega \dot{v} \alpha$, II (Athens 2011) 1233-84; G. Tzedopoulos,

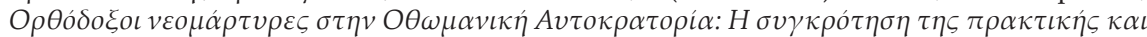

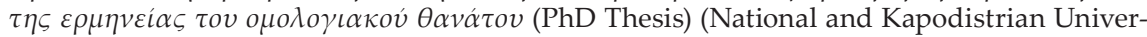
sity of Athens, Athens 2012) 223-40, 249-59, 266-75; M. M. Bernatskij, 'Kariofill', in Pravoslavnaja Enciklopedija, XXXI (Moscow 2013) 115-7; N. Miladinova, The Panoplia Dogmatike by Euthymios Zygadenos. A Study on the First Edition Published in Greek in 1710 (Leiden-Boston 2014) 38-43, 112-8; I. M. Croitoru, 'Contribuția Sfântului Antim Ivireanul la controversa dintre patriarhul Ierusalimului Dositei Notaras și marele logofăt al Patriarhiei Ecumenice Ioan Cariofil', in Ș.Zară (ed.), Spiritualitatea mărturisitoare a culturii românești în perioada Sfântului Martir Constantin Brâncoveanu (Râmnicu Vâlcea 2014) 201-32; I. I. Ică Jr., 'Patriarhul Dositei al Ierusalimului, conștiință a Ortodoxiei în Europa secolului XVII și o uitată apologie a sfântului 
('Vyzantion'). He was educated at the Patriarchal School in the Phanar (1625-1628), the Greek neighbourhood in Constantinople, under the direct supervision of the theologian and philosopher Theofilos Korydallefs (1574-1646). ${ }^{11}$ For his excellent scholarship in theology and philosophy, sometime after 1640, Karyofyllis was promoted as rector of the Patriarchal School, following his mentor. ${ }^{12}$ On the other hand, thanks to his close connection with the powerful Cantacuzino family, he was appointed to different positions in the ecclesiastical administration, starting

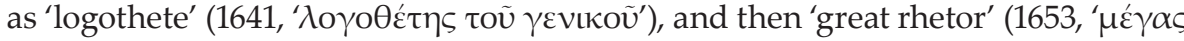

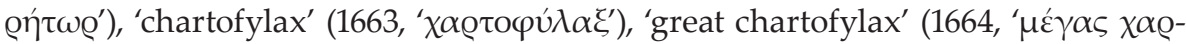

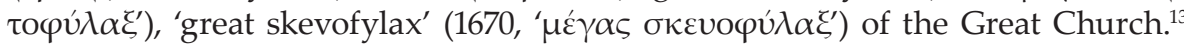
Later on, in 1676, Patriarch Dionysios IV (1671-1673, 1676-1679, 1682-1684, 16861687, 1693-1694) elevated him to the position of the 'great logothete', the head of the Patriarchal chancellery. ${ }^{14}$ His close friend, the Wallachian prince Radu Leon (1664-1669), invited him to Bucharest to act as chief treasurer for three years (16661668/9). ${ }^{15}$ Indeed, his name as 'Giannakis the Treasurer' ('Ianache Vistiernicul' or 'Ianache vel vistiar') is to be found in several documents issued during the last years of Radu Leon's rule as prince of Wallachia. ${ }^{16}$ Finally, after the 'endemousa'

Grigorie Palama scrisă în Ungrovlahia sfântului voievod Constantin Brâncoveanu', in N. Chifăr, I. O. Abrudan and P. Guran (eds), Epoca lui Constantin Brâncoveanu în context sud-est european: Biserică, Societate, Geopolitică (Sibiu 2014) 95-7; Olar, 'Un temps pour parler', 239-42; O.-V. Olar, La boutique de Théophile : les relations du patriarche de Constantinople Kyrillos Loukaris (1570-1638) avec la Réforme (Paris 2019) 324-8; C. G. Rene, In Search of a Confessional Identity: Dositheos Notaras, the Patriarch of Jerusalem (1669-1707), confronts the Challenges of Modernity (PhD Thesis) (University of Minnesota, Minneapolis-Saint Paul MN 2020) 144-9. This long bibliographical list can be enlarged with other entries (especially Greek titles) included in:

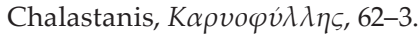

9 See the fifth chapter, entitled 'Regarding logothetis' heresy', of Book 13 of the History concerning the Patriarchs of Jerusalem by Dositheos II, Patriarch of Jerusalem, in Papadopoulos-Keramefs (ed.), Avód $\varepsilon \kappa \tau \alpha, 300$.

10 Dositheos, Treatise, 69; a letter of Konstantinos Goulianos to Ioannis Karyofyllis, in Gedeon,

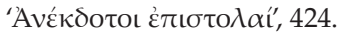

11 For more information on Theofilos Korydallefs, see Tsourkas, Théophile Corydalée; Tzirakis, Пع $\rho i$

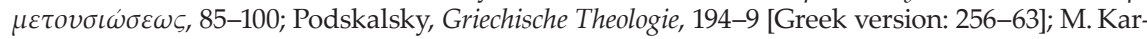

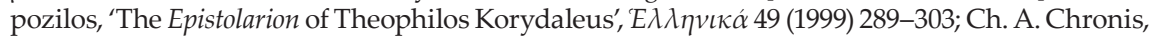

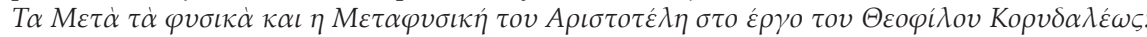

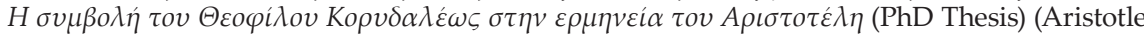

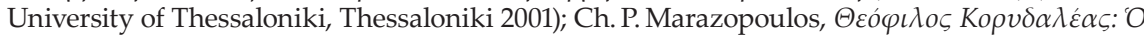

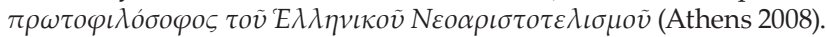

12 Most likely the maximum time frame of his term as rector of the Patriarchal School would

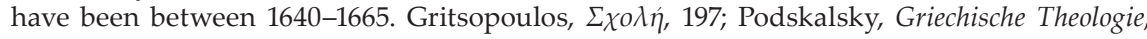
237-8 [Greek version: 306].

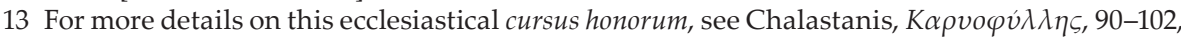
$106-29$.

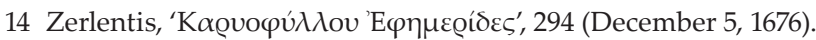

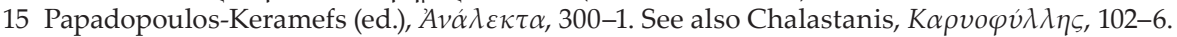

16 For more information, see Năsturel, 'Cariofil', 512-6; N.Stoicescu, Dicționar al marilor dregători din Țara Românească și Moldova (sec. XIV-XVII) (Bucharest 1971) 198-9; Chalastanis,

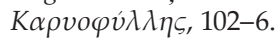


Synod in Constantinople (February 1691), Karyofyllis left the capital city on the Bosphorus for Bucharest (Summer 1692), where he died (September 22, 1692) and was buried (September 23, 1692) at the Radu-Vodă Monastery. ${ }^{17}$

The second person involved in this quarrel is the famous Patriarch of Jerusa-

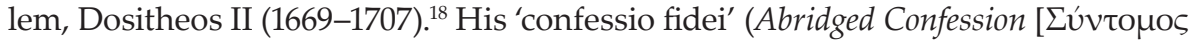

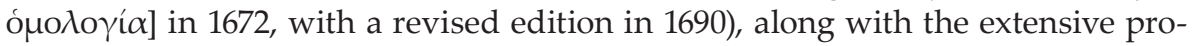
gramme of printing the anti-Latin and anti-Calvinist treatises of Symeon of Thessaloniki, Georgios Koressios, Nektarios of Jerusalem, Maximos Peloponnisios, and Meletios Syrigos in Iași, Bucharest, or Râmnic made him one of the leading figures

17 The exact date (September 22, 1692) was indicated by both the former Patriarch Dionysios IV of Constantinople, then temporarily retired in Wallachia, in his letter to the ' $\mu \varepsilon \gamma_{\alpha} \alpha$ $\dot{\varepsilon} \kappa \kappa \lambda \eta \sigma i ́ \alpha \varrho \chi 0 \varsigma^{\prime}$ Ralakis Karyofyllis, dated October 2, 1692. This unedited document is kept in the Greek manuscript collection of Romanian Academy (Bucharest, Biblioteca Academiei Române [= BAR], Ms. gr. 974 [Diktyon 11048], f. 163r-v). For more information about this letter, see N. Camariano, Catalogul manuscriselor grecești, II (Bucharest 1940) 94-5 (n. 102); Năsturel, 'Cariofil', 523 (inaccurate date: September 28 instead of September 22)] and the anonymous author who assembled Karyofyllis' 'Ephemerides', in his short introduction about the latter's

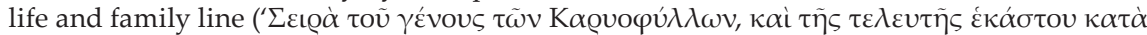

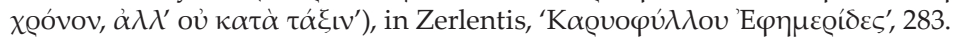

18 An updated bibliography on Dositheos is available in: Podskalsky, Griechische Theologie, 282-94 [Greek version: 357-71]; K.-P. Todt, 'Dositheos II. von Jerusalem', in C. G. Conticello and V. Conticello (eds), La théologie byzantine et sa tradition, II (XIIIe-XIXe s.) (Turnhout 2002)

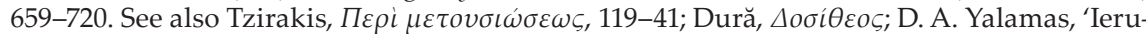
salimskij patriarh Dosifej i Rossija. 1700-1706 gg. Po materialam Rossijskogo gosudarstvennogo arhiva drevnih aktov. Chast' 2 (1701 g.)', in Rossiia i Khristianskii Vostok 2-3 (2004) 472-92;

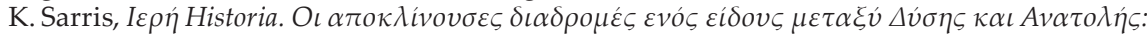

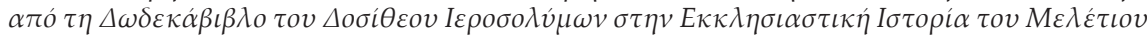

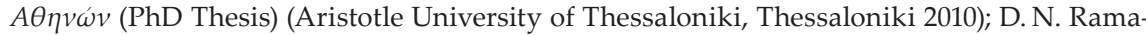
zanova, 'Istorija Ierusalimskih patriarhov ... Dosifeja Notara (Buharest, 1715): bytovanie i perevod', in Rumjancevskie chtenija 2011, II (Moscow 2011) 56-60; N. Russell, 'From the Shield of Orthodoxy to the Tome of Joy: the Anti-Western Stance of Dositheos II of Jerusalem (1641-1707)', in G. E. Demacopoulos and A. Papanikolaou (eds), Orthodox Constructions of the West (New York 2013) 71-82; Ică Jr., 'Patriarhul Dositei', 81-118; Olar, 'Un temps pour parler', 215-50; S. Garnier, 'Lédition Dosithée (1683) des Opera omnia de Syméon de Thessalonique', Annuaire de l'École Pratique des Hautes Études (EPHE). Section des sciences religieuses. Résumé des conferences et travaux 123 (2014-2015) 215-28; D. N. Ramazanova, 'Istorija Ierusalimskih patriarhov Dosifeja v russkoj kul'ture XVIII-XIX vv.' and D. A. Yalamas, 'Ierusalimskij patriarh Dosifej i Rossija. 1700-1706 gg. Po materialam Rossijskogo gosudarstvennogo arhiva drevnih aktov. Chast' 1 (1700 g.)', in Rossiia i Khristianskii Vostok 4-5 (2015) 435-58 and 593-647, respectively; V. Kontouma, 'Christianisme orthodoxe. Recherches sur Dosithée II de Jérusalem (1669-1707)', Annuaire de l'École Pratique des Hautes Études (EPHE). Section des sciences religieuses. Résumé des conferences et travaux 124 (2015-2016) 207-18; V. Kontouma, 'La Confession de foi de Dosithée II de Jérusalem: les versions de 1672 et de 1690', in M.-H. Blanchet and F. Gabriel (eds), L'Union à l'épreuve du formulaire : professions de foi entre Églises d'Orient et d'Occident (XIIIe-XVIIIe siècle) (Leuven-Paris-Bristol CT 2016) 341-72; D. Moschos, 'Approaching the Byzantine Past in the Historical Work of Dositheos of Jerusalem and Meletios of Athens', in A. Alshanskaya, A. Gietzen and Chr. Hadjiafxenti (eds), Imagining Byzantium: Perceptions, Patterns, Problems (Mainz 2018) 71-5; V. Kontouma, 'Christianisme orthodoxe, XVe-XXIe siècles', Annuaire de l'École Pratique des Hautes Études (EPHE). Section des sciences religieuses. Résumé des conferences et travaux 126 (2019) 239-53. 
of the Orthodox world in the seventeenth century. Dositheos pursued a strict ecclesiastical career: ordained deacon in 1652 (at the age of eleven!), ${ }^{19}$ archdeacon in 1661, and archbishop of Caesarea in Palestine in 1666, finally being elected to continue the pastoral oversight over the Holy Land after the resignation on grounds of infirmity of Patriarch Nektarios in 1669.

Despite their longstanding friendship, ${ }^{20}$ Karyofyllis and Dositheos did not frequent the same intellectual circles in Constantinople. Thus, through his professor, Theofilos Korydallefs, the future Great Logothete was directly connected with the party around the former Patriarch Kyrillos Loukaris (1620-1623, 1623-1633, 16331634, 1634-1635, 1637-1638), ${ }^{21}$ while Dositheos, on the other hand, was an ardent admirer of Meletios Syrigos (1585-1663), ${ }^{22}$ the great theologian who corrected and in 1642 translated into Greek the Orthodoxa Confessio Fidei of Petro Mohyla, Metropolitan of Kiev. ${ }^{23}$ Considering this background, the theological discrepancies between Karyofyllis and Dositheos at the local Synod in Constantinople in 1691 can be seen in a new light.

Their theological debate had its origin in the Greek terminology employed by Patriarch Dositheos in his confession of faith ratified by the Council in Jerusalem

19 For a brief comment on the uncanonical age of Dositheos' ordination as deacon, see Russell, 'Anti-Western Stance', 287.

20 According to Karyofyllis, their friendship lasted for about forty years. This information is given in two letters addressed to protosynkellos Chrysanthos Notaras in September 1690.

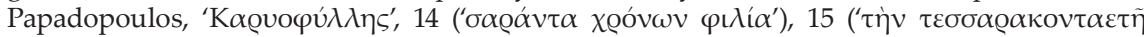
$\varphi\left(\lambda \mathbf{i}^{\prime} \alpha v^{\prime}\right)$. The dates of the two letters were discussed in ibid., 10-11. Nevertheless, the information should not be taken ad litteram, since in 1650 Dositheos was only nine years old. On the other hand, taking into consideration the future patriarch's precocious ecclesiastical career, most probably Karyofyllis was not exaggerating too much.

21 An extended and updated bibliography (including references to unedited manuscripts) related to the Patriarch Kyrillos I Loukaris of Constantinople is available in Olar, La boutique de Théophile, 351-76. See also M. M. Bernatskij, 'Kirill I Lukaris', in Pravoslavnaja Enciklopedija, XXXIV (Moscow 2014) 553-9; V. Nosilia and M. Prandoni (eds), Trame controluce: Il patriarca protestante Cirillo Lucaris (Firenze 2015); Kermeli, 'Loukaris' Legacy', 737-53.

22 For more details on the life and work of Meletios Syrigos, see A. Papadopoulos-Keramefs, ' $\Sigma \eta$ -

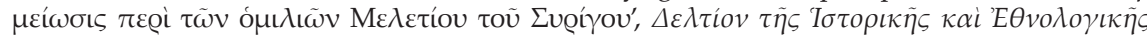

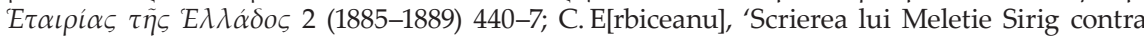
Calvinilor şi a lui Ciril Lucaris, compusă prin ordinul Sinodului ținut în Iaşi la 1642', Biserica Orthodoxă Română 18 (1894-1895) 6-27; A. Elian, 'Contribuția grecească la Mărturisirea Ortodoxă',

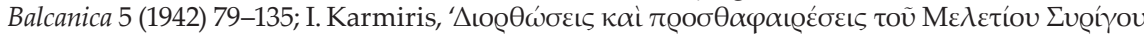

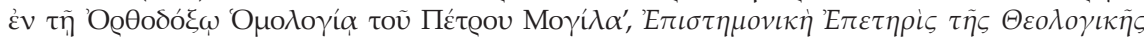

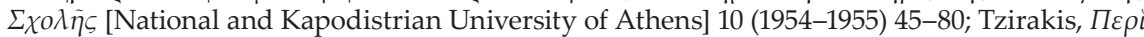

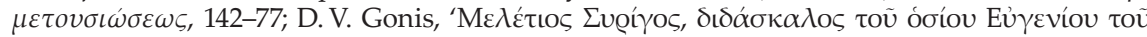

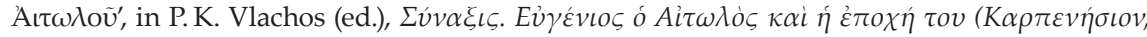

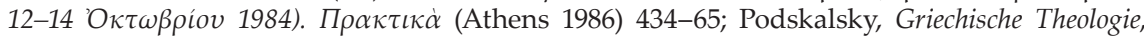
207-13 [Greek version: 271-8]; V. Tchentsova, 'Les documents grecs du XVIIe siècle: pièces authentiques et pièces fausses. 3. Mélétios Syrigos, véritable auteur de la lettre adressée au patriarche de Moscou Nikon par les zôgraphoi Jean et Georges', Orientalia Christiana Periodica 73 (2007) 311-45; V. Tchentsova, 'Meletij Sirig', in Pravoslavnaja Enciklopedija, XLIV (Moscow 2016) 591-4.

23 For the most important bibliographical references on Mohyla's Orthodoxa Confessio Fidei see supra footnote 6. 
(1672). ${ }^{24}$ Hence, in chapter 17, where he emphasized the real presence of Christ in the Eucharist, the patriarch decided to use the Greek word for the Latin 'trans-

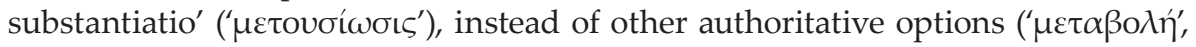

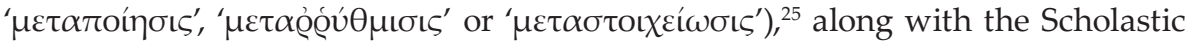

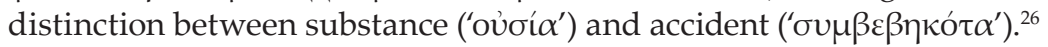

The paradox is that although Dositheos II claimed to defend the conservative Orthodox tradition, fighting against both Calvinist and Roman-Catholic influences upon the Eastern Christian flock, he deliberately decided to employ a term borrowed from Latin theology, which not only underlined the real presence of Christ in the Eucharist but had other connotations as well. Theologically speaking, 'transubstantiation' was obviously related to the Aristotelian philosophical explanation by Thomas Aquinas of how the mystery of the Holy Eucharist 'happens and how it is made'. Related to these questions, the Orthodox view was clearly stated by John of Damascus (c. 655-c. 745):

[t]he Body is truly united to the divinity, the Body from the Holy Virgin, not that this assumed body is taken from the heavens, but the very bread and wine are transformed into God's Body and Blood. If you enquire how

24 For more information on this Council, see A. V. Gorskij, 'O Sobore Ierusalimskom 1672 goda', Pribavlenija k Tvorenijam sv. Otcov 24 (1871) 568-620; Palmieri, Dositeo, 15-24; Karmiris, 'O $\rho$ -

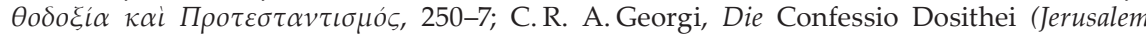

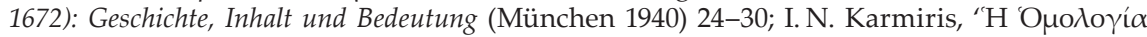

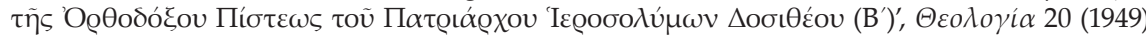

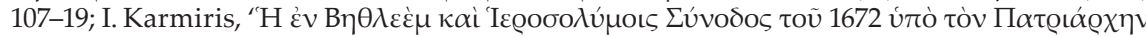

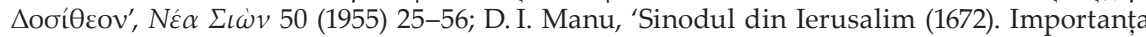
lui pentru întărirea Ortodoxiei secolului al XVII-lea', Glasul Bisericii 33 (1974) 445-53; Manu, 'Importanța Sinoadelor Răsăritene', 56-67; Kontouma and Garnier, '1672: Concilium Hierosolymitanum', 265-327. For a broader picture of the French mission in the Levant (1670-1673), involving both the Orientalist Antoine Galland and the diplomat Charles-Marie-François Olier, marquis de Nointel, and its success in the religious affaires, see [P. Nicole], La perpétuité de la foy de l'Église catholique touchant l'eucharistie deffendue contre les livres du sieur Claude, Ministre de Charenton, III (Paris 1674) 561-810; [Renaudot], La perpétuité de la foy sur les sacrements, 42-4; Antoine Galland, Journal d'Antoine Galland pendant son séjour à Constantinople (1672-1673), 2 vols, ed. Ch. Schefer (Cambridge 2012); A. Vandal, L'odyssée d'un ambassadeur: les voyages du marquis de Nointel (1670-1680) (Paris 1900); C. Michaud, 'Raison d'État et conscience chrétienne. L'ambassade du marquis de Nointel auprès de la Porte ottomane', Revue des Études SudEst Européennes 17 (1979) 257-67; Hamilton, 'From East to West', 85-92; Gabriel, 'Les témoins orientaux d'une querelle latine', 379-84.

25 This Greek terminology used during the Byzantine period to express the real presence of Christ in the Eucharist is exhaustively analysed in J. Betz, Die Eucharistie in der Zeit der griechischen Väter, I/1 (Freiburg 1955) 308-18. See also J. Betz, Eucharistie: in der Schrift und Patristik (Freiburg-Basel-Wien 1979) 86-141.

26 See the Greek original text of this chapter (revised edition in 1690) in Karmiris, $M v \eta \mu \varepsilon i \tilde{\alpha}$, 761-4; especially p. 763-4, for the use of ' $\mu \varepsilon \tau \sigma o v \sigma i \omega \sigma \iota \varsigma^{\prime}$. For the use of Latin terminology in

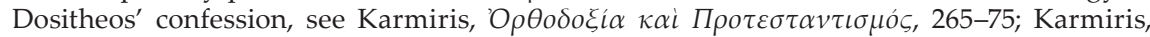

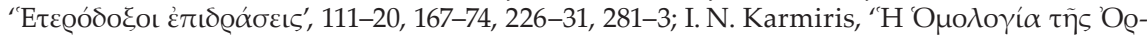

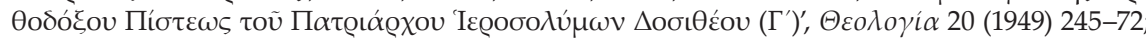

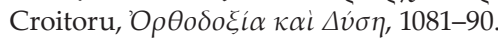


this happens, it is enough for you to know that it happens through the Holy Spirit, in the same way as the Lord has created flesh for Himself and in Himself from the Holy Mother of God through the Holy Spirit. And we know nothing more, but that the word of God is true, and efficient, and omnipotent, but the way it works is impossible to examine. ${ }^{27}$

What is more, this Eucharistic theology was not the only obvious Latin influence on Dositheos' 'confessio fidei'. The Patriarch of Jerusalem extended the list of the Old Testament canonical texts with the so-called 'deuterocanonical' books, in line with the decisions of 'Concilium Tridentinum' (1546) ${ }^{28}$ and the permanent

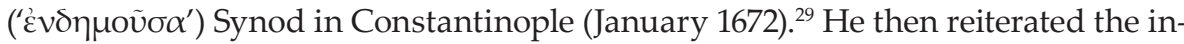
terdict on reading the Scriptures by the common people, ${ }^{30}$ and, going even further, included the doctrine of Purgatory as the intermediate state between heaven and hell, where some of those ultimately destined for Paradise must first undergo purification. ${ }^{31}$ As a result of his study of the late Byzantine authors, this view of

27 John of Damascus, Die Schriften des Johannes von Damaskos, ed. B. Kotter, II (Berlin-New York

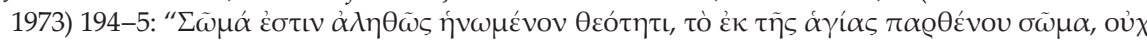

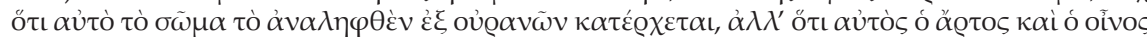

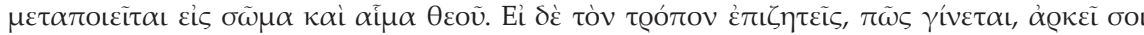

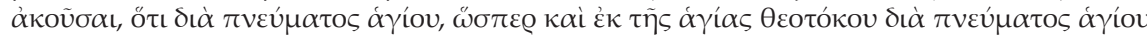

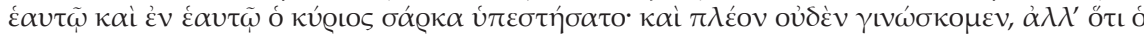

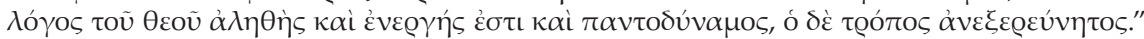
For the annotated French translation, see John of Damascus, La foi orthodoxe, II. (45-100), ed. B. Kotter, transl. P. Ledrux and G.-M. de Durand [Sources chrétiennes 540] (Paris 2011) $210-1$. For further bibliography on John of Damascus, see V. Kontouma, John of Damascus: New Studies on his Life and Work (Farnham-Burlington VT 2015); P. Schadler, John of Damascus and Islam: Christian Heresiology and the Intellectual Background to Earliest Christian-Muslim Relations (Leiden-Boston 2018). The great influence of John of Damascus' Expositio fidei upon the seventeenth-century Orthodox theology is clearly expressed in the high number of citations by Petro Mohyla in his Orthodoxa Confessio Fidei. Malvy and Viller, La Confession orthodoxe, 171-5.

28 For the original Latin text of this decree, approved during the fourth session of the Council, on April 8, 1546, see K. Ganzer, '1545-1563: Concilium Tridentinum', in K. Ganzer, G. Alberigo and A. Melloni (eds), Conciliorum Oecumenicorum Generaliumque Decreta, III (Turnhout 2010) 15-16.

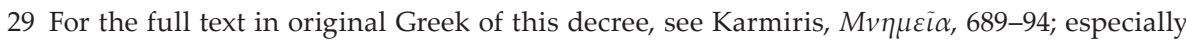
p. 693, for the discussion about the list of the Old Testament canonical texts. Also see E. Pentiuc, The Old Testament in Eastern Orthodox Tradition (New York 2014) 126-8. For a different opinion on this issue, underlining that the extended list of the Old Testament books given by Dositheos is not a Roman-Catholic influence, but a rightful revision according to the Christian tradition from the first centuries, see A. Mihăilă, 'În multe rânduri și în multe chipuri': $O$ scurtă introducere ortodoxă în Vechiul Testament (Iași 2017) 29-31.

30 Despite the opinion that the list of the Old Testament books given by Dositheos is a genuine Orthodox tenet (see supra footnote 29), the above-cited scholar interpreted this issue as being inspired by the Roman-Catholic Counter-Reformation: Mihăilă, Vechiul Testament, 67-9, especially p. 69. For a pertinent analysis of Dositheos' position regarding the Scriptures, see

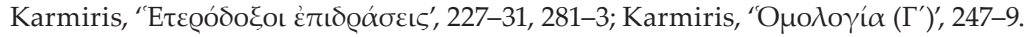

31 See the Greek original texts of the three issues (revised edition in 1690) in Karmiris, Mv $\eta \mu \varepsilon \tilde{\varepsilon} \alpha$, 764-70. 
Purgatory was later corrected for the revised edition published in Bucharest in $1690,{ }^{32}$ though account of the real presence of Christ in the Eucharist was not. ${ }^{33}$

32 Compare the revised version (1690) of chapter 18 indicated above (see supra footnote 31) with the original text (written in 1672, editio princeps in 1676): M. F[oucqueret] (ed.), Synodus Bethlehemitica adversus Calvinistas haereticos, Orientalem Ecclesiam de Deo rebusque divinis haeretice cum ipsis sentire mentientes, pro reali potissimum praesentia, anno MDCLXXII sub Patriarcha Jerosolymorum Dositheo celebrata (Paris 1676) 298-303. For a comparative theological approach to the

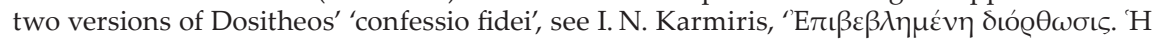

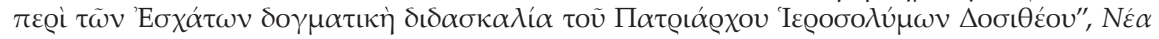
$\Sigma \iota \omega े v 40$ (1945) 184-205; Todt, 'Dositheos', 696-706, 713-20 (an annotated German translation of this chapter in 1672 and 1690 editions); Kontouma, 'La Confession de foi de Dosithée', 341-72. According to V. Kontouma, this correction of the initial statement on purgatory by Patriarch Dositheos in the revised edition of his 'confessio fidei' (September 1690) was a result of the 'wise advice' he received from the Great Logothete. This conclusion is at least questionable since, precisely in September 1690, in one of his two letters addressed to hieromonk Chrysanthos Notaras, Karyofyllis described Dositheos as the defender of two Latin innovations:

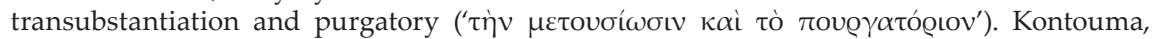
'Christianisme orthodoxe', 249.

33 Indeed, sometime after 1672 Dositheos started to scrutinize the late Byzantine theological writings to prepare his extensive editorial project (1682-1705) that included several authors like Symeon of Thessaloniki, Marc of Ephesus, Macarius of Ancyra, John Eugenikos, Makarios Makris, Theodoros Agallianos, Gregory Palamas, Philotheos Kokkinos, Gennadios Scholarios and Matthew Blastares, along with some other anonymous tracts belonging to the same period (fourteenth centuy to first half of fifteenth century). Certainly, a mere survey of these theological productions highlighted the needed revision of his chapter on Purgatory in order to adjust it to the Greek discourse presented during the Ferrara debates (June 4-July 17, 1438). For more information on the Latin-Byzantine conversations on Purgatory in 1438, see L. Petit, Documents relatifs au Concile de Florence, I (Paris 1927); G. Hofmann, 'Erstes Gutachten der Lateiner über das Fegfeur. Text mit Einführung', Orientalia Christiana 16 (1929) 257-302; G. Hofmann, 'Zweites Gutachten der Lateiner über das Fegfeur. Text mit Einführung', Orientalia Christiana 17 (1930) 183-244; Mark of Ephesus, Opere, I (Bucharest 2009) 454-645; I. N. Ostroumov, The History of the Council of Florence (London 1861) 47-58]; M. Jugie, 'La question du Purgatoire au Concile de Ferrare-Florence', Échos d'Orient 20 (1921) 269-82; A. d'Alès, 'La question du Purgatoire au Concile de Florence en 1438', Gregorianum 3 (1922) 9-50; G. Hofmann, 'Die Konzilsarbeit in Ferrara. II. Die Sitzungen nach Ankunft der Griechen (9. März 1438-10. Januar 1439)', Orientalia Christiana Periodica 3 (1937) 418-24; J. Gill, The Council of Florence (Cambridge 1959) 118-25; J. Décarreaux, Les Grecs au Concile de l'Union Ferrare-Florence (1438-1439) (Paris 1970) 46-53; A. de Halleux, 'Problèmes de méthode dans les discussions sur l'eschatologie au Concile de Ferrare et Florence', in G. Alberigo (ed.), Christian Unity: The Council of Ferrara-Florence, 1438/39-1989 (Leuven 1991) 251-99. On the other hand, the same intellectual immersion in the late Byzantine theology convinced Dositheos that his explanation on the real presence of Christ in the Eucharist is accurate, since even Gennadios Scholarios (see infra footnote 57), famous anti-unionist and the first patriarch under the Ottoman rule (1454-1456), used a similar terminology. For more information regarding Gennadios' Eucharistic theology, see E. Renaudot (ed.), Gennadii Patriarchae Constantinopolitani, Homiliae de Sacramento Eucharistiae: Meletii Alexandrini, Nectarii Hierosolymitani, Meletii Syrigi, et aliorum, de eodem argumento opuscula graece et lat., seu appendix ad acta quae circa Graecorum de transubstantiatione fidem relata sunt in opere de perpetuitate fidei (Paris 1709) 1-29; Georgios-Gennadios Scholarios, CEuvres complètes de Georges Scholarios, eds L. Petit, X. A. Sidéridès and M. Jugie, I (Paris 1928) 123-36; Jugie, 'Transsubstantiation', 10; M. Jugie, 'La forme de l'Eucharistie d'après Georges Scholarios',

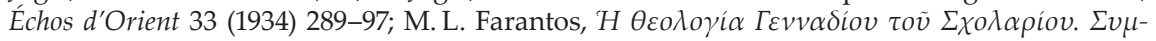

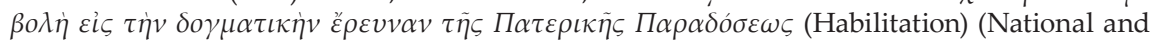


Taking everything into consideration, the 'orthodoxy' of the famous Patriarch of Jerusalem becomes at the very least questionable.

\section{'The heresy of Calvin against the Sacrament'}

According to two biased sources of Dositheos II of Jerusalem, Karyofyllis rejected the Latin transubstantiation and, implicitly, the terminology translated into

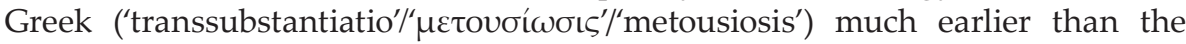
events that preceded the local Synod in Constantinople (1691). Thus, he mentioned that, in 1644-1645, 'Ioannis Vyzantios' (i.e. Karyofyllis), instigated by his mentor,

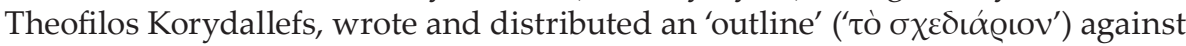
the term 'metousiosis'. For this reason, he was summoned and threatened with excommunication by the Patriarch Parthenios II of Constantinople (1644-1646, 1648-1651). Only the intervention of Karyofyllis' father-in-law, the Great Oikonomos (' $\mu \varepsilon^{\prime} \gamma \alpha \varsigma$ oikovó $\mu \varsigma^{\prime}$ ') of the Great Church, and the remorse showed by himself changed the mind of the patriarch, who granted forgiveness to the 'heretic' after he anathematized his own writing and theological ideas. Later on, both Meletios Syrigos and Patriarch Nektarios of Jerusalem unsuccessfully attempted to expose him as a heretic and to convert him to Orthodoxy. ${ }^{34}$

De facto Karyofyllis wrote this outline against the term 'metousiosis' in 1641, during the term of the Patriarch Parthenios I the Elder (July 1639-September 1644); ${ }^{35}$ this quickly gave rise to an open conflict on dogmatic grounds with Meletios Syrigos. ${ }^{36}$ Later on, during the term of Parthenios II, Karyofyllis was exposed as 'Ian-

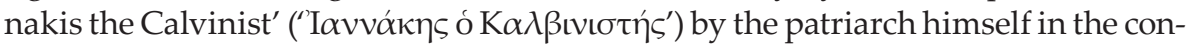
text of another theological controversy between a certain Athanasios (1571-1663), rhetor of the Patriarchal School, and Paisios/Pantaleon Ligaridis (ca 1609-1678). ${ }^{37}$

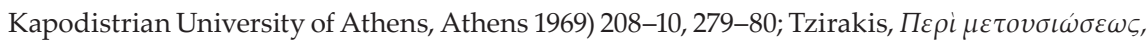
39-48; G. Podskalsky, 'De Rezeption der thomistischen Theologie bei Gennadios II. Scholarios

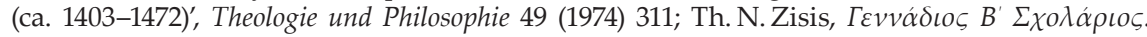

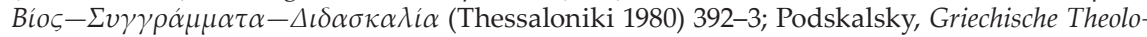
gie, 83 [Greek version: 125-6]; M. M. Bernatskij, 'Prisutstvie Hrista v Evharistii "po sushhnosti

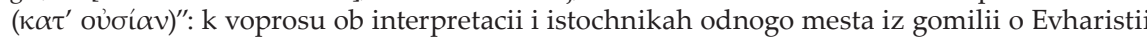
Georgija (Gennadija) Sholarija', Bogoslovskie Trudy 42 (2009) 169-82.

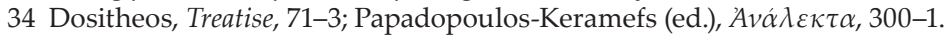

35 Both G. Podskalsky and V. Kontouma place this episode in 1644-1645, during the first term of Patriarch Parthenios II (September 1644-November 1646). Podskalsky, Griechische Theologie, 238 [Greek version: 306]; Kontouma, 'Christianisme orthodoxe', 242.

36 According to V. Chalastanis, a very short dogmatic tract, titled Inquiry and solution by himself

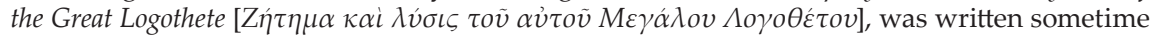
during this early stage of the Eastern controversy regarding the real presence of Christ in the Eucharist. The Inquiry was related to the ubiquity of the Body of Christ in heaven, at the right hand of the Father, and in the churches after the special prayer of invocation of the Holy Spirit

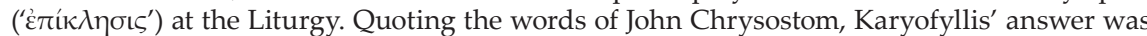
underlining the Orthodox teaching about the supernatural omnipresence of the Body of Christ.

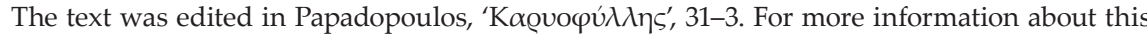

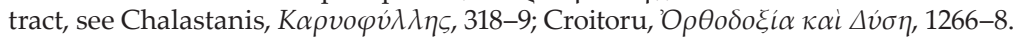

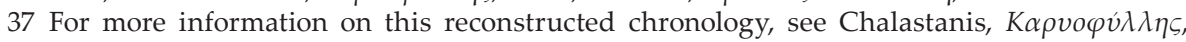


Only in the second half of 1689, in a completely different context, most likely well-informed through his contacts in Wallachia about the content of Dositheos' editorial pojects, did Karyofyllis decide to address this issue again: Great Logo-

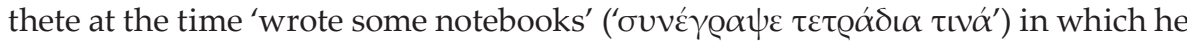

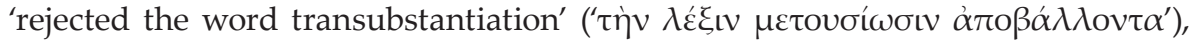
'obviously denying altogether the redemptory Sacrament of the Eucharist' (' $\tau$ '

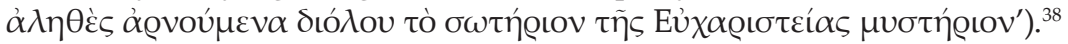

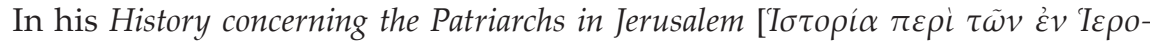
$\sigma o \lambda v ́ \mu \iota \varsigma \Pi \alpha \tau \rho \iota \alpha \rho \chi \varepsilon v \sigma \alpha \dot{v} \tau \omega v]$, Dositheos mentioned that Karyofyllis' notebooks

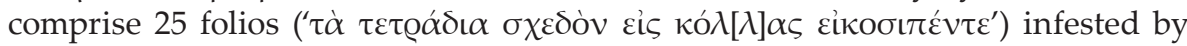

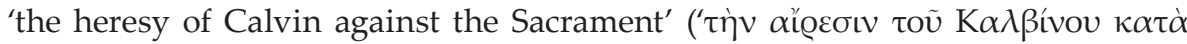

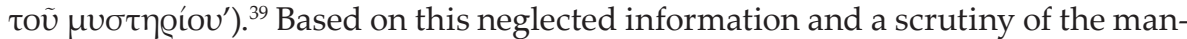
uscript tradition, Vasileios Chalastanis identified Karyofyllis' notebooks on Eucharist, divided into three parts: the first 13 folios, written in 1641, are preserved in the Greek manuscript collection of the Benaki Museum, Ms. gr. 93 (TA 250) [Diktyon 8360], f. 48r-60v (unedited, ${ }^{40}$ with the title: Evidence from the Divine words and testimonies gathered from almost all the Holy Doctors of the Church at the urge of the

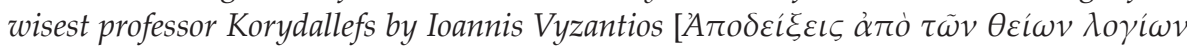

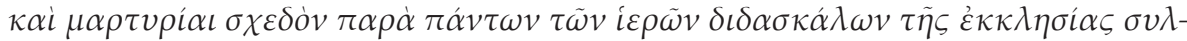

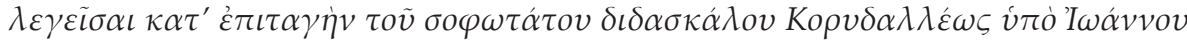
$\tau o \tilde{v} B v \zeta \alpha v \tau i o v])$; the second set, consisting of 8 folios written in 1689, is to be found both in the collection of the Athonite Monastery of Iviron, Ms. gr. 156 [Diktyon 23753], f. 33r-40v and in the National Library of Greece, fonds of the Metochion

90-4. The controversy on dogmatic issues with Meletios Syrigos was testified by Karyofyl-

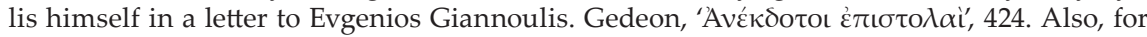
more details about these two Greek theologians, see D. J. O'Meara, 'The Philosophical Writings, Sources, and Thought of Athanasius Rhetor (ca. 1571-1663)', Proceedings of the American Philosophical Society 121 (1977) 483-99; Podskalsky, Griechische Theologie, 191-3, 251-8 [Greek version: 253-5, 321-30]; M. de Leeuw, 'Der Coislinianus 345 im Kloster Megisti Lavra (Athos)', Zeitschrift für Papyrologie und Epigraphik 131 (2000) 58-64; D. N. Ramazanova, 'Buharestskij spisok Hrismologiona Paisija Ligarida: paleograficheskoe i kodikologicheskoe issledovanie', Vestnik RGGU. Nauchnyj zhurnal (Serija Istoricheskie nauki. Istoriografija, istochnikovedenie, meto-

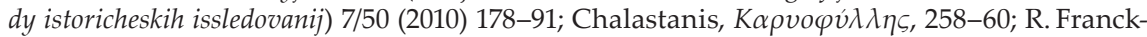
owiak, 'Athanasius Rhetor: a Greek in Paris, a Priest in Alchemy', in G. Katsiampoura (ed.), Scientific Cosmopolitanism and Local Cultures: Religions, Ideologies, Societies. Proceedings (Athens, 1-3 November 2012) (Athens 2014) 95-100; O. Olar, 'Prophecy and History. Matthew of Myra († 1626), Paisios Ligaridis († 1678) and Chrysanthos Notaras († 1731)', in R. G. Păun, Histoire, mémoire et dévotion. Regards croisés sur la construction des identités dans le monde orthodoxe aux époques byzantine et post-byzantine (Seyssel [2016]) 367-77; O. Olar, 'Païsios Ligaridēs', in D. Thomas and J. Chesworth (eds), Christian-Muslim Relations: A Biographical History, X (Leiden-Boston 2017) 282-91; O. Olar, 'The Father and His Eldest Son. The Depiction of 1667 Muscovite Palm Sunday Procession by the Metropolitan of Gaza Paisios Ligarides and its Significance', Revue de l'histoire des religions 235 (2018) 5-36.

38 Dositheos, Treatise, 74-5.

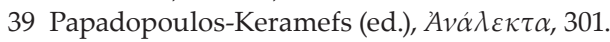

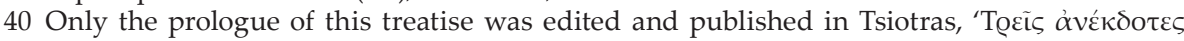
$\dot{\varepsilon} \pi\lrcorner \sigma \tau 0 \lambda \dot{\varepsilon} \zeta^{\prime}, 26-7$. 
of the Holy Sepulchre, Ms. gr. 352 [Diktyon 6749], f. 143v-150v (edited, with the title: About the Holy Communion of the immaculate Sacraments of Our Lord, Jesus Christ

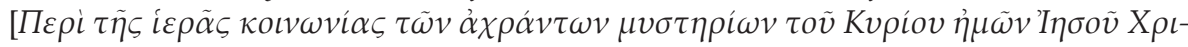
$\sigma \tau o \tilde{v}])^{41}$ and the last 4 folios, written in $1690,{ }^{42}$ are kept in the cited Greek manuscript from the collection of the Benaki Museum, Ms. gr. 93 (TA 250) [Diktyon 8360], f. 91r-94v (unedited, with the title: Other testimonies which are not in the short

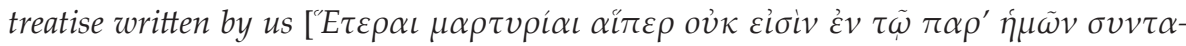
$\chi \theta \dot{v} v \tau \iota \sigma v v \tau \alpha \gamma \mu \alpha \tau i \omega]) .^{43}$

A closer look at Karyofyllis' triptych reveals an authentic 'florilegium patristi-

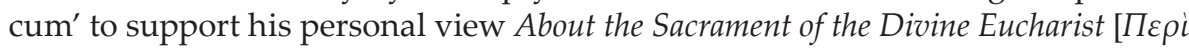

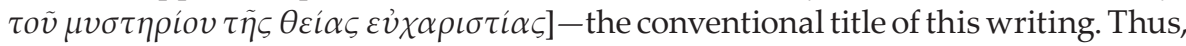
in the first part, augmented by the third one, he started to comment on a few passages from the New Testament (Synoptic Gospels, Acts and Epistles of the Apostles) and after that referred mostly (but not exclusively) to Church Fathers from the first millennium, both from the East and West (here in chronological order): Clement of Rome, Ignatius of Antioch, Justin Martyr, Irenaeus of Lyon, Clement of Alexandria, Tertullian, Cyprian of Carthage, Athanasius of Alexandria, Eusebius of Caesarea, Macarius of Egypt, Ambrose of Milan, Basil of Caesarea, Gregory of Nazianzus, John Chrysostom, Cyril of Jerusalem, Augustine of Hippo, Jerome, Cyril of Alexandria, Theodoret of Cyrus, Pope Gelasius I, Pseudo-Dionysius the Areopagite, Oecumenius, Maximus the Confessor, John of Damascus, Photius, Theophylact of Ohrid, Niketas Seides, Theodore Balsamon, and George Pachymeres. In the final part of his first text, Karyofyllis also commented on some excerpts

41 Apart of the two manuscripts cited, this text is also preserved in the Greek manuscript collections of the Athonite StPanteleimon Monastery, Panteleimon gr. 229 [Diktyon 22368], f. 363r-368r, and of the Mega Spilaio Monastery, Mega Spilaio gr. 224 [Diktyon 36409], f. 396r-400v. S. P. Lambros, Catalogue of the Greek Manuscripts on Mount Athos, II (Cambridge

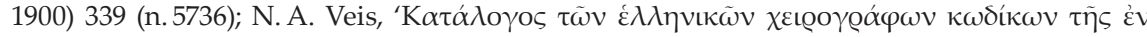

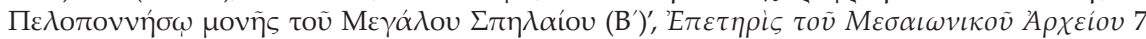
(1957) 29. V. Chalastanis mentioned on purpose only these two manuscripts: first, in both Karyofyllis' text is 8 folios long, exactly the figure needed for his argument $(13+8+4=25$ folios); second, it is more plausible that Dositheos had access to this text from a manuscript kept in his residence in Constantinople, Metochion of the Holy Sepulchre, before any other possible option from Mount Athos or Peloponnese.

42 This sequential reaction of Karyofyllis in 1690 could be connected with the publication in Bucharest (January 1690), under the editorship of Dositheos, of the anti-Latin treatise of Max-

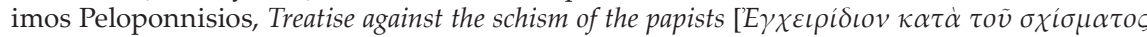
$\tau \tilde{\omega} v \pi \alpha \pi \iota \sigma \tau \tilde{\omega} v]$, including a chapter suggestively titled: 'About the change or rather transub-

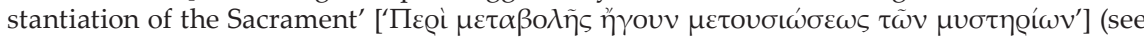
infra footnote 100).

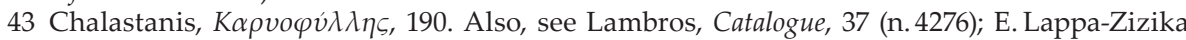

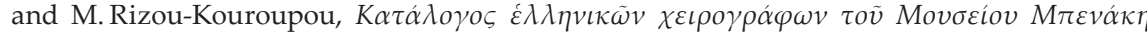

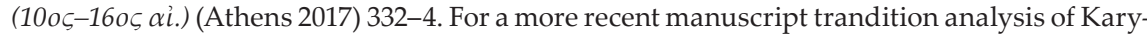
ofyllis' writings (without following Chalastanis' hypothesis), see Kontouma, 'Christianisme orthodoxe', 246-9. 
from the Divine Liturgies of John Chrysostom and Basil of Caesarea. ${ }^{44}$ Without mentioning once the famous reformer from Geneva, Jean Calvin (1509-1564), a certain influence of Institutio christianae religionis (1536) is traceable with respect to the New Testament citations (Benaki Museum, Ms. gr. 93, f. 49r-50v), but more clear when it comes to the succession of excerpts from the writings of Augustine of Hippo (Benaki Museum, Ms. gr. 93, f. 93v-94v). ${ }^{45}$

On the other hand, the second part ${ }^{46}$ of the triptych is an attack on the Western influences, based mostly on quotations from John Chrysostom: the Latins were the first to innovate and teach that the Holy Spirit proceeds from both the Father and the Son (Filioque); then there was the controversy about the use of unleavened bread (' $\alpha$ $\left.\zeta u \nu^{\prime} \varsigma^{\prime}\right)$; and, finally, the innovation regarding Eucharistic terminology, that is, to accept as a truly orthodox expression the word 'metousiosis', instead of using more traditional terms:

for the bread which is eaten is the true Body of Christ, who sits on the right side of the Father, and the wine [is] His most Holy Blood, which was shed for the redemption of the world; and do not seek out of curiosity or, rather, thoughtlessness ways of origin and change

and

the Holy Doctors [...] proclaimed these words: that the bread and wine are changed, transformed, transmuted, transelemented into the most Holy Body and Blood of our Saviour, by these words stating the supernatural and superrational change of the Sacrament into the most Holy Body, not having other words to point this out. ${ }^{47}$

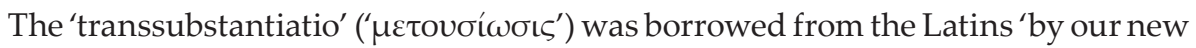

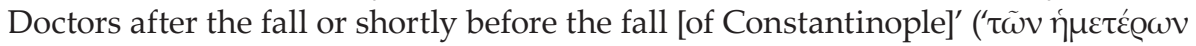

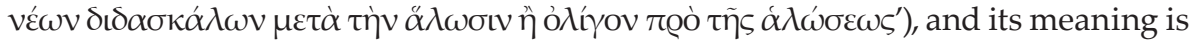

becoming a substance after another substance, with the result that such a change becomes comprehensible [...] If it is comprehensible, how [is it] a

44 For more information on the first (1641) and the third part (1690) of Karyofyllis' notebooks, see Chalastanis, K $\alpha \rho v o \varphi v ́ \lambda \lambda \eta \varsigma, 333-6,338-40$.

45 See the comparative analysis, ibid., 499-501.

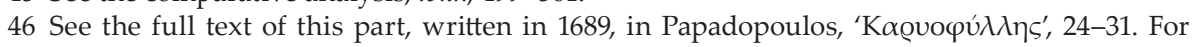

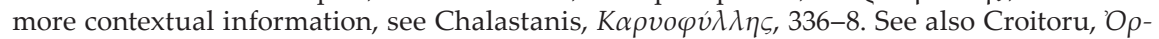

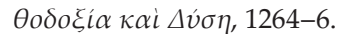

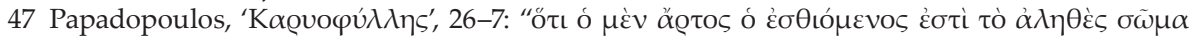

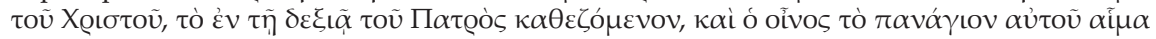

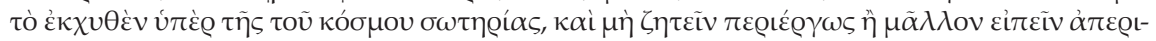

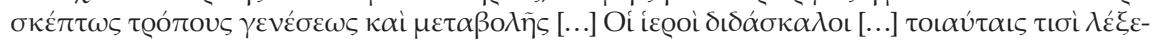

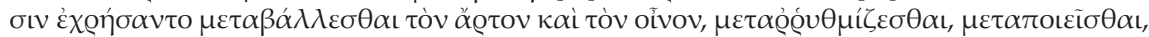

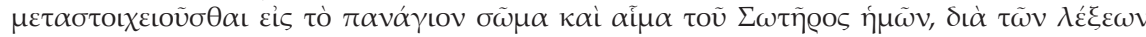

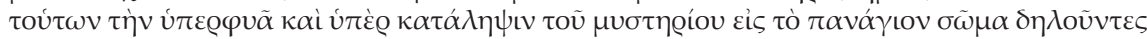

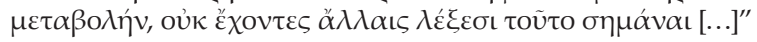


Sacrament? How [is it] spiritual worship? How [is it] a bloodless and mysterious sacrifice? For all that is understandable [is] not a Sacrament, neither supernatural, nor mystical. ${ }^{48}$

Finally, Karyofyllis strongly reaffirms that

the bread and wine on the Holy Table are sanctified through the words of the Lord recited by the minister and through his intercession and prayer are changed, transmuted, transelemented, and transformed, with the omnipotent strength of the most Holy Spirit, [in a way that is] supernatural, unspoken, mysterious, superrational, into the most Holy Body of our Lord, Jesus Christ, who stands on the right side of God and the Father. ${ }^{49}$

Based on the public statement (About the Holy Communion of the immaculate Sacraments of Our Lord, Jesus Christ-written in 1689) in which Karyofyllis rejected the orthodoxy of the expression 'metousiosis', Dositheos started to accuse him of Calvinism and that he denies the real presence of Christ in the Eucharist.

The allegations against the Great Logothete were mentioned in three letters that the latter addressed in September-October 1690 to hieromonk Chrysanthos Notaras. ${ }^{50}$ In the first epistle, ${ }^{51}$ Karyofyllis tried to convince the beloved nephew of

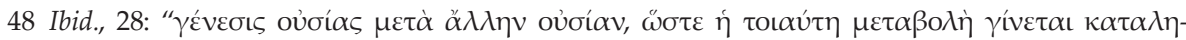

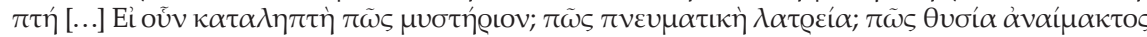

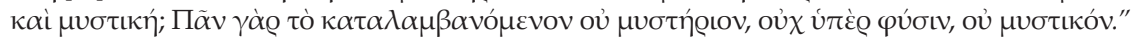

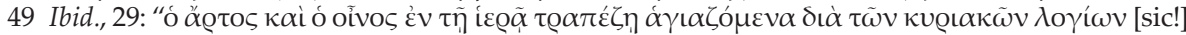

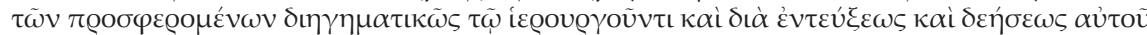

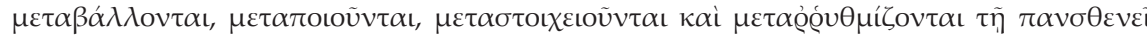

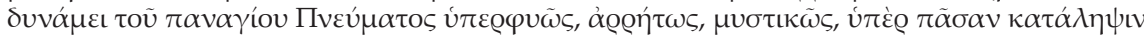

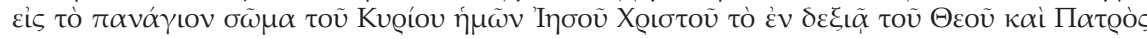
$\kappa \alpha \theta \eta \dot{\mu \varepsilon v o v . " ~}$

50 For more information about Chrysanthos Notaras, Patriarch of Jerusalem (1707-1731), see

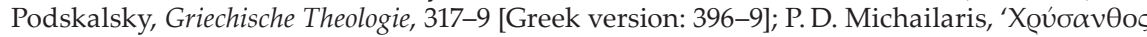

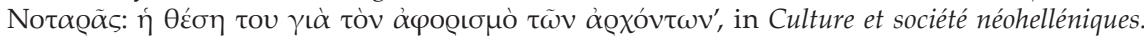
Actes d'un Congrès International dédié à la mémoire de C. Th. Dimaras (Athens 1995) 43-50; P. Sta-

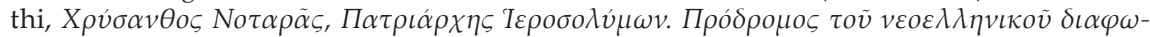

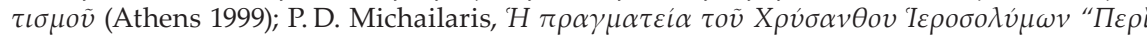

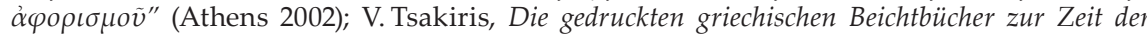
Türkenherrschaft. Ihr kirchenpolitischer Entstehungszusammenhang und ihre Quellen (Berlin-New York 2009) 209-42; D. N. Ramazanova, 'Ekzempljary sochinenij Ierusalimskogo Patriarha Hrisanfa Notara v sobranii muzeja knigi RGB', in Vivliofika: Istorija knigi i izuchenie knizhnyh pamjatnikov, II (Moscow 2011) 166-86; D. N. Ramazanova, 'Spiski propovedej Ierusalimskogo Patriarha Hrisanfa Notary v perevodah Stefana Pisareva (1741-1760-e gg.)', in Y. Shustova (ed.), Vspomogatel'nye istoricheskie discipliny v sovremennom nauchnom znanii. Materialy XXV Mezhdunarodnoj nauchnoj konferencii Moskva, 31 janvarja-2 fevralja 2013 g., II (Moscow 2013) 490-5; D. N. Ramazanova, 'Perevody sochinenij Ierusalimskogo Patriarha Hrisanfa Notary v russkih spiskah XVIII v.', in B. L. Fonkich (ed.), Special'nye istoricheskie discipliny, I (Moscow 2014) 317-47; D. N. Ramazanova, 'Propovedi Ierusalimskogo Patriarha Hrisanfa Notary v russkoj rukopisnoj tradicii XVIII v.', Vestnik RGGU. Nauchnyj zhurnal (Serija Istorija. Filologija. Kul'turologija. Vostokovedenie) 9/152 (2015) 97-105; Olar, 'Prophecy and History', 365-88. 
the Patriarch Dositheos II to act as his advocate, since he had no interest in the case of the jurisdiction over Saint Catherine's Monastery on Mount Sinai. ${ }^{52}$ Obviously, Karyofyllis thought that his alleged support of the deposed Archbishop of Sinai, Ananias, was the major reason behind the recent change of mind of the patriarch.

In the second letter ${ }^{53}$ he shared the news that, in order to spread the accusations,

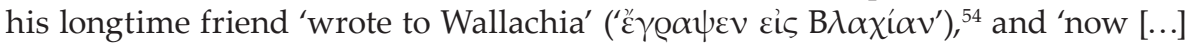
that one [Dositheos] writes and speaks [about him] the nasty name of [the one] living in a hut, Calvinist, [the one] made of a stalk' (' $\tau \omega \varrho \alpha[. ..] \gamma \varrho \alpha ́ \alpha \varepsilon \iota ~ \kappa \alpha i ~ \lambda \varepsilon ́ \gamma \varepsilon \iota$

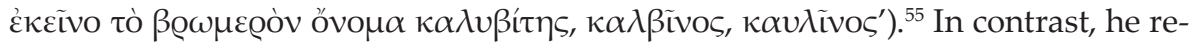
fuses to call the Patriarch of Jerusalem a 'papist', although he says he would have sufficient reason to do so since the patriarch defended 'transubstantiation and

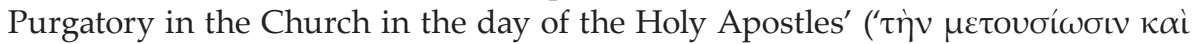

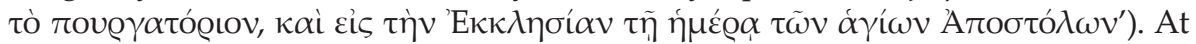
the end of his epistle, Karyofyllis points out the major difference between the two lines of argumentation:

I demonstrate my views from the Church Fathers, let us see from where he [Dositheos] demonstrates his views. Ours is not the faith of Koressios, ${ }^{56}$ and Gennadios, ${ }^{57}$ and Symeon, ${ }^{58}$ and Syrigos, ${ }^{59}$ but the faith that the God-bearing

51 See the full text of this letter in Papadopoulos, 'K $\alpha \varrho v o \varphi v ́ \lambda \lambda \eta \varsigma^{\prime}, 14-15$.

52 This jurisdictional dispute lasted for more than two decades (1670-1692): starting with the deposition of Archbishop Ananias of Sinai by the permanent Synod in Constantinople (1670) and continuing until his death (1692), when the monastery finally accepted the decision. For more information on this issue and the connection with Karyofyllis, see Dură, $\Delta \circ \sigma i \theta \varepsilon o \varsigma, 149-$

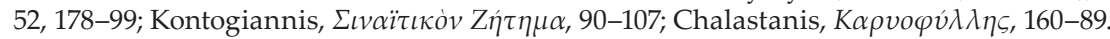

53 See the full text of this letter in Papadopoulos, 'K $\alpha \varrho v o \varphi v ́ \lambda \lambda \eta \varsigma^{\prime}, 15-16$.

54 Most probably, Karyofyllis was informed about the edition of Maximos Peloponnisios' Treatise against the schism of the papists, published in Bucharest in January 1690. On the other hand, during the very same month (September 1690) the Wallachian printing press in Bucharest published in a single volume, two anti-Calvinist works, under the editorship of Patriarch Dositheos: the first was Meletios Syrigos' Refutation against the Calvinist chapters and questions of Ky-

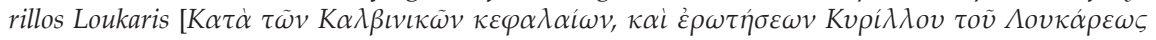

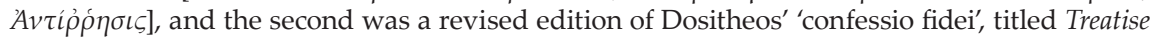
against the Calvinist Madness ['E $\gamma \chi \varepsilon \iota \rho i \delta \iota 0 v \kappa \alpha \tau \dot{\alpha} \tau \tilde{\eta} \varsigma \kappa \alpha \lambda \beta \iota v \iota \tilde{\eta} \varsigma \varphi \rho \varepsilon v o \beta \lambda \alpha \beta \varepsilon i \alpha \varsigma]$, with a special emphasis on the chapter 17 about the real presence of Christ in the Eucharist (see infra footnote 100). Therefore, through his very well-informed people in Wallachia, it is possible that already at the time of this missive the Great Logothete may have heard about this editorial project.

55 In original Greek it is a deliberate wordplay, misspelling twice the intended word: 'Calvinist'.

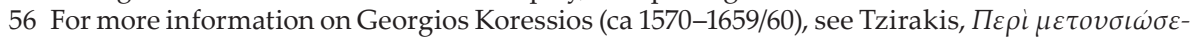
$\omega \varsigma$, 194-234; Podskalsky, Griechische Theologie, 183-90 [Greek version: 244-52]; N. M. Stoupa-

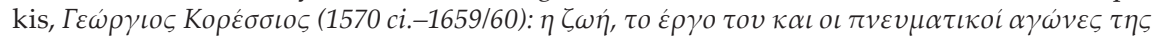
$\varepsilon \pi 0 \chi \eta \dot{~} \tau o v$ (Chios 2000).

57 For more details about the first Patriarch of Constantinople after the Ottoman conquest (1453),

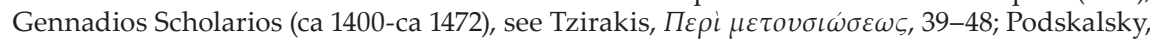
Griechische Theologie, 81-3 [Greek version: 123-6]; Ch. H. Barbour, The Byzantine Thomism of Gennadios Scholarios and His Translation of the Commentary of Armandus de Bellovisu on the De ente et essentia of Thomas Aquinas (Vatican 1993); F. Tinnefeld, 'Georgios Gennadios Scholarios', in C. G. Conticello and V. Conticello (eds), La théologie byzantine et sa tradition, II (XIIIe- 
Fathers and Doctors have explained [to us]. And we have also their commands not to dare to change either any word, or any concept. ${ }^{60}$

This short list of the Byzantine and Greek theologians given by the Great Logothete (which needs to be augmented with a few other important names: Maximos Margounios, ${ }^{61}$ Meletios Pigas of Alexandria, ${ }^{62}$ Gavriil Seviros of Philadelpheia, ${ }^{63}$

XIXe s.) (Turnhout 2002) 477-549; Ch. Livanos, Greek Traditions and Latin Influence in the Work of George Scholarios (Piscataway NJ 2006); M.-H. Blanchet, 'L'ambiguïte du statut juridique de Gennadios Scholarios après la chute de Constantinople (1453)' and D. Tsourka-Papastathi, 'À propos des privilèges octroyés par Mehmet II au patriarche Gennadios Scholarios: Mythes et réalités', in Le Patriarcat CEcuménique de Constantinople aux XIVe-XVIe siècles: rupture et continuité. Actes du colloque international, Rome, 5-6-7 décembre 2005 (Paris 2007) 195-211 and 213-74, respectively; Ch. Kappes, 'The Latin Sources of the Palamite Theology of George-Gennadius Scholarius', in J. Demetracopoulos and Ch. Dendrinos (eds), When East Met West. The Reception of Latin Theological and Philosophical Thought in Late Byzantium. Actes of the Institute of Classical Studies. International Byzantine Colloquium. London, 11-12 June 2012 (Bari 2013) 71-114; M.-H. Blanchet, Georges-Gennadios Scholarios (vers 1400-vers 1472). Un intellectuel orthodoxe face à la disparition de l'Empire byzantine (Paris 2008); M. C. Briel, A Greek Thomist: Providence in Gennadios Scholarios (Notre Dame 2020).

58 It is not clear who this Symeon could be, but it is likely that Karyofyllis had in mind the Byzantine theologian Symeon of Thessaloniki (ca 1381-1429). Indeed, there is a strong connection over the centuries between Dositheos and Symeon, Metropolitan of Thessaloniki, since the Patriarch of Jerusalem edited the opera omnia of the fifteenth-century Byzantine theologian. Yet in his multiple treatises he does not mention even once the Greek word for 'transsubstan-

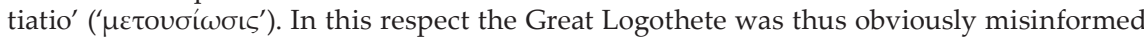
and Symeon's name should not be included in this short list. For more information about the editorial program of Dositheos regarding the works of Symeon of Thessaloniki and its context, see Garnier, 'L'édition Dosithée (1683)', 215-28.

59 For the most relevant references to the life and work of Meletios Syrigos, see supra footnote 22.

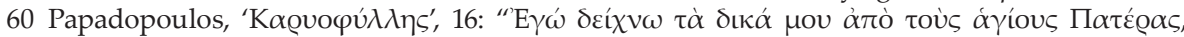

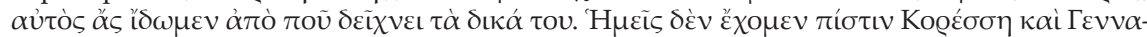

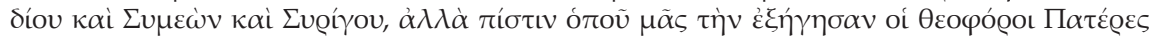

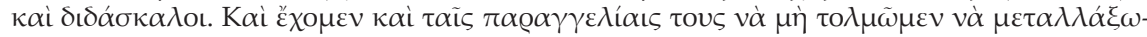

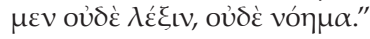

61 For more details about the life and work of the Metropolitan of Kythira, Maximos Margounios (1549-1602), see D. J. Geanakoplos, 'An Overlooked Post-Byzantine Plan for Religious Union with Rome: Maximos Margounios the Cretan Humanist-Bishop and his Latin Library Bequeathed to Mt. Athos', in D. J. Geanakoplos, Byzantine East and Latin West: Two Worlds of Christendom in Middle Ages and Renaissances. Studies in Ecclesiastical and Cultural History (Oxford 1966) 165-93, 199-200 (further bibliography); Podskalsky, Griechische Theologie, 135-51

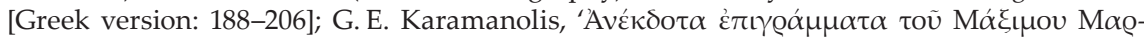

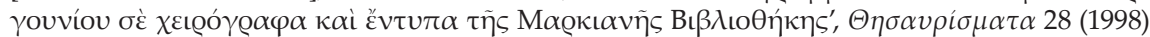

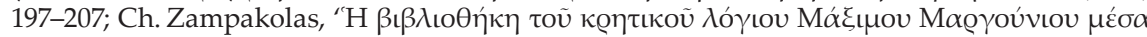

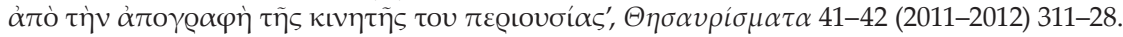

62 For more information and bibliographical references regarding the activity of the Patriarch of

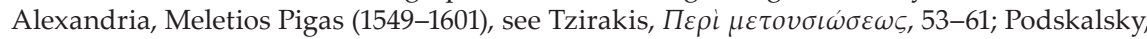
Griechische Theologie, 128-35 [Greek version: 179-88]; D. N. Ramazanova, 'Atticheskij kalendar' v sisteme hronologicheskih predstavlenij Aleksandrijskogo Patriarha Meletija Pigasa (1590-1601)', in R. A. Simonov (ed.), Kalendarno-hronologicheskaja kul'tura i problemy ee izuchenija:

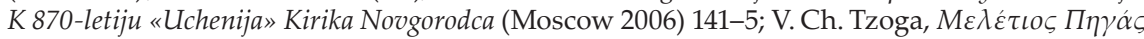

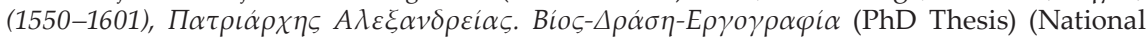


Maximos Peloponnisios, ${ }^{64}$ and Nektarios of Jerusalem), ${ }^{65}$ all of them adopting Eucharistic expressions similar to the transubstantiation theory, raises two issues. First, Karyofyllis missed a great opportunity to discredit Dositheos and his Eucharistic terminology: long before the mid-fifteenth century Patriarch Gennadios, who indeed praised the word 'metousiosis', this term is to be found in the confession of faith sent by Emperor Michael VIII Palaiologos to Pope Gregory X in 1274

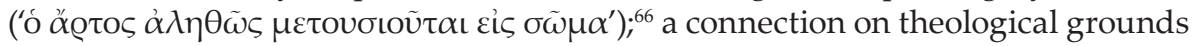
with the 'confessio fidei' signed by this impious emperor, excommunicated both by the Byzantine and Latin Churches, would have been highly detrimental to the

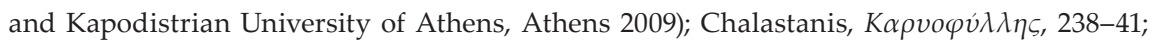
D. N. Ramazanova, 'Poslanija Aleksandrijskogo Patriarha Meletija Pigasa kak istochnik po istorii kalendarno-hronologicheskih predstavlenij vtoroj poloviny XVI-nachala HVII v.', in M. F. Rumyantseva, (ed.), Kognitivnaja istorija. Koncepcija-Metody-Issledovatel'skie praktiki. Chtenija pamjati professora Ol'gi Mihajlovny Medushevskoj (Moscow 2011) 296-315; D. N. Ramazanova, 'Patriarshie gramoty i pis'ma Meletija Pigasa i Kirilla Lukarisa kak istochnik po istorii kalendarno-hronologicheskih predstavlenij na Hristianskom Vostoke', in Problemy diplomatiki, kodikologii i aktovoj arheografii (Moscow 2012) 435-8.

63 For more information and further bibliography on Gavriil Seviros (ca 1540-1616), see Tzirakis,

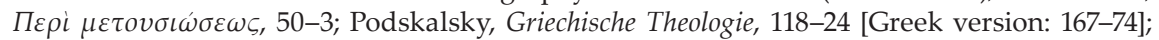
S.D. Birtachas, 'Il clero greco-ortodosso a Venezia. Dal papàs-Michalis e San Biagio fino

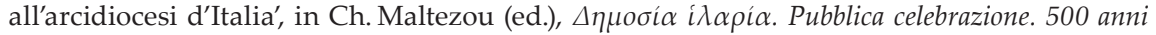
dalla fondazione della communità dei greci ortodossi di Venezia, 1498-1998 (Venice 1999) 75-103; E. Birtachas, 'Un secondo vescovo a Venezia: il metropolita di Filadelfia (secoli XVI-XVIII)', in M. F. Tiepolo and E. Tonetti (eds), I Greci a Venezia. Atti del Convegno internazionale di studio, Venezia, 5-7 novembre 1998 (Venice 2002) 103-21; D. G. Apostolopoulos (ed.), Gavriil Seviros, arcivescovo di Filadelfia a Venezia e la sua epoca. Atti della giornata di studio dedicate a la memoria di Manussos Manussacas (Venezia, 26 settembre 2003) (Venice 2004); P. V. K[uzenkov], 'Gavrijl

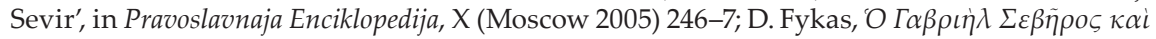

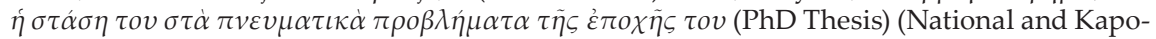
distrian University of Athens, Athens 2008); R. M. Piccione, 'Libri greci da Venezia a Torino e l'eredità di Gavriil Seviros', Medioevo Greco 17 (2017) 193-210.

64 For more information and further bibliography on Maximos Peloponnisios, see Podskalsky,

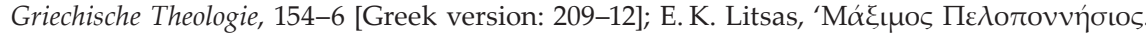

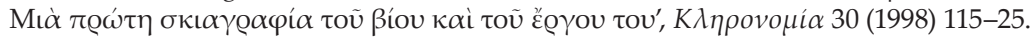

65 For more information on the Patriarch Nektarios of Jerusalem (1602-1676), see Podskalsky, Griechische Theologie, 244-8 [Greek version: 313-8]; F. Gabriel, 'Tradition orientale et vera Ecclesia: une critique hiérosolymitaine de la primauté pontificale. Nektarios, de Jassy à Londres (v. 1671-1702)', in M.-H. Blanchet and F. Gabriel (eds), Réduire le schisme ? Ecclésiologies et politiques de l'Union entre Orient et Occident (XIIIe-XVIIIe siècle) (Paris 2013) 197-236; A. S.

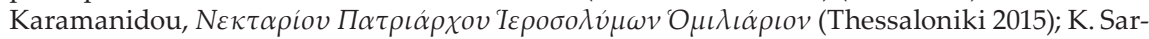
ris, 'Nektarios of Jerusalem', in D. Thomas and J. Chesworth (eds), Christian-Muslim Relations: A Biographical History, X (Leiden-Boston 2017) 308-18.

66 For the original Greek version of this 'confessio fidei', along with a Latin translation, see A. L. Tăutu (ed.), Acta Urbani IV, Clementis IV, Gregorii X (1261-1276) e Regestis Vaticanis aliisque Fontibus ([Rome] 1953) 116-23, especially p. 120. The two other Latin versions are available in: L. Pieralli, La corrispondenza diplomatica dell'imperatore bizantino con le potenze estere nel tredicesimo secolo (1204-1282). Edizione critica e studio storico-diplomatistico (Vatican 2006) 219-37. For

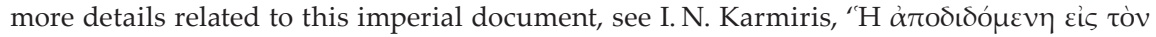

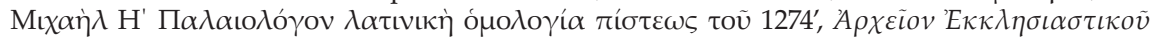

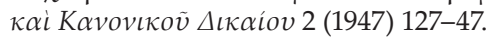


interests of Patriarch Dositheos II. ${ }^{67}$ Second, although important, the authority of the theologians cited by Dositheos who supported transubstantiation cannot be on par with that of the Church Fathers quoted by Karyofyllis in his Evidence from the Divine words and testimonies gathered from almost all the Holy Doctors of the Church at the urge of the wise professor Korydallefs by Ioannis Vyzantios (1641), continued with the Other testimonies which are not in the short treatise written by us (1690); thus, on one side stand Athanasios of Alexandria, the Cappadocian Fathers, Cyril of Jerusalem, Maximos the Confessor, John of Damascus or Photios, and on the other there are great theologians from the fifteenth century onwards (Gennadios Scholarios, Maximos Margounios, Meletios Pigas, Georgios Koressios, or Meletios Syrigos); the mere chronology shows who is 'introducing novelties'. However, Karyofyllis chose not to respond with a similar asperity, but to plead again for a settlement for the sake of their friendship.

Finally, the third letter ${ }^{68}$ dispatched on October 15, 1690, was longer and more bitter: the Great Logothete was not teaching an innovation, but only what the Holy Councils decreed and the Church Doctors confirmed; on the contrary, they (Dositheos and Chrysanthos) were teaching transubstantiation, which was considered to be inappropriate to explain the mystery of the Eucharist by the Church Fathers; the major reference they have is Meletios Syrigos' 'expositio fidei' (Iași, 1642); he is regarded by some former students from the Patriarchal School in Constantinople

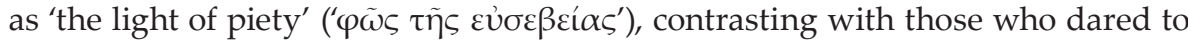
label him as 'Calvinist'; both Calvin and those who think like him are anathema; Dositheos and Chrysanthos are asked to give any example of one single Church Father who spoke or wrote in support of the two Latin innovations, Purgatory and transubstantiation; Karyofyllis reassured the Patriarch of Jerusalem-via hieromonk Chrysanthos Notaras-that he was not involved in any way in the jurisdictional dispute regarding the Saint Catherine's Monastery.

On the other hand, in two episodes connected to the years 1689-1690, Dositheos II was not able to easily and clearly point out the Calvinist heresy in the answers provided by the Great Logothete. According to a biased source by the powerful Patriarch of Jerusalem, the first incident happened in 1689, when a hieromonk from Ioannina, recently arrived in Constantinople, addressed to Karyofyllis

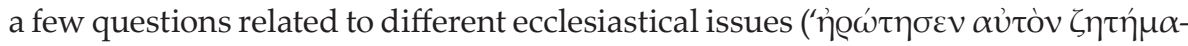

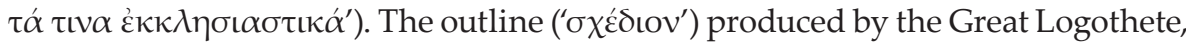

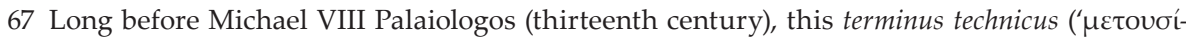
$\left.\omega \sigma \iota \varsigma^{\prime}\right)$ was used by Leontius of Jerusalem (seventh century) in the context of Christological controversies. However, this first occurrence of the term is not connected to a discussion

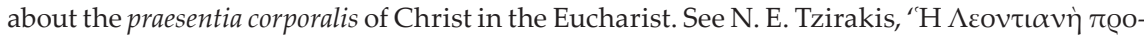

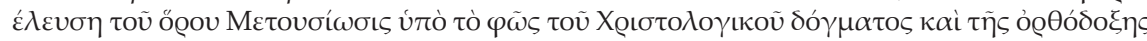

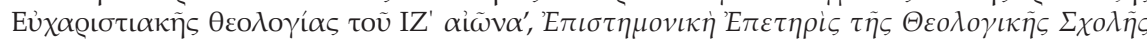
[National and Kapodistrian University of Athens] 35 (2000) 463-519. For an expanded analysis of the use of this term in the Byzantine tradition up to Gennadios Scholarios, see Kappes and Albrecht, The Secret History of Transubstantiation, 81-179.

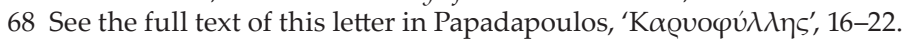




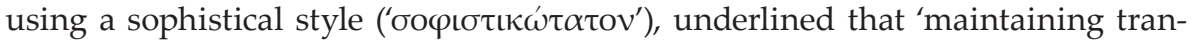
substantiation in the Sacrament is a great obstacle to the Christians' redemption'

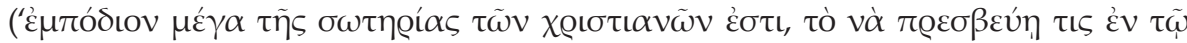
$\left.\mu v \sigma \tau \eta \emptyset i ́ \omega \tau \eta \dot{v} \mu \varepsilon \tau o v \sigma i ́ \omega \sigma เ v^{\prime}\right) \cdot{ }^{69}$ Based on the chronology provided by Dositheos, the second incident occurred by the end of 1689 or the beginning of 1690, a short time after Karyofyllis finished the second part of his triptych on Eucharist. This

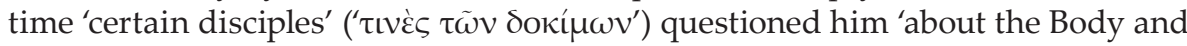

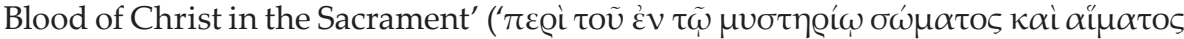

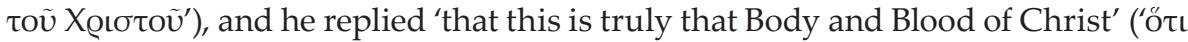

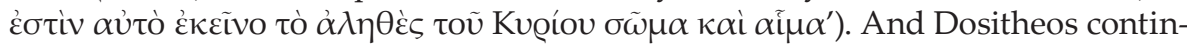
ued: 'and about the most Holy Sacrament [he] confesses all that is said by the Or-

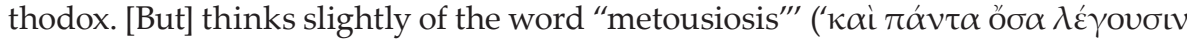

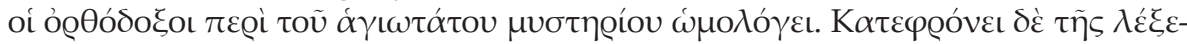
$\left.\omega \varsigma \mu \varepsilon \tau o v \sigma i \omega \sigma \iota \varsigma^{\prime}\right)$. The next question targeted precisely one point that could reveal a disguised Orthodox: if the faithful receive the true Body and Blood of Christ through the Eucharist, what would then receive the sinners? And, according to the patriarch, Karyofyllis' answer exposed him as a heretic like Berengarius of Tours, Calvin or the followers of Mani: 'simple bread, or rather a morsel free from

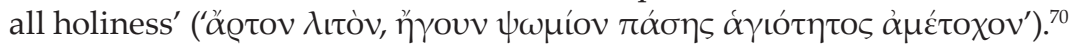

It is an obvious discrepancy between Karyofyllis' Eucharistic theology ${ }^{71}$ as expressed in his triptych and the information provided by the Patriarch of Jerusalem. The Great Logothete rejected transubstantiation as a purely scholastic term, a true innovation in relation to Byzantine Eucharistic theology, underlining his opinion that the patristic terminology should be favored in verbalizing the real presence of Christ in the Eucharist. He was able to quote clear passages where the Eucharistic elements (bread and wine) are depicted as being 'changed' through the Holy Spirit into the very Body and Blood of Christ. In light of this noticeably negative view of Dositheos II about Karyofyllis' stance on the Eucharist, ${ }^{72}$ it is difficult to under-

69 Dositheos, Treatise, 74.

70 Ibid., 75-6.

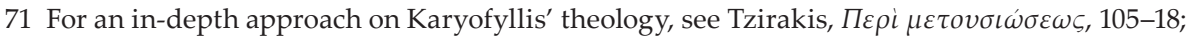

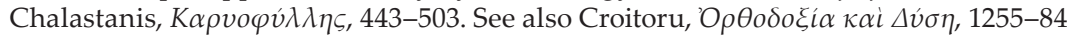

72 In his Treatise against Ioannis Karyofyllis, published post factum in 1694 (see infra footnote 106), Dositheos added to this heretical portrait of Karyofyllis another piece of information meant to underline the lifelong tendency of the Great Logothete to heterodoxy: he introduces Karyofyllis to the readers as a descendant of the 'Athinganoi', an anti-Trinitarian Eastern Christian sect from Asia Minor. Dositheos, Treatise, 69-70. Also see Papadopoulos-Keramefs (ed.),

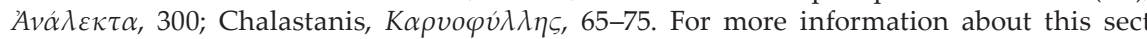
during the Byzantine period, see J. Starr, 'An Eastern Christian Sect: The Athinganoi', Harvard Theological Review 29 (1936) 93-106; G. C. Soulis, 'The Gypsies in the Byzantine Empire and the Balkans in the Late Middle Ages', Dumbarton Oaks Papers 15 (1961) 141-65; G. Puhon, 'Romite vo Makedonija i Vizantija', Glasnik 18 (1974) 81-94; I. Rochow, 'Die Häresie der Athinganer im 8. und 9. Jahrhundert und die Frage ihres Fortlebens', in H. Köpstein and F. Winkelmann (eds), Studien zum 8. und 9. Jahrhundert in Byzanz (Berlin 1983) 163-78; I. Rochow and K.-P. Matschke, 'Neues zu den Zigeunern im byzantinischen Reich um die Wende vom 13. zum 14. Jahr- 
stand the rationale behind his invitation extended to the Great Logothete to write

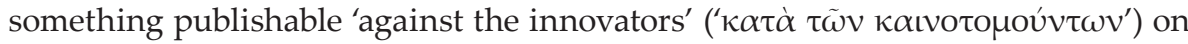
the sensitive topic of the Holy Sacrament of Eucharist. This letter by Dositheos to Ioannis Karyofyllis was sent from Adrianople on May 31, 1690. ${ }^{73}$ Later on, in his History concerning the Patriarchs in Jerusalem, the powerful Patriarch of Jerusalem clarified this episode mentioning that he wrote to the Great Logothete in an

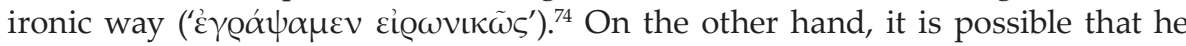
thought that in this new context Karyofyllis would change his mind for the sake of their longstanding friendship or, foreseeing the stubbornness of his opponent, Dositheos considered himself prepared to terminate this conflict over dogmatic grounds, which had erupted back in the first part of the seventeenth century and his own mentor, Meletios Syrigos.

\section{'He who kept silence to all that they spoke and prattled against him'}

The dispute reached a new level in 1691, in the first week of Lent, when the powerful Patriarch of Jerusalem persuaded Kallinikos II of Constantinople (1688; 1689_ $1693 ; 1694-1702)$ to convene a permanent Synod in the city on the Bosporus in order to put an end to this dogmatic controversy. The gathering took place on the Saturday before the first Sunday of Lent (the Sunday of Orthodoxy), and according to the Julian calendar that was on February 28, $1691 .{ }^{75}$ Despite the fact that Karyofyllis' name was not mentioned in the synodical letter, he was targeted as 'Calvinist':

Again he was asked: 'Why you do not confess the change of the bread and wine into the real Body and Blood of the Lord, as it was confessed by the Holy Fathers?' And he answered: 'Anathema to whoever denies the change of the bread and wine into the Body and Blood of the Lord.' But he meant the non-essential and accidental change [...] Once more the faithful asked him: 'Why don't you believe in the teaching and the dogma of the Universal Church, who teaches the whole truth about the Sacrament?' Karyofyllis answered: 'Anathema to whoever is not obedient to the teaching of the Universal Church.' But by Universal Church he meant Simon, Basilides, the Gnostics, Marcion, Ebion, Mani, the Messalians, the Bogomils, the Council of the Iconoclasts in Blachernae during the time of the Kopronymos, ${ }^{76}$

hundert', Jahrbuch der Österreichischen Byzantinistik 41 (1991) 241-54; P. Speck, 'Die vermeintliche Häresie der Athinganoi', Jahrbuch der Österreichischen Byzantinistik 47 (1997) 37-50.

73 See the full text of this letter in Dură, $\Delta \circ \sigma i \theta \varepsilon o \varsigma, 267-8$. For more information, see Camariano,

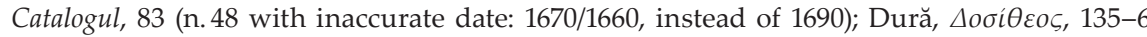

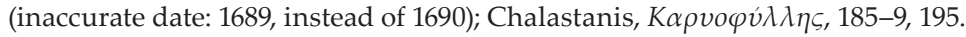

74 Papadopoulos-Keramefs (ed.), 'Avá $\lambda \varepsilon \kappa \tau \alpha, 301$.

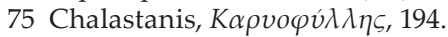

76 Dositheos is reffering here to the very last session of the iconoclast Council of Hieria (754) that took place in the palace of Blachernai in Constantinople during the time of the Byzantine emperor Constantine V Copronymus (741-775). For more information about this Council, see M. V. Anastos, 'The Ethical Theory of Images Formulated by the Iconoclasts in 754 and 815', Dumbarton Oaks Papers 8 (1954) 151-60; M. V. Anastos, 'The Argument for Iconoclasm as 
Berengarius, Calvin, Luther, Loukaris, Korydallefs, himself and his companions. ${ }^{77}$

A slightly different report about this 'endemousa' Synod was provided by the Metropolitan of Athens, Meletios (1661-1714), in his Ecclesiastical History: ${ }^{78}$

In 1691, when Kallinikos of Bursa [former Metropolitan of Bursa] was Patriarch in Constantinople, a Synod was held there against Ioannis Karyofyllis, with the support and care of Patriarch Dositheos of Jerusalem, about a certain writing in which 'metousiosis' was rejected for having content that was not in agreement with the Church; although the aforementioned Ioannis Karyofyllis was present at the Synod, he kept silence to everything that they said and prattled against him, knowing that this Synod was gathered not so for the orthodoxy of the word, as rather for his condemnation, since some of them sought to throw him out from his ecclesiastical office (for he was the Great Logothete of the Church); the Synod being held in this way at that time,

Presented by the Iconoclastic Council of 754', in K. Weitzmann (ed.), Late Classical and Mediaeval Studies in Honor of Albert Matthias Friend, Jr. (Princeton NJ 1955) 177-88; Th. Sideris, 'The Theological Arguments of the Iconoclasts during the Iconoclastic Controversy', Byzantine Studies 6 (1979) 178-92; N. Chifăr, 'Teologia iconoclastă a împăratului Constantin al V-lea şi Sinodul de la Hiereia (754)', in Studia historica et theologica. Omagiu profesorului Emilian Popescu (Iași 2003) 289-99; N. Chifăr, 'Sinodul de la Hiereia (754) şi sinodul de la Niceea (787). O comparație istorică', in Cinstirea icoanelor în Ortodoxie. Retrospectivă istorică, momente cruciale de stabilire a teologiei icoanei și de criză majoră (Iași 2008) 124-41; S. Nazâru, 'Hotărârea sinodală de la Hiereia (754) - summa gândirii iconoclaste', Studii Teologice NS 4 (2008) 195-216.

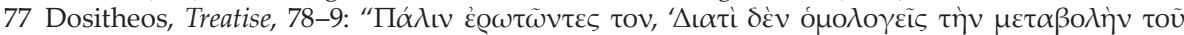

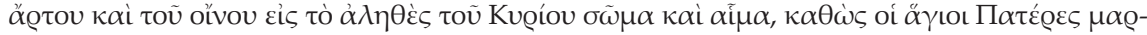

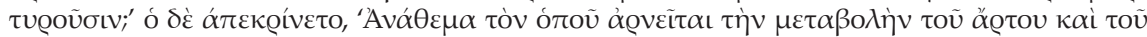

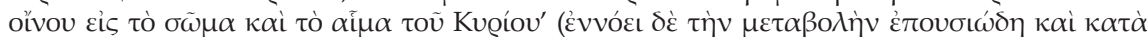

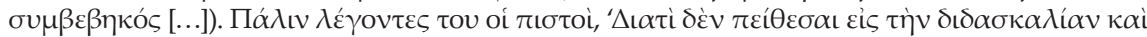

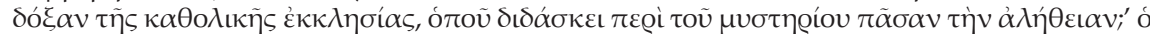

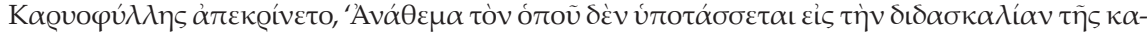

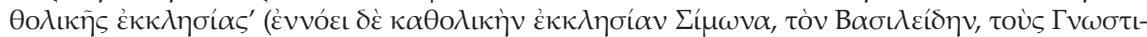

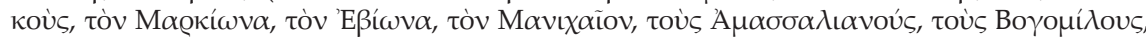

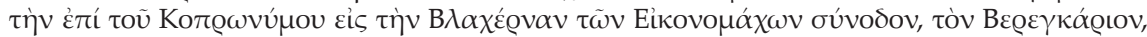

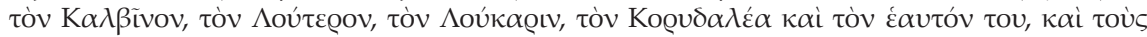

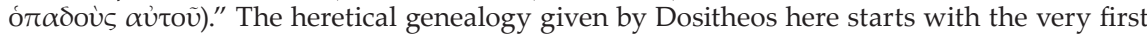
heresiarch, Simon Magus, continued with famous examples from the first millennium, then he nominated Berengarius as one of the first Latin theologians who denied the real presence of Christ in the Eucharist, followed by the two major representatives of the Reformation (Luther and Calvin), and, finally, back to the Greek Orthodox community, the patriarch indicated two mentors of the new heretic (Loukaris and Korydallefs). Miladinova, Zygadenos, 116-7, 122-7.

78 K. Sarris has carefully analysed Meletios' account of this Eastern Eucharistic controversy in a forthcoming article, which the author graciously shared with me: 'Composing and publishing a non-confessional history in the age of Greek Orthodox confessions: The Ecclesiastical History by Meletios of Athens', in T. Anastassiadis, A. Girard, B. Heyberger, V. Kontouma (eds), Livres et confessions chrétiennes orientales. Histoire connectée entre Empire ottoman, monde slave et Occident (XVI'-XVIII e siècles). Actes du colloque de Rome, 15-16 décembre 2016, Bibliothèque de l'École des Hautes Études (forthcoming). 
and a synodal decree was issued against that writing and the alleged heresy, [decree] which begin with 'The simple word etc.' [...] which was signed even by the aforementioned Ioannis, subscribing in everything to the Church. ${ }^{79}$

According to the biased statement of Dositheos, completely terrified by the threat of anathema (' $\varphi$ o $\left.\beta \eta \theta \varepsilon \dot{~ i \varsigma ~ \tau o ̀ ~} \alpha v \alpha \dot{\theta} \theta \mu \alpha \alpha^{\prime}\right),{ }^{80}$ the Great Logothete agreed to sign the official document issued by the Synod convened in Constantinople (February 1691), along with the two Patriarchs (Kallinikos II of Constantinople and Dositheos II of Jerusalem), nine Metropolitans, and six more high-ranking Church officials. The synodal decree confirmed the right usage of the word 'metousiosis':

the Church at last, for a clearer manifestation of the truth in the Sacrament, according to her proper authority and custom, by the invocation of the most Holy Spirit, made use of the word 'metousiosis', stating nothing else thereby than that there is a change in the Sacrament. She made use of this because she abhorred ambiguities, and was above all heretical sophisms against the Sacrament, not having borrowed this from the Latins, but having acquired it from her own proper and genuine Orthodox Doctors, many ages ago. ${ }^{81}$

On the other hand, some recent writings,

in pretext, seem to fight against the word 'metousiosis', as if it was a new one and not old, but truly are attacking the integrity of the Sacrament itself, inasmuch as they deny, although covertly, the Real and Substantial Presence of the Saviour therein [...] For it is not concluded from these [notebooks, i.e. Karyofyllis' writings] that the bread and wine that are visible and eaten,

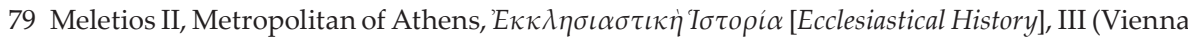

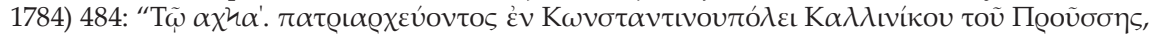

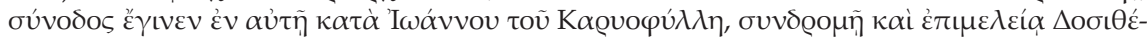

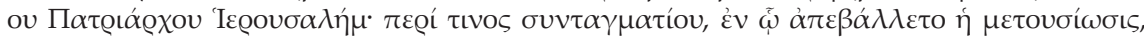

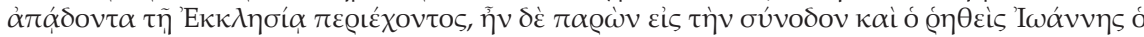

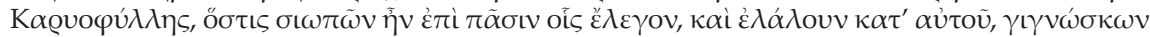

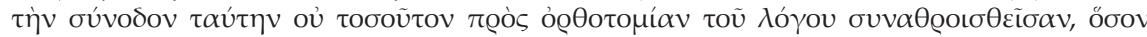

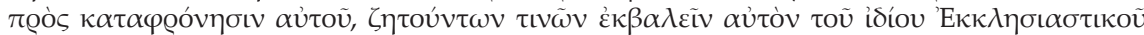

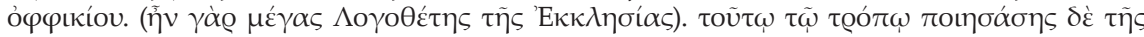

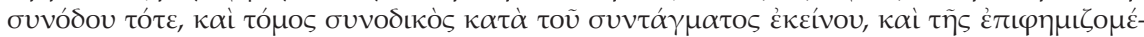

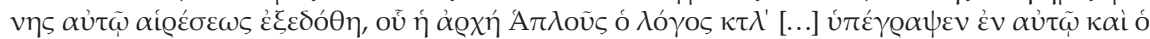

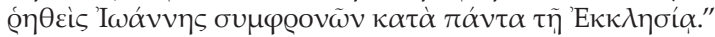

80 Papadopoulos-Keramefs (ed.), Avád $\varepsilon \kappa \tau \alpha, 302$.

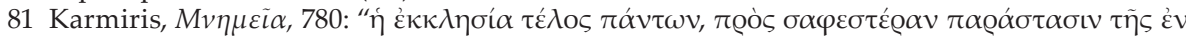

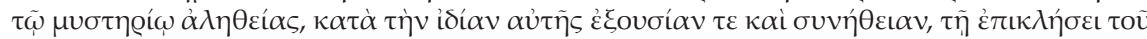

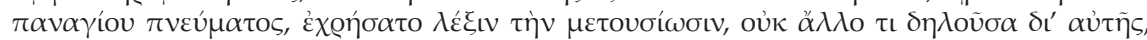

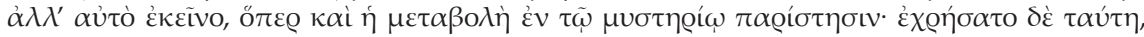

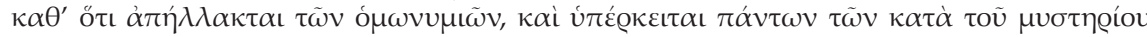

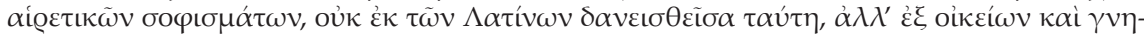

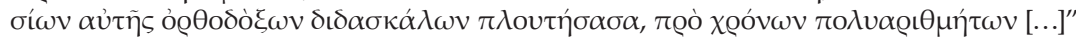


already consecrated, are essentially the true Body and Blood of Christ, but is spiritually understood or better said is fantasized, which is full of impiety. ${ }^{82}$

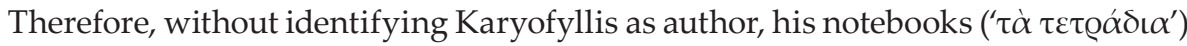
on the Eucharist were officially rejected, prohibiting any Christian under the penalty of excommunication to read, study or copy them.

The reception process of this dogmatic statement and the dynamic of its circulation, both in the East and the West, was remarkable. Only two weeks after the Synod, on March 14, 1691, Dositheos II of Jerusalem sent this synodal decree to the Patriarch Adrian of Moscow and All Russia (1690-1700), along with a fresh publication (Bucharest, September 1690; two works in one volume: Meletios Syrigos, Refutation against the Calvinist chapters and questions of Kyrillos Loukaris and Dositheos II, Patriarch of Jerusalem, Treatise against the Calvinist Madness). ${ }^{83}$ Afterwards, in 1694, the text was first published in Greek by Dositheos himself, ${ }^{84}$ and in 1703 it was translated into Latin and published in Venice as part of the response letter of Nikolaos Komninos-Papadopoulos to the Anglican theologian Joannes Hokstonus. ${ }^{85}$ The very same Latin version was republished (with a short introduction) in 1709 by the Orientalist Eusèbe Renaudot, ${ }^{86}$ and two years later, in 1711, the Lutheran theologian Johann Michael Heineccius published a German translation in Leipzig. ${ }^{87}$ Finally, the Greek text was attached at the end of the very first reply of the three Orthodox Patriarchs to the Nonjuror Anglicans in April 12, 1718, translated into English in 1722 by the schismatic bishop Thomas Wagstaffe, but published only in 1868, along with the full correspondence between the two parties. ${ }^{88}$ Thus, in less then three decades this theological clarification on Orthodox

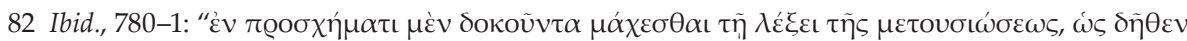

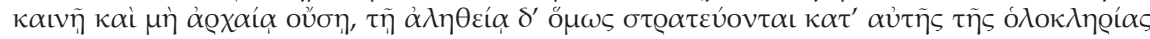

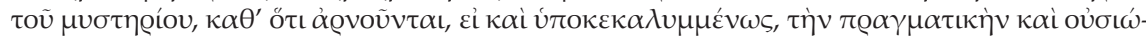

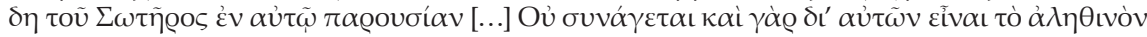

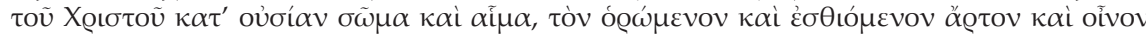

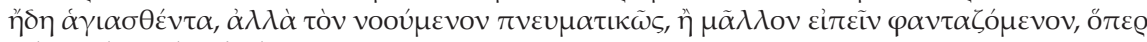

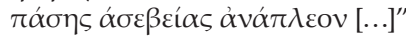

83 For more details about this correspondence, see Bernatskij, 'Konstantinopol'skij Sobor 1691 g.', 133-45. For a bibliography on these two treatises edited by Dositheos II, see infra footnote 100.

84 Dositheos, Treatise, 98-108.

85 N. Komninos-Papadopoulos, Adversus haereticam epistolam Joannis Hokstoni responsio ad sacratissimum \& sapientissimum Antistitem Chrysanthum Notaram metropoliten Caesariensem Palaestinae primatem. Addita est in calce ipsa Jo. Hokstoni Epistola (Venice 1703) 40-9.

86 Renaudot (ed.), De transubstantiatione fidem, 187-94. In the following years the same editor introduced to the Western audience Karyofyllis' case: [Renaudot], La perpétuité de la foy touchant l'eucharistie, 384-401; [Renaudot], La perpétuité de la foy sur les sacrements, 41-8.

87 J. M. Heineccius, Abbildung der alten und neuen Griechischen Kirche, nach ihrer Historie, GlaubensLehren und Kirchen-Gebräuchen, in III. Theilen, Nebst einem curieusen Anhange Unterschiedlicher hierzu dienlicher und zum Theil noch ungedruckter Schrifften Gerhardi Titii, Stephani Gerlachii, und anderer mehr; Alles mit höchster Treu und Fleiß abgefasset, auch mit nöthigen Kupfern und Registern versehen (Leipzig 1711) 40-7.

88 G. Williams (ed.), The Orthodox Church of the East in the Eighteenth Century, being the Correspon- 
understanding of the real presence of Christ in the Eucharist was translated into Old Slavonic, Latin, German and English, published in Greek, Latin and German, reaching Russian Orthodox, Roman-Catholic, Lutheran and Anglican circles in Moscow, Venice, Paris, Leipzig and London.

Back in Constantinople, on the very next day after the Synod, the Sunday of Orthodoxy (March 1, 1691), during the homily delivered at the end of the Divine Liturgy, as

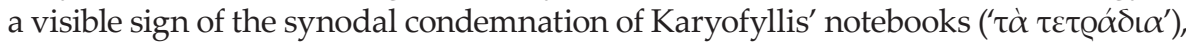
Patriarch Dositheos tore them apart in front of the Christian community and openly threatened to anathematised all those who copied them if they did not throw them

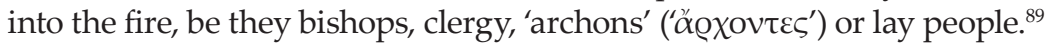

Despite this public denunciation, at least in his private correspondence, Karyofyllis continued to openly speak against those who use the word 'metousiosis' and teach the Latin doctrine of Purgatory. Thus, in a letter sent to the former Patriarch

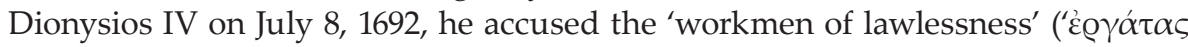

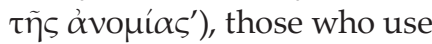

words invented by heretics and enemies of our Holy Church; and they are not content with those words that the God-speaking Fathers uttered regarding the most Holy Sacrament of the most Holy Body and Blood of our Saviour, but they seek to understand what even the angels cannot comprehend, namely the way of change [in the Sacrament], and for this reason they took over one word which comes from the Latin language, namely 'metousiosis', a word which is to be found neither in the Old Testament, nor in the New [Testament], nor in the Holy Councils, nor [in the works of] the Holy Doctors, even not in the dictionaries which comprise the whole Greek language, but [was used] by some people who lived among the Latins, and

dence between the Eastern Patriarchs and the Nonjuring Bishops, with an Introduction on Various Projects of Reunion between the Eastern Church and the Anglican Communion (London-OxfordCambridge 1868) 76-83.

89 Dositheos, Treatise, 85-6; Papadopoulos-Keramefs (ed.), Avá $\lambda \varepsilon \kappa \tau \alpha, 302$. The anonymous author who wrote a bitter attack on Ioannis Karyofyllis, titled About the Luthero-Calvinist Karyofyllis and the heretical booklet he wrote and his rejection by Dositheos of Jerusalem and the place where

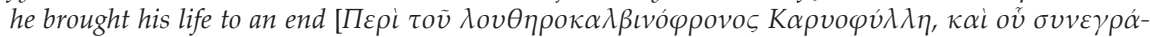

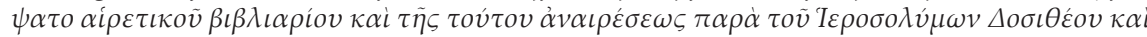
$\pi \circ \tilde{v} \gamma \tilde{\eta} \varsigma \kappa \alpha \tau \dot{\varepsilon} \sigma \tau \rho \varepsilon \psi \varepsilon \tau \dot{o} v \beta i ́ v]$, erroneously connected this event with one that also happened on a Sunday of Orthodoxy, a brawl at the end of the Divine Liturgy between the Great Logothete and the Great Interpreter Alexandros Mavrokordatos, thus referring to the 1691 Sunday

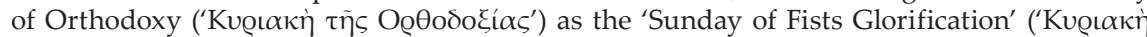

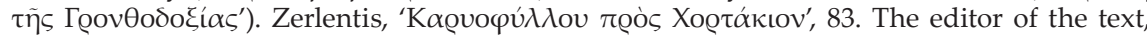
Periklis G. Zerlentis, was not able to discern the chronological error: the Great Interpreter was involved in a Turkish diplomatic mission at the court of the Holy Roman Emperor Leopold I in Vienna for about four years, starting from the Summer of 1688; he arrived back in Constantinople only in November 1692. Thus, this physical punishment of Karyofyllis by his former pupil, Alexandros Mavrokordatos, took place on March 4, 1688 (Sunday of Orthodoxy), the moment of enthronement of Kallinikos II as Patriarch of Constantinople. Zerlentis, 'K $\alpha \varrho v o-$

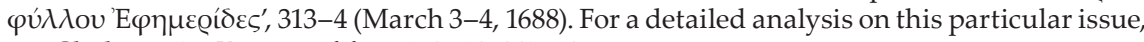

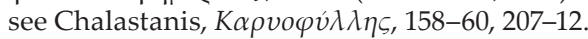


mingled with them, and learned their works and heresies. Moreover, they proclaim Purgatory, and that no matter how many sins one has committed, with just a "[God,] have mercy!" that human is cleansed to participate in the Sacraments; and on the contrary, I say, although I have no one to judge me, that they all have gone astray: for truth is swept away by gold..$^{0}$

\section{'The [Church] laws were not prepared in the mountains of Wallachia'}

Facing such powerful opponents in Constantinople, namely the two Patriarchs, Kallinikos $\mathrm{II}^{91}$ and Dositheos $\mathrm{II}^{92}$ but also the Great Interpreter (' $\mu \varepsilon \dot{\varepsilon} \gamma \alpha \varsigma \delta \varrho \alpha \gamma o u \mu \alpha \alpha_{-}$ vos'/'baș tercüman') Alexandros Mavrokordatos $^{93}$ in absentia, Ioannis Karyofyllis

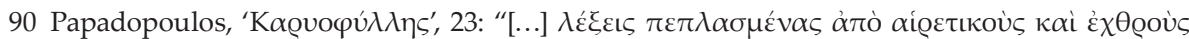

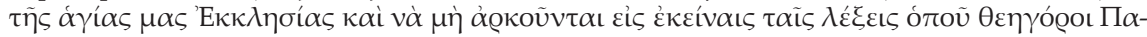

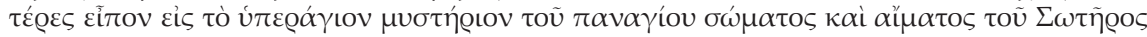

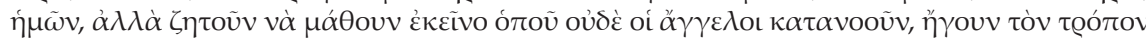

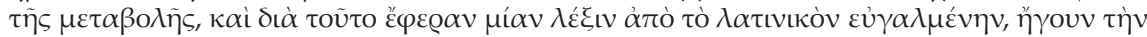

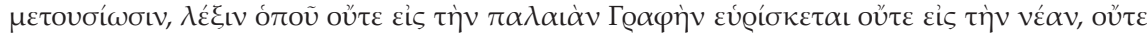

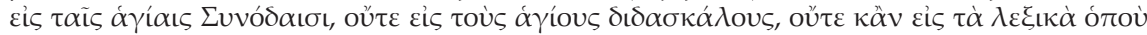

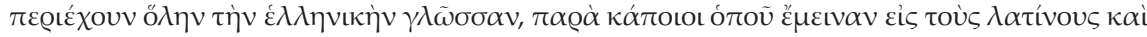

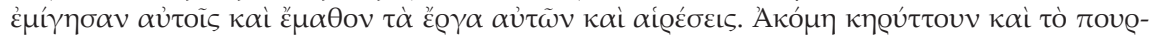

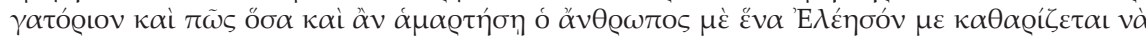

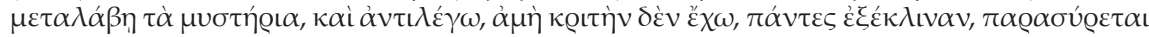

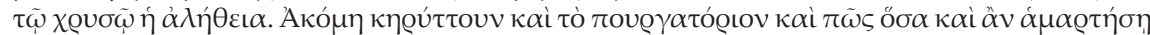

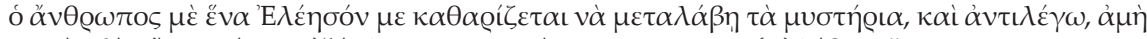

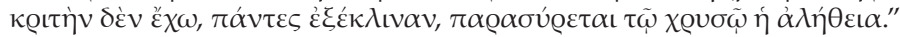

91 This conflict started as early as 1688, when the former Metropolitan of Brusa was acting for a few months as Patriarch of Constantinople. The Great Logothete openly expressed his true feelings toward Kallinikos II both at the official enthronization in March 4, 1688 ('Sunday of Fists Glorification', see supra footnote 89), and later on, in December 1688-January 1689, when former Metropolitan of Adrianople, Neofytos, was elected as patriarch (Karyofyllis went to Adrianople and personally led the newly elected patriarch to Constantinople to be invested).

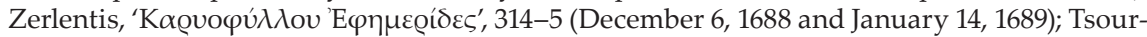

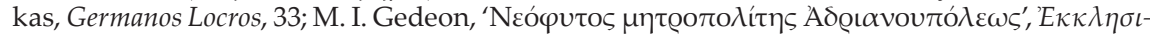

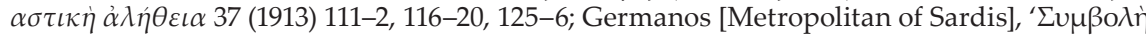

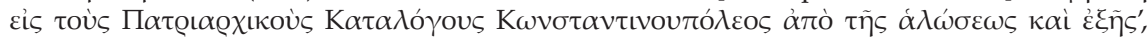

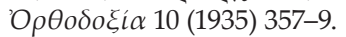

92 Apart of the alleged intervention of the Great Logothete during the jurisdictional dispute between the Patriarchate of Jerusalem and Saint Catherine's Monastery on Mount Sinai, supporting the position of the deposed archbishop Ananias (see supra footnote 52), and the firm rejection of the word 'metousiosis' to underline the real presence of Christ in the Eucharist, the longstanding friendship between Ioannis Karyofyllis and Dositheos was gradually deteriorated also as a consequence of close contacts between the former and Dionysios IV of Constantinople, Metropolitan Germanos Lokros of Nyssa, or Metropolitan Neofytos of Adrianople. All of them were in open conflicts with Dositheos either for their divergent theological ideas (Germanos Lokros) or for representing a rival ecclesiastical party (Dionysios IV and Neofytos of Adrianople). For more details, see Tsourkas, Germanos Locros, 48-54; Chalastanis,

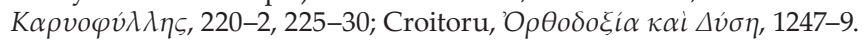

93 The powerful Ottoman high-official mischievously wanted the position of the Great Logothete in the administration of the Great Church, and he was indeed ultimately appointed to this role (1691/3-1709). See Gennadios [Metropolitan of Helioupolis and Theira], 'Tò $\alpha \dot{\alpha} \xi-$

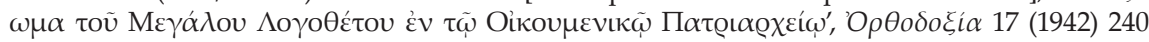


decided in the Summer of 1692 to take refuge in Bucharest, where he arrived in mid-July 1692. ${ }^{94}$ For the last two months of his life (July-September 1692), having the Radu-Vodă Monastery in Bucharest as his residence, the Great Logothete was protected by two powerful friends: the Prince of Wallachia, Constantin Brâncoveanu (1688-1714), ${ }^{95}$ and Constantin Cantacuzino (stolnic), ${ }^{96}$ the uncle of the former.

More than offering a needed shelter, the Wallachian prince even wrote a letter to Kallinikos II, before September 9, 1691, attempting to defend Karyofyllis' point

(Mavrokordatos took the position as early as 1691, sometime after the local Synod in Constantinople, February 1691, although he was away from the Ottoman capital city); Năsturel, 'Cariofil', 521-2 (until his death, Karyofyllis was called with this ecclesiastical title in several private letters he received); Papadopoulos, 'K $\alpha \varrho v o \varphi v ́ \lambda \lambda \eta \varsigma^{\prime}, 22-4$ (Karyofyllis signed as the Great Logothete the letter dated July 8, 1692, to the former Patriarch Dionysios IV of Constantinople). For a detailed analysis of the relationship between Karyofyllis and Mavrokordatos, see Cha-

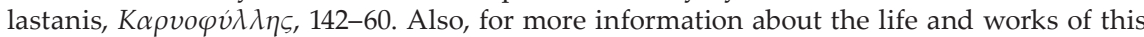

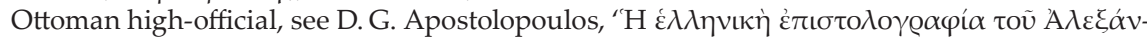

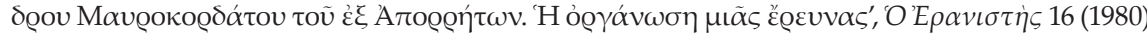

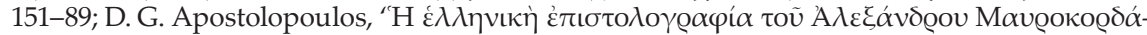

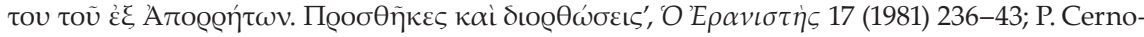
vodeanu and M. Caratașu, 'Correspondance diplomatique d'Alexandre Mavrocordato 1'Exaporite, 1676-1703' (I-III), Revue des Etudes Sud-Est Européennes 20 (1982) 93-128, 327-48; 22 (1984) 327-58; P. Cernovodeanu, 'Alexandros Mavrokordatos ex Apporiton (Alexandru Mavrocordat Exaporitul) (1641-1709)', in Diplomați iluștri, IV (Bucharest 1983) 5-64; Podskalsky, Griechische

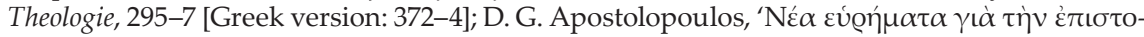

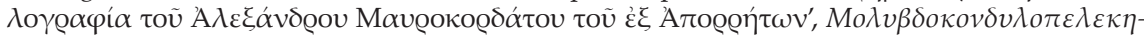
$\tau \eta \dot{\varsigma} 1$ (1989) 26-36; J. Irmscher, 'Alexandros Mavrokordatos, Greek Scholar and Turkish Diplomat', in XII. Türk Tarih Kongresi, Ankara, 12-16 Eylül 1994. Kongreye sunulan bildiriler, III (Ankara 1999) 1005-8; D. Livanios, 'Pride, Prudence, and the Fear of God: the loyalties of Alexander and Nicholas Mavrocordatos (1664-1730)', Dialogos. Hellenic Studies Review 7 (2000) 1-22; D. Janos, 'Panaiotis Nicousios and Alexander Mavrocordatos: The Rise of the Phanariots and the Office of Grand Dragoman in the Ottoman Administration in the Second Half of the Seventeenth Century', Archivum Ottomanicum 23 (2005-2006) 177-96; R. G. Păun, 'Well-Born of the Polis. The Ottoman Conquest and the Reconstruction of the Greek Orthodox Elites under Ottoman Rule (15th-17th Centuries)', in R. Born and S. Jagodzinski (eds), Türkenkriege und Adelskultur in Ostmitteleuropa vom 16. bis zum 18. Jahrhundert (Ostfildern 2014) 64-6.

94 See one unedited letter of Ralakis Karyofyllis to his father, dated July 13, 1692, preserved in the Greek manuscript collection of Romanian Academy (BAR, Ms. gr. 974, f. 121r-v). For more information about this letter, see Camariano, Catalogul, 88 (n. 68); Năsturel, 'Cariofil', 522-3 [based on this letter and two missives from Brâncoveanu, P. Năsturel erroneously concluded that the Great Logothete must have arrived in Bucharest sometime between July 29 and August 4]. Also, see the two edited letters of Constantin Brâncoveanu, the prince of Wallachia (1688-1714), to Ioannis Karyofyllis, dated July 29, 1692 and August 4, 1692: Cernovodeanu and Caratașu, 'Lettres du prince de Valachie', 146-7, 153-4. For the chronology of Karyofyllis' journey from Constantinople to Bucharest during the first part of July 1692 see Chalastanis,

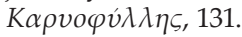

95 The correspondence between Constantin Brâncoveanu and Ioannis Karyofyllis was edited and published in Cernovodeanu and Caratașu, 'Lettres du prince de Valachie', 152-5. See also:

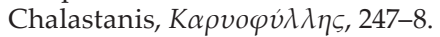

96 The only preserved letter of Constantin Cantacuzino to Ioannis Karyofyllis, dated May 12, 1692, was edited and published in Tsourkas, Germanos Locros, 113-4. Cf. Năsturel, 'Cariofil',

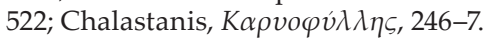


of view, but the patriarch was not open at all to his advice. ${ }^{97}$ Later on, sometime in July-September 1692, when Patriarch Dositheos II was visiting Wallachia in order to raise money for the Church of the Holy Sepulchre in Jerusalem, Constantin Brâncoveanu upbraided him for the attitude toward the Great Logothete. The next day, in front of the Christian community gathered for the Liturgy, the patriarch defended himself and the prince came personally to rebuke Dositheos. The anonymous author who included this information in a biased short tract titled About the Luthero-Calvinist Karyofyllis and the heretical booklet he wrote and his rejection by Dositheos of Jerusalem and the place where he brought his life to an end recounts the final position of the patriarch:

'the [Church] laws were not prepared in the mountains of Wallachia, nor by the Wallachian princes, but in Constantinople and by Emperors and Councils. Therefore, if Karyofyllis has something to say, we can go together to Constantinople and he can speak. And thus Basarab [i.e. Brâncoveanu] was silenced. ${ }^{98}$

Most likely, this public dispute between the two personalities changed Dositheos' printing press policy for his next editorial projects: ${ }^{99}$ after a promising start in Bucharest in $1690,{ }^{100}$ the Patriarch of Jerusalem suddenly decided to continue at

97 The information is given in a letter of Constantin Brâncoveanu to Ioannis Karyofyllis, dated September 9, 1691. Cernovodeanu and Caratașu, 'Lettres du prince de Valachie', 152-3. For other details related to the relationship between Brâncoveanu and Kallinikos II, see Iorga, 'Quelques données nouvelles', 153-8).

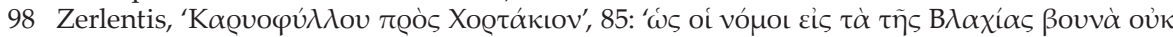

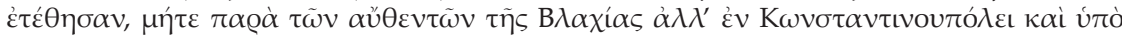

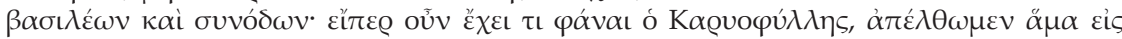

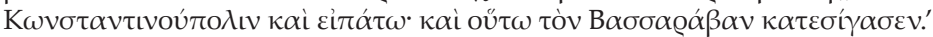

99 For the broader context, see D. Stăniloae, 'Viața și activitatea patriarhului Dosofteiu al Ierusalimului și legăturile lui cu Țările Românești', Candela 40 (1929) 250-76. In this respect, Dositheos even explored the possibility of opening a Greek printing press in Moscow. Protosynkellos Chrysanthos Notaras, his nephew, was entrusted with this plan. He was sent to Moscow in November 1692 and brought with him 11 printed books and 18 manuscripts to be edited and printed. In April 3, 1693, the Russian authorities issued a decree ('указ') regarding the foundation of a Greek printing press, but the following year (1694) Chrysanthos left Moscow and the project was temporarily put on hold. For more information, see N. Kapterev, Snoshenija Ierusalimskogo patriarha Dosifeja s russkim pravitel'stvom (1669-1707 g.) (Moscow 1891) 99-113; É. Turdeanu, ‘Le livre grec en Russie: l'apport des presses de Moldavie et de Valachie (1682-1725)', Revue des Études Slaves 26 (1950) 72-4; B. L. Fonkich, 'Terusalimskij patriarh Dosifej i ego rukopisi v Moskve', Vizantijskij vremennik 29 (1969) 275-99;

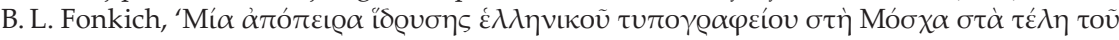
$170 v \alpha i \omega v \alpha^{\prime}$, in T. E. Sklavenitis and K. S. Staikos (eds), The Printed Greek Book (15th-19th century). Acts of the International Congress, Delphi, 16-20 May 2001 (Athens 2004) 195-204, especially p. 200-4; Ică Jr., 'Patriarhul Dositei', 97-8.

100 The following titles were published in Bucharest: Maximos Peloponnisios, Treatise against the schism of the papists (January 1690); Meletios Syrigos, Refutation against the Calvinist chapters and questions of Kyrillos Loukaris, as well as, Dositheos, Treatise against the Calvinist Madness - the last two works in a single volume (September 1690). For more details about these 
the Cetățuia Monastery in Iași (1692-1698), ${ }^{101}$ and only returned to the Wallachian capital city in 1699.102

One more reason to search for an alternative printing press was Dositheos' decision to continue this theological controversy even after the death of Ioannis Karyofyllis (September 22, 1692). Thus, in 1694 he published in Iași a lengthy refutation of the former Great Logothete's Calvinist tenets, conventionally titled Treatise against Ioannis Karyofyllis. ${ }^{103}$ The first part of this tract (p.1-68) started with a list of the Orthodox theologians from Patriarch Ieremias II Tranos (1572-1579, 1580-1584, 1587-1595) ${ }^{104}$ to protosynkellos Grigorios Myrmigousianos, ${ }^{105}$ one of Georgios Koressios' pupils, who successfully defended the validity of the seven Sacraments of the Church in response to the Reformation, represented by Luther

publications, see Legrand, Bibliographie hellénique, II, 458-73 (n. 632), 475-8 (n. 635); I. Bianu and N. Hodoș, Bibliografia românéscă veche (1508-1830), I (Bucharest 1903) 297-315 (n. 89-90).

101 Three important volumes were printed in Iași: Tó $\mu \circ \varsigma K \alpha \tau \alpha \lambda \lambda \alpha \gamma \tilde{\eta} \varsigma$ [Tome of Reconciliation]

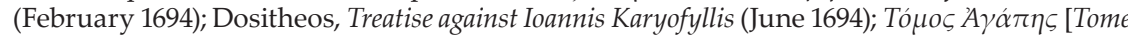
of Love] (March 1698). The two Tomes, parts of Dositheos' trilogy, compiled unedited works of Byzantine and post-Byzantine authors that refuted different Latin theological statements. For more details about these two impressive volumes, see É. Legrand, Bibliographie hellénique ou description raisonnée des ouvrages publiés par des Grecs au dix-septième siècle, III (Paris 1895) 28-9 (n. 658), 54-9 (n. 681); Bianu and Hodoș, Bibliografia românéscă, 338-9 (n. 99), 369 (n. 112). It is important to note that, according to the chronology provided by Dositheos in his dedicatory letter to the former Patriarch of Constantinople, Dionysios III Vardalis (1662-1665), and the introductory epistle to the readers, both pieces included at the beginning of the Tome of Reconciliation, the publication process of this volume started as early as October 1692, a very short time after the public dispute with Prince Brâncoveanu in Bucharest (July-September 1692), when the Patriarch of Jerusalem was visiting Iași. For more information about the printing activity at the Cetățuia Monastery, see D. Simonescu, 'Le monastère de Cetătzuia (Iassy), foyer de culture de l'Orient orthodoxe', Balcania 6 (1943) 357-65.

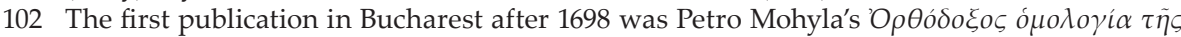

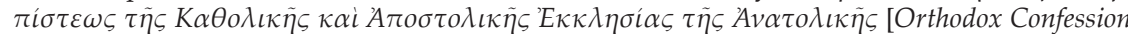
of the Catholic and Apostolic Eastern Church] (February 1699). For more details about this volume, see Legrand, Bibliographie hellénique, III, 61-75 (n. 684); Bianu and Hodoș, Bibliografia românéscă, 378-89 (n. 117).

103 Legrand, Bibliographie hellénique, III, 30-7 (n. 661); Bianu and Hodoș, Bibliografia românéscă, 337-8 (n. 97); Podskalsky, Griechische Theologie, 292-3 [Greek version: 368-9]; Todt, 'Dosi-

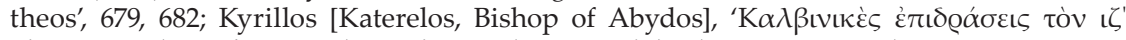

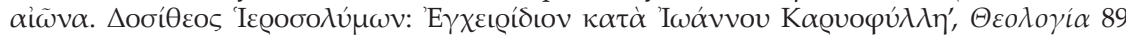
(2018) 15-61; Kontouma, 'Christianisme orthodoxe', 240-2.

104 For more information, including an updated list of bibliographical references, on Ieremias II, Patriarch of Constantinople, see Ch. Hannick and K.-P. Todt, 'Jérémie II Tranos', in C. G. Conticello and V. Conticello (eds), La théologie byzantine et sa tradition, II (XIIIe-XIXe s.)

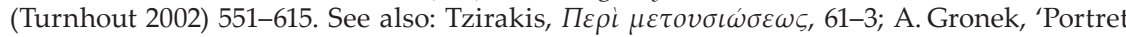
Konstantinopol'skogo Patriarha Ieremii II iz Muzeja Jagellonskogo Universiteta v Krakove', in Rossiia i Khristianskii Vostok 2-3 (2004) 136-48; V. Tzoga, 'Un sigillion inédit du patriarche de Constantinople Jérémie II et d'Alexandre Sylvestre sur la réforme du calendrier', Byzantinische Zeitschrift 107 (2014) 221-52.

105 For more information about protosynkellos Grigorios, see Podskalsky, Griechische Theologie,

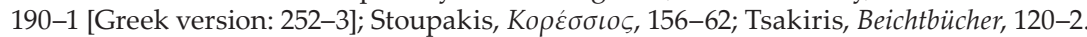


and Calvin (p. 2). ${ }^{106}$ This short introduction is followed by an episode involving Karyofyllis and an unnamed Metropolitan of Adrianople, ${ }^{107}$ the latter raising a question regarding the validity of the Sacraments performed by an ordinary Christian, without ordination, and the former answering that it was not the ordination, but the faith of the Christians that makes the Sacraments effective (p. 3). Succesively, Dositheos quoted eight shorter or longer excerpts ('خń $\tau \eta \mu \alpha$ ') from an unknown treatise ${ }^{108}$ of Karyofyllis dealing with: the Priesthood (p. 3-8), the free will and faith as prerequisites for the Sacraments (p. 17-18), the Holy Spirit as agent and performer of the Sacraments (p. 22-3), when the Sacraments could be repeated (p. 31-2), the accountability of bishops for the ordination of the clergy (p. 38-9), the diligent examination of the foreign clergy by the bishops (p. 46), the punishment of pseudo-clergy (p. 48-9), and the validity of the Sacraments (p. 54-6). To each of

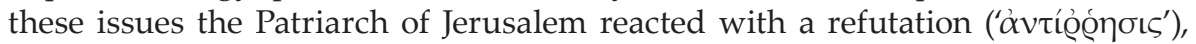
furnished with quotations from Church Fathers and Scriptures, clearly affirming the validity of the Sacraments independently of the faith of the minister ${ }^{109}$ (p. 9-17, 18-22, 23-31, 32-8, 39-46, 47-8, 49-54, 56-62). This first part ended with a short 'Conclusion' ('Eтíl

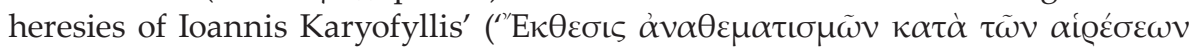

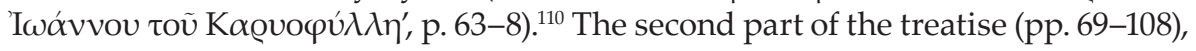
divided into seven small chapters, recounted several episodes of the Great Logothete's blasphemies on the real presence of Christ in the Eucharist (p. 69-79) and reasserted the true meaning of the word 'metousiosis' (p.79-98). In order to un-

106 This introductory passage was translated into French and published in: [Renaudot], La perpétuité de la sur les sacrements, 44-5.

107 This unnamed Metropolitan of Adrianople could be either Neofytos (1644-1688), future Patriarch of Constantinople (1688-1689) and one of Karyofyllis' best friends (see supra footnotes 91-92), or his successor, Klimis (1689-1692). Germanos [Metropolitan of Sardis], "Етıбкотıкоі

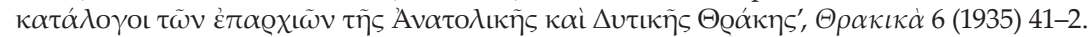

108 This treatise of Karyofyllis, most probably written as a direct consequence of the theological conversation with the Metropolitan of Adrianople, is not to be found in the manuscript

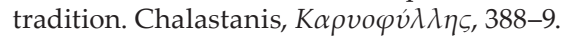

109 This controversy started as early as the beginning of 5th century between the Donatists and Augustine of Hippo: the former affirmed that the ethical status of the clergy directly affects the efficacy of the Sacraments, while the latter underlined that God is the true performer of the Sacraments, therefore God's grace works regardless of the attitude of the clergy. Later on, in the 13th century, Thomas Aquinas clearly pointed out the two positions by the following formulas: 'ex opere operato' (the Sacraments are efficacious automatically and independently of the faith of those involved) and 'ex opere operantis' (the efficacy of the Sacraments depends on the ethical status both of the minister and the recipient). G. Wenz, 'Sakramente I', in H. Balz et al. (eds), Theologische Realenzyklopädie, XXIX (Berlin-New York 1998) 664-70; H. Vorgrimler, 'Sakrament: III. Theologie- und dogmengeschichtlich' and A. Kallis, 'Sakrament: V. Ostkirchliche Theologie', in M. Buchberger, W. Kasper et al. (eds), Lexikon für Theologie und Kirche, 3rd edn, VIII (Freiburg-Basel-Rom-Wien 1999) 1440-2 and $1445-6$, respectively.

110 This solemn 'List of excommunications against the heresies of Ioannis Karyofyllis' by Dositheos was translated into French and published in [Renaudot], La perpétuité de la foy sur les sacrements, $46-8$. 
derline his refutation, at the end of the volume Dositheos added the very text of the decree issued by the permanent Synod in Constantinople (February 1691) that condemned the dogmatic teachings from Karyofyllis' notebooks and proclaimed the orthodoxy of his own argument (p. 98-108).

Certainly, this bitter attack on the memory of the former Great Logothete would have never been published in Constantin Brâncoveanu's printing press located at the Snagov Monastery. This reasoning is confirmed by the posthumous publication in 1697, in Bucharest, of Karyofyllis' book titled Treatise about some difficulties and solutions or about examination and confirmation of some necessary dogmas of the Church, ${ }^{111}$ under the auspices of the same Wallachian prince and having the blessing of Metropolitan Theodosios (1668-1672, 1679-1708). During one of his trips to Wallachia (March 1679-April 1680; February-July 1686; May-August 1688; July-September 1692), ${ }_{112}$ the Great Logothete was asked by his friend, high steward (stolnic) Constantin Cantacuzino, ${ }^{113}$ to answer a series of theological questions related

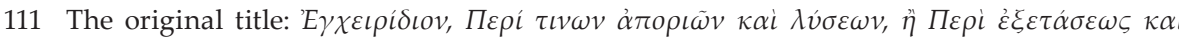

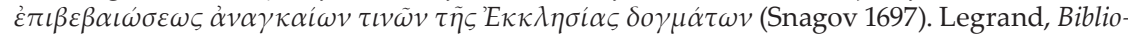
graphie hellénique, III, 45-50 (n. 673); Bianu and Hodoș, Bibliografia românéscă, 349-50 (n. 107);

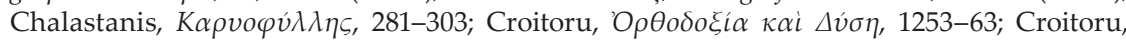
'Antim Ivireanul', 217-25, 227-32; I. C[roitoru], 'Ioan Cariofil, Manual ..., Snagov, 1697', in P. Chițulescu (ed.), Antim Ivireanul: opera tipografică (Bucharest 2016) 60-1.

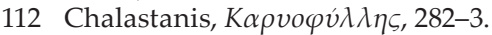

113 For more information about Constantin Cantacuzino, see I. Minea, ‘Ceva despre Constantin Cantacuzino stolnicul', Cercetări Istorice. Revistă de Istorie Românească 8-9 (1932-1933) 73-9; N. Iorga, 'Constantin Stolnicul Cantacuzino', Revista Fundațiilor Regale 2 (1935) 3-22; R. Ortiz and N. Cartojan, Un grande erudito romeno a Padova: Lo stolnic Constantin Cantacuzino (Bucharest 1943); C. Dima-Drăgan, ‘Un catalog necunoscut al bibliotecii Stolnicului Constantin Cantacuzino', Revista arhivelor 7 (1964) 286-303; C. Dima-Drăgan, 'Cultural relations between the Serbian chronicler George Brancovich and the stolnic Constantin Cantacuzino', Revue des Études Sud-Est Européennes 2 (1964) 553-60; C. Dima-Drăgan, 'Cultura teologică a Stolnicului Constantin Cantacuzino-în lumina reconstituirii Bibliotecii de la Mînăstirea Mărgineni', Biserica Ortodoxă Română 83 (1965) 943-75; I. Ionașcu, 'Din viața și activitatea stolnicului Constantin Cantacuzino (1640-1716)', Studii. Revistă de Istorie 19 (1966) 633-50; V. Cândea, 'Stolnicul Constantin Cantacuzino: omul politic-umanistul' (I-II), Studii. Revistă de Istorie 19 (1966) 651-65 and 20 (1967) 45-61; C. Dima-Drăgan, ‘Orizonturi umaniste în cultura românească din secolul al XVII-lea (biblioteca unui mare cărturar român, stolnicul Constantin Cantacuzino', Studii. Revistă de Istorie 19 (1966) 667-82; C. Șerban, 'Contribuție la repertoriul corespondenței stolnicului Constantin Cantacuzino', Studii. Revistă de Istorie 19 (1966) 683-705; C. Dima-Drăgan, Biblioteca unui umanist român: Constantin Cantacuzino Stolnicul (Bucharest 1967); L. Rossetti, 'Constantin Cantacuzino, studente romeno a Padova', Quaderni per la storia dell'Università di Padova 1 (1968) 147-54; C. Dima-Drăgan and L. Bacâru, Constantin Cantacuzino Stolnicul (un umanist român) (Bucharest 1970); V. Cândea, Stolnicul între contemporani (Bucharest 1971); C. Dima-Drăgan, 'Le stolnic Constantin Cantacuzène', Revue Roumaine d'Histoire 10 (1971) 853-68; M. Ruffini, Biblioteca Stolnicului Constantin Cantacuzino (Bucharest 1973); C. Dima-Drăgan, 'Nicolas Papadopoulos Comnène et le Stolnic Constantin Cantacuzène',

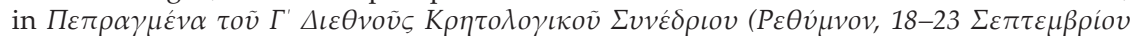
1971), III (Athens 1975) 89-93; P. Binder, 'Ein Siebenbürgischer Freund des Rumänischen Humanisten Constantin Cantacuzino-Stolnicul: Arzt Martin Hermann aus Brașov', Revue des Études Sud-Est Européennes 15 (1977) 365-7; R.-Ș. Ciobanu, Pe urmele stolnicului Constantin

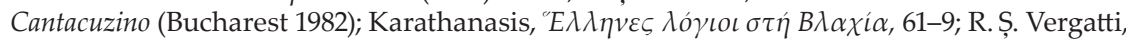


to Anthropology, Free Will, Predestination, Original Sin, Salvation through Faith and Good Works, Eschatology, Heaven and Hell, and Last Judgement, as a direct consequence of the contemporary debates in the Orthodox circles generated by the Protestant ideas. Although Karyofyllis' answers were already circulating in several manuscripts, the decision to publish them in 1697 should be connected to the broader context: the 'unjust' condemnation by the local Synod in Constantinople (February 1691) and the publication of Dositheos' refutation in Iași (1694) triggered a counter-reaction of Karyofyllis' supporters to posthumously clear his name of what they considered to be a false accusation of Calvinism. ${ }^{114}$ Thus, after a needed theological revision of the manuscript by Sevastos Kyminitis, ${ }^{115}$ the principal of the Princely Academy in Bucharest, the hegumen of the Snagov Monastery and future Metropolitan of Wallachia (1708-1715), Anthim the Iberian, wrote two introductory letters (the first dedicated to Constantin Brâncoveanu and the second for the readers) ${ }^{116}$ and edited the volume to be printed. This work was written in a catechetical format, comprising 24 questions by Cantacuzino and 24 answers by Karyofyllis, divided into two parts ( 8 and 16, respectively).

The intention of the Great Logothete's Wallachian friends to highlight his purely Orthodox teachings was partially achieved, although a comparative analysis between the manuscript tradition and the published version of the Treatise is required in order to identify those loci that were revised by Sevastos Kyminitis. On the other hand, none of the questions raised by stolnic Cantacuzino opened the most sensitive topic of the real presence of Christ in the Eucharist. In a broader way, even the publication itself was already an expression of defiance toward the decisions of the permanent Synod in Constantinople (February 1691) by those

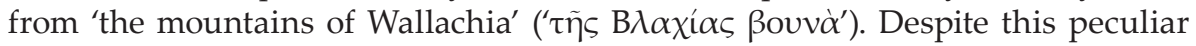
context of its publication, this posthumous Treatise had a large circulation in the Wallachian intellectual circles, being translated into Romanian as early as the first part of eighteenth century by the priest Florea (BAR, Ms. rom. 458). ${ }^{117}$

'Început de drum în viața unui intelectual român: Constantin Cantacuzino', in A. Bogdan et al. (eds), Gabriel Ștrempel la 80 de ani: ... o viață închinată cărții (Satu-Mare 2006) 818-37.

114 Russo, 'Cariofil', 188; Ică Jr., 'Patriarhul Dositei', 97.

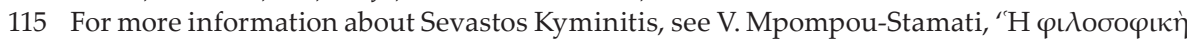

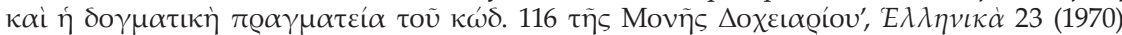
320-30; A. Camariano-Cioran, Les Académies princières de Bucarest et de Jassy et leurs pro-

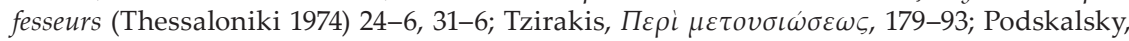
Griechische Theologie, 271-6 [Greek version: 344-50]; Ch. Karanasios, 'Sebastos Kymine-

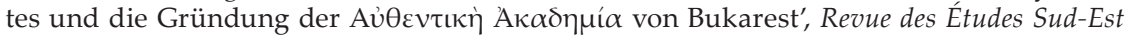
Européennes 31 (1993) 347-58; Ch. Karanasios, Sebastos Trapezuntios Kyminetes (1632-1702): Biographie, Werkheuristik und die editio princeps der Exegese zu De virtute des Pseudo-Aris-

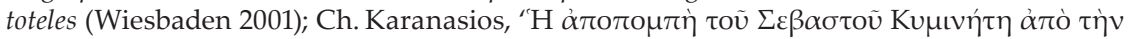

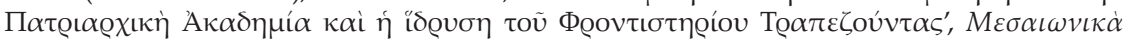

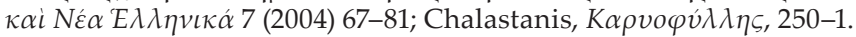

116 The hypothesis that the letter to the reader was authored by the same Anthim the Iberian was developed in Croitoru, 'Antim Ivireanul', 221-2.

117 I. Bianu and R. Caracaș (eds), Catalogul manuscriptelor românești, II (Bucharest-Leipzig- 


\section{Conclusions}

The entangled history of the Eucharistic controversy involving Patriarch Dositheos II of Jerusalem and the Great Logothete Ioannis Karyofyllis revealed opposite views held by these prominent Orthodox theologians that are usually evaluated through the narrow lens of the decree issued by the permanent Synod gathered in Constantinople in February 1691. Since officially in Orthodox Christianity this synodal decision, drafted by the illustrious Patriarch of Jerusalem, was not amended, only very few scholars questioned the confessional attributes usually attached to their respective names: 'Calvinist' for Ioannis Kaaryofyllis and 'Orthodox' for Dositheos II.

The unchallenged dogmatic clarification of the document endorsed by the Synod in Constantinople lies in the moment of the consecration of the Eucharist, a theological issue briefly discussed in June 1439 in Florence, but still a blurred topic for someone like the Metropolitan Petro Mohyla (mid-seventeenth century), or the Russian 'latinized' theologians (Simeon Polotskiy, Silvestr Medvedev, Gavriil Dometskiy) that were sentenced by the local Synod in Moscow (1690). ${ }^{118}$ Thus, through this decision regarding the consecration of the Eucharist during the special prayer of 'invocation' ('غ̇ $\epsilon_{i} \kappa \lambda \eta \sigma \iota \varsigma$ '), a longtime Latin-Byzantine controversy came to an end. This was also a clear separation with respect to the Roman-Catholic teaching in the complex confessional context of the second half of the seventeenth century. With regard to transubstantiation, although no official attempt to dismantle this synodal decision was made, in the last two centuries a number of Orthodox theologians (Aleksey Khomyakov, ${ }^{119}$ Chrysostomos Papadopou$\operatorname{los}_{1}^{120}$ Konstantinos Dyovouniotis, ${ }^{121}$ Stefan Tsankov/Cankov) ${ }^{122}$ expressed harsh criticism of the use of the Greek word 'metousiosis', and this theological opin-

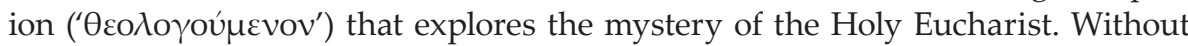
an explicit mention of the synodal decree issued in Constantinople in 1691, these scholars obviously targeted Dositheos' view highlighted both in his 'confessio fidei' (1672, revised in 1690) and the above-mentioned theological document. The academic and ecclesiastical authority of the quoted theologians is widely known: they were renowned professors at different universities (Athens, Sofia), both lay (Aleksey Khomyakov) and clergy (Chrysostomos Papadopoulos even becoming Archbishop of Athens in 1923). Therefore, their criticism is not to be ignored when it comes to the reception process of this synodal decision.

Vienna 1913) 184-185; G. Ștrempel, Catalogul manuscriselor românești. B.A.R., 1-1600 (Bucharest 1978) 117. For more information about the manuscript tradition of this Romanian trans-

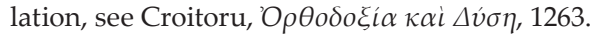

118 For more bibliographical references, see infra footnote 6.

119 [A.-S. Khomiakoff], Quelques mots sur les communions occidentales à l'occasion d'un Mandement de l'archevêque de Paris, par un chrétien orthodoxe (Leipzig 1855) 49-50.

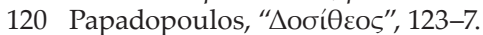

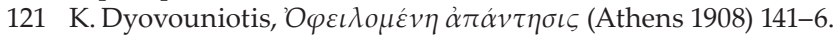

122 S. Zankow, Das orthodoxe Christentum des Ostens: sein Wesen und seine gegenwärtige Gestalt (Berlin 1928) 107. 
A closer look at Dositheos' Eucharistic theology reveals, at first glance, a high degree of ambiguity. On one hand, he clearly stated that

further [we believe] that the word 'metousiosis' is not intended to explain the manner by which the bread and wine are changed into the Body and Blood of the Lord; for that is altogether incomprehensible and impossible, except by God Himself, and those who imagine that Universal Church supposes this are involved in ignorance and impiety. ${ }^{123}$

Along with this accurate theological definition, the Patriarch of Jerusalem trespassed the terminological boundaries of the Orthodox Church using the Scholas-

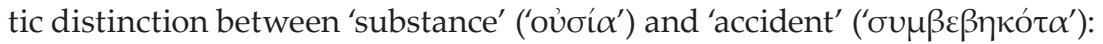

Further [we believe] that after the consecration of the bread and of the wine, there no longer remains the substance of the bread and of the wine, but the very Body and Blood of the Lord, under the species and form of bread and wine, that is to say under the accidents of the bread and the wine. ${ }^{124}$

Based on the rigorous study of the Late Byzantine authors and those after the fall of Constantinople (1453), Dositheos was able to detect and correct his view on Purgatory. By contrast, for the Eucharistic theology he found several authors, starting with Gennadios Scholarios (mid-sixteenth century) ${ }_{1}^{125}$ who used a Latin-borrowed terminology. The dogmatic content of his Eucharistic theology highlighted the pure Orthodox tenet against any tendency to a Calvinist typological interpretation of the real presence of Christ, but the usage of this Latin theological concept, completely unknown to the Church Fathers from the first millennium, generated much misunderstanding as well. Finally, the entangled confessional history of the seventeenth-century Greek-speaking Eastern Orthodoxy, especially the debate that followed the publication of Loukaris' Calvinist 'confessio fidei', demanded a clear answer in response to this vehement attack to the 'invented transubstantiation' ('excogitata [...] transsubstantiatio'). ${ }^{126}$ Dositheos II thus had to strongly defend the praesentia corporalis of Christ in the Eucharist, surpassing the usual Byzantine Eucharistic language.

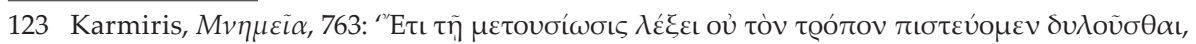
$\kappa \alpha \theta^{\prime}$ ôv ó ăQ

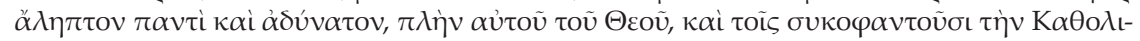

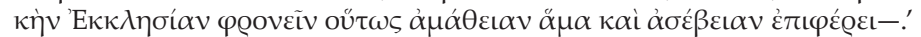

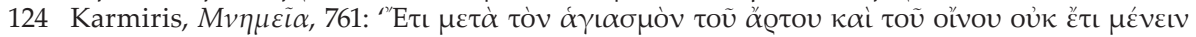

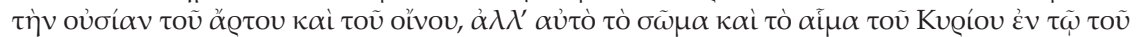

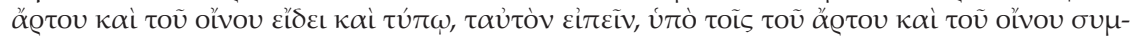

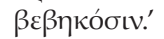

125 For more bibliographical references see infra footnote 33.

126 The most recent critical editions of the Latin and Greek versions of Loukaris' confession was published in: O. Olar, 'Les Confessions de foi de Cyrille Loukaris (+1638)', in M.-H. Blanchet and F. Gabriel (eds), L'Union à l'épreuve du formulaire : professions de foi entre Églises d'Orient et d'Occident (XIIIe-XVIIIe siècle) (Leuven-Paris-Bristol CT 2016) 271-310 (here p. 296). 
Karyofyllis' strong reaction against 'metousiosis' was perfectly legitimate: this term was not used by the Church Fathers, thus constituting an 'innovation' (' $\kappa \alpha$ เvo$\left.\tau o \mu \alpha^{\prime} \alpha^{\prime}\right)$. In order to express the real presence of Christ in the Eucharist, the Orthodox faithful do not need to explore the mysterium fidei of 'how it happens and how it is made'. Although a certain degree of similarity can be traced between his writings and Calvin's Institutio christianae religionis, especially in respect to the sequence of citations of Augustine of Hippo, his Eucharistic theology is consistent with the Byzantine tradition. More than that, Karyofyllis felt no constraints in openly sentencing Calvin and those who think like him with anathema, as mentioned in the letter to Chrysanthos Notaras (October 15, 1690). This is to be interpreted as a clear indication that Karyofyllis was unaware of the Calvinist reading of his theological discourse rather than being a coherent promoter of Protestant ideas within the canonical jurisdiction of the Patriarchate of Constantinople and beyond.

The decisive factor that helped the 'Orthodox' Dositheos to win the Eastern Eucharistic controversy was his ecclesiastical authority: he was a powerful Patriarch of Jerusalem, while the 'Calvinist' Karyofyllis, although a high-official of the Great Church, was still a layman. In all likelihood, without this whip in his hand Dositheos II would have never succeeded in this attempt to insert a Latin term into the dogmatic glossary of Eastern Christianity. The lack of flexibility from both sides led to a synodal decision that is at least questionable, generating much more confusion than clarification.

\section{Bibliography}

Adam M., L'Eucharistie chez les penseurs français du dix-septième siècle (HildesheimZürich-New York 2000).

Alès A. d', 'La question du Purgatoire au Concile de Florence en 1438', Gregorianum 3 (1922) 9-50.

Anastos M. V., 'The Ethical Theory of Images Formulated by the Iconoclasts in 754 and 815', Dumbarton Oaks Papers 8 (1954) 151-60.

- 'The Argument for Iconoclasm as Presented by the Iconoclastic Council of 754', in K. Weitzmann (ed.), Late Classical and Mediaeval Studies in Honor of Albert Matthias Friend, Jr. (Princeton NJ 1955) 177-88.

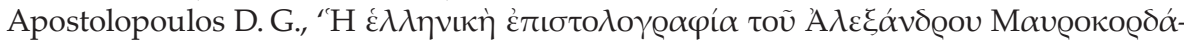

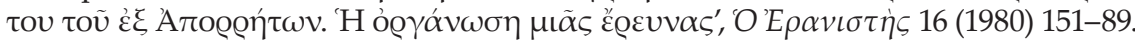

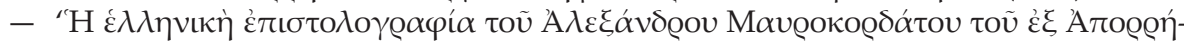

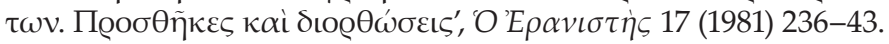

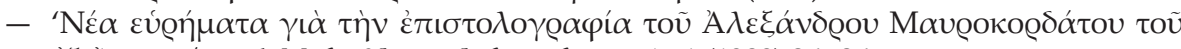

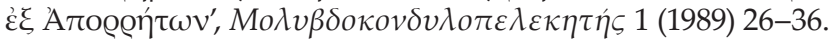

- (ed.), Gavriil Seviros, arcivescovo di Filadelfia a Venezia e la sua epoca. Atti della giornata di studio dedicate a la memoria di Manussos Manussacas (Venezia, 26 settembre 2003) (Venice 2004).

Barbour Ch. H., The Byzantine Thomism of Gennadios Scholarios and His Translation of the Commentary of Armandus de Bellovisu on the De ente et essentia of Thomas Aquinas (Vatican 1993). 
Bârlea O., De Confessione Orthodoxa Petri Mohilae (Frankfurt a.M. 1948).

Bartolini M. G., 'Visible Rituals: Theology and Church Authority in the Iconography of the Seven Sacraments in Peter Mohyla's Trebnik (1646)', The Slavonic and East European Review 98 (2020) 60-105.

Bernatskij M. M., 'Osvjashhenie pominal'nyh chastic v kontekste spora o vremeni presushhestvlenija Svjatyh Darov, sostojavshegosja v poslednej chetverti XVII v. v Moskve: Glava o pominal'nyh chasticah v "Shhite very" i "Ostene" (publikacija po rukopisjam GIM. Sin. 346, 452, 546)', Vestnik PSTGU (Serija I: Bogoslovie. Filosofija) 16 (2006) 129-44.

- 'Konstantinopol'skij Sobor 1691 g. i ego recepcija v Russkoj Pravoslavnoj Cerkvi (k voprosu o kanonicheskom statuse termina «presushhestvlenie»)', Bogoslovskie Trudy 41 (2007) 133-45.

- 'Dogmaticheskoe uchenie o Evharistija v opredelenijah Pomestnyh Soborov XVII v.', in Pravoslavnaja Enciklopedija, XVII (Moscow 2008) 641-5.

- 'Spory o vremeni prelozhenija Darov i dr. voprosy bogoslovsko-liturgicheskogo haraktera v rossijskom bogoslovii XVII v.', in Pravoslavnaja Enciklopedija, XVII (Moscow 2008) 647-51.

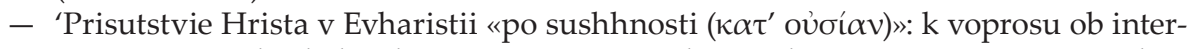
pretacii i istochnikah odnogo mesta iz gomilii o Evharistii Georgija (Gennadija) Sholarija', Bogoslovskie Trudy 42 (2009) 169-82.

- 'Kariofill', in Pravoslavnaja Enciklopedija, XXXI (Moscow 2013) 115-7.

- 'Kirill I Lukaris', in Pravoslavnaja Enciklopedija, XXXIV (Moscow 2014) 553-9.

Betz J., Die Eucharistie in der Zeit der griechischen Väter, I/1 (Freiburg 1955).

Betz J., Eucharistie: in der Schrift und Patristik (Freiburg-Basel-Wien 1979).

Bianu I. and Hodoș N., Bibliografia românéscă veche (1508-1830), I (Bucharest 1903).

Bianu I. and Caracaș R. (eds), Catalogul manuscriptelor românești, II (Bucharest-LeipzigVienna 1913).

Binder P., 'Ein Siebenbürgischer Freund des Rumänischen Humanisten Constantin Cantacuzino-Stolnicul: Arzt Martin Hermann aus Brașov', Revue des Études Sud-Est Européennes 15 (1977) 365-7.

Birtachas S. D., 'Il clero greco-ortodosso a Venezia. Dal papàs-Michalis e San Biagio

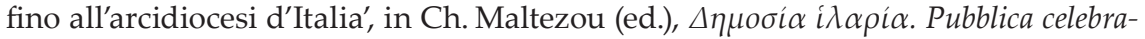
zione. 500 anni dalla fondazione della communità dei greci ortodossi di Venezia, 1498-1998 (Venice 1999) 75-103.

Birtachas E., ‘Un secondo vescovo a Venezia: il metropolita di Filadelfia (secoli XVIXVIII)', in M. F. Tiepolo and E. Tonetti (eds), I Greci a Venezia. Atti del Convegno internazionale di studio, Venezia, 5-7 novembre 1998 (Venice 2002) 103-21.

Blanchet M.-H., 'L'ambiguïte du statut juridique de Gennadios Scholarios après la chute de Constantinople (1453)', in Le Patriarcat CEcuménique de Constantinople aux XIVe-XVIe siècles: rupture et continuité. Actes du colloque international, Rome, 5-6-7 décembre 2005 (Paris 2007) 195-211.

- Georges-Gennadios Scholarios (vers 1400-vers 1472). Un intellectuel orthodoxe face à la disparition de l'Empire byzantine (Paris 2008).

Bost H., 'Jean Claude controversiste: Charenton contre Port-Royale?', Chroniques de PortRoyale 47 (1998) [Port-Royale et les Protestants] 149-77.

Boularand E., 'L'Epiclèse au Concile de Florence', Bulletin de Littérature Ecclésiastique 60 (1959) 241-73. 
Brandmüller W., 'Die theologischen Themen des Konzils von Ferrara-Florenz', in A. Ziegenaus (ed.), Sendung und Dienst im bischöflichen Amt. Festschrift der KatholischTheologischen Fakultät der Universität Augsburg für Bischof Josef Stimpfle zum 75. Geburstag (St Ottilien 1991) 155-75.

Bréhier L., Le schisme oriental du XIe siècle (Paris 1899).

Briel M. C., A Greek Thomist: Providence in Gennadios Scholarios (Notre Dame 2020).

Burger P.-F., 'Pierre Nicole, la Perpétuité et l'abbé Eusèbe Renaudot', Chroniques de PortRoyale 45 (1996) [Pierre Nicole (1625-1695)] 115-48.

Camariano N., Catalogul manuscriselor grecești, II (Bucharest 1940).

Camariano-Cioran A., Les Académies princières de Bucarest et de Jassy et leurs professeurs (Thessaloniki 1974).

Cândea V., 'Stolnicul Constantin Cantacuzino: omul politic-umanistul' (I-II), Studii. Revistă de Istorie 19 (1966) 651-65 and 20 (1967) 45-61.

Cândea V., Stolnicul între contemporani (Bucharest 1971).

Cernovodeanu P., 'Alexandros Mavrokordatos ex Apporiton (Alexandru Mavrocordat Exaporitul) (1641-1709)', in Diplomați iluștri, IV (Bucharest 1983) 5-64.

- and Caratașu M., 'Lettres du prince de Valachie Constantin Brancovan aux savants grecs Jean et Ralakis Caryophyllis', Revue des Études Sud-Est Européennes 14 (1976) 143-64.

- and Caratașu M., 'Correspondance diplomatique d'Alexandre Mavrocordato l'Exaporite, 1676-1703' (I-III), Revue des Études Sud-Est Européennes 20 (1982) 93-128, 32748 and 22 (1984) 327-58.

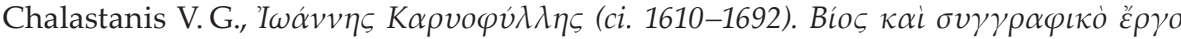
(PhD Thesis) (National and Kapodistrian University of Athens, Athens 2010).

Chelebi Kātib, The Balance of Truth, transl. G. L. Lewis (London 1957).

Chifăr N., 'Teologia iconoclastă a împăratului Constantin al V-lea şi Sinodul de la Hiereia (754)', in Studia historica et theologica. Omagiu profesorului Emilian Popescu (Iași 2003) 289-99.

- 'Sinodul de la Hiereia (754) şi sinodul de la Niceea (787). O comparaţie istorică', in Cinstirea icoanelor în Ortodoxie. Retrospectivă istorică, momente cruciale de stabilire a teologiei icoanei şi de criză majoră (Iași 2008) 124-41.

- 'O dispută dogmatică din veacul al XVII-lea la care au luat parte Dositei al Ierusalimului, Constantin Brâncoveanu și Antim Ivireanu', Biserica Ortodoxă Română 63 (1945) 319-52.

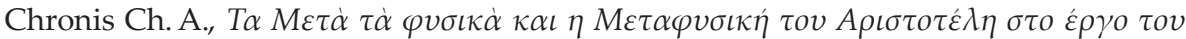

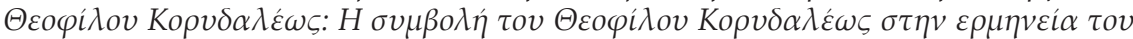

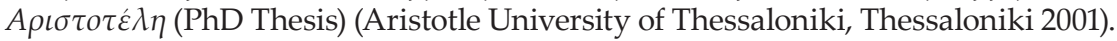

Ciobanu R.-Ș., Pe urmele stolnicului Constantin Cantacuzino (Bucharest 1982).

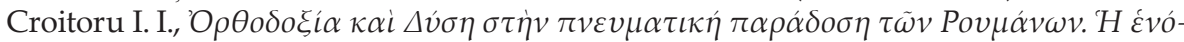

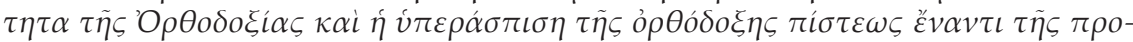
$\tau \varepsilon \sigma \tau \alpha v \tau \iota \kappa \tilde{\eta} \varsigma \pi \rho \circ \pi \alpha \gamma \alpha \dot{v} \delta \alpha \varsigma \kappa \alpha \tau \dot{\alpha} \tau \dot{\partial} v$ IZ' $\alpha i \omega \omega \alpha$, II (Athens 2011).

Croitoru I. M., 'Contribuția Sfântului Antim Ivireanul la controversa dintre patriarhul Ierusalimului Dositei Notaras și marele logofăt al Patriarhiei Ecumenice Ioan Cariofil', in Ș. Zară (ed.), Spiritualitatea mărturisitoare a culturii românești în perioada Sfântului Martir Constantin Brâncoveanu (Râmnicu Vâlcea 2014) 201-32.

C[roitoru] I., 'Ioan Cariofil, Manual ..., Snagov, 1697', in P. Chițulescu (ed.), Antim Ivireanul: opera tipografică (Bucharest 2016) 60-1. 
Décarreaux J., Les Grecs au Concile de l'Union Ferrare-Florence (1438-1439) (Paris 1970).

Dieten J.-L. van, 'Die Erklärung Bessarions zur Forma Eucharistiae. Kritische Fragen zu einem Protokoll', Annuarium Historiae Conciliorum 16 (1984) 369-84.

Dima-Drăgan C., 'Un catalog necunoscut al bibliotecii Stolnicului Constantin Cantacuzino', Revista arhivelor 7 (1964) 286-303.

- 'Cultural relations between the Serbian chronicler George Brancovich and the stolnic Constantin Cantacuzino', Revue des Études Sud-Est Européennes 2 (1964) 553-60.

- 'Cultura teologică a Stolnicului Constantin Cantacuzino-în lumina reconstituirii Bibliotecii de la Mînăstirea Mărgineni', Biserica Ortodoxă Română 83 (1965) 943-75.

- 'Orizonturi umaniste în cultura românească din secolul al XVII-lea (biblioteca unui mare cărturar român, stolnicul Constantin Cantacuzino', Studii. Revistă de Istorie 19 (1966) 667-82.

- Biblioteca unui umanist român: Constantin Cantacuzino Stolnicul (Bucharest 1967).

- 'Le stolnic Constantin Cantacuzène', Revue Roumaine d'Histoire 10 (1971) 853-68.

- 'Nicolas Papadopoulos Comnène et le Stolnic Constantin Cantacuzène', in $\Pi \varepsilon$ -

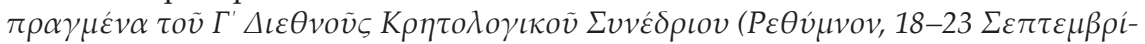
ov 1971), III (Athens 1975) 89-93.

- and Bacâru L., Constantin Cantacuzino Stolnicul (un umanist român) (Bucharest 1970).

Dositheos II, Patriarch of Jerusalem, 'E $\gamma \chi \varepsilon \iota \rho i ́ \delta ı v ~ \kappa \alpha \tau \dot{\alpha} ~ ' I \omega \alpha ́ v v o v ~ \tau o \tilde{v ~ K \alpha \rho v o \varphi v ́ ~} \lambda \lambda \eta$ [Treatise against Ioannis Karyofyllis] (Iași 1694).

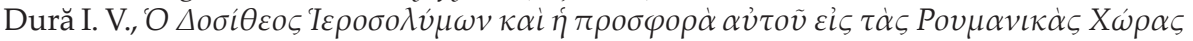
$\kappa \alpha i \tau \eta \dot{v}{ }^{\prime} E \kappa \kappa \lambda \eta \sigma i \alpha v \alpha \hat{v} \tau \tilde{\omega} v$ (PhD Thesis) (National and Kapodistrian University of Athens, Athens 1977).

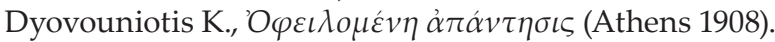

Elian A., 'Contribuția grecească la Mărturisirea Ortodoxă’, Balcanica 5 (1942) 79-135.

- 'Cultura teologică în epoca brâncovenească', Biserica Ortodoxă Română 106 (1988) 104-15.

E[rbiceanu] C., 'Scrierea lui Meletie Sirig contra Calvinilor şi a lui Ciril Lucaris, compusă prin ordinul Sinodului ținut în Iaşi la 1642', Biserica Orthodoxă Română 18 (1894-1895) 6-27.

Erickson J.H., 'Leavened and Unleavened: Some Theological Implications of the Schism of 1054', St Vladimir's Theological Quarterly 14 (1970) 155-76.

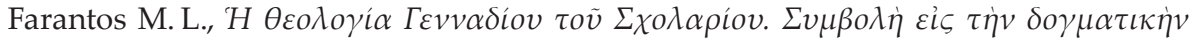

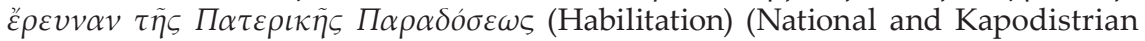
University of Athens, Athens 1969).

Florovsky G., Ways of Russian Theology, I [The Collected Works of Georges Florovsky 5] (Belmont MA 1979).

Fonkich B. L., 'Avtografy Ioanna Kariofillisa', in B. L. Fonkich, Grecheskie rukopisi evropejskih sobranij. Paleograficheskie i kodikologicheskie issledovanija 1988-1998 gg. (Moscow 1999) 132-6.

- 'Diplomatika i paleografija', Vspomogatel'nye istoricheskie discipliny 27 (2000) 341-54.

- 'Ierusalimskij patriarh Dosifej i ego rukopisi v Moskve', Vizantijskij vremennik 29 (1969) 275-99.

- 'Ioann Kariofillis i ego rol' v istorii russko-grecheskih svjazej v XVII v.', in Rossiia i Khristianskii Vostok 2-3 (2004) 392-5.

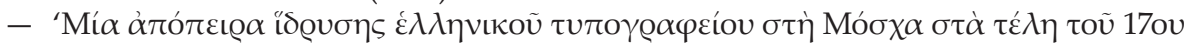
$\alpha \mathfrak{i} \omega \dot{v} \alpha$ ', in T. E. Sklavenitis and K. S. Staikos (eds), The Printed Greek Book (15th-19th 
century). Acts of the International Congress, Delphi, 16-20 May 2001 (Athens 2004) 195-204.

F[oucqueret] M. (ed.), Synodus Bethlehemitica adversus Calvinistas haereticos, Orientalem Ecclesiam de Deo rebusque divinis haeretice cum ipsis sentire mentientes, pro reali potissimum praesentia, anno MDCLXXII sub Patriarcha Jerosolymorum Dositheo celebrate (Paris 1676).

Franckowiak R., 'Athanasius Rhetor: a Greek in Paris, a Priest in Alchemy', in G. Katsiampoura (ed.), Scientific Cosmopolitanism and Local Cultures: Religions, Ideologies, Societies. Proceedings (Athens, 1-3 November 2012) (Athens 2014) 95-100.

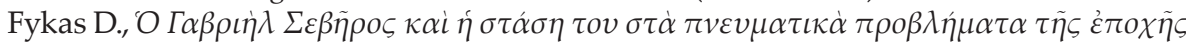
$\tau o v$ (PhD Thesis) (National and Kapodistrian University of Athens, Athens 2008).

Gabriel F., 'Tradition orientale et vera Ecclesia: une critique hiérosolymitaine de la primauté pontificale. Nektarios, de Jassy à Londres (v. 1671-1702)', in M.-H. Blanchet and F. Gabriel (eds), Réduire le schisme? Ecclésiologies et politiques de l'Union entre Orient et Occident (XIII - XVIII siècle) (Paris 2013) 197-236.

- 'Les témoins orientaux d'une querelle latine: Orthodoxie et professions de foi dans La Perpétuité de la foi', in M.-H. Blanchet and F. Gabriel (eds), L'Union à l'épreuve du formulaire : professions de foi entre Églises d'Orient et d'Occident (XIIIe-XVIIIe siècle) (Leuven-Paris-Bristol CT 2016) 373-89.

Galland A., Journal d'Antoine Galland pendant son séjour à Constantinople (1672-1673), 2 vols, ed. Ch. Schefer (Cambridge 2012).

Garnier S., 'L'édition Dosithée (1683) des Opera omnia de Syméon de Thessalonique', Annuaire de l'École Pratique des Hautes Études (EPHE). Section des sciences religieuses. Résumé des conferences et travaux 123 (2014-2015) 215-28.

Gastgeber Ch., 'The So-Called Schism of 1054 and Its Impact on Byzantine Society', in B. Crostini and G. Peers (eds), A Book of Psalms from Eleventh-Century Byzantium: The Complex of Texts and Images in Vat. Gr. 752 (Vatican 2016) 193-225.

Geanakoplos D. J., 'An Overlooked Post-Byzantine Plan for Religious Union with Rome: Maximos Margounios the Cretan Humanist-Bishop and his Latin Library Bequeathed to Mt. Athos', in D. J. Geanakoplos, Byzantine East and Latin West: Two Worlds of Christendom in Middle Ages and Renaissances. Studies in Ecclesiastical and Cultural History (Oxford 1966) 165-93.

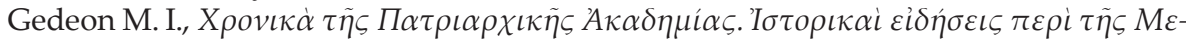

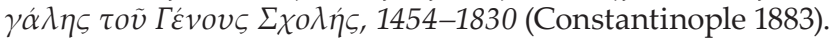

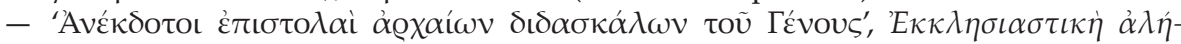
$\theta \varepsilon\llcorner\alpha 3$ (1882-1883) 423-5.

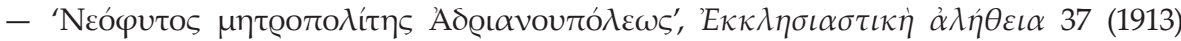
111-2, 116-20, 125-6.

Gemeinhardt P., Die Filioque-Kontroverse zwischen Ost- und Westkirche im Frühmittelalter (Berlin-New York 2002).

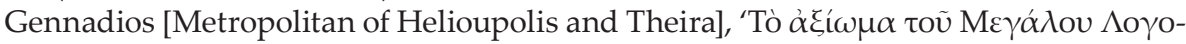

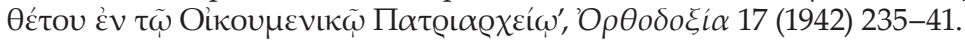

Georgi C. R. A., Die Confessio Dosithei (Jerusalem 1672): Geschichte, Inhalt und Bedeutung (München 1940).

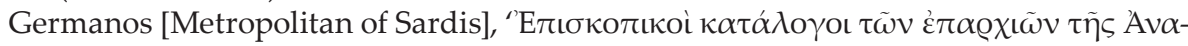

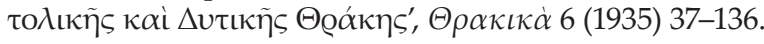




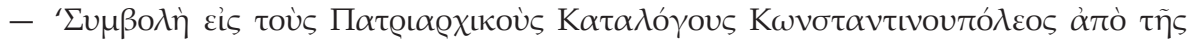

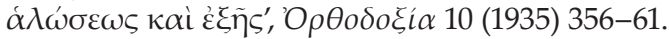

Gill J., The Council of Florence (Cambridge 1959).

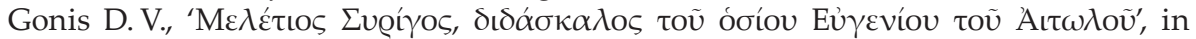

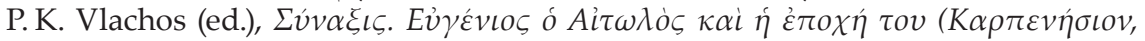

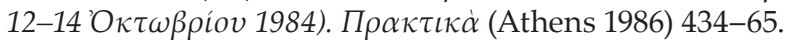

Gorskij A. V., 'O Sobore Ierusalimskom 1672 goda', Pribavlenija k Tvorenijam sv. Otcov 24 (1871) 568-620.

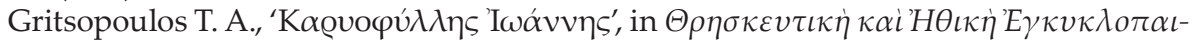
$\delta \varepsilon i \alpha$, VII (Athens 1965) 379-81.

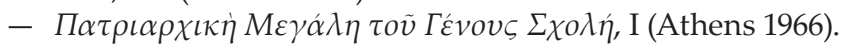

Grolimund V., 'Die Entwicklung der Theologie der Eucharistie in Byzanz von 10541453', in I. Perczel, R. Forrai and G. Geréby (eds), The Eucharist in Theology and Philosophy: Issues of Doctrinal History in East and West from the Patristic Age to the Reformation (Leuven 2005) 157-97.

Gronek A.,' Portret Konstantinopol'skogo Patriarha Ieremii II iz Muzeja Jagellonskogo Universiteta v Krakove', in Rossiia i Khristianskii Vostok 2-3 (2004) 136-48.

Grumett D., Material Eucharist (New York 2016).

Gundlach R., 'Kirche und Sakrament in der Confessio Orthodoxa des Petrus Mogilas', Kirche im Osten 4 (1961) 15-36.

Hadzimanou D., La vie et l'œuvre d'Eugène Yannoulis d'après sa correspondance (1638-1682) (PhD Thesis) (Université de Paris-Sorbonne IV, Paris 1991).

Halleux A. de, 'Problèmes de méthode dans les discussions sur l'eschatologie au Concile de Ferrare et Florence', in G. Alberigo (ed.), Christian Unity: The Council of Ferrara-Florence, 1438/39-1989 (Leuven 1991) 251-99.

Hamilton A., 'From East to West: Jansenists, Orientalists, and the Eucharistic Controversy', in W. Otten et al. (eds), How the West Was Won: Essays on Literary Imagination, the Canon, and the Christian Middle Ages for Burcht Pranger (Leiden-Boston 2010) 83-100.

Hannick Ch. and Todt K.-P., 'Jérémie II Tranos', in C. G. Conticello and V. Conticello (eds), La théologie byzantine et sa tradition, II (XIIIe-XIXe s.) (Turnhout 2002) 551-615.

Hauptmann P., 'Petrus Mogilas (1596-1646)', in H. Fries and G. Kretschmar, Klassiker der Theologie, I (München 1981) 378-91.

Heineccius J. M., Abbildung der alten und neuen Griechischen Kirche, nach ihrer Historie, Glaubens-Lehren und Kirchen-Gebräuchen, in III. Theilen, Nebst einem curieusen Anhange Unterschiedlicher hierzu dienlicher und zum Theil noch ungedruckter Schrifften Gerhardi Titii, Stephani Gerlachii, und anderer mehr; Alles mit höchster Treu und Fleiß abgefasset, auch mit nöthigen Kupfern und Registern versehen (Leipzig 1711).

Hering G., 'Karyophylles, Johannes', in F. W. Bautz and T. Bautz, (eds), BiographischBibliographisches Kirchenlexikon, III (Herzberg 1992) 1194-6.

Hofmann G., 'Erstes Gutachten der Lateiner über das Fegfeur. Text mit Einführung', Orientalia Christiana 16 (1929) 257-302.

- 'Zweites Gutachten der Lateiner über das Fegfeur. Text mit Einführung', Orientalia Christiana 17 (1930) 183-244.

- 'Die Konzilsarbeit in Ferrara. II. Die Sitzungen nach Ankunft der Griechen (9. März 1438-10. Januar 1439)', Orientalia Christiana Periodica 3 (1937) 418-24.

Hurmuzaki E. de (ed.), Documente privitóre la Istoria Românilor, IV/1. (1600-1649) (Bucharest 1882). 
Hütter R., Aquinas on Transubstantiation: The Real Presence of Christ in the Eucharist (Washington 2019).

Ică Jr. I. I., '950 de ani de la Marea Schismă. Interpretări și documente (I-II)', Revista Teologică 14/86 (2004) 8-41, 79-113.

- 'Patriarhul Dositei al Ierusalimului, conștiință a Ortodoxiei în Europa secolului XVII și o uitată apologie a sfântului Grigorie Palama scrisă în Ungrovlahia sfântului voievod Constantin Brâncoveanu', in N. Chifăr, I. O. Abrudan and P. Guran (eds), Epoca lui Constantin Brâncoveanu în context sud-est european: Biserică, Societate, Geopolitică (Sibiu 2014) 81-118.

Ionașcu I., 'Din viața și activitatea stolnicului Constantin Cantacuzino (1640-1716)', Studii. Revistă de Istorie 19 (1966) 633-50.

Ionesco T., La vie et l'œuvre de Pierre Movila, Métropolite de Kiev (Paris 1944).

Iorga N., 'Quelques données nouvelles au sujet des relations entre les Principautés Roumaines et l'Église Constantinopolitaine dans la seconde moitié du XVIIe siècle', Bulletin de la Section Historique [Académie Roumaine] 3 (1915) 143-62.

- 'Constantin Stolnicul Cantacuzino', Revista Fundațiilor Regale 2 (1935) 3-22.

Irmscher J., 'Alexandros Mavrokordatos, Greek Scholar and Turkish Diplomat', in XII. Türk Tarih Kongresi, Ankara, 12-16 Eylül 1994. Kongreye sunulan bildiriler, III (Ankara 1999) 1005-8.

Janeras S., 'L'Esperit Sant en la Confessio Orthodoxa de Pere Moguila', in J. Busquets and M. Martinell (eds), Fe i teologia en la història. Estudis en honor del Prof. Dr. Evangelista Vilanova (Barcelona 1997) 345-53.

Janos D., 'Panaiotis Nicousios and Alexander Mavrocordatos: The Rise of the Phanariots and the Office of Grand Dragoman in the Ottoman Administration in the Second Half of the Seventeenth Century', Archivum Ottomanicum 23 (2005-2006) 177-96.

John of Damascus, Die Schriften des Johannes von Damaskos, II, ed. B. Kotter (BerlinNew York 1973).

- La foi orthodoxe, II. (45-100), ed. B. Kotter, transl. P. Ledrux and G.-M. de Durand [Sources chrétiennes 540] (Paris 2011).

Jugie M., 'Le mot transsubstantiation chez les Grecs après 1629', Échos d'Orient 10 (1907) 65-77.

- 'La question du Purgatoire au Concile de Ferrare-Florence', Échos d'Orient 20 (1921) 269-82.

- 'La Confession orthodoxe de Pierre Moghila: à propos d'une publication récente', Échos d'Orient 28 (1929) 414-30.

- 'La forme de l'Eucharistie d'après Georges Scholarios', Échos d'Orient 33 (1934) 289-97.

- Le schisme byzantin. Aperçu historique et doctrinal (Paris 1941).

- 'Caryophyllès ou Karyophyllès (Jean)', in G. Jacquemet (ed.), Catholicisme. Hier-Aujourd'hui-Demain, II (Paris [1954]) 609-10.

Kallis A., 'Sakrament: V. Ostkirchliche Theologie', in M. Buchberger, W. Kasper et al. (eds), Lexikon für Theologie und Kirche, 3rd edn, VIII (Freiburg-Basel-Rom-Wien 1999) 1445-6.

Kappes Ch., 'The Latin Sources of the Palamite Theology of George-Gennadius Scholarius', in J. Demetracopoulos and Ch. Dendrinos (eds), When East Met West. The Reception of Latin Theological and Philosophical Thought in Late Byzantium. Actes of the 
Institute of Classical Studies. International Byzantine Colloquium. London, 11-12 June 2012 (Bari 2013) 71-114.

- The Epiclesis Debate at the Council of Florence (Notre Dame 2019).

- and W. Albrecht, The Secret History of Transubstantiation: Pulling Back the Veil on the Eucharist (Eagle Pass TX 2021).

Kapterev N., Snoshenija Ierusalimskogo patriarha Dosifeja s russkim pravitel'stvom (16691707 g.) (Moscow 1891).

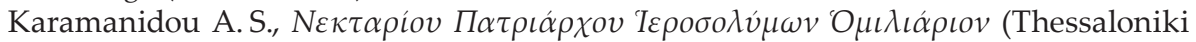
2015).

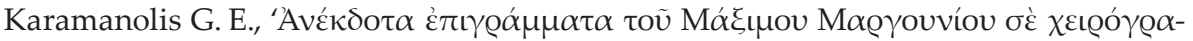

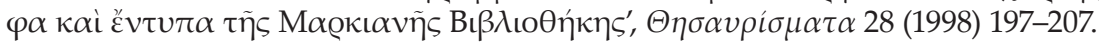

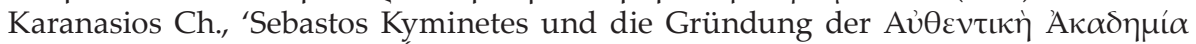
von Bukarest', Revue des Études Sud-Est Européennes 31 (1993) 347-58.

- Sebastos Trapezuntios Kyminetes (1632-1702): Biographie, Werkheuristik und die editio princeps der Exegese zu De virtute des Pseudo-Aristoteles (Wiesbaden 2001).

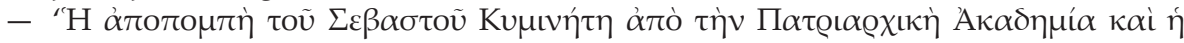

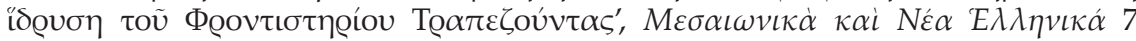
(2004) 67-81.

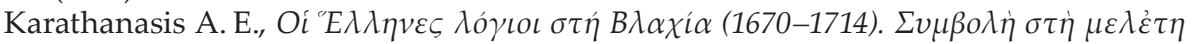

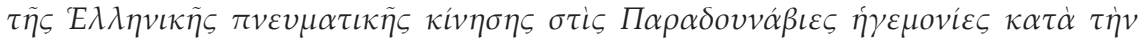

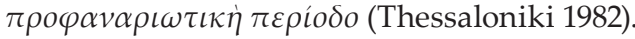

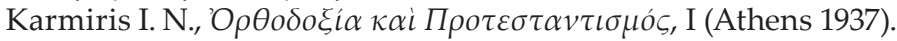

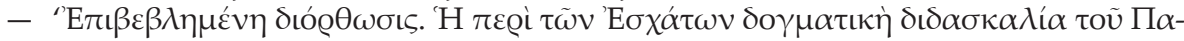

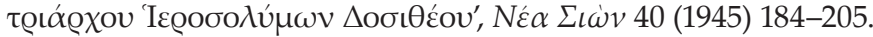

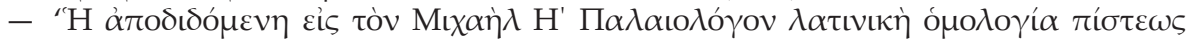

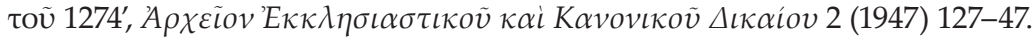

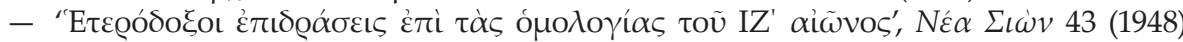
111-20, 167-74, 226-31, 281-3.

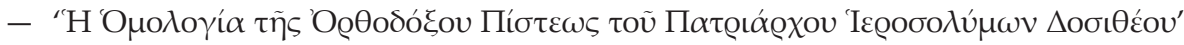

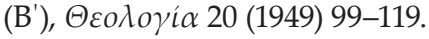

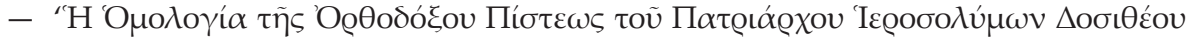

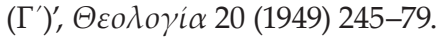

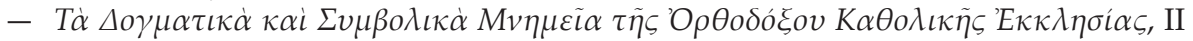
(Athens 1953).

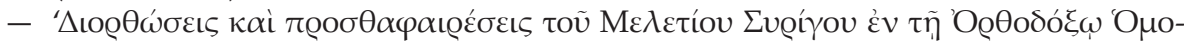

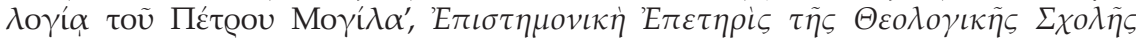
[National and Kapodistrian University of Athens] 10 (1954-1955) 45-80.

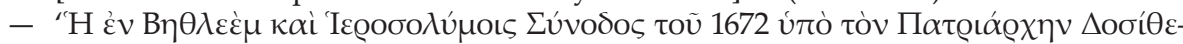
ov', NÉ $\alpha \iota \iota \dot{\omega} v 50$ (1955) 25-56.

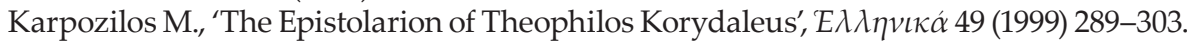

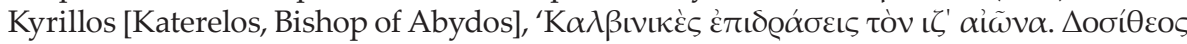

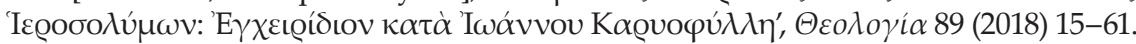

Kazhdan A. P., 'Innovation in Byzantium', in A. R. Littlewood (ed.), Originality in Byzantine Literature, Art and Music. A Collection of Essays (Oxford 1995) 1-14.

K[azhdan] A. and C[utler] A., 'Innovation', in A. P. Kazhdan (ed.), The Oxford Dictionary of Byzantium, II (New York-Oxford 1991) 997-8. 
Kermeli E., 'Kyrillos Loukaris' Legacy: Reformation as a Catalyst in the 17th Century Ottoman Society', The Muslim World 107 (2017) 737-53.

[Khomiakoff A.-S.], Quelques mots sur les communions occidentales à l'occasion d'un Mandement de l'archevêque de Paris, par un chrétien orthodoxe (Leipzig 1855).

Kolbaba T. M., 'The Legacy of Humbert and Cerularius: the Tradition of the Schism of 1054 in the Byzantine Texts and Manuscripts of the Twelfth and Thirteenth Centuries', in Ch. Dendrinos et al. (eds), Porphyrogenita. Essays on the History and Literature of Byzantium and the Latin East in Honour of Julian Chrysostomides (Aldershot-Burlington VT 2003) 47-61.

- 'On the Closing of the Churches and the Rebaptism of Latins: Greek Perfidy or Latin Slander?', Byzantine and Modern Greek Studies 29 (2005) 39-51.

- '1054 Revisited: Response to Ryder', Byzantine and Modern Greek Studies 35 (2011) $38-44$.

Komninos-Papadopoulos N., Adversus haereticam epistolam Joannis Hokstoni responsio ad sacratissimum \& sapientissimum Antistitem Chrysanthum Notaram metropoliten Caesariensem Palaestinae primatem. Addita est in calce ipsa Jo. Hokstoni Epistola (Venice 1703).

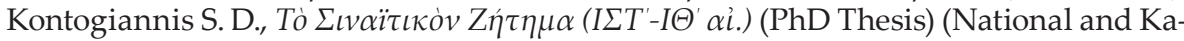
podistrian University of Athens, Athens 1987).

Kontouma V., John of Damascus: New Studies on his Life and Work (Farnham-Burlington VT 2015).

- 'Christianisme orthodoxe. Recherches sur Dosithée II de Jérusalem (1669-1707)', Annuaire de l'École Pratique des Hautes Études (EPHE). Section des sciences religieuses. Résumé des conferences et travaux 124 (2015-2016) 207-18.

- 'La Confession de foi de Dosithée II de Jérusalem: les versions de 1672 et de 1690', in M.-H. Blanchet and F. Gabriel (eds), L'Union à l'épreuve du formulaire : professions de foi entre Églises d'Orient et d'Occident (XIIIe-XVIIIe siècle) (Leuven-Paris-Bristol CT 2016) 341-72.

- 'Christianisme orthodoxe, XVe-XXIe siècles', Annuaire de l'École Pratique des Hautes Études (EPHE). Section des sciences religieuses. Résumé des conferences et travaux 126 (2019) 239-56.

- and Garnier S., '1672: Concilium Hierosolymitanum', in A. Melloni (ed.), Conciliorum Oecumenicorum Generaliumque Decreta, IV/1 (Turnhout 2016) 265-327.

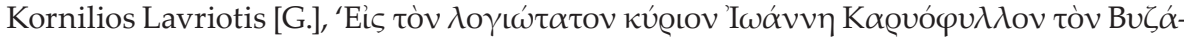

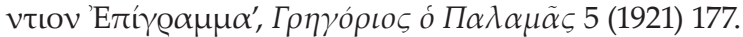

K[uzenkov] P. V., 'Gavrijl Sevir', in Pravoslavnaja Enciklopedija, X (Moscow 2005) 246-7.

Lambros S. P., Catalogue of the Greek Manuscripts on Mount Athos, II (Cambridge 1900).

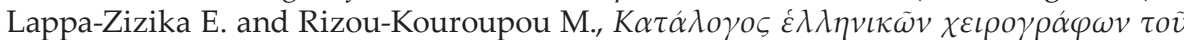

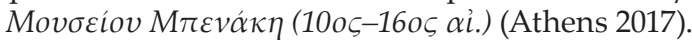

Leeuw M. de, 'Der Coislinianus 345 im Kloster Megisti Lavra (Athos)', Zeitschrift für Papyrologie und Epigraphik 131 (2000) 58-64.

Legrand É., Bibliographie hellénique ou description raisonnée des ouvrages publiés par des grecs au dix-septième siècle, II (Paris 1894).

- Bibliographie hellénique ou description raisonnée des ouvrages publiés par des Grecs au dix-septième siècle, III (Paris 1895).

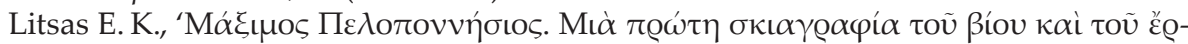

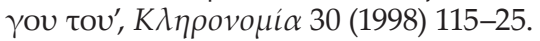


Livanios D., 'Pride, Prudence, and the Fear of God: the loyalties of Alexander and Nicholas Mavrocordatos (1664-1730)', Dialogos. Hellenic Studies Review 7 (2000) 1-22.

Livanos Ch., Greek Traditions and Latin Influence in the Work of George Scholarios (Piscataway NJ 2006).

Maloney G. A., A History of Orthodox Theology since 1453 (Belmont MA 1976).

Malvy A. and Viller M., La Confession orthodoxe de Pierre Moghila, Métropolite de Kiev (1633-1646) approuvée par les Patriarches grecs du XVII siècle [Orientalia Christiana 10 (1927), n. 39] (Rome-Paris 1927).

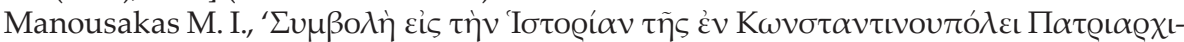

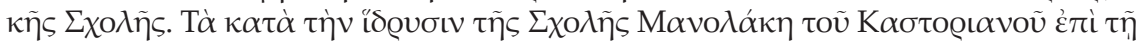

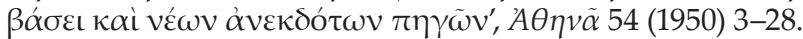

Manu D. I., 'Sinodul din Ierusalim (1672). Importanța lui pentru întărirea Ortodoxiei secolului al XVII-lea', Glasul Bisericii 33 (1974) 445-53.

- 'Importanța Sinoadelor Răsăritene din secolul al XVII-lea pentru unitatea Ortodoxiei' (teză de doctorat-partea a II-a), Ortodoxia 39 (1987) 31-99.

Mapelli E., La questione dell'epiclesi al Concilio di Firenze (Venegono Inferiore 1940).

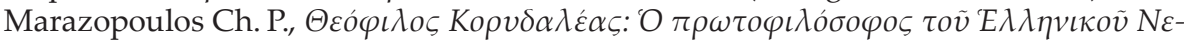
о $\propto\llcorner\sigma \tau о \tau \varepsilon \lambda \iota \sigma \mu о \tilde{v}$ (Athens 2008).

Mark of Ephesus, Opere, I (Bucharest 2009).

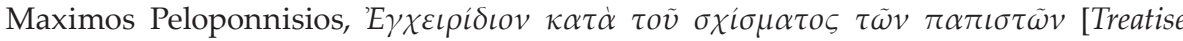
against the schism of the papists] (Bucharest 1690).

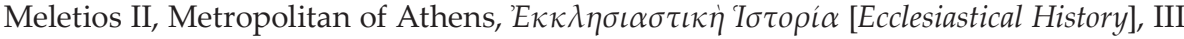
(Vienna 1784).

Muhammad Umar Memon (ed.-transl.), Ibn Taimìya's Struggle against Popular Religion. With an Annotated Translation of his Kitāb iqtidā' as-sirāt al-mustaqīm mukhālafat așāb al-jabìm (The Hague-Paris 1976).

Meyendorff P., 'The Liturgical Reforms of Peter Moghila: A New Look', St Vladimir's Theological Quarterly 29 (1985) 101-14.

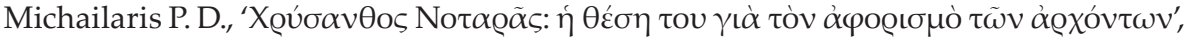
in Culture et société néohelléniques. Actes d'un Congrès International dédié à la mémoire de C. Th. Dimaras (Athens 1995) 43-50.

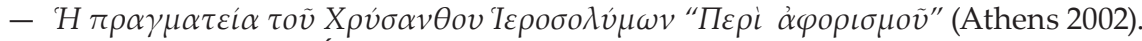

Michaud C., 'Raison d'État et conscience chrétienne. L'ambassade du marquis de Nointel auprès de la Porte ottomane', Revue des Études Sud-Est Européennes 17 (1979) 257-67.

Michel A., Humbert und Kerullarios. Quellen und Studien zum Schisma des XI. Jahrhunderts, 2 vols (Paderborn 1924-1930).

- 'Schisma und Kaiserhof im Jahre 1054: Michael Psellos', in 1054-1954. L'Église et les Églises : neuf siècles de douloureuse séparation entre l'Orient et l'Occident. Études et travaux sur l'Unité chrétienne offerts à Dom Lambert Beauduin, I ([Chevetogne] 1954).

Michelson D. A., La Perpétuité de la foi: The Appeal to Eastern Christianity of Jean Claude's Eucharistic Polemics Viewed in its French Reformation and Counter Reformation Contexts (MA Thesis) (Trinity Evangelical Divinity School, Deerfield IL 2001).

Mihăilă A., 'În multe rânduri și în multe chipuri' : O scurtă introducere ortodoxă în Vechiul Testament (Iași 2017).

Miladinova N., The Panoplia Dogmatike by Euthymios Zygadenos. A Study on the First Edition Published in Greek in 1710 (Leiden-Boston 2014). 
Minea I., 'Ceva despre Constantin Cantacuzino stolnicul', Cercetări Istorice. Revistă de Istorie Românească 8-9 (1932-1933) 73-9.

Mirkovich G., O vremeni presushhestvlenija Sv. Darov: Spor, byvshij v Moskve vo vtoroj polovine XVII-go veka (Opyt istoricheskago izsledovanija) (Vilnius 1886).

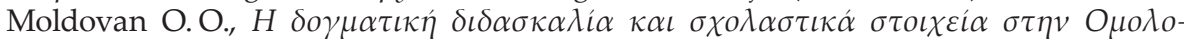

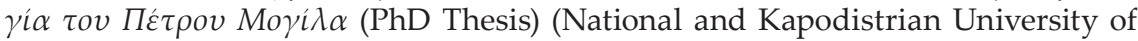
Athens, Athens 2012).

Moschos D., 'Approaching the Byzantine Past in the Historical Work of Dositheos of Jerusalem and Meletios of Athens', in A. Alshanskaya, A. Gietzen and Chr. Hadjiafxenti (eds), Imagining Byzantium: Perceptions, Patterns, Problems (Mainz 2018) 71-5.

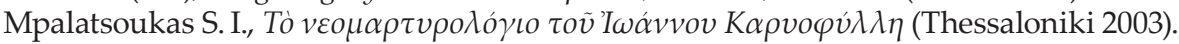

Mpompou-Stamati V., "H

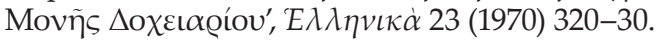

Nazâru S., 'Hotărârea sinodală de la Hiereia (754) - summa gândirii iconoclaste', Studii Teologice 4 (2008) 195-216.

Năsturel P. Ș., 'Contribuții la viața lui Ioan Cariofil în legătură cu Biserica Romînească', Mitropolia Olteniei 10 (1958) 511-27.

[Nicole P.], La perpétuité de la foy de l'Église catholique touchant l'eucharistie deffendue contre les livres du sieur Claude, Ministre de Charenton, III (Paris 1674).

Nosilia V. and Prandoni M. (eds), Trame controluce: Il patriarca protestante Cirillo Lucaris (Firenze 2015).

O'Meara D. J., 'The Philosophical Writings, Sources, and Thought of Athanasius Rhetor (ca. 1571-1663)', Proceedings of the American Philosophical Society 121 (1977) 483-99.

Olar O., 'Un temps pour parler. Dosithée de Jérusalem et le Synode de Jassy (1642)', Analele Putnei 10 (2014) 215-50.

- 'Prophecy and History. Matthew of Myra († 1626), Paisios Ligaridis († 1678) and Chrysanthos Notaras († 1731)', in R. G. Păun (ed.), Histoire, mémoire et dévotion. Regards croisés sur la construction des identités dans le monde orthodoxe aux époques byzantine et post-byzantine (Seyssel [2016]) 365-88.

- 'Les Confessions de foi de Cyrille Loukaris (+1638)', in M.-H. Blanchet and F. Gabriel (eds), L'Union à l'épreuve du formulaire : professions de foi entre Églises d'Orient et d'Occident (XIIIe-XVIIIe siècle) (Leuven-Paris-Bristol CT 2016) 271-310.

- 'Païsios Ligaridēs', in D. Thomas and J. Chesworth (eds), Christian-Muslim Relations: A Biographical History, X (Leiden-Boston 2017) 282-91.

- 'The Father and His Eldest Son. The Depiction of 1667 Muscovite Palm Sunday Procession by the Metropolitan of Gaza Paisios Ligarides and its Significance', Revue de l'histoire des religions 235 (2018) 5-36.

- La boutique de Théophile : les relations du patriarche de Constantinople Kyrillos Loukaris (1570-1638) avec la Réforme (Paris 2019).

Ortiz R. and Cartojan N., Un grande erudito romeno a Padova: Lo stolnic Constantin Cantacuzino (Bucharest 1943).

Ostroumov I. N., The History of the Council of Florence (London 1861).

Palmieri A., Dositeo, patriarca greco di Gerusalemme (1641-1707): Contributo alla storia della teologia greco-ortodossa nel secolo XVII (Firenze 1909).

- 'Caryophylles Jean', in A. Vacant, E. Mangenot and É. Amann (eds), Dictionnaire de Théologie Catholique contenant l'exposé des doctrines de la Théologie Catholique, leurs preuves et leur histoire, II/2 (Paris 1932) 1812-3. 
Panich T. V., Kniga «Shhit very» v istoriko-literaturnom kontekste konca XVII veka (Novosibirsk 2004).

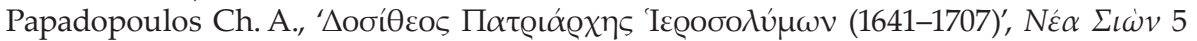
(1907) 97-168.

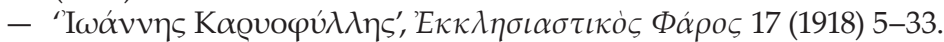

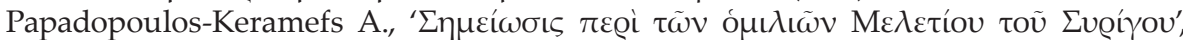

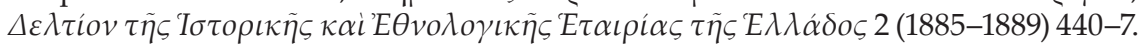

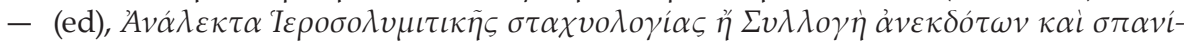

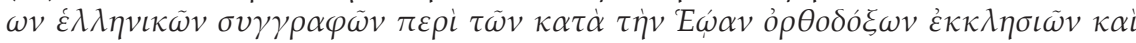
$\mu \alpha \dot{\lambda} \iota \sigma \tau \alpha \tau \tilde{\eta} \varsigma \tau \tilde{\omega} v \prod \alpha \lambda \alpha \iota \sigma \tau \iota v \tilde{\omega} v$, I (Petersburg 1891).

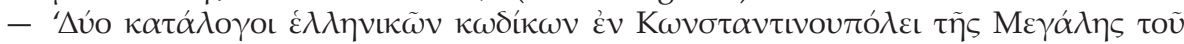

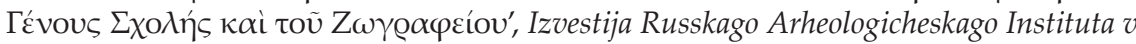
Konstantinopole 14 (1909) 101-53.

Păun R. G., 'Well-Born of the Polis. The Ottoman Conquest and the Reconstruction of the Greek Orthodox Elites under Ottoman Rule (15th-17th Centuries)', in R. Born and S. Jagodzinski (eds), Türkenkriege und Adelskultur in Ostmitteleuropa vom 16. bis zum 18. Jahrhundert (Ostfildern 2014) 59-85.

Pentiuc E., The Old Testament in Eastern Orthodox Tradition (New York 2014).

Petit L., Documents relatifs au Concile de Florence, I (Paris 1927).

Piccione R. M., 'Libri greci da Venezia a Torino e l'eredità di Gavriil Seviros', Medioevo Greco 17 (2017) 193-210.

Pieralli L., La corrispondenza diplomatica dell'imperatore bizantino con le potenze estere nel tredicesimo secolo (1204-1282). Edizione critica e studio storico-diplomatistico (Vatican 2006).

Podskalsky G., 'De Rezeption der thomistischen Theologie bei Gennadios II. Scholarios (ca. 1403-1472)', Theologie und Philosophie 49 (1974) 305-23.

- Griechische Theologie in der Zeit der Türkenherrschaft (1453-1821). Die Orthodoxie im Spannungsfeld der nachreformatorischen Konfessionen des Westens (München 1988).

Popivchak R. P., Peter Mohila, Metropolitan of Kiev (1633-1647). Translation and Evaluation of His Orthodox Confession of Faith (1640) (PhD Thesis) (Catholic University of America, Washington DC 1975).

Popoviciu N. I., Epicleza euharistică (Sibiu 1933).

Puhon G., 'Romite vo Makedonija i Vizantija', Glasnik 18 (1974) 81-94.

Quantin J.-L., 'De la Contre-Réforme comme monopole: les anti-jansénistes et la Perpétuité de la foi', Chroniques de Port-Royale 47 (1998) [Port-Royale et les Protestants] 115-48.

- Le catholicisme classique et les Pères de l'Église. Un retour aux sources (1669-1713) (Paris 1999).

Ramazanova D. N., 'Atticheskij kalendar' v sisteme hronologicheskih predstavlenij Aleksandrijskogo Patriarha Meletija Pigasa (1590-1601)', in R. A. Simonov (ed.), Kalendarno-hronologicheskaja kul'tura i problemy ee izuchenija: K 870-letiju «Uchenija» Kirika Novgorodca (Moscow 2006) 141-5.

- 'Buharestskij spisok Hrismologiona Paisija Ligarida: paleograficheskoe i kodikologicheskoe issledovanie', Vestnik RGGU. Nauchnyj zhurnal (Serija Istoricheskie nauki. Istoriografija, istochnikovedenie, metody istoricheskih issledovanij) 7/50 (2010) 178-91.

- 'Poslanija Aleksandrijskogo Patriarha Meletija Pigasa kak istochnik po istorii kalendarno-hronologicheskih predstavlenij vtoroj poloviny XVI-nachala HVII v.', in M. F. 
Rumyantseva, (ed.), Kognitionaja istorija. Koncepcija-Metody-Issledovatel'skie praktiki. Chtenija pamjati professora Ol'gi Mihajlovny Medushevskoj (Moscow 2011) 296-315.

- 'Istorija Ierusalimskih patriarhov ... Dosifeja Notara (Buharest, 1715): bytovanie i perevod', in Rumjancevskie chtenija 2011, II (Moscow 2011) 56-60.

- 'Ekzempljary sochinenij Ierusalimskogo Patriarha Hrisanfa Notara v sobranii muzeja knigi RGB', in Vivliofika: Istorija knigi i izuchenie knizhnyh pamjatnikov, II (Moscow 2011) 166-86.

- 'Patriarshie gramoty i pis'ma Meletija Pigasa i Kirilla Lukarisa kak istochnik po istorii kalendarno-hronologicheskih predstavlenij na Hristianskom Vostoke', in Problemy diplomatiki, kodikologii i aktovoj arheografii (Moscow 2012) 435-8.

- 'Spiski propovedej Ierusalimskogo Patriarha Hrisanfa Notary v perevodah Stefana Pisareva (1741-1760-e gg.)', in Y. Shustova (ed.), Vspomogatel'nye istoricheskie discipliny $v$ sovremennom nauchnom znanii. Materialy XXV Mezhdunarodnoj nauchnoj konferencii Moskva, 31 janvarja-2 fevralja 2013 g., II (Moscow 2013) 490-5.

- 'Perevody sochinenij Ierusalimskogo Patriarha Hrisanfa Notary v russkih spiskah XVIII v.', in B. L. Fonkich (ed.), Special'nye istoricheskie discipliny, I (Moscow 2014) 317-47.

- 'Propovedi Ierusalimskogo Patriarha Hrisanfa Notary v russkoj rukopisnoj tradicii XVIII v.', Vestnik RGGU. Nauchnyj zhurnal (Serija Istorija. Filologija. Kul'turologija. Vostokovedenie) 9/152 (2015) 97-105.

- 'Istorija Ierusalimskih patriarhov Dosifeja v russkoj kul'ture XVIII-XIX vv.', in Rossiia i Khristianskii Vostok 4-5 (2015) 435-58.

Renaudot E. (ed.), Gennadii Patriarchae Constantinopolitani, Homiliae de Sacramento Eucharistiae: Meletii Alexandrini, Nectarii Hierosolymitani, Meletii Syrigi, et aliorum, de eodem argumento opuscula graece et lat., seu appendix ad acta quae circa Graecorum de transubstantiatione fidem relata sunt in opere de perpetuitate fidei (Paris 1709).

- La perpétuité de la foy de l'Église catholique touchant l'eucharistie, IV (Paris 1711).

- La perpétuité de la foy de l'Église catholique sur les sacrements, et sur tous les autres points de religion $\mathcal{E}$ de discipline, que les premiers Réformateurs ont pris pour prétexte de leur schisme; prouvée par le consentement des Églises orientales, V (Paris 1713).

Rene C. G., In Search of a Confessional Identity: Dositheos Notaras, the Patriarch of Jerusalem (1669-1707), confronts the Challenges of Modernity (PhD Thesis) (University of Minnesota, Minneapolis-Saint Paul MN 2020).

Rochow I., 'Die Häresie der Athinganer im 8. und 9. Jahrhundert und die Frage ihres Fortlebens', in H. Köpstein and F. Winkelmann (eds), Studien zum 8. und 9. Jahrhundert in Byzanz (Berlin 1983) 163-78.

- and Matschke K.-P., 'Neues zu den Zigeunern im byzantinischen Reich um die Wende vom 13. zum 14. Jahrhundert', Jahrbuch der Österreichischen Byzantinistik 41 (1991) 241-54.

Rossetti L., 'Constantin Cantacuzino, studente romeno a Padova', Quaderni per la storia dell'Università di Padova 1 (1968) 147-54.

Ruffini M., Biblioteca Stolnicului Constantin Cantacuzino (Bucharest 1973).

Russell N., 'From the Shield of Orthodoxy to the Tome of Joy: the Anti-Western Stance of Dositheos II of Jerusalem (1641-1707)', in G. E. Demacopoulos and A. Papanikolaou (eds), Orthodox Constructions of the West (New York 2013) 71-82.

Russo D., 'Ioan Cariofil și operele lui', in D. Russo, Studii istorice greco-române. Opere postume, I (Bucharest 1939) 181-91. 
Ryder J. R., 'Changing Perspectives on 1054', Byzantine and Modern Greek Studies 35 (2011) 20-37.

Salaville S., 'Épiclèse eucharistique', in A. Vacant, E. Mangenot and É. Amann (eds), Dictionnaire de Théologie Catholique contenant l'exposé des doctrines de la Théologie Catholique, leurs preuves et leur histoire, V/I (Paris 1939) 194-300.

Sariyannis M., 'The Kadızadeli Movement as a Social and Political Phenomenon: the Rise of a Mercantile Ethic', in A. Anastasopoulos (ed.), Political Initiatives 'From the Bottom U Up' in the Ottoman Empire: Halcyon Days in Crete VII. A Symposium Held in Rethymno, 9-11 January 2009 (Rethymno 2012) 263-89.

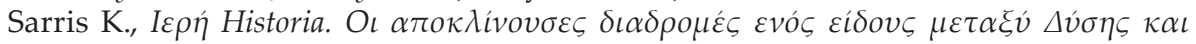

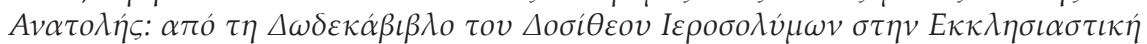

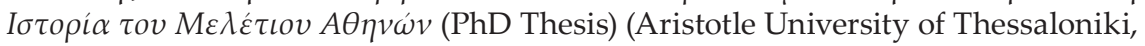
Thessaloniki 2010).

- 'Nektarios of Jerusalem', in D. Thomas and J. Chesworth (eds), Christian-Muslim Relations: A Biographical History, X (Leiden-Boston 2017) 308-18.

- 'Composing and publishing a non-confessional history in the age of Greek Orthodox confessions: The Ecclesiastical History by Meletios of Athens', in T. Anastassiadis, A. Girard, B. Heyberger, V. Kontouma (eds), Livres et confessions chrétiennes orientales. Histoire connectée entre Empire ottoman, monde slave et Occident (XVI ${ }^{e}-X V I I I^{e}$ siècles). Actes du colloque de Rome, 15-16 décembre 2016, Bibliothèque de l'École des Hautes Études (forthcoming).

Schadler P., John of Damascus and Islam: Christian Heresiology and the Intellectual Background to Earliest Christian-Muslim Relations (Leiden-Boston 2018).

Scheliha W. von, Russland und die orthodoxe Universalkirche in der Patriarchatsperiode (1589-1721) (Wiesbaden 2004).

Scholarios Georgios-Gennadios, CEuvres complètes de Georges Scholarios, eds L. Petit, X. A. Sidéridès and M. Jugie, I (Paris 1928).

Șerban C., 'Contribuție la repertoriul corespondenței stolnicului Constantin Cantacuzino', Studii. Revistă de Istorie 19 (1966) 683-705.

Shliapkin I., 'K istorii polemiki mezhdu moskovskimi i malorusskimi uchenymi v konce XVII veka', Zhurnal Ministerstva Narodnago Prosveshhenija 241 (1885) 210-52.

Sideris Th., 'The Theological Arguments of the Iconoclasts during the Iconoclastic Controversy', Byzantine Studies 6 (1979) 178-92.

Simonescu D., 'Le monastère de Cetătzuia (Iassy), foyer de culture de l'Orient orthodoxe', Balcania 6 (1943) 357-65.

Smith III M. H., And Taking Bread ... Cerularius and the Azyme Controversy of 1054 (Paris 1978).

Snoeks R., L'argument de tradition dans la controverse eucharistique entre catholiques et réformés français au XVIIe siècle (Louvain-Gembloux 1951).

Soulis G. C., 'The Gypsies in the Byzantine Empire and the Balkans in the Late Middle Ages', Dumbarton Oaks Papers 15 (1961) 141-65.

Spáčil Th., Doctrina Theologiae Orientis separati de SS. Eucharistia, II [Orientalia Christiana 14 (1929), n. 50] (Rome 1929).

Spanos A.,' To Every Innovation, Anathema (?). Some Preliminary Thoughts on the Study of Byzantine Innovation', in H. Knudsen et al. (eds), Mysterion, strategike og kainotomia. Et festskrift til ære for Jonny Holbek (Oslo 2010) 51-9. 
- 'Was Innovation Unwanted in Byzantium?', in I. Nilsson and P. Stephenson (eds), Wanted: Byzantium. The Desire for a Lost Empire (Uppsala 2014) 43-56.

Speck P., 'Die vermeintliche Häresie der Athinganoi', Jahrbuch der Österreichischen Byzantinistik 47 (1997) 37-50.

Stăniloae D., ‘Viața și activitatea patriarhului Dosofteiu al Ierusalimului și legăturile lui cu Țările Românești', Candela 40 (1929) 208-76.

Starr J., 'An Eastern Christian Sect: The Athinganoi', Harvard Theological Review 29 (1936) 93-106.

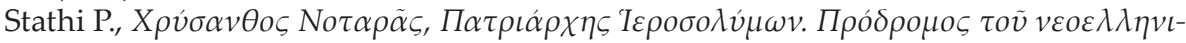

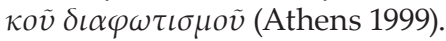

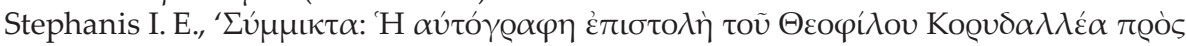

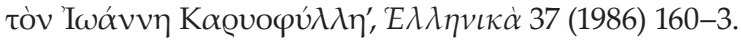

Stoicescu N., Dicționar al marilor dregători din Țara Românească și Moldova (sec. XIV-XVII) (Bucharest 1971).

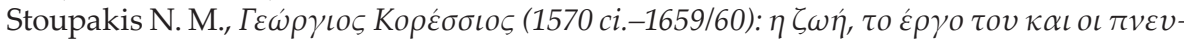

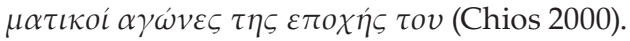

Strakhov O. B., The Byzantine Culture in Muscovite Rus': The Case of Evfimii Chudovskii (1620-1705) (Köln-Weimar-Wien 1998).

Ștrempel G., Catalogul manuscriselor românești. B.A.R., 1-1600 (Bucharest 1978).

Tăutu A. L. (ed.), Acta Urbani IV, Clementis IV, Gregorii X (1261-1276) e Regestis Vaticanis aliisque Fontibus ([Rome] 1953).

Tchentsova V., 'Les documents grecs du XVIIe siècle: pièces authentiques et pièces fausses. 3. Mélétios Syrigos, véritable auteur de la lettre adressée au patriarche de Moscou Nikon par les zôgraphoi Jean et Georges', Orientalia Christiana Periodica 73 (2007) 311-45.

- 'Meletij Sirig', in Pravoslavnaja Enciklopedija, XLIV (Moscow 2016) 591-4.

Thomson F. J., 'Peter Mogila's Ecclesiastical Reforms and the Ukrainian Contribution to Russian Culture. A Critique of Georges Florovsky's Theory of The Pseudomorphosis of Orthodoxy', Slavica Gandensia 20 (1993) 67-119.

Tinnefeld F., 'Georgios Gennadios Scholarios', in C. G. Conticello and V. Conticello (eds), La théologie byzantine et sa tradition, II. (XIIIe-XIXe s.) (Turnhout 2002) 477-549.

Todt K.-P., 'Dositheos II. von Jerusalem', in C. G. Conticello and V. Conticello (eds), La théologie byzantine et sa tradition, II (XIIIe-XIXe s.) (Turnhout 2002) 659-720.

Tsakiris V., Die gedruckten griechischen Beichtbücher zur Zeit der Türkenherrschaft. Ihr kirchenpolitischer Entstehungszusammenhang und ihre Quellen (Berlin-New York 2009).

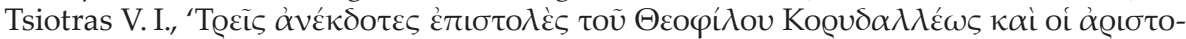

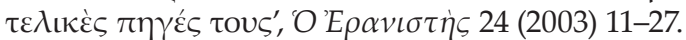

Tsourka-Papastathi D., 'À propos des privilèges octroyés par Mehmet II au patriarche Gennadios Scholarios: Mythes et réalités', in Le Patriarcat CEcuménique de Constantinople aux XIVe-XVI siècles: rupture et continuité. Actes du colloque international, Rome, 5-6-7 décembre 2005 (Paris 2007) 213-74.

Tsourkas C., Les débuts de l'enseignement philosophique et de la libre pensée dans les Balkans: la vie et l'oeuvre de Théophile Corydalée (1570-1646), 2nd edn (Thessaloniki 1967).

- Germanos Locros, archevêque de Nysse et son temps (1645-1700). Contribution à l'histoire culturelle des Balkans au XVIIe siècle (Thessaloniki 1970).

Turdeanu É., 'Le livre grec en Russie : l'apport des presses de Moldavie et de Valachie (1682-1725)', Revue des Études Slaves 26 (1950) 69-87. 


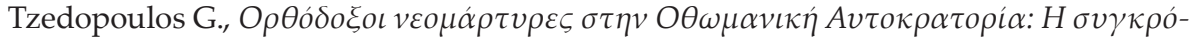

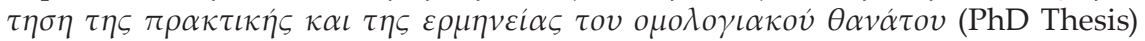
(National and Kapodistrian University of Athens, Athens 2012).

Tzirakis N. E., H $\pi \varepsilon \rho i \mu \varepsilon \varepsilon \tau o v \sigma \iota \omega ́ \sigma \varepsilon \omega \varsigma$ (transsubstantiatio) $\varepsilon \dot{v} \chi \alpha \rho \iota \sigma \tau \iota \alpha \kappa \eta \dot{~ \varepsilon ́ \rho ı \varsigma . ~ \Sigma v \mu \beta o-~}$

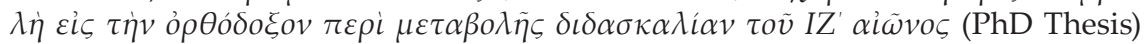
(National and Kapodistrian University of Athens, Athens 1977).

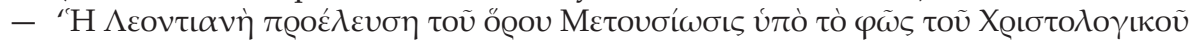

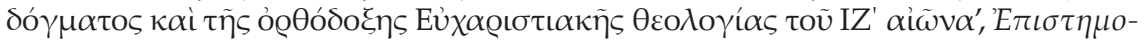
$\nu \iota \kappa \dot{\eta} ' E \pi \varepsilon \tau \eta \rho i \varsigma \tau \tilde{\eta} \varsigma \Theta \varepsilon o \lambda o \gamma \iota \kappa \tilde{\eta} \varsigma \Sigma \chi \propto \lambda \hat{\eta} \varsigma$ [National and Kapodistrian University of Athens] 35 (2000) 463-519.

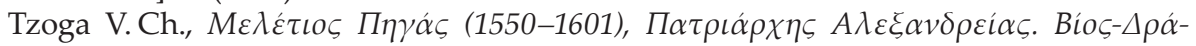
$\sigma \eta-E \rho \gamma о \gamma \rho \alpha \varphi i \alpha$ (PhD Thesis) (National and Kapodistrian University of Athens, Athens 2009).

- 'Un sigillion inédit du patriarche de Constantinople Jérémie II et d'Alexandre Sylvestre sur la réforme du calendrier', Byzantinische Zeitschrift 107 (2014) 221-52.

Vandal A., L'odyssée d'un ambassadeur : les voyages du marquis de Nointel (1670-1680) (Paris 1900).

Vaporis N. M., 'A Study of the Ziskind MS No. 22 of the Yale University Library: Some Aspects of the History of the Ecumenical Patriarchate of Constantinople in the Seventeenth and Eighteenth Centuries', The Greek Orthodox Theological Review [Supplement] 12 (1967) 1-40; 13 (1968) 41-84; 14 (1969) 85-124.

- 'Codex $\left(\Gamma^{\prime}\right)$ Gamma of the Ecumenical Patriarchate of Constantinople', The Greek Orthodox Theological Review [Supplement] 18 (1973) 1-88.

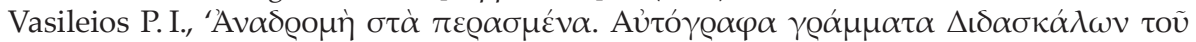

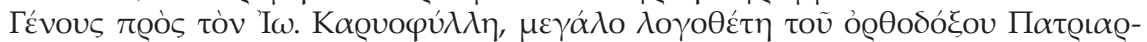

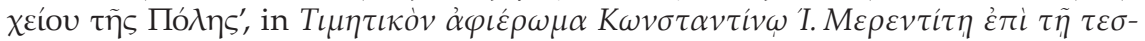
$\sigma \alpha \rho \alpha \kappa o v \tau \alpha \varepsilon \tau \eta \rho \iota \delta \iota \tau \tilde{\eta} \varsigma \dot{\varepsilon} \kappa \tau \alpha \iota \delta \varepsilon v \tau \iota \kappa \tilde{\eta} \varsigma \alpha \hat{v} \tau o \tilde{v} \delta \rho \alpha ́ \sigma \varepsilon \omega \varsigma / F e s t s c h r i f t$ für Konstantinos J. Merentitis (Athens 1972) 17-39.

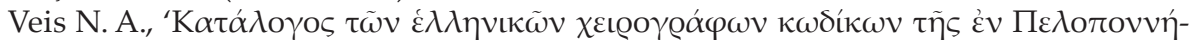

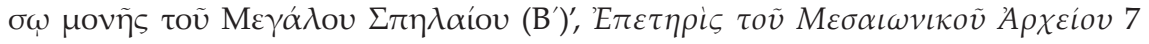
(1957) 3-37.

Vergatti R. Ș., 'Început de drum în viața unui intelectual român: Constantin Cantacuzino', in A. Bogdan et al. (eds), Gabriel Ștrempel la 80 de ani: ... o viață închinată cărții (Satu-Mare 2006) 818-37.

Viller M., 'Notes et mélanges: Une infiltration latine dans la théologie orientale. La Confession orthodoxe attribuée à Pierre Moghila et le Catéchisme de Canisius', Recherches de Science Religieuse 3 (1912) 159-68.

Vorgrimler H., 'Sakrament: III. Theologie- und dogmengeschichtlich', in M. Buchberger, W. Kasper et al. (eds), Lexikon für Theologie und Kirche, 3rd edn, VIII (FreiburgBasel-Rom-Wien 1999) 1440-2.

Wenger A., 'Les influences du rituel de Paul V sur le Trebnik de Pierre Moghila', in Mélanges en l'honneur de Monseigneur Michel Andrieu (Strasbourg 1956) 477-99.

Wenz G., 'Sakramente I', in H. Balz et al. (eds), Theologische Realenzyklopädie, XXIX (Berlin-New York 1998) 663-84.

Will C. (ed.), Acta et scripta quae de controversiis Ecclesiae Graecae et Latinae saeculo undecimo composita extant (Leipzig-Marburg 1861). 
Williams G. (ed.), The Orthodox Church of the East in the Eighteenth Century, being the Correspondence between the Eastern Patriarchs and the Nonjuring Bishops, with an Introduction on Various Projects of Reunion between the Eastern Church and the Anglican Communion (London-Oxford-Cambridge 1868).

Wohlmuth J., Realpräsenz und Transsubstantiation im Konzil von Trient: eine historischkritische Analyse der Canones 1-4 der Sessio XIII, I-II (Bern-Frankfurt a.M. 1975).

Woodbridge J. D., 'La grande chasse aux manuscrits, la controverse eucharistique et Richard Simon', in O. Elyada and J. Le Brun (eds), Conflits politiques, controverses religieuses: Essais d'histoire européenne aux 16e-18e siècles (Paris 2002) 143-75.

Yalamas D. A., ‘'Terusalimskij patriarh Dosifej i Rossija. 1700-1706 gg. Po materialam Rossijskogo gosudarstvennogo arhiva drevnih aktov. Chast’ 2 (1701 g.)', in Rossiia i Khristianskii Vostok 2-3 (2004) 472-92.

- 'Ierusalimskij patriarh Dosifej i Rossija. 1700-1706 gg. Po materialam Rossijskogo gosudarstvennogo arhiva drevnih aktov. Chast' 1 (1700 g.)', in Rossiia i Khristianskii Vostok 4-5 (2015) 593-647.

Yarnold E., 'Transsubstantiation', in I. Perczel, R. Forrai and G. Gerebý (eds), The Eucharist in Theology and Philosophy: Issues of Doctrinal History in East and West from the Patristic Age to the Reformation (Leuven 2005) 381-94.

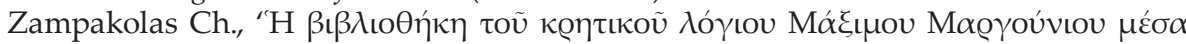

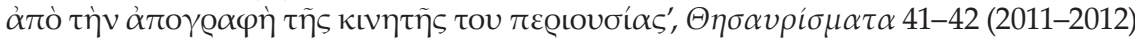
$311-28$.

Zankow S., Das orthodoxe Christentum des Ostens: sein Wesen und seine gegenwärtige Gestalt (Berlin 1928).

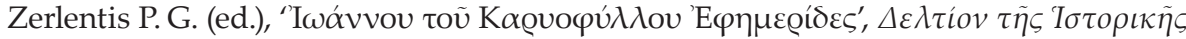

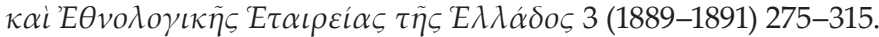

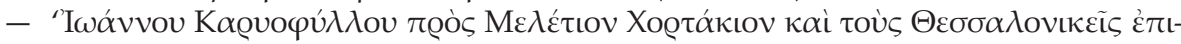

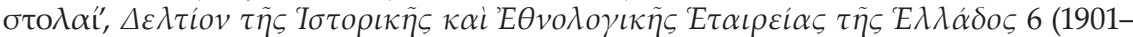
1906) 73-87.

Zilfi M. C., 'The Kadızadelis: Discordant Revivalism in Seventeenth-Century Istanbul', Journal of Near Eastern Studies 45 (1986) 251-69.

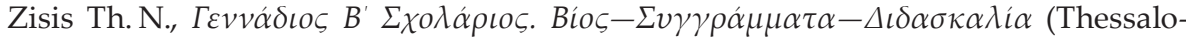
niki 1980).

Zhukovs'kij A., Petro Mogila i pitannja ednosti Cerkov (Paris 1969).

Žužek R., 'L'escatologia di Pietro Moghila', Orientalia Christiana Periodica 54 (1988) 353-80. 



\title{
Confessionalization in Ottoman Orthodoxy in Comparative Perspective: The Publishing Program of the Kollyvades and Jewish Ladino Musar Literature in the 'long' Eighteenth Century
}

\author{
Ioannis Zelepos, Ruhr-Universität Bochum
}

\section{Preliminary remarks}

The confessionalization paradigm, since its first appearance in German historiography in the late $1950 \mathrm{~s},{ }^{1}$ has developed into a valuable hermeneutical tool for historical research on Early Modern Europe. In that time, the paradigm has seen modifications and a flexibilization of its initially quite narrow axioms, which, for example, considered the state as the exclusive protagonist of confessionalization practices, ${ }^{2}$ as well as a broadening of its geographical scope, which initially was limited essentially to Protestant German respectively Western Central European lands. As a result, today there is considerable research on the confessionalization paradigm also for regions beyond the Holy Roman Empire, in the Catholic West as well as in East-Central Europe. ${ }^{3}$ Orthodox East- and Southeast Europe, however, has remained virtually outside the focus of this scholarship, forming in this respect a white spot on the map of European Christianity. The reason for this void is not necessarily the incompatibility of this paradigm, but rather that research in this regard is still in its very infancy. ${ }^{4}$

1 Cf. E. W. Zeeden, 'Grundlagen und Wege der Konfessionsbildung im Zeitalter der Glaubenskämpfe', Historische Zeitschrift 85 (1958) 249-99; E. W. Zeeden, Die Entstehung der Konfessionen (Munich 1965). For the development of the confessionalization paradigm in subsequent scholarship, cf. Th. Brockmann and D. Weiss (eds), Das Konfessionalisierungsparadigma-Leistungen, Probleme, Grenzen (Münster 2013).

2 Cf. H. Schmidt, 'Sozialdisziplinierung? Ein Plädoyer für das Ende des Etatismus in der Konfessionalisierungsforschung', Historische Zeitschrift 265 (1997) 639-82.

3 See for example J. Bahlke and A. Strohmeyer (eds), Konfessionalisierung in Ostmitteleuropa. Wirkungen des religiösen Wandels in im 16. und 17. Jahrhundert in Staat, Gesellschaft und Kultur (Stuttgart 1999); U. Lotz-Heumann, Die doppelte Konfessionalisierung in Irland. Konflikt und Koexistenz im 16. und in der ersten Hälfte des 17. Jahrhunderts (Tübingen 2000); J. Headley et al. (eds), Confessionalization in Europe, 1555-1700. Essays in Honor and Memory of Bodo Nischan (London 2004).

4 See, however, for Russian Orthodoxy the chapter 'Confessionalization in a Multi-ethnic Empire', in N. Shields Kollmann, The Russian Empire 1450-1801 (Oxford 2017). See also three international workshops in Germany, 'Orthodoxa Confessio? Konfessionsbildung, Konfessionalisierung und ihre Folgen in der östlichen Christenheit Europas (13.-20. Jahrhundert)' 
The hypothesis of the present paper is that historical research on Orthodox Christianity in the Early Modern period can indeed be methodologically enriched by the confessionalization paradigm, provided that it is applied in an undogmatic manner and with reference to the specific organizational structures and socio-political frameworks of the Orthodox world, which in many aspects differed from those in Central and Western Europe. One such difference was the near absence of systematic state-run efforts to achieve religious homogenization as part of imperial strategies of rule, something that allowed religious diversity to become a structural element of society, as can be observed in particular with the Ottomans, but to a considerable extent also with the Venetians, with Habsburgian Hungary and likewise with the Russian Empire. Viewing this multi-religious setting in context of the multifold entanglements between Southeast European Orthodoxy and the Western Christian Churches in the Early Modern period, it seems obvious to look for affinities and influences in this regard, as well as for possibly specific paths to the confessionalization or, as the case may be, self-confessionalization of Ottoman Orthodoxy ${ }^{5}$. This follows from the basic consideration that, on the one hand, it may be problematic to underestimate socio-economic, political and cultural differences between these regions, but, on the other hand, it is analytically no less dangerous to assume that they formed two completely different worlds, as ideologists of Orthodoxy tirelessly assert. ${ }^{6}$

The first part of this contribution examines the publishing program of the Kollyvades ('Ko $\left.\lambda \lambda v \beta \alpha \alpha \delta \varepsilon \varsigma^{\prime}\right)$ in the last third of the eighteenth and the first decades of the nineteenth century under the aspect of confessionalization, giving an outline of its contents as well as of the programmatic profile of the movement that created it. ${ }^{7}$ The second part places these observations in an interreligious context by

(5-7 March 2015, Mainz), cf. M.-D. Grigore and Fl. Kührer-Wielach (eds), Orthodoxa Confessio? Konfessionsbildung, Konfessionalisierung und ihre Folgen in der östlichen Christenheit Europas (Göttingen 2018); ‘Confessionalization and-as Knowledge Transfer in Greek-orthodox Church' (13-16 December 2017, Berlin), cf. the present volume; 'Religious Diversity and Confessionalization in Ottoman Europe' (4-6 July 2019, Munich) (volume forthcoming). Besides, there is the ongoing project at the CEU Budapest 'Ottoconfession: The Fashioning of a Sunni Orthodoxy and the Entangled Histories of Confession-Building in the Ottoman Empire, 15th-17th Centuries'.

5 On "self-confessionalization" see Schmidt, 'Sozialdisziplinierung?'.

6 Modern projections of an almost ontological dichotomy between the Orthodox 'spiritual East' and the non-Orthodox 'materialist West' are heavily influenced by the concept of 'pseudomorphosis', articulated first time by Georgij Florovsky (1893-1979) in Puti russkago bogoslovija [Ways of Russian Theology] (Paris 1937). The term initially originates from mineralogy, but in a cultural sense was shaped by Oswald Spengler in Der Untergang des Abendlandes. Umrisse einer Morphologie der Weltgeschichte (Munich 1963), across the work's two volumes-Gestalt und Wirklichkeit (Vienna 1918) and Welthistorische Perspektiven (Munich 1922). Offering a formidable reference point for tautological reasoning about 'authenticity' and 'distortion', the 'pseudomorphosis' concept was soon eagerly adopted by Orthodox ideologists, and in this way contributed at least indirectly to the hampering of critical research on the cultural history of Orthodoxy.

7 The basic reference for this section is I.Zelepos, Orthodoxe Eiferer im osmanischen Südost- 
comparing them with a popular genre of Jewish religious literature that flourished during the same period among the Sephardim of the Ottoman Empire, the so called 'Musar' books. ${ }^{8}$ This comparative approach is part of a broader research project on Early Modern multi-denominational interaction in the overlapping zones of the Ottoman Empire and Venice's maritime possessions on the example of Orthodox Christians and Jews, who in both cases constituted only tolerated religious communities, though with a remarkable presence in the urban centers as well as in the socio-economic life of both states. ${ }^{9}$ Considerable research has been carried out on denominational groups in the Early Modern Mediterranean world, focusing strongly on the permeability of religious identities and favoring phenomena such as grassroots syncretism in everyday culture, religious conversions and so called trans-imperial subjects. ${ }^{10}$ While these observations are revealing in many aspects, the current project follows a different approach in turning the focus of attention away from the fringes of religious identities to their very core, and by asking how the specific multi-denominational framework in which the communities lived under conditions of relative tolerance, influenced their normative religious discourses and thus shaped their denominational identities. The main focus is therefore on the question how spiritual authorities dealt practically with

europa. Die Kollyvadenbewegung (1750-1820) und ihr Beitrag zu den Auseinandersetzungen um Tradition, Aufklärung und Identität (Wiesbaden 2012).

8 This section relies necessarily on secondary source evidence and is particularly indebted to Matthias Lehmann, Ladino rabbinic literature and Ottoman Sephardic culture (Bloomington 2005). Cf. M. Angel, Foundations of Sephardic spirituality; the inner life of Jews of the Ottoman Empire (Woodstock 2006); H. Beinart (ed.), Moreshet Sepharad: The Sephardi Legacy, 2 vols (Jerusalem 1992); E. Benbassa and A. Rodrigue, The Jews of the Balkans: The Judeo-Spanish Community, 15th to 20th Centuries (Oxford 1995); E. Benbassa and A. Rodrigue, Sephardi Jewry. A History of the Judeo-Spanish Community, 14th to 20th Centuries (Berkeley 2000); A. Levy (ed.), The Jews of the Ottoman Empire, 2nd edition (Princeton 2003); I. Twersky and B. Septimus (eds), Jewish Thought in the Seventeenth Century (Cambridge 1987).

9 The title is 'Early modern multi-denominationalism "East" vs. "West"? A comparative analysis on the Ottoman Empire and Venice in the 17th and 18th centuries', cf. http://gepris.dfg. de/gepris/projekt/222859978.

10 On religious syncretism, cf. the classical monograph of Frederick William Hasluck, Christianity and Islam under the Sultans, 2 vols (Oxford 1929). On conversions and trans-imperial subjects, cf. A. Minkov, Conversion to Islam in the Balkans. Kisve Bahası Petitions and Ottoman social Life, 1670-1730 (Leiden 2004); E. Dursteler, Venetians in Constantinople. Nation, Identity, and Coexistence in the Early Modern Mediterranean (Baltimore 2006); E. Dursteler, Renegade Women: Gender, Identity and Boundaries in the Early Modern Mediterranean (Baltimore 2011); E. Dursteler, 'Fearing the "Turk" and Feeling the Spirit: Emotion and Conversion in the Early Modern Mediterranean', Journal of Religious History 39/4 (2015) 484-505; T. Krstić, Contested Conversions to Islam. Narratives of Religious Change in the Early Modern Ottoman Empire (Stanford 2011); E. N. Rothman, 'Becoming Venetian: Conversion and Transformation in the Seventeenth-Century Mediterranean', Mediterranean Historical Review 21/1 (June 2006) 39-75; E. N. Rothman, 'Interpreting Dragomans: Boundaries and Crossings in the Early Modern Mediterranean', Comparative Studies in Society and History 51/4 (2009) 771-800; E. N. Rothman, Brokering Empire: Trans-Imperial Subjects between Venice and Istanbul (Cornell 2012); E. N. Rothman, 'Afterword: Intermediaries, Mediation, and Cross-Confessional Diplomacy in the Early Modern Mediterranean', Journal of Early Modern History 19 (2015) 245-59. 
and gave religious meaning to the reality around them-that is, a hetero-denominational society under conditions of largely non-assimilative political rule-and what mechanisms of reception and idea transfer went along with it, the spectrum of the latter extending from deliberate adoption to polemical stereotyping.

\section{The publishing program of the Kollyvades-movement}

The noun 'Kollyvades' denotes a movement of Orthodox monks that emerged on the Athos peninsula in the mid-eighteenth century. ${ }^{11}$ This time is commonly characterized as a period of crisis and transition in Ottoman Southeast Europe in a political as well as in an intellectual and cultural sense-keywords in this context are the erosion of central state authority, the growing economic and political penetration of the Empire by the European powers along with a series of military conflicts, and, furthermore, the increasing reception of modern scientific thought and the ideas of European Enlightenment. ${ }^{12}$ The Kollyvades themselves definitely believed that they were living in times of deep crisis. For this reason, they undertook various activities in order to defend what they imagined to be traditional religious order against menacing foreign intrusions from the 'West'. The most sustained aspect of these activities was an extensive publishing program, which in terms of quantity, thematic diversity and methods of dissemination had no precedent in the history of Greek-speaking (and beyond) Orthodox religious literature. It consisted of a huge amount of writings systematically published as printed books and written in vernacular language in order to reach broad audiences. ${ }^{13}$

In terms of content, these publications can be divided roughly into five categories, the first of them being texts with programmatic character which in a certain

11 On the formation and spread of this movement, see in detail Zelepos, Orthodoxe Eiferer, 132-89.

12 From the extensive literature relating thereto, see for example H. Inalcik and D. Quataert (eds), An economic and social history of the Ottoman Empire 1300-1914 (Cambridge 1994); S. Faroqhi (ed.), The Cambridge History of Turkey, III. The Later Ottoman Empire, 1603-1839 (Cambridge 2006); G. P. Henderson, The Revival of Greek Thought 1620-1830 (Edinburgh 1971); P. Kitromilides, Enlightenment and Revolution. The Making of Modern Greece (Cambridge MA 2013); K. Gavroglou (ed.), The Sciences in the European Periphery during the Enlightenment (Dordrecht 1999).

13 Only a few of them remained in manuscript form because their scheduled publication was canceled for external reasons, e.g. the edition of the collected works of Gregory Palamas (1296/7-1359), the leading figure of Byzantine Hesychasm, which failed because the manuscript sent to Vienna for printing in 1797 was confiscated by the Austrian security organs, or

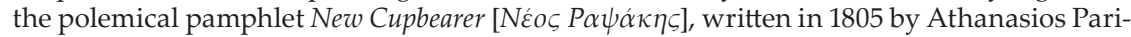
os (1721-1813), whose printing was prevented by supporters of Adamantios Korais (1748-

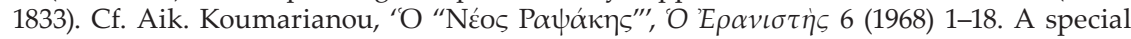
case seems to be the Christian pedagogy, that is, talk about good education, rearing and behavior of

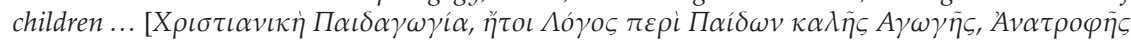

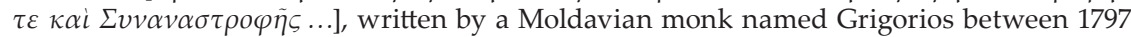
and 1801 and proofread by Nikodimos Agioreitis (1749-1809), which from the design of the manuscript was presumably meant to be used and copied in handwritten form (the first printed edition followed more than two hundred years later in Athens, 2005). 
way also defined the specific group identity of the Kollyvades. Among them was

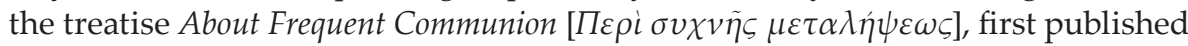
in 1777 and again in 1783 in a revised form, which can be considered as kick-off publication, dealing as it does with a major controversial issue that had been one of the triggers for the formation of the movement in the 1750s ${ }^{14}$ Another important

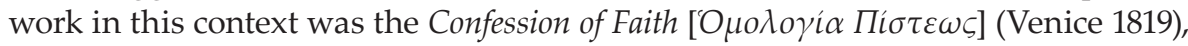
in which a general apology of the dogmatic positions of the movement is articulated together with its self-designation as 'Kollyvades'. ${ }^{15}$

A second category is made up of canon-building publications, beginning with the famous Filokalia (i.e. Love for the good) (Venice 1782), ${ }_{1}^{16}$ an encyclopedic collection of Orthodox Church Fathers with a strong focus on Hesychasm, a Slavonic version of which was published under the conterminous title Dobrotoljublje (St Petersburg 1793). ${ }^{17}$ Other significant examples of this category are the collection of neo-martyr-lives New Collection of Martyrs [NÉov M $\alpha \rho \tau v \rho o \lambda o ́ \gamma \iota 0 v]$ (Venice 1799)18, the hagiological collection for every day of the year Collection reader for the twelve

14 The first version by Neofytos Kafsokalyvitis (1713-1784) was published as Manual of anonymous authorship which proves that the Christians owe to take part more often in the Holy Commu-

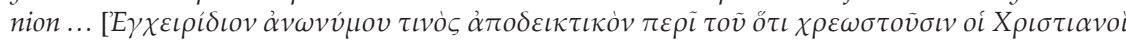

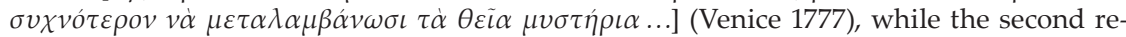
vised version by Nikodimos Agioreitis and Makarios Notaras (1731-1805) was titled Book of most spiritual benefit about the continuous Communion of the Holy Sacraments of Christ. Now for

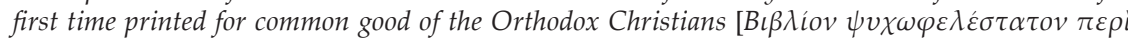

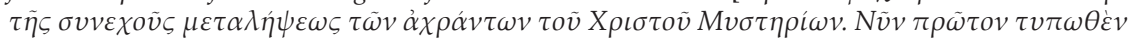

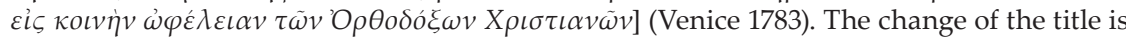
indicative for the pronounced pedagogical impetus of the second version, corroborated also by its even more vernacular language in comparison to the first version. Older scholarship assumed that Neofytos' book derived from the treatise of the Spanish Quietist Miguel de Molinos, Breve tratado de la comunión cotidiana (Rome 1675), but that is unlikely in view of textual evidence (cf. Zelepos, Orthodoxe Eiferer, 273 and 286). There are, however, indications of Quietist influences on Ottoman-Orthodox religious discourse in the eighteenth century in other cases (ibid., 190).

15 The book was published ten years after the death of its author, Nikodimos Agioreitis, with the subtitle: which is a most righteous apology against those who dared ignorantly and viciously to misunderstand and to slander some traditions of the Holy Church, together with some other healthy

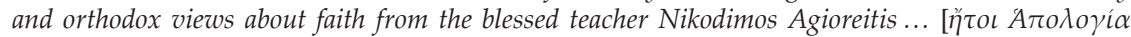

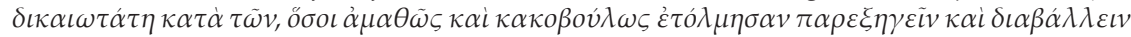

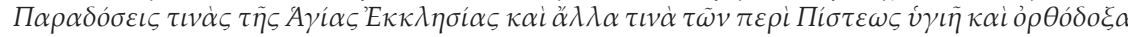

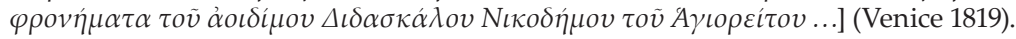

16 The collection was made by Nikodimos Agioreitis and Makarios Notaras and its edition in Venice was sponsored by Ioannis Mavrogordatos, a wealthy merchant from Smyrna. A supplement to the Love for the good was published in the following year under the title The

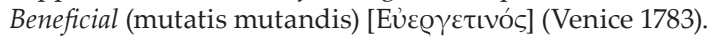

17 The initiator of this edition was the Ukranian starets Paisij Velichkovskij (1721-1794), see S. Chetverikov, Starets Paisii Velichkovskii. His Life, Teachings, and Influence on Orthodox Monasticism (Belmont MA 1980, English translation of the Russian manuscript from 1933); Zelepos, Orthodoxe Eiferer, 345-58.

18 The collection was made by Nikodimos Agioreitis and exclusively contains martyrdoms that took place in the Ottoman Empire after the fall of Constantinople in 1453. It was extensively supplemented by Athanasios Parios in his New Meadow (mutatis mutandis) [Néov 


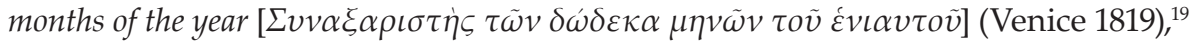

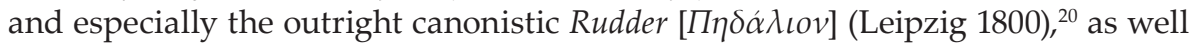

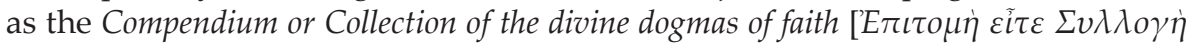
$\tau \tilde{\omega} v \Theta \varepsilon i \omega v \tau \tilde{\eta} \varsigma ~ \Pi i \sigma \tau \varepsilon \omega \varsigma \Delta o \gamma \mu \alpha \dot{\tau} \tau \omega v]$ (Leipzig 1806). ${ }^{21}$

A third category is made up by publications with didactic and, in a broader sense, regulative purposes, which applies, however, already to the aforementioned canonistic collections. Significant examples are the Confession Book [ $E \xi o-$ $\mu о \lambda o \gamma \eta \tau \alpha \dot{\rho} \rho \circ \mathrm{v}]$ (Venice 1794), a practical guide addressed to confessors as well as

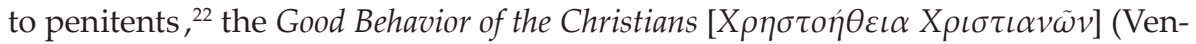
ice 1803), a practical guide for an 'Orthodox Christian way of life' according to a strongly pietistic ideal, ${ }^{23}$ and the Christian Pedagogy [X (1797-1801). ${ }^{24}$ In this context are also to be mentioned grammatical treatises like

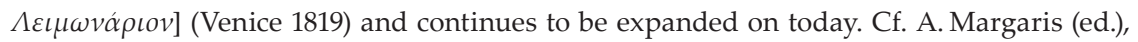

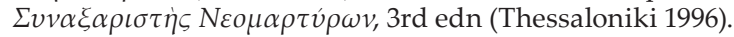

19 This was the first printed edition of this kind, whose templates were of course older collections in manuscript form, which Nikodimos Agioreitis translated into vernacular Greek.

20 This was likewise the first printed edition of this kind, prepared by Nikodimos Agioreitis and Agapios Leonardos in the 1780s, whose publication was delayed, however, by the Patriarchate of Constantinople for more than a decade (on the reasons, see in detail Zelepos, Orthodoxe Eiferer, 175-9). This publication was innovative not only with regard to its consistent use of vernacular language in the greater part of the text (paraphrases of the canons and extensive explanatory footnotes, which alone cover more than two thirds of the whole book), but also to its practice-oriented structure, e.g. a keyword index at the end of the text.

21 This edition by Athanasios Parios, followed by a Romanian translation in 1816, seems to

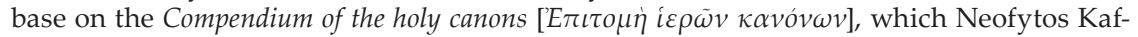
sokalyvitis had begun writing in the 1770s (or even earlier), but remained unpublished (for

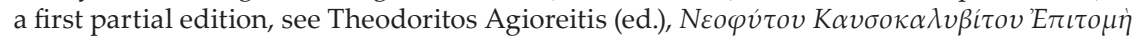

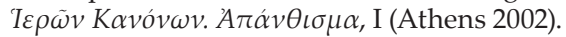

22 The original sources of this guide, written by Nikodimos Agioreitis, were the books $I l$ confessore istruito and the Il penitente istruito, of the known Jesuit Paolo Segneri (1624-1694), which were first translated into Greek by Emmanouil Romanitis in 1742. Cf. V. Tsakiris, Die gedruckten griechischen Beichtbücher zur Zeit der Türkenherrschaft: Ihr Entstehungszusammenhang und ihre Quellen (Berlin 2008) 303-29. Nikodimos however extended it with a large footnote apparatus of his own (as he did usually in his editions). The Confession Book was published in Karamanlı Turkish translation five years later (Constantinople 1799) and saw two new editions in a relative short time (Venice 1804 and 1818), something that points to its great popular success.

23 The author of this publication, Nikodimos Agioreitis, leaned there to a considerable degree on his own comments in the Rudder (cf. footnote 20), many of which he transferred wordfor-word. The text consists of an extensive list of commandments and prohibitions forbidding activities like gambling, singing, dancing, playing music and even laughing, and simultaneously propagates a religiously founded work-ethic. Such restrictive regulations were not unknown in Orthodoxy, but up to that time concerned only monks, while the Good Behavior of the Christians was explicitly addressed to lay people. A Romanian translation was published 1937 in Bucharest.

24 Cf. footnote 13. This text goes far beyond the scope of religious catechism, since it deals with elementary education as a whole, focusing on practical didactic matters and emphasizing the consistent use of vernacular language. Regarding such features, there are only few comparable examples in contemporary Greek pedagogical literature, as is the case with the 


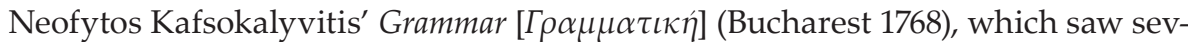
eral revised new editions in the following decades under different titles. ${ }^{25}$

The Kollyvadic publishing program also included a series of spiritual guides as

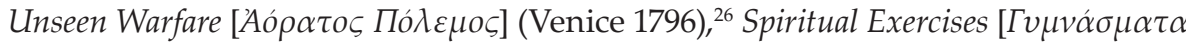

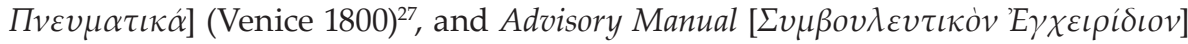
(Venice 1801), ${ }^{28}$ which form a separate category. The fact that all of them derived originally from post-Tridentine Catholic literary sources does not lack a touch of irony, given their perception among the Greek-speaking public (and beyond), at the time and later, as true manifestations of authentic Orthodox spirituality. ${ }^{29}$

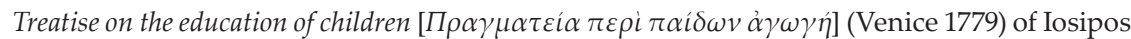
Moisiodax (1725-1800) that is strongly influenced by John Locke's Some Thoughts concerning Education (London 1693). P. Kitromilides, The Enlightenment as Social Criticism. Iosipos Moisiodax and Greek Culture in the Eighteenth Century (Princeton 1992) 153-66.

25 The title of Neofytos' edition was: Commentary on the fourth part of four of the Grammar of The-

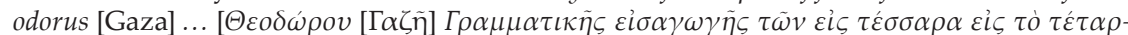
$\tau o v, \Upsilon \tau o ́ \mu v \eta \mu \alpha$...]. A first revised version was published by Athanasios Parios under the title The grammar of that mister Neofytos, summarized but now freed from anything superfluous ...

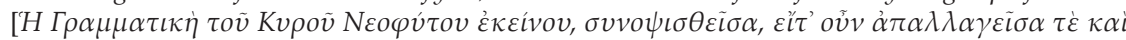
$\kappa \alpha \theta \alpha \rho \theta \varepsilon \tilde{\iota} \sigma \alpha \tau \alpha \dot{\alpha} v \tau \omega \nu \tau \tilde{\omega} v \dot{\varepsilon} v \alpha v \tau \tilde{\eta} \pi \varepsilon \rho \iota \tau \tau \tilde{\omega} v . .$.$] (Venice 1787) and a second by Nikitas Kon-$ taratos under the title The Fourth Part of Theodorus Gaza, that is, the Syntax Part. Translated in

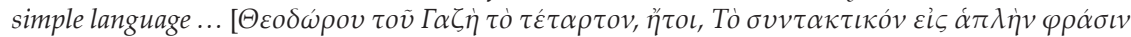
$\mu \varepsilon \tau \varepsilon v \varepsilon \chi \theta \varepsilon \dot{\varepsilon} v . .$.$] (Venice 1802). In the guise of a mere philological comment to a Byzantine$ grammarian, this text was actually a treatise on the didactics of scholarly Greek, arguing against the then widespread method of so called 'psychagogia' (see on ' $\psi v \chi \alpha \gamma \omega \gamma$ í $\alpha$ '

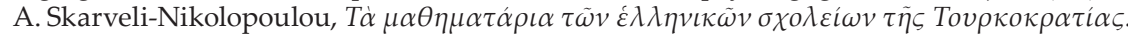

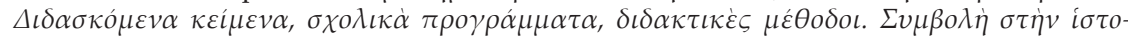

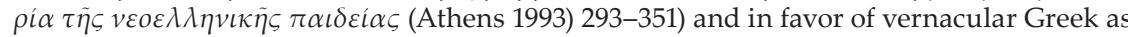
teaching language. This system was adopted and further developed by various scholars of Greek Enlightenment, like Grigorios Konstantas (1753-1844) who had been a pupil of Neofytos in Bucharest.

26 This book goes back through intermediate stages to the Combattimento Spirituale, written

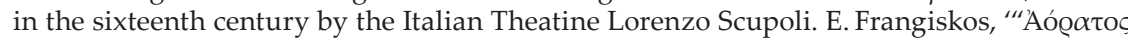

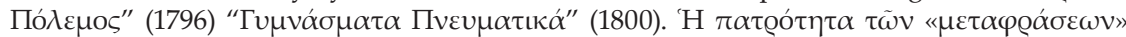

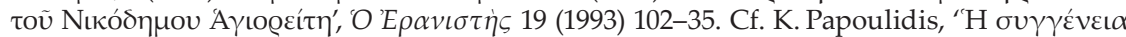

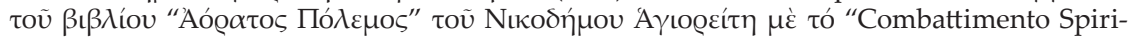

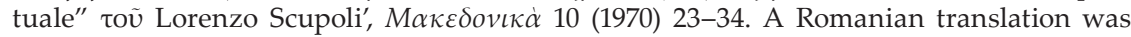
published in 1826 in Neamts.

27 This book goes back through intermediate stages to the Esercizi Spirituali di S. Ignazio di Loyola, written in the seventeenth century by the Italian Jesuit Giovanni Pietro Pinamon-

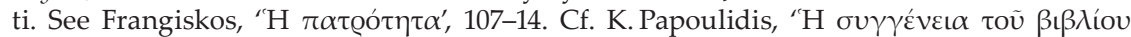

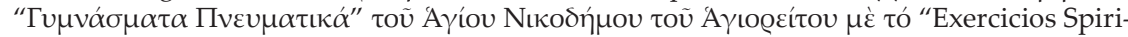

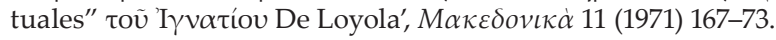

28 This book goes back to an anonymous Italian treatise that was translated into Greek by Emmanouil Romanitis in the first half of the eighteenth century under the title Ethical Phi-

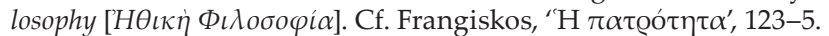

29 Only few contemporaries seem to have known the actual sources of these publications

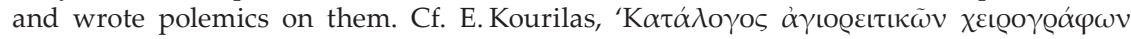

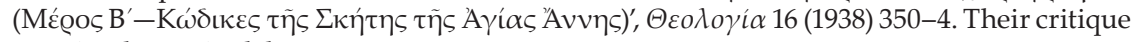
remained marginal, however. 
Finally, a fifth category is made up by polemical treatises. These were a specialty of Athanasios Parios (1721-1813) who achieved prominence through this form as a kind of godfather of Counter-Enlightenment in Greek letters. While his Anti-Pope [O Avтiт $\alpha \pi \alpha \varsigma$ ] (Vienna 1785) was, as its title declares, essentially directed against the Pope of Rome and the Catholic Church as the 'source of all evil' including the Protestant 'heresies', in his later publications like Christian Apology

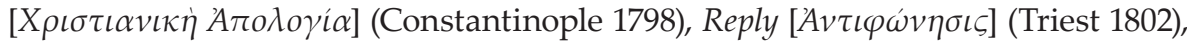

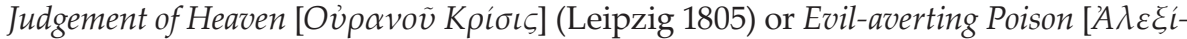

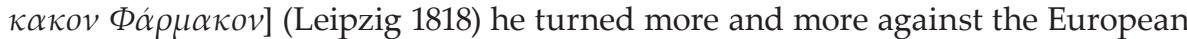
Enlightenment and its representatives, as well as against the 'West' in general, which he considered to be the true 'whore of Babylon' of the Revelation of John.

\section{The programmatic profile of the Kollyvades-movement}

Despite its quantitative abundance and thematic diversity, the publication program of the Kollyvades obviously followed certain patterns, which enable a programmatic profile of their movement to be traced. This can be done best along the four central issues the Kollyvades propagated and which reveal their deeper motivations:

First of all, the defense of the so called 'privileges of Sunday', ${ }^{30}$ which was the main trigger for the formation of the movement in the early 1750s on Mount Athos. This concerned the question of whether the reading of requiems on Sundays and other religious holidays was compatible with the holy traditions of the Orthodox Church, something the Kollyvades fiercely denied. The resulting quarrel gave them occasion to present themselves as guardians of authentic Orthodoxy, but was simultaneously consistent with a new understanding of tradition that can be characterized as rationalist insofar as its normative authority was no longer based primarily on the ascription of (real or imagined) seniority in the sense of 'custom', ${ }^{31}$ but much more on the ascription of logical coherence and precision. This understanding of tradition was based on a bipolar perception of 'right' and 'false' which could not tolerate ambiguities and consequently required systematic and comprehensive codification.

The second issue was the above-mentioned demand for frequent communion for every Christian, which the Kollyvades eagerly propagated not only against the official clerical establishment, represented by the Patriarchate of Constantinople, but, as a matter of fact, also against tradition (in the sense of custom) as it had evolved in Orthodox religious practice since the times of the Byzantine emperors. ${ }^{32}$ The demand of the Kollyvades articulated a latent anti-hierarchical stance

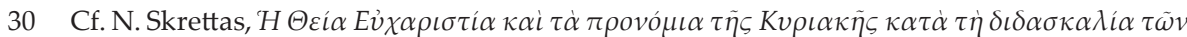
Ko $\lambda \lambda v \beta \alpha \delta \delta \omega v$ (Thessaloniki 2004), for an extensive depiction of the dogmatic-theological aspects of this issue.

31 Cf. E. Hobsbawm and T. Ranger (eds), The Invention of Tradition (Cambridge 1992) 2.

32 For laymen, participation in the Holy communion was usually limited to three times a year on occasion of the highest religious holidays (Easter, Christmas and Assumption of Mary). 
which ultimately aimed at a principal re-determination of the customary relationship between clergy and laymen in favor of the emancipation of the latter and the cultivation of an intensified and internalized form of individual religiosity. ${ }^{33}$ The arguments presented in this context show some affinities to Protestant currents, by which they may indeed have been influenced. ${ }^{34}$

The third central issue, which was to dominate later perceptions of the Kollyvades movement, was the pronounced reference to Orthodox Church Fathers and Late Byzantine Hesychasm with its mystical practices, especially the so called

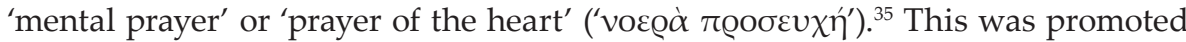
chiefly by the edition of the Love for the good in 1782, an innovative work not only with respect to its scope and systematic structure, but also to its intended readership, which explicitly included laymen. The aim was to place Hesychasm within everyday religious life, something that was meant to help cultivate internalized forms of individual religiosity, as was the demand for frequent communion, though it also had a further dimension: Hesychasm, since its official acknowledgement in the fourteenth century, ${ }^{36}$ was a unique feature of Orthodoxy without real equivalent in the Western Churches and thus could serve as a specific identity marker. The popularizing reference to Hesychasm can therefore be interpreted as an attempt to activate 'cultural capital' of Orthodoxy. ${ }^{37}$

This motivation is even more evident in the fourth central issue, the propagation, as well as the actual recruitment, of Orthodox neo-martyrs, which the Kollyvades pursued systematically and with great zeal. ${ }^{38}$ The promotion of the ideal of martyrdom had manifold functions. Regarding the confessionalization paradigm, however, there is one aspect to be focused on in particular: the symbolical underpinning of Orthodox collective identity and its simultaneous demarcation

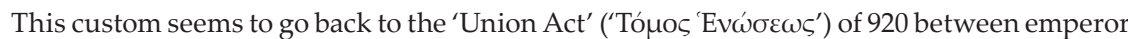
Leon the Wise and the Patriarch of Constantinople. It was codified since early modern times in several normative texts, e.g. in Petro Mohyla's, Metropolitan of Kiev, Orthodox Confession of 1643 and even in devotional literature like Agapios Landos' Salvation of the Sinners [A $\mu \alpha \rho$ $\tau \omega \lambda \tilde{\omega} v \Sigma \omega \tau \eta \rho i \alpha]$ (Venice 1641).

33 Cf. Zelepos, Orthodoxe Eiferer, 272-83. For example, the revised version of About Frequent Communion (Venice 1783) emphasizes repeatedly that the priests are not omnipotent, that everybody who knows the Scriptures is obliged to scrutinize the teachers and even to be disobedient towards impious masters.

34 Source evidence for such influences is, however, sparse and of indirect character. Cf. Zelepos, Orthodoxe Eiferer, 341ff.

35 For an introduction, see J. Meyendorff, Introduction a l'étude de Grégoire Palamas (Paris 1959); J. Meyendorff, Byzantine Hesychasm: historical, theological and social problems. Collected Studies (London 1974). Cf. E. von Ivánka, 'Byzantinische Yogis?', Zeitschrift der Deutschen Morgenländischen Gesellschaft, Neue Folge 27 (1952) 234-59; von Ivánka, 'Zur hesychastischen Lichtvision', Kairos 13 (1971) 81-95.

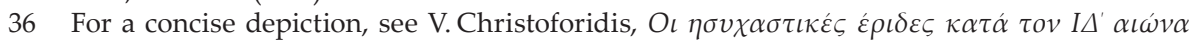
(Thessaloniki 1993).

37 Cf. P. Bourdieu, 'The Forms of Capital', in J. Richardson (ed.), Handbook of Theory and Research for the Sociology of Education (New York 1986) 241-58.

38 Cf. Zelepos, Orthodoxe Eiferer, 293-310. 
against the 'other', something that in the present case not only had a religious but also a geographical dimension. The printed collections of neo-martyr lives edited by the Kollyvades (see footnote 18) depict, by and large, the cultural-geographical zone of Ottoman Orthodoxy, in a chronological as well as spatial sense, by deliberately excluding martyrdoms which took place before 1453 or outside the Ottoman Empire. ${ }^{39}$ It is remarkable, however, that the intensive propagandistic use the Kollyvades made of their neo-martyr narratives was not primarily directed against Muslim oppression-as one might expect given that a good deal of them concerned double converts to and from Islam-but rather against Western Christianity and, ultimately, also against the ideas of European Enlightenment, which were perceived as an external menace. ${ }^{40}$

Summarizing, it seems obvious that the publishing program of the Kollyvades in many aspects matches what can be characterized as a confessionalizing practice regarding its central aims, i.e. the clarification, codification, intensification and demarcation of religious identity, as well as social disciplining through regulation of everyday behavior, with an explicit orientation to Ottoman-Orthodox society as a whole, ${ }^{41}$ where it indeed achieved a lasting impact, at least in terms of the normative authority most of their texts continue to enjoy today.

In order to evaluate the significance of the Kollyvades for the confessionalization of Ottoman Orthodoxy-as far as such a term is viable - their publishing program should be put in its broader historical context by comparison with similar phenomena in earlier periods. One such case would be the Crete-born Athonite monk Agapios Landos (ca. 1600-1656/7) who was without doubt one of the most

39 Ibid., 308. Geographically, the martyrdoms included in the New Collection of Martyrs (Venice 1799) describe roughly Ottoman Southeast Europe together with the western part of Asia Minor.

40 References to Orthodox neo-martyrs in argumentations against Western Christian confessions were by no means limited to the Kollyvades. See, for example, Evgenios Voulgaris' (1716-1806) letter to Peter Leclercq about Saints and Miracles of the Orthodox Church since the schism of 1054, written between 1759-1761 and edited by A. Koromilas, 'E

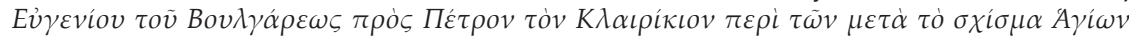

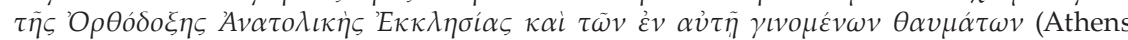
1844). The Kollyvades, however, used them extensively in their polemical treatises (cf. Christian Apology, Reply, Judgement of Heaven etc.) with an increasing shift against enlightenment and secularism (cf. Evil-averting Poison).

41 This applies in a twofold sense: First, although publishing in Greek as the regional lingua franca of Orthodoxy, it is evident that their intended audience was not exclusively Greek but included all Orthodox subjects of the Sultan regardless of ethnicity or language. Second, their intended audience was not limited to the clergy but explicitly included laymen as well, who in many publications were even the main addressees, as their prologues show (in clear contrast to an erroneous assumption made in some older scholarship, that these books were produced essentially for hermits). On the term 'Ottoman-Orthodox' in the sense of a specific communication space, see I. Zelepos, Orthodoxe Eiferer, 13-15 and 340-4. Cf. I. Zelepos, "'Unser orientalisch-christliches Geschlecht"-Zur Formierung eines osmanisch-orthodoxen Identitätskonzepts in der zweiten Hälfte des 18. Jahrhunderts', in M. Oikonomou, M. Stassinopoulou and I. Zelepos (eds), Griechische Dimensionen südosteuropäischer Kultur seit dem 18. Jahrhundert (Frankfurt a.M. 2011) 111-24. 
popular Greek religious authors of his time. ${ }^{42}$ Landos likewise launched a publishing program, whose most successful piece became the Salvation of the Sinners, first published 1641 in Venice and a true bestseller for the following centuries. But it comprised more than a dozen further editions of religious content, mostly homiletic, hagiologic and liturgical collections ${ }^{43}$ and also a Guiding of the Christians

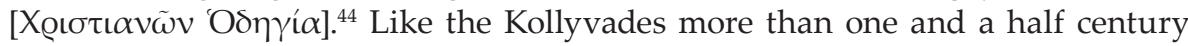
later, Landos systematically used the printed book in vernacular Greek as a medium, and his writings were also translated in other languages. ${ }^{45} \mathrm{He}$ also reveals a clear mass-educational impetus by turning directly to his intended readership, explaining his purposes, giving practical advice as to how to read his books, and meticulously referring to his sources. ${ }^{46}$

It is remarkable, however, that regarding the latter, he obviously had no problem in openly citing Roman-Catholic texts, chiefly of Italian provenance, which he used frequently, ${ }^{47}$ something that for the Kollyvades in the late eighteenth century was barely thinkable, as it would have undermined their self-presentation as guardians of authentic Orthodoxy against the Latin West (regardless of the fact that they actually used such sources too, see footnotes 26-29). Another important difference to the Kollyvades is that Landos published his books essentially on his own initiative without being part of an organized network as far as is known today. In this respect, he seems to be closer to the Sephardic authors of the Ladino Musar literature that developed significantly in the Ottoman Empire during the eighteenth century.

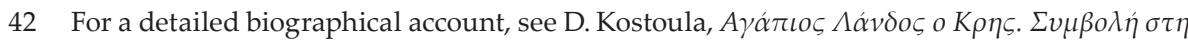

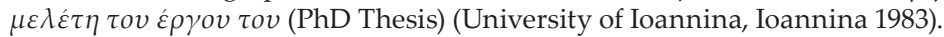

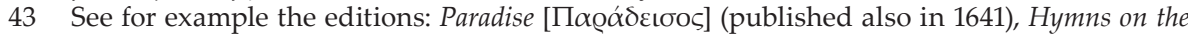

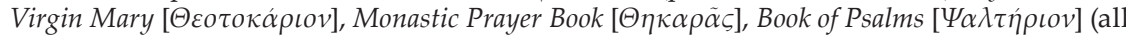

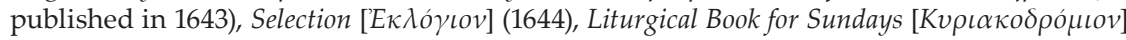
(1657). The only thematically divergent publication of Landos is his Agricultural Guide

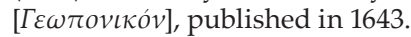

44 It was only published almost twenty years after his death in 1685, but it is most likely that Landos brought the manuscript as early as 1656 to the printing house in Venice where all

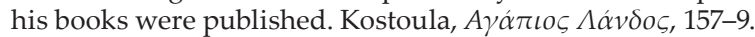

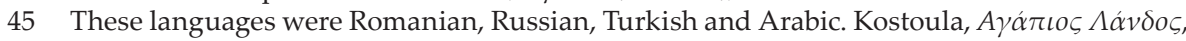
293-8.

46 See e.g. the 'Foreword' in the Paradise (explanation of the use of vernacular language, together with the advice to read the texts loudly in front of an audience in Churches as well as at home, but also silently alone), as well as the Salvation of the Sinners. A. Landos, Salvation of the Sinners (Venice 1798) 34, 44, 66, 211, 257. Remarkably, he often states that he has reduced a text in order not to bore the audience-reader and thus to harm its purpose, while occasionally referring to further reading for those interested. Cf. A. Landos, Paradise (Venice 1797) 2; A. Landos, Salvation of the Sinners, 186, 194, 225 etc.

47 He mentions those texts even in the first place before Greek-Orthodox sources. Cf. the introduction to the section on miracles in Salvation of the Sinners. Ibid., 285. 


\section{Jewish Musar-Literature in eighteenth century Ottoman Empire}

'Musar' (literally 'Correction') is commonly defined as a genre of Jewish ethical didactic literature whose aim is to shape religious everyday culture by regulating behaviors and beliefs, but which is clearly distinguished from classical Rabbinic (Halachic) literature-a genre accessible only to specialists-due to its popular character in terms of linguistic forms as well as intended audiences. ${ }^{48}$ The roots of this genre trace back to Antiquity, and in the Middle Ages it seems that it was to some degree reactive to the challenge posed by philosophical currents of Aristotelianism as they had been received since Maimonides in the twelfth century. Musar literature flourished impressively in Eastern Europe and in the Ottoman Empire during the eighteenth century, when publications reached almost double the total production since the Late Middle Ages. ${ }^{49}$ This quantitative growth was accompanied by an increasing use of vernacular Hebrew as well as of other vernacular languages, Yiddish and Ladino, the latter being codified as a literary prose language to a considerable degree through such Musar publications. ${ }^{50}$

Important works to be mentioned in this context are the encyclopedic Torah-exegesis From a People of Strange Language [Me'am Lo'ez] (Constantinople 1730), ${ }^{51}$ and Way of Correction [Shevet Musar], published in 1712 in Constantinople in Hebrew, and in 1748 in Ladino at the same place. ${ }^{52}$ Another example is Shining Candlestick [Menorat ha-Ma’or], published 1762 in Constantinople in Ladino by Abraham Asa. ${ }^{53}$

48 Cf. J. Dan, 'Ethical Literature (sifrut ha-musar)', in M. Berenbaum and Fr. Skolnik (eds), Encyclopaedia Judaica, 2nd edn, VI (Detroit 2007) 525-31.

49 Matthias Lehmann indicates 516 titles against 285 since the beginning of Jewish print in the middle of the fifteenth century (Lehmann, Ladino Rabbinic Literature, 4); on the latter, cf. M. Heller, Studies in the Making of the Early Hebrew Book (Leiden 2008). The first Hebrew printing press in the Ottoman Empire was established already in 1493. Cf. A. Yaari, Had-defūs

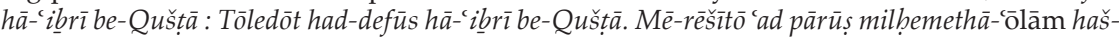
šenniya [Hebrew Printing at Constantinople: Its History and Bibliography] [Supplement to Kirjath Sepher, 42] (Jerusalem 1967). There was a relative quantitative decline in the production of Musar books from the late eighteenth century until the 1820s, followed by a new increase in the middle of the nineteenth century, which reached its peak in the 1860-1870s.

50 Cf. Matthias Lehmann, who describes this as a gradual development from a Spanish variety into an autonomous linguistic system in analogy to the relation between Yiddish and German. Lehmann, Ladino Rabbinic Literature, 18.

51 The title quotes Psalm 114:1 and can therefore also be translated as 'from a foreign land'. The work From a People of Strange Language was written in Thessaloniki by the famous Talmudist Jacob Huli (also Chuli or Choli), but not completed by him owing to his death in 1732. It was continued by various subsequent authors until it reached a total of twelve volumes, the last of them being published in 1899. The work proved to be an extraordinary success and continues to be one of the classics of Jewish religious literature. Cf. M. Molho, Le Meam-Loez, encyclopédie populaire du séphardisme levantin (Thessaloniki 1945).

52 The Way of Correction was written by Elijah ha-Kohen and soon became one of the most popular works of its genre. The Ladino translation of 1748 was preceded by a Yiddish translation published 1726 in Vilna. Cf. I. Zinberg, A history of Jewish Literature, Translated and Edited by Bernard Martin (New York 1975) 166.

53 This work was originally written in the fourteenth century by the Spanish Talmudist Isaac Aboab. On the version of Abraham Asa, see P. Albarral and A. Riaño López, 'La primera 
Asa was also the author of the Ladino version of Way of Correction, as well as of the first complete translation of the Jewish Bible in Ladino with Hebrew characters, published from 1739 to $1744 .{ }^{54}$ Further examples are Ascension to the Ethical Virtues [Ma'alot ha-Midot] (Constantinople 1824), ${ }^{55}$ and finally Wonderful Counsellor [Pele Yóetz] (Constantinople 1824). ${ }^{56}$

There were presumably manifold reasons for the intense growth of Sephardic Musar from the eighteenth century; these have not, however, been definitively clarified. In older scholarship it was perceived above all as a reaction to the deep spiritual crisis that had been caused by the messianic movement of Sabbatai Zevi in the second half of the seventeenth century. ${ }^{57}$ According to this, it was a deliberate attempt to restore disrupted religious order and to revive eroding traditions, whose perpetuation, however, also contributed to intellectual and cultural backwardness in the Age of Enlightenment, something that corresponds to the dominant historical narrative on the socio-economic decline of Ottoman Jewry during this period. ${ }^{58}$

version Sefardí de Menorat Hamaor: ¿Traduccion o Interpretación?', Miscelanea de Estudios Arabes y Ebraicos, sección Hebreo 47 (1998) 75-94.

54 Cf. Benbassa and Rodrigue, Sephardi Jewry, 63.

55 The Ascension to the Ethical Virtues originally goes back to an ethical treatise written in the late thirteenth century by the Italian Halachist Yehiel ben Yekutiel. Cf. J. Dan, 'Yehiel ben Yekutiel Anav of Rome', in Religion Past and Present, http://dx.doi.org/10.1163/1877-5888_rpp_ SIM_10768.

56 The Wonderful Counsellor, first published in Hebrew by the Sarajevo-born Rabbi Eliezer Papo (who wrote it between 1815 and 1823 in Silistra), was also translated into Yiddish and Arabic, while a first Ladino translation, made by his son, was published in 1870 (1872) in Vienna, followed by a second one in Thessaloniki 1899. An English translation was made by Marc Angel, The Essential Pele Yoetz (New York 1991). Together with ha-Kohen's Way of Correction, it belongs today to the most popular works of its genre. According to Lehmann, it is also one of the most interesting examples of Musar literature because it represents the cultural values of the Ottoman Sephardic rabbinate in the nineteenth century in a particularly eloquent way.' Lehmann, Ladino Rabbinic Literature, 9.

57 On Sabbatai Zevi (also Sevi, Tzvi or Zvi) and its movement, see G. Sholem, Sabbatai Sevi. The Mystical Messiah 1626-1676 (London 1973). Cf. J. Hacker, 'The Intellectual Activity of the Jews of the Ottoman Empire During the Sixteenth and Seventeenth Centuries', in Twersky and Septimus (eds), Jewish Thought, 95-125; M. Idel, 'Differing Conceptions of Kabbalah in Early 17th Century', in Twersky and Septimus (eds), Jewish Thought, 137-99; M. Angel, Voices in Exile. A study in Sephardic Intellectual History (New York 1991) 68-84; Y. Liebes, Studies in Jewish Myth and Jewish Messianism (Albany 1993); M. Goldish and R. Popkin, Millenarianism and Messianism in Early Modern European Culture, I. Jewish Messianism in the Early Modern World (Dordrecht 2001); M. Goldish, The Sabbatean Prophets (Cambridge MA 2004); C. Şişman, The Burden of Silence. Sabbatai Sevi and the Evolution of the Ottoman-Turkish Dönmes (Oxford 2015). On its impacts on Jewish confessionalization see also G. Lauer, 'Die Konfessionalisierung des Judentums. Zum Prozeß der religiösen-Ausdifferenzierung im Judentum am Übergang zur Neuzeit', in K. von Greyerz et al. (eds), Interkonfessionalität-Transkonfessionalität-binnenkonfessionelle Pluralität. Neue Forschungen zur Konfessionalisierungsthese (Göttingen 2003) 250-83.

58 See for example J. Barnai, 'The Jews of the Ottoman Empire in the Seventeenth and Eighteenth Centuries', in Beinart (ed.), The Sephardi Legacy, II (Jerusalem 1992) 134-65. 
According to a different approach, however, the rise of Ottoman Sephardic Musar literature in the eighteenth century is interpreted not as a mere backward-looking reaction of religious orthodoxy, but rather in terms of cultural change, if we take into account not only the general traditionalist profile of its content, but also the modernizing aspects which went along with it. ${ }^{59}$ The latter tendency does not primarily concern the regulation of religious everyday culture in itself, for this had always been a central feature of Halacha literature ${ }^{60}$, and especially of the vast amount of rabbinic 'responsa' texts produced over the centuries, ${ }^{61}$ something that in no small part reflected the decentralized structure of Jewish communities.

In fact, the modernizing impulse in the growth of this new type of vernacular Musar literature manifested itself in its mass-educative motivation, that is to say, the declared aim of making religious knowledge directly accessible beyond the narrow circle of specialists. This was of course far from ever questioning the normative authority of the latter, but it did enhance the position of the simple believer. Moreover, Musar literature encouraged and even propagated the formation of reading circles, the so called 'Meldados', which offered religiously legitimated spaces of public socializing beyond the synagogue and from the end of the eighteenth century also began to include women. ${ }^{62}$ In this way it contributed also to

59 Cf. Lehmann, Ladino Rabbinic Literature, 'Introduction' and p. 202-7, with a critical discussion of the binary scheme of 'tradition' vs 'progress', limiting the latter exclusively to secular discourses. The methodological problem of identifying religious discourses simplistically with 'tradition' concerns certainly not only research on Jewish but also on Christian and especially Orthodox cultural history.

60 Halacha (also Halakha, Halakhah etc.) denotes the juridical part of Jewish tradition with explicit normative authority (in contrast to exegetical Aggadah), based on 613 Talmudian commandments ('mitzvot'), cf. 'Halacha' in Berenbaum and Skolnik (eds), Encyclopaedia Judaica, VIII, 251-9.

61 On Jewish responsa (literally 'answer') in general see Berenbaum and Skolnik (eds), Encyclopaedia Judaica, XVII, 228-39; cf. Z. Frankel, Entwurf einer Geschichte der Literatur der Nachtalmudischen Responsen (Breslau 1865). On Ottoman Sephardic responsa in particular see V. Weissberg, Jewish Life in Seventeenth Century Turkey as Reflected in the Responsa of Rabbi Jacob Alfandari and Rabbi Joseph Katzavi (PhD Thesis) (Hebrew Union College, Cincinnati 1970); A. Shemuelevitz, The Jews of the Ottoman Empire in the late fifteenth and the sixteenth centuries; administrative, economic, legal and social relations as reflected in the responsa (Leiden 1984); M. Goldish, Jewish Questions. Responsa on Sephardic Life in the Early Modern Period (Oxford 2008).

62 Cf. Lehmann, Ladino Rabbinic Literature, 68f. Specifically, he describes the integration of female audiences as a gradual process, referring to the example of the Way of Correction (the Hebrew edition in 1712 and the Ladino one in 1748), which still considers women only indirectly as audience, by admonishing the believers to listen to the Torah and then also to pass on its teachings to their wives, in contrast to the example of the Wonderful Counsellor (the Hebrew edition in 1824, while the Ladino one in 1870 (1872) ), which directly addresses female readerships and even suggests the formation of particular women's Meldados. The term 'Meldado' etymologically derives from the Greek verb ' $\mu \varepsilon \lambda \varepsilon \tau \alpha \alpha \omega^{\prime}$ ('study', 'examine', 'investigate'). On linguistic influences of Greek on Ladino see generally Haralambos Symeonidis, Das Judenspanische von Thessaloniki. Beschreibung des Sephardischen im griechischen Umfeld, Bern 2002. 
the emergence of a critical public readership in Ottoman Sephardic society, which became noticeable later in the nineteenth century. ${ }^{63}$

Apart from such hardly intended long-term effects, Musar literature contributed to a gradual re-determination of the traditional relationship between rabbinate and laymen. By providing a more or less standardized set of religious guidelines accessible for the non-specialized reader, it limited the rabbinate's monopoly of interpretation, while simultaneously it made it easier, due to its transregional dissemination in form of printed books, to practically regulate religious everyday behaviors in the geographically scattered Sephardic communities.

This was crucial for another aspect connected with it, the stabilization of social order in a vertical as well as in a horizontal sense. Vertical, because Musar texts explicitly legitimized social inequality and corresponding hierarchies as God's will, ascribing to different social classes specific complementary duties: the wealthy had to engage themselves philanthropically, the poor had to endure their fate and live as godly as possible, while the learned had to teach their unlearned brethren in order to lead them to divine truth. ${ }^{64}$ Horizontal, because Musar texts also promoted the demarcation of Ottoman Sephardic collective identity. Such demarcation was not primarily directed against the prospect of possible assimilation into an overwhelmingly Ottoman majority society, because this, in contrast to Jewish communities in Western Europe during the same period, was never considered a real danger. It was, however, directed against the challenge of secularism and the ideas of Enlightenment, which were perceived as menacing foreign intrusions from the 'West'. From the late eighteenth century, it became a veritable commonplace in Musar texts to warn against the adoption of Western attitudes and lifestyle while in the same context to emphasize the advantages of living in the Ottoman Empire, 'the domain of Islam where the flag of Torah flies high', and to warn against a life in Europe, where the Israelites have kicked off the yoke of Torah [...] and many evils follow in the wake of freedom. ${ }^{\prime 65}$

There is a striking similarity between such contrasting presentations of 'our pious self' and 'impious Europe' as an outside space and analogous statements in contemporary Kollyvadic publications. ${ }^{66}$ The affinities are, however, not limited

63 This is emphasized by Lehmann (ibid., 71ff.), who also points out in this context an intensifying reception of non-religious and even non-Jewish literature by this readership, as is documented by the growth of admonishments in contemporary Musar texts to keep away from such literature.

64 Cf. Lehmann, Ladino Rabbinic Literature, 103-20. The latter part of this division of labor of course also meant an implicit improvement of the social prestige of the authors of Musar books themselves, who as popular writers ranked clearly below the erudite rabbinic establishment.

65 The passage is from the Wonderful Counsellor, quoted after the translation of Angel, The Essential Pele Yoetz, 45. Cf. Lehmann, Ladino Rabbinic Literature, 148.

66 This is true for virtually all polemical publications of Athanasios Parios, e.g. Reply and Judgement of Heaven, but can be found also in many other texts, e.g. the treatise Apology of

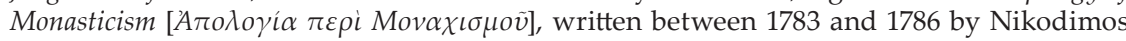
Agioreitis, who even claims that it is physically impossible to live in Europe and to remain 
to the demarcation of identities, but also concern the mass-educative impetus observable in both cases, as well as the declared aim at social disciplining through regulation of everyday life of their respective communities, which despite all differences between the Sephardic-Jewish and the Orthodox-Christian milieus, can be described in categories of confessionalization practices. This leads to the question of a possible relationship between the two, or to put it more concretely: is there any link between the publications of the Ottoman Greek-Orthodox Kollyvades and the Ottoman Sephardic Musar literature?

\section{Interreligious transfer of ideas or coincidence of parallel developments?}

In light of the geographical as well as the chronological closeness of the phenomena outlined above, it seems tempting to conclude that there must have been some mutual influence and even an interreligious transfer of ideas. Yet it is much easier to make such an assumption than to substantiate it with positive source evidence. In this regard one has to consider that Ottoman society was indeed multi-religious, but also of a segmentary character, ${ }^{67}$ and despite various transgressions in the form of syncretism or conversions (see footnote 10) actually provided only limited contact zones for idea exchange between different normative religious knowledge-systems.

In the present case, however, there is such a possible contact zone in the person of Neofytos Kafsokalyvitis (1713-1784) who was the founder of the Kollyvades-movement and its leading figure in the first decades. Neofytos, whose worldly name is unknown, came from a family of Jewish converts in the Peloponnese, for which reason he was nicknamed 'the one who is descended from Jews' ('o $\dot{\varepsilon} \xi$ 'Iov $\left.\alpha \alpha \omega^{\prime} \omega v^{\prime}\right)$ by his contemporaries, an attribution he also used himself in his writings. ${ }^{68}$ It is thus not completely unthinkable that Neofytos, who was incidentally not the only prominent personality in the Kollyvadic cycle with a Jewish convert

unrestrictedly faithful, i.e. an Orthodox Christian, due to the 'flood of indifference and impiety' prevailing there. Cf. Zelepos, Orthodoxe Eiferer, 326f. On the underlying concept of collective identity, which was by far not restricted to Kollyvadic authors, see Zelepos, 'Zur Formierung eines osmanisch-orthodoxen Identitätskonzepts', 111-24.

67 On segmentary societies, cf. Fr. R. Vivelo, 'Segmentäre Gesellschaften', in Fr. R. Vivelo (ed.), Handbuch der Kulturanthropologie. Eine grundlegende Einführung (Stuttgart 1981) 198-201.

68 On his biography, see Zelepos, Orthodoxe Eiferer, 189-96. Older research even assumed that Neofytos had been a convert himself, identifying him with the author of the pamphlet Refutation of [the Religion of] the Jews, published in Romanian and Greek (Infruntarea jidovilor,

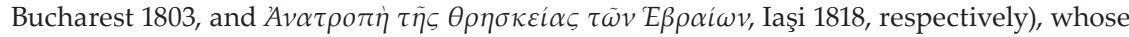
name was also Neofytos, but that is rather unlikely for several reasons, as is the assumption made in this context that he had been a Jewish rabbi before his conversion to Christianity. It is remarkable, however, that Neofytos never distanced himself from his Jewish ancestry, despite the fact that this had a clearly negative image in the Orthodox Christian milieu he lived in, and, as a matter of fact, was often used against him in the Kollyvades-controversy by his opponents, who accused him of being 'Jewish minded' and even a 'crypto-Jew'. Cf. Zelepos, Orthodoxe Eiferer, $134 \mathrm{f}$. 
family background, ${ }^{69}$ could have been acquainted to some degree with Musar literature and may have adopted some of its motifs. But due to the lack of further source evidence this is not provable and probably never will be.

From a methodological point of view, it seems more appropriate therefore to focus on the affinities in the socio-cultural setting of Orthodox Christianity and Sephardic Jewry in Ottoman society in order to understand the affinities in their religious discourses during the eighteenth and nineteenth centuries:

Both communities held an institutional minority status here, and both were entangled in many ways with the world beyond the Empire's borders, where their co-religionists usually also had a minority status. ${ }^{70}$ Both communities thus increasingly came into contact with intellectual currents from Western Europe, and their educational elites were faced with very similar dilemmas: either to adopt them, in order to acculturate along an idealized, and in many aspects only imaginary, 'Western' paradigm, or to counter them, in order to protect their own cultural identity, which they essentially perceived as a religious one. For the latter purpose, the recourse to 'tradition' was in both cases self-evident due to its enormous value as cultural capital. Its activation, however, under the changing conditions, could no longer rely on tried and trusted means, but required enhanced and thus 'untraditional' methods in order to be successful. It seems that precisely this was understood very well by the Kollyvades and by the authors of Musar literature, as their publications show. Although decided defenders of religiously-determined traditional value systems, they were themselves simultaneously representatives of intellectual and cultural development, contributing to the shaping of their communities by means of confessionalization.

\section{Bibliography}

Albarral P. and Riaño López A., ‘La primera version Sefardí de Menorat Hamaor: ¿Traduccion o Interpretación?', Miscelanea de Estudios Arabes y Ebraicos, sección Hebreo 47 (1998) 75-94.

Angel M. (ed.), The Essential Pele Yoetz (New York 1991).

- Voices in Exile. A study in Sephardic Intellectual History (New York 1991).

- Foundations of Sephardic spirituality; the Inner Life of Jews of the Ottoman Empire (Woodstock 2006).

Asa Abraham, Menorat ha-Ma'or [Shining Candlestick] (Constantinople 1762).

69 This was also the case with Paisij Velichkovskij (1721-1794) from Ukrainian Poltava (cf. footnote 17), whose grandfather was a Jewish merchant who had converted to Orthodox Christianity.

70 For the Orthodox - of course - with the exception of the Russian Empire, and the Romanian Principalities which, however, despite their semi-autonomous status were commonly perceived as being an integral part of the Ottoman Empire. On Russian relations, whose peak was, however, more in the seventeenth than in the eighteenth century, cf. E. Kraft, Moskaus griechisches Jahrhundert. Russisch-griechische Beziehungen und metabyzantinischer Einfluß 16191694 (Stuttgart 1995); N. Pissis, Russland in den politischen Vorstellungen der griechischen Kulturwelt 1645-1725 (Göttingen 2020). 
Bahlke J. and Strohmeyer A. (eds), Konfessionalisierung in Ostmitteleuropa. Wirkungen des religiösen Wandels in im 16. Und 17. Jahrhundert in Staat, Gesellschaft und Kultur (Stuttgart 1999).

Barnai J., 'The Jews of the Ottoman Empire in the Seventeenth and Eighteenth Centuries', in Beinart (ed.), The Sephardi Legacy, II (Jerusalem 1992) 134-65.

Beinart H. (ed.), Moreshet Sepharad: The Sephardi Legacy, 2 vols. (Jerusalem 1992).

Benbassa E. and Rodrigue A., The Jews of the Balkans: The Judeo-Spanish Community, 15th to 20th Centuries (Oxford 1995).

- Sephardi Jewry. A History of the Judeo-Spanish Community, 14th to 20th Centuries (Berkeley 2000).

Berenbaum M. and Skolnik Fr. (eds), Encyclopaedia Judaica, 2nd edn (Detroit 2007).

Bourdieu P., 'The Forms of Capital', in John Richardson (ed.), Handbook of Theory and Research for the Sociology of Education (New York 1986) 241-58.

Brockmann Th. and Weiss D. (eds), Das Konfessionalisierungsparadigma-Leistungen, Probleme, Grenzen (Münster 2013).

Chetverikov S., Starets Paisii Velichkovskii. His Life, Teachings, and Influence on Orthodox Monasticism (Belmont MA 1980).

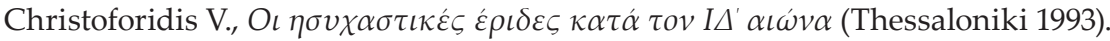

Dan J., 'Yehiel ben Yekutiel Anav of Rome', in H. D. Betz (ed.), Religion Past and Present: Encyclopedia of Theology and Religion, 4th edn (London 2007). http://dx.doi.org/ 10.1163/1877-5888_rpp_SIM_10768.

Dursteler E., Venetians in Constantinople. Nation, Identity, and Coexistence in the Early Modern Mediterranean (Baltimore 2006).

- Renegade Women: Gender, Identity and Boundaries in the Early Modern Mediterranean (Baltimore 2011).

- "Fearing the "Turk" and Feeling the Spirit: Emotion and Conversion in the Early Modern Mediterranean', Journal of Religious History 39/4 (2015) 484-505.

Faroqhi S. (ed.), The Cambridge History of Turkey, III. The Later Ottoman Empire, 1603-1839 (Cambridge 2006).

G. Florovsky, Puti russkago bogoslovija (Paris 1937).

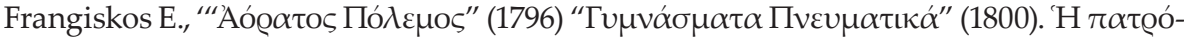

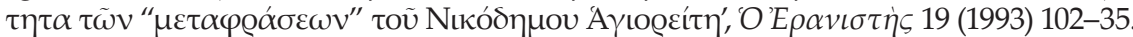

Frankel Z., Entwurf einer Geschichte der Literatur der Nachtalmudischen Responsen (Breslau 1865).

Gavroglou K. (ed.), The Sciences in the European Periphery during the Enlightenment (Dordrecht 1999).

Goldish M. and Popkin R., Millenarianism and Messianism in Early Modern European Culture, I. Jewish Messianism in the Early Modern World (Dordrecht 2001).

- The Sabbatean Prophets (Cambridge MA 2004).

- Jewish Questions. Responsa on Sephardic Life in the Early Modern Period (Oxford 2008).

Grigore M.-D. and Kührer-Wielach Fl. (eds.), Orthodoxa Confessio? Konfessionsbildung, Konfessionalisierung und ihre Folgen in der östlichen Christenheit Europas (Göttingen 2018).

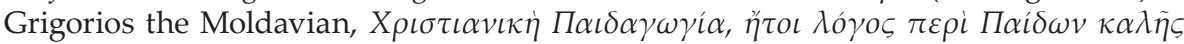

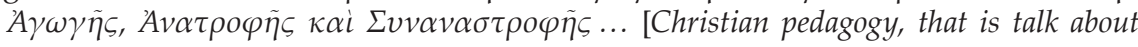
good education, rearing and behavior of children...] (manuscript work composed between 1797-1801).

Hasluck Fr., Christianity and Islam under the Sultans, 2 vols (Oxford 1929). 
Headley J. et al. (eds), Confessionalization in Europe, 1555-1700. Essays in Honor and Memory of Bodo Nischan (London 2004).

Heller M., Studies in the Making of the Early Hebrew Book (Leiden 2008).

Henderson G. P., The Revival of Greek Thought 1620-1830 (Edinburgh 1971).

Hobsbawm E. and Ranger T. (eds), The Invention of Tradition (Cambridge 1992).

Huli Jacob, Me'am Lo'ez [From a People of Strange Language] (Constantinople 1730).

Inalcik H. and Quataert D, (eds), An economic and social history of the Ottoman Empire 1300-1914 (Cambridge 1994).

Ivánka E. von, 'Byzantinische Yogis?', Zeitschrift der Deutschen Morgenländischen Gesellschaft, Neue Folge 27 (1952) 234-59.

- 'Zur hesychastischen Lichtvision', Kairos 13 (1971) 81-95.

Kitromilides P., The Enlightenment as Social Criticism. Iosipos Moisiodax and Greek Culture in the Eighteenth Century (Princeton 1992).

- Enlightenment and Revolution. The Making of Modern Greece (Cambridge MA 2013).

ha-Kohen Elija, Shevet Musar [Way of Correction (mutatis mutandis)] (Constantinople 1712 in Hebrew and 1748 in Ladino).

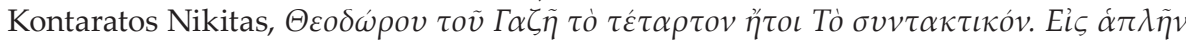

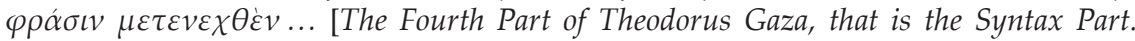
Translated in simple language...] (Venice 1802).

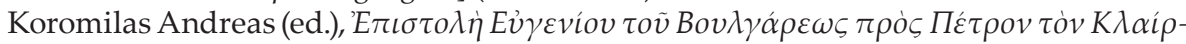

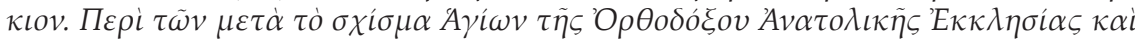
$\tau \tilde{\omega} v \gamma \iota v o \mu \varepsilon \dot{\varepsilon} v \omega v \dot{\varepsilon} v \alpha \dot{v} \tau \tilde{\eta} \theta \alpha v \mu \alpha \dot{\tau} \tau \omega v$ (Athens 1844).

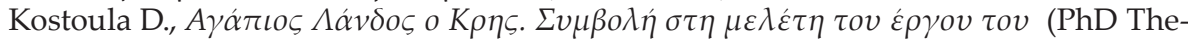
sis) (University of Ioannina, Ioannina 1983).

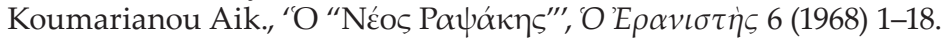

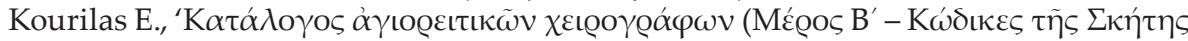

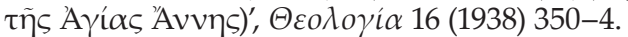

Kraft E., Moskaus griechisches Jahrhundert. Russisch-griechische Beziehungen und metabyzantinischer Einfluß 1619-1694 (Stuttgart 1995).

Krstić T., Contested Conversions to Islam. Narratives of Religious Change in the Early Modern Ottoman Empire (Stanford 2011).

Landos Agapios, A $\mu \alpha \rho \tau \omega \lambda \tilde{\omega} v \Sigma \omega \tau \eta \rho i \alpha . .$. [Salvation of the Sinners ...] (Venice 1641).

- A $\mu \alpha \rho \tau \omega \lambda \tilde{\omega} v \Sigma \omega \tau \eta \rho i \alpha . .$. [Salvation of the Sinners ...] (Venice 1798).

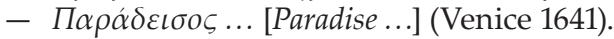

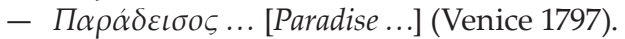

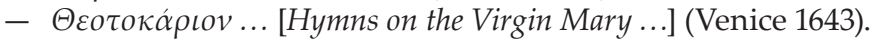

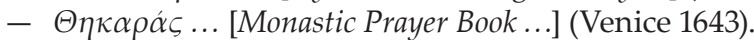

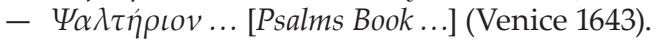

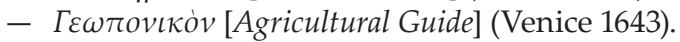

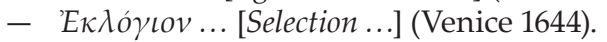

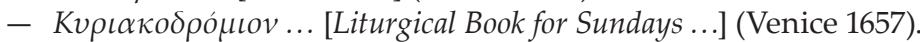

- X

Lauer G., 'Die Konfessionalisierung des Judentums. Zum Prozeß der religiösen - Ausdifferenzierung im Judentum am Übergang zur Neuzeit', in K. von Greyerz et al. (eds), Interkonfessionalität - Transkonfessionalität - binnenkonfessionelle Pluralität. Neue Forschungen zur Konfessionalisierungsthese (Göttingen 2003) 250-83. 
Lehmann M., Ladino Rabbinic Literature and Ottoman Sephardic Culture (Bloomington 2005).

Levy A. (ed.), The Jews of the Ottoman Empire, 2nd edn (Princeton 2003).

Liebes Y., Studies in Jewish Myth and Jewish Messianism (Albany 1993).

Locke John, Some Thoughts concerning Education (London 1693).

Lotz-Heumann U., Die doppelte Konfessionalisierung in Irland. Konflikt und Koexistenz im 16. und in der ersten Hälfte des 17. Jahrhunderts (Tübingen 2000).

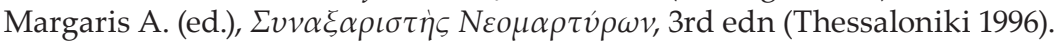

Meyendorff J., Introduction a l'étude de Grégoire Palamas (Paris 1959).

- Byzantine Hesychasm: historical, theological and social problems. Collected Studies (London 1974).

Minkov A., Conversion to Islam in the Balkans. Kisve Bahası Petitions and Ottoman social Life, 1670-1730 (Leiden 2004).

Molho M., Le Meam-Loez, encyclopédie populaire du séphardisme levantin (Thessaloniki 1945).

Molinos Miguel de, Breve tratado de la comunión cotidiana (Rome 1675).

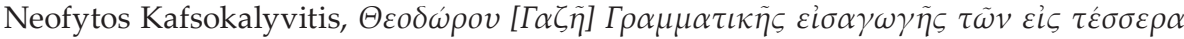

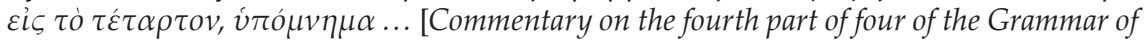
Theodorus [Gaza]...] (Bucharest 1768).

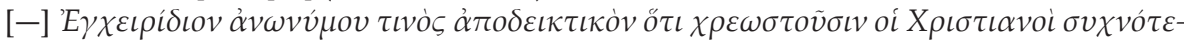
$\rho o v v \dot{\alpha} \mu \varepsilon \tau \alpha \lambda \alpha \mu \beta \dot{\alpha} v \omega \sigma \iota \tau \dot{\alpha} \theta \varepsilon \tilde{\varepsilon} \alpha \mu v \sigma \tau \eta \dot{\rho} \rho \iota . .$. [Manual of some anonymous which proves that the Christians owe to take part more often in the Holy Communion ...] (Venice 1777).

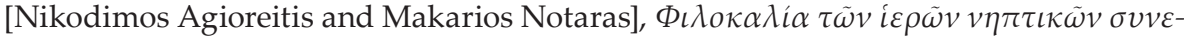

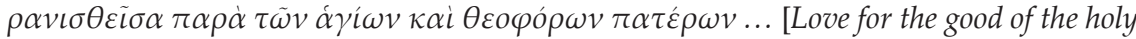
neptics collected from the holy and god-inspired fathers ...] (Venice 1782).

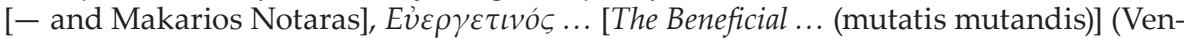
ice 1783).

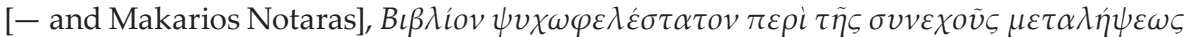

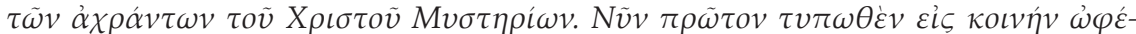

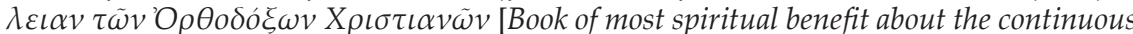
Communion of the Holy Sacraments of Christ. Now for first time printed for common good of the Orthodox Christians] (Venice 1783).

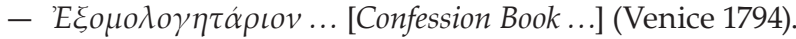

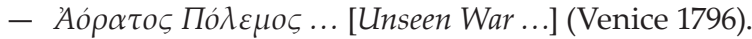

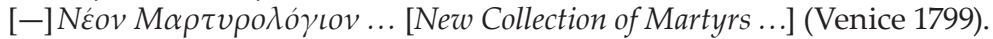

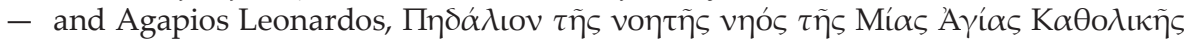

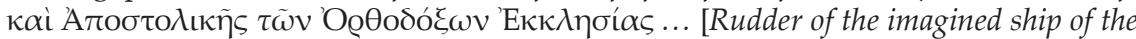
one Holy Catholic and Apostolic Church of the Orthodox .... (Leipzig 1800).

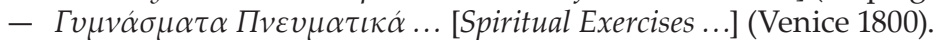

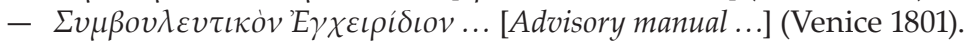

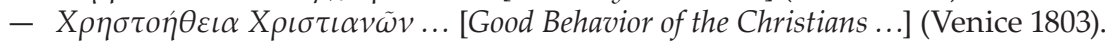

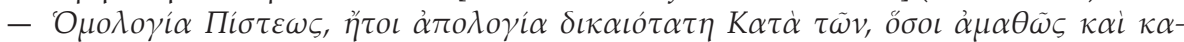

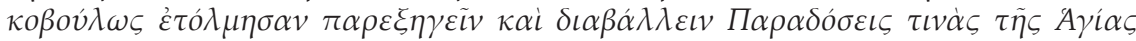

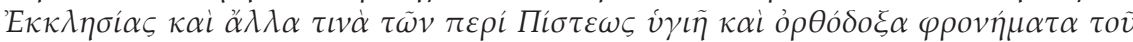

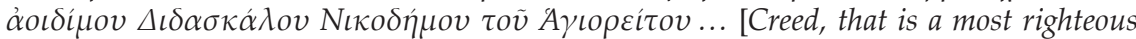
apology against those who dared ignorantly and viciously to misunderstand and to slander some traditions of the Holy Church, together with some other healthy and orthodox views about faith from the blessed teacher Nikodimos Agioreitis .... (Venice 1819). 


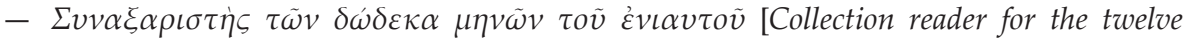
months of the year] (Venice 1819).

Papo Eliezer, Pele Yo'etz [Wonderful Cou nsellor] (Constantinople 1824).

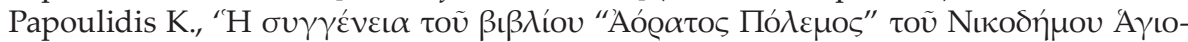

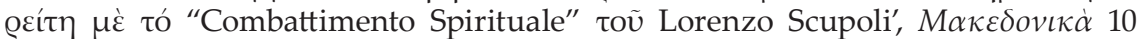
(1970) 23-34.

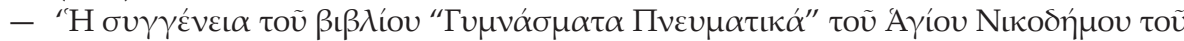

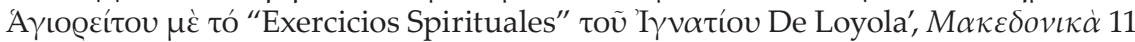
(1971) 167-73.

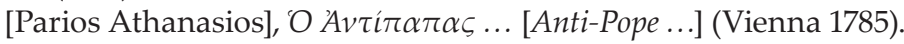

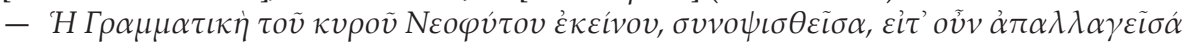

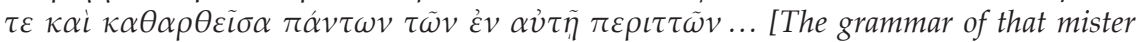
Neofytos, summarized but now freed from anything superfluous ...] (Venice 1787).

[-] X

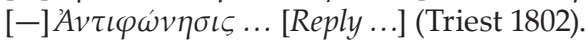

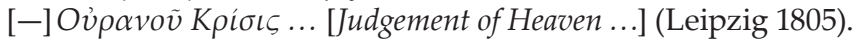

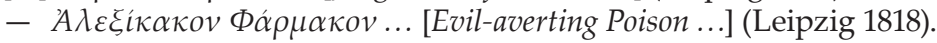

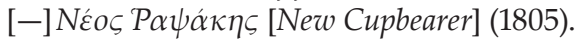

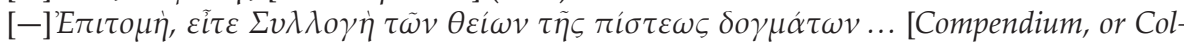
lection of the divine dogmas of faith...] (Leipzig 1806).

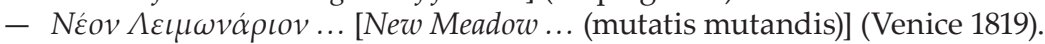

Pissis N., Russland in den politischen Vorstellungen der griechischen Kulturwelt 1645-1725 (Göttingen 2020).

Rothman E. N., 'Becoming Venetian: Conversion and Transformation in the Seventeenth-Century Mediterranean', Mediterranean Historical Review 21/1 (June 2006) 39-75.

- 'Interpreting Dragomans: Boundaries and Crossings in the Early Modern Mediterranean', Comparative Studies in Society and History 51/4 (2009) 771-800.

- Brokering Empire: Trans-Imperial Subjects between Venice and Istanbul (Cornell 2012).

- 'Afterword: Intermediaries, Mediation, and Cross-Confessional Diplomacy in the Early Modern Mediterranean', Journal of Early Modern History 19 (2015) 245-59.

Schmidt H., 'Sozialdisziplinierung? Ein Plädoyer für das Ende des Etatismus in der Konfessionalisierungsforschung', Historische Zeitschrift 265 (1997) 639-82.

Shemuelevitz A., The Jews of the Ottoman Empire in the late fifteenth and the sixteenth centuries; administrative, economic, legal and social relations as reflected in the responsa (Leiden 1984).

Shields Kollmann N., The Russian Empire 1450-1801 (Oxford 2017).

Sholem G., Sabbatai Sevi. The Mystical Messiah 1626-1676 (London 1973).

Şişman C., The Burden of Silence. Sabbatai Sevi and the Evolution of the Ottoman-Turkish Dönmes (Oxford 2015).

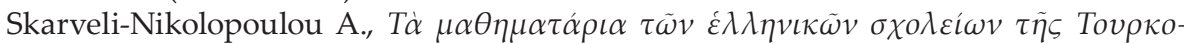

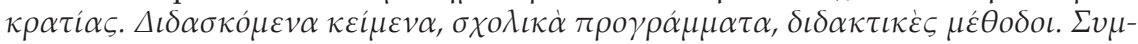

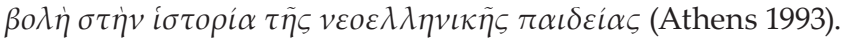

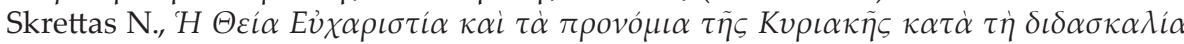
$\tau \tilde{\omega} v$ Ko $\lambda \lambda v \beta \alpha \dot{\alpha} \delta \omega v$ (Thessaloniki 2004).

Spengler O., Der Untergang des Abendlandes. Umrisse einer Morphologie der Weltgeschichte (Munich 1963). 


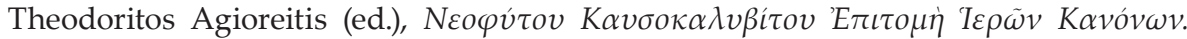
A $\pi \dot{\alpha} v \theta \iota \sigma \mu \alpha$, I (Athens 2002).

Tsakiris V., Die gedruckten griechischen Beichtbücher zur Zeit der Türkenherrschaft: Ihr Entstehungszusammenhang und ihre Quellen (Berlin 2008).

Twersky I. and Septimus B. (eds), Jewish Thought in the Seventeenth Century (Cambridge 1987).

Vivelo Fr. R., 'Segmentäre Gesellschaften', in Fr. R. Vivelo (ed.), Handbuch der Kulturanthropologie. Eine grundlegende Einführung (Stuttgart 1981) 198-201.

Weissberg V., Jewish Life in Seventeenth Century Turkey as Reflected in the Responsa of Rabbi Jacob Alfandari and Rabbi Joseph Katzavi (PhD Thesis) (Hebrew Union College, Cincinnati 1970).

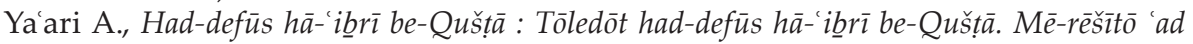
pārūṣ milhemethāa-ōlām haš-šenniyā [Hebrew Printing at Constantinople: Its History and Bibliography] [Supplement to Kirjath Sepher, 42] (Jerusalem 1967).

Zeeden E.W., 'Grundlagen und Wege der Konfessionsbildung im Zeitalter der Glaubenskämpfe', Historische Zeitschrift 85 (1958) 249-99.

- Die Entstehung der Konfessionen (Munich 1965).

Zelepos I., "“Unser orientalisch-christliches Geschlecht" - Zur Formierung eines osmanisch-orthodoxen Identitätskonzept in der zweiten Hälfte des 18. Jahrhunderts', in Maria Oikonomou, Maria Stassinopoulou and Ioannis Zelepos (eds), Griechische Dimensionen südosteuropäischer Kultur seit dem 18. Jahrhundert. Verortung, Bewegung, Grenzüberschreitung (Frankfurt a.M. 2011) 111-24.

- Orthodoxe Eiferer im osmanischen Südosteuropa. Die Kollyvadenbewegung (1750-1820) und ihr Beitrag zu den Auseinandersetzungen um Tradition, Aufklärung und Identität (Wiesbaden 2012).

Zinberg I., A history of Jewish Literature, Translated and Edited by Bernard Martin (New York 1975). 


\title{
Ecumenical Orthodoxy vs Confessional Orthodoxy: Evgenios Voulgaris and Nikiforos Theotokis Addressing Russian Orthodoxy
}

\author{
Vasilios N. Makrides, University of Erfurt
}

\section{Introduction: Applying the Confessionalization Paradigm to the Orthodox Christian World}

It is well known that the research paradigm of confessionalization in early modern Europe has proven to be very attractive and fruitful in a rather short period of time. Originally initiated almost at the same time in the 1970s first with regard to Protestantism by Heinz Schilling and second to Roman Catholicism by Wolfgang Reinhardt, it has triggered major discussions and debates within these contexts and became more or less established within academia. Interestingly enough, research has gone far beyond the initial historical character of this paradigm, which has thus acquired an interdisciplinary orientation and relevance. It goes without saying that its application gradually became much wider than its original one, including Islam and non-European religions and cultures. At the same time, the enhanced discussion on this topic generated much criticism from various angles-a normal process when a paradigm enjoys such popularity within the academic community. ${ }^{1}$

As was to be expected, this paradigm was also applied to the other historical branch of Christendom, namely to Orthodox Christianity, although with considerable delay. Aside from previous sporadic and rather insufficient attempts, the first systematic examination of the topic took place during a conference in Mainz in 2015, whose proceedings have already been published in a rich collective volume. ${ }^{2}$ The relevance and the scope of this volume are essential for any further discussion on the overall topic. Since then, there has been increased interest in the 'Orthodox

1 From the most recent bibliography on this topic, see C. Strohm, 'Confessionalisation et sécularisation au début de la modernité', in F. Lienhard and C. Grappe (eds), Konfessionalisierung und Säkularisierung am Beginn der Moderne (Vienna 2017) 31-9; C. A. Zwierlein, “'Konfessionalisierung" europäisch, global als epistemischer Prozess: Zu den Folgen der Reformation und zur Methodendiskussion', in C. Strohm (ed.), Reformation und Recht. Zur Kontroverse um die Kulturwirkungen der Reformation (Tübingen 2017) 1-51; J.Stievermann and R. C. Zachman (eds), Multiple Reformations? The Many Faces and Legacies of the Reformation (Tübingen 2018); M. Habermann (ed.), Sprache, Reformation, Konfessionalisierung (Berlin-Boston 2018); J. Hodapp, Habsburgerinnen und Konfessionalisierung im späten 16. Jahrhundert (Münster 2018).

2 See M.-D. Grigore and F. Kührer-Wielach (eds), Orthodoxa Confessio? Konfessionsbildung, Konfessionalisierung und ihre Folgen in der östlichen Christenheit Europas (Göttingen 2018). 
confessionalization' through publications, conferences and other events, which attest further to the importance and the heuristic power of this perspective for understanding various processes within the Orthodox world. ${ }^{3}$ One basic problem, however, relates to the particularities of Orthodox Christianity, which are in many respects different from those of Western Christianity. Is this paradigm applicable to the Eastern Orthodox world as such, especially from the early modern period onwards, when the differences between East and West in Europe grew much bigger because of the Reformation? In any event, the term 'confession' is not used as a self-characterization by the various Orthodox Churches. Orthodox ecclesiology has always put emphasis on the universal and holistic understanding of the church, which was thus opposed to the particular, limited and fragmented character of a confession. Furthermore, the Orthodox Churches have always criticized the steady growth of Protestant confessionalism with the constant multiplication of respective churches/confessions/denominations. This critique took place in recent years within the World Council of Churches, and this also explains why many Orthodox Churches have expressed their dissatisfaction with the overall course of this inter-Christian institution. ${ }^{4}$ Yet, even if de jure the Orthodox Churches do not constitute confessions, they have de facto become ones in the course of their nationalization especially during the last three centuries, as I shall show later on. The same holds true for the Roman Catholic Church, which is neither de jure a confession, nor considers itself to have confessional characteristics. However, after the 'Professio fidei' of the Council of Trento in 1564, this church has also become de facto a confession, namely one that is defined by such an official and normative document delineating its specific Christian identity. Responding to and reacting against the Protestant confessionalization, the Roman Catholic Church also initiated its own confessionalization process, which led to its modern transformation as an institution.

In general terms, the confessionalization process ('Konfessionalisierung') under consideration should be considered independently of the existence of a specific 'Confessio fidei' for a given Christian Church or group. This is because the confessionalization process is not limited to the religious domain, but includes many other aspects that affect a certain society as a whole. An officially proclaimed confession of faith is necessary, given that it basically contributes to the building of

3 See, for example, the workshop 'Confessionalization vs Secularization Paradigms? Comparative Perspectives in Western and Eastern/Southeastern Europe', Freiburg, FRIAS, 25-26 May 2018, https://www.frias.uni-freiburg.de/downloads/veranstaltungen/ConferenceBookWorkshop Stamatopoulos.pdf. See further the conference 'Religious Diversity and Confessionalization in Ottoman Europe', Munich, 4-6 July 2019, https://www.hsozkult.de/event/id/event-90006.

4 See M. Käßmann, 'Der Ökumenische Rat am Scheideweg-die Konflikte zwischen Orthodoxie und Protestantismus bedrohen den Weltkirchenrat', Evangelischer Pressedienst: Dokumentation 50 (2002) 25-7; A. M. Aagaard and P. Bouteneff (eds), Beyond the East-West Divide: The World Council of Churches and 'the Orthodox Problem' (Geneva 2001); D. Heller, 'Der Dialog zwischen der Orthodoxie und den Kirchen der Reformation-Probleme und Perspektiven', Una Sancta 66 (2011) 31-41. 
a confessional identity ('Konfessionsbildung') and the creation of a confessional culture ('Konfessionskultur'). Yet it is not a conditio sine qua non for a confessionalization process, which is much broader and exhibits various other facets. First, the articulation of confessional identities takes place here in clear demarcation from and competition with other churches or confessions and results in the intensification of confessional plurality and diversity through various discursive means and practices, both verbal and non-verbal. This may be a top-down process initiated by the state (the Protestant version) or by the official church (the Roman Catholic version). Second, it may also involve a constant, parallel interaction among various authorities and actors from all societal layers in a given setting. All this happens under conditions of increased religious, cultural, social and political pluralization, differentiation, rivalry, competition, and last but not least, growing secularization (in the West European version). Among the key features of this process are: identity building; religious and cultural unity, uniformity, homogeneity, conformity and loyalty; social disciplinary strategies and measures vis-à-vis the respective adherents; strengthening of institutional structures; confrontational spirit; distancing and demarcation mechanisms (e.g., rationalization, doctrinal clarity) from competing churches and confessions; modernizing adaptations and reforms; increase in competence; transformation of society and social mentalities; close connection between confession, state, politics and society; and creation of modern state and governance forms. It is thus evident that the confessionalization process is related to religion, yet it includes much more than this. In this sense, confessionalization is basically a modern, post-Reformation, thorough and transformative process and has little to do with various pre-modern professions and confessions of faith, which obeyed other rules and had other objectives. It is also not directly related to phenomena of inter-, multi-, and trans-confessional coexistence in religiously mixed areas in which confessional identities often overlapped. This is because such areas mostly lacked systematic confessional competition, strict confessional demarcation, and strong confessional confrontation. Such areas can be found in Eastern and South Eastern Europe, as well as in the Levant from the early modern period onwards; for example, the Ionian islands under Venetian rule, the Cyclades islands, Crete, the regions of Vojvodina and Transylvania, and various cosmopolitan cities like Constantinople, Smyrna and Odessa. ${ }^{5}$

Bearing all this mind, it appears at first sight difficult to talk about a confessionalization process of this kind within Orthodox Christianity. For instance, social disciplinary measures, religious conformity and loyalty, doctrinal clarity and reform potential were in most cases rather weak in Orthodox cultures. The Orthodox Church structure is also less bureaucratic and rationalized than those of the Western Churches. Furthermore, written confessional texts were less important

5 See V. N. Makrides, 'Konfessionalisierungsprozesse in der orthodox-christlichen Welt: Ein Periodisierungs- und Systematisierungsversuch', in M.-D. Grigore and F. Kührer-Wielach (eds), Orthodoxa Confessio? Konfessionsbildung, Konfessionalisierung und ihre Folgen in der östlichen Christenheit Europas (Göttingen 2018) 77-110, here p. 77-84. 
for the Orthodox Churches, which in fact had a large array of discursive practices (especially including non-verbal ones) in order to disseminate their message. There is also an Orthodox predilection for mysticism, ascetic practices, contemplation and spirituality, which cannot be easily controlled and channelled following central church directives. More importantly, Orthodox Churches usually enjoyed a privileged or even monopoly status due to their support by the respective political powers/states, a situation that does not favour confessional differentiation. In such contexts, there were no serious confessional competitors of the official Orthodox Churches. How then is it possible to talk about a confessionalization within the coordinates of the Orthodox Christian world?

\section{Orthodox Confessionalization, Nationalization, and the Russian Orthodox Case}

Looking for traces of a confessionalization within the Orthodox world, one should avoid directly transferring Western patterns of confessionalization one to one to the Orthodox case. The latter exhibits its own characteristics and specificities, which need to be taken into account. Usually, in the borderlands between East and West, one may thus locate different forms of an Orthodox confessionalization under Western influence, such as in the Polish-Lithuanian Commonwealth. More importantly, the issue of nationalization, a central one in the Orthodox world, may offer some useful hints as to the ways an Orthodox confessionalization has taken place. This is because a key characteristic of the confessionalization process in the West has precisely been its close connection with ethnicity and nationality, especially in mixed, multi-confessional areas (Germany Switzerland, Poland-Lithuania, Hungary). The confessionalization of the nation in Germany during the nineteenth century and in the early twentieth century (e.g., through the cult of Luther) has been thus considered as the 'Second Confessional Age' that in the wake of the Reformation. The question posed here is whether Orthodox Christianity, which has a long and influential ecumenical background and history, can be connected with such a nationalization process. However, if one looks at the situation of the Orthodox world from the nineteenth century until today, one realizes easily that such a nationalization has thoroughly taken place. In fact, there is a large number of national, independent Orthodox Churches, especially in Eastern and South Eastern Europe. Indeed, the nationalization process unfolded at an incredibly rapid pace and led to a radical transformation of the entire Orthodox world, despite reactions and countermeasures by the Ecumenical Patriarchate of Constantinople, which tried unsuccessfully to maintain Pan-Orthodox unity in highly troubled times. Nationalization was equated with a fragmentation of the Orthodox unity, ecumenicity and universality on the basis of ethnic, linguistic, cultural and other particularisms. This is why it was condemned at a Synod in

6 See O. Blaschke (ed.), Konfessionen im Konflikt: Deutschland zwischen 1800 und 1970. Ein zweites konfessionelles Zeitalter (Göttingen 2002). 
Constantinople in 1872 reacting against the unilateral foundation of an Orthodox Bulgarian Exarchate (1870), a first step to the autocephaly of the Bulgarian Orthodox Church. ${ }^{7}$ There are several endogenous reasons explaining this deep internal transformation of the Orthodox world. In all probability, it has to do with certain distinctive features and historical practices within Orthodox Christianity (e.g., church-state relations, indigenization, vernacularization, administrative pluralism), which in the modern era were easily nationalized and enabled this quick transition from an ecumenical Orthodoxy to the many national local Orthodoxies. ${ }^{8}$ Seen in this perspective, the nationalization of the Orthodox world in modern times should be regarded as part of its own confessionalization, even if a partial and fragmented one. No doubt, there exist here clear analogies between the initial Protestant confessional pluralization after the Reformation and the later Orthodox ethnic/national internal differentiation. In other words, the Protestant confessional variety is mutatis mutandis comparable to the Orthodox ethnic and national diversity. ${ }^{9}$

The modern nationalization process of the Orthodox world should, however, be distinguished from its pre-modern ethnicization, that is from the emergence of Orthodox ethnic identities and specific ethnic Orthodoxies in earlier times. This happened, for instance, in the Bulgarian and Serbian cases in the Balkans during the late Middle Ages when both challenged the Byzantine (East Roman) Empire and the Patriarchate of Constantinople at a time when Orthodox ecumenicity was prevailing. No doubt, there was a pervasive 'Greek' character of this ecumenical Orthodoxy in the context of the gradual Hellenization of the Byzantine Empire (in terms of language, education, literature etc.), yet this character was understood in purely cultural terms and in no way in the modern national sense. ${ }^{10}$ The Patriarchate of Constantinople was mostly in 'Greek hands' during its long history, but it did not identify itself with the narrow Greek national interests, especially after the foundation of the modern Greek state in 1830. The repeated conflicts between Constantinople and Athens, not only on the ecclesiastical, but also at times on the political level, attest to this. ${ }^{11}$

7 See D. Stamatopoulos, 'Orthodox Ecumenicity and the Bulgarian Schism', Études Balkaniques 51/1 (2015) 70-86.

8 See V. N. Makrides, 'Why are Orthodox Churches Particularly Prone to Nationalization and even to Nationalism?', St Vladimir's Theological Quarterly 54 (2013) 325-52.

9 See Makrides, 'Konfessionalisierungsprozesse', 94-102.

10 See V. N. Makrides, 'Orthodoxie, griechische Ethnie, Nation, griechischer Nationalstaat und Nationalismus: Mythen und Realitäten', in I. Keul (ed.), Religion, Ethnie, Nation und die Aushandlung von Identität(en). Regionale Religionsgeschichte in Ostmittel- und Südosteuropa (Berlin 2005) 67-92; V. N. Makrides, Hellenic Temples and Christian Churches: A Concise History of the Religious Cultures of Greece from Antiquity to the Present (New York-London 2009) passim.

11 See V. Roudometof, 'Greek Orthodoxy, Territoriality, and Globality: Religious Responses and Institutional Disputes', Sociology of Religion 69 (2008) 67-91; P. K. Kitromilides, Religion and Politics in the Orthodox World: The Ecumenical Patriarchate and the Challenges of Modernity (London 2019). 
A special case relates, however, to the emergence of the independent Russian Orthodoxy in modern times, which after the fall of Constantinople in 1453 to the Ottoman Turks developed autonomously and gradually enhanced its power and influence, even beyond its borders. Thus, at that time, the Russian Empire and Church had become the protectors of the Orthodox subjects in the Ottoman Empire. More importantly, in the course of this period the Russian Church also acquired its own particular characteristics, especially compared to the Patriarchate of Constantinople under Ottoman rule. This happened principally with the Council of Stoglav (Moscow 1551), which decisively contributed to the standardization of the Russian Orthodox ritual practice. The final outcome of all these developments was the official recognition of the autocephaly of the Patriarchate of Moscow (1589/1593) by the rest of the Orthodox Churches, ${ }^{12}$ an important event in the budding differentiation of the Orthodox world in modern times. Later developments, such as the Schism of the Old Believers in 1666/1667 and the church reforms of Peter the Great in 1721 (including the important constitutional document of the Russian Church entitled Spiritual Regulation [Dukhovnyi Reglament] by the Archbishop of Novgorod Feofan Prokopovich, 1681-1736), contributed further to the differentiation of Russian Orthodoxy from other Orthodox Churches. This Russification was not coterminous with a nationalization process in the modern sense. Rather, it was more about the rise of a specific russified, pre-national confessional Orthodox Church, which was distinct from the traditional trans-ethnic and ecumenical Orthodoxy and at the same time raised strong universal claims to the imperial Byzantine heritage. No doubt, this differentiation process did not pose any threat to Pan-Orthodox unity at that time. Nevertheless, it was a clear differentiation of the Orthodox world along ethnic confessional lines, which led to further specific developments within Russian Orthodoxy that fall under the characteristics of the Western confessionalization paradigm; for example, strengthening of the church institution, attempts at greater homogeneity and uniformity, disciplinary measures, competition and demarcation from other churches and confessions, as well as concomitant identity construction. ${ }^{13}$

Such changes can also be observed in the way the Greek Orthodox world and the Russian Orthodox world interacted with one another across history and in the transfer of religious knowledge in this context. Traditionally and historically, there was rather a one-way process of influence from the Greek Orthodox world, headed by the Patriarchate of Constantinople, to Russia after the Christianization of the Kievan Rus'.14 This dependence on the 'Greeks' of Byzantium caused vari-

12 See H. Ohme, 'Die “Heilige und Große Synode" der Orthodoxen Kirche vom Jahre 1593 und die Erhebung des Moskauer Patriarchates', Kirche im Osten 33 (1990) 70-90; K. C. Felmy et al. (eds), Der Ökumenische Patriarch Jeremias II. von Konstantinopel und die Anfänge des Moskauer Patriarchats (Erlangen 1991).

13 See W. von Scheliha, Russland und die orthodoxe Universalkirche in der Patriarchatsperiode 15891721 (Wiesbaden 2004).

14 See G. Podskalsky, Christentum und theologische Literatur in der Kiever Rus' (988-1237) (Mu- 
ous Russian reactions later on, including the famous statement of Tsar Ivan IV the Terrible (1533-1584): 'I do not believe in the Greeks, but in Jesus Christ. ${ }^{\prime 15}$ This also concerned the 'colonization' of the Russian Orthodox mind through the influence of Byzantine Orthodoxy, which became evident on various occasions (e.g., in the church reforms of Patriarch of Moscow Nikon, 1652-1658). ${ }^{16}$ However, the Russian Orthodox tradition slowly came of age and began exerting a counter-influence on the Greek Orthodox world-with the eighteenth century being a turning point. The characteristic evidence of this is provided by the translations of Russian works into Greek at that time. For example, an eminent Greek physician and philologist Adamantios Korais (1748-1833) translated into Greek and published in 1782 the Orthodox Catechism of the Metropolitan of Moscow Platon Levshin (1737-1812), an Orthodox prelate combining the Orthodox tradition with selected modern ideas in the age of the Enlightenment. ${ }^{17}$ Hence, Russian Orthodoxy started to emerge gradually as an important confessional Orthodox Church with its own particular characteristics and a concomitant self-awareness and self-confidence, able to influence other Orthodox Churches and cultures, inter alia in transmitting religious knowledge. All this provided the appropriate background for the later nationalization of the Russian Church in the nineteenth century, which also happened in parallel with other emerging confessional-national Orthodox Churches in the Balkans.

Undoubtedly, such an early emergence of a confessional Orthodox Church (in the sense of its stronger Russification and wider influence) did not go unnoticed, and this was perceived exactly in this way at that time by the rest of the Orthodox Churches and actors. So, when Petro Mohyla, the Metropolitan of Kiev (16331647), published his Orthodox Confession of Faith in 1640, this was first regarded as being a 'Russian Orthodox Catechesis'; in other words, as having particular Russian Orthodox characteristics. In the Synod of Iasi in 1642, this confession was then corrected, completed and translated into Greek by the cleric and theologian Meletios Syrigos (1585/6-1663/4), while in the following Synod of Constantinople in 1643 and also in the Synod of Jerusalem in 1672 it was accepted as an official 'Confession of Faith' of all Orthodox Christians, and not only of the Russians. ${ }^{18}$ In this case, we observe an overcoming of the narrow confessional character of this document and its transformation into a broader ecumenical one. This example

nich 1982); G. Podskalsky, 'Die Rolle der griechischen Kirche und Theologie innerhalb der Gesamtorthodoxie in der Zeit der Türkenherrschaft (1453-1821)', in R. Lauer and P. Schneider (eds), Die Kultur Griechenlands in Mittelalter und Neuzeit. Bericht über das Kolloquium der Südosteuropa-Kommission, 28.-31. Oktober 1992 (Göttingen 1996) 222-41.

15 See P. Nitsche, 'Nicht an die Griechen glaube ich, sondern an Christus'. Russen und Griechen im Selbstverständnis des Moskauer Staates an der Schwelle zur Neuzeit (Düsseldorf 1991).

16 See P. Meyendorff, Russia, Ritual, and Reform: The Liturgical Reforms of Nikon in the 17th Century (Crestwood, NY 1991).

17 See I. Carras, 'Understanding God and Tolerating Humankind: Orthodoxy and the Enlightenment in Eugenios Voulgaris (1716-1806) and Platon Levshin (1737-1812)', in P. M. Kitromilides (ed.), Enlightenment and Religion in the Orthodox World (Oxford 2016) 79-139.

18 See Makrides, 'Konfessionalisierungsprozesse', 101. 
makes clear the ongoing dynamics and tensions between traditional universality and growing confessionalization within the Orthodox world. This was about to happen in a more intensive form from the nineteenth century onwards with far-reaching repercussions. In this novel context, many new Orthodox Churches were fully nationalized and developed their own distinct confessional characteristics. The confessionalization of the Orthodox world in terms of its nationalization thus became a fact and lingers on until today.

From this perspective, it is highly interesting to pay closer attention to this transition process from an Orthodox universality to an Orthodox confessionalism through nationalization at the end of the eighteenth and the beginning of the nineteenth century. Examples from this period reveal that various Orthodox actors, despite their distinct ethnic origins, did not operate strictly in ethnic terms, but tried to overcome them. We thus observe at that time an Orthodox identity, which was, on the one hand, defined by local parameters, but, on the other hand, had no problems crossing ethnic boundaries and borders. Such a flexibility and adaptability, however, gradually disappeared with the subsequent increase of nationalization currents from the second half of the nineteenth century onwards. In what follows I shall take a closer look at the ecumenical and supra-regional role and impact of two eminent Greek clerics, scholars and friends, namely of Evgenios Voulgaris (1716-1806) ${ }^{19}$ and Nikiforos Theotokis (1731-1800), ${ }^{20}$ who had distinguished careers as leading ecclesiastics in Russia and were highly esteemed and honoured by their contemporaries.

Through the active support of the Orthodox Greeks and other subjects of the Ottoman Empire, the Russian foreign policy of that time aimed at territorial expansion to the south and, if possible, the capturing of Constantinople. The related 'Greek Plan' of Empress Catherine II (1762-1796) is a case in point, with which both Voulgaris and Theotokis were familiar. During that period, the idea of Russia's role as a protector of all Orthodox peoples under Ottoman rule and the associated oracular hopes for an eventual liberation from the Ottomans developed immense-

19 From the rich bibliography on Voulgaris, see S. K. Batalden, Catherine II's Greek Prelate: Eugenios Voulgaris in Russia, 1771-1806 (Boulder-New York 1982); D. Stiernon, 'Eugène Boulgaris', in C. G. Conticello and V. Conticello (eds), La théologie byzantine et sa tradition, II. XIIIe-XIXe s.

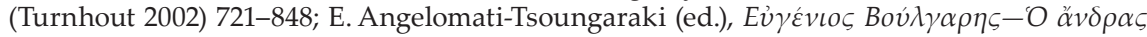

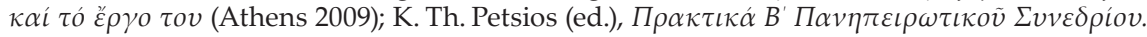

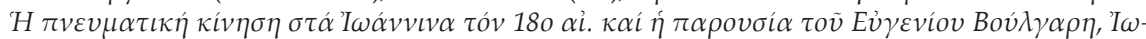

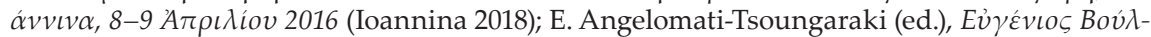

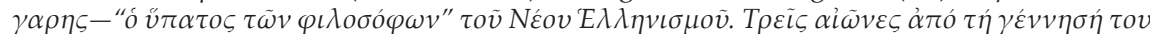

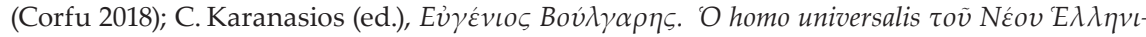

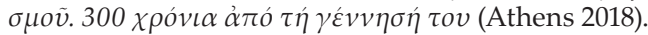

20 From the rich bibliography on Theotokis, see G. L. Bruess, Religion, Identity and Empire: A Greek Archbishop in the Russia of Catherine the Great (Boulder-New York 1997); V. N. Makrides, 'Nicéphore Théotokès', in C. G. Conticello and V. Conticello (eds), La théologie byzantine et sa tradition, II. XIIIe-XIXe s. (Turnhout 2002) 849-903; Igumen Innokentii (Ol'khovoi), E. Zhukova and I. Bykova (eds), Arkhiepiskop Nikifor Feotokis. Blagoslovennym Khristianam Gretsii i Rossii (Moscow 2006). 
ly. ${ }^{21}$ In this regard, both Voulgaris and Theotokis became supportive of the Russian expansionist policies and were also instrumentalized to that purpose by the Russians. Among other things, Voulgaris published a study on the reported Christian baptism of the Russian Princess Olga in 956 in Constantinople (St. Petersburg $1792)^{22}$ and wrote another study on the history of the ancient Tauris, namely the Crimean Peninsula, which had been incorporated into the Russian Empire and was of great strategic importance, a work that remained unpublished for a long time. ${ }^{23}$ Yet the support Voulgaris and Theotokis offered to the Russian side was not unconditional. In terms of religion and ethnicity, although Greek by origin, both Voulgaris and Theotokis constantly moved and acted in a broader, non-ethnic Orthodox context. While the Greek character of their Orthodoxy shaped their views, actions and initiatives, there was no sign of a conflict with the idea of an Orthodox ecumenicity. The Greek dimension of their Orthodoxy did not draw separation lines between various peoples, but rather functioned in a unifying way. It is thus interesting to examine from such a perspective their activities on Russian soil, especially in light of the aforementioned confessional Russification of the Orthodox Church there.

\section{Evgenios Voulgaris and the Problem of Uniatism in the Russian Empire}

The phenomenon of Uniatism, especially in the form of the Greek Catholic Churches of the Byzantine Rite, has been always considered by the Orthodox as a grave problem and a most serious challenge ( $\mathrm{a}$ 'Trojan horse') until today. ${ }^{24} \mathrm{~A}$ decisive event was the Council of Brest-Litovsk (1595-1596), by which many previously Orthodox Christians accepted their union with the Roman Catholic Church according to the decisions of the Council of Ferrara-Florence in $1438-1439 .{ }^{25}$ Yet there was great variation within the different Uniate communities, especially as far as their degree of Latinization was concerned, for various reasons (coercion, opportunism, conviction etc.). ${ }^{26}$ The same concerns the overall relations between Uniates and Orthodox Christians, which, despite tensions and enmities, were not a priori negative. For example, the interactions between them in the field of culture and education were in many respects quite positive. Yet this should not obscure the

21 See V. N. Makrides, 'Orthodoxie und Politik: Die russisch-griechischen Beziehungen zur Zeit Katharinas II.', in C. Scharf (ed.), Katharina II., Rußland und Europa. Beiträge zur internationalen Forschung (Mainz 2001) 85-119.

22 See Stiernon, 'Eugène Boulgaris', 758.

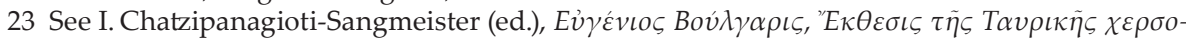

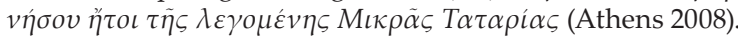

24 See T. Zissis, 'Uniatism: A Problem in the Dialogue Between the Orthodox and Roman Catholics', The Greek Orthodox Theological Review 35 (1990) 21-31.

25 See W. van den Bercken and B. Groen (eds), Four Hundred Years Union of Brest (1596-1996): A Critical Re-evaluation (Leuven 1999); J. Marte and O. Turij (eds), Die Union von Brest (1596) in Geschichte und Geschichtsschreibung. Versuch einer Zwischenbilanz (Lviv 2008).

26 See S. Senyk, 'The Ukrainian Church and Latinization', Orientalia Christiana Periodica 56 (1990) $165-87$. 
continuous tensions that existed between them, especially because of the strong politicization of the entire issue and the expansionist policies of the involved or neighbouring countries. ${ }^{27}$ This was especially the case with the Russian Empire, an aspiring regional power, which was particularly interested in all kinds of dissidents across its borders and followed an overall anti-Catholic policy. Such an interest in the peripheral regions of the empire was in line with the Russian policy of territorial expansion and the smooth integration of religious minorities into Russian society following the decree on religious tolerance, officially promulgated by Empress Catherine II in 1773. The issue of Uniatism thus appeared to be particularly challenging after the three partitions of Poland, namely the successive annexations of territories of Poland-Lithuania in 1772, 1793 and 1795 by the Russian Empire, the Kingdom of Prussia, and the Austrian Empire. In these territories, large numbers of Uniates were living, who had to be re-integrated into Russian Orthodoxy, a process that was far from an easy and smooth. The question for Russia, then, was how to deal with this situation in the best and most appropriate way.

Before becoming Archbishop in Russia and because of his experience with the Roman Catholics in his birthplace Corfu under Venetian rule, Voulgaris was particularly sensitive to this issue generally and maintained a tough, anti-Catholic stance on the subject. His anti-Catholic tenor can be observed quite early, as in his

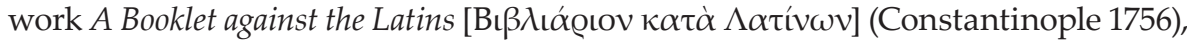
as well as in the correspondence with the French Jansenist Pierre Leclerc (17061781) between 1759 and $1761 .{ }^{28}$ While still living in the German area (1764-1771), he composed an anti-Catholic and anti-Uniate text that finally appeared anonymously in Halle in 1775 and was later reprinted several times. In all probability, his friend Nikiforos Theotokis, also stemming from Corfu, participated in the final composition, redaction and publication of this text. ${ }^{29}$ The reason for this publication lay in the great problems with the Uniates after the first partition of Poland in 1772 and their re-integration into the Russian Orthodox Church. Voulgaris had also anonymously translated and published in Leipzig in 1768 an anti-Catholic work by Voltaire on the religious problems and confrontations in Poland, to which he added his own treatise on religious tolerance. ${ }^{30}$ Being thus keenly aware of the long-standing tensions between Roman Catholics, Uniates and Orthodox, he was very sceptical of the rapid, smooth and uncomplicated re-integration of Uniates

27 See S. Rohdewald, D. Frick and S. Wiederkehr (eds), Litauen und Ruthenien. Studien zu einer transkulturellen Kommunikationsregion (15.-18. Jahrhundert)/Lithuania and Ruthenia. Studies of a Transcultural Communication Zone (15th-18th Centuries) (Wiesbaden 2007); A. Brüning, Unio non est unitas: Polen-Litauens Weg im konfessionellen Zeitalter (1569-1648) (Wiesbaden 2008).

28 See Stiernon, 'Eugène Boulgaris', 742 and 754-7.

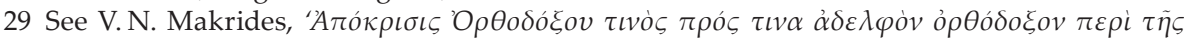

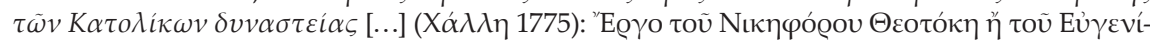

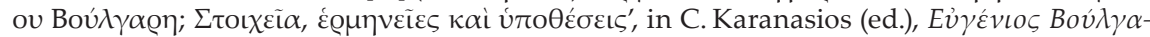

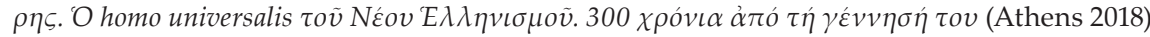
463-522.

30 See Stiernon, 'Eugène Boulgaris', 775-7. 
into the Russian Orthodox Church. Such a policy was strongly supported by the Russian side, both state and church, following the consequent partitions of Poland and because of the political interest in homogenizing the annexed territories religiously as soon as possible, even with the use of force. By contrast, Voulgaris was more of an idealist and was interested in seeing a truthful and trustworthy conversion of the Uniates back to the Russian Orthodox Church. The question was of course how practical and realizable his suggestions were, given the large numbers of Uniates that were being re-integrated. In any case, he tried to apply his own careful policy vis-à-vis the Uniates in his Diocese of Slavyansk and Kherson (1776-1779). Very representative is thus the case of the Uniate priest Vasilii Moiseevich Zrazhevskoi in this diocese, who had returned to Russian Orthodoxy back in 1768. Yet Voulgaris as Archbishop suspended him from his priestly office because he was not persuaded of the sincerity of his conversion and overall stance. Voulgaris' successor, Theotokis, was also later involved in this debate and held the same position on the issue. Zrazhevskoi then appealed to the Russian Church Synod and explained his situation, arguing that he had been forced in the first place to join the Uniate Church against his will. Consequently, the Synod asked Theotokis to revoke his decision, as it was more interested in overcoming minor problems (theological or canonical) and allow for the smooth re-integration of the Uniates into the Russian Church. Theotokis had no other possibility than to obey the order of this superior ecclesiastical body, yet he made his dissatisfaction clear and corroborated it with further theological arguments. ${ }^{31}$

After the second partition of Poland in 1793, the problem of the Uniates became even more pressing for Russia. It was in this context that Voulgaris was asked by the Chief Procurator of the Holy Synod of the Russian Orthodox Church (17911797), Prince Aleksei Ivanovich Musin-Pushkin (1744-1817), on behalf of Empress Catherine II to write a report on the theme of how to integrate the Uniates in the best and most appropriate way into the Orthodox Church. Voulgaris did that in 1793 and submitted a lengthy report entitled: Ad illustris[simu]m Comitem Alexium Johanidem Puschinum, qui ex mandato Augustissimae Catharinae II. proposuit Eugenio 'Quinam rectior et aptior sit modus quo uti oporteret cum Uniatis Polonicis, in revocandis illis, et convertendis, et reduniendis cum propria inde ab origine Matre eorum Orthodoxa Catholica Ecclesia?'. The original report was written in Greek, but we only know today of a Russian translation of this text under the title Report on the Best Way to Unite the Uniates with the Orthodox Church [Zapiska o luchshem sposobe vozsoedineniya Uniatov s pravoslavnoyu Tserkoviyu], first edited and published in St. Petersburg in 1887 by an anonymous scholar. ${ }^{32}$

Here Voulgaris discussed at length the topic by bringing numerous examples and contextualizing the whole issue in the broad framework of Orthodox the-

31 See Batalden, Catherine II's Greek Prelate, 61-2; Bruess, Religion, Identity and Empire, 159-61; Makrides, 'Nicéphore Théotokès', 871-3.

32 Evgenios Voulgaris, 'Zapiska [...] o luchshem sposobe vozsoedineniya Uniatov s pravoslavnoyu Tserkoviyu', Khristianskoe Chtenie [Part II] 7-8 (1887) 19-93. 
ology, history and practice. More specifically, he examined seven possible ways and methods to bring the Uniates back to the Russian Church, taking into consideration the limits of religious freedom and the ideal situation concerning unity in the Orthodox faith, whose absolute religious truth he never questioned. The first method involved violence, force and coercion, of which Voulgaris completely disapproved. The second method concerned the convocation of an ecumenical or local council to solve this problem, which he found unrealistic under the circumstances. The third method included discussions and debates on a personal level, which were deemed by him as useless for bridging the theological and other differences between Orthodox and Latin Christianity. The fourth method related to the publication of special anti-Latin treatises, a useful one for Voulgaris, but rather ineffective in practical terms. The fifth method involved the placing of the most able Orthodox clergy in the areas where Uniates lived, in order to persuade them of the truth of Orthodoxy. Voulgaris considered this a positive measure with longterm consequences. The sixth method concerned the role of pertinent education and the creation of Orthodox schools for the instruction of the Uniates and their children. Given the emphasis always put by Voulgaris on educational issues, his full approval of this method here does not occasion any surprise. The seventh and last method related to an understanding of the profound differences between the Orthodox experiential and empirically-based theology and the Latin intellectually-based and rationally-constructed theology. This method was considered the most important by Voulgaris, yet he admitted that its realization presupposed a lot, since this method was not easily accessible to and understandable by the wider body of Orthodox believers.

Although it is doubtful whether Voulgaris' proposals were actually applied in specific cases by the Russian authorities, this document is extremely valuable in many respects. It not only reveals Voulgaris' mature theological thinking, but also attests to his truly ecumenically reflected and conceived Orthodoxy as opposed to the narrower Russian confessional Orthodoxy. ${ }^{33}$ In other words, it involved an Orthodox perspective that was much broader than the Russian Orthodox ethnic/ national aspirations of the day. The main question at that time was whether there could be an Orthodox ecumenical or an Orthodox confessional solution to the problem of Uniatism. In fact, Voulgaris shared an ecumenical and imperial vision to unite all Orthodox peoples under the protective force of Orthodox Russia. Based on an imperial decree of 12 April 1794, more than 1.5 million Uniates returned to Russian Orthodoxy in the years 1794 and $1795 .{ }^{34}$ We can safely assume that this

33 See V. N. Makrides, 'Evgenii Bulgaris i problema Unii v vostochnoi Evrope', in F. A. Eloeva and D. Letsios (eds), Sankt-Peterburg i Gretsiya. Proshloe i nastoyashchee. Materialy mezhdunarodnoi konferentsii, 26-29 Oktyabrya 2006 g. (St. Petersburg 2008) 76-87; V. N. Makrides, " Ev $\alpha \pi \alpha-$

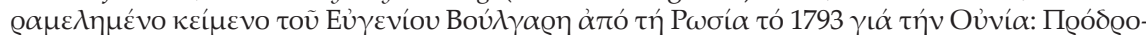

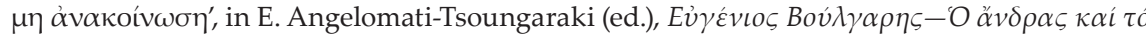

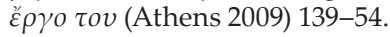

34 See I. Smolitsch, Geschichte der russischen Kirche, II, edited by G. L. Freeze (Berlin 1991) 400-1. 
did not happen according to the criteria outlined by Voulgaris in his report. Even so, the latter attests to a truly ecumenical Orthodox orientation that was to suffer a few decades later due to the augmenting problems of the national confessionalization of the Orthodox world.

\section{Nikiforos Theotokis and the Russian Old Believers}

Let me turn now to another issue, which is equally important for understanding the differences between ecumenical and confessional Orthodoxy. This time it is about Voulgaris' friend and successor, Nikiforos Theotokis, Archbishop of Slavyansk and Kherson (1779-1786) and then of Astrakhan and Stavropol' (17861792). He had also to face the problem of Russian Old Believers or Old Ritualists (commonly called 'Raskol'niki', i.e. schismatics), whose schism back in 1666-1667 had caused serious problems to the Russian Church and state. Old Believers faced severe persecution at times, yet they were also tolerated, aside from the attempts to re-integrate them into Russian Orthodoxy. It was Voulgaris who had initially dealt with this problem, ${ }^{35}$ but the main burden fell later on the shoulders of Theotokis, who addressed it more systematically. Did the Old Believers deviate only from the Orthodox ritual tradition or from the Orthodox doctrine?-this was a major question at that time. In a detailed criticism of the Old Believers back in 1765, the aforementioned Metropolitan of Moscow Platon argued in his study Exhortation to the schismatics ... how to receive those who convert from them to the Orthodox faith [Uveshchanie raskol'nikam ... kak prinimat' obrayushchikhsya iz nikh k Pravoslavnoi vere] that they had moved away from Orthodoxy in both respects. However, due to his many years of experience and extensive knowledge of the Orthodox tradition, Theotokis tried to find a solution to the problem through a more flexible strategy. Has variety in rituals, but within the one right faith, been allowed in the church in previous eras? This was certainly not the ideal situation, yet it was supported, according to Theotokis, by church history and practice in many cases. The whole issue was also related to the principles of 'Oikonomia' and 'Akribeia' in Orthodox Canon Law, namely the mild versus the strict application of ecclesiastical rules and canons. For Theotokis, such problematic situations had largely been dealt with in the past by applying leniency with very good results. There was thus no reason not to apply it again to the case of the Old Believers.

Hence, the most important thing in the case of the Old Believers was their reunion with the Russian Orthodox Church, whereby the exact modalities of this process played a completely secondary role. Based on this, Theotokis pleaded for a tolerant acceptance of the Old Believers by the church while they could also maintain and practice their traditional rituals and customs. More important in this context were the recognition of the faith of the Russian Orthodox Church and the acceptance of its authority. This signalled the beginning of the so-called 'Edinoverie' (i.e. one and the same faith), which Theotokis applied to some communities of Old

35 See Batalden, Catherine II's Greek Prelate, 58-60. 
Believers within the borders of his diocese with considerable success; for example, in the villages Znamenka and Zlynka, to which Theotokis had sent in 1780 a pastoral letter explaining his strategy. ${ }^{36} \mathrm{He}$ thus accepted the Old Believers into a formal communion with the Russian Orthodox Church, but under the terms of that conditional union. Theotokis was aware of the great linguistic, geographical and cultural variety existing among Orthodox Christians in numerous local contexts. He also knew that what kept them together was the unity in the Orthodox Christian faith, which was absolutely non-negotiable. The rest was always open to discussion, so that a viable solution to eventual problems could be found. This was a truly ecumenical approach to the overall situation in the broad Orthodox world, which acknowledged its pluriformity and the consequences thereof.

However, such a stance in favour of an ecumenical Orthodoxy did not please the official Russian Church, which disagreed with Theotokis' policies on this matter, once he had reported about them. He was subsequently criticized of having acted arbitrarily in reuniting these Old Believers with the Russian Church and without previous consultation with the Russian Synod. The Metropolitan of Novgorod and St. Petersburg (1770-1810), Gavriil Petrov, thus, severely criticized in 1781 Theotokis' actions as arbitrary and precarious, because he had paid insufficient attention to the Russian Orthodox specificities and sensitivities. Theotokis also received a similar critical letter from the Metropolitan of Moscow Platon in 1781. The differences and the conflict between an ecumenical and a confessional Orthodoxy once again become evident here. Although Theotokis eventually bowed to the will and authority of the Synod, he substantiated the appropriateness and the accuracy of his particular strategy towards the Old Believers with many additional arguments, analogous cases from history, and his own experience from the broader Orthodox world and the culturally different Orthodox milieus. ${ }^{37} \mathrm{He}$ also followed the same strategy towards the Old Believers themselves, trying to convince them of the contingency of their views, customs, and ritual practices, which should have not been considered as absolute and sacrosanct. In this way, he was a proponent of a truly ecumenical Orthodoxy, which operated beyond borders, regions and local particularities.

Theotokis remained adamant in his views and actions on the issue, yet he again appeared ready vis-à-vis the Synod to annul his previous actions. However, this proved to be unnecessary, as the Russian Synod ultimately did not revoke them. It is also noteworthy that, despite the initial reactions, this particular strategy of Theotokis towards the Old Believers was also applied at that time by other Russian bishops (e.g., Ambrosii of Kazan'). Later on, it even enjoyed the official approval of the Synod, which in 1796 decided to publish all Theotokis' texts on the cause of the Old Believers. In 1798, even Metropolitan Platon supported this

36 See Makrides, 'Nicéphore Théotokès', 862.

37 Especially in his report A Short Narrative on the Conversion of the Schismatics of the Village of Znamenka [Kratkoe povestvovanie o obrashchenii raskol'nikov seleniya Znamenki] in 1781, first published in Bratskoe Slovo 2 (1892) 128-38. 
strategy by articulating specific ways for its practical implementation. However, the 'Edinoverie strategy' was not always as successful as in the above case, and Theotokis experienced this, for example, in his second diocese of Astrakhan and Stavropol'. Be that as it may, under Tsar Paul I (1796-1801) the 'Edinoverie' became (from 27 October 1800) the official ecclesiastical strategy towards the Old Believers. Interestingly enough, Theotokis' various writings on the cause of the Old Believers were collected and published in Moscow in a volume titled Answers ... to the Questions of the Old Ritualists [Otvety ... na voprosy staroobryadtsev] in 1800 (with several later editions, as well). This clearly attests to the final recognition that his contributions enjoyed in Russia, not only from the Russian Church, but also from the Old Believers. ${ }^{38}$

Let me mention here two characteristic statements of Theotokis that are indicative of his ecumenical Orthodox vision in addressing this issue. The first one is from his correspondence with the Old Believers, where he refers to his ecumenical Orthodox background, which informed him of his decision to solve the problem:

I am of the Greek race, born in Greece, [I was] raised, educated and took the monk's habit there. I have seen and spent time with the sacred Patriarchs of Constantinople and Jerusalem; I have met and discussed the condition of the Church with bishops from Iberia [i.e. Georgia] and Dalmatia, Christian Arabs as well as with the learned holy monks of Athos and Mt. Sinai, who keep in the minutest and greatest detail the practices of the old Church. I went to Bulgaria, Moldavia and Wallachia and now have the honor of being a hierarch in Russia. ${ }^{39}$

The second is from his correspondence with the Russian Church Synod, which he tried to persuade to follow a lenient policy towards the Old Believers in order to reunite them with Russian Orthodoxy:

If they [i.e. the Old Believers] want union with the Church, some say, let them reunite in such a way that no differences will be between them and us. This idea, which is very severe ('akribeia'), I both respect and esteem. I accept it in the hope that finally there will no longer exist differences between them and us, not in the use of the new books, nor in the celebration of all the rites, no matter how minor. But the other idea, the idea of leniency ('oikonomia'), I praise and welcome. ${ }^{40}$

38 See Makrides, 'Nicéphore Théotokès', 861-2. For another perspective on the 'Edinoverie' in the context of a confessionalization of the Orthodox world, see J. M. White, 'Edinoverie i kontseptsiya konfessionalizatsii: Diskursivnye zametki', Quaestio Rossica 4/4 (2016) 177-89.

39 Cited in Bruess, Religion, Identity and Empire, 143.

40 Cited in Bruess, Religion, Identity and Empire, 153. 


\section{Concluding Remarks}

This interesting encounter between an ecumenical and a confessional Orthodoxy in the eighteenth century attests to the beginning of the national confessionalization of the Orthodox world, which led to the curtailing of its previous ecumenical character. Orthodoxy then came to be defined to a large degree on the basis of particular ethnic and national elements, coupled with the construction of a related identity of demarcation. This process can also explain to a large degree the problems of communication and cooperation that the entire Orthodox world has been facing since then and until today. The problems surrounding the Pan-Orthodox Council in Crete in 2016 are a case in point. ${ }^{41}$ Nevertheless, it has hopefully become clear that, despite their deep roots in Greek Orthodoxy, the respective stances of Voulgaris and Theotokis did not remain exclusive. Both were prepared not only to overcome their Greek Orthodox borders, but also to enrich their repertoire of theology and knowledge from other Orthodox sources and cultures. Whereas there was a particular Greek dimension in their argumentation concerning the Uniates and the Old Believers, this argumentation had a clear ecumenical character. In their eyes, Orthodoxy, despite its Greek origins, was an overarching entity that was also relevant to other Orthodox peoples and cultures. Greek Orthodoxy certainly enjoyed a 'hegemony', yet not in the sense of superiority and as a reason for arrogance, but as a tool of instruction. Greek language proficiency was a unique asset for both hierarchs, as it provided access to the historical treasures of Greek patristics and tradition, which they particularly valued. As Orthodox Greeks, they also considered themselves to be perhaps the most appropriate stewards of this heritage, which had to be made accessible to others.

Their common birthplace, their first experiences, their first education, and the environment of the Ionian Islands, which had never been under Ottoman rule, decisively shaped their later Orthodox profile. ${ }^{42}$ Belonging to the Greek ethnicity was also of great importance to them. Voulgaris used for his compatriots the name

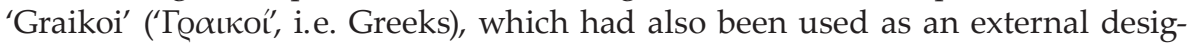
nation for the Greeks at that time. He used the term 'Ellines' ("E $\lambda \lambda \eta v \varepsilon \varsigma^{\prime \prime}$, i.e. Hellenes) less often because of its connection to ancient paganism. Likewise, he also

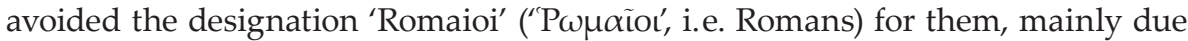
to the possible misunderstanding between the Eastern Orthodox Romans ('Romaioi') and the Western Latin Romans. He thus usually called the latter 'Romanoi'

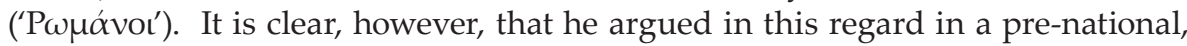
more ecumenical framework. As a result, he used the Greek term 'genos' (' $\left.\gamma \varepsilon \dot{\varepsilon} \nu 0 \varsigma^{\prime}\right)$, which refers to the Orthodox supranational ties in the related kindred group, and he avoided the term 'ethnos' ('c $\theta v o \varsigma^{\prime}$, i.e. nation), which relies rather on historical

41 See V. N. Makrides, 'Le concile panorthodoxe de 2016. Quelques réflexions sur les défis auxquels le monde orthodoxe doit faire face', Istina 62 (2017) 5-26.

42 See Stiernon, 'Eugène Boulgaris', 721-37; Makrides ‘Nicéphore Théotokès', 849-52. 
continuity. ${ }^{43}$ In Theotokis, one also finds a similar, distinctive emphasis on his Greek identity and Orthodoxy. As already mentioned from his letter to the Russian Old Believers, he emphasized that he was 'of the Greek race, born in Greece. ${ }^{44}$ No doubt, both hierarchs were extremely proud of their Greek identity. As reported by the Metropolitan of Kiev, Evgenii Bolkhovitinov (1767-1837), during one of his numerous encounters with Voulgaris at an advanced age, the latter had once shown to him many books in Greek (including those of Theotokis) from his personal library. His aim was to show the intellectual achievements of his subjugated countrymen. He had also suggested that Evgenii Bolkhovitinov would celebrate regularly the liturgy in ancient Greek in St. Petersburg with the permission of the local bishop, a development that was very popular and attractive among many Russians. ${ }^{45}$ It is also interesting to mention that the presence of both Voulgaris and Theotokis in Russia is also associated with a revival of classical philology and studies there. ${ }^{46}$

In addition to this, they both showed a strong interest in learning and profiting from other Orthodoxies and here especially from the Russian one, which they did not necessarily considered as inferior. Voulgaris had thus translated a posthumously published work of Feofan Prokopovich (Gotha 1772) on the procession of the Holy Spirit into Greek (Leipzig 1784). He also translated the Spiritual Regulation of Prokopovich (1721) into Greek (first published much later in 1916)-perhaps a sign of his admiration for the ecclesiastical reforms of Tsar Peter I, who was generally presented as a model to be emulated in the Greek and the wider Balkan context at that time. Voulgaris had translated into Greek other Russian texts (by Platon Levshin, Gavriil Petrov etc.), which in turn shows that he was no less convinced of their respective achievements. During his time in Russia, Voulgaris also translated the anti-Catholic work of an ex-Lutheran from Prussia and convert to Orthodoxy, Adam Zernikav, on the procession of the Holy Spirit (2 volumes, Königsberg 1774). ${ }^{47}$ The same interest in Russian Orthodoxy also applies to Theotokis, as is clear from his regular contacts with the Russian Synod, the related correspondence, and his numerous reports. ${ }^{48}$ The extensive corpus of their edited as well as not yet edited correspondence and other documents allow important

43 See I. C. Carras “"Topos” and Utopia in Eugenios Voulgaris' Life and Work (1716-1806)', The Historical Review/La Revue Historique 1 (2004) 127-56, here p. 141-2.

44 See Bruess, Religion, Identity and Empire, 143.

45 See Batalden, Catherine II's Greek Prelate, 89.

46 See T. Fedorova, 'Grecheskaya gimnaziya v Sankt-Peterburge i ee vospitanniki', in F. A. Eloeva and D. Letsios (eds), Sankt-Peterburg i Gretsiya. Proshloe i nastoyashchee. Materialy mezhdunarodnoi konferentsii, 26-29 Oktyabrya 2006 g. (St. Petersburg 2008) 48-53; S. K. Batalden, 'Evgenii Bulgaris v Peterburge: Pravoslavnyi Ėkumenizm i pereorientatsiya russkoi religioznoi kul'tury novogo vremeni', in F. A. Eloeva and D. Letsios (eds), Sankt-Peterburg $i$ Gretsiya. Proshloe i nastoyashchee. Materialy mezhdunarodnoi konferentsii, 26-29 Oktyabrya 2006 g. (St. Petersburg 2008) 88-97, here p. $94-7$.

47 See Stiernon, 'Eugène Boulgaris', 752-3, 757-8, 762, 765-6, 770-1.

48 For more details, see Bruess, Religion, Identity and Empire, 135-208. 
insights into this world of numerous contacts and connections beyond strict confessional borders. ${ }^{49}$

Characteristically enough, both of them showed the same openness mutatis mutandis towards the Western theological production, both Protestant and Roman Catholic (and despite their anti-Catholicism), from which they gleaned whatever they deemed good and necessary for their own Orthodox interests, which they never jeopardized..$^{50}$ In other words, they always remained firm and staunch defenders of the Orthodox faith and criticized Western theological deviations from their Orthodox point of view, yet they were also ready to learn from Western theology in an eclectic way and benefit from it by enriching their knowledge and perspectives. Thus, in 1794 in Vienna Theotokis anonymously translated and published a work by the French Guillaume-Joseph Clémence (1717-1792) directed against Voltaire, to which he added his own detailed comments and notes. The translation was intended to serve the Orthodox struggle against Voltaire, which was quite bitter at that time. ${ }^{51}$ For his part, Voulgaris made several translations of Western theological works, which in turn testify to his astonishing spiritual openness. ${ }^{52}$ At the same time, both did not shy away from criticism on all sides, especially if they suspected problematic positions and attitudes from their Orthodox point of view. This related both to the Latin West (e.g., Uniatism, intolerance, violence, propaganda) and to dissident religious movements in the Orthodox East (Old Believers, Uniates)..$^{53}$

It is also worth mentioning here that the same Orthodox ecumenical attitude was shown by both Voulgaris and Theotokis not only with regard to Russian Orthodoxy, but also with regard to the broader Balkan Orthodoxy at that time. ${ }^{54}$ This becomes even more important in light of the fierce ecclesiastic and political nationalisms that swept across the Balkans from the second half of the nineteenth century onwards. In this pre-national era, nevertheless, there was a broader Orthodox community in the Balkans under Ottoman rule beyond ethnic cleavages, which shared a lot of things together (e.g., the use of Greek language and the fondness for Greek culture, though not in a national sense). ${ }^{55}$ Voulgaris had experienced

49 See Stiernon, 'Eugène Boulgaris', 772-4, 831-2; Makrides, 'Nicéphore Théotokès', 866-7, 890-1;

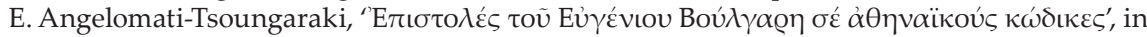

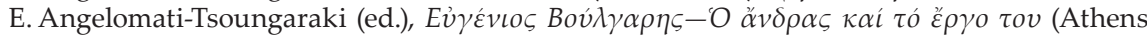
2009) $175-236$.

50 See Stiernon, 'Eugène Boulgaris', 742, 757; Makrides, 'Nicéphore Théotokès', 860-1.

51 See Makrides, 'Nicéphore Théotokès', 860-1.

52 See Stiernon, 'Eugène Boulgaris', 742-3, 756-8.

53 Ibid., 806-21; Makrides, 'Nicéphore Théotokès', 870-8.

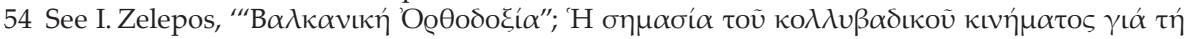

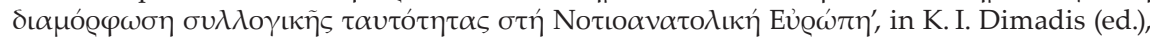

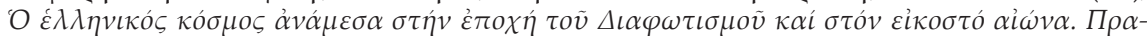

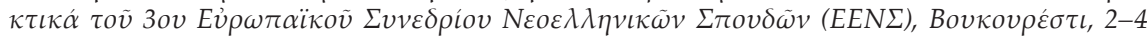
Iovvíov 2006), I (Athens 2007) 511-23.

55 For more details, see P. M. Kitromilides, Enlightenment, Nationalism, Orthodoxy: Studies in the Culture and Political Thought of South-Eastern Europe (Aldershot 2003); P. M. Kitromilides, An 
this as well, given that he had worked in the Greek area for a long time and had students from the wider Balkan area (e.g., the Serb Dositei Obradović, 1739-1811). ${ }^{56}$ He also wrote, while on the Holy Mountain Athos, the aforementioned anti-Catholic work A Booklet against the Latins, which was addressed in the form of an epistle to the Orthodox Serbs, who were living at that time in the Habsburg Empire and were surrounded by Roman Catholics. There he made a list of the Roman Catholic deviations from Orthodoxy, not only the doctrinal ones, but also those pertaining to other areas, such as in sacred art and representation. This work shows that he was well informed about the situation of the non-Greek Orthodox at the border areas to Central and Western Europe. ${ }^{57}$ His contacts with the princes in the Danubian Principalities also testify to a perception of a specific Balkan Orthodoxy. ${ }^{58}$ His short book on euthanasia (St. Petersburg 1804) was originally inspired by the Romanian prince of Wallachia, Stephan Michael Racoviță (1764-1765). ${ }^{59}$ Before his trip to the German areas, he had spent several months in Wallachia, where on 1 December 1763 he provided the then Prince of Wallachia Constantin Michael Racoviță (1763-1764) with a manuscript copy of his Greek translation of Jacques-Bénigne Bossuet's Politique. ${ }^{60}$ Even after his final departure for Russia, he was still interested in the existence of various Orthodox ethnic groups from the Balkans beyond the Greeks. In a letter of 1775 to his nephew Dimitrios Valsamos on the island of Zakynthos, he spoke of the new territories acquired by Russia in the south (Novorossiya) inhabited by various Orthodox peoples, namely Greeks, Moldavians, Wallachians and Serbs. ${ }^{61}$ A little later, in a report of February 1777, as Archbishop of Kherson and Slavyansk in southern Russia, based in Poltava, he again mentioned the many migrants from the broad Balkan area in his diocese, such as Greeks, Wallachians, Moldavians, Albanians, Serbs, Bosnians, and a number of others that he was observing. ${ }^{62}$

A parallel sensitivity for the Orthodox ethnic differentiation in the Balkans can also be observed in Theotokis, considering his relations with the Ukrainian elder (starets) Paisii Velichkovskii (1722-1794), who at that time sought to revive and renew Orthodox monasticism in Moldavia. Specifically, Velichkovskii was already in search of Orthodox ascetic-mystical literature and was therefore inter-

Orthodox Commonwealth: Symbolic Legacies and Cultural Encounters in Southeastern Europe (Aldershot 2007).

56 See G. R. Noyes (ed.), The Life and Adventures of Dimitrije Obradović (Berkeley-Los Angeles 1953) 252.

57 See Stiernon, 'Eugène Boulgaris', 747-8.

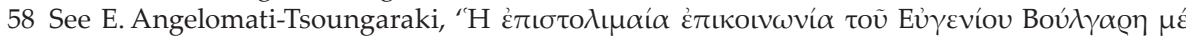

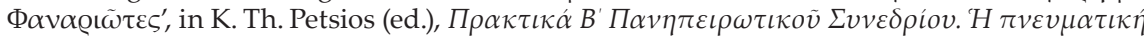

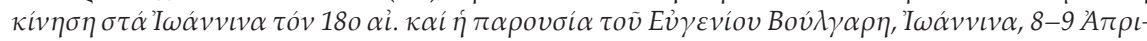
Niov 2016 (Ioannina 2018) 247-309.

59 See Stiernon, 'Eugène Boulgaris', 761.

60 Ibid., 732, 757.

61 See Carras, “"Topos” and Utopia', 152.

62 See Batalden, Catherine II's Greek Prelate, 55. 
ested in Theotokis' work, who in 1770 had published the ascetic works of Isaac the Syrian as an editio princeps in Leipzig. Velichkovskii used this edition as a basis for his Slavonic translation of this work. ${ }^{63}$ Later on, he also translated the Philokalia [Love for the Beautiful/Good] (Venice 1782) of Nikodimos Agioreitis (1749-1809) and Makarios Notaras (1731-1805), a florilegium of ascetic-mystical literature of the Orthodox East from several centuries, which subsequently enjoyed great popularity among the Orthodox Slavs. ${ }^{64}$ Here we have an interesting inter-Orthodox transfer of spiritual literature that has been of great importance to the Orthodox world in the long term. Theotokis also maintained good contacts with the princes in the Danubian Principalities, especially with Grigore III Ghica, at whose house in Constantinople he lived and worked between 1763 and 1764. It was in Ghica's library where he also found the codex with the Patristic comments on the Octateuch, which he compared with other manuscripts and finally published in Leipzig in two volumes in 1772-1773. ${ }^{65}$ In 1768, Theotokis also delivered a funeral oration in Constantinople for Helena, the deceased mother of Prince Grigore III Ghica, a fact that underlines once more his close relationship with this family ${ }^{66}-$ the same also holds true for Voulgaris. ${ }^{67}$

To sum up: The examples of Voulgaris and Theotokis show the existence of an ecumenically-oriented Orthodoxy at the end of the eighteenth century, which was initially confronted with the Russian confessionally-based Orthodoxy. In the later centuries, the number of confessional-national Orthodoxies would multiply significantly, contributing to the considerable loss of the previous ecumenical heritage. This was perhaps an unavoidable process, but the cases of Voulgaris and Theotokis remind us of the last moments before the waves of nationalism gradually began to conquer, restructure and fundamentally change the entire Orthodox world. It is thus highly interesting that in his first address to Empress Catherine II on 27 July 1771, Voulgaris referred to his own Slavic-Bulgarian roots (cf. his surname). In addition, he mentioned that he was a native Greek, but that he was also becoming a Russian by inclination-a fascinating juxtaposition of multiple ethnic identities in one and the same person. ${ }^{68}$ One should not be surprised at this statement, because it was formulated in a pre-national context and was thus completely unproblematic. In the late nineteenth century or later, however, such a statement would have been utterly impossible due to virulent and all-encompassing nationalistic conflicts. There were also other patterns of a non-national identification at that time, such as 'Orthodox-Ottoman', 69 which were also lost because

63 See Makrides, 'Nicéphore Théotokès', 857.

64 See E. Citterio, 'Nicodemo Agiorita', in C. G. Conticello and V. Conticello (eds), La théologie byzantine et sa tradition, II. XIIIe-XIXe s. (Turnhout 2002) 905-1021, here p. 919-21.

65 See Makrides, 'Nicéphore Théotokès', 857-8, 902-3.

66 Ibid., 855.

67 See Stiernon, 'Eugène Boulgaris', 730, 760.

68 See Batalden, Catherine II's Greek Prelate, 22.

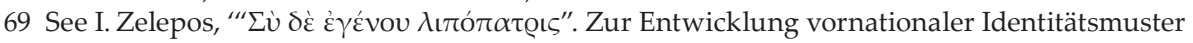
in Südosteuropa. Der "osmanisch-orthodoxe" Heimatbegriff von Michailos Perdikaris (1766- 
of the mounting and pervasive nationalisms among the Orthodox peoples. The nationalization of the Orthodox world was thus a way through which the Orthodox experienced a particular form of confessionalization and internal confessional variation. No doubt, this cannot be equated to the confessionalization process in Western Europe and the stronger inter-confessional interaction, exchange and dynamics between Roman Catholics and Protestants there. Yet it was a crucial transformation process for the Orthodox world, and the cases of Voulgaris and Theotokis addressing the growing Russian confessional Orthodoxy attest to the last phases of this traditional ecumenical Orthodoxy. The Orthodox ecumenical legacy of these two Greek hierarchs is thus of great relevance for capturing the gradual changes that took place within the wider Orthodox body in the context of its unavoidable confessionalization in modern times. ${ }^{70}$

\section{Bibliography}

Aagaard A. M. and Bouteneff P. (eds), Beyond the East-West Divide: The World Council of Churches and 'the Orthodox Problem' (Geneva 2001).

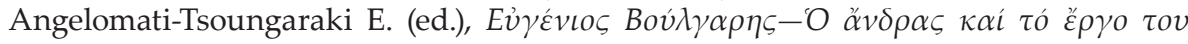
(Athens 2009).

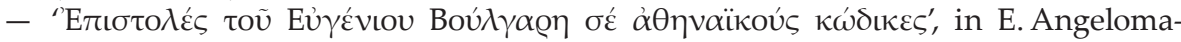

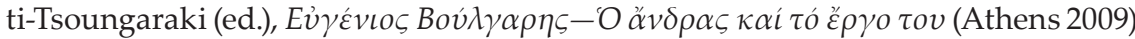
175-236.

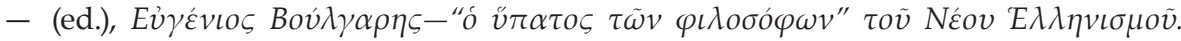

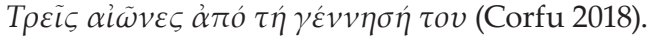

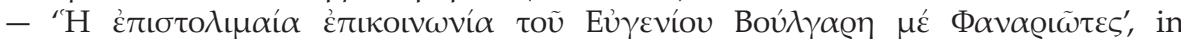

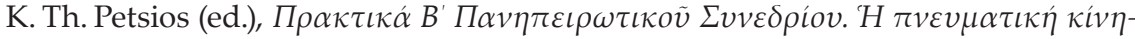

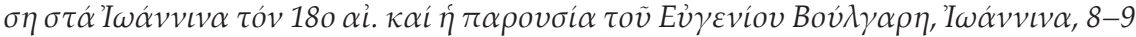

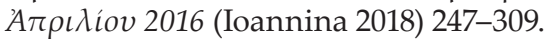

Batalden S. K., Catherine II's Greek Prelate: Eugenios Voulgaris in Russia, 1771-1806 (Boulder-New York 1982).

- 'Evgenii Bulgaris v Peterburge: Pravoslavnyi Ėkumenizm i pereorientatsiya russkoi religioznoi kul'tury novogo vremeni', in F. A. Eloeva and D. Letsios (eds), Sankt-Peterburg i Gretsiya. Proshloe i nastoyashchee. Materialy mezhdunarodnoi konferentsii, 26-29 Oktyabrya 2006 g. (St. Petersburg 2008) 88-97.

- “O Eủ

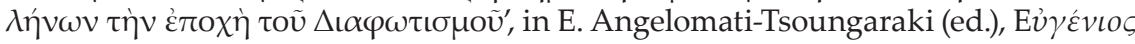

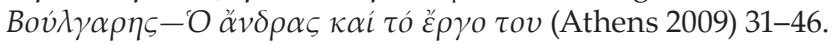

Blaschke O. (ed.), Konfessionen im Konflikt: Deutschland zwischen 1800 und 1970. Ein zweites konfessionelles Zeitalter (Göttingen 2002).

1828)', in U. Brunnbauer, A. Helmedach and S. Troebst (eds), Schnittstellen. Gesellschaft, Nation, Konflikt und Erinnerung in Südosteuropa. Festschrift für Holm Sundhaussen zum 65. Geburtstag (Munich 2007) 189-200, here p. 194-5.

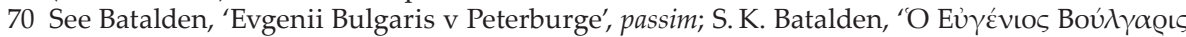

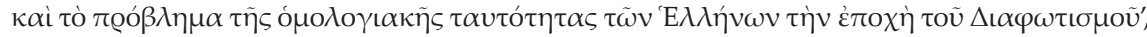

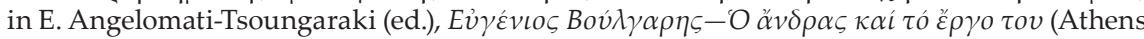
2009) 31-46; Bruess, Religion, Identity and Empire, 28-60. 
Brüning A., Unio non est unitas: Polen-Litauens Weg im konfessionellen Zeitalter (15691648) (Wiesbaden 2008).

Bruess G. L., Religion, Identity and Empire: A Greek Archbishop in the Russia of Catherine the Great (Boulder-New York 1997).

Carras I. C., “Topos” and Utopia in Eugenios Voulgaris' Life and Work (1716-1806)', The Historical Review/La Revue Historique 1 (2004) 127-56.

- 'Understanding God and Tolerating Humankind: Orthodoxy and the Enlightenment in Eugenios Voulgaris (1716-1806) and Platon Levshin (1737-1812)', in P. M. Kitromilides (ed.), Enlightenment and Religion in the Orthodox World (Oxford 2016) 79-139.

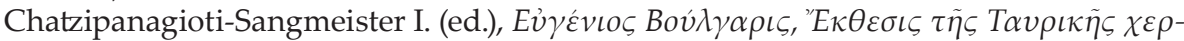

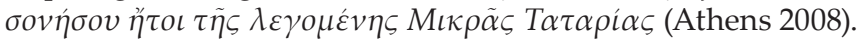

Citterio E., 'Nicodemo Agiorita', in C. G. Conticello and V. Conticello (eds), La théologie byzantine et sa tradition, II. XIIIe-XIXe s. (Turnhout 2002) 905-1021.

Fedorova T., 'Grecheskaya gimnaziya v Sankt-Peterburge i ee vospitanniki', in F. A. Eloeva and D. Letsios (eds), Sankt-Peterburg i Gretsiya. Proshloe i nastoyashchee. Materialy mezhdunarodnoi konferentsii, 26-29 Oktyabrya 2006 g. (St. Petersburg 2008) 48-53.

Felmy K. C. et al. (eds), Der Ökumenische Patriarch Jeremias II. von Konstantinopel und die Anfünge des Moskauer Patriarchats (Erlangen 1991).

Grigore M.-D. and Kührer-Wielach F. (eds), Orthodoxa Confessio? Konfessionsbildung, Konfessionalisierung und ihre Folgen in der östlichen Christenheit Europas (Göttingen 2018).

Habermann M. (ed.), Sprache, Reformation, Konfessionalisierung (Berlin-Boston 2018).

Heller D., 'Der Dialog zwischen der Orthodoxie und den Kirchen der ReformationProbleme und Perspektiven', Una Sancta 66 (2011) 31-41.

Hodapp J., Habsburgerinnen und Konfessionalisierung im späten 16. Jahrhundert (Münster 2018).

Innokentii Igumen (Ol'khovoi), Zhukova E. and Bykova I. (eds), Arkhiepiskop Nikifor Feotokis. Blagoslovennym Khristianam Gretsii i Rossii (Moscow 2006).

Käßmann M., 'Der Ökumenische Rat am Scheideweg-die Konflikte zwischen Orthodoxie und Protestantismus bedrohen den Weltkirchenrat', Evangelischer Pressedienst: Dokumentation 50 (2002) 25-7.

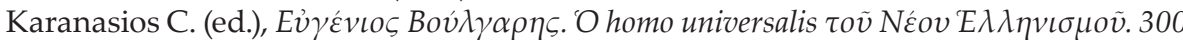

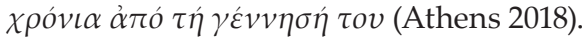

Kitromilides P. M., Enlightenment, Nationalism, Orthodoxy: Studies in the Culture and Political Thought of South-Eastern Europe (Aldershot 2003).

- An Orthodox Commonwealth: Symbolic Legacies and Cultural Encounters in Southeastern Europe (Aldershot 2007).

- Religion and Politics in the Orthodox World: The Ecumenical Patriarchate and the Challenges of Modernity (London 2019).

Makrides V. N., 'Orthodoxie und Politik: Die russisch-griechischen Beziehungen zur Zeit Katharinas II.', in C. Scharf (ed.), Katharina II., Rußland und Europa. Beiträge zur internationalen Forschung (Mainz 2001) 85-119.

- 'Nicéphore Théotokès', in C. G. Conticello and V. Conticello (eds), La théologie byzantine et sa tradition, II. XIIIe-XIXe s. (Turnhout 2002) 849-903.

- 'Orthodoxie, griechische Ethnie und Nation, griechischer Nationalstaat und Nationalismus: Mythen und Realitäten', in I. Keul (ed.), Religion, Ethnie, Nation und die 
Aushandlung von Identität(en). Regionale Religionsgeschichte in Ostmittel- und Südosteuropa (Berlin 2005) 67-92.

- 'Evgenii Bulgaris i problema Unii v vostochnoi Evrope', in F. A. Eloeva and D. Letsios (eds), Sankt-Peterburg i Gretsiya. Proshloe i nastoyashchee. Materialy mezhdunarodnoi konferentsii, 26-29 Oktyabrya 2006 g. (St. Petersburg 2008) 76-87.

- Hellenic Temples and Christian Churches: A Concise History of the Religious Cultures of Greece from Antiquity to the Present (New York-London 2009).

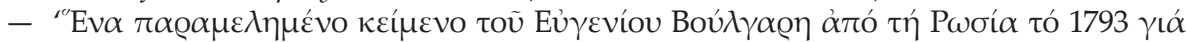

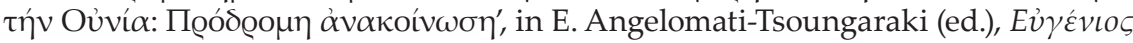

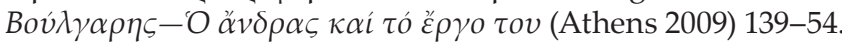

- 'Why are Orthodox Churches Particularly Prone to Nationalization and even to Nationalism?', St Vladimir's Theological Quarterly 54 (2013) 325-52.

- 'Le concile panorthodoxe de 2016. Quelques réflexions sur les défis auxquels le monde orthodoxe doit faire face', Istina 62 (2017) 5-26.

- 'Konfessionalisierungsprozesse in der orthodox-christlichen Welt: Ein Periodisierungs- und Systematisierungsversuch', in M.-D. Grigore and F. Kührer-Wielach (eds), Orthodoxa Confessio? Konfessionsbildung, Konfessionalisierung und ihre Folgen in der östlichen Christenheit Europas (Göttingen 2018) 77-110.

- 'Aтóк

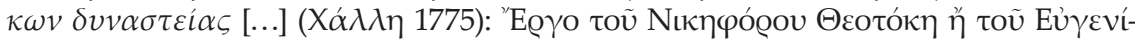

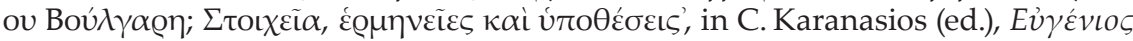

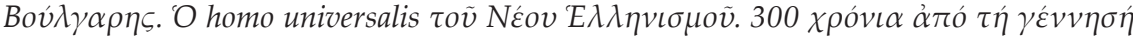
Tov (Athens 2018) 463-522.

Marte J. and Turij O. (eds), Die Union von Brest (1596) in Geschichte und Geschichtsschreibung. Versuch einer Zwischenbilanz (Lviv 2008).

Meyendorff P., Russia, Ritual, and Reform: The Liturgical Reforms of Nikon in the 17th Century (Crestwood, NY 1991).

Nitsche P., 'Nicht an die Griechen glaube ich, sondern an Christus'. Russen und Griechen im Selbstverständnis des Moskauer Staates an der Schwelle zur Neuzeit (Düsseldorf 1991).

Noyes G. R. (ed.), The Life and Adventures of Dimitrije Obradović (Berkeley-Los Angeles 1953).

Ohme H., 'Die "Heilige und Große Synode" der Orthodoxen Kirche vom Jahre 1593 und die Erhebung des Moskauer Patriarchates', Kirche im Osten 33 (1990) 70-90.

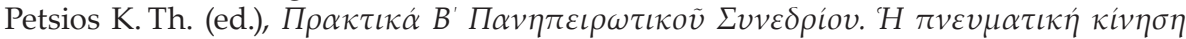

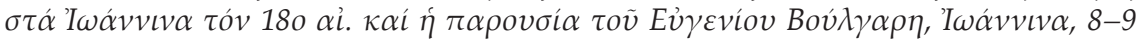
Aтpıliov 2016 (Ioannina 2018).

Podskalsky G., Christentum und theologische Literatur in der Kiever Rus' (988-1237) (Munich 1982).

- 'Die Rolle der griechischen Kirche und Theologie innerhalb der Gesamtorthodoxie in der Zeit der Türkenherrschaft (1453-1821)', in R. Lauer and P. Schneider (eds), Die Kultur Griechenlands in Mittelalter und Neuzeit. Bericht über das Kolloquium der Südosteuropa-Kommission, 28.-31. Oktober 1992 (Göttingen 1996) 222-41.

Rohdewald S., Frick D. and Wiederkehr S. (eds), Litauen und Ruthenien. Studien zu einer transkulturellen Kommunikationsregion (15.-18. Jahrhundert)/Lithuania and Ruthenia. Studies of a Transcultural Communication Zone (15th-18th Centuries) (Wiesbaden 2007).

Roudometof V., 'Greek Orthodoxy, Territoriality, and Globality: Religious Responses and Institutional Disputes', Sociology of Religion 69 (2008) 67-91. 
Scheliha W. von, Russland und die orthodoxe Universalkirche in der Patriarchatsperiode 1589-1721 (Wiesbaden 2004).

Senyk S., 'The Ukrainian Church and Latinization', Orientalia Christiana Periodica 56 (1990) 165-87.

Smolitsch I., Geschichte der russischen Kirche, II, edited by G. L. Freeze (Berlin 1991).

Stamatopoulos D., 'Orthodox Ecumenicity and the Bulgarian Schism', Études Balkaniques 51/1 (2015) 70-86.

Stiernon D., 'Eugène Boulgaris', in C. G. Conticello and V. Conticello (eds), La théologie byzantine et sa tradition, II. XIIIe-XIXe s. (Turnhout 2002) 721-848.

Stievermann J. and Zachman R. C. (eds), Multiple Reformations? The Many Faces and Legacies of the Reformation (Tübingen 2018).

Strohm C., 'Confessionalisation et sécularisation au début de la modernité', in F. Lienhard and C. Grappe (eds), Konfessionalisierung und Säkularisierung am Beginn der Moderne (Vienna 2017) 31-9.

Theotokis Nikiforos, 'Kratkoe povestvovanie o obrashchenii raskol'nikov seleniya Znamenki' ['A Short Narrative on the Conversion of the Schismatics of the Village of Znamenka'], Bratskoe Slovo 2 (1892) 128-38.

Van den Bercken W. and Groen B. (eds), Four Hundred Years Union of Brest (1596-1996): A Critical Re-evaluation (Leuven 1999).

Voulgaris Evgenios, 'Zapiska [...] o luchshem sposobe vozsoedineniya Uniatov s pravoslavnoyu Tserkoviyu', Khristianskoe Chtenie [Part II] 7-8 (1887) 19-93.

White J.M., 'Edinoverie i kontseptsiya konfessionalizatsii: Diskursivnye zametki', Quaestio Rossica 4/4 (2016) 177-89.

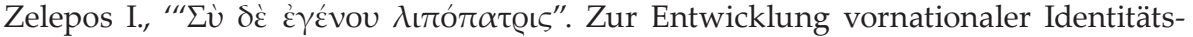
muster in Südosteuropa. Der "osmanisch-orthodoxe" Heimatbegriff von Michailos Perdikaris (1766-1828)', in U. Brunnbauer, A. Helmedach and S. Troebst (eds), Schnittstellen. Gesellschaft, Nation, Konflikt und Erinnerung in Südosteuropa. Festschrift für Holm Sundhaussen zum 65. Geburtstag (Munich 2007) 189-200.

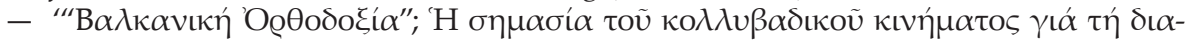

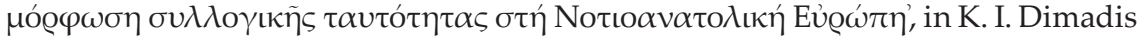

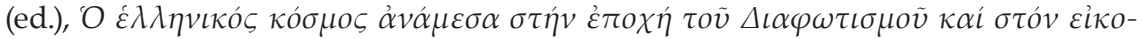

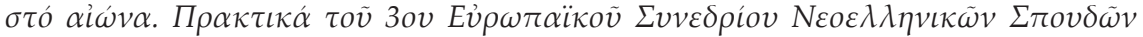

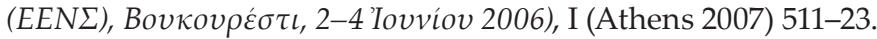

Zissis T., 'Uniatism: A Problem in the Dialogue Between the Orthodox and Roman Catholics', The Greek Orthodox Theological Review 35 (1990) 21-31.

Zwierlein C. A., "“Konfessionalisierung” europäisch, global als epistemischer Prozess: $\mathrm{Zu}$ den Folgen der Reformation und zur Methodendiskussion', in C. Strohm (ed.), Reformation und Recht. Zur Kontroverse um die Kulturwirkungen der Reformation (Tübingen 2017) 1-51. 


\title{
Confessionalization vs Secularization Paradigm?
}

\author{
The Patriarchate of Constantinople and the Problem of \\ the Management of the Private Sphere in the Eighteenth and \\ Early Nineteenth Centuries
}

Dimitris Stamatopoulos, University of Macedonia, Thessaloniki

\section{Enlightenment's Paradigm in Crisis}

Modern Greek history has been interpreted as a moment of transition from the Ottoman era to the era of national states through the model of the Modern Greek Enlightenment. The term was introduced by K. Th. Dimaras in 1945, and its gradual prevalence in the public sphere and education following the collapse of the Colonels' junta in 1974 created the prerequisites for reinterpreting that transition - not as a 'rebirth' and consequent 'awakening' of the nation-as the Greek independence revolt was usually described in the nineteenth century and early twentieth century-but rather as a break from the 'medieval' Ottoman past. In short, it corresponded exactly to the French Enlightenment's rupture with the Ancien Régime and the established classes in revolutionary France.

To a large extent, in most of the Balkan cases-for instance, those of Serbia or Romania-both national historiography and the process of creating a national identity were articulated on the Enlightenment model, that is, on a model of rupture with the medieval past. The fact that their national movements peaked in the 'enlightening' passage from the eighteenth to the nineteenth century was a factor. Nonetheless, one must also examine the predominance of this narrative in later histories, as each of the national movements passed quickly into its Romantic phase. Conversely, we can say that the fact that Bulgarian, Albanian, and Slavo-Macedonian nationalisms peaked in the late nineteenth century necessitated a narrative of 'rebirth', or 'rilindja' in Albanian and 'vazdrazdane' in Bulgarian.

The Enlightenment model, and especially that of the Modern Greek Enlightenment, has proven particularly productive at the scientific level, smoothly incorporating the final phase of Ottoman rule into the national narrative. Reflecting one of history's fundamental motifs on the Eastern Question, the Ottoman Empire's decline coincided with the rapid ascent of the Phanariot aristocracy and the merchant bourgeois diaspora, which served as prerequisites for a spiritual revolution that synchronized, as has been widely noted, with the corresponding intellectual developments in the West. However, there was always a contradiction that needed to be resolved: anti-clericalism was marginalized, despite being one of the basic 
characteristics of both moderate and, to a greater extent, radical Enlightenment. This marginalization occurred because many representatives of the first period of the Modern Greek Enlightenment emerged from the ranks of the clergy-something which also applies in the cases of other Balkan intellectuals, such as Dositej Obradović, Paìsiy Hilendàrski, and, of course, Iosipos Moisiodax. Consequently, an offsetting blend of Enlightenment ideals and 'tradition-based' Orthodoxy was promoted. By contrast, the schemes supported by the French-leaning Dimaras school, as well as the solitary case of Paschalis Kitromilides with his nod towards the Anglo-Saxon academy, were built around the figure of Adamantios Korais. Without diminishing the importance of the Korais case, one could dispute not only the movement's originality-as Panagiotis Kondylis did-but also its ultimate impact on the revolutionary process. Perhaps what Kitromilides describes as the defeat of the 'liberal pro-Korais' current in the addendum to the Greek edition of his book was predetermined by the movement's momentum.

Thus, resolving the paradox of the Modern Greek Enlightenment model requires the establishment of the identification of an intellectual dividing line-an 'enlightening', even if conservative or inspired by the Enlightened Absolutismfrom the Orthodox Church's cultural hegemony. The awkward attempts to present these two forces as compatible only magnifies the problem. This becomes even more pronounced when one realizes that the early stirrings of the Greek Enlightenment occurred as late as the 1760s; the movement was thus absent for more than half of the eighteenth century. The solutions offered for the period's beginnings in the interpretive scheme of the Enlightenment speak of an Early Enlightenment or an Enlightenment before the Enlightenment. However, the problem with this idea is that in this alleged early Enlightenment one cannot easily discern a dominant theme regarding the nation as is the case in Modern Greek scholarship, especially after the 1774 Treaty of Kucuk Kaynarca.

It is particularly difficult-and, for some, inappropriate-to identify a line clearly demarcating the worlds of Church and Enlightenment, a line separating the declaration of legality from the threat of secularization, tradition from modernization, the pre-national from the national period. Nevertheless, understanding the period some would call 'Early Enlightenment' may prove definitive for how we understand classic Enlightenment.

\section{The Confessionalization Paradigm}

Thus, another solution must be found. In the last two decades the Confessionalization paradigm-as developed by Wolfgang Reinhard and Heinz Schilling in the late 1970s and early 1980s-has also influenced the fields of Eastern and Southeastern Historical Studies. The dominant role of religion in the construction of collective or individual identities in the Balkans and Middle East began to be interpreted through Confessionalization, although the experience of the Wars of Religion was relatively unknown to the peoples of the Christian Orthodox East 
(Russian or Ottoman). ${ }^{1}$ This contradiction constituted the starting point for understanding as well as comparing not only the different historical experiences in Southeastern and Western Europe, but also the two paradigms of Secularization and Confessionalization concerning the management of religious-political relations in the Western European, Russian and Ottoman cases.

Two great works attempted to decipher this crucial transitional period by focusing on the effect of the Western Europe's Wars of Religion on the Orthodox East, namely: the German Gunnar Hering's work on the clash between the Catholic and Protestant embassies in Constantinople over Kyrillos Loukaris, ${ }^{2}$ and the German Jesuit Gerhard Podskalsky's work on the influences of the Reformation and Enlightenment on Orthodox intellectuals, among them prominent thinkers like Theofilos Korydallefs, Loukaris's personal choice for the 'Patriarchal Academy'. ${ }^{3}$ The fact that both writers are of German background should not be underestimated: their interests actually echoed a broader discussion on confessionalization begun in the German academic sphere in the 1970s. Thus, the historiographic paradigm of confessionalization concerned the introduction of the Catholic Count-

1 However, the anti-Latin as well as the anti-Islamic literacy of the late Byzantine Empire had left a significant heritage to the intellectuals of the Ecumenical Patriarchate, but the sixteenth century with its resonance of the Reformation was critical. For the Patriarchate, the greatest personality of the sixteenth century was Ieremias II Tranos; this three-time Patriarch of Constantinople would be the one who in his first patriarchy led the talks with the Protestants of Tübingen University, rejecting the Lutheran doctrines one by one; he was the first patriarch who viewed the adoption of the Gregorian calendar positively (which probably led to his second removal from the patriarchal throne), while in his third term he was forced (though the degree of compulsion is still an open historical question) to recognize the Russian Patriarchate and to rank it fifth in the constitutional order of the ecclesiastical hierarchy. Ieremias represents, in my opinion, a fundamental moment for the history of the Orthodox East: the understanding that the Protestant doctrines were far more threatening to the mediating role of the Orthodox clergy than the papal model of centralized administration of the Church.

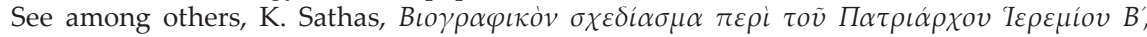

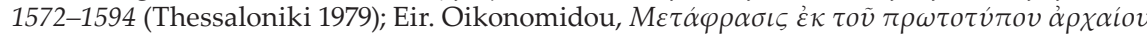

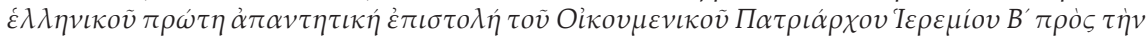

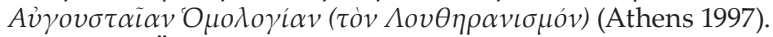

2 G. Hering, Ökumenisches Patriarchat und europäische Politik 1620-1638 (Wiesbaden 1968). The seventeenth century, on the contrary, will be characterized by a heretic: Kyrillos Loukaris. This patriarch of Alexandria who was elected Patriarch of Constantinople in the midst of the Thirty Years' War had developed close contacts with Anglican theologians, gaining the favor of the English and Dutch embassies, but for this very reason also the extreme hostility of the French and Austrians which steered him away from the patriarchal throne, and was eventually to lead to his execution by the Ottomans. Whether or not he signed his famous Calvinist Confession of Faith, it is certain that Loukaris became a 'controversial point' for the later. As far as the supreme clergy is concerned, it seems to have consolidated its pro-Catholic shift in the sense described above. But his thought certainly influenced significant sections of the Empire's intellectual elites towards the West. See also Eug. Kermeli, 'Kyrillos Loukaris' Legacy: Reformation as a catalyst in the 17th century Ottoman Society', The Muslim World 107 (2017) 737-53.

3 G. Podskalsky, Griechische Theologie in der Zeit der Türkenherrschaft (1453-1821). Die Orthodoxie im Spannungsfeld der nachreformatorischen Konfessionen des Westens (Munich 1988). 
er-Reformation into modernity, altering the dominant Weberian schema on the link between the Protestant (particularly Calvinist) ethic and the rise of capitalism. The emergence of 'cuius regio eius religio', with which the 1555 Pax Augustana resolved the issue regarding the choice of confession as well as the process for constructing religious identities from above, ceding this privilege to the monarch at the time, was a touchstone of sorts for interpreting both religious competition and the origins of bourgeois modernization or even the emergence of proto-national identities. Mere disenchantment of the people did not seem sufficient for the emergence of modernity: it had to be supplemented with the State's active role in composing collective identities, including-and above all-religious ones. The old Weberian distinction between religion and modernity, medieval church-centered life and secularization, tradition and modernization thus not only appeared to be softened but for the first time was viewed as a prerequisite for managing the process for composing religious identities as the fundamental element of early modern life rather than as a remnant of the medieval world. ${ }^{4}$

This is precisely why it seemed difficult to transfer this discourse into the Russian and Ottoman Orthodox East, given the influence of the Wars of Religion, especially after the penetration of Protestant ideas into Hungary, the Uniate churches in eastern Europe, and the Jesuit missionaries in the Balkans and Middle East. This impact was significant and prompted numerous upheavals, albeit not to the degree of fundamentally reversing the dogmatic base of Eastern confession. Loukaris' Protestant Confession and its condemnation by the Synod of Iași (1642), the Schism against the Old Believers or Raskol (1666), the Moscow Patriarchate's annexation of the Kiev metropolis to avert its penetration by the Polish-Lithuanians (1686, and the Ecumenical Patriarchate's condemnation of the Melkites (1735) are certainly milestones in this regard, but they did not change the confessional base of the Orthodox of eastern and north-eastern Europe. Significantly, all of this reaffirmed the privileged position of the Orthodox clergy as the Sublime Porte's favored interlocutors and at the same time as political intermediaries between the Porte and the Orthodox flock. ${ }^{5}$

4 See among others, H. Schilling, 'Confessionalization: Historical and Scholarly Perspectives of a Comparative and Interdisciplinary Paradigm', in J. M. Headley, H. J. Hillerbrand and A. J. Papalas (eds), Confessionalization in Europe, 1555-1700. Essays in Honor and Memory of Bodo Nischan (New York 2016) 21-35. On the crisis of the secularization paradigm see for example J. Casanova, Public Religions in the Modern World (Chicago 1994); J. Casanova, Global Religious and Secular Dynamics. The Modern System of Classification (Leiden 2019).

5 Although Loukaris functioned as counter-paradigm, anti-Catholic dogmatic discourses continued to be produced by a series of scholars of the late seventeenth and early eighteenth centuries, including the Patriarch of Jerusalem Dositheos. The attitude of the Eastern Orthodox Church towards the Catholics became particularly acute after 1721 when a Synod was convened in Constantinople to condemn the accession of the Catholic Melchites to the Uniate camp. 


\section{Secularizing the Private}

In recent years a discussion has taken place on one of the cases of confessionalization from above, which affected the reorganization of the Rum millet as it took place in the passage from the seventeenth century to the eighteenth. ${ }^{6}$ It remains unresolved, however, whether this process, can be characterized as one of quasisecularization.

Aside from the institutionalisation of the term 'Rum millet' in the patriarchal berats, two other major institutional changes in the millet's internal structure contributed to the administrative and legal restructuring of the Patriarchate. In the 1740s, particularly at the Patriarchate, the establishment of the Gerontist regime weakened patriarchal integrity. The patriarchal seal was split in four and divided among members of the Holy Synod, which acquired a 'standing' status. The Gerontist Holy Synod in fact imported to Constantinople the model of the Standing Holy Synod from Peter the Great's reforms. The system seems to have been weighted towards the clergy-laity elite rather than bolstering the Phanariots. This is evident from the fact that the imposition of this administrative system was based mainly on stringent financial monitoring of the provincial metropolitans by the Gerontes, that is, the permanent metropolitans on the Holy Synod.

Gerontism is an instance of a distant effect of the Wars of Religion, i.e. of how the model of the Church as being subservient to the State travelled from Henry VIII's England to the Balkans via Moscow; to see a clearer, more organized manner of constructing identities at work, however, it is necessary to examine the judicial level.

As is widely known, the Ecumenical Patriarchate defended a system of justice before the Porte-a system based on the application of the Constantine Harmenopoulos's Hexabiblos (or Procheiron), a private collection of Byzantine law and the last important work of its kind before the Fall of Constantinople. ${ }^{7}$ Har-

6 For example, it has been prompted largely developed by the work of Tijana Krstić on a topic that it was well known in the earlier bibliography as 'sunnitization'. See among others N. Clayer, "Des agents du pouvoir ottoman dans les Balkans: les Halvetis", Revue des mondes musulmans et de la Méditerranée, 66 (1992) 21-30; N. Clayer, Mystiques, État Et Société: Les Halvetis Dans l'Aire Balkanique de la Fin du XVe Siècle à nos jours, Leiden: Brill 1994; D. Terzioğlu, "How to conceptualize Ottoman Sunnitization: A historiographical discussion" Turcica 44 (2012), 301-338; T. Krstić, 'State and Religion, "Sunnitization" and "Confessionalism" in Süleyman's Time', in P. Fodor (ed.), The Battle for Central Europe: The Siege of Szigetvar and the Death of Suleyman the Magnificent and Miklos Zrinyi (1566) (Leiden-Boston 2019) 65-92; T. Krstić, 'From Shahāda to 'Aqīda: Conversion to Islam, Catechization, and Sunnitization in Sixteenth-Century Ottoman Rumeli', in A. C. S. Peacock (ed.), Islamisation: Comparative Perspectives from History (Edinburgh 2017) 296-314. On the problem of Confessionalization especially in the Arab provinces of the Ottoman Empire, see B. Heyberger, 'Pour une "histoire croisée" de l'occidentalisation et de la confessionnalisation chez les chrétiens du Proche-Orient', The MIT-Electronic Journal of Middle Eastern Studies 3 (2003) 36-49.

7 See the following reference in Constantine Harmenopoulos' Procheiron or Exabiblos edited and prefaced by Konstantinos Pitsakis: "This work is also known as the Procheiron. With this manual, Harmenopoulos hoped to complete Basil I the Macedonian's Procheiron. The Procheiron was the basis for the Exabiblos despite a differently-ordered table of contents. Har- 
menopoulos, a judge and legislator based in Thessaloniki, edited the collection in 1345 , and it was translated into various languages in the post-Byzantine years. It was rendered into vernacular Greek in 1744 and widely distributed in western and central Europe, Georgia, Russia, the Danubian Principalities, Asia Minor, and the entire Balkan peninsula. From the eighteenth century onwards, it was used in the latter two regions by the church and mixed courts of the Constantinople-affiliated metropolises, particularly the Alexios Spanos edition, which eventually superseded Manouel Malaxos's Nomokanon, a collection of sixteenth century laws (likely from 1560-1563). ${ }^{8}$

The Hexabiblos was gradually translated into other, mostly Slavic, languages. The 1754 Serbian translation by the scholar and cleric Petar Vitković in Egger, Hungary, emerged in the context of the cultural renaissance of Serbs in Austria-Hungary and the Karlowitz metropolis, but was never published. The 1831 Russian translation was intended for use in the Bessarabia courts in accordance with an order issued in 1828 by the Russian administration.

If Paisios II's second patriarchal tenure (1740-1743) was definitive for establishing Gerontism, then Metropolitan Gerasimos of Heraclea's directive to Alexios Spanos to render the old Attic edition into vernacular Greek (and financing provided to him) was decisive in the wide distribution of the Hexabiblos. The edition was published in Venice in 1744 by Nikolaos Glykys, which suggests the directive was also issued during the reign of Paisios II. Here it is important to emphasize that in the same circle of hierarchs as Paisios and Gerasimos also included the patriarch Kallinikos III, who had opposed the conservative circles that supported the practice of Anabaptism (i.e. the compulsory baptism of a Catholic who would be converted to Orthodoxy), and who after his expulsion from the patriarchal throne as pro-Catholic, undertook the difficult task of developing an argument against the Kollyvades.9 In one sense, this group undertook a task of 'modernizing' or 'rationalizing' the administrative mechanisms of the Patriarchate in the middle of the

menopoulos used other sources too, Vasilika, both Synopses, the Eklogi of Leo III the Isaurian and Constantine V the Copronymus, the Epanagogi, imperial novellae, and Holy Synod

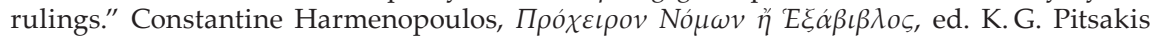

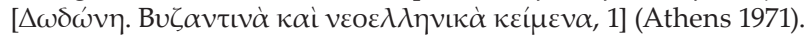

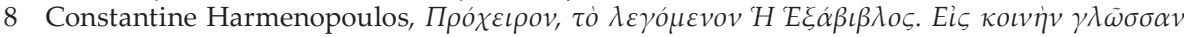

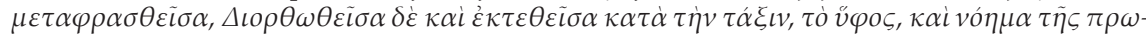

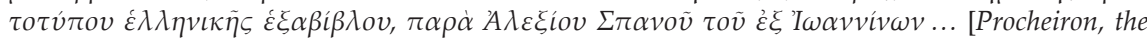
so-called Hexabiblos. Rendered in the common language. Corrected and augmented according to the order, the style and the meaning of the original [Byzantine] Greek Hexabiblos, by Alexios Spanos from Ioannina...] (Venice 1744).

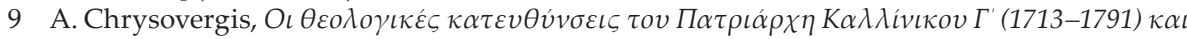

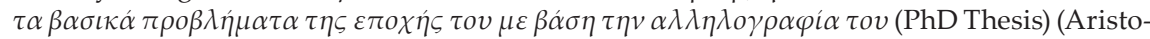
tle University of Thessaloniki, Thessaloniki 1998) 55-6. See also A. Tselikas (ed.), K $\alpha \lambda \lambda \iota v i k o v$

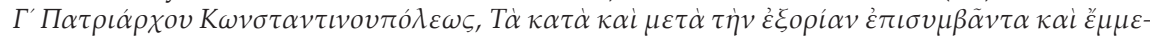
$\tau \rho о \iota \dot{\varepsilon} \tau \iota \sigma \tau o \lambda \alpha i$ (Athens 2004). On the Kollyvades movement, see among others I. Zelepos, Orthodoxe Eiferer im osmanischen Südosteuropa. Die Kollyvadenbewegung (1750-1820) und ihr Beitrag $z u$ den Auseinandersetzungen um Tradition, Aufklärung und Identität (Wiesbaden 2012). 
eighteenth century. However, if the administrative system of 'Gerontism' favored the establishment of a double centralism (the weakening of the Patriarch favored the Phanariot intervention in the Patriarchate and consequently Ottoman state centralism, in exchange for the strengthening of the Gerontes' position against the regional bishops and metropolitans), would the imposition of a legal code from the end of the Byzantine Empire favor such a 'rationalization'?

Alexios Spanos' introduction is addressed directly to Gerasimos. In it, he summarizes the theoretical foundations of the Ecumenical Patriarchate's reformists in the eighteenth and nineteenth centuries, which means that he treats of the distinction between 'material' (mainly monetary) and 'spiritual' jurisdictions. Nonetheless, there was a substantive difference to the reorganization of the millet in the mid-nineteenth century under the Tanzimat reforms. ${ }^{10}$ Whereas the latter's differentiation between 'material' and 'spiritual' authority aimed at legitimizing lay participation in Church administration-lay members would, presumably, take care of material duties while the clergy would tend to spiritual matters-the eighteenth-century restructuring aimed at demonstrating that the Church itself had a 'material' component that it should regulate according to the law. Spanos notes:

Man is comprised of two parts, soul and body, and life is divided into two, the theoretical and the practical [...] This duality cannot be discerned at the most perfect and divine level despite the law which, like that fiery and glowing pillar that once led the Israelites, leads man to the righteous and just life.

After emphasizing the importance of justice being administered by the Church, he adds:

The Church is not something that is not considered, as some heretics maintain. The Church is both considered and visible [...] God himself first proved the benefit of the law by establishing it as a guidepost for man to heaven [...] second, nature itself showed people its own law, which was designated natural law. Third, God himself gave the God-seeing Moses the written law that became the basis for all laws that the human species later wrote.

The interesting reference to natural law acquires even greater significance with the reference to the Kingdom of the Romans (i.e., the Byzantine Empire). Importantly, Spanos seems to have a clear sense of the identity of the modern 'Hellenes', as he calls them, in relation to Roman state tradition. The text's adaptation into vernacular Greek, he notes, is for the benefit of 'the Christian genos of Hellenes. ${ }^{\prime 11}$

The Hexabiblos comprises a synopsis of the Eastern Roman Empire's old laws (of the Kingdom of the Romans as Spanos also noticed ${ }^{12}$ ). Indeed, this is its essential difference from other collections of legal canons: it is a collection of exclusively

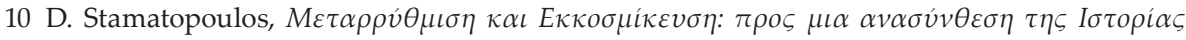

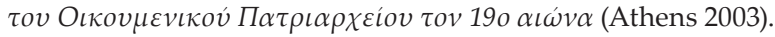

11 Harmenopoulos, Procheiron, the so-called Hexabiblos, 6.

12 Ibid., 5. 
secular laws without any reference to 'Sacred Canons' - something that completely sets it apart from works such as Matthaios Vlastaris's Syntagma (Constitution), written in the same city a mere ten years earlier.

Yet if this is the case, why had the Patriarchate already consented the mid-eighteenth century to its establishment as the primary legal frame of reference? Could this decision be considered a confessionalisation process? Pantazopoulos, the wellknown Greek historian of law, took the view 'the Church sought and achieved the de facto extension of its jurisdiction by making use of its leadership role between the Christian population and the "proof of jurisdiction" it derived from this position?"13 Even if we accept this essentially correct assessment, however, questions remain.

From the mid-eighteenth century onwards, the Church sought to apply Harmenopoulos (the earlier patriarchal letter we discovered with a direct reference to Harmenopoulos is dated 1784). But this 'extension' of Church's authorities, based on a text of 'secular law', corresponds to some form of secularization of its own thinking. The Church would shoulder the 'cost' for this, precisely because applying such a text opens a path for a posteriori intervention in the private sphere. This seems to be the basic difference to the tradition of the previous period's legal collections: it was no longer sufficient to apply discipline to the bodies (and thus souls) of the faithful; the Church now had to seriously take into account the development of a bourgeois private sphere, or rather it now perceived private space to be bourgeois in nature, thus effectively transforming its own 'bio-politics'. And is this much more than just an 'extension of authority'.

If the position on confessionalization frees the interpretation of modernization processes from the Weberian interpretation of secularization-given that the construction of religious identities should not be understood as a pre-modern remnant but as a component part of early modern societies-then the Patriarchate's move to control the private space of the faithful, not just on the basis of the Sultan's berats but by invoking a 'secular' legal collection of the Late Byzantine period, could be interpreted precisely as an attempt to reorganize the millet's collective identity. This is what I call confessionalization from above: the reproduction of the dominance of the Orthodox clergy and clerical elite through the use of 'secularized means'.

Of course, we must point out two things here, the first of which is a paradox, the second something expected. The paradox of the Hexabiblos is that it was a text that was not accorded any gravitas by lawyers-especially in the nineteenth century-despite being the Patriarchate's emblem and reference point. Most found the text lacking, especially if they compared it to other Byzantine collections such as the Basilika or Epanagoge ${ }^{14}$. Nonetheless, one could say that this was precisely its

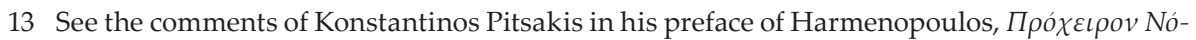
$\mu \omega v \eta^{\prime} E \xi \alpha \dot{\alpha} \measuredangle \beta \lambda o \zeta, \zeta^{\prime}-\mathrm{e} \iota \alpha$ '. Cf. N. Pantazopoulos, Church and Law in the Balkan Peninsula during the Ottoman rule (Thessaloniki 1967).

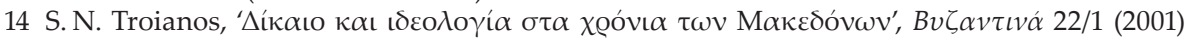
239-61. 
advantage: the elliptical character of the rules it contained gave an advantage to the church courts but also allowed the Holy Synod of the Patriarchate of Constantinople to be especially flexible in administering justice-which in the Orthodox Church was awarded according to 'oikonomia' (' $\kappa \alpha \tau^{\prime}$ oikovouí $\left.\alpha v^{\prime}\right) .{ }^{15}$ However, the Hexabiblos' 'inadequacy' presented an array of solutions-often against its very letter-that was unprecedented for the administration of church justice.

The second thing to note is that such an option, even promoted by a grand cleric of the Patriarchate, did not find the requisite consensus among the clergy's ranks. Many patriarchs and bishops had reservations about applying the Hexabiblos as a rule for justice. The fear of secularization was greater than the appeal of expanding the Patriarchate's authorities. Thus, in the late eighteenth century, it can be said that there were constant regressions on the issue of implementing or simply invoking the Hexabiblos. Patriarchal sources like Samouil Hançerli, scion of a great Phanariot family, supported its implementation, while one of the leading advocates for the Patriarchate's return to the rationale of Sacred Canons was Grigorios V, the patriarch executed by the Ottomans in April 1821. This dispute in the passage from the eighteenth to the nineteenth century had two interesting outcomes: first the defenders of the Hexabiblos started referring to its author as 'Sacred Harmenopoulos'. The only legal compilation of the Late Byzantine period with pure secular character, it was sanctified by its defenders for confronting the argumentation of the supporters of the Sacred Canons. But if this was a way for the Constantinople elite to 'sanctify' a text it could not evade the criticism levelled at it by the most important group of 'religious fundamentalism': the Kollyvades of Mount Athos. As mentioned above, the Kollyvades emerged as the most important opponents of the group of hierarchs that promoted the internal reorganization of the Orthodox Church in the middle of the eighteenth century.

The Kollyvades criticized the Enlightenment and its representatives with a 'return' to the logic of the 'Sacred Canons'. We might point to Agapios the Hiero-

15 The problem of the 'economy'/'oikonomia' or the 'accuracy'/'akribeia' of the implementation of the Sacred Canons was discussed extensively under circumstances of fierce opposition between the disclaimers and the supporters of the repetition of baptism ('Anabaptism') in the case of former Latin Catholics or Armenians who wanted to be converted to the Orthodoxy.

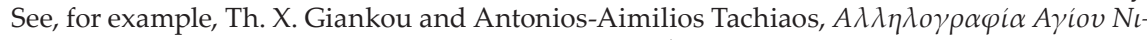

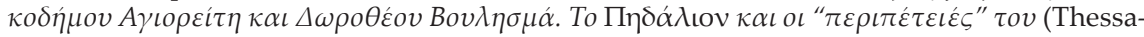
loniki 2020) 163-7. Finally, the supporters of the 'Anabaptism' prevailed when the Patriarch of Constantinople Kyrillos V, who succeeded Kallinikos III, with the patriarchs of Alexandria

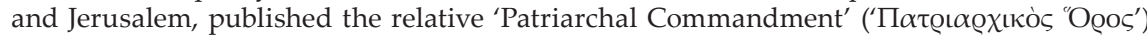
in 1756. However, the problem of 'oikonomia' and of the flexibility of the implementation of the Sacred Canons has become more intense in the cases of the family or hereditary law. The transformation of Hexabiblos as 'canonical symbol' by the 'modernists' (the disclaimers of Anabaptism) was related with this process. See on this issue D. Stamatopoulos, 'The Christian Orthodox family in crisis: the Ecumenical Patriarchate's courts and the reconstruction of the private sphere in southeast Europe in the nineteenth and early twentieth centuries', in E. Avdela, Sh. D'Cruze and J. Rowbotham (eds), Problems of Crime and Violence in Europe, 1780 2000. Essays in Criminal Justice (Lewiston NY-Queenston ON-Lampeter PA 2010) 91-118. 
monk and Nikodimos Agioreitis' text Rudder [Pedalion] as an exemplary synthesis of this thinking. ${ }^{16}$ Although the introduction to this work refers to the Hexabiblos among other legal texts, its underlying logic is the return of the Sacred Canons as a charter reference of the church courts. Today we are well aware that the authors were directly influenced by the works of the Anglican theologian William Beveridge $^{17}$ as well as by Jean du Tillet, ${ }^{18}$ while in his writings Nikodimos in particular used texts of the Counter-Reformation Jesuits, like Loyola's Exercitia spiritualia. ${ }^{19}$ Rudder's 'Sacred Canons' are not identical to the Sacred Canons of the Ecumenical Synods. But that is not all. Rudder was not simply characterized by 'consiliarism' and 'antiquarianism' aimed at replacing older ecclesiastical legal collections. ${ }^{20}$ The authors in their introduction clearly focused their criticism on the supremacy of secular laws, and not accidentally. What they were trying to deconstruct was the secular symbolic reference established by the proclamation of Hexabiblos as the dominant rule of ecclesiastical justice.

This, however, required a turn from 'materiality' to 'spirituality', which contained elements of the recognition of a 'natural law':

The Holy Trinity created this first material world by assembling its elements on the basis of various natural rules from which order arises, and through order the coherence of everything is ensured, and as Orpheus said, all nature becomes a musical harmony [...]. This same Trinity created also this second intelligible world of the Universal Church and formed it using these divine and sacred canons.

The priority of a review of the sacred rules was necessary to confirm the ecclesiastical hierarchy 'as an imitation and seal of the heavenly hierarchy.' Just as if the natural laws were catalyzed, the universe would be dissolved; thus, if the Sacred Canons were to be removed from ecclesiastical life, it would cause disorder that would dissolve the 'sacred decoration' of the church itself. ${ }^{21}$ Yet while this argumentation seems to be based on a spirit of acceptance of the mild versions of natural philosophy in representatives of the Modern Greek Enlightenment such as Evgenios Voulgaris, there was a problem that needed to be solved: the management of secular laws, practically the Church's relationship with the State. The authors emphasize that they have included in their work enactments and laws of kings, and especially of Justinian, only where they were in accordance (or com-

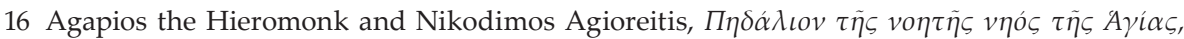

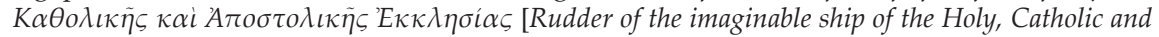
Apostolic Church], 2nd edn (Athens 1841).

17 G. Beveregius, $\Sigma v v o \delta ı$ ı́v, sive Pandectae Canonum (Oxford 1672).

$18 \mathrm{~J}$. Tilius, Apostolorum et sanctorum conciliorum decreta (Paris 1540).

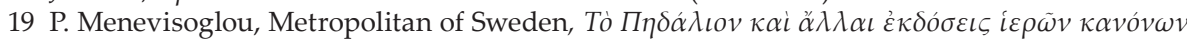

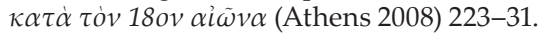

20 D. Heith-Stade, The Rudder of the Church: A Study of the Theory of Canon Law in the Pedalion (PhD Thesis) (Lund University, Lund 2015).

21 Agapios the Hieromonk and Nikodimos Agioreitis, Rudder, 10. 
plementary) to the Sacred Canons. Yet they also stress, that whenever they found out that the laws invalidated the spirit of the latter, they rejected them, adding that this was provided for by the political laws themselves. This statement is accompanied by a long footnote where they mention the three most important summaries of the Byzantine legislation: the Nomocanon of Patriarch Photius ${ }^{22}$, the Diataxis of Michael Attalliates ${ }^{23}$ and the Hexabiblos of Constantine Harmenopoulos. However, they consider the work of Photius to be superior to the others. ${ }^{24}$ Such an observation, even if made in a specious way, showed the direction of their own project: Thus, after defining the concept of the 'canon', they proceeded to those provisions of the Ecumenical Councils which proved that the Sacred Canons take precedence over the Royal Laws. Specific reference is made to the fourth rule of the Fourth Ecumenical Council ('Nothing can be done against the Canons'/'Katì

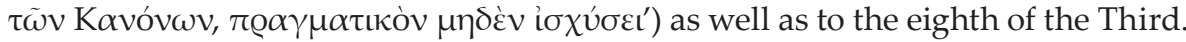
In reality, however, this position was based on the following declaration in the Nomocanon: 'The actual types/laws that oppose to the Canons are invalid'25 as well as on the relevant interpretive commentary of Balsamon on the above specific passage of Photius. Balsamon specifically states:

The Canons were created and supported by both the Holy Fathers and the Kings, as the Divine Scriptures say. By contrast, the Laws were accepted or created only by Kings, and therefore it is not possible for them to prevail over the Divine Scriptures, nor, of course, over the Sacred Canons. ${ }^{26}$

The Rudder was in fact trying to undermine the assumption on which the dominant ideology of the Patriarchate had been based during the former centuries of the Ottoman domination: the subordination of ecclesiastical to political power. And a gesture like this was favored by a section of the ecclesiastical elite of Constantinople which saw the prospect of secularization combined with the rise of nationalism as a threat to the unity of the Orthodox Church's flock.

\section{The Private and the State}

Contemporary sociology of religion usually describes two historical versions of secularization: the Church's submission to the state (usually through nationalization of the Church) or the separation of Church and State (usually by including the Church in what we call 'Civil Society'). In one sense, these two paradigms were produced through the experience of the Wars of Religion, even though they did not effectively result in the abolition of the religious monopoly in the countries of Western and Central Europe. The theoretical discussion has focused on the revi-

22 Photius I, Patriarch of Constantinople, Nomocanon (Paris 1615).

23 See among others, P. Gautier, 'La Diataxis de Michel Attaliate', Revue des Etudes Byzantines 39 (1981) 5-143.

24 Agapios the Hieromonk and Nikodimos Agioreitis, Rudder, 9, footnote 10.

25 Photius, Nomocanon, Book I, Title B, Provision 12.

26 Agapios the Hieromonk and Nikodimos Agioreitis, Rudder, 13. 
sion of the classical position on secularization, discussing the case of the Orthodox Churches of Eastern and Southeastern Europe. It has also attempted to categorize them both in relation to the Catholic and the Protestant model as well as in relation to the historical patterns of State control of the church, whether in the Colonial Empires of Western Europe or in the Continental Empires of Eastern Europe. On the other hand, the confessionalization paradigm was constructed precisely in order to cast doubt on a linear historical approach which directly connected the secularization process of modernity with the Reformation and Counter-Reformation. But if it is necessary to adopt a critical stance towards an idealized version of secularization (as for example took place in 1905 France) we equally have to deal with the following question: Was the contribution of the political elites in Eastern and Southeastern Europe to the stabilization and/or demarcation of religious identities also pivotal for controlling and manipulating the interests of powerful religious elites? And to what degree was political manipulation like this successful and how influential was to the state-building process in the imperial as well as in the post-imperial (national) states?

Gennadios Scholarios, the first Patriarch after the fall of Constantinople, had organized the theoretical paradigm of the Church's subordination to Ottoman political power as early as the fifteenth century. The next great moment of a theoretical elaboration of the above thesis took place in 1663: On the occasion of the great upheaval in the Russian Church caused by the reforms of Patriarch Nikon, after the request of Tsar Alexis, the Patriarchate (manipulated by Ligaridis) was asked to answer twenty-five questions concerning the relationship between political and ecclesiastical power ${ }^{27}$.

The first question was answered by the reference to the Ecloga of the Isaurians ('What is a king?' The answer: 'King is a legal overseer'), ${ }^{28}$ the answer to the second was based to a response of the Patriarch Michael III to the Emperor Manuel I that made it clear that the bishop or the Patriarch had to submit to ruler. ${ }^{29}$ Along similar lines, in a 1723 letter Patriarch Ieremias ratified the decision of Peter the Great to abolish the Patriarchate and replace it with a permanent Holy Synod.$^{30}$ It is therefore extremely interesting that in both cases in the mid-seventeenth and in

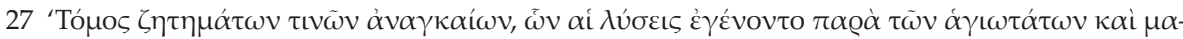

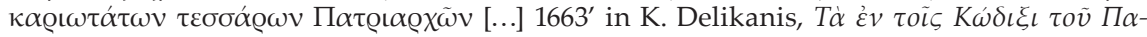

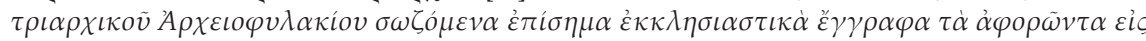

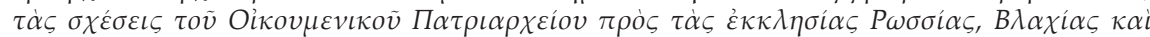

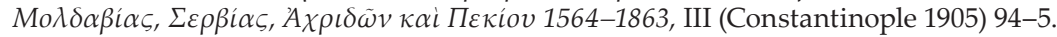

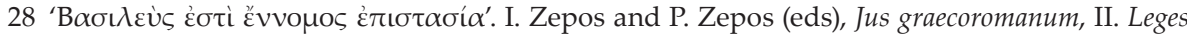
imperatorum Isaurorum et Macedonum. Ecloga legum. Leges rusticae, militares, navales. Prochiron. Epanagoge legis. Leonis Sapientius liber Praefecti (Aalen 1962) 240

29 Both of texts were included in the Law Compilation ('Mé $\gamma \alpha$ Nó $\mu \mu \nu^{\prime}$ ') of the Great Church

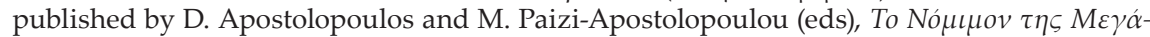

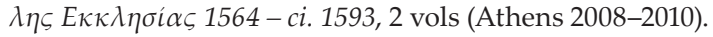

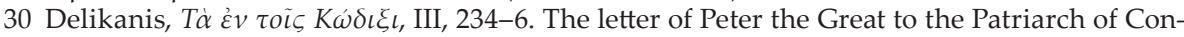
stantinople, ibid., 231-4. 
the early eighteenth century the Patriarchate (and despite the ambiguous criticism of hierarchs such as Dositheos of Jerusalem ${ }^{31}$ ) inspired by the Russian example took a clear position in favor of a model of subordination of the Church to vital interests of the State. In doing so, they remained faithful to a tradition that led closer to Eusebius of Caesarea than to the theories of a supposed balanced relation between them (the model of 'synallelia' or 'symphonia', in Latin: 'consonantia') that had been formulated mainly in the late Byzantine period.

There is an argument that the Patriarchate in both cases found the opportunity to reduce the power of the Russian Orthodox Church by standing on the shoulders of the Tsars. However, while the text of 1663 acquired a more general theoretical character with serious consequences for the Church's position within the Ottoman state, the defense of the synodal model in 1723 should be directly connected to the administrative reconstruction of the Patriarchate in the following decades. Just as in the Russian case, when a movement from below, that of the Old Believers, raised the issue of confessionalization of the Church, the Kollyvades Movement in the eighteenth-century Ottoman Empire did the same, trying to confront the secularization trends at the level of ecclesiastical management or the formation of a private sphere. And in both these cases, the intellectuals who raised the issue of confessionalization from below were inspired by the relative literature of Counter-Reformation ${ }^{32}$.

However, they were by no means motivated by the basic element of Catholicism, namely, administrative centralism. On the contrary, their opponents, even if they compromised with a solution to weaken the position of Patriarch through Gerontism, imposed a system of strict financial control on the metropolitans of the provinces. The invocation of the synodal system may have resulted in the weakening of the Patriarch but by no means led to the weakening of the Patriarchate. When the conditions allowed in the middle of the nineteenth century with the Tanzimat reforms, the request of patriarchal centralism will be back.

If, therefore, we can see in these reactions the attempt of sections of the Orthodox clergy to defend their privileges especially with regard to the organization of

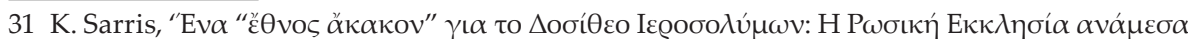

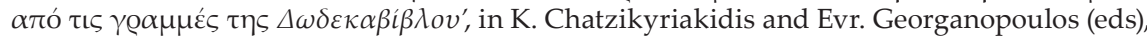

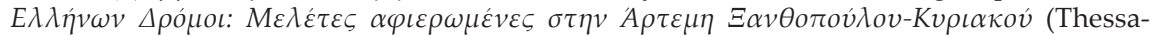
loniki 2014) 9-40.

32 See for example Andrey V. Ivanov, A Spiritual Revolution. The Impact of Reformation and Enlightenment in Orthodox Russia, (Madison, Wiskonsin: The University of Wisconsin Press, 2020). On the issue of probable relation of the Old Believers with the Weberian thesis on the "protestant ethic of capitalism", see among others W. L. Blackwell, 'The Old Believers and the Rise of Private Industrial Enterprise in Early Nineteenth-Century Moscow', Slavic Review 24 (1965) 407-424. A. Gerschenkron, Europe in the Russian Mirror: Four Lectures in Economic History (London 1970). For a critical reconsideration of the above thesis see H. Hillmann, and B. L. Aven, 'Fragmented Networks and Entrepreneurship in Late Imperial Russia', American Journal of Sociology 117 (2011) 484-538; D. Raskov, V. Kufenko, "The role of Old Believers' enterprises: Evidence from the Nineteenth Century Moscow Textile Industry", Schriftenreihe des Promotionsschwerpunkts Globalisierung und Beschäftigung, No. 40/2014, Universität Hohenheim, Stuttgart, http://nbn-resolving.de/urn:nbn:de:bsz:100-opus-9791 
the private sphere against the reformist attempts of Ottoman power or parts of the Phanariot world, then Ottoman and Russian Orthodoxy should also be compared from a long-term perspective. In Russia, the movement of confessionalization from below is preceded by, and in the Ottoman Empire followed by institutional reform. Of course, the relationship between these movements and the institutional changes that took place in the two churches must be studied more carefully and in depth. But it is interesting that in both cases, the traditionalist discourse, in addition to its anti-Westernist direction, tends towards anti-statism. At the risk of generalization, then, the following may be proposed as a working hypothesis: before the French Revolution and the emergence of national movements, the question of reforming the Church was either raised from above (as an administrative reorganization) or from below (as a dogmatic upgrading); but it does not necessarily reflect the existence of a wider state reconstruction program.

\section{Conclusions}

The Hexabiblos and the Rudder (to be precise the introductions of each in the 1744 and 1800 editions, respectively) are two texts in which one can discover the echo of a new dualistic 'Cartesian' perception of the world, as suggested by the texts of either the New Aristotelianism of the late seventeenth or the Enlightenment of the eighteenth century. But they represent two different conceptions of how the Orthodox clergy would reproduce its political, ideological and social hegemony within the Ottoman state-an Ottoman state that was facing the challenges of an era of great rivalry with the other continental empires as well as of a prolonged 'crisis' of its 'classical' institutions.

From this point of view, although both cases do not clearly represent a kind of confessionalization, the problem of secularization that pervades them must be interpreted in a broader context of redefining Eastern Orthodoxy in relation to its confrontation with other Christian doctrines and the dangers of progressive Islamization. As such, we can say that in this case the example of secularization was encapsulated in the paradigm of confessionalization.

The publication of Hexabiblos in 1744 reflected the view that the clergy could reproduce its hegemony by extending the sphere of its influence through a legal collection of secular laws of the late Byzantine period. This necessarily involved accepting the supremacy of the secular over the spiritual, the political over the religious. By contrast, the Rudder represents a return to the domination of the 'spiritual': but we would be wrong to believe that this traditional approach is of a pre-modern nature. On the contrary: its 'fundamentalist' features are fully integrated into a new reception of the religious that is itself fully integrated into modernity through a process of the discipline of bodies. Effectively exercising harsh criticism of Constantinople, or segments of the dominant Church and Phanariot elite for their tolerance of Enlightenment ideas, the intellectuals of this trend maintained that the response to the Enlightenment must be a reconstitution of the religious identity. 


\section{Bibliography}

\section{Literature}

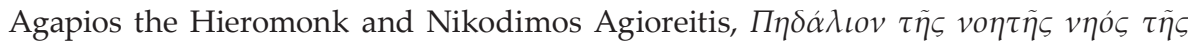

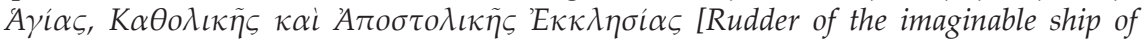
the Holy, Catholic and Apostolic Church], 2nd edn (Athens 1841).Apostolopoulos D.

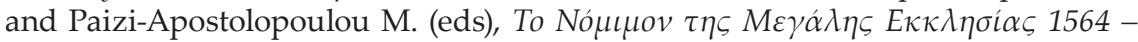
ci. 1593, 2 vols (Athens 2008-2010).

Bayraktar Tellan E., The Patriarch and the Sultan: The Struggle for Authority and the Quest for Order in the Eighteenth-Century Ottoman Empire (PhD Thesis) (Bilkent University, Ankara 2011).

Casanova J., Public Religions in the Modern World (Chicago 1994).

- Global Religious and Secular Dynamics. The Modern System of Classification (Leiden 2019).

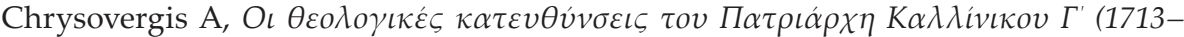

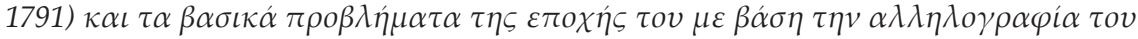
(PhD Thesis) (Aristotle University of Thessaloniki, Thessaloniki 1998).

Clayer N., "Des agents du pouvoir ottoman dans les Balkans : les Halvetis", Revue des mondes musulmans et de la Méditerranée, 66 (1992) 21-30,"

- Mystiques, État Et Société: Les Halvetis Dans l'Aire Balkanique de la Fin du XVe Siècle à nos jours , Leiden: Brill 1994,

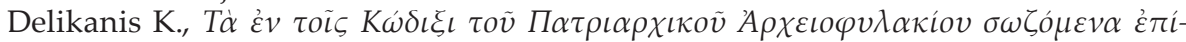

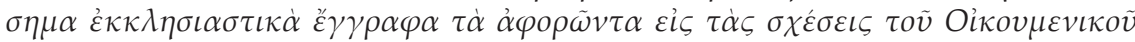

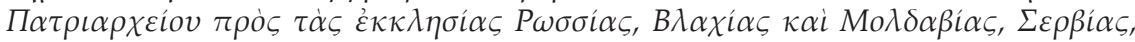

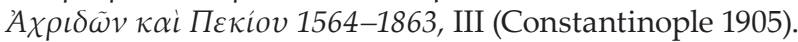

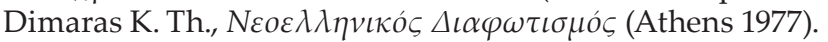

Gautier P., 'La Diataxis de Michel Attaliate' Revue des Etudes Byzantines 39 (1981) 5-143.

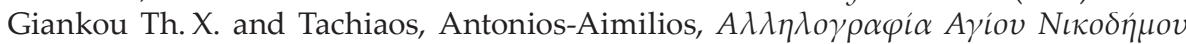

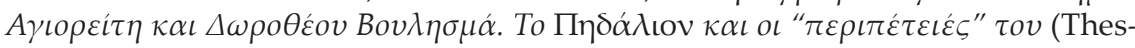
saloniki 2020).

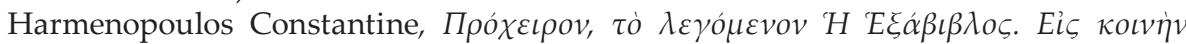

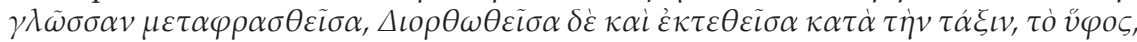

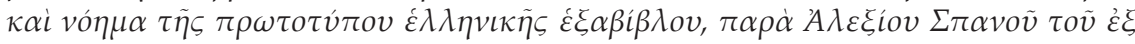
I I avvivwv ... [Procheiron, the so-called Hexabiblos. Rendered in the common language. Corrected and augmented according to the order, the style and the meaning of the original [Byzantine] Greek Hexabiblos, by Alexios Spanos from Ioannina ...] (Venice 1744).

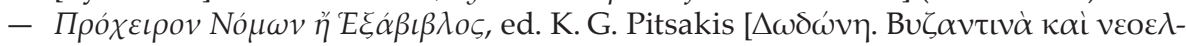
$\lambda \eta v \iota \kappa \dot{\alpha} \kappa \varepsilon \dot{\mu} \mu \varepsilon v \alpha, 1]$ (Athens 1971).

Heith-Stade D., The Rudder of the Church: A Study of the Theory of Canon Law in the Pedalion (PhD Thesis) (Lund University, Lund 2015).

Hering G., Ökumenisches Patriarchat und europäische Politik 1620-1638 (Wiesbaden 1968).

Heyberger B., 'Pour une "histoire croisée" de l'occidentalisation et de la confessionnalisation chez les chrétiens du Proche-Orient", The MIT-Electronic Journal of Middle Eastern Studies 3 (2003) 36-49.

Ivanov Andrey V., A Spiritual Revolution. The Impact of Reformation and Enlightenment in Orthodox Russia, (Madison, Wiskonsin 2020)

Kermeli Eug., 'Kyrillos Loukaris' Legacy: Reformation as a catalyst in the $17^{\text {th }}$ century Ottoman Society', The Muslim World 107 (2017) 737-53. 
Kitromilides P., Enlightenment, Nationalism and Orthodoxy: Studies in the Culture and Political Thought of South-Eastern Europe (Aldershot 1994).

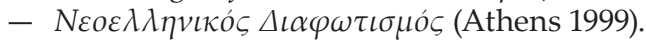

Krstić T., 'State and Religion, "Sunnitization" and "Confessionalism" in Süleyman's Time', in P. Fodor (ed.), The Battle for Central Europe: The Siege of Szigetvar and the Death of Suleyman the Magnificent and Miklos Zrinyi (1566) (Leiden-Boston 2019) 65-92.

- 'From Shahāda to 'Aqīda: Conversion to Islam, Catechization, and Sunnitization in Sixteenth-Century Ottoman Rumeli', in A. C. S. Peacock (ed.), Islamisation: Comparative Perspectives from History (Edinburgh 2017) 296-314.

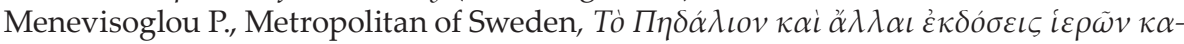

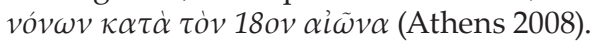

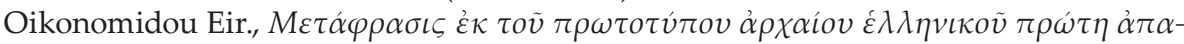

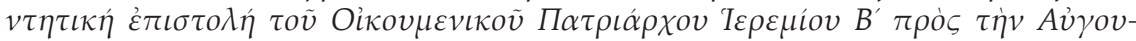

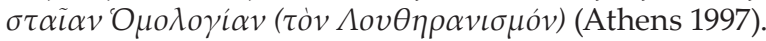

Pantazopoulos N., Church and Law in the Balkan Peninsula during the Ottoman rule (Thessaloniki 1967).

Photius I, Patriarch of Constantinople, Nomocanon (Paris 1615).

Podskalsky G., Griechische Theologie in der Zeit der Türkenherrschaft (1453-1821). Die Orthodoxie im Spannungsfeld der nachreformatorischen Konfessionen des Westens (Munich 1988).

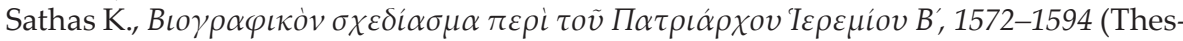
saloniki 1979).

Schilling H., 'Confessionalization: Historical and Scholarly Perspectives of a Comparative and Interdisciplinary Paradigm', in J. M. Headley, H. J. Hillerbrand and A. J. Papalas (eds), Confessionalization in Europe, 1555-1700. Essays in Honor and Memory of Bodo Nischan (New York 2016) 21-35.

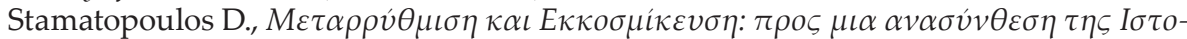

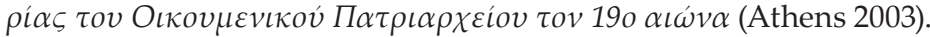

- 'The Christian Orthodox family in crisis: the Ecumenical Patriarchate's courts and the reconstruction of the private sphere in southeast Europe in the nineteenth and early twentieth centuries', in E. Avdela, Sh. D'Cruze and J. Rowbotham (eds), Problems of Crime and Violence in Europe, 1780-2000. Essays in Criminal Justice (Lewiston NY-Queenston ON-Lampeter PA 2010) 91-118.

Terzioğlu D., "How to conceptualize Ottoman Sunnitization: A historiographical discussion" Turcica 44 (2012), 301-338,

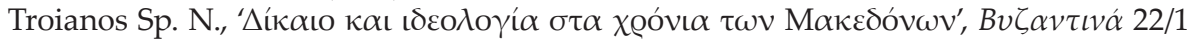
(2001) 239-61.

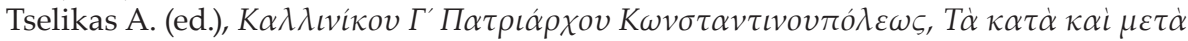

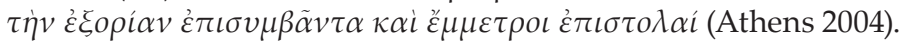

Zelepos I., Orthodoxe Eiferer im osmanischen Südosteuropa. Die Kollyvadenbewegung (17501820) und ihr Beitrag zu den Auseinandersetzungen um Tradition, Aufklärung und Identität (Wiesbaden 2012).

- and Zepos P. (eds), Jus graecoromanum, II. Leges imperatorum Isaurorum et Macedonum. Ecloga legum. Leges rusticae, militares, navales. Prochiron. Epanagoge legis. Leonis Sapientius liber Praefecti (Aalen 1962) 


\title{
Afterword
}

\author{
Tijana Krstić, CEU, Vienna
}

Until recently, it appeared that the theory (or "paradigm", as its fathers Heinz Schilling and Wolfgang Reinhard referred to it) of confessionalization may have exhausted its heuristic potential after more than forty years of debate and criticism. Within the last decade, however, numerous publications and research projects began to engage with it in a new way. With the rise of global and entangled approaches to history and the recent five-hundredth anniversary of the Protestant Reformation, the nature of early modern Christian missions and their global effects have come into the sharper focus, giving rise to research on various local responses to Catholic and Protestant proselytization around the globe. This development coincided with the growth in the fields of early modern Eastern Christian and Islamic studies over the last two decades, which were also inevitably affected by the rise of global history and questions of connectivity, both within and beyond confessional boundaries of the early modern world. ${ }^{1}$ In the confluence of these recent historiographic trends and attempts to understand whether there were any religious dynamics that were shared across parts of the early modern world, the concept of confessionalization emerged as a useful heuristic tool. Rather than the original and much criticized "paradigm", however, what attracted researchers' attention was its reconceptualization as a competitive and to some extent emulative process of building communal identities around creedal and/or ritual norms, as well as the epistemic principles that were involved in the phenomenon. ${ }^{2}$

The present volume epitomizes these various trends in several respects, making an important contribution both to the study of early modern Orthodox history

1 On the developments in Eastern Christian Studies, see Bernard Heyberger, "Eastern Christians, Islam, and the West. A Connected History," International Journal of Middle East Studies 42/3 (2010), pp. 475-478; Heleen Murre-van den Berg, "The Unexpected Popularity of the Study of Middle Eastern Christianity", in Sidney H. Griffith and Sven Grebenstein (eds.), Christsein in der islamischen Welt. Festschrift für Martin Tamcke zum 60. Geburtstag (Wiesbaden, 2015), 1-11; on the developments in the study of post-classical (after 1300) Islam, see Shahab Ahmed, What Is Islam? The Importance of Being Islamic (Princeton, NJ, 2016); see also essays in Tijana Krstić and Derin Terzioğlu (ed.), Historicizing Sunni Islam in the Ottoman Empire, c. 1450 - c. 1750 (Leiden, 2020).

2 Cornel A. Zwierlein, "'Konfessionalisierung' europäisch, global als epistemischer Prozess. $\mathrm{Zu}$ den Folgen der Reformation und zur Methodendiskussion," in C. Strohm (ed.), Reformation und Recht (Tübingen, 2017), 1-52; Tijana Krstić, "Can We Speak of 'Confessionalization' beyond the Reformation? Ottoman Communities, Politics of Piety, and Empire Building in an Early Modern Eurasian Perspective," in T. Krstić and D. Terzioğlu (eds.), Entangled Confessionalizations? Dialogic Perspectives on the Politics of Piety and Community Building in the Ottoman Empire, 15th-18th centuries (Piscataway, NJ, forthcoming). 
of knowledge and the dynamics of early modern Orthodoxy from a trans-imperial perspective (Ottoman, Russian, Venetian, and Habsburg). Indeed, in light of the fact that the original paradigm of confessionalization was criticized for an overly comparative emphasis that elided theological differences between different Latin confessions, it is noteworthy that more recent studies engaging with the concept of confessionalization from a global perspective, including this one, have resulted in exactly the opposite outcome. Specifically, they have generated new insights into the confessional propria of early modern Judaism, various denominations of Eastern Christianity, as well as of Islam, which had previously been neglected as supposedly inferior "deviations" from the medieval or "classical" theological discourses. ${ }^{3}$ The impetus to compare and connect has thus also raised the question of what is particularly "local" or peculiar to certain religious traditions, how the local and global interacted in a longue durée, and with what outcomes, as well as which mechanisms informed their interplay.

As the editors point out in the introduction, the existing literature has heretofore viewed confessional processes in Eastern Orthodoxy largely as a "collateral effect" of the Reformation and Counter-Reformation. It has also approached various types of Orthodox confessional statements and polemical treatises as a reaction to the questions raised by the Catholic and Protestant theologians in their exchanges with their Orthodox counterparts. By contrast, the present volume aspires to take this analysis further in order to grasp both how various Orthodox individuals and groups reacted to external factors, and how they mobilized the epistemic and hermeneutic resources of the Orthodox tradition itself-and with what results. In order to do so, this volume approaches confessionalization in the Orthodox context as a form of multi-directional knowledge transfer, not only between Christian West and East, but also synchronically, among various Orthodox traditions (Greek, Russian, Serbian, Wallachian, etc.) and diachronically, between various generations of Orthodox theologians and historians. The goal, ultimately, is to shed light on how groups and individuals from the clerical circles of the Orthodox Church understood the Orthodox tradition, and how that understanding varied depending on educational background, chronological period, as well as the context of writing and/or confessing.

Four characteristics of the volume particularly stand out for their potential to generate further research and to shed light on the confessional processes in Or-

3 As Gerhard Lauer pointed out in his pioneering effort to chart out the merits of the concept of confessionalization for the study of early modern Judaism, in order to gauge its heuristic potential, confessionalization cannot be something relevant only to the society in which Jews lived but something identifiable in the Jewish tradition itself. See G. Lauer, 'Die Konfessionalisierung des Judentums: Zum Prozess der religiösen Ausdifferenzierung im Judentum am Übergang zur Neuzeit', in K. von Greyerz, M. Jakubowski-Tiessen, T. Kaufmann and H. Lehmann (eds.), Interkonfessionalität-Transkonfessionalität-binnenkonfessionelle Pluralität: Neue Forschungen zur Konfessionalisierungsthese (Heidelberg, 2003), pp. 250-283. For an exploration of "confessional" dynamics within early modern Islam, see the essays in Krstić and Terzioğlu (eds.), Historicizing Sunni Islam in the Ottoman Empire. 
thodox Christianity and on their entanglements with those in other communities-both Christian and non-Christian-in the various political contexts where Orthodox Christians lived.

1) Firstly, rather than privileging published theological and polemical treatises as sources on confessional politics and knowledge transfer, a number of papers in the volume emphasize the importance of archival and manuscript sources as well as private correspondence for reconstructing the movement of people and ideas involved in confessional exchanges and correcting some of the theories established in historiography.

Thus, for instance, Ovidiu Olar meticulously reconstructs Antoine Léger's efforts at building a Protestant library in Ottoman Constantinople in the late 1620s and 1630s, the period encompassing the tenure of the "Calvinist" patriarch Cyril Loukaris. By combing through Léger's book orders and correspondence as well as various other contemporary sources, Olar demonstrates that the Protestant ambitions for expanding their ranks through proselytization in the Ottoman capital and beyond was more serious than previously surmised. However, he also shows on the basis of Loukaris' interest (or lack thereof) in these books that the infamous patriarch was much more ambivalent towards the Calvinist agenda than the excitement surrounding his confession in historiography would suggest. Olar argues that he was in fact devoted to a different notion of reform, one that drew on Protestant methods and strategies of proselytization but remained within the spirit of the Orthodox tradition. At the same time, Loukaris himself was highly sceptical as to the success of this goal. Building on Olar's efforts, as well as those of other scholars who work on archival sources related to Orthodox confessional politics, future scholarship could shed further light on how Russian and Ottoman officials hindered or facilitated this notion of the reform. ${ }^{4}$ Of particular interest from the Ottomanist perspective would be a deeper investigation into Loukaris' relations with various Ottoman officials and contemporary Muslim scholars and jurists. This could make it possible to evaluate to what extent he was aware of the intellectual discourses not only in Europe, the Polish-Lithuanian Commonwealth or Russia but among Ottoman Muslims as well. ${ }^{5}$

Archival sources are also central to Stefano Saracino's illuminating study of the Greek Orthodox alms collectors from the Ottoman Empire as brokers of confessional knowledge with the Protestant and Catholics in the Habsburg territories. Like other recent studies on Eastern Christian alms collectors from the Ottoman

4 See, for instance, Vera Tchentsova, "Moscou face à la tentation protestante du patriarche oecumenique Cyrille Loukaris," in L'Union à l'épreuve du formulaire, éd. M.-H. Blanchet et F. Gabriel (Peeters, 2016), 311-340; Eleni Gara and Ovidiu Olar, "Confession-Building and Authority: The Great Church and the Ottoman State in the First Half of the Seventeenth Century," in Krstić and D. Terzioğlu (eds.), Entangled Confessionalizations? (forthcoming).

5 This topic was opened by Eugenia Kermeli in her "Kyrillos Loukaris' Legacy: Reformation as a Catalyst in the $17^{\text {th }}$-Century Ottoman Society," The Muslim World 107 (2017), pp. 737-753 but would merit further comparative research. 
Empire who ventured beyond imperial borders ${ }^{6}$, this article sheds light on the greater than imagined mobility of monks and clergy who were driven by compulsion, opportunism, and various other motives to travel long distances to raise money for their monasteries and churches back home. Archival sources and correspondence on their presence in the Habsburg Empire in the sixteenth and early seventeenth centuries remind us that the process of confessional exchange and transfer between Orthodox Christians and representatives of various Latin confessions-regardless of the conditions under which it transpired, and the "quality" of the information exchanged-was much more continuous and encompassed a wider network of actors than historiography would have us believe. This study also raises the question of what Ottoman authorities' attitudes were towards these mobile monks and clergymen visiting foreign territories-especially territories of enemies such as the Habsburgs-and how the benefits brought by the knowledge and money collected played themselves out in the context of monastic communities in the Ottoman Empire. With a recent boom in the exploration of various monastic archives in Ottoman lands, which have revealed not only monasteries' role in preservation and perpetuation of the Orthodox spiritual and material culture but also their expert navigation of and participation in the Ottoman legal culture, ${ }^{7}$ it is increasingly clear that a closer dialogue between scholars working on Ottoman, Greek, and sources in various European languages is highly desirable.

Niki Papailiaki's study of Pantelis Sevastopoulos' establishment of the Evangelical School in Smyrna in the 1730s highlights the importance of archival diplomatic sources for understanding the wider context, both Ottoman and European, behind the school's foundation. Contrary to the nineteenth-century Greek historiography, which viewed the school as an "Orthodox" anti-Jesuit project, she shows that the Reformed (both English and Dutch) influence on its curriculum was quite prominent. Furthermore, based on French and other consular sources, she situates the school's foundation in the context of trade competition between the French, Dutch, and local Greek traders in Smyrna. Tantalizingly, she suggests that the French actions against Sevastopoulos and the Greek traders were also closely intertwined with the Ottoman policies against the Catholic missionaries supported by France,

6 Cesare Santus, "Wandering Lives-Eastern Christian Pilgrims, Alms-Collectors and 'Refugees' in Early Modern Rome," in Emily Michelson and Matthew Coneys Wainwright (eds.). A Companion to Religious Minorities in Early Modern Rome (Leiden, 2020), pp. 237-271; John-Paul Ghobrial, "Migration from Within and From Without: In the Footsteps of Eastern Christians in the Early Modern World", Transactions of the RHS 27 (2017), pp. 153-173.

7 See especially various studies by Elizabeth Zachariadou (e.g. "Ottoman Documents from the Archives of Dionyisou (Mount Athos) 1595-1520, Südost Forschungen 30, (1971): 1-36), Aleksandar Fotić (Sveta Gora i Hilandar u Osmanskom carstvu XV-XVII vek (Belgrade, 2000)), Elias Kolovos (studies collected in his Across the Aegean Islands, Monasteries and Rural Societies in the Ottoman Greek Lands), various articles in Greek by Phokion Kotzageorgis, E. Kermeli, "The Right to Choice: Ottoman Justice vis-à-vis Ecclesiastical and Communal Justice in the Balkans, Seventeenth-Nineteenth Centuries," in A. Christmann and R. Gleave (eds.), Studies in Islamic law: A Festschrift for Colin Imber (Oxford, 2007), pp. 165-210, etc. 
as well as with the French attempt to cover up the kidnapping of the Armenian Patriarch Awetik, who had also opposed Catholic missionary efforts. ${ }^{8}$ The use of archival sources in this case reveals the need to look beyond the narrow communal boundaries and highlights the sources' potential for reconstructing the wider Ottoman and international context of confessional entanglements, which has not been fully explored.

In her article on Chrysanthos Notaras' visit to the Observatory of the French Royal Academy of Sciences in 1700 and exchanges with the Italian astronomer Giovanni Domenico Cassini, Vassa Kontouma also deploys a wide range of manuscript and published sources across confessional and political contexts to explore what kind of epistemic "project" was behind Notaras' visit and what expectations both Notaras and Cassini had for the meeting. She highlights how an issue that carried considerable import in relations between Catholics and Protestants (i.e., the issue of the reform of the Gregorian calendar), in which the Orthodox were expected to weigh in, could be perceived from a completely different epistemic angle by the Orthodox actors. Unlike his European interlocutors, Notaras seems to have had a purely astronomical interest in Cassini's calculations, possibly suggesting that in terms of the intellectual outlook and the scope of interest he would be better contextualized in the framework of the Ottoman trans-confessional scientific community. It would be particularly interesting to explore further his intellectual exchanges with the Muslim bureaucrats and intellectuals gathered at the court of the Ottoman sultan Ahmed III, such as Esad of Ioannina (d. 1731?), scholar of natural philosophy who introduced Paduan humanist interpretation of Aristotle to the Ottoman Muslim scholarship, and who is known to have been Notaras' friend and protegé. ${ }^{9}$

2) Secondly, engaging with the recent historiography on confessionalization and confessional dynamics in the early modern world, the papers highlight the performative and contextual aspect of various iterations of confessional identity. ${ }^{10}$

Nikolas Pissis' exploration of Zacharias Gerganos' confessional views during and after his studies in Wittenberg, Stefano Saracino's study of Orthodox alms collectors in various locations in the Habsburg Empire and Marco Cerasoli's investigation of Antonios Katiforos' career in Rome all highlight how context, power equations, intentions, ambitions, and expectations of the various actors involved in confessional exchanges informed the particular articulations of confessional identity and the nature of the knowledge exchanged. Kostas Sarris' study of the

8 On Awetik's resistance to the French-supported Catholic missionaries and the open support he received from the Ottoman chief jurist Feyzullah Efendi because of this, see Cesare Santus, "Sheikh ül-islam Feyzullah Efendi and the Armenian Patriarch Awetik': a Case of Entangled Confessional Disciplining?," in Krstić and D. Terzioğlu (eds.), Entangled Confessionalizations? (forthcoming).

9 See Harun Küçük, Science Without Leisure (Philladelphia, 2019), pp. 177-182.

10 See, for instance, B. Stollberg-Rilinger, 'Einleitung' in A. Pietsch and B. Stollberg-Rilinger eds, Konfessionelle Ambiguität-Uneindeutigkeit und Verstellung als religiöse Praxis in Frühen Neuzeit (Göttingen, 2013), pp. 9-26 
two translations of Diego de Ledesma's Catholic catechism to Greek, one in late sixteenth-century Chios and other in late seventeenth-century Venice, also illustrates how different confessional and political contexts can result in different strategies of translation and editing of the same text.

In their conceptualization of the movement of people and knowledge transfer, these studies echo other recent work on Ottoman Eastern Christians and their "moving stories," as John-Paul Ghobrial has insightfully named them. Ghobrial has suggested that rather than being interested in the movement itself, we should be striving to understand the mechanics and meaning of mobility as they were experienced by contemporaries. He has asked what it means to feel "out of place" and how this story of "unbelonging" varies across different historical contexts, suggesting that in order to understand the relationship between mobility and identity, we must engage with both global processes of movement and local processes of identification. ${ }^{11}$ While they do not explicitly engage with the issues of microhistory and global history, many of the papers in the volume explore precisely this interaction, with insightful results.

3) Thirdly-and related to the performative and contextual aspects of confessional identities and knowledge transfer - a number of papers in the volume are informed by the concepts of confessional ambiguity, inter-confessionality (in the sense of exchanges with reciprocal impact) and/or trans-confessionality (openness to other confessions). These are also highlighted as perhaps the most productive analytical concepts within the wider confessionalization debate for the purposes of understanding the intellectual outlook of the Orthodox clergy.

Nikolas Pissis illustrates the tendency towards inter- and trans-confessionality in his study of Gerganos' weaving together of Lutheran and Orthodox views in his various theological works (especially apocalyptic exegesis). He considers the question of which elements Gerganos adopted from different theological traditions and why, as well as how Gerganos integrated and accommodated them or not within the Orthodox dogmatic framework. Pissis also emphasizes the reciprocal nature of the knowledge transfer, remarking that the Lutheran theologians benefited from the exchange with the Orthodox church by familiarizing themselves with the latter's objections against the Catholics.

Nikolaos Chrissidis emphasizes the openness of the Orthodox literati towards the Jesuit curriculum and educational strategies, including the underlying Aristotelian influence, but emphasizes that their impact on the way in which Orthodoxy was understood and taught is still poorly understood. Addressing the example of Jesuit education and the practice of issuing indulgences, Chrissidis suggests that the Orthodox in some cases adopted practices from the Catholics without the accompanying theology, resulting in transplants whose domestication within Or-

11 John-Paul Ghobrial, "Moving Stories and What They Tell Us: Early Modern Mobility between Microhistory and Global History," Past E Present (2019), supplement 14, pp. 246-249. 
thodoxy and the meaning they were endowed with need to be further researched before we can speak of Orthodox confessionalization.

The papers by Cerasoli, Sarris, and Vasilios Makrides shed further light on the issues of transconfessionality, especially as it informed the careers and proselytizing strategies of intellectuals born or working in multi-confessional Orthodox and Catholic contexts, such as those of Venetian-ruled islands or Venice itself. Here we encounter additional notions of irenicism (Sarris) and ecumenicity (Makrides, who studies the confessional strategies of eighteenth-century Orthodox archbishops Eugenios Voulgaris and Nikiforos Theotokis, both stemming from Venetian-ruled Corfu, but tasked with resolving the challenges of integrating the Uniates and Old Believers in the Russian Empire).

In the context of recent research on confessional dynamics in Ottoman communities, such as Armenians and Sunni Muslims, the questions of confessional ambiguity, trans-confessionality and inter-confessionality have also come to the fore as crucial aspects of the age of confessional polarization that, depending on the community, spanned early sixteenth and mid-eighteenth centuries. For instance, the issue of communicatio in sacris between Apostolic and Catholic Armenians in the Ottoman Empire and its prohibition by Propaganda Fide in 1729 has been central to the research on the issue of confessionalization among Ottoman and Safavid Armenians. ${ }^{12}$ Scholars working on early modern Ottoman Sunnism have also pointed to the persistent confessional ambiguity (between Sunnism and Shi'ism, often via Sufism) in the sixteenth and seventeenth centuries. However, as Derin Terzioğlu has shown, this ambiguity was not some timeless feature of Islam but a phenomenon that evolved and changed in lockstep with the growing push for greater differentiation between Sunnism and Shi'ism in the sixteenth and seventeenth centuries. She and others have also demonstrated that the discourses of orthodoxy and orthopraxy had a clear spatial and social dimension, and that Ottoman Sunnism, similarly to Orthodoxy, was characterized by multiple discursive registers privy to particular social groups. ${ }^{13}$

One concept that is only mentioned but not explored in the papers in the volume is the issue of "crypto" religion-a concept which, by contrast, has received considerable attention in recent research on Christian, Jewish and Muslims communities in the Ottoman Empire, in particular from the seventeenth century on-

12 See C. Santus, Transgressioni necessarie: Communicatio in sacris, coesistenza e conflitti tra le comunità cristiane orientali (Levante e impero ottomano, XVII-XVIII secolo) (Rome, 2019); C. Windler, 'Ambiguous Belongings: How Catholic Missionaries in Persia and the Roman Curia Dealt with Communicatio in Sacris', in R. Po-chia Hsia, ed., A Companion to Early Modern Catholic Global Missions (Leiden, Boston, New York, 2018), pp. 206-236

13 See Derin Terzioğlu, "Confessional Ambiguity in the Confessional Age: Philo-Alidism, Sufism and Sunni Islam in the Ottoman Empire, Late Fifteenth to Late Seventeenth Centuries," in Krstić and D. Terzioğlu (eds.), Entangled Confessionalizations? (forthcoming); on multiple discursive registers within Greek Orthodoxy in the Ottoman Empire see Yorgos Tzedopoulos, "Orthodox Martyrdom and Confessionalization in the Ottoman Empire, Late FifteenthMid-Seventeenth Centuries," in ibid. 
wards. ${ }^{14}$ One wonders whether this could also be a relevant concept for some of the contexts in which Orthodox clergy and theologians operated.

4) Fourthly, one of the most important contributions of the volume is that it highlights the myriad ways in which Orthodoxy was internally diverse and thus not subjectable to a uniform definition of confessionalization or explanation of confessional dynamics. Going beyond the often emphasized diversity of Orthodox culture arising from the existence of various national churches (Makrides), some of the papers also point to different receptions of Aristotelianism within Orthodox intellectual tradition (Chrissidis, Kontouma), different understandings of key theological terms across generations of Orthodox theologians (Tudorie), lenient versus strict understandings of tradition-i.e. oikonomia vs. akribeia (Makrides, Zelepos), patriarchal church vs. monks (Zelepos), clergy who accepted the primacy of political power over religious vs. clergy who believed in supremacy of spiritual over political (Stamatopoulos), and so on.

This emphasis on inner diversity and polyglossia within Orthodoxy stands as a crucial reminder that any generalization about Orthodox Christians would take us only so far. In fact, as Ioannis Zelepos suggests in his paper, there are grounds for pursuing a meaningful cross-communal and cross-confessional analysis of the politics of piety along similar social strata in particular localities. Zelepos explores the phenomenon of self-confessionalization of the common Orthodox and Jewish believers in the eighteenth-century Ottoman Empire on the basis of the pietistic literature produced by the Kollyvades movement and the Jewish Ladino moralistic musar literature. However, it should come as no surprise that a similar emphasis on the shunning of religious authorities, the importance of reading and understanding texts on one's own, and a sort of "self-confessionalization" was also evident among Ottoman Sunni Muslims. ${ }^{15}$ Although none of the recently published studies on the subject draw an explicit parallel with German pietism, the question arises of how the contemporaneous emergence of similar religious sensibilities among various groups of Christians, Jews and Muslims in the Ottoman Empire and beyond could be explained, and constitutes a desideratum for further research. ${ }^{16}$

14 See, for instance, Maurus Reinkowski, "Keine Kryptoreligion, aber doch kryptoreligiös-Zur Frage einer realen Existenz von Kryptojuden und Kryptochristen im islamisch geprägten Mittelmeerraum und Nahen Osten', in Pietsch and Stollberg-Rilinger (eds.), Konfessionelle Ambiguität, pp. 75-98; C. Sisman, The Burden of Silence-Sabbatai Sevi and the Evolution of the Ottoman-Turkish Dönmes (Oxford, 2015); Malcolm, 'Crypto-Christianity and Religious Amphibianism in the Ottoman Balkans: The Case of Kosovo," in Rebels, Believers, Survivors (Oxford, 2020), pp. 55-67, etc.

15 See Marion Kurz, Ways to Heaven, Gates to Hell: Fazlizade 'Ali's Struggle with the Diversity of Ottoman Islam (Berlin, 2011); Nir Shafir, "Moral Revolutions: The Politics of Piety in the Ottoman Empire Reimagined," Comparative Studies in Society and History 61/3 (2019), pp. 595-623; Guy Burak, "Prayers, Commentaries, and the Edifications of the Ottoman Supplicant," in Historicizing Sunni Islam, 232-254.

16 One should refer here to the debate generated by Reinhard Schulze's hypothesis about an "Islamic Enlightenment" in the eighteenth century, some of which relates in interesting ways 
In this context, the challenge of "secularism" and the reactions to it, as suggested by Zelepos and Stamatopoulos in their papers, is indeed something that might be explored further from both community-specific and cross-communal perspectives in the Ottoman context. In addition to rethinking the concept of "secularism" and what it could mean in the context of eightenth-century Orthodoxy, they show that it would be productive to explore the changing perception of the role of religion and religious specialists' authority in regulating communal affairs, as well as these specialists' strategies for meeting the challenges of the changing world. Here, too, it would be interesting to look both "vertically," i.e., for differentiated attitudes within the community based on social habitus (for instance, common believers, archons, traders, clergy of various rank, monks, etc.) - and "horizontally," across communal boundaries, to see how groups with a similar social habitus viewed each other's authority. For instance, recent research on Ottoman letters of appointment (berat) issued to the Greek Orthodox patriarchs and metropolitans suggests that Ottoman administrators sought to reinforce the authority of the patriarchs and metropolitans in the early to mid-eighteenth century by making their jurisdictions, rights, and overall authority over their communities more explicit in the clauses of the appointment letters. ${ }^{17}$ At the very same time, around the mid-eighteenth century, as Stamatopoulos shows, the Patriarchate moved to extend its sphere of control over not just the ecclesiastical and spiritual spheres but also private sphere by adopting a fourteenth-century body of secular Byzantine law that made no reference to "Sacred Canons." A closer and integrated study of this interplay of intra-Orthodox and larger Ottoman administrative strategies promises to shed light on the broader context in which roles and perceptions of clergy and religion were changing. ${ }^{18}$

In conclusion, the present volume greatly enriches the growing body of literature on the relevance of the concept of confessionalization beyond Latin Europe and specifically on its relevance to various Orthodox individuals and communities living in or moving through Ottoman, Venetian, Russian, and Habsburg Empires.

to the question of edification of a common believer and even the notion of "pietism." See, for instance, Albrecht Hofheinz, "Illumination and Enlightenment Revisited, or: Pietism and the Roots of Islamic Modernity" (available at https://www.academia.edu/7488358/Illumination_and_Enlightenment_revisited_or_What_has_Sufism_got_to_do_with_modernity) ; Albrecht Hofheinz, "The Islamic Eighteenth Century: A View from the Edge," in Islam in der Moderne, Moderne im Islam-Eine Festschrift für Reinhard Schulze zum 65. Geburtstag (Brill, 2018), pp. 234-253. It should be mentioned, however, that these studies rarely refer to the Ottoman Balkans and Anatolia, looking, instead, to the Islamic world and especially Sufi networks beyond the Ottoman domains.

17 See especially Elif Bayraktar Tellan, "The Patriarch and the Sultan: Struggle for Authority and the Quest for Order in the Eighteenth-Century Ottoman Empire' (unpublished PhD thesis, Bilkent University, 2011); Hasan Çolak and Elif Bayraktar Tellan, The Orthodox Church as an Ottoman Institution-A Study of Early Modern Patriarchal Berats (Istanbul, 2019).

18 On this issue, see also Kermeli, "The Right to Choice: Ottoman Justice vis-à-vis Ecclesiastical and Communal Justice." 
The volume epitomizes the growing methodological and theoretical sophistication with which scholars of Eastern Christianity are approaching the phenomenon of confessionalization and the historiographic debate around it as a heuristic device to generate further insights into specific communities and inter-communal knowledge transfer. Most of the papers agree that confessionalization is a useful heuristic concept as a broader term to describe the dynamic of the age that bound Latin Christianity and Eastern Orthodoxy. However, they also suggest that other terms from the broader spectrum of concepts associated with the debate on confessionalization, such as trans- or inter-confessionality or confessional ambiguity, are more useful for discussing the confessional outlook of various Orthodox clergy and theologians. Does that mean that the volume suggests that Orthodoxy itself did not become or was not a confession?

Based on the volume, it can be concluded that Orthodoxy's emergence as a confession was a drawn-out process that entailed multi-directional knowledge transfers as well as the mobilization of Orthodox epistemic frameworks that over time resulted in ever new understandings of Orthodox tradition and its relationship to various Christian denominations - as demonstrated particularly well in Ionuț-Alexandru Tudorie's paper. For his part, Makrides emphasizes that Orthodoxy did not think of itself as a confession at the beginning of the sixteenth century (something it shared with Catholicism). However, as a result of the "epistemic pressures" arising from knowledge transfers as well as the evolution of the state-building discourses in the early modern empires in which the Orthodox population lived, it progressively became confessionalized in the sense that Orthodox ecclesiastics and theologians eventually articulated clearer boundaries with other denominations, largely through ritual rather than a succinct and distinct formulation of belief. Makrides argues that the creation of the national Orthodox churches in the late eighteenth and throughout the nineteenth century completed this process by eliminating the ecumenical Orthodox framework of the early modern era and replacing it with more exclusive, national boundaries and discourses of belonging. While the states certainly had a role to play in the process, as Zelepos demonstrates, confessionalization was also possible "from below" or against the ecclesiastical authorities, carried out by monks and common believers who sought a greater individual responsibility and entitlement in determining what tradition was and how communal morality should be defined and guarded. The volume thus makes it clear that there is no universal explanation for an "Orthodox confessionalization." By discussing different political and multi-confessional contexts papers highlight the peculiarity of confessional dynamics within different Orthodox communities and the necessity to study them not only in relation to one another, through a connected history of Eastern Orthodoxy, but also in relation with other local communities and their internal social differentiation. 


\section{Notes on Contributors}

Marco Cerasoli studied Classics and Literature of Modern Greece at the "Sapienza" University in Rome. After some years spent as a teacher in secondary education, since 2016 he has been working on a doctoral thesis at the Freie Universität Berlin, focusing on cultural transfer processes in Venice and the Ionian Islands between Italian-speaking and Greek-speaking scholars in the first half of the 18th century.

Nikolaos A. Chrissidis is Professor of Russian History at Southern Connecticut State University. His research interests include the religious and cultural history of early and modern modern Russia.

Vassa Kontouma is Director of Studies at the École pratique des Hautes études (PSL, Paris), where she teaches "Orthodox Christianity, 15th-21th Centuries", and Dean of the Religious Sciences Department. She is also President of the French Institute for Byzantine Studies (IFEB, Paris). Her publications deal with post-Byzantine Greek theology, but also John of Damascus. She currently codirects Villa Vigoni workshop on "Eastern Christians and the Republic of Letters between the 16th and 18th centuries".

Tijana Krstić is Associate Professor in the Department of Medieval Studies at Central European University in Vienna. From 2015 to 2021 she led the ERC project entitled The Fashioning of a Sunni Orthodoxy and the Entangled Histories of Confession Building in the Ottoman Empire, 15th-17th Centuries. Her research focuses on religious, cultural, and intellectual history of the early modern Ottoman Empire and its various communities.

Vasilios N. Makrides has been since 1999 Professor for Religious Studies (specializing in Orthodox Christianity) at the Faculty of Philosophy, University of Erfurt, Germany. His research interests include, among other topics, sociology and cultural history of Orthodox Christianity, Greek Orthodox diaspora, and religious and cultural East-West relations.

Ovidiu Olar is a Senior Researcher at the "N. Iorga" Institute of History of the Romanian Academy (Bucharest, 2010-present) and a Postdoctoral Researcher in the Balkan Studies Research Unit (HEMSEE project) of the Austrian Academy of Sciences (Vienna, 2019-present). His research interests include the early modern confessional cold wars and history writing in Southeast Europe. 
Niki Papaïliaki has a PhD in History of the École pratique des Hautes études (EPHE-Paris). She has worked at the École des Hautes études en Sciences Sociales (EHESS) and at the École pratique des Hautes études (EPHE). She continues her researches in the National French archives with main interests in the cultural and social history of the Aegean world from the 17th to the 19th century and the history of French catholic missions to the Greeks of the Ottoman Empire.

Miltos Pechlivanos is Professor of Modern Greek Studies at the Freie Universitaet Berlin and Director of the "Centrum Modernes Griechenland". He is a board member of the EXC 2020 "Temporal Communities" and of the CRC "Episteme in Motion", where, since 2012, he heads the project "Transfer and Overlapping. Patterns of Knowledge Configuration in the era of the Greek homines novi of the Ottoman Empire (1641-1769)".

Nikolas Pissis has been since 2012 Research Associate at the CRC "Episteme in Motion", in the project "Transfer and Overlapping. Patterns of Knowledge Configuration in the era of the Greek homines novi of the Ottoman Empire (1641-1769)". His research interests include, among other topics, early modern Russian-Greek relations, apocalypticism and the Phanariotes' knowledge culture.

Stefano Saracino is Assistant Professor at the "Historisches Institut" at the University of Jena. He has collaborated in the FWF-project on the last wills and endowments of the Greeks of Vienna (University of Vienna). His research interests include the migration of Greek-Orthodox to Europe, the history of knowledge between East and West, material history and Renaissance political thought.

Kostas Sarris worked between 2012 and 2021 as Research Associate at the CRC "Episteme in Motion", in the project "Transfer and Overlapping. Patterns of Knowledge Configuration in the era of the Greek homines novi of the Ottoman Empire (1641-1769)". His research interests encompass, along with other topics, the early modern European historiography, the history of ideas and the social history of knowledge in south-eastern Europe and Ottoman Empire.

Dimitris Stamatopoulos is Professor of Balkan and Late Ottoman History at the Department of Balkan, Slavic, and Oriental Studies, University of Macedonia, Thessaloniki, Greece. Member of the Institutes for Advanced Studies at Princeton and Freiburg, Visiting Fellow of the Seeger Center for Hellenic Studies, Princeton University and École des Hautes Études en Sciences Sociales, Paris, he has been specialized on the history of the Ecumenical Patriarcate in the Late Ottoman Period as well as on the history of the Orthodox Christian populations in the Ottoman Balkans.

Ionuț-Alexandru Tudorie is the Academic Dean and Professor for Church History at St Vladimir's Orthodox Theological Seminary (Yonkers NY). His research 
interests include Byzantine imperial ideology, State-Church relations, Rome-Constantinople theological controversies, Eastern Orthodox confessions of faith (15th18th century).

Ioannis Zelepos is a historian and cultural scientist with venia docendi for Southeast-European History and Modern Greek Studies from the University of Vienna (2011), currently working at the Center for Mediterranean Studies of the Ruhr-University of Bochum. His research interests focus i.a. on early modern religious identities, enlightenment and nationalism in Southeast Europe. 



\section{List of Ilustrations}

Fig. 1: Zacharias Gerganos, Encheiridion tis dialexeos ..., Wittenberg 1618. (Thüringer Universitäts- und Landesbibliothek, Jena).

Fig. 2: Zacharias Gerganos, Dissertatio de controversiis ..., Wittenberg 1618. (Thüringer Universitäts- und Landesbibliothek, Jena).

Fig. 3: Handwritten map of Mount Athos from Martin Crusius' Diary, which was made with the help of the monk Daniil Palaiologos (Universitätsbibliothek Tübingen)

Fig. 4: Engraving with a portrait of Athanasius Dorostamus from Eliner's Neueste 'Beschreibung derer Griechischen Christen in der Türkey' (1737).

Fig. 5: Diego de Ledesma, Christian Doctrine, transl. Vincenzo Castagnola, Rome 1595 (Jagiellonian Library, Cracow).

Fig. 6: The first page of Michail Mitros, Christian Doctrine (Venice 1686) (Anemi, Digital Library of Modern Greek Studies).

Fig. 7: Michail Mitros (later Metropolitan Meletios)

(Österreichische Nationalbibliothek, Vienna).

Fig. 8: Ioannis Makolas, Book called Justin, Venice 1686

(Onassis Library, Athens).

Fig. 9: Meletios Typaldos

(Österreichische Nationalbibliothek, Vienna). 



\section{Index}

The Index includes persons, places as well as key terms related to the volume's topic, with the exception of obvious ones such as "Orthodoxy", "Orthodox Church", "Confession", "Confessionalization" etc. as well as "Constantinople".

A

Abbot, George, Archbishop of Canterbury $20 n$

Absolution 120-123, 154-155, 158

Accommodation 5-6, 9-10, 49, 54, 66, 71, 87, 91, 98-99, 101-102, 137-138, 150, 157, $177-178,180,198,396$

Acquaviva, Claudio 146

Adiaphora 54, 136, 172, 175, 178

Adrian, Patriarch of Moscow 300

Adrianople 244n, 245n, 247, 263, 297, 302n, 306

Adriatic Sea 137n, 173

Aegean Islands / Sea 8, 143, 145-146, 150, $177-178,251 n$,

Africa 31, 239

Agallianos. Theodoros 286n

Agapios, hieromonk 383-385

Ainos 33-34

Akribeia 5, 10, 363, 365, 383, 398

Akropolites, George 28

Albani, Giovanni Francesco, cardinal 249, 251, 258, 261

Albania 60

Alexander of Aphrodisias 264-265

Alexander of Hales 22

Alexander, the Great 64

Alexander VII, Pope 253

Alexandria 20, 67n, 105, 122, 257-258, 260, 383n

Alexis I, Tsar of Russia 242-243, 262, 386

Ali Efendi 240

Allatios, Leon 8

Alsted, Johann Heinrich 27, 30n, 31, 63

Amantos, Konstantinos 217
Ambrose, Bishop of Milan 59, 157, 252, 289

Ambrosii, Bishop of Kazan' 364

America 239

Ammonius, Hermiae 246, 265

Amoiridou, Evangelia 69

Amsterdam 88, 204, 216-217, 250

Anabaptism 9, 380, 383n

Ananias, Archbishop of Sinai 292, 302n

Ananias, Metropolitan of Smyrna 222

Ancona 84

Andreae, Samuel 82n, 93, 94n

Andrew, Bishop of Caesarea 66

Angelos, Christoforos 7, 63, 65, 70

Anthim, Metropolitan of Wallachia, the Iberian 308

Anthrakitis, Methodios 170, 179

Antichrist 62-63, 65-66, 68-70

Antioch 105, 122

Apostle's Creed 153, 158

Aquinas, Thomas 21-22, 157-158, 278, 284, 306

Arethas, Archbishop of Caesarea 66, 68 Argyriou, Asterios 48, 64n, 67n, 69n, 70

Argentis, Philip P. 217

Argyros, Andreas 90

Argyros, Isaac 242

Argyros, Lucas 90

Aristotle / Aristotelianism 19, 21, 116-119, 124, 242, 246, 249, 264, 278, 284, 340, 388, 395-396, 398,

Arkoudios, Petros 8, 133n

Armenians 138, 144, 383n, 397

Arminius, Jacobus 22-23

Arnold, Christoph 82, 84, 87-93, 96-97, 102 
Arrian of Nicomedia 28, 31

Arta 50-52, 61, 64, 86n, 101, 105, 159

Asia 239

Asia Minor 296n, 338n, 380

Asopios, Eirinaios 218

Astronomy 51, 70, 237, 239-242, 244, 246-249, 251n-253, 257-261

Athanasios, Archbishop of Sinai 123

Athanasios, Rhetor 287

Athanasios I, Archbishop of Ohrid 93n

Athanasius I, Patriarch of Alexandria, the Great 289, 295

Athens 18n, 20, 61, 95, 159, 161-163n, 222, 309, 355

Athos 80n, 82, 86n-87, 95, 103-105

Attalliates, Michael 385

Auger, Émond 133n, 149

Augustine, of Hippo 21-22, 157, 289-290, 306n, 311

Austria / Habsburg Empire 80n, 245n, 332n, 360, 369, 380, 394-395, 399

Avetik of Tokat, Armenian Patriarch of Constantinople 225

Avgerinou, Loxandra 217

\section{B}

Balbani, Niccolò 35

Balduin, Friedrich 51, 54, 59-60, 62, 64, 69

Balkans 84, 115, 355, 357, 368-369, 376, 378-379, 399

Balsamon, Theodore 289, 385

Baptism 9, 22, 99, 101n, 154, 210, 359, 380, $383 n$

Barbarigo, Gregorio, cardinal 250

Barboni, Michelangelo 160-161

Barclay, employee of the English Resident in Constantinople 245, 263

Basel 25, 28-29n, 85

Basil, of Caesarea, the Great 21, 24, 27, 289-290,

Basil I, Byzantine Emperor, the Macedonian 379n

Becanus, Martin 155-158, 165-166, 170, $175 n$

Beijing 243

Beijing Observatory 243-244

Belgic Confession 25, 27, 32-33

Bellarmino, Roberto, cardinal 6, 21-22, 31n, 33, 38, 40, 55, 133, 136, 145, 156, 203, 275

Bellon, Pierre 22

Berlin 88-90, 92, 96, 102, 104-105, 247

Berengarius of Tours 278, 296, 298

Beroardi, Filippo 201

Bessarabia 380

Beveridge, William 384

Bianchini, Francesco 253-254, 258, 261

Biblical Exegesis 5, 50, 155-158, 165

Black Sea 247

Blastares, Matthew 286n

Bolkhovitinov, Evgenii, Metropolitan of Kiev 367

Boniface III, Pope 62

Bosporus 19, 24, 297

Bonnal, Jean-François 223-226

Bortoli, Antonio 204

Bossuet, Jacques-Bénigne, Bishop of Meaux 369

Botero, Giovanni 27, 39

Brâncoveanu, Constantin, Prince of Wallachia 249-251, 259, 262, 303-305n, 307-308

Brahe, Tycho 249

Brescia 176

Brederode, Pieter van 25-26n

Brüning, Alfons 112-113, 123

Bucceri, Simone 145, 147, 149

Bucharest 281-282, 286, 289n, 292n, 300, 303-305n, 307-308, 334n-335, 344n

Budé, Guillaume 26

Bulgaria 105, 365

Burke, Peter 137

Byzantine Empire 63, 125, 355, 377n, 381

C

Calepino, Ambrogio 27

Calice (chalice) 142

Calixt, Georg 57

Calvin, Jean 21-22, 24, 32-33, 36n, 38, 40, 287-288, 290, 295-296, 298, 306, 311

Calvinism 8-9, 24, 37, 50, 56, 97, 101, 291, 308

Cambridge 85n, 244-246, 266

Camerarius, Ludwig 19

Camilli, Camillo 26, 39

Campanus, Johannes 51n 
Canisius, Peter 133, 149n, 276n

Canons 5, 207, 242n, 257, 334n, 363, 381-385, 399

Cantacuzino, Constantin, stolnic 240n, 249-251, 258, 303, 307-308

Cantacuzino, Rădu 234n, 249, 258, 261

Cappel, Jacques 32, 39

Cassini, Giovanni Domenico 233-234, 236-238, 240-241n, 248, 251-262, 395

Cassini, Jacques 237n, 252

Castagnola, Vincenzo 6, 136, 138-143, 145-155, 157-158, 163, 176-178, 180

Catechism(s) 6, 25, 28, 32-33, 36, 51-58, 60, $62,64,69,112,131-159,163,165,169-172$, 175-178, 180, 276n, 334n, 357, 396

Catherine II, Empress of Russia 358, 360-361, 370

Catholic Reformation 177-178, 225, 285n, 384, 386, 392

Cedrenus, George 21

Cephalonia / Kefalonia 166-167n, 196, 199-200

Chalastanis, Vasileios G. 287n-289n

Chalikiopoulos, Ioannis 169n

Chalkias, Ioannis 199

Chalkokondyles, Laonikos 28

Chamier, Daniel 33

Charipova, Liudmilla 113, 124n

Chatzikyriakis, from Vourla / Vourliotis 123

Châteillon, Sébastien 175n

Chemnitz, Martin 27

China 149n, 243-244, 252, 262

Chios 32, 116, 136, 138-139, 143n-150, 180, 216-217, 219, 223-226, 228, 239, 396

Chiotis, Panagiotis 193-195, 198

Chourmouzis, Michail 216n

Chrissidis, Nikolaos 10, 111, 396, 398

Christian I, Elector of Saxony 88

Christianization 356

Church in Eschwege 88

Church of 'Madonna del Trave', Chios 145

Church of St George, Tübingen 88

Church of St Jacob, Einbeck 88

Church of Saint Nikolas, Venice 197

Church San Giorgio dei Greci, Venice 166, 174, 199-200, 210

Church tithes 150, 158, 175
Chytraeus, David 69-70

Clémence, Guillaume-Joseph 368

Clement of Alexandria 24, 289

Clement I, Pope 289

Clement IX, Pope 253

Clement XI, Pope 249, 253, 258

Coke, Thomas 244-246, 263-266

Collegio Romano 135, 138, 146, 148n

Colbert, Jean Baptiste 233, 251n

Como 85

Confessional ambiguity 2, 7-9, 142, 159, 171-172, 177, 192, 310, 396-397, 400

Confessio Dosithei 6, 135, 282, 286n, 309

Congregation of the Calendar 253

Congregation of Propaganda Fide 33n, 50, 55-56, 193, 195, 250, 397,

Conring, Herman 57

Constantine I, Roman Emperor 68

Constantine V, Byzantine Emperor, the Copronymus 297n, 380n

Consubstantiation 203

Cops, Hendrik 36

Corfu 84n, 134, 360, 397

Cottunian College 117-118, 198

Cottunius, Ioannes / Kottounios, Ioannis 198

Council of Brest-Litovsk 359

Council of Constantinople 121

Council of Ferrara-Florence 93, 96, 151, 172,359

Council of Iași 357, 378

Council of Moscow, Stoglav 356

Council of Nicaea 257, 259

Council of Trent 27-28, 31, 133n, 151, 178, 278,352

Counter-Reformation (see Catholic Reformation)

Covel, John 244-247, 261, 263-266

Cranach, Lucas, the Elder 66

Cremonini, Cesare 242

Crespin, Jean 31

Crete 84n, 101, 104-105, 251n, 338, 353, 366

Crimea 359

Crusius, Martin 22, 27, 29, 49, 60-61, 79-80n, 82-98, 100-102

Crypto-Christians 2, 67, 397

Cultural translation 137-138, 150, 153, 157, 176-178, 180 
Cyclades Islands 353

Cyprian, Bishop of Carthage 289

Cyprus 8, 17, 34n, 60, 88, 92

Cyril I, Bishop of Jerusalem 289, 295

Cyril I, Patriarch of Alexandria 289

D

Dalmatia 365

Daniel, J. 223n, 227n

Danubian/Romanian Principalities 84, 85n, 259, 345n, 369-370, 380

De Viazis, Spyridon 194-195

Dendrinos, Ierotheos 221-222

Denmark 63, 256

Devil 64, 68-69

Devotional practice(s) 133, 143, 150, 154-155, 158, 171-172, 177-178

Dieterich, Konrad 27

Diez, Philippus 21

Dimaras, K. Th. 375-376

Dimitrios, priest from Agia 52, 61

Dimitrios, priest from Thessaloniki 85

Diodati, Giovanni 28, 31, 36n,

Dionysios, Metropolitan of Larisa and Trikala, the Filosofos 67

Dionysios III, Patriarch of Constantinople, Vardalis 305n

Dionysios IV, Patriarch of Constantinople, Mouselimis 281-282n, 301-303n

Dometskiy, Gavriil 309

Dominic, Nicolas Melchior 33

De Dominis, Marco Antonio 23, 28n, 70

Donatos, Stamatios 87n, 92

Dondis, Ioannis 101

Dorostamos, Athanasios 79n-80, 82-84, 86, 89-90, 96, 98

Dositheos II, Patriarch of Jerusalem 6, 9, 63, 99, 122-123, 135, 233-235, 237, 243-247, 251, 258-261, 263-266, 278, 282-289, 291-311, 378n, 387

Doxas, Iosif, bishop 134

Drelincourt, Charles 35, 38

Dresden 88, 104

Dresser, Matthaeus 59

Dupin, Louis Ellies 235

Dutch Republic 165n, 173

Dyovouniotis, Konstantinos 309
E

East Indies 35n, 248, 252

Ecumenical Orthodoxy 355-356, $363-365,371,400$

Edict of Nantes 225

Edinoverie 363, 365

Efthymios, archimandrite 82

Egger 380

Egypt 23, 60

Eideneier, Hans 94

Elias, prophet 197

Elßner, Jacob 89-90, 96-97, 102, 105

Emden 91

England 23, 63, 84-85, 87, 205, 245-245, $254,261,263,265,379$

English Residency in Constantinople 244, 245n

Enlightenment 134n, 260, 332, 336, 338, 341, 343, 357, 375-377, 383-384, 388,

Ephraim, Patriarch of Antioch 203

Epifanios School in Ioannina 159-160

Epiphanius, Bishop of Salamis 20n, 24

Erfurt 88, 90n, 105

Esad Efendi 239, 395

Eschatology 308

Essentials 136, 172, 175, 178

Eucharist 7, 10, 22, 56, 59, 69, 92, 96, 99, 113, 138n, 175, 200, 203, 207, 275-278, 284-301, 304, 308-311

Eugenikos, John 286n

Europe 2, 18, 32, 80n, 84-87, 137, 165, 173, 180, 199, 237, 239, 244, 255-258, 262, $329,343,352,393,399$

Eusebius, Pamphili, Bishop of Caesarea 289,387

Evangelical School in Smyrna 215-228, 394

Evvoia 83n, 85, 92, 104

F

Fasting 98-99, 143, 195

Ferdinand II, Habsburg Emperor 156

Ferrari, Filippo 246

Ferriol, Charles de 223-225

Ferus, Johannes 26

Filaras, Leonardos 133n

Filioque 54, 141-142, 150, 153, 158, 172, 290 
Flanginian College 117, 166, 167n, 198-200, 210

Flanginian Hospital 168n

Florea, priest 308

Florentine Decree 174-175, 178

Florovsky, Georges 5, 48-49, 330n

Fontenelle, Bernard de 255

Fontrier, Aristotelis 220-221

France 132n, 151n, 176n, 178, 209, 218220, 223-225, 234-235, 248-249, 251n, 253, 256-259, 262, 375, 386, 394

Francis Xavier 252

Franciscus Lucas of Bruges 26

Francke, August Hermann 81

Francochiotic books 139, 143n, 145, 149

Frankfurt 85, 89n, 105

Frederick II, King of Prussia 195

Freeze, George 114

French Royal Academy of Sciences 233234, 248, 252-255, 257-258, 395

Frick, David 125

Fyrigos, Antonis 191

G

Gabelentz, Anna Maria von 51n

Galata 22, 143n, 145

Galilei, Galileo 242

Garetto, Benedetto, Catholic Bishop of Chios 146

Gavriil, Archbishop of Ohrid 83n, 86n, 91, 98, 100-102

Gavriil, Metropolitan of Nafpaktos and Arta 50

Gavriil of Vryoula 217

Gavriil III, Patriarch of Constantinople 222

Gelasius I, Pope 289

Geneva 24, 25n, 27, 28n, 35, 37-38, 40, 290

Genos 163, 366, 381

Georgeirinis, Iosif, Bishop of Samos 87

Georgia 60, 365, 380

Gerasimos, Metropolitan of Herakleia 380-381

Gerganos, Zacharias 6, 8, 48-71, 132n, 395-396

Gerlach, Stephan 48

Germany 88, 91, 235, 256-257, 354

Gerontism 379-381, 387
Ghica, Grigore, Prince of Moldavia and Wallachia 370

Ghobrial, John-Paul 396

Giannina (see Ioannina)

Glocality 137

Glykys, Nikolaos 160, 165n, 380

Glyzounis, Manouil 60

Gordios, Anastasios 70

Gordon, Alexander, general 206

Gotha 82, 83n, 85, 92-94, 98-100, 104-105

Great Schism 8, 207, 275n, 338n,

Greece 51, 55, 58, 94, 124, 195, 216, 365, 367

Greek College of Saint Athanasius in Rome 8, 117, 145, 192-198, 199n, 210

Greek Confraternity of Venice 162n, 163n, 166, 168n, 169-171, 174, 179, 199

Greek Rite 171, 174, 192, 195-196, 209

Gregoras, Nicephorus 28

Gregory, Bishop of Nyssa 203

Gregory of Nazianzus, the Theologian 21, 24, 59, 289

Gregory I, Pope, the Great 157

Gregory X, Pope 294

Gregory XIII, Pope 133, 175n, 253, 256, 258, 261

Grell, Ole Peter 38

Greyerz, Caspar von 65

Grigorios V, Patriarch of Constantinople 383

Gropper, Johann 133

Grotius, Hugo 35, 173

Gymnasium of Hamburg 96n

H

Haga, Cornelis 20, 23-25n, 28, 33, 36-37, 56

Halacha literature 340-342

Halle 23, 47, 80-81, 104-105, 360

Hamburg 105

Hançerli / Chantzeris, Samouil I, Patriarch of Constantinople 383

Hannover 257

Harmenopoulos, Constantine 379, 382-383, 385

Heerbrandt, Jacob 101

Heidelberg 23, 88, 104

Heidelberg Catechism 22, 25n, 27, 32 
Heineccius, Johann Michael 80-81, 102, 300

Helmstedt 57, 93

Hemmingsen, Niels 21, 24

Henry VIII, King of England 379

Heraclea 380

Hering, Gunnar 377

Hesychasm 332n, 333, 337,

Hilary, Bishop of Poitiers 24

Himara 85, 93n

Hippolytus of Rome 68, 255

Hofmann, Georg 18

Holbein, Hans, the Younger 66

Holland (see Netherlands)

Holy Communion 22, 55, 99, 142, 146n, 150, 155, 273, 277, 289, 291, 333, 336-337,

Holy See 179, 194n

Holy Spirit 22, 54, 153, 158, 207-208, 273, 277, 285, 287n, 290-291, 296, 299, 306, 367

Hostia (host) 142

Höschel, David 21

Hsia, Ronnie Po-Chia 137

Hungary 83-85, 104-105, 263, 330, 354, 378,380

Hutter, Leonhard 22-23

\section{I}

Iași / Jassy 245, 282, 295, 305, 308, 357, 378

Ieremias II, Patriarch of Constantinople, the Tranos 7, 47-48, 54, 84n, 100-101, $114 n, 258,305,377 n$

Ieremias III, Patriarch of Constantinople 135, 180, 386

Ignatius, Patriarch of Antioch, 289

Ignatius of Loyola 384

Indulgences 27, 111, 116, 120-125, 396

Interconfessionality $1,7,10,71,81,91,98$, 115, 136, 174-175n, 177, 371, 396-397, 400

Ioannina 52, 84n, 136, 152, 159, 168, 170, 295, 395

Ioannis Damaskinos (see John of Damascus)

Ioannis Vyzantios (see Karyofyllis, Ioannis)

Ionian Islands 8, 173, 192, 195-197, 353, 366 Irenaeus, Bishop of Lyon 68, 201, 289
Irenicism 8, 71, 173n, 175-180, 397

Isidore, Archbishop of Seville 24

Islamization 388

Italy $84,90,118,132 \mathrm{n}, 176,179,234-235$, $244,253,258$

Ithaca 51, 216

Ivan IV, Tsar of Russia, the Terrible 361

J

James II, King of England 88, 254, 261

Jena 52, 255

Jerome of Stridon, Saint 22, 69, 157, 289

Jerusalem 86, 105, 122, 235, 238-240, 247, 260-265, 283, 302n, 304, 357, 365

Jesuits (see Society of Jesus)

Jews 2, 22, 35, 61, 68, 144, 146n, 331, 340-345, 392n, 397-398

Joachim, Patriarch of Moscow 277n

Johann Georg, Prince of Saxony 50, 52, 66,88

John of Damascus 21, 59, 284, 289, 295

John the Chrysostom 21, 59, 287n, 289-290,

John VIII, Byzantine Emperor, Palaiologos 62

Jon, François du / Franciscus Junius 24

Jovanović, Vikentije 99

Justin, Martyr 289

Justin, historian (Justinus, Marcus Junianus) 136, 160-164, 169-170, 180

K

K'ang-hsi, Emperor of China 243

Kalamata 93, 104

Kallinikos, Metropolitan of Bursa (see Kallinikos II, Patriarch of Constantinople)

Kallinikos II, Patriarch of Constantinople 92, 297-299, 301n-304

Kallinikos III, Patriarch of Constantinople 380, 383n

Kanas, Ioannis 216

Kankellarios, Alexandros 204n, 209

Kapetanakis, Leonardos 169n

Karathanasis, Athanasios E. 191

Karlowitz 179, 380

Karyofyllis, Ioannis 8, 273-275, 278-283, 286n, 311 
Karyofyllis, Ioannis-Matthaios 8,55n, 56, Laskarefs, Andreas 87n $62,133 n$

Kassel 88, 105

Kastrisios, Daniil 87-91, 96, 104

Katiforos, Antonios 191-211, 395

Katiforos, Dimitrios 196

Katramis, Nikolaos 192-194

Keramefs, Nikolaos 6

Kholmogorskii, Afanasii 113

Khomyakov, Aleksey 309

Kiev 283, 378

Kievan Mohyla Academy 119

Kigalas, Matthaios 17

Kitromilides, Paschalis M. 376

Kokkinos, Filotheos (see Philotheus I, Patriarch of Constantinople)

Kollyvades Movement 9, 330-339, 343-344, 380, 383, 387, 398

Komninos-Papadopoulos, Nikolaos 179, 199n, 233, 249, 251, 259, 261, 300

Komoutos, Antonios 200

Kondylis, Panagiotis 376

Kontaris, Kyrillos II, Patriarch of Constantinople 20

Kontis, Georgios 34

Kontonis, Ioannis 192, 198, 200, 203

Kontos, Antonios, priest 192n, 193, 195

Korais, Adamantios 134n, 215-217, 332n, 357, 376

Koressios, Georgios 6, 32, 122, 282, 292, 295, 305,

Korinthos 196

Korydallefs, Theofilos 117-119, 216, 242, 281, 283, 287-288, 295, 298, 377

Korydallism 117-119

Koumas, Konstantinos 216n-217

Koursoulas, Nikolaos 118, 122-123

Kritopoulos, Mitrofanis 6-7, 23, 57-58, 70,93

Kyminitis, Sevastos 242, 308

Kyrillos V, Patriarch of Constantinople $383 n$

L

Lagny, Paul de 133n

Landos, Agapios 337n-339

Langius, Josephus 26

Larissa $84 \mathrm{n}$
Laskaris, Konstantinos

Last Judgement 308

Last Supper 22, 59

Latin Rite 194, 196

Latinization 277n, 309, 359

Laud, William, Archbishop of Canterbury 64-65

Lauer, Gerhard 392n

Lazzaroni, Giammaria 204

Leclerc, Pierre 338n, 360

Ledesma, Diego de 133n, 135-145, 149-158, 161, 176-177, 180, 396

Lefkada 82, 103

Léger, Antoine 19, 24-38, 40, 56, 393

Leibniz, Gottfried Wilhelm 257-259

Leichoudes, Ioannikios 117-118

Leichoudes, Sofronios 117-118

Leichoudian Academy 116-119

Leiden 18, 22, 25n, 27-28, 37

Leipzig 23, 89n, 90, 99n, 104-105, 134n, 300-301, 360, 370

Lentulo, Scipione 35

Leo III, Byzantine Emperor, the Isaurian 380n

Leo VI, Byzantine Emperor, the Wise $337 \mathrm{n}$

Leon, Radu, Prince of Wallachia 281

Lequien, Michel 236-237

Leucorea, Theological School of Wittenberg 50

Levant $8,22,133,137,147,149,172-173$, 178-180, 220n, 225, 228, 284n, 353

Levant Company 37n, 215, 228n, 244, 246-247, 251, 261

Levshin, Platon, Metropolitan of Moscow 134n, 357, 363-364, 367

Library of the Patriarchate of Alexandria 20

Ligaridis, Paisios / Pantaleon 6, 8, 287, 386

Lipsius, Justus 21, 23n

Livieratos, Evangelos 250

Logotheta, Joasaph, from Kalamata, monk 92n, 93, 104

London 28n, 65, 85n, 88n, 246, 264-265, 301

Loredan, family 201

Losacco, Margherita 191-193, 194n, 202-203 
Louis de Granada 27

Louis XIV, King of France 233-234, 245, 252, 257

Loukaris, Kyrillos, Patriarch of Alexandria and Constantinople 6, 8, 10, 17-25, 28-38, 50, 55-57, 64-65, 70, 82, 84, 93-96, 115-118, 125, 278, 283, 298, 310, 377-378, 393

Loverdos, Agapios 200

Lucaris, Cyrillus (see Loukaris, Kyrillos, Patriarch of Alexandria and Constantinople)

Luther, Martin 21, 50, 63, 69, 136n, 175n, $298,305,354$

Lutherans / Lutheranism 7, 22-23, 47-56, 61-71, 80, 93-98, 100-102, 114, 146n, 206, 300-301, 367, 377n, 396

Luyts, Jan 250

Lviv / Lwiw / Leopolis 21, 85

Lycophron of Chalcis 21

Lynden, Josina Carolina van 216n

Lyon 27,35n

\section{M}

Macarius of Egypt 289

Macarius, Metropolitan of Ancyra 286n

Macedonia 88, 98n, 104, 375

Magdeburg 90

Maimonides 140

Mainz 156

Makolas, Ioannis 136, 152, 160-164, 168-170, 180

Makris, Makarios 286n

Makris, Vissarion 160

Malaxos, Manuel 380

Mamoukas, Andreas 217, 219, 227

Manasses, Constantine 28

Manuel I, Byzantine Emperor, Komnenos 386

Manuel II, Byzantine Emperor, Palaiologos 62

Maragha School 242

Maraldi, Giacomo Filippo 253, 261

Marburg 82, 93, 104

Marc of Ephesus 245n, 286n

Marcheville, Henri Gournay de 33

Margounios, Maximos, Bishop of Kythira 21, 293, 295
Marin, Carl 19

Marseille 27, 28n, 220n, 223-228

Martini, Jakob 51n, 57, 65

Matthaios, Bishop of Myra 20

Mavrikios, Filippos 90n

Mavrogordatos, Ioannis 216n, 333n

Mavrokordatos, Alexandros 224-225, 228, 240, 260, 301n, 302, 303n

Mavrokordatos, Nikolaos 2, 239

Maximos the Peloponnesian 20,64n, 66-68, 70, 282, 289n, 292n, 294, 304n

Maximus, the Confessor 289, 295

Medvedev, Silvestr 309

Meisner, Balthasar 58

Melanchton, Philip 24, 50, 68

Meldados 342

Melkites 378

Menshikov, Aleksander Danilovich 195

Metaxas, Nikodimos 65

Metochion of the Holy Sepulcher 238$239,289 n$

Meursius, Johannes 26

Michael, Prince of Wallachia and Moldavia, the Brave 60

Michael III, Patriarch of Constantinople 386

Michael VIII, Byzantine Emperor, Palaiologos 294, 295n

Michos, Apostolos 199n

Michou, Maria 196

Milan 85

Spathar, Nicolae 243

Miloitis, Iakovos 88, 90-91

Miniatis, Ilias 171, 179

Mirabelli, Domenico Nani 26

Missionaries 3, 7, 30, 33, 55, 64, 81, 117, $131,135-138,143,145-149,178,180$, 208, 220, 224-225, 242, 249, 251-252, 260, 262, 275, 378, 394-395

Missy, Jean Rousset de 205-206, 209

Mitros, Meletios, Metropolitan of Nafpaktos and Arta (see Mitros, Meletios II, Metropolitan of Athens)

Mitros, Meletios II, Metropolitan of Athens 6, 136, 138, 152-180, 239, 240n, 298

Mitros, Michail, priest (see Mitros, Meletios II, Metropolitan of Athens) 
Moennig, Ulrich 79n, 81, 94

Mohyla, Petro, Metropolitan of Kiev 6, 112-114, 119, 124n, 134n, 135, 276n, 283, Neofytos IV, Patriarch of Constantinople 285n, 305n, 309, 337n, 357

Moisiodax, Iosipos 335n, 376

Moldavia 25, 60, 85, 117n, 239, 243, 263, 365

Molinos, Miguel de 176, 179-180

Monaco 258

Monastery of Agia Paraskevi (Himara) 85

Monastery of Saint Catherine (Sinai) 103-105, 292, 295, 302n,

Monastery of San Giorgio Maggiore (Venice) 201

Monastery of San Nicola e del profeta Elia (Zakynthos) 197

Monastery of the Holy Cross (Jerusalem) 238

Monastery, Cetățuia 305

Monastery, Dionysiou 66

Monastery, Hurezi 249

Monastery, Iviron 86, 88, 95-96, 103-105

Monastery, Mărgineni 249

Monastery, Radu-Vodă 282, 303

Monastery, Snagov 307-308

Moravius, Petrus 86

Mornay, Philippe du 20n, 29n, 35

Moscow 116-119, 206, 238, 242-244, 261, $277 \mathrm{n}, 301,304 \mathrm{n}, 309,365,379$

Moses 381

Mpachatoris, Dimitrios 216n

Mpompou-Stamati, Vasiliki 191, 195

Multiconfessionalism 1, 7-8, 137-138, 173, $176,178,180,331,353-354,397,400$

Musar literature 331, 339-345, 398

Musculus, Wolfgang 24

Musin-Pushkin, Aleksei Ivanovich 361

Musso, Cornelio 21-22

Myrmigousianos, Grigorios, protosynkellos 305

$\mathbf{N}$

Napoli / Naples 84, 123

Nathanail, Metropolitan of Lefkada 82, 103

Naxos 83, 84n, 104, 221

Nazione greca 8, 166, 169-170, 174, 176, 180

Nektarios, Patriarch of Jerusalem 6, 245, 247, 282-283, 287, 294
Neofytos, Kafsokalyvitis 333n, 334n, 335, 344 302n, 306n

Nestesuranoi, Ivan 204

Netherlands 31, 32n, 84, 85, 91, 173n, 256

Nicene Creed 153, 158, 257, 259, 278

Nijs, Daniel 26

Nikiforos, Bishop of Ierissos 52, 61

Nikodimos, Agioreitis 332n-334n, 343n, 370, 384

Nikolaïdis, Euthymios 243

Nikolopoulos, Konstantinos 236

Nikon, Patriarch of Moscow 357, 386

Nikousios, Panagiotis 245n

Nkiou(n)ma School in Ioannina 159

Nointel, Charles-Marie-François Olier, marquis de $7,284 \mathrm{n}$

Noris, Enrico, cardinal 253, 257n

Nosseri, Giovanni Maria 58n, 69

Notaras, Chrysanthos, Patriarch of Jerusalem 9, 179, 199n, 209, 233-247, 250-251, 256, 258-262, 273n, 274, 278, 283n, 286n, 288n, 291, 295, 304n, 311, 395

Notaras, Makarios 216n, 333n, 370

\section{O}

Obradović, Dositej 369, 376

Odessa 353

Oecolampadius, Johannes 175n

Oecumenius 289

Oikonomia 5, 363, 365, 383, 398

Oikonomos, Konstantinos 217-218, 220, 227

Oikonomos, Sofoklis 220, 222

Old Believers 112, 356, 363-368, 378, 387, 397

Olga, Princess of Kiev 359

Omiros, Georgios 221

Omiros, Ioannis 216n

Oosterwyck, Volkerus van 26

Origen of Alexandria 24

Original Sin 62, 308

Orpheus 384

Osman II, Ottoman Sultan 64n, 67

Ottoman Empire 2-3, 19, 36, 55, 67, 79-88, $90,94,98,103,112,117,137,138 \mathrm{n}, 143$, 
145, 177-178, 204, 219, 225-228, 238, $244,259,331,338-340,343-345,356$, $358,375,379 n, 381,385-388,393-399$ Ovid 161-162, 164, 169

\section{$\mathbf{P}$}

Pachymeres, George 289

Padua 117-118, 124, 166, 167n, 197-198, 233, 236n, 242-243, 249-251, 256, 258, 261

Paget, William 249

Paisios II, Patriarch of Constantinople 380, 399n

Paìsiy Hilendàrski 376

Paleokapas' College 198

Palaiologos, Daniil 86n, 87n, 95

Palaiologos, Thomas 88, 98

Palamas, Gregory, Archbishop of Thessaloniki 286n, 332n

Palestine 241n, 260, 283

Palmer, Thomas 246, 264-266

Pankalos, from Corfu / Pancalus, Corcyrensis $84 n$

Pantazopoulos, Nikolaos 382

Papadatos, Mohammed / Kosmas 101-102

Papadopoulos, Chrysostomos I, Archbishop of Athens 309

Papadopoulos, Thomas 148n, 149n

Papal Primacy 37, 49, 51, 55, 59, 62, 112, $114,142,150,158,172,175,207-208$, 245,247

Papal States 253

Paranikas, Matthaios 216n, 220, 222-223, 227

Pareus, David 24

Parios, Athanasios 332n-335n, 336, 343n

Paris 33, 86n, 136, 204n, 207, 233-238, 241, 244, 248, 250-251, 256, 258, 260-262, 301

Paris Observatory 233-234, 237-238, 241, 243-244, 248, 254, 256-262, 395,

Parthenios I, Patriarch of Constantinople, the Elder 287

Parthenios II, Patriarch of Constantinople, the Younger 287

Paschal Moon 254-257,

Patmos 88, 96, 104

Patoussas, Ioannis 199n

Patriarchal Academy / School 242, 281, $287,295,377$
Paul I, Emperor of Russia 365

Pavlos, Athanasios, monk 79n, 80, 82,

83n, 84, 86, 87n, 89, 91, 97n, 98-99

Pax Augustana 378

Pecora, Santo 204

Peloponnese 8, 104, 173, 200, 289, 344

Perkins, William 24

Perone / Perrone, Antonio 263n

Perot community 143n

Peroulis, Michail 161, 163n, 164n, 169n

Perpiniano, Giorgio 133n

Perrault, Claude 233

Perry, John 204-205

Peter I, Tsar / Emperor of Russia, the Great 191-192, 201, 203-204, 207-211, 356, 367, 379, 386

Petrov, Gavriil 364, 367

Phanariots 2-3, 375, 381, 383, 388

Philippos of Cyprus 17, 25n

Philotheus I, Patriarch of Constantinople 286n

Phocas, Byzantine Emperor 62-63, 69

Photius I, Patriarch of Constantinople 192, 200-203, 210, 289, 295, 385

Picard, Jean 234, 248n

Pigas, Meletios, Patriarch of Alexandria 6, 20n, 21-22, 63, 173n, 293, 295

Piscator, Anthonis 25

Pitteri, Francesco 201. 203-205

Pitzipios, Iakovos 218

Pius IV, Pope $133 n$

Plato 19, 20n

Plokhy, Serhii 112

Podskalsky, Gerhard 53, 55, 64, 172n, 71n, 273n, 287n, 377

Poland-Lithuania 84, 113, 235, 247, 263 , 354, 360-361

Polanus, Amandus, von Polansdorf 30n, 31

Polotskiy, Simeon 309

Poltava 345n, 369

Polyeidis, Theoklitos 79n, 80, 82, 83n, 84, 97n, 98-100, 102, 105

Polynesia 239

Pontchartrain, Jérôme Phélypeaux de 223, 258

Porfyrios, Archbishop of Ohrid 83

Porfyritis, Ioannakis 245n, 263n 
Positive Theology 175

Possevino, Antonio 35

Posznan 85

Prague 86

Predestination 22, 308

Princely Academy in Bucharest 117n, 308

Private sphere 382-383, 387-388, 399

Prokopiou Pamperis, Dimitrios 194, 200, 237

Prokopovich, Feofan, Archbishop of Novgorod 356, 367

Proselytism $8,101,112,144,148 n$, 177-178, 198, 210, 215, 218-219, 227, 261, 391, 393, 397

Protopapas, Dimitrios $84 \mathrm{n}$

Prussia 88, 360, 367

Pseudo-Dionysius, the Areopagite 289

Ptolemy, Claudius 240n, 242, 247-248, 252, 261

Purgatory 30, 33, 55, 59, 114, 116, 122, 125, $142,150,154,158,171-172,285-286$, 292, 295, 301-302, 310

Q

Querini, Angelo Maria 192, 209-210

Quietism 175-179, 333n

$\mathbf{R}$

Racoviță, Stephan Michael, Prince of Wallachia 369

Racoviță, Constantin Michael, Prince of Wallachia 369

Rainolds, John 22-23

Ratramnus, of Corbie 278

Realm of the Morea 179

Reformation, Protestant 19, 24, 34, 63, 65, 101, 137, 228, 274, 298n, 305, 352, 354-355, 377, 386, 391-392

Reformation, Catholic 177-178, 225, 377, 384, 386, 392

Reibold, Johann 51n

Reinhard, Wolfgang 37-38, 101, 124, 351, 376, 391

'Religious hybridity' 10, 171

Revelation 56, 61-70, 173, 336

Revius, Jacobus 25, 32n

Rhine 85

Riccioli, Giovanni Battista 249, 251, 261
Riformatori dello studio di Padova 167n, 204

Rivet, André 25n, 27-34, 35n, 38n

Rodios, Maximos, of Kallipoli / Kallioupolitis 31

Rodotà, Pietro Pompilio 193-194

Roe, Thomas 23, 31, 34n,

Romania 375

Rome 8, 29, 31, 36-37, 47, 50, 52-57, 63, 68-69, 87, 117, 133, 135-141, 145-146, 148-149, 156n, 167, 172-173, 178-180, 192-199, 207-208, 210-211, 235, 253, 255, 257-261, 289, 336, 395

Rota, Francesco 201

Rousmelis, Michail 197-199

Runciman, Steven 47

Russia 10, 60n, 80, 84-85, 90n, 112-118, 125, 203-205, 208, 237, 244, 247, 277n, $300,356,358,360-362,365,367,380$, 388,393

Russian Church Synod 361, 365

Russification 356-359

Ruthenia 112, 117, 205-207

Ruzzini, family 201

Rysios, Diamantis 216, 217n, 222, 227

\section{S}

Saarls, B. F. 220

St. Petersburg 361, 364, 367, 369

Sandys, George 23

Santorini 90n

Sari, Pantelis (see Sevastopoulos, Pantelis)

Saros, Nikolaos 160, 168n

Sarpi, Paolo 28-31, 35, 37

Sartoris, David 36

Sathas, Konstantinos N. 192-193

Schilling, Heinz 101, 111n, 112n, 116n, $124,351,376,391$

'Schismatics' 69, 171n, 174, 193, 250

Schmidt, Erasmus 51n, 53, 57-58

Schmitt, Charles 119

Scholarios, Georgios / Gennadios, Patriarch of Constantinople 286n, 292n, 295, 310386

School of the Greek Confraternity in Venice 166n, 200

Schott, André 202-203 
Schwarzenhorn, Johann Rudolf Schmid Freiherr von 84

Scultetus, Abraham 31

Second Confessional Age 354

Secularization 353, 375-379, 382-388

Seides, Niketas 289

Serbia 60,375

Serres 17

Sevastopoulos, Pantelis 215-228, 394

Sevin, François 241

Seviros, Gavriil, Metropolitan of Philadelphia / Venice 293-294

Sfoini, Alexandra 136

Siam 252

Simon, Richard 165

Sins 61, 63, 120-122, 140, 142-143, 151, $154,158,302$

Sinai 80n, 103-105, 123, 292, 302n, 365

Sitia 84n, 93, 104

Skiadas, Athanasios 204n, 209

Skinner, Barbara 112

Slavo-Greco-Latin Academy (see Leichoudian Academy)

Smyrna 6, 88, 215-224, 227-228, 251n, $333 n, 353,394$

Society of Jesus 7, 22, 29-30, 56, 115-116, $118,139,143-149,151,156,165,177-178$, 180, 197, 209, 215, 218-222, 235, 243 249, $251,262,384$

Sofia 309

Spain 151n

Spanos, Alexios 380-381

Spengler, Oswald 5, 48, 330n

Spinoza, Baruch 165n

Stapleton, Thomas 21

Stathi, Pinelopi, 237, 260n

Stuß, Johann 98, 100, 102

Stuttgart 57, 89, 96, 101, 102n

Sunnitization 2,379n

Surius, Laurentius 22

Sweden 63, 256

Switzerland 354

Sylburg, Friedrich 21, 25n

Symeon, Archbishop of Thessaloniki 282, 285, 286n, 292, 293n

Symeon, monk 85

Symphonia / Synallelia 387

Synadinos, priest 17
Synod of Constantinople 135, 180, 285

Syrigos, Meletios 6, 202, 282-283, 287,

288n, 292, 293n, 295, 297, 300, 357

Syropoulos, Sylvestros 93

T

Tentzel, Wilhelm Ernst 82, 85, 92, 94, 97, 102

Tertullian 24, 289

Teseo, Ambrogio 26

Themistius 246, 265

Theodore, Archbishop of Mopsuestia 203

Theodoret, Bishop of Cyrus 289

Theodosios, Metropolitan of Wallachia 307

Theodosiou, Dimitrios 201

Theofanis III, Patriarch of Jerusalem 32

Theologoumena 136

Theophylact, Archbishop of Ohrid 289

Theotokis, Nikiforos 358-371, 397,

Thirty Years' War 50, 82, 377n

Thomas de Kempis 27

Thüringen 90-91

Tillet, Jean du, bishop 384

Toufexis, Panagiotis 94

Transconfessionality 7, 111, 113-116, 123-126, 396-397

Transculturality 137

Translational policy 149

Transubstantiation 92, 96, 114-115, 203, 207, 273, 278, 284, 286n, 287-289, 292, 294-296, 309-310

Transylvania 85, 90, 353

Trautson, Paul Sixt III von 86

Trebizond 60, 242

Tridentine doctrine $194 \mathrm{n}$

Tridentine Rite Mass 151, 158

Trogus, Gnaeus Pompeius 161

Trucello, Alexander 88, 89n

Tsakiris, Vasilios 37, 80-81

Tsankov / Cankov, Stefan 309

Tsimplitis, Filippos 197-198

Tsourkas, Kleovoulos 117

Turrettini, Bénédict 25n, 27, 28n, 29, 31-33, 35

Tuscany 253

Tübingen $7,47,49,79,83-85,88,90 \mathrm{n}$, 91-93, 95, 98, 100-102, 105, 377, 
Typaldos, Matthaios / Meletios, Metropolitan of Philadelfia / Venice 138, 166-180, 199, 210

Tzetzes, Isaac 21

Tzitzilianos, Mitrofanis, 83n, 85, 92-94, 104

U

Ukraine 112, 259

Ulrich, Johann Jakob 28

Uniates 93, 112 171, 193, 206, 359-362, $366,368,397$

Union (with Rome) 8, 37, 93, 133, 172-175, 177-179, 208-209, 211, 260, 359

University of Erfurt 88

University of Padua 117, 166, 167n, 197, 242n, 249

Unleavened bread 172, 275, 290

V

Valsamos, Dimitrios 369

Varvianis, Dionysios 194-195

Vatican 167, 170

Vavatenis, Nikolaos / Nikodimos 168-170

Velichkovskij, Paisij 333n, 345n, 369-370

Venediktos, monk 52

Venetian Republic 162n, 173,

Vendotis, Georgios 194

Venice $8,10,19,21,25-28,84-87,117,136-$ 138, 155, 158-160, 162n, 163n, 165-176, 178-180, 192-201, 204, 206, 210, 239n, 240n, 250, 265, 300-301, 333n, 339, 380, 396-397

Verbiest, Ferdinand 242-244, 249, 251, 252n, 261-262

Vermigli, Peter Martyr 24, 33

Vervosius, Petrus, presbyter 84n, 93, 104

Vienna 81-86, 90n, 103-105, 156, 179, $301 \mathrm{n}, 332,341 \mathrm{n}, 368$

Vilna $85,340 \mathrm{n}$

Vitalis, Zorzis 221

Vitković, Petar 380

Vlachos, Gerasimos, Metropolitan of Philadelfia / Venice 118, 165-166

Vlastaris, Matthaios 382

Vojvodina 353
Voltaire, François-Marie Arouet 360, 368

Voulgaris, Evgenios 84n, 192, 338n, 358-363, 366-368, 370-371, 384, 397

Voulgaris, Nikolaos 6, 134, 155

Vuccula, Gaetano 168n

Vyrton, Adrian 216n

\section{W}

Wagstaffe, Thomas, bishop 300

Wallachia 52n, 249-250, 262, 281, 282n, 288, 292, 302-304, 307-308, 365, 369

Wandel, Lee Palmer 132n

Wars of Religion 376-379, 385

Warsaw 87

Weber, F. Christian 204-205

Weidner, Johann Friedrich 90n

Weigel / Wegelius, Erhard 255

Weinmann, Erhard 57

Weißensee 90

Westernization 111, 115, 119, 123-125

Wigand, Johann 23

Wilhem, David de 22-24

Wittenberg 50-58, 60, 62-65, 70-71, 88, 395

Wolf, Johann Christoph 89, 96

Wtenbogaert, Johannes 22

Württemberg 79, 89, 101

Würzburg 156

\section{$\mathrm{Z}$}

Zakynthos 134, 193-200, 210, 369

Zanchi, Girolamo 21, 22, 24

Zandiris, Georgios 168

Zannetti, Luigi 139

Zaveiras, Georgios I. 194

Zeno, Apostolo 200, 201

Zernikav, Adam 367

Zevi, Sabbatai 341

Zlynka 364

Znamenka 364

Zrazhevskoi, Vasilii Moiseevich, priest 361

Zürich 19, 28

Zwierlein, Cornel 3,100

Zygomalas, Theodosios 61, 80n, 82, 102n 